\title{
Growth, fruiting body development and laccase production of selected coprini
}

\author{
Dissertation \\ zur Erlangung des Doktorgrades \\ der Mathematisch-Naturwissenschaftlichen Fakultäten \\ der Georg-August-Universität zu Göttingen
}

vorgelegt von

Mónica Navarro González

(aus Cuernavaca, Mexiko)

Göttingen, den 18.03.2008 
D 7

Referent: Prof. Dr. Gerhard Braus

Korreferent: Prof. Dr. Andrea Polle

Tag der mündlichen Prüfung: 30.04.2008 


\title{
To my parents: Othón and Isabel
}

and to my nieces and nephews:

Samy, Marco, Claus, Aldo, Andy, Lucero, and Montse

\author{
...for bringing me always motivation, joy and love
}



If you think you are a mushroom, jump into the basket

Russian prover6 



\section{Since performing $\mathrm{Ph}$. D is more than experiments, tables, graphs, monday seminars, conferences and so on I would like to express my gratitude:}

I am immensely happy to thank all those who have helped me in this hard way. My gratitude goes to Prof. Dr. Ursula Kües for giving me the opportunity to work in her group and for providing any opportunities for developing myself in many directions during my doctoral studies, and my life in Germany. I sincerely thank Dr. Andrzej Majcherczyk for his advices and direction on part of this work. My special thanks to Dr. Patrik Hoegger for his invaluable support and his endless patience during large part of my work.

Furthermore, I would like to thank Prof. Dr. Gerhard Braus, Prof. Dr. Andrea Polle and Prof. Dr. Stefany Pöggeler for their readiness to evaluate my thesis and being my examiners.

Víctor Mora-Pérez deserves part of the acknowledgments, without his primary motivation my interest for working with mushrooms during my bachelor studies probably would have never been appeared in my mind. Dr. Mercedes Sobal Cruz motivated me for continuing master studies in the same field. In the same way, I would like to extend my gratitude to Dr. Daniel Martínez-Carrera for making, through his motivation and support, possible this adventure called $\mathrm{PhD}$. If I continue motivated to work with mushrooms is thank to you!

By now, it is not easy to find the appropriate words to describe all the feelings towards all the people with whom, in different times, I have been sharing this period of my life. Easy to say, but full of experiences, happiness, disappointments, laughs, anger and even tears... All of you guys have a space in my heart and will never forget all the time we spend together. Thanks for being my colleagues, friends and family at the same time: Akiko Ono, Matthias Hoffmann, Ravi Dwivedi, Rajesh Velagapudi, Sreedhar Kilaru, Prayook Srivilai, Wassana Chaisaena, Kateřina Svobodová, Sudhakar Peddireddi, Kalyani Pemmasani, Annette Naumann, Martin Rühl, Dorothea Fragner, Banyat Cherdchim and Dong Sheng Wei. 
Katka, Wassana, Sudhakar, and Dong Sheng, deserve a special mention (5 stars!) for their invaluable support in the last part of the PhD. Thanks a lot!

Impossible to forget Mojtaba Zomorrodi for being always ready to provide anything one ever can imagine for working in the lab, always with a smile on his face. Karin Lange and Alexandra Dolynska deserve a special place for being nice co-workers and loyal friends.

I would like to take this opportunity to thank all the members of the Section Molecular Wood Biotechnology and Technical Mycology, and the Section Forest Botany and Physiology of Trees of the Büsgen-Institute, who were always very friendly and kind, especially Andrea Olbrich for their readiness to help me with microscopy stuff; Bernd Kopka for solving the endless problems with the computer and Gisbert Langer-Kettner for solving many of our technical problems in the lab and in the office.

During the studies I had the support in the lab form different students, to whom I am also grateful to discover, develop and improve my abilities in teaching: Carmen Yen, Samantha Navarro, Alberto Domingo, Frauke Kleemann, Olivia Sánchez, David Ris and Marlit Arndt.

I would like to thank Prof. Stefan Schütz and Pavel Plašil from the Section Forest Zoology and Forest Conservation of the Büsgen-Institute for the collaboration in the mite project. Without your interest in the topic, we would have not gone too far.

Prof. Ottmar Holdenrieder from ETH Zurich is greatly acknowledged for his idea to work with coprini, for his valuable comments and his readiness to discuss about my work. I am very grateful to Prof. Susanna Badalyan and her students Lilit Melikyan and Helen Avetisyan from Yerevan State University, Armenia for the nice collaboration built during all these years, hopefully we will continue with our coprini studies! Dr. Peter Beutelmann from the Johannes Gutenberg-University of Mainz is gratefully acknowledged for providing the strains that initiated the chapter 5 of this thesis. 
International and national friends gave a multicultural invaluable friendship during this time: Crina Vulpe, Tanja Dučić, and especially Artemio Carrillo and Rosa Isela Rasura from bringing a piece of Mexiko to the table every time we had opportunity to share knowledge and Mexican songs! Thank you for being there in good and bad times.

I would like to thank to my cousin Miguel Cagigal Navarro, who always encouraged and supported me to continue with postgraduate studies.

Special position in this list is given to František Vilčko for the time he has shared with me, his invaluable support and for giving color to my life.

No words to express the immense gratitude to my parents Isabel Gonzalez-Vizcarra and Othón Navarro-Tobón, to my sister Diana, brothers Saul, Mario Alberto and Héctor for the immense support given all this years. Thank you all for being there during this time.

Last but not least I am very grateful to the Mexican folk, without the money provided for my studies through the Mexican Council for Science and Technology (CONACYT, grant 118752) all this would have not been possible, and the DBU (Deutsche Bundesstiftung Umwelt) for financial support to the laboratory. 



\section{Table of contents}

Acknowledgments

Table of contents

Summary xi

Zusammenfassung $\quad$ Xv

1. Introduction 1

1.1 Fungi 2

1.2 Wood degradation 3

1.3 Laccases 4

$\begin{array}{ll}1.4 \text { Mushrooms as economical resources } & 4\end{array}$

$\begin{array}{ll}1.5 \text { Coprini } & 6\end{array}$

$\begin{array}{ll}1.6 \text { The model fungus Coprinopsis cinerea } & 10\end{array}$

$\begin{array}{ll}1.7 \text { Aims of this thesis } & 16\end{array}$

$\begin{array}{ll}1.8 \text { References } & 18\end{array}$

2. Lignocellulolytic activities within coprini species 27

$\begin{array}{ll}2.1 \text { Abstract } & 28\end{array}$

$\begin{array}{ll}2.2 \text { Introduction } & 29\end{array}$

2.3 Growth of coprini species on wood and other living and dead plant material 31

2.4 Brown-rot or white-rot fungi? $\quad 55$

$\begin{array}{ll}2.5 \text { Lignocellulolytic enzymes from coprini species } & 61\end{array}$

$\begin{array}{ll}2.6 \text { Conclusions } & 67\end{array}$

$\begin{array}{ll}2.7 \text { Acknowledgments } & 67\end{array}$

$\begin{array}{ll}2.8 \text { References } & 67\end{array}$

3. Growth of selected coprini on lignocellulosic substrates and $\begin{array}{lr}\text { detection of laccase activities } & 87\end{array}$

$\begin{array}{ll}3.1 \text { Abstract } & 88\end{array}$

$\begin{array}{ll}3.2 \text { Introduction } & 89\end{array}$

$\begin{array}{ll}\text { 3.3 Materials and methods } & 90\end{array}$ 
3.3.1 Evaluating ITS sequences from coprini $\quad 90$

3.3.2 Screening of the strains on different media 91

3.3.3 Phenoloxidase activity on solid media 91

3.3.4 Growth on lignocellulosic substrates 91

$\begin{array}{ll}3.4 \text { Results and discussion } & 92\end{array}$

3.4.1 Identification of the strains 92

3.4.2 Growth of the strains on artificial media (MEA) at different environmental conditions 97

A. Effect of temperature 97

B. Effect of $\mathrm{pH}$

$\begin{array}{ll}\text { C. Phenoloxidase activity } & 100\end{array}$

D. Growth of selected strains on lignocellulosic substrates $\begin{array}{ll}\text { and laccase activities } & 102\end{array}$

E. Degradation of ${ }^{14} \mathrm{C}$-labelled lignin: $\quad 104$

$\begin{array}{ll}3.5 \text { Conclusions and outlook } & 106\end{array}$

$\begin{array}{ll}3.6 \text { Acknowledgments } & 107\end{array}$

$\begin{array}{ll}3.7 \text { References } & 107\end{array}$

\section{Biologically active metabolites and medicinal properties of} coprinoid mushrooms

$\begin{array}{ll}4.1 \text { Abstract } & 112\end{array}$

$\begin{array}{ll}4.2 \text { Introduction } & 113\end{array}$

$\begin{array}{ll}\text { 4.2.1 Biological safety } & 114\end{array}$

4.2.2 The Coprinus syndrome 116

$\begin{array}{ll}\text { 4.2.3 Antimicrobial compounds within coprini } & 121\end{array}$

4.2.4 Hypoglycemic properties 123

$\begin{array}{ll}4.2 .5 \text { Antitumor properties } & 123\end{array}$

$\begin{array}{ll}4.2 .6 \text { Proteinases } & 129\end{array}$

$\begin{array}{ll}\text { 4.2.7 Surface proteins } & 129\end{array}$

$\begin{array}{ll}4.3 \text { Conclusions } & 132\end{array}$

$\begin{array}{ll}4.4 \text { Acknowledgments } & 133\end{array}$

$\begin{array}{ll}4.5 \text { References } & 133\end{array}$ 
5. Monstrosities under the inkcap mushrooms

143

5.1 Abstract

144

5.2 Introduction

145

5.3 Material and methods 146

5.3.1 Strains, culture conditions and spore germination 146

5.3.2 Microscopy

146

147

148

148

5.4.2 Culture and mycelial characteristics of the four newly isolated strains

5.4.3 Fruiting abilities of the Coprinellus sp. 1

5.4.4 Fruiting abilities of the Coprinopsis clastophylla 2, 3 and 4 isolates

156

5.4.5 Fruiting abilities of the Coprinopsis clastophylla type strain

5.4.6 Fruiting bodies and related sterile structures in Coprinopsis clastophylla, and its anamorph Rhacophyllus lilacinus 161

5.5 Conclusions 163

5.6 Acknowledgments 164

5.7 References 164

\section{The course of fruiting body development in the basidiomycete}

\section{Coprinopsis cinerea (Coprinus cinereus)}

6.1 Abstract 168

6.2 Introduction 169

6.3 Material and methods 170

$\begin{array}{ll}\text { 6.3.1 Strain and general culture conditions } & 170\end{array}$

6.3.2 Fruiting bodies dissection in fresh material 170

$\begin{array}{ll}\text { 6.3.3 Microscopic preparations } & 170\end{array}$

$\begin{array}{ll}6.4 \text { Results and discussion } & 171\end{array}$

6.4.1 Time course of fruiting body development 171

$\begin{array}{ll}\text { 6.4.2 Hyphal aggregation } & 173\end{array}$

$\begin{array}{ll}\text { 6.4.3. Primordia development } & 175\end{array}$

$\begin{array}{ll}\text { 6.4.3.1 Gill development } & 179\end{array}$ 
6.4.4. Sexual reproductive development 181

6.4.5. Fruiting body maturation 186

$\begin{array}{ll}\text { 6.4.6. Autolysis } & 187\end{array}$

$\begin{array}{ll}\text { 6.5 Conclusions } & 188\end{array}$

$\begin{array}{lc}6.6 \text { References } & 188\end{array}$

7. Effect of copper in Coprinopsis cinerea (Coprinus cinereus) development 195

$\begin{array}{ll}7.1 \text { Abstract } & 196\end{array}$

$\begin{array}{ll}7.2 \text { Introduction } & 197\end{array}$

$\begin{array}{ll}7.3 \text { Materials and methods } & 198\end{array}$

7.3.1 Coprinopsis cinerea strain and culture conditions 198

7.3.2 Sampling procedures 199

$\begin{array}{ll}\text { 7.3.3 Enzymatic assays } & 199\end{array}$

7.3.3.1 Extracellular laccase activity 199

7.3.3.2 Nitrate reductase and Nitrite reductase activity 200

7.3.3.3 Ammonium determination $\quad 200$

7.3.3.4 Glucose determination $\quad 201$

$\begin{array}{ll}\text { 7.3.4 Nitrate assimilation gene cluster prediction } & 201\end{array}$

7.3.5 DNA isolation, RNA isolation, cDNA synthesis and $\begin{array}{ll}\text { transcript analysis } & 201\end{array}$

$\begin{array}{ll}7.4 \text { Results and discussion } & 204\end{array}$

7.4.1 Copper, laccase activity and fruiting in liquid cultures 204

7.4.2 Fruiting pathway of etiolated stipes in liquid cultures 209

7.4.3 Copper and fruiting in solid cultures 211

7.4.4 Other effects by copper in liquid cultures at $37^{\circ} \mathrm{C} \quad 217$

7.4.5 Transcript profiles for the nitrate assimilation gene cluster 220

$\begin{array}{ll}7.5 \text { Conclusions } & 222\end{array}$

7.6 Acknowledgments 222

$\begin{array}{ll}7.7 \text { References } & 222\end{array}$

8. Transcript profiles of laccase genes during fruiting body development in Coprinopsis cinerea (Coprinus cinereus) 229

$\begin{array}{ll}8.1 \text { Abstract } & 230\end{array}$ 
8.2 Introduction 231

$\begin{array}{ll}\text { 8.3 Materials and Methods } & 232\end{array}$

8.3.1 Coprinopsis cinerea strains and culture conditions 232

8.3.2 DNA, and RNA isolation, cDNA synthesis and transcript analysis 233

$\begin{array}{ll}\text { 8.3.3 Enzymatic assays } & 237\end{array}$

8.3.3.1 Laccase activity in mycelial fresh tissues 237

$\begin{array}{ll}8.4 \text { Results and discussion } & 237\end{array}$

8.4.1 PCR conditions for transcript detection 237

8.4.2 Expression of laccase genes 238

$\begin{array}{ll}8.5 \text { Conclusions } & 245\end{array}$

8.6 Acknowledgments 245

$\begin{array}{ll}8.7 \text { References } & 245\end{array}$

9. Grazing preferences on developmental structures of Coprinopsis cinerea (Coprinus cinereus): Symbiotic mite-fungal interaction? 251

9.1 Abstract 252

9.2 Introduction 253

9.3 Materials and methods $\quad 254$

9.3.1 Strains, culture conditions and mites 254

9.3.2 Grazing preferences on developmental structures 255

9.3.3 Faecal pellets and sclerotia isolation, microscopy and germination 255

9.3.4 Larvae hatching 256

9.3.5 Speed rate of mites walk 257

$\begin{array}{ll}9.4 \text { Results } & 257\end{array}$

9.4.1 Identification of the mite 257

9.4.2 Grazing on developmental structures of Coprinopsis cinerea 258

9.4.2.1 Mycelium 258

9.4.2.2 Basidiospores 260

$\begin{array}{ll}\text { 9.4.2.3 Sclerotia } & 261\end{array}$

9.4.2.4 Fruiting bodies $\quad 261$

9.4.3 Larvae hatching 264

9.4.4 Mite populations in fungal cultures 266 
$\begin{array}{ll}9.5 \text { Discussion } & 268\end{array}$

$\begin{array}{ll}9.6 \text { Acknowledgments } & 270\end{array}$

$\begin{array}{ll}9.7 \text { References } & 270\end{array}$

10. General discussion and conclusions: Is it worth to work with coprini? 275

$\begin{array}{ll}10.1 \text { References } & 280\end{array}$

$\begin{array}{lr}\text { Curriculum Vitae } & 283\end{array}$ 


\section{Summary}

The coprini are a form group of mushrooms that grow mainly on compost and horse dung and that for over 100 years were thought to present one genus. Only in 2001 it was discovered by Redhead and coworkers by molecular analysis that the traditional genus comprises species of 4 different genera: Coprinus, Coprinopsis, Coprinellus and Parasola. Several species of the traditional genus, amongst the basidiomycete model species Coprinopsis cinerea (formerly Coprinus cinereus), found previously attention for mushroom development by the ease to grow and fruit the fungi in culture.

Surprisingly therefore, not even the pathway of fruiting body development for the model species $C$. cinerea was well presented in all different developmental stages in the literature. A task in this study was therefore to establish a picture catalogue of the events in the course of fruiting body development, up to fruiting body maturation and subsequent rapid autolysis of the mushrooms, a feature that is specific for many species of the coprini. Due to this autolysis, mushroom of coprini have so far made little use of e.g. for medicinal purposes. A literature compilation in medical and pharmaceutical compounds shows however that coprini have a potential for such applications.

C. cinerea mycelia cultures attract mites that graze on the mycelium of the fungus. Upon an unintended infection of a culture by mites of the species Tyrophagus putrescentiae, the chance was taken to observe the behavior of the two species with each other. The mites were found to consume, albeit at different rates, mycelium of monokaryons and dikaryons including asexual spores (oidia) in the aerial mycelia. Furthermore, the animals consume cap tissues of fruiting bodies together with basidiospores but they leave the stipes aside. Basidiospores are ingested but not digested. They are excreted in compact faecal pellets. Basidiospores can still germinate after passing the gut of the mites. Since there are about 400 spores in a faecal pellet, mycelia of all mating types will arise and upon germination directly mate giving rise to dikaryons able to fruit. Dikaryon formation between germinated siblings promotes inbreeding in a fungus that naturally is an outbreeding organism. Thus, mites clearly affect the fungal life cycle. In turn, the fungus also influences the mites. Eggs are laid by the mites next to the faecal spore pellets. When the larvae hatch 
after about 5 days, the germinated mycelium will have obtained already a considerable colony size, presenting food for the young mites.

Fruiting body development in the laboratory is not restricted to C. cinerea. In this thesis, fruiting body development was also followed up in Coprinopsis clastophylla and a species related to Coprinellus curtus, initiated by the observation that these species form unusual shaped mushrooms. Sometimes the structures are fully sterile, not forming basidiospores. The obtained fruiting body like structures are considered as anamorphs producing special mitotic cells (bulbils, lysomeres, or spherocytes) for vegetative reproduction. Molecular analysis of ITS sequences confirm that the strains described in the literature as anamorph Rhacophyllus lilacinus belongs to the genus Coprinopsis and the species C. clastophylla (Coprinus clastophyllus). Other strains with unusual shaped mushrooms were assigned by ITS sequences to the genus Coprinellus to a species closely related to C. curtus. Morphologically, the mushrooms of this unidentified species are not distinguishable from mushroom descriptions of Coprinopsis stercorea. Orton and Watling (1979) described C. stercorea to be heterothallic. Our isolate however is homothallic. This difference in the breeding systems can explain contradictory reports on C. stercorea in earlier literature on occurrence of homothallism and heterothallism in the species. Another reason to study C. clastophylla in this thesis was because of reports on the fungus in the literature as growing on wood. Also other species of the coprini were said to grow on wood, but a systematic study so far was not available. Therefore, all available literature on coprini on wood was collected and analyzed. It was found that about $30 \%$ of species in the new genera (Coprinus, Coprinopsis, Coprinellus, and Parasola) have been observed on wood, suggesting that the ability of the fungi to grow on wood was more extended amongst these fungi than formerly thought. Attempts were undertaken with collections of coprini to grow the fungi on lignocellulosic material including wood (poplar, beech), wheat straw and oak and maple leave litter. Prior to the growth test, species identity was controlled by analysis of ITS sequences. It was found that several isolates were assigned to wrong coprini species, and in one case even to a wrong genus indicating the difficulty of morphological identification of coprini. Several of the tested strains identified to the species Coprinus comatus, Coprinopsis strossmayeri, Coprinellus curtus, Coprinellus micaceus, Coprinellus radians, Coprinellus xanthothrix, and 2 unidentified Coprinellus 
species, grow on wood and straw, but degradation of lignocellulose by these species appears not to be considerable. Probably, the fungi rather grow on the storage material present in the parenchymatic cells of the wood and straw. On leave litter, growth occurred only in exceptional cases, suggesting that phenolic compounds in the fallen leaves inhibit fungal growth and/or that the leaves do not contain easily accessible nutrients. To further get insight into the ability of the species to degrade lignocellulose, phenoloxidase activities and in particular laccase activities of the strains were tested. At least on straw, most strains had visible enzymatic activities. Participation of these enzymes in substrate degradation has to be studied further in the future.

Laccase activity had also been connected in the past to fruiting body development. Therefore, laccase activity and laccase gene expression was followed up during growth and development in C. cinerea. Activity of gene transcription and enzymatic activity was highest in the later stages of fruiting body development (primordia, karyogamy, meiosis and basidiospore formation, and in maturation and autolysis of the fruiting bodies). Laccases were found to be induced by addition of copper in the medium but induction levels were relatively low. The result suggests that in this fungus laccases have rather developmental functions, such as in pigment formation, than functions in substrate utilization. Copper addition had further surprising effects on fruiting body development of the species. Fruiting was induced at the unusual temperature of $37^{\circ} \mathrm{C}$ together with nitrate reductase activity at a stage when the fungus actively increased the $\mathrm{pH}$ of the medium by ammonium production. Since nitrite reductase activity was not found, it is unlikely that ammonium secretion is due to combined actions of nitrate and nitrite reductases. 



\section{Zusammenfassung}

Coprini sind eine Gruppe von Pilzen, die meist auf Kompost und Pferdemist wachsen und mehr als 100 Jahre in einer einzigen Gattung zusammengefasst waren. Erst im Jahr 2001 wurde von Redhead und Mitarbeitern entdeckt, dass die Gattung aus vier unterschiedlichen Gattungen: Coprinus, Coprinopsis, Coprinellus und Parasola besteht. Einige Arten aus dieser Gattung, darunter der Modellorganismus für Basidiomyzeten Coprinopsis cinerea (früher Coprinus cinereus), wurden bereits zuvor zur Untersuchung der Fruchtkörperentwicklung verwendet, weil sie leicht im Labor anzuziehen sind und Fruchtkörper bilden.

Somit überrascht, dass die Fruchtkörperentwicklung von C. cinerea bisher nicht vollständing in der Literatur beschrieben wurde. Eine Aufgabe dieser Arbeit war es deshalb einen Bildkatalog mit allen wichtigen Entwicklungsphasen bis zur Fruchtkörperreifung und Autolyse zu erstellen. Ein Merkmal für einige Pilze aus dieser Gattung ist die schnelle Zersetzung, weswegen die Fruchtkörper z.B. für medizinische Anwendung wenig attraktiv sind. Eine Literaturrecherche $\mathrm{zu}$ medizinischen und pharmazeutischen Inhaltsstoffen belegt jedoch das große Potential der Coprini für die Isolierung von pharmazeutisch relevanten Verbindungen.

Weiterhin locken C. cinerea Kulturen Milben an. Nach einer unerwünschten Infektion von Pilzkulturen mit der Milbe Tyrophagus putrescentiae wurde die Gelegenheit genutzt, die Wechselwirkung zwischen diesen beiden Arten zu untersuchen. Die Milben ernährten sich sowohl von dem Myzel der Monokaryonten als auch von dem der Dikaryonten inklusive der asexuellen Sporen (Oidien), allerdings in unterschiedlichem Maße. Außerdem wurde auch Hutgewebe aus den Fruchtkörpern zusammen mit den Basidiosporen gefressen, der Stiel blieb unangetastet. Die Basidiosporen wurden zwar gefressen, allerdings nicht verdaut. Sie werden später mit dem Milbenkot ausgeschieden. Solche Sporen waren noch in der Lage zu keimen. Aus den circa 400 Sporen pro Milbenkotpellet wächst zunächst Myzel aller Kreuzungstypen, was eine Kreuzung direkt nach der Keimung ermöglicht. Das so entstehende Dikaryon kann wieder fruktifizieren. Die Dikaryonbildung zwischen Geschwistern fördert Inzucht bei einem Pilz, der normalerweise ein „Outbreeding“-Organismus ist. Auf diese Weise, können die Milben den Pilz beeinflussen. Der Pilz hingegen beinflusst die Milben 
dadurch, dass die Milbeneier neben dem Milbenkot abgelegt werden. Die Larven schlüpfen nach ungefähr fünf Tagen und ernähren sich von dem Myzel, das bereits aus dem Kot gekeimt ist.

Fruchtkörperentwicklung unter Laborbedingungen ist nicht auf C. cinerea beschränkt. Auch bei Coprinopsis clastophylla und einer mit Coprinellus curtus verwandten Art wurde die Fruchtkörperentwicklung beobachtet. Diese Arten produzierten ungewöhnliche Formen, und die Fruchtkörper waren zum Teil unfruchtbar. Solche Fruchtkörperformen, sogenannte Anamorphe, produzieren besondere mitotische Zellen (Bulbillen, Lysomere, oder Sphärocysten) für die vegetative Vermehrung. ITSAnalysen zeigten, dass die in der Literatur als anamorph beschriebenen Stämme Rhacophyllus lilacinus zu der Gattung Coprinopsis und zu der Art C. clastophylla (Coprinus clastophyllus) gehören. Andere Stämme mit ungewöhnlichen Pilzformen wurden durch ITS-Analysen der Gattung Coprinellus, verwandt mit C. curtus, zugeordnet. Morphologisch sind Pilze dieser nicht identifizierten Art nicht von Pilzen, die der Beschreibungen von Coprinopsis stercorea entsprechen, zu unterscheiden. Orton und Watling (1979) beschrieben C. stercorea als heterothallisch. Unser Stamm ist jedoch homothallisch. Dieser Unterschied in den Kreuzungssystemen könnte gegensätztliche Berichte von homothallischen und heterothallischen Formen von C. stercorea in der Literatur erklären. Berichte aus der Literatur zeigen, dass C. clastophylla auf Holz wächst, was ein weiterer Grund war, sich in dieser Arbeit mit dieser Pilzart zu beschäftigen. Von anderen Coprini ist bekannt, dass sie auf Holz wachsen, allerdings gibt es zurzeit keine systematische Studie. Aus diesem Grund, wurde sämtliche verfügbare Literatur über Coprini auf Holz gesammelt und ausgewertet. So stellte sich heraus, dass ungefähr 30\% der Arten aus den neuen Gattungen (Coprinus, Coprinopsis, Coprinellus, and Parasola) auf Holz beobachtet wurden. Solche Beobachtungen deuten darauf hin, dass Coprini auf Holz gut wachsen können. Anzuchtversuche mit Coprinisammlungen auf lignocellulotischen Substraten (Pappel, Buche), Weizenstroh sowie Eichen- und Ahornblättern wurden durchgeführt. Die Identität dieser Arten wurde mittels ITS-Analysen ermittelt. So stellte sich heraus, dass einige Isolate zuvor falschen Copriniarten zugeordnet wurden, in einem Fall sogar der falschen Gattung. Das zeigt, wie schwierig es ist, aus morphologischen Merkmalen eine Art zu identifizieren. Einige der untersuchten Stämme gehörten zu den Arten 
Coprinus comatus, Coprinopsis strossmayeri, Coprinellus curtus, Coprinellus micaceus, Coprinellus radians, Coprinellus xanthothrix. Diese wuchsen auf Holz und Stroh, ebenso wie zwei unbekannte Coprinellus Arten. Allerdings scheint der Abbau von Lignocellulose nicht in nennenswertem Ausmaß zu erfolgen. Wahrscheinlich wachsen die Pilze auf Speicherstoffen aus den parenchymatischen Zellen von Holz und Stroh. Wachstum auf Blättern wurde selten beobachtet, vermutlich weil Phenole aus den Blättern das Pilzwachstum hemmen oder weil Blätter nicht genug leicht verfügbare Nährstoffe enthalten. Zusätzlich wurden die Stämme auf ihre Phenoloxidaseproduktion getestet, insbesondere auf die Laccaseproduktion. Die Stämme konnten diese Enzyme zumindest auf Stroh produzieren. Dennoch sind weitere Untersuchungen notwendig.

Der Laccaseaktivität wurde schon früher eine wichtige Rolle bei der Fruchtkörperentwicklung zugeschrieben. Deshalb wurde die Laccaseaktivität und die Laccasegenexpression während der Fruchtkörperentwicklung von C. cinerea untersucht. Die Gentranskription und die enzymatische Aktivität waren in den letzten Phasen der Fruchtkörperentwicklung (Primordia, Karyogamy, Meiose und Basidiospore Bildung, und Reifung und Autolyse) am höchsten. Obwohl Laccasen mit Kupfer induziert wurden, war die Aktivität auf dem Medium sehr gering. Die Ergebnisse deuten darauf hin, dass diese Enzyme eher eine Rolle bei der Entwicklung, z.B. bei der Pigmentenbildung, spielen als bei der Nährstoffnutzung. Kupferzugabe hatte starken Einfluss auf die Fruchtkörperentwicklung. Obwohl sonst bei $37^{\circ} \mathrm{C}$ keine Fruchtkörperbildung stattfindet, wurde diese durch Kupferzugabe induziert. Dies war verbunden mit erhöhter Nitratereduktase-Aktivität und gleichzeitig erhöhtem pH-Wert durch Ammoniumproduktion. Da keine Nitritreduktase-Aktivität nachgewiesen wurde, ist es unwahrscheinlich, dass die Ammoniumproduktion auf einer Kombination von Nitrat- und Nitritreduktase-Aktivität beruht. 



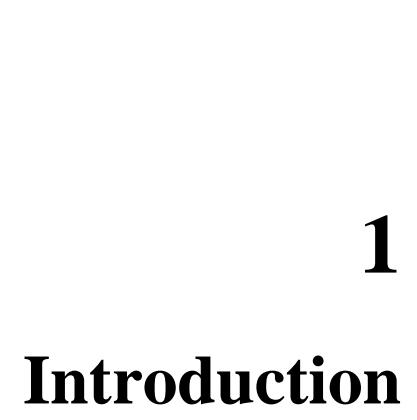




\section{Introduction}

\subsection{Fungi}

The fungi constitute a group of eukaryotic heterotrophic organisms with cells devoid of chlorophyll. These organisms mostly develop very diffuse bodies cellular bodies made up as a spreading network (mycelium) of very narrow, tubular, branching filaments called hyphae. These filaments exude enzymes, and absorb food at their growing tips. Hyphae are collectively very long, and can explore and exploit food substrates very efficiently. Fungi usually reproduce by means of spores, which develop directly on, and are released by the hyphae or by a range of unique and complex structures formed on the fungal mycelium that are called fruiting bodies (Alexopoulos et al. 1996, Kendrick 1992).

About 74,000 species have been described so far; however some estimates of total numbers suggest that 1.5 million species may exist (Hawksworth 2001). From this amount, it is calculated that more than 12,000 are mushrooms, from which only 2,0002,500 are edible. A mushroom is a macrofungus with a distinctive fleshy fruiting body that can be either hypogeous (underground) or epigeous (above ground), large enough to be picked up by hand (Kirk et al. 2001). Most of the edible mushrooms are basidiomycetes with the exceptions of the truffles and morels that are ascomycetes (Chang 1999, Yun and Hall 2004). Within their varied natural habitats, fungi are usually the primary decomposers present, being of crucial importance in the breakdown of the vast amounts of organic carbon produced annually by photosynthesis, and thus are the main recyclers. However, they are also among the strongest and most aggressive opportunists, not restricting their habitats to naturally occurring dead wood and leaves (Dix and Webster 1995). Wherever some moisture is available, the spores present in the environment will germinate, and the hyphae arising from them will attack almost any kind of organic matter including human food, fabric, paper and paint, wooden material above a certain water threshold and any other issue based on organic matter. Some of their metabolites (mycotoxins) are extremely dangerous (sometimes carcinogenic) if they contaminate food. Damage to human beings therefore can be manifold, including to the human bodies themselves upon fungal infections (Kendrick 1992). 
Fungi can be broadly grouped into three eco-physiological groups: saprophytes, symbiotic and parasitic species. The saprophytes fungi are free living organism nourishing from dead organic matter; the symbiotic species live in association usually with plants for example mycorrhiza and lichens. The parasitic ones will live at the expense of (an) other organism(s), usually invading them and causing disease, being often the most important plant pathogens and in other cases animal parasites (Alexopoulos et al. 1996).

\subsection{Wood degradation}

After cellulose, lignin is the most abundant organic polymer on Earth and the most abundant aromatic material accounting for about $40 \%$ of the solar energy stored in plants (Leonowicz et al. 1999). It constitutes a quarter to a third of the dry biomass of wood. This compound is essential for the structure of the plant cell wall where it is responsible for the stiffness and strength of the stem. Furthermore, it waterproofs the cell wall and protects against plant pathogens (Boerjan et al. 2003). Lignocellulose is a compact, partially crystalline complex. Cellulose is the polysacharide as the structural component of the plant cell walls, it forms microfibers and these are densely packed in layers of lignin, which protects them against the activity of hydrolytic enzymes from microorganisms and other external factors (Fengel 1971). The degradation of lignocellulosic material is currently understood as an enzymatic process where fungi play the main role (Leonowicz et al. 1999, Martínez et al. 2005). Depending on the preferential degradation of certain cell wall structures, two basic forms of wood decay are known in homobasidiomycetes: white rot and brown rot. In white rot, lignin, cellulose and hemicellulose are degraded with the consequence that the wood bleaches. The white to pale colored remnants of the wood have a spongy, stringy or laminated structure (Rayner and Boddy 1988, Blanchette 1991, Worall et al. 1997, Schwarze et al. 2000). In contrast, in brown rot, lignin is not appreciably degraded but only slightly modified whereas cellulose is selectively removed. The modified lignin is responsible for the characteristic color of brown-rotted wood. Because of the preferential degradation of cellulose and hemicellulose, the brown-rotted wood acquires a brittle, amorphous consistency, splits into cubes and finally disintegrates into a fine lignin powder (Green and Highley 1997, Schwarze et al. 2000). The main enzymes involved in wood degradation are phenoloxidases such as lignin peroxidase, manganese-dependent peroxidase, laccase and dioxygenases, to mention a few of them (Leonowicz et al. 1999, 
Schwarze et al. 2000). Among them, laccase seems to play a prominent role in lignin degradation (Eggert et al. 1997, Leonowicz et al. 2001, Pointing 2001).

\subsection{Laccases}

Fungal laccase (benzenediol:oxygen oxidoreductase, EC 1.10.3.2) is an enzyme secreted into the medium by mycelia of Basidiomycetes, Ascomycetes and Deuteromycetes (Bollag and Leonowicz 1984, Agematu et al. 1993). Due to the ability of laccase to oxidase both phenolic and nonphenolic lignin-related compounds, they have gained considerable biotechnological interest in detoxification of industrial effluents, mostly from the paper and pulp industries, from textile and petrochemical industries, as well as a bioremediation agent to clean up herbicides and pesticides in soil (Durán and Esposito 2000, Pointing 2001, Wesenberg et al. 2003, Couto and Herrera 2006, Husain 2006). Laccases are also used as cleaning agents for certain water purification systems, as catalysts for the manufacture of anti-cancer drugs and even as ingredients in cosmetics (Minussi et al. 2002, Couto and Herrera 2006).

Besides their prominent role in delignification, fungal laccases participate in various physiological and developmental processes; they have particularly been linked to fruiting-body formation in ascomycetes (Labarère and Bernet 1978, Hermann et al. 1983, Broxholme et al. 1991) and basidiomycetes (Wessels 1993, Kües and Liu 2000) and in fungal pigment formation (Langfelder et al. 2003, Nosanchuk and Casadevall 2003).

\subsection{Mushrooms as economical resources}

For millennia, mushrooms have been valued as edible and healthy food, medical source, psychoactive drugs, and religious symbols for humankind (Alexopoulos et al. 1996, Rühl and Kües 2007). Mushroom utilization as food or in medical application has been practised traditionally in Asian countries for centuries (Chang 1993). In contrast, in western countries, interest towards mushrooms is on a much lower scale. Among other reasons there is the fear of mushroom poisoning (Benjamin 1995).

Mushrooms are a very good dietary food contributing to the general well-being of humans (nutraceuticals). They are rich in proteins, carbohydrates, fibers, unsaturated fatty acids, vitamins and minerals but low in calories (Buswell and Chang 1993, 
Rajarathnam et al. 1993). The word "nutraceuticals" indicate the dual role of edible mushrooms as natural food and facilitator of maintaining good health. The term "nutriceutical" is used for mushroom or mycelium extracts that possesses both nutritional and medicinal attributes, and that, incorporated into a capsule or tablet, are consumed as a dietary supplement for therapeutic purposes (Chang and Buswell 1996). A wide variety of fungi have been studied as a source of medical compounds (Jong and Donovick 1989, Mizuno et al. 1995, Borchers et al. 1999, Smith et al. 2002, Wasser 2002). For example, fungal polysaccharides are recognized to have anti-tumor effects by activating various immunoresponses. Most of these bioactive polysaccharides belong to the $\beta$-glucans, like Lentinan from Lentinula edodes (Shiitake) and Schizophyllan from Schizophyllum commune (split gill fungus), both of which are commercially available (Wasser 2002). However, many species are still poorly or not at all studied. Myco-pharmacological investigations of bioactive metabolites and medicinal properties of mushrooms play an important role for the development of new biotech-products and bio-pharmaceuticals.

A wide variety of fungi can recycle lignocellulosic waste materials into edible and/or medicinal mushrooms (Rühl and Kües 2007). In the last years, with the popularization of mushroom farming, mushroom production is steadily increasing. It is estimated that more than 10,000 tones of edible and medicinal mushrooms were produced only in China in 2003, which is the leading country in mushroom production in the world (Chang 2005). The environmental friendly cultivation of specialty mushrooms on lignocellulosic wastes represents one of the most economical and cost-effective organic recycling processes (Poppe 2000).

Among the basidiomycetes, the mushroom-forming fungi are of commercial value and, thus the conditions for the production of fruiting bodies have been studied to some extent in detailed series of experiments in the laboratories. Even though it is reported that about 628 species are eaten in one or more regions of the world including cultivated, semi-cultivated and wild mushrooms (Chandra 1989), up to date methods for commercial cultivation have been developed for about 50 species only (Chen 2004, Chang 2005, Yamanaka 2005). Mushroom growers are interested in the basic mechanisms underlying fruit body formation in order to improve the yield and to find stable conditions in which high crop yields can be obtained on a regular basis (Kothe 
2001). Information regarding fruiting body development mainly comes from research done on a few model species, such as Coprinopsis cinerea and Schizophyllum commune (Kües 2000, Kües et al. 2004, Wösten and Wessels 2006, Kües et al. 2007).

\subsection{Coprini}

Inkcaps also known as coprini are a very diverse group of homobasidiomycetes of about 200 basidiomycetes species. Traditionally, they have been broadly recognized as mainly growing on dung and soil (Redhead 2000). However, these fungi occur in a wide variety of substrates including wood (Breitenbach and Kränzlin 1995, Redhead 2000). Next to the black basidiospores, one of the striking characteristic of the mushrooms of this group is the typical autolysis or auto digestion of the gills during cap maturation (Buller 1922, Arora 1986). The sequential development of basidia and spores is termed inaequihymeniiferous development (Buller 1922). After the spores have maturated and been released, the gill tissue digests itself and begins to curl up, allowing easy release of the basidiospores above. Shortly after the cap expands completely, the cap deliquesces fully (Figure 1). However, sometimes it has been misunderstood as a unique characteristic of this genus which is neither present in all the species nor only in coprini (Redhead 2000, Keirle et al. 2004). Due to the broadly distributed characteristic of autolysis, with the exception of Coprinus comatus, most coprini are not cultivated, but a few species are regularly consumed by humans and a toxic-lethal species appears not to exist (Benjamin 1995). Noteworthy, the model species C. cinerea is cultivated as specialty in small farming business in Thailand and consumed by workers on sisal and sugar cane farmers in African countries and Sri Lanka, where the species fruits abundantly on plant waste heaps (Kües et al. 2007, see below).

Another feature linked to coprini is the presence of inflated sterile cells, paraphyses (brachybasidia or pseudoparabasidia), between basidia (Redhead et al. 2001). The former systematic of this group of fungi was exclusively based on morphological characteristics (Kühner and Romagnesi 1978, Uljé and Noordelos 1997, 1999; Orton and Watling 1979), grouping all the coprini fungus under the single genus Coprinus. However, molecular data divided this group into four new genera: Coprinus, Coprinopsis, Coprinellus and Parasola (Redhead et al. 2001). 

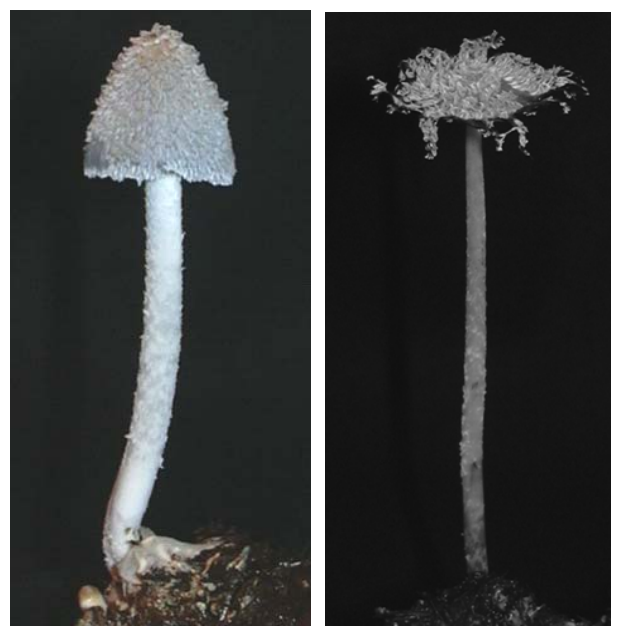

Figure 1 Mushrooms of Coprinopsis cinerea strain AmutBmut (about $12 \mathrm{~cm}$ in size) formed under laboratory conditions on horse dung (Granado et al. 1997), the natural substrate of the species. Left. Adolescent fruiting body at the stage of cap expansion. Right. Aging mushroom at autolysis, about $12 \mathrm{~h}$ later in development.

The edible, very tasty Coprinus comatus (Figure 2) is the type species of the new genus Coprinus (corresponding to the formerly defined section Coprinus subsect. Coprinus http://www.grzyby.pl/coprinus-site-Kees-Uljée/species/Coprinus.htm). Only two other species, Coprinus sterquilinus and Coprinus spadiceisporus, are known in this genus that cluster within the Family Agaricaceae. A typical characteristic of these species is a central, elastic, cottony and extractable cord suspended in the hollow stipe (Figure 2B, Redhead 2000, Redhead et al. 2001).

The three other newly defined genera belong into the family of Psathyrellaceae. Of these, Coprinopsis forms the largest genus with more than hundred defined species (Hopple and Vilgalys 1999, Redhead et al. 2001, Keirle et al. 2004) and includes well known species such as Coprinus cinereus (Dungheap Inkcap, Dunghill Mushroom; Figure 1), Coprinus lagopus (Woolly Inkcap, Hare's Foot), Coprinus atramentarius (Common Inkcap, Alcohol Inkcap) and Coprinus stercoreus, now termed Coprinopsis cinerea, Coprinopsis lagopus, Coprinopsis atramentaria, and Coprinopsis stercorea, respectively (Redhead et al. 2001). These species scatter over the formerly defined Coprinus section Coprinus subsect. Lanatuli and Atramentarii and section Veliformis subsect. Narcotici, respectively. A typical character of the subsect. Lanatuli is an easily removed hairy veil composed of sausage-shaped elements. In contrast, species of subsect. Atramentarii have a scarce veil. Typical veil elements of the subsection 


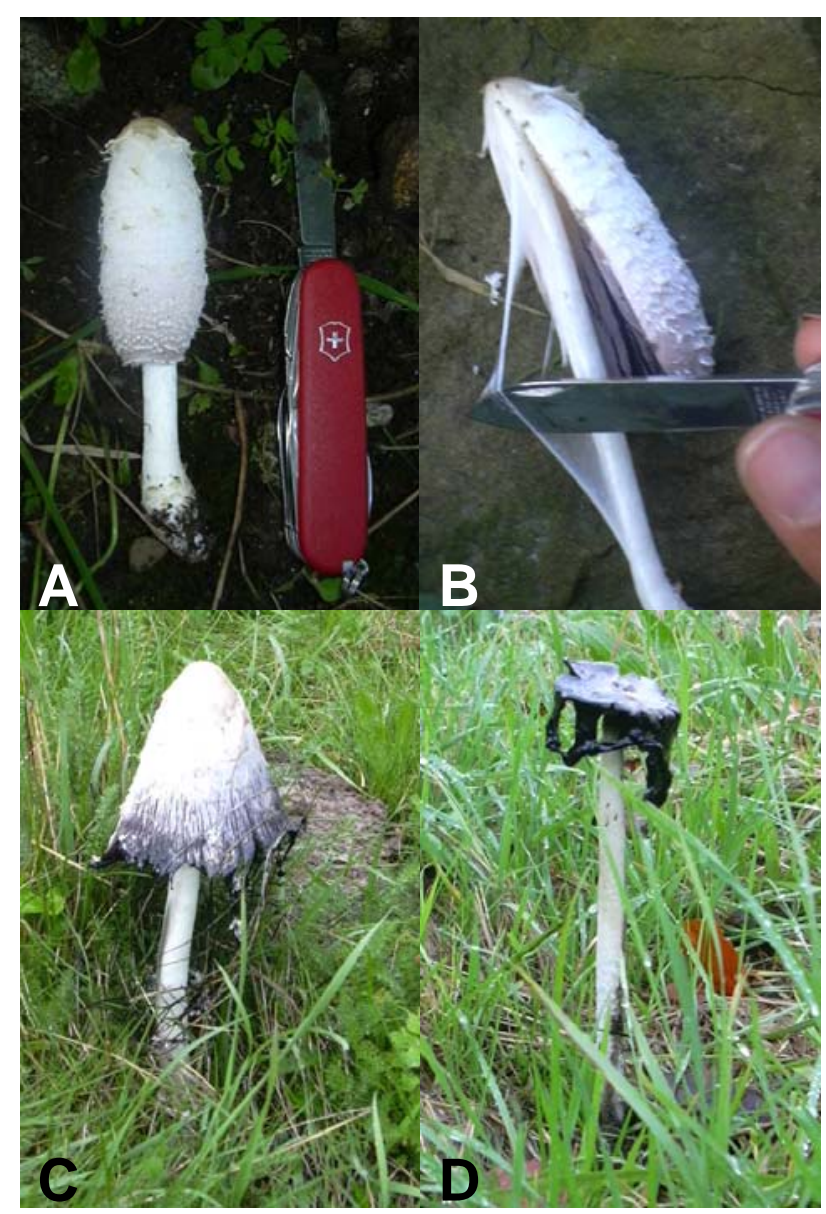

Figure 2 A. Young, not fully developed fruiting body of Coprinus comatus (Shaggy Mane, Laywer's Wig). B. Typical central cord suspended inside the stipe. C. Mature and D. autoylsed fruiting body (about $15 \mathrm{~cm}$ in size) on a meadow in the Forest Botanical Garden (Arboretum) of the Georg-August-University Göttingen.

Narcotici are persistent warty cells and mushrooms have a strong gas smell (Orton and Watling 1979, Breitenbach and Kränzlin 1995). Other Coprinopsis species not listed here were grouped into formerly defined Coprinus section Coprinus subsect. Alachuani or into Coprinus section Veliformis subsect. Nivei (http://www.grzyby.pl/ coprinus-siteKees-Uljée/ species/Coprinus.htm).

Coprinellus is the second largest group of Psathyrellaceae with more than 40 defined species (Redhead et al. 2001, Figure 3), most of which belong to the formerly defined Coprinus section Pseudocoprinus subsect. Setulosi. Other members of the genus Coprinellus are found in the formerly defined Coprinus section Veliformis subsect. Domestici and Micacei. Well known members of this genus are Coprinus disseminatus (Fairy Bonnet, Little Helmet, Figure 3A), now Coprinellus disseminatus, from the 
formerly defined section Pseudocoprinus subsect. Setulosi and Coprinus micaceus (Glistening Inkcap Figure 3B), now Coprinellus micaceus, from the formerly defined section Veliformis subsect. Micacei, respectively. Species of the formerly defined section Pseudocoprinus subsect. Setulosi have either no veil or very fine veils and hairlike structures (setulae or setae) on stipe and pileus. Veils of species of the formerly defined section Veliformis subsect. Micacei are made up of small granular flocks and stipes may be smooth or pruinose due to surface covering by crystals (http://www.grzyby.pl/coprinus-site-Kees-Uljée/species/Coprinus.htm). Fruiting bodies of Coprinellus species are often very delicate by a less fleshly cap and stipes are often brittle (Breitenbach and Kränzlin 1995).

Parasola is the smallest of the three new genera within the Psathyrellaceae with currently 18 defined species. The type species is Parasola plicatilis (Pleated Inkcap, Figure 3C), previously Coprinus plicatilis (Breitenbach and Kränzlin 1995, Redhead et al. 2001) grouped in the formerly defined section Pseudocoprinus subsect. Glabri like most other Parasola species. Parasola auricoma (formerly Coprinus auricomus) is the only species belonging to the formerly defined section Pseudocoprinus subsect. Auricomi (http://www.grzyby.pl/coprinus-site-Kees-Uljée/ species/Coprinus.htm).

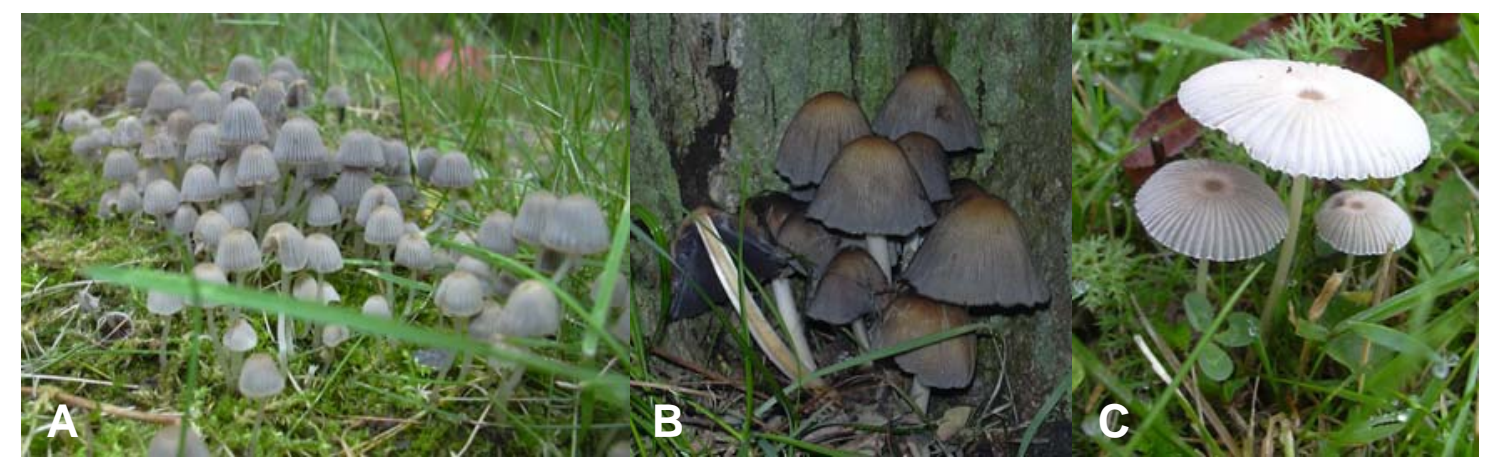

Figure 3 A. Coprinellus disseminatus fruiting body (about $4 \mathrm{~cm}$ ) growing on moss at the base of a Cotinus obovatus tree. B. Coprinellus micaceus fruiting body (about $9 \mathrm{~cm}$ in size) growing at the base of a Robinia pseudoacacia tree. C. Parasola plicatilis fruiting body (about $6 \mathrm{~cm}$ in size). Specimens were collected in the gardens of the Sport Center (A), and the North Campus of the Georg-August University-University Göttingen (B-C), respectively. 
The new classification of the coprini agrees well with Uljé's Coprinus key based on macro- and micro-morphologies of fruiting bodies and spores (http://www.grzyby.pl/ coprinus-site-Kees-Uljée/species/Coprinus.htm) that most likely makes use also of previous classifications of Kühner and Romagnesi (1978) and Orton and Watling (1979) (Table 1). However, the coprini species list is not exhaustive, and a few species are still pending to be reassigned (Table 2).

Due to the ease to work in the laboratory with this type of mushrooms, several coprini have already early been chosen as model fungi for studying basic questions of physiology and development within the basidiomycetes (Brefeld 1877, Knoll 1909, Bensaude 1918, Brunswick 1924, Hanna 1925, Brodie 1931, Buller 1931). Several fields of research have been explored with these mushroom particularly with $C$. cinerea (see below), such as Mendelian genetics (Guerdoux 1974, Challen and Elliot 1989, Stephens et al. 1991, Pukkila 1993, Walser et al. 2001), DNA-mediated transformation which opens up ways of genetic manipulation [C. cinerea (Binninger et al. 1987, 1991, Granado et al. 1997, Cummings et al. 1999), Coprinus bilanatus now Coprinopsis scobicola (Burrows et al. 1990, Challen et al. 1994) and Coprinus congregatus now Coprinellus congregatus (Leem et al. 1999)], asexual sporulation (Brodie 1931, 1932, Polak et al. 1997, 2001), fruiting body development (Ross 1985, Manachère 1988, Moore 1998, Kües 2000, Kües et al. 2004), karyogamy, meiosis and basidiospore formation ( $\mathrm{Lu}$ 1982, 2000, McLaughlin 1982, Thielke 1982, Zolan et al. 1995), just to mention a few examples as a demonstration of the feasibility to work with this group of fungi.

\subsection{The model fungus Coprinopsis cinerea}

C. cinerea is a saprophytic fungus, which in nature grows on dung (Buller 1931, Uljé and Noordeloos 1999). However, it can easily grow on simple artificial media based on e.g. malt extract (Rao and Niederpruem 1969, Walser 1997). In contrast to many other basidiomycetes, it can readily fructify under laboratory conditions (Moore and Pukkila 1985). Although it is quite easy to get fructifications from C. cinerea, this fungus in general is considered being of little edible value because of the fast autolysis of the cap at maturity (http://www.fao.org/docrep/007/y5489e/ y5489e14.htm). However, mushroom growers in Thailand cultivate $C$. cinerea on agricultural wastes, harvest them 
before maturation and sell them in pre-conserves (Kües et al. 2007, Figure 4). Another example of use of this fungus as food is the case reported by Härkönen et al. (1993) where primordia of $C$. cinerea freely developed on compost heaps in sisal plantations on Tanzania are collected and consumed by the local people.

C. cinerea has served as a model fungus for almost a century in order to study developmental processes in the basidiomycetes (Kües 2000). Besides its short life cycle and the facility to easily obtain fructifications from this fungus, it is accessible to classical genetics (Moore and Pukkila 1985) and molecular biological techniques (Pukkila 1993, Walser et al. 2001) and has a well established transformation system (Binniger et al. 1987, Granado et al. 1997, Cummings et al. 1999).
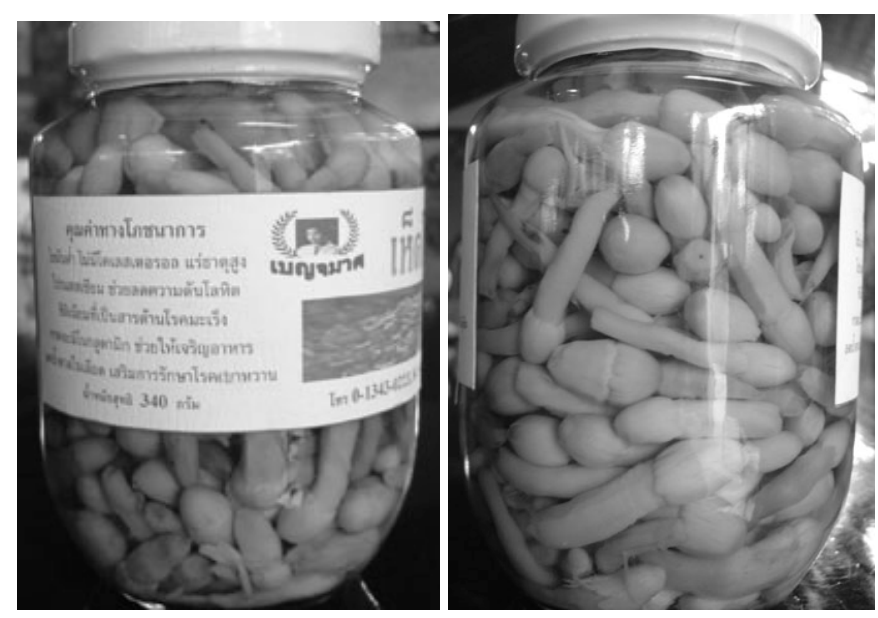

Figure 4 A commercial dikaryotic strain of Hed-Cone-Noy (Coprinopsis cinerea) from Thailand grows and fruits at $28^{\circ} \mathrm{C}$ on wheat straw and other plant waste. Hed-Cone-Noy pickled in a $50 \%$ salt solution from a Thai food store. The fungus is cultivated under dark conditions in order to obtain immature primordia, otherwise mature fruiting bodies would autolyse. The inscription on the glass states as values for nutrition low fat, no cholesterol, high mineral content, and potassium. The producer also promises consumers decrease of blood pressure, protection against cancer cells by selenium, quickening the appetite by glutamic acid, and decrease of blood sugar as a preventive action in diabetes. Photos courtesy of J. Supadit. 
Table 1 Comparison of the disposition of the coprini by different authors.

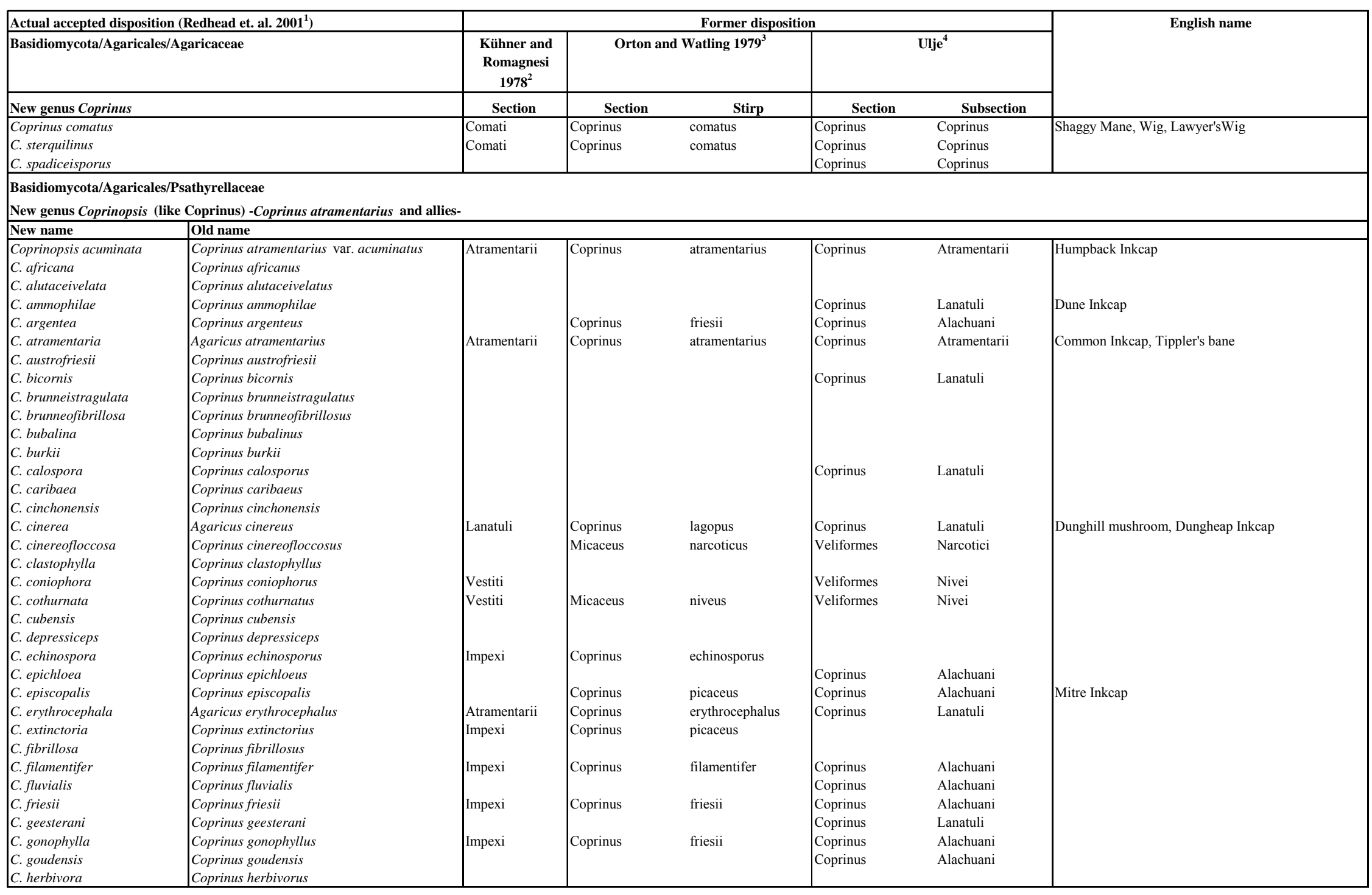


Table 1 continued

\begin{tabular}{|c|c|c|c|c|c|c|c|}
\hline \begin{tabular}{|l|} 
C. herinkii \\
C. heterocoma
\end{tabular} & \begin{tabular}{|l|} 
Coprinus herinkii \\
Coprinus heterocomus
\end{tabular} & & & & Coprinus & Alachuani & \\
\hline $\begin{array}{l}\text { C. heterocoma } \\
\text { C. insignis }\end{array}$ & $\begin{array}{l}\text { Coprinus heterocomus } \\
\text { Coprinus insignis }\end{array}$ & Atramentarii & Coprinus & atramentarius & & & \\
\hline C. jamaicensis & Coprinus jamaicensis & & & & & & \\
\hline C. jonesii & Coprinus jonesii & & & & Coprinus & Lanatuli & Bonfire Inkcap \\
\hline C. kimurae & Coprinus kimurae & Impexi & Coprinus & atramentarius & Coprinus & Alachuani & \\
\hline C. krieglsteineri & Coprinus krieglsteineri & & & & Coprinus & Lanatuli & \\
\hline C. Kubickae & Coprinus kubickae & & & & Coprinus & Alachuani & \\
\hline C. laanii & Coprinus laanii & & Micaceus & narcoticus & Veliformes & Narcotici & \\
\hline C. lagopides & Coprinus lagopides & Lanatuli & Coprinus & lagopus & & & \\
\hline C. lagopus & Agaricus lagopus & Lanatuli & Coprinus & lagopus & Coprinus & Lanatuli & Woolly Inky cap, Hare's foot Inkcap \\
\hline C. luteocephala & Coprinus luteocephalus & Vestiti & Micaceus & cortinatus & Coprinus & Alachuani & \\
\hline $\begin{array}{l}\text { C. macrocephala } \\
\text { C. macropus }\end{array}$ & $\begin{array}{l}\text { Agaricus macrocephalus } \\
\text { Coprinus macropus }\end{array}$ & Lanatuli & Coprinus & lagopus & Coprinus & Lanatuli & \\
\hline C. marcida & Coprinus marcidus & & & & & & \\
\hline C. martinii & Coprinus martinii & Vestiti & Micaceus & narcoticus & Veliformes & Narcotici & \\
\hline $\begin{array}{l}\text { C. maysoidispora } \\
\text { C. mexicana }\end{array}$ & $\begin{array}{l}\text { Coprinus maysoidisporus } \\
\text { Coprinus mexicanus }\end{array}$ & & & & & & \\
\hline C. myceliocephala & Coprinus myceliocephalus & & & & & & \\
\hline C. narcotica & Agaricus narcoticus & Vestiti & Micaceus & narcoticus & Veliformes & Narcotici & \\
\hline $\begin{array}{l}\text { C. neolagopus } \\
\text { C. neotropica }\end{array}$ & Coprinus neoloagopus & & & & & & \\
\hline C. neotropica & Coprinus neotropicus & Vestiti & Micaceus & niveus & Veliformes & Nivei & Snowy Inkcan. Snow white Inkcan \\
\hline $\begin{array}{l}\text { C. nivea } \\
\text { C. ochraceolanata }\end{array}$ & $\begin{array}{l}\text { Agaricus niveus } \\
\text { Coprinus ochraceolanatus }\end{array}$ & Jestur & & & Coprinus & Lanatuli & 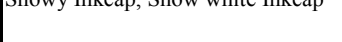 \\
\hline C. pachyderma & Coprinus pachydermus & & & & Coprinus & Lanatuli & \\
\hline C. pachysperma & Coprinus pachyspermus & & Micaceus & niveus & Veliformes & Nivei & \\
\hline C. paleotropica & Coprinus paleotropicus & & & & & & \\
\hline C. papagoensis & Coprinus papagoensis & & & & & & \\
\hline C. phaeospora & |"phaeosporus" & Impexi & & & Coprinus & Alachuani & \\
\hline C. phlyctidospora & Coprinus phlyctidosporus & Impexi & Coprinus & echinosporus & & & \\
\hline C. picaсеа & Agaricus picaceus & Impexi & Coprinus & picaceus & Coprinus & Alachuani & Magpie Inkcap \\
\hline C. piepenbroekii & Coprinus piepenbroekii & & & & Coprinus & Alachuani & \\
\hline C. pinguispora & Coprinus pinguisporus & & & & & & \\
\hline C. pseudofriesii & Coprinus pseudofriesii & & & & Coprinus & Alachuani & \\
\hline C. pseudonivea & Coprinus pseudoniveus & & & & Veliformes & Nivei & \\
\hline C. pseudoradiata & Coprinus pseudoradiatus & Lanatuli & Coprinus & lagopus & Coprinus & Lanatuli & \\
\hline C. psychromorbida & Coprinus psychromorbidus & & & & & J anatuli & \\
\hline C. radiata & Agaricus radiatus & Lanatuli & Coprinus & lagopus & Coprinus & Lanatuli & Miniature Woolly Inky Cap \\
\hline C. radicans & Coprinus radicans & Vestiti & Micaceus & narcoticus & Veliformes & Narcotici & \\
\hline C. romagnesiana & Coprinus romagnesianus & Atramentarii & Coprinus & atramentarius & Coprinus & Atramentarii & \\
\hline C. rugosobispora & Coprinus rugosobisporus & & & & & & \\
\hline C. sclerotiger & Coprinus sclerotiger & Vestiti & Micaceus & narcoticus & & & \\
\hline C. sclerotiorum & Coprinus sclerotiorum & & & & Coprinus & Alachuani & \\
\hline C. scobicola & Coprinus scobicola & Lanatuli & Coprinus & picaceus & Coprinus & Lanatuli & \\
\hline C. semitalis & Coprinus semitalis & Vestiti & Micaceus & narcoticus & Veliformes & Narcotici & \\
\hline C. spelaiophila & Coprinus spelaiophilus & Impexi & & & $\begin{array}{l}\text { Coprinus } \\
\text { Conrinus }\end{array}$ & $\begin{array}{l}\text { Lanatuli } \\
\text { Alachuani }\end{array}$ & \\
\hline C. spilospora & Coprinus spilosporus & Impexi & & & Coprinus & Alachuani & \\
\hline
\end{tabular}


Table 1 continued

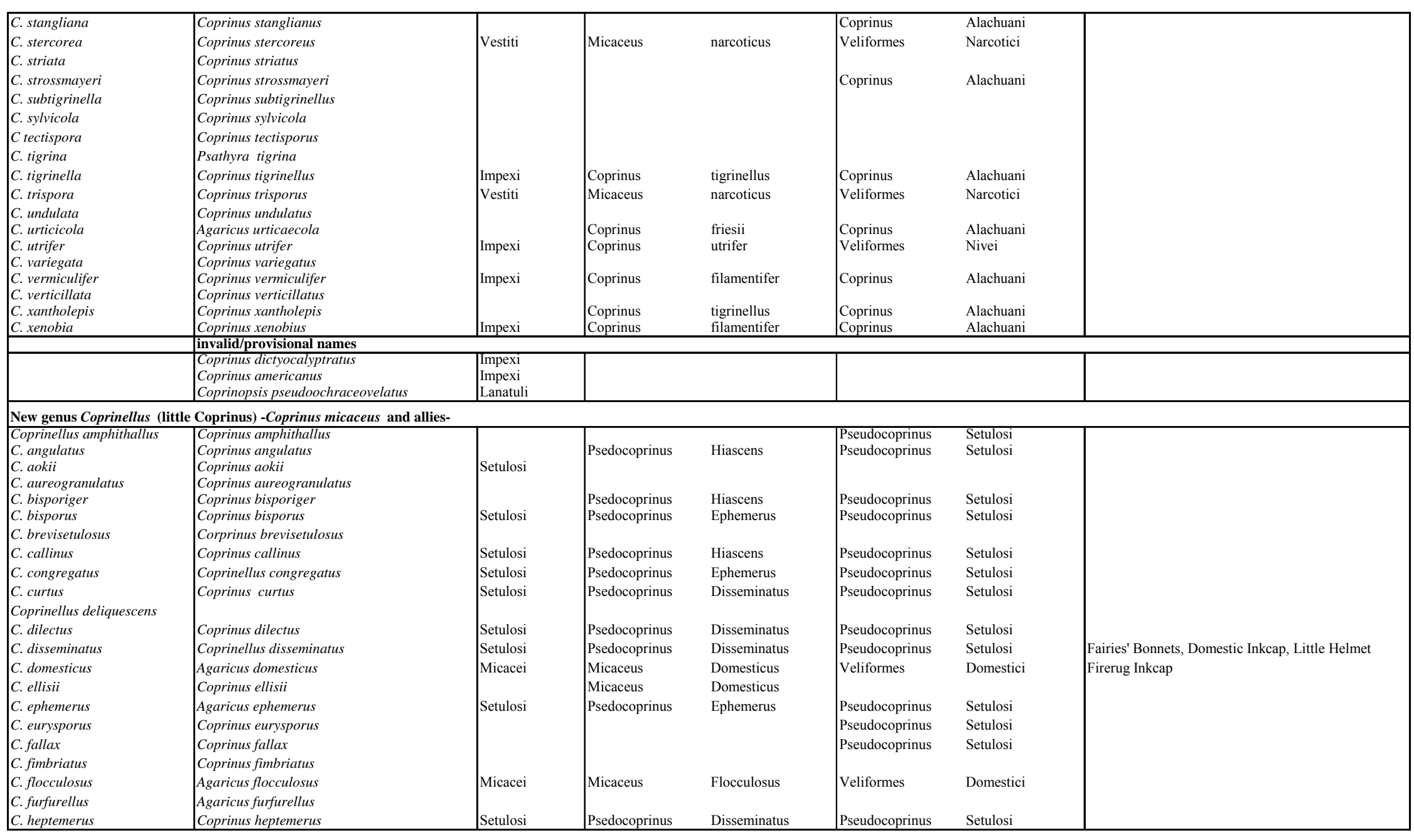


Table 1 continued

\begin{tabular}{|c|c|c|c|c|c|c|c|}
\hline C. heterosetulosus & Coprinus heterosetulosus & Setulosi & Psedocoprinus & Ephemerus & Pseudocoprinus & Setulosi & \\
\hline C. heterothrix & Coprinus heterothrix & Setulosi & & & Pseudocoprinus & Setulosi & \\
\hline C. hiascens & Agaricus hiascens & Setulosi & Psedocoprinus & Hiascens & Pseudocoprinus & Setulosi & \\
\hline Coprinellus impatiens & Coprinellus impatiens & Setulosi & Psedocoprinus & Hiascens & Pseudocoprinus & Setulosi & \\
\hline C. marculentus & Coprinus marculentus & & & & Pseudocoprinus & Setulosi & \\
\hline С.micaceus & Agaricus micaceus & Micacei & Micaceus & Micaceus & Veliformes & Micacei & Mica cap, Glistening Inky cap \\
\hline C. pellucidus & Coprinus pellucidus & Setulosi & Psedocoprinus & Ephemerus & Pseudocoprinus & Setulosi & \\
\hline C. plagioporus & Coprinus plagioporus & Setulosi & Psedocoprinus & Hiascens & Pseudocoprinus & Setulosi & \\
\hline C. pyrrhanthes & Coprinus pyrrhanthes & Setulosi & & & Pseudocoprinus & Setulosi & \\
\hline C. radians & Agaricus radians & Micacei & Micaceus & Domesticus & Veliformes & Domestici & \\
\hline C. sassii & Coprinus sassii & Setulosi & & & Pseudocoprinus & Setulosi & \\
\hline C. sclerocystidiosus & Coprinus sclerocystidiosus & Setulosi & & & Pseudocoprinus & Setulosi & \\
\hline C. singularis & Coprinus singularis & & & & Pseudocoprinus & Setulosi & \\
\hline C. subdisseminatus & Coprinus subdisseminatus & Setulosi & Psedocoprinus & Hiascens & Pseudocoprinus & Setulosi & \\
\hline C. subimpatiens & Coprinus subimpatiens & Setulosi & Psedocoprinus & Hiascens & Pseudocoprinus & Setulosi & \\
\hline C. subpurpureus & Coprinus subpurpureus & Setulosi & Psedocoprinus & Hiascens & Pseudocoprinus & Setulosi & \\
\hline C. truncorum & Agaricus truncorum & Micacei & Micaceus & Micaceus & Veliformes & Micacei & \\
\hline C. velatopruinatus & Coprinus velatopruinatus & & & & Pseudocoprinus & Setulosi & \\
\hline C. verrucispermus & Coprinus verrucispermus & Setulosi & & & Pseudocoprinus & Setulosi & \\
\hline \begin{tabular}{|l|} 
C. xanthothrix \\
New appusParasolg
\end{tabular} & Coprinus xanthothrix & Micacei & Micaceus & Domesticus & Veliformes & Domestici & \\
\hline \multicolumn{8}{|c|}{ New genusParasola (Parasol shaped) -Coprinus plicatilis and allies- } \\
\hline Parasola plicatilis & Agaricus plicatilis & Hemerobii & Psedocoprinus & Hemerobius & Pseudocoprinus & Glabri & Little Japanese umbrella, Pleated Inkcap \\
\hline P. auricoma & Coprinus auricomus & Hemerobii & Psedocoprinus & 20 Auricomus & Pseudocoprinus & Auricomi & \\
\hline P. besseyi & Pseudocoprinus besseyi & & & & & & \\
\hline P. brunneola & Pseudocoprinus brunneolus & & & & & & \\
\hline P. galericuliformis & Coprinus galericuliformis & Hemerobii & Psedocoprinus & Hemerobius & Pseudocoprinus & Glabri & \\
\hline P. hemerobia & Coprinus hemerobius & & Psedocoprinus & Hemerobius & & & \\
\hline P. hercules & Coprinus hercules & & & & Pseudocoprinus & Glabri & \\
\hline P. kuehneri & Coprinus kuehneri & & & & Pseudocoprinus & Glabri & \\
\hline P. lactea & Pseudocoprinus lacteus & & & & & & \\
\hline P. leiocephala & Coprinus leiocephalus & & Psedocoprinus & Hemerobius & Pseudocoprinus & Glabri & \\
\hline P. lilatincta & Coprinus lilatinctus & & & & Pseudocoprinus & Glabri & \\
\hline $\begin{array}{l}\text { P. megasperma } \\
\text { P. mirabilis }\end{array}$ & $\begin{array}{l}\text { Coprinus megaspermus } \\
\text { Coprinus mirabilis }\end{array}$ & Hemerobii & Psedocoprinus & Hemerobius & Pseudocoprinus & Glabri & \\
\hline P. miser & $\begin{array}{l}\text { Coprinus miser } \\
\text { Copris }\end{array}$ & Hemerobii & Psedocoprinus & Hemerobius & Pseudocoprinus & Glabri & \\
\hline P. nudiceps & Coprinus nudiceps & Hemerobii & Psedocoprinus & Hemerobius & 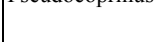 & & \\
\hline P. pachytera & Coprinus pachyterus & & & & & & \\
\hline $\begin{array}{l}\text { P. schroeteri } \\
\text { P. setulosa }\end{array}$ & Coprinus schroeteri & & & & & & \\
\hline P. setulosa & Coprinus setulosus & & & & & & \\
\hline
\end{tabular}

${ }^{1}$ Redhead et al. 2001; ${ }^{2}$ Kühner and Romagnesi 1978; ${ }^{3}$ Orton and Watling 1979; ${ }^{4}$ Uljé (http://www.homepages.hetnet.nl/ idakees/) 
Table 2 Coprini not reassigned yet.

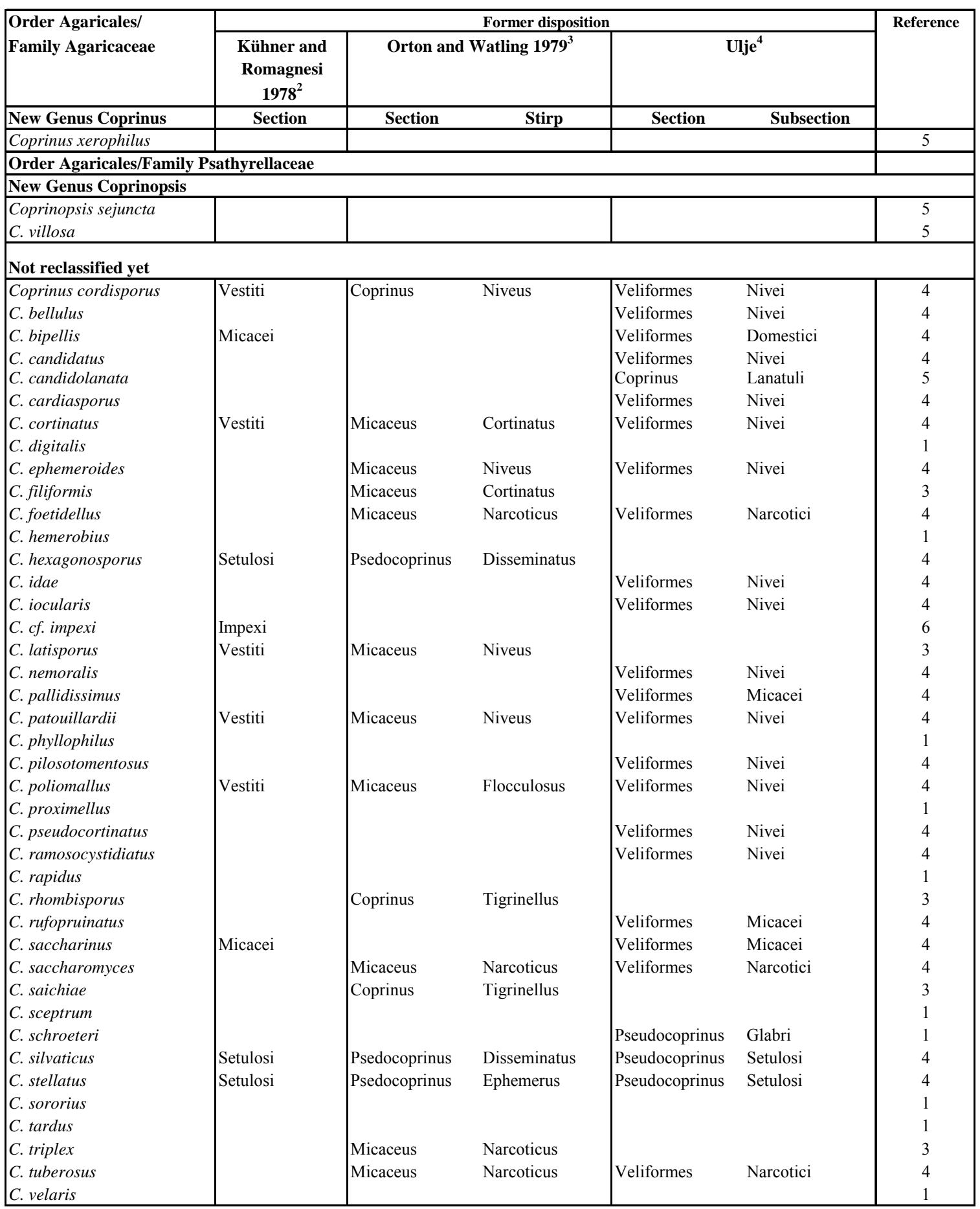

${ }^{1}$ Redhead et al. 2001; ${ }^{2}$ Kühner and Romagnesi $1978 ;{ }^{3}$ Orton and Watling $1979 ;{ }^{4}$ Uljé (http://www.homepages.hetnet.nl/ idakees/); ${ }^{5}$ Keirle et al. 2004; ${ }^{6}$ Hopple and Vilgalys 1999

\subsection{Aims of this thesis}

Fungal laccases act in decomposition of compact organic substrates (natural substrate of C. cinerea: horse dung), delignification and phenolic compounds degradation (see 
above). A first objective of this work was therefore to compile available information from the literature linking coprini to growth on dead and living plant materials (Chapter 2). These data were supplemented with own observations from collections of coprini at the grounds of the North Campus of the Georg-August-University of Göttingen. For the future, these data might direct screening approaches for specific enzymatic activities in order to exploit them in biotechnological applications e.g. by cloning their genes, and overexpressing the gene products in a suitable expression host (Kilaru 2006, Kilaru et al. 2006). As a first of such screening approach, growth of selected coprini on lignocellulosic substrates and detection of laccase activities was further tested in the laboratory. Mushroom formation on the cheap lignocellulosic substrates was recorded for some species (Chapter 3).

Mushrooms have been shown be a natural source of biological compounds with various medical properties; coprini mushrooms are so far poorly studied and not at all exploited. Hence, another objective in this work was to review medicinal properties on this group of fungi that might help to direct further studies towards their biotechnological applications (Chapter 4).

Although coprini are a group of fungi started to be described already 200 years ago, species within these genera are nevertheless often difficult to recognize beyond doubt and, most likely, many species are still undescribed. As part of this work, a description and characterization of several unusual isolates of the coprini forming abnormal shaped fruiting bodies were done (Chapter 5).

Despite the biological potential of mushrooms, it is probably far from being exploited. This is mainly because only a few species can be induced to fruit in culture. The knowledge on the biological processes of fruiting body initiation and development is limited and arises mostly from studies of selected model organisms that are accessible to molecular genetics. A better understanding of the developmental processes underlying fruiting in these selected model organisms is expected to help mushroom cultivation of other basidiomycetes in the future (Kües and Liu 2000). Surprisingly, even the best understood species, $C$. cinerea (C. cinereus), is only poorly described in the developmental course of events occurring during fruiting body development (Buller 1909, Moore 1998, Kües 2000, Kües et al. 2004, Walser et al. 2003). Therefore, in this 
work a catalog of pictures was produced to define all the main cytological and physiological stages during fruiting body development (Chapter 6).

Enzymes belonging to the group of phenoloxidases, in particular the copper-containing laccases, have repeatedly been linked to fruiting body development in fungi (Kües and Liu 2000), among these in C. cinerea (Vnenchak and Schwalb 1989, Kües and Liu 2000). A further aim of this work was to determine functions of laccases in fungal development in $C$. cinerea. The knowledge from the morphological definition of distinct stages in the course of fruiting body development from Chapter 6 helped to accurately study the main processes of fruiting body development and their relations with activities of the copper containing enzyme laccase (Chapter 7 and 8).

Laccases were found to be frequently active during fruiting body development of C. cinerea (Chapter 7). One of the functions discerned for the enzyme is in melanin pigment formation (Bell and Wheeler 1986, Langfelder et al. 2003). In C. cinerea, laccase activity has been discussed in terms of basidiospore staining (Leatham and Stahmann 1981, Vnenchak and Schwalb 1989). Melanins are darkly pigmented polymers that mediate protection to cells against heat, toxic metals and free radicals, UV and other radiation, osmotic stress, lytic and antifungal agents (Butler and Day 1998, Jacobson 2000, Nosanchuk and Casadevall 2003). Protection to the fungal spores against enzymatic degradation from herbivorous and fungivorous small grazing animals is another function (Richardson 2001, own unpublished observations on wild type and melanin free-laccase mutants of the ascomycete Sordaria macrospora). Relationships between fungi and other organisms in nature are frequently overlooked. Therefore in this work the relationship between $C$. cinerea and the mycophagous mite Tyrophagus putrescentiae was studied over the whole life cycle of the fungus (Chapter 9).

Finally, chapter 10 brings together the main results from all chapters in order to link and discuss these in a more global way.

\subsection{References}

Agematu H, Shibamoto N, Nishida H, Okamoto R, Shin T, Murao S (1993) Oxidative decarboxylation of 4-hydroxymandelic acid and 2-(4-hydroxyphenyl)glycine by 
laccase from Trachyderma tsunodae and Myrothecium verrucaria. Biosci. Biotechnol. Biochem., 57, 1877-1881.

Alexopoulos CJ, Mims CW, Blackwell M (1996) Introductory mycology. John Wiley and Sons, N.Y., USA.

Arora D (1986) Mushrooms demystified. A comprehensive guide to the fleshy fungi (2nd ed.). Ten Speed Press, Berkeley, California.

Bell AA, Wheeler MH (1986) Biosynthesis and functions of fungal melanins. Ann. Rev. Phytopathol., 24, 411-451.

Benjamin DR (1995). Mushrooms: poisons and panaceas. W.H. Freeman and Company, New York, N.Y., USA.

Bensaude M (1918) Recherches sur le cycle évolutif et la sexualité chez les Basidiomycètes. Ph.D. thesis. Univ. Paris, Nemours, France.

Binninger DM, Skrzynia C, Pukkila PJ, Casselton LA (1987) DNA-mediated transformation of the basidiomycete Coprinus cinereus. EMBO J., 6, 835-840.

Binninger DM, Le Chevanton L, Skrzynia C, Shubkin CD, Pukkila PJ (1991) Targeted transformation in Coprinus cinereus. Mol. Gen. Genet., 227, 245-251.

Blanchette RA (1991) Delignification by wood-decay fungi. Annu. Rev. Phytopathol., 29, 381-398.

Boerjan W, Ralph J, Baucher M (2003) Lignin biosynthesis. Annu. Rev. Plant Biol., 54, 519-546.

Bollag JM, Leonowicz A (1984) Comparative studies of extracellular fungal laccase. Appl. Environ. Microbiol., 48, 849-854.

Borchers AT, Stern JS, Hackman RM, Keen CL, Gershwin ME (1999) Mushrooms, tumors, and immunity. Proc. Soc. Exp. Biol. Med., 221, 281-293.

Brefeld O (1877) Botanische Untersuchungen über Schimmelpilze. III. Basidiomyceten. Arthur Felix, Leipzig, Germany.

Breitenbach J, Kräzlin F (1995) Pilze in der Schweiz. Vol. 4. Mykologia, Luzern, Switzerland.

Brodie HJ (1931) The oidia of Coprinus lagopus and their relation with insects. Ann. Bot., 45, 315-344.

Brodie HJ (1932) Oidial mycelia and diploidization process in Coprinus lagopus. Ann. Bot., 46, 727-732.

Broxholme SJ, Read ND, Bond DJ (1991) Developmental regulation of proteins during fruit-body morphogenesis in Sordaria brevicollis. Mycol. Res., 95, 958-969. 
Brunswick H (1924) Untersuchungen über die Geschlechts- und Kernverhältnisse bei der Hymenomyzetengattung Coprinus. Gustav Fisher Verlag, Jena, Germany.

Buller AHR (1909) Researches on fungi. Vol. I. An account of the production, liberation, and dispersion of the spores of hymenomycetes treated botanically and physically. Also some observations upon the discharge and dispersion of the spores of ascomycetes and of Pilobolus. Hafner Publishing Co., New York, N.Y., USA.

Buller AHR (1922) Researches on Fungi. Vol. II. Further investigations upon the production and liberation of spores in hymenomycetes. Hafner Publishing Co., New York, N.Y., USA.

Buller AHR (1931) Researches on Fungi. Vol. IV. Further observations on the Coprini together with some investigations on social organization and sex in the hymenomycetes. Hafner Publishing Co., New York, N.Y., USA.

Burrows DM, Elliot TJ, Casselton L (1990) DNA-mediated transformation of the secondarily homothallic basidiomycete Coprinus bilanatus. Curr. Genet., 17, 175-177.

Buswell JA, Chang ST (1993) Edible mushrooms: attributes and applications. In: Chang ST, Buswell JA, Miles PG (eds.) Genetics and breeding of edible mushrooms. Gordon and Breach, Y-Parc, Switzerland, pp. 297-324.

Butler MJ, Day AW (1998) Fungal melanins: A review. Can. J. Microbiol., 44, 11151136.

Challen MP, Elliot TJ (1989) Segregation of genetic markers in the 2 spored secondarily homothallic basidiomycete Coprinus bilanatus. Theor. Appl. Genet., 78, 601607.

Challen MP, Bhattiprolu GR, Warner PJ, Elliot TJ (1994) Cloning the Coprinus bilanatus TRP2 gene and its use as a selectable marker in transformation. Mycol. Res., 98, 179-185

Chandra A (1989) Dictionary of edible mushrooms: Botanical and common names in various languages in the world. Elsevier Science, New York, N.Y., USA.

Chang ST (1993) Mushroom biology: the impact on mushroom production and mushroom products. In: Chang ST, Buswell JA, Chiu SW (eds.) Proceedings of the first international conference on mushroom biology and mushroom products, The Chinese University Press, Hong Kong, Hong Kong, pp. 3-20. 
Chang ST (1999) World production of edible and medicinal mushrooms in 1997 with emphasis on Lentinus edodes (Berk.) Sing. in China. Int. J. Med. Mushrooms, 1, 291-301.

Chang ST (2005) Witnessing the development of the mushroom industry in China. Acta Edulis Fungi, 12 (Supplement), 3-19.

Chang ST, Buswell JA (1996) Mushroom nutriceuticals. World J. Microb. Biot., 12, 473-476.

Chen MM (2004) Species of edible mushrooms in China. Mushroom Sci., 16, 155-163.

Couto SR, Herrera JLT (2006) Industrial and biotechnological applications of laccases: A review. Biotechnol. Adv., 24, 500-513.

Cummings WJ, Celerin M, Crodian J, Brunick LK, Zolan ME (1999) Insertional mutagenesis in Coprinus cinereus: use of a dominant selectable marker to generate tagged, sporulation-defective mutants. Curr. Genet., 36, 371-382.

Dix NJ, Webster J (1995) Fungal ecology. (2nd ed.). Chapman and Hall, London, UK.

Durán N, Esposito E (2000) Potential applications of oxidative enzymes and phenoloxidases-like compounds in wastewater and soil treatment: a review. Appl. Cat B: Environ., 28, 83-99.

Eggert C, Temp U, Eriksson KEL (1997) Laccase is essential for lignin degradation by the white-rot fungus Pycnoporus cinnabarinus. FEBS Lett., 407, 89-92.

Fengel D (1971) Ultrastructural organization of the cell wall components. J. Polym. Sci. C, 36, 383-392.

Granado JD, Kertesz-Chaloupková K, Aebi M, Kües U (1997) Restriction enzymemediated DNA integration in Coprinus cinereus. Mol. Gen. Genet., 256, 28-36.

Green F, Highley TL (1997) Mechanism of brown-rot decay: Paradigm or paradox. Int. Biodeter. Biodegr., 39, 113-124.

Guerdoux JL (1974) Coprinus. In: King RC (ed.), Handbook of Genetics, Plenum Press, New York, N.Y., USA.

Hanna WF (1925) The problem of sex in Coprinus. Ann. Bot., 34, 431-457.

Härkönen M, Saarimäki T, Mwasumbi L (1993) Tanzanian mushrooms and their uses 2. An edible species of Coprinus section Lanatuli. Karstenia, 33, 51-59.

Hawksworth DL (2001) The magnitude of fungal diversity: the 1.5 million species estimate revisited. Mycol. Res., 105, 1422-1432.

Hermann TE, Kurtz MB, Champe SP (1983) Laccase localized in hulle cells and cleistothecial primordia of Aspergillus nidulans. J. Bacteriol., 154, 955-964. 
Hopple JS Jr, Vilgalys R (1999) Phylogenetic relationships in the mushroom genus Coprinus and dark-spored allies based on sequence data from the nuclear gene coding for the large ribosomal subunit RNA: Divergent domains, outgroups, and monophyly. Mol. Phylogenet. Evol., 13, 1-19.

Husain Q (2006) Potential applications of the oxidoreductive enzymes in the decolorization and detoxification of textile and other synthetic dyes from polluted water: A review. Cr. Rev. Biotechn., 26, 201-221.

Jacobson ES (2000) Pathogenic roles for fungal melanins. Clin. Microbiol. Rev., 13, 708-717.

Jong SC, Donovick R (1989) Antitumor and antiviral substances from fungi. Adv. Appl. Microbiol., 34,183-262.

Keirle MR, Hemmes DE, Desjardin DE (2004) Agaricales of the Hawaiian Islands. 8. Agaricaceae: Coprinus and Podaxis; Psathyrellaceae: Coprinopsis, Coprinellus and Parasola. Fungal Divers., 15, 33-124.

Kendrick B (1992) The fifth kingdom. Focus Information Group, Newburyport, Massachusetts, USA.

Kilaru S (2006) Identification of fungal multi-copper oxidase gene families: Overexpression and characterization of Coprinopsis cinerea laccases for applications in biotechnology. $\mathrm{PhD}$ Thesis. Georg-August University of Göttingen, Göttingen, Germany.

Kilaru S, Hoegger PJ, Kües U (2006) The laccase multi-gene family in Coprinopsis cinerea has seventeen different members that divide into two distinct subfamilies. Curr. Genet., 50, 45-60.

Kirk PM, Cannon PF, David JC, Stalpers JA (2001) Ainsworth \& Bisby's Dictionary of the Fungi (9th ed.). International Mycological Institute, CAB International, Wallingford, UK.

Knoll F (1909) Untersuchungen über Längenwachstum und Geotropismus der Fruchtkörperstiele von Coprinus stiriacus. Sitzgsber. Akad. Wiss. Wien Math.Naturwiss. Kl. I, 118, 575-634.

Kothe E (2001) Mating-type genes for basidiomycete strain improvement in mushroom farming. Appl. Microbiol. Biotechnol., 56, 602-612.

Kües U (2000) Life history and developmental processes in the basidiomycete Coprinus cinereus. Microbiol. Mol. Biol. Rev., 64, 316-353. 
Kües U, Liu Y (2000) Fruiting body production in basidiomycetes. Appl. Microbiol. Biotechnol., 54, 141-152.

Kües U, Künzler M, Bottoli APF, Walser PJ, Granado JD, Liu Y, Bertossa RC, Ciardo D, Clergeot P-H, Loos S, Ruprich-Robert G, Aebi M (2004) Mushroom development in higher basidiomycetes. Implications for human and animal health. In: Kushwaha RKS (ed.), Fungi in Human and Animal Health. Scientific Publishers, Jodhpur, India, pp. 431-470.

Kües U, Navarro-González M, Srivilai P, Chaisaena W, Velagapudi R (2007) Chapter 24. Mushroom Biology and Genetics. In: Kües U (ed.), Wood production, wood technology and biotechnological impacts. Universitätsverlag-Verlag, Göttingen, Germany.

Kühner R, Romagnesi H (1978) Flore Analytique des Champignons Supérieurs. Masson, Paris, France.

Labarère J, Bernet J (1978) Mutation inhibiting protoplasmic incompatibility in Podospora anserina that suppresses an extracellular laccase and protoperithecium formation. J. Gen. Microbiol., 109, 187-189.

Langfelder K, Streibel M, Jahn B, Haase G, Brakhage AA (2003) Biosynthesis of fungal melanins and their importance for human pathogenic fungi. Fungal Genet. Biol., 38, 143-158.

Leatham GF, Stahmann MA (1981) Studies on the laccase of Lentinus edodes: specificity, localization and association with the development of fruiting bodies. J. Gen. Microbiol., 125, 147-157.

Leem YE, Kim SJ, Ross IK, Choi HT (1999) Transformation and laccase mutant isolation in Coprinus congregatus by restriction enzyme-mediated integration. FEMS Microbiol. Lett., 172, 35-40.

Leonowicz A, Matuszwska A, Luterek J, Ziegenhagen D, Wojtas-Wasilewska M, Cho NS, Hofrichter M, Rogalski J (1999) Biodegradation of lignin by white rot fungi. Fungal Genet. Biol., 27, 175-185.

Leonowicz A, Cho NS, Luterek J, Wilkolazka A, Wojtas-Wasilewska M, Matuszwska A, Hofrichter M, Wesenberg D, Rogalski J (2001) Fungal laccase: properties and activity on lignin. J. Basic Microbiol., 3-4, 185-227.

Lu BC (1982) Replication of deoxyribonucleic acid and crossing over in Coprinus. In Wells K. and Wells E. K. (ed.), Basidium and basidiocarp. Evolution, cytology, funtion and development. Springer-Verlag, New York, N.Y., USA. 
Lu BC (2000) The control of meiosis progression in the fungus Coprinus cinereus by light/dark cycles. Fungal Genet. Biol., 31, 33-41.

Manachère G (1988) Regulation of sporophore differentiation in some macromycetes particularly in Coprini: An overview of some experimental studies, from fruiting initiation to sporogenesis. Crypt. Mycol., 9, 291-323.

Martínez AT, Speranza M, Ruiz-Dueñas FJ, Ferreira P, Camarero S, Guillén F, Martínez MJ, Gutiérrez A, del Río JC (2005) Biodegradation of lignocellulosics: microbial, chemical and enzymatic aspects of the fungal attack of lignin. Int. Microbiol., 8, 195-204.

McLaughlin DJ (1982) Ultrastructure and cytochemistry of basidial and basidiospore development. In: Wells K, Wells EK (eds.) Basidium and basidiocarp: Evolution, cytology, function and development. Springer-Verlag, New York, USA, pp. 37-74.

Minussi RC, Pastore GM, Duran N (2002) Potential applications of laccase in the food industry. Trends Food Sci. Tech., 13, 205-216.

Mizuno T, Saito H, Nishitoba T, Kawagishi H (1995) Antitumor-active substances from mushrooms. Food Rev. Int., 11, 23-61.

Moore D, Pukkila PJ (1985) Coprinus cinereus: an ideal organism for studies of genetics and developmental biology. J. Biol. Educ., 19, 31-40.

Moore D (1998) Fungal morphogenesis. Cambridge University Press, Cambridge, UK.

Nosanchuk JD, Casadevall A (2003) The contribution of melanin to microbial pathogenesis. Cell. Microbiol., 5, 203-223.

Orton PD, Watling R (1979) British fungus flora. Agarics and Boleti 2. Coprinaceae Part 1: Coprinus. Her Majesty's Stationary Office, Edinburg, UK.

Polak E, Hermann R, Kües U, Aebi M (1997) Asexual sporulation in Coprinus cinereus: Structure and development of oidiophores and oidia in an Amut Bmut homokaryon. Fungal Genet. Biol., 22, 112-126.

Polak E, Aebi M, Kües U (2001) Morphological variations in oidium formation in the basidiomycete Coprinus cinereus. Mycol. Res., 105, 603-610.

Pointing SB (2001) Feasibility of bioremediation by white-rot fungi. Appl. Microbiol. Biotechnol., 57, 20-33.

Poppe J (2000) Use of agricultural waste materials in the cultivation of mushrooms. Mushroom Sci., 15, 3-23. 
Pukkila PJ (1993) Methods of genetic manipulation in Coprinus cinereus. In: Chang ST, Buswell JA, Miles PG (eds.), Genetics and Breeding of Edible Mushrooms. Gordon and Breach Science Publishers, Y-Parc, Switzerland, pp. 249-264.

Rajarathnam S, Shashireka MN, Bano Z (1993) Biopotentialities of the basidiomycetes. Adv. Appl. Microbiol., 37, 233-361.

Rao PS, Niederpruem DJ (1969) Carbohydrate metabolism during morphogenesis of Coprinus lagopus (sensu Buller). J. Bacteriol., 100, 1222-1228.

Rayner ADM, Boddy L (1988) Fungal communities in the decay of wood. Adv. Microb. Ecol., 10, 115-166.

Redhead SA (2000) Bully for Coprinus - a story of manure, minutiae, and molecules. McIlvainea, 14, 5-14.

Redhead SA, Vilgalys R, Moncalvo JM, Johnson J, Hopple JS Jr (2001) Coprinus Pers. and the disposition of Coprinus species sensu lato. Taxon, 50, 203-241.

Richardson MJ (2001) Diversity and occurrence of coprophilous fungi. Mycol. Res., $105,387-402$.

Ross IK (1985) Determination of the initial steps in differentiation in Coprinus congregatus. In: Moore D, Casselton LA, Wood DA, Frankland JC (eds.) Developmental biology of higher fungi. Cambridge University Press, Cambridge, UK, pp. 353-373.

Rühl M, Kües U (2007) Chapter 23. Mushroom production. In: Kües U (ed.), Wood production, wood technology and biotechnological impacts. UniversitätsverlagVerlag, Göttingen, Germany.

Schwarze FWMR, Engels J, Mattheck C (2000) Fungal Strategies of Wood Decay in Trees. Springer Verlag, Heidelberg, Germany.

Smith JE, Rowan NJ, Sullivan R (2002) Medicinal mushrooms: a rapidly developing area of biotechnology for cancer therapy and other bioactives. Biotechnol. Lett., $24,1839-1845$.

Stephens SK, Elliott TJ, Wood DA (1991) Extracellular enzyme mutants of Coprinus bilanatus. Enzyme Microb.Tech., 13, 976-981.

Thielke C (1982) Meiotic divisions in the basidium. In: Wells K, Wells EK (eds.), Basidium and basidiocarp. Springer-Verlag, New York, USA, pp. 75-92.

Uljé CB (2003) All about inkcaps. (http://www.homepages.hetnet.nl/ idakees/)

Uljé CB, Noordeloos ME (1997) Studies in Coprinus IV. Coprinus section Coprinus. Subdivision and revision of subsection Alachuani. Persoonia, 16, 265-333. 
Uljé CB, Noordeloos ME (1999) Studies in Coprinus V. Coprinus section Coprinus. Revision of subsection Lanatuli Sing. Persoonia, 17, 165-199.

Vnenchak P, Schwalb MN (1989) Phenol oxidase activity during development of Coprinus cinereus. Mycol. Res., 93, 546-548.

Walser PJ (1997) Environmental regulation of asexual sporulation and fruit body formation in the basidiomycete Coprinus cinereus. Diploma thesis. Institut für Mikrobiologie, ETH Zürich, Switzerland.

Walser PJ, Hollenstein M, Klaus MJ, Kües U (2001) Genetic analysis of basidiomycete fungi. In: Talbot NJ (ed.), Molecular and cell biology of filamentous fungi: a practical approach. Practical Approach Series, IRL Press, Oxford, England, pp. 59-90.

Walser PJ, Velagapudi R, Aebi M, Kües U (2003) Extracellular matrix proteins in mushroom development. Recent Res. Devel. Microbiology, 7, 381-415.

Wasser SP (2002) Medicinal mushrooms as a source of antitumor and immunomodulating polysaccharides. Appl. Microbiol. Biotechnol., 60, 258-274.

Wesenberg D, Kyriakides I, Agathos SN (2003) White-rot fungi and their enzymes for the treatment of industrial dye effluents. Biotechnol. Adv., 22, 161-187.

Wessels JHG (1993) Fruiting in higher fungi. Adv. Microb. Physiol., 34, 147-202.

Worall JJ, Anagnost SE, Zabel RA (1997) Comparison of wood decay among diverse lignicolous fungi. Mycologia, 89, 199-219.

Wösten HAB, Wessels JGH (2006) The emergence of fruiting bodies in Basidiomycetes. In: Kües U, Fischer R (eds.) The Mycota, Vol. I, $2^{\text {nd }}$ Edition. Growth, differentiation and sexuality. Springer, Berlin, pp. 393-414.

Yamanaka K (2005) Cultivation of new mushroom species in East Asia. Acta Edulis Fungi, 12 (Supplement), 343-349.

Yun W, Hall IR (2004) Edible ectomycorrhizal mushrooms: challenges and achievements. Can. J. Bot., 82, 1063-1073.

Zolan ME, Stassen NY, Ramesh MA, Lu BC, Valentine G (1995) Meiotic mutants and DNA repair genes of Coprinus cinereus. Can. J. Bot., 73, S226-S233. 


\section{Lignocellulolytic activities \\ within \\ coprini species}

Contribution to this chapter: The author of this thesis prepared Tables 1-3, pictures, collecting and sorting of most of the literature, designing together with Prof. U. Kües the structure of the paper and manuscript writing. The idea of this study originated from Prof. O. Holdenrieder (Institute for Integrative Biology, ETH Zürich) who together with Prof. S.M. Badalian and H.K Avetisyan (Laboratory of Fungal Biology and Biotechnology, Yerevan State University) contributed literature to the document. S.M. Badalian additionally performed phenoloxidase tests on cultures of several coprini. 


\section{Lignocellulolytic activities within coprini species}

\subsection{Abstract}

Coprinaceae are known as basidiomycetes occuring mainly on hervibore dung and soil. Several of them have been choosen as model fungi to study physiological and developmental processes within basidiomycetes. In this paper, we compiled available information on growth of coprini on dead and living plant materials. Production of wood degrading enzymes by different coprini species as well as factors hindering these fungi from colonizing compact wood are described. Finally, we analyze the wood and straw-rotting abilities within the coprini in relation to the recently suggested new phylogenetic classification of the former genus Coprinus, now divided into four clades Coprinus, Coprinopsis, Coprinellus and Parasola, the first within the Agaricaceae and the others within the family of Psatyrellaceae.

Keywords: coprini, wood and straw degraders, saprotropic fungi, fimicolous fungi 


\subsection{Introduction}

Coprinaceae were known as a family of homobasidiomycetes that mainly occur on herbivore dung and soil (Orton and Watling 1979). Major genera within this family include Coprinus, Psathyrella, Lacrymaria, Annelaria, Paneolus and Panaeolina (Singer 1996, Hopple and Vilgalys 1999). The genus Coprinus is the largest group comprising more than 200 species (Uljé and Bas 1988, 1991, Uljé and Noordeloos 1993, 1996, 1997, 2000, Uljé et al. 2000, Redhead et al. 2001, Table 1). The ecological behaviour of these fungi reflected in their naming - the Greek word "kopros" translates in English to faeces, dung. Commonly, coprini are called ink cap mushrooms (Tintlinge in German; Encriers or Bouteilles à l'encre in French; seta de tinta in Spanish). This is because in most species upon fruiting body maturation, the mushroom's cap autolyses in order to release the dark-brown to black coloured meiotic basidiospores. In the middle ages, this liquid, blackish due to the presence of spores, has been collected and used as ink (Buller 1933). Recent molecular analysis of ITS regions suggests that the type species of the traditional genus Coprinus, C. comatus (O. F. Müll.:Fr.) Pers., is not monophyletic with other "coprini" (Hopple and Vilgalys 1999, Park et al. 1999a,b,c). From these studies the former family of Coprinaceae was divided into two different families: Coprinaceae and Psathyrellaceae. This means that only Coprinus comatus, Coprinus sterquilinus and allies belong to the first family and most of the former "coprini" should be moved to family Psathyrellaceae. This change includes also the creation of three new genera for latter family: Coprinopsis, Coprinellus and Parasola (Redhead 2000, Redhead et al. 2001, Table 1).

By the ease to grow and reproduce in the laboratory, several of the coprini have already early been chosen as model fungi for the basidiomycetes (Brefeld 1877, Knoll 1909, Bensaude 1918, Brunswick 1924, Hanna 1925, Brodie 1931, Buller 1931). Accordingly, in our hands for example strains of Coprinopsis cinerea (Coprinus cinereus), Coprinellus curtus (Coprinus curtus), Coprinellus domesticus (Coprinus domesticus), Coprinellus ellisii (Coprinus ellisii), Coprinellus micaceus (Coprinus micaceus), Parasola plicatilis (Coprinus plicatilis) and Coprinellus xanthothrix (Coprinus xanthothrix) fruited directly on the first trial at $25^{\circ} \mathrm{C}$ on artificial malt-extract medium (Badalyan, unpublished). The possibility to obtain fruiting bodies in the laboratory allows Mendelian genetics (Guerdoux 1974, Challen and Elliot 1989, Stephens et al. 1991, Pukkila 1993, Walser et al. 2001). Furthermore, three coprini species have 
successfully been appointed in DNA-mediated transformation which opens up ways of genetic manipulation [C. cinerea (Binninger et al. 1987, Granado et al. 1997, Cummings et al. 1999), Coprinopsis scobicola (Coprinus bilanatus) (Burrows et al. 1990, Challen et al. 1994) and Coprinellus congregatus (Coprinus congregatus) (Leem et al. 1999)]. Coprini are therefore very attractive in studying basic questions of physiology and development within the basidiomycetes. Mating and sexual incompatibility (Casselton and Olesnicky 1998, Hiscock and Kües 1999, Brown and Casselton 2001, Kothe 2001, Kamada 2002, Casselton and Kües 2007), speciation and interspecies competition (Kemp 1970, Schmit 1999, 2001), mitochondrial inheritance (Econoumou et al. 1987, May and Taylor 1988), fruiting body development (Ross 1985, Manachère 1988, Moore 1998, Kües 2000, Kües et al. 2004, 2007), karyogamy, meiosis and basidiospore formation (Lu 1982, 2000, McLaughlin 1982, Thielke 1982, Zolan et al. 1995), mitotic sporulation (Brodie 1931, Polak et al. 1997, 2001, Kües et al. 2002 a) and sclerotia development (Waters et al. 1975a,b, Kües et al. 2002b) have been addressed in academic research, as well as photobiology (Durand 1987, Manachère 1994, Kües et al. 1998), gravitrophism (Moore et al. 1996, Meskauskas et al. 1999), nutrition, metabolism and other physiological aspects (Moore 1998, Kües 2000, Fischer and Kües 2003, Kües et al. 2004). This vast variety of subjects is a compelling demonstration of the feasibility to work with this group of fungi.

Basidiomycetous macrofungi (falling under the term "mushrooms") can be broadly grouped into three eco-physiological groups: saproptropic, symbiotic (mycorrhizal) and parasitic. As stated above, coprini appear to be saprotropic living on herbivore dung and soil rich on organic material processed before by other organisms. Saprotropic fungi may not be expected to possess high physiological enzymatic activities in attacking complex organic matter as compared to xylotrophs (Steffen et al. 2000). A handful of enzymes of coprini species with possible functions in hemicellulose, cellulose and lignin degradation have however been characterized and in some cases appointed in biotechnological applications (see below). Enzymes from different sources usually distinguish in their specific characteristics. For instance, a recently described secreted acidic laccase CLAC2 of $C$. congregatus is expressed and functionally active towards o-tolidine at pH 4.0 to $\mathrm{pH} 4.5$ (Kim et al. 1991, 2001, Choi et al. 1994). In contrast, the best characterized enzyme of $C$. cinerea Lcc1 is active over a wide $\mathrm{pH}$ range from $\mathrm{pH}$ 4.0 to $\mathrm{pH} 10.0$ with an optimum for oxidation of ABTS [2,2'-azinobis(3- 
ethylbenzthiazoline-6-sulfonate)] at $\mathrm{pH} 4.0$ and $\mathrm{SGZ}$ (syringaldazine) at $\mathrm{pH} 6.5$ (Schneider et al. 1999, Kilaru 2006).

The features of known enzymes such as $\mathrm{pH}$ optimum, substrate specificity, enzyme stability and temperature tolerance might not always be best fitting for biotechnological purposes. In addition, particular applications might request quite distinct enzymatic qualities (Schneider et al. 1999). There is therefore considerable industrial interest in increasing the variety of available enzymes with degrading activities on hemicellulose, cellulose and lignin containing plant materials. So far, coprini species have been little evaluated with respect to their ability of rotting raw plant materials, especially when of lignocellulosic character (Redhead and Ginns 1985). An objective of this paper is therefore to compile available information linking coprini to growth on dead and living plant materials. Where possible, we will deduce the kind of rot coprini species are able to perform. For the future, these data might direct screening approaches for specific enzymatic activities.

From the ecological and evolutionary view of species distribution within the one genus Coprinus in the Agaricaceae and the three new genera Coprinopsis, Coprinellus and Parasola in the Psathyrellaceae it is interesting to analyze the abilities of wood, and straw rotting within these newly defined traits. Even though wood rotting ability appears in all new genera, the most aggressive species belong to the new proposed genus Coprinellus, suggesting that possibly between this group the abilities of colonize this substrates have been further developed than within the other genera.

\subsection{Growth of coprini species on wood and other living and dead plant material}

Most fungal guide books indicate three different coprini species regularly to occur on wood. The first species is Coprinopsis atramentaria (Coprinus atramentarius) whose fruiting bodies are usually found growing in groups in association with decaying deciduous stumps or dying trees, in close proximity to buried rotting wood and occasionally also at the base of living trees (Lange and Hora 1963, Arora 1986, Phillips 1990, Jordan 1995, Ewald 2000, Læssøe and Lincoff 1998). In contrast, Breitenbach and Kränzlin (1995) list the fungus to occur in refuse areas, in gardens and within undergrowth. However, the latter authors also refer to Orton and Watling (1979) stating that the fruiting bodies in reality were connected to buried wood. Fruiting bodies of the 
second wood-associated species, Coprinellus disseminatus (Coprinus disseminatus), are usually observed, sometimes in many thousands, on decaying logs, stumps, trunks, and at the base of unhealthy deciduous trees. From there, they are spreading into the soil, where they may be detected on buried wood. Fruiting bodies of the third species, Coprinellus micaceus, occur in groups mainly on and around (old and rotting) stumps, trunks, roots and buried or burned wood of broad-leaf trees and also on or around unhealthy deciduous trees (Lange and Hora 1963, Arora 1986, Breitenbach and Kränzlin 1995, Læssøe and Lincoff 1998). Own observations document C. micaceus fruiting bodies on living trees of Acer platanoides and Robinia pseudoacacia (Figure 1 and Figure 3). In addition, fruiting bodies of all three species may occur on beds of wood chips, rotten straw or soil close to wood (Stamets 1993).

Other species sporadically mentioned in guidebooks to occur on trees, trunks, stumps or buried wood are Parasola auricoma (Coprinus auricomus), Coprinopsis laanii (Coprinus laanii), C. comatus, C. domesticus, C. ellisii, Coprinopsis narcotica (Coprinus narcoticus), P. plicatilis, Coprinopsis spelaiophila (Coprinus spelaiophilus),
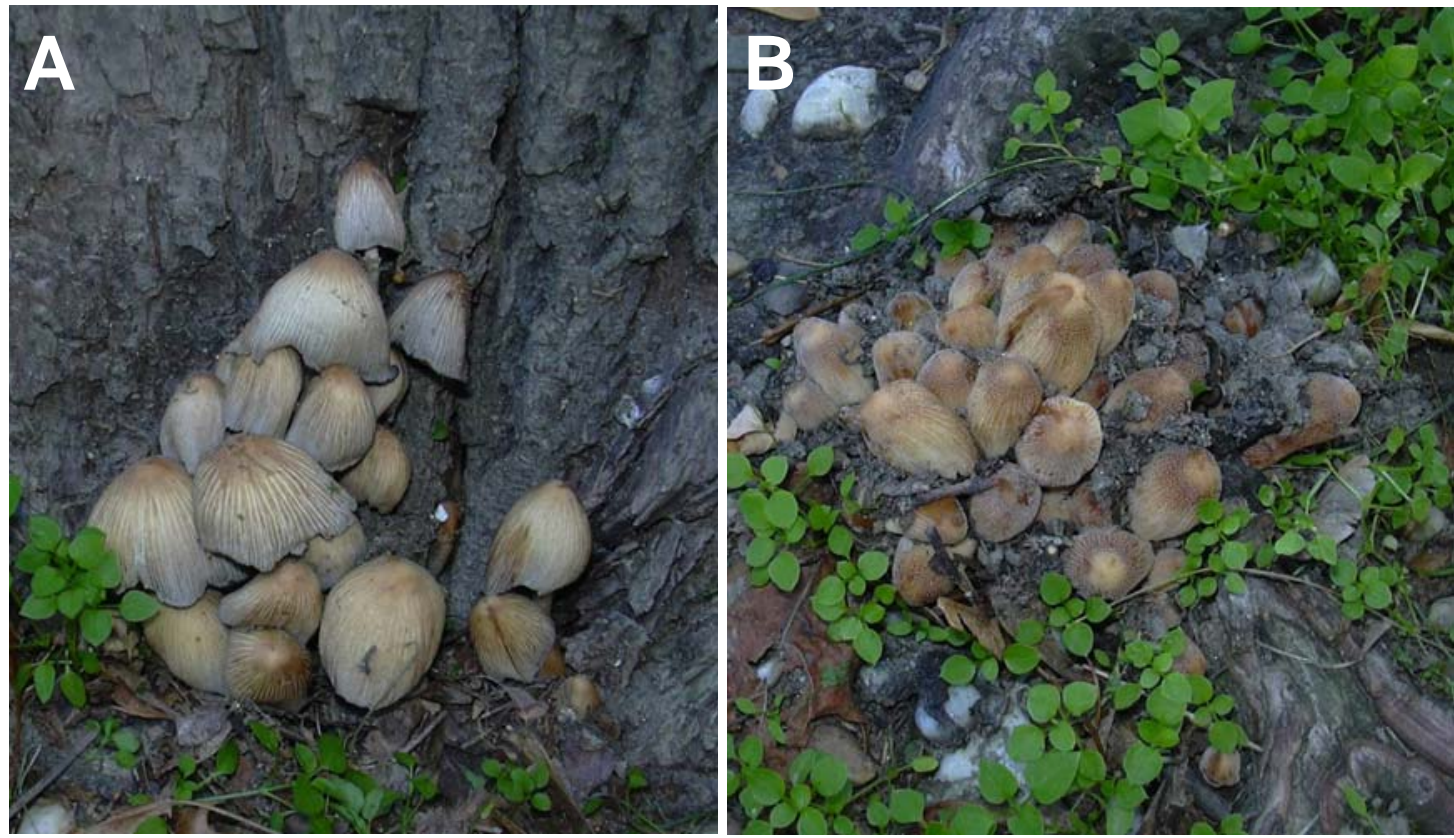

Figure 1 Coprinellus micaceus fruiting bodies (about $6 \mathrm{~cm}$ in size) growing on a living tree of Acer platanoides. Note that the fruiting bodies are sprouting directly through the bark at the base of the trunk (A) and from the roots on the ground (B). The mushrooms were observed in a Park of Bratislava, Slovakia. 

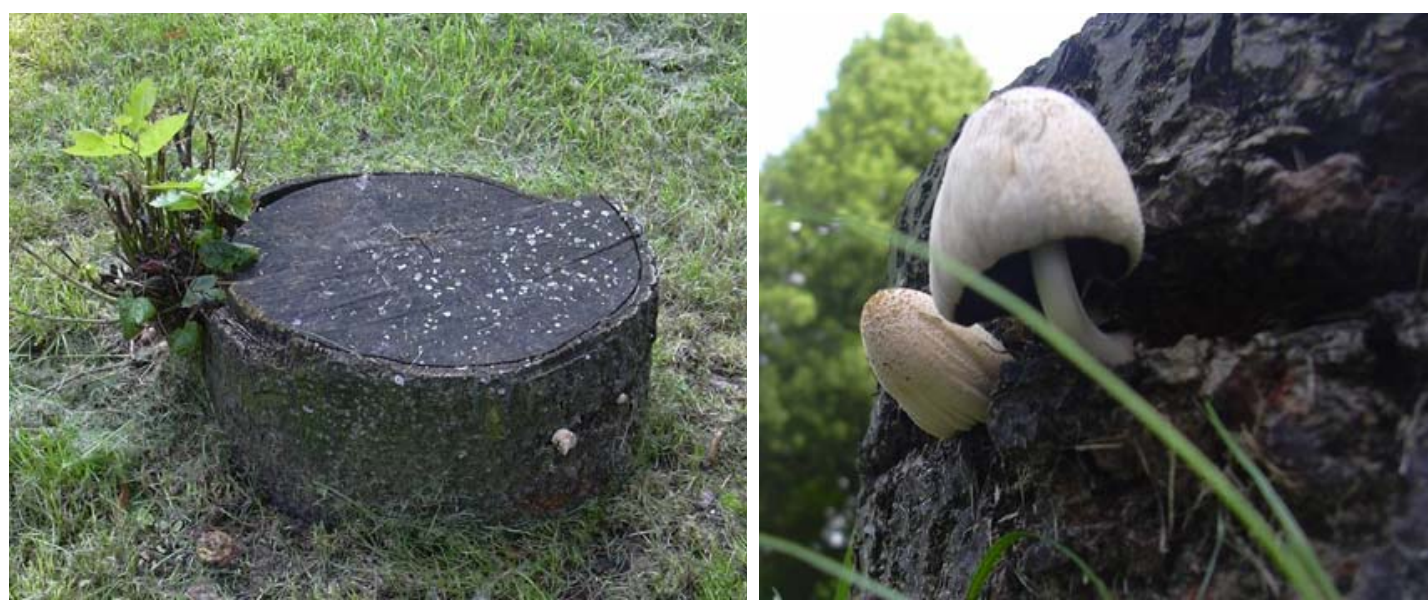

Figure 2 Coprinellus xanthothrix fruiting bodies (about $4 \mathrm{~cm}$ in size) growing on a living stump of Tilia cordata. The mushrooms were observed in gardens of the North Campus of the GeorgAugust-University, Göttingen.

Coprinus saccharinus, Coprinellus truncorum (Coprinus truncorum) and Coprinellus xanthothrix (Coprinus xanthothrix). Own isolates document C. xanthothrix on a living stump of Tilia cordata (Figure 2). Species such as C. cinerea, C. congregatus, Coprinopsis cothurnata (Coprinus cothurnatus), Coprinellus pellucidus (Coprinus pellucidus), Coprinopsis echinospora (Coprinus echinosporus), Coprinopsis kimurae (Coprinus kimurae) and Coprinopsis tigrinella (Coprinus tigrinellus) are reported to occur on substrates of lower lignin content such as rotting or manured straw (Lange and Hora 1963, Arora 1986, Schlechte 1986, Phillips 1990, Breitenbach and Kränzlin 1995, Jordan 1995, Moser and Jülich 1995, Ewald 2000, Dähncke 2001).

When comparing the reports from guide books with original literature, most of the above mentioned coprini species appeared in both data sources as associated to wood. Interestingly, many more other coprini were reported in association to wood in original literature (Table 1). Accordingly, the abilities of degrading wood and other compact plant materials among the coprini might be more widespread than assumed so far. Consistent with the guidebooks, C. atramentaria, C. disseminatus and C.micaceus appear to be most aggressive towards dead wood as well as living trees. They have worldwide repeatedly been detected on various types of deciduous wood with poplars appearing to be the most prominent wooden substrate (Table 1). Compared to dead material, occurrence on living trees is obviously less regular up to exceptional (see references in Table 1), suggesting only a latent pathogenic potential of lower potency. 
Nevertheless, $C$. atramentaria and $C$. micaceus have been connected to aspen decline in wide areas of Northern America (Basham 1958, Basham and Morawski 1964, Ross 1976, Lindsey and Gilbertson 1978, Mitchel and Smith 1978, Gilbertson 1981) and C. disseminatus in Poland (Domański 1983, 1984). Moreover, C. micaceus was made responsible of sudden death of citrus in Australia. However, targeted inoculation to reproduce the disease failed (Broadbent and Fraser 1977, Shearman et al. 1996) and infection experiments of other living trees are still missing. Own observations over three years on C. micaceus growing on the base, roots and bark of Robinia pseudoacacia trees did not reveal fatal consequences for the tree during this period (Figure 3).

In nature, the potential pathogenicity of the three coprini species might be negligible considering the strength of the various other pathogenic basidiomycetes present within the forest ecosystems, parklands and other tree-stands (Kreisel 1979, Shaw and Kile 1991, Dix and Webster 1995, Woodward et al. 1998, Schwarze et al. 2000). Where living trees were affected, the hosts in most cases were either wounded [C. spelaiophila (Uljé and Noordeloos 1999), C. disseminatus (Domański 1984)], and/or the species occurred next to strong fungal pathogens such as the basidiomycetous wood-rotters Armillaria mellea [C. disseminatus (Domański 1984)], Heterobasidion annosum and Aurantioporus fissilis [C. disseminatus (Domański 1983)], Ganoderma applanatum, or
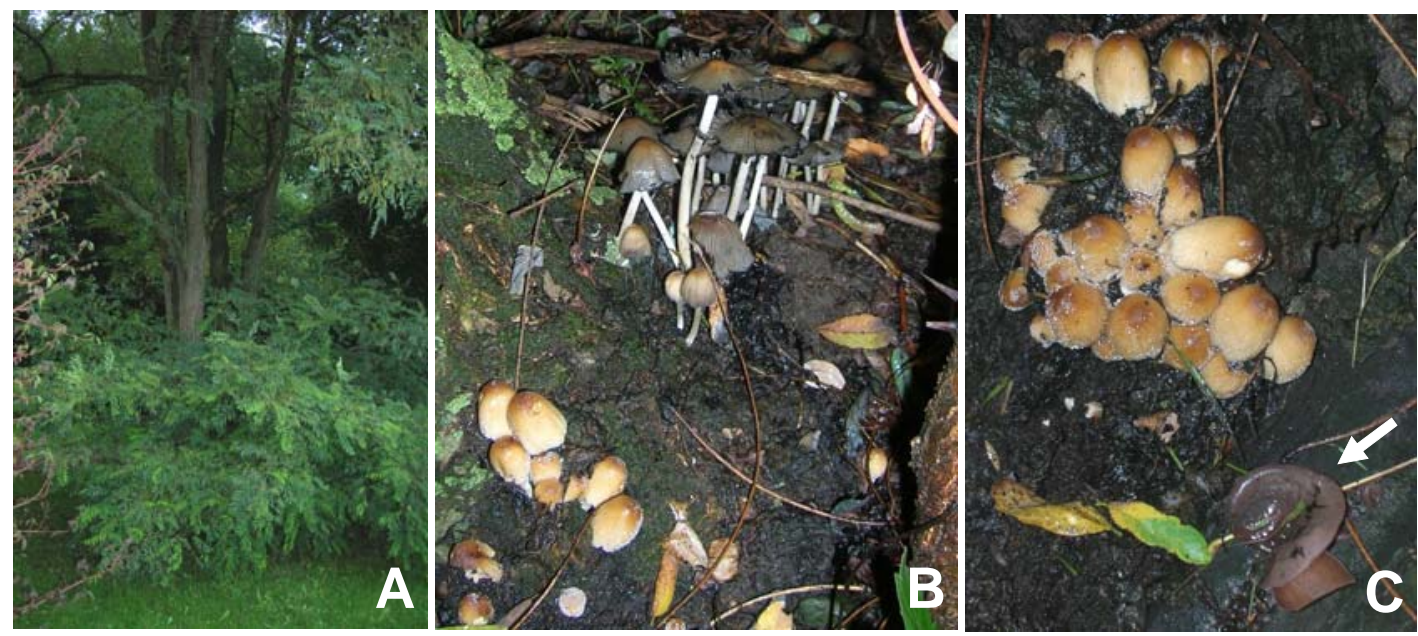

Figure 3 Young fruiting bodies of Coprinellus micaceus (about $4-10 \mathrm{~cm}$ in size) (B-C) are sprouting directly through the bark of the base of a Robinia pseudoacacia tree (A) in the gardens of the sports center of the Georg-August-University Göttingen. In close vicinity to C. micaceus, a fruiting body of the fungus Auricularia sp. was seen (arrow). 
the lignicolous ascomycete Ascocoryne sp. [C. atramentaria (Ross 1976)]. Similarly than on living trees, C. micaceus and C.disseminatus were usually not the solely species observed on stumps. C. disseminatus appeared on rotting cherry wood in Poland next to or alternately with myxomycetes (Arcyria, Comatricha, Dictydium, Lycogala, Physarum, and Stemonitis) (Stojanowska 1981).

C. micaceus has also been found replacing wood-rotting fungi such as the basidiomycete Trametes versicolor and the ascomycete Xylaria hypoxylon on beech logs 51 months after felling the trees (Chapela et al. 1988). From our own observations on Robinia pseudoacacia trees, a fruiting body from Auricularia sp. has been detected growing in close vicinity to mushrooms of $C$. micaceus (Figure 3). On hybrid poplar stumps in a small Northern-German Carpinus-Quercus forest, C.disseminatus and C. laanii appeared in succession to an extended list of initial wood colonizing myxomycetes, asco- and basidiomycetous fungi (in succesion order: Chondrostereum purpureum, Cylindrobasidium evolvens, Peziza micropus, some unidentified Hyphomycetes, Epicoccum purpurescens, Cercophora solaris, Scutellina cf. scutellata, Ascocoryne sarcoides, Sphaerobolus stellatus, Lasiosphaeria spermoides, Xylaria hypoxylon and Dacrymyces stillatus). The coprini appeared in the third year after felling at the phase of optimal wood degradation when the outer bark came off (Runge 1982). The coprini species, in particular C. laanii, persisted over the optimal and the final phase of degradation of several poplar stumps (Runge 1986). In another study, C. micaceus and C. disseminatus were found on Tilia stumps in the main phase, and P. plicatilis in the final phase of degradation along with other basidiomycetes (T. versicolor, Bjerkandera adusta, Polyporus varius, Pluteus atricapillus, C. purpureum), ascomycetes (Xylosphaera hypoxylon, X. polymorpha, Ustulina deusta, Dacrymyces cf. deliquescens) and myxomycetes (Lycogala epidendron) fungi (Runge 1975).

These studies suggest that the coprini species might be rather secondary than primary invaders, colonizing wood only after myxomycetes, ascomycetes and other stronger wood rotter fungi. The species which occur in the course of the succession might vary according to changes in a number of environmental variables, especially temperature and water availability (Dix and Webster 1995). 
From the observations in nature it is not clear whether the fungi live on metabolic products coming from primary intruders or whether they indeed disintegrate themselves the wood. A handful of coprini (see below) have been reported growing on a wide range of woody substrates (Tables 1 and 2, species of the genera: Alnus, Acacia, Acer, Aesculus, Artocarpus, Betula, Broussonetia, Celtis, Eucalyptus, Fagus, Fraxinus, Grossularia, Hevea, Juglans, Macaranga, Mulberry, Poncirus, Populus, Prunus, Quercus, Robinia, Salix, Tilia and Ulmus). According to the European standard of Natural Durability of wood (EN 350-2 1994), with the exception of some species of Quercus, Fagus and Tilia, the wood of these trees is classified of low durability. Besides, due to the fast growth of the trees, their wood is not strongly lignified, and thus of easier access to not-aggressive wood degrading fungi.

In total, we found reports on 119 different coprini species growing on plant material, respectively on 86 species to occur on wooden material (Table 1), sometimes on such unusual places as on parts of an automobile (Routien and Simonzi 1960) or in Dutch wooden clogs (English 1995).

Coprinoid mushrooms growing on wood are found in all of the four newly defined genera (Table 2). Despite 27 species not yet reclassified in the new taxonomic system, at least 1 of the 3 species (33\%) in the genus Coprinus, 14 of 102 species $(\sim 13 \%)$ in the genus Coprinopsis, 6 of 42 species (14\%) in the genus Coprinellus, and 2 of 18 species $(\sim 11 \%)$ in the genus Parasola appear to have some ability to grow on wood from known tree species (Table 2). However, there are also a high number of reports from species growing on lignocellulosic substrates where the woody species are unknown or not reported: 2 of 3 species $(66 \%)$ in the genus Coprinus, 34 of 102 species $(\sim 33 \%)$ in the genus Coprinopsis, 23 of 42 species (14\%) in the genus Coprinellus, and 5 of 18 species $(\sim 27 \%)$ in the genus Parasola. It appears that there is no strong preference towards growth on wood in one specific genus as compared to the others. However, there is a slightly higher number of reports from Coprinellus species growing on unknown woody substrates.

Many of the species [(C. atramentaria, C. cinerea, Coprinopsis geesterani, C. lagopus Figure 4, Coprinopsis ochraceolanata (C. ochraceolanatus), Coprinopsis phaeospora 
(C. phaeosporus), Coprinopsis strossmayeri (C. strossmayeri), Coprinopsis urticicola (C. urticicola), Coprinellis bisporiger (C. bisporiger), C.disseminatus, C. micaceus, Parasola setulosa (C. setulosus), Coprinus patouillardii, and Coprinellus plagioporus (C. plagiosporus)] observed once or more often fruiting on wood were also reported to form fruiting bodies on straw, grass and/or leaves. Unfourtunately, from all these observations very few strains were isolated and further studied in the laboratory (see below). This lack of isolates from the several fungi implies also that the identity of them could not be completely guarantied (Agerer et al. 2000). Several species have been so far found only on straw and/or grasses [Coprinopsis austrofriesii (Coprinus austrofriesii), Coprinopsis herinkii (Coprinus herinkii), Coprinopsis kubickae (Coprinus kubickae), Coprinopsis martinii (Coprinus martinii), and Coprinopsis pseudofriesii (Coprinus pseudofriesii)]. A variety of coprini are reported to grow on leaves of deciduous trees [Coprinopsis africana (Coprinus africanus), C. lagopus, Coprinopsis picacea (Coprinus picaceus), Coprinopsis stercorea (Coprinus stercoreus), Coprinopsis sylvicola (Coprinus sylvicola), C. bisporiger, Coprinellus callinus (Coprinus callinus), Coprinellus flocculosus (Coprinus flocculosus), Coprinellus subpurpureus (Coprinus subpurpureus), P. plicatilis, P. setulosa, Coprinus digitalis, Coprinus impatiens, C.patouillardii, C. plagioporus, C.ramosocystidiatus and C. saccharinus)]. In particular C. echinospora, Coprinopsis episcopalis (Coprinus episcopalis), and Coprinus giganteoporus are reported growing on Fagus leaves. These species confirm the capability of at least some coprini to degrade easily high cellulosecontent material.

Cellulose degrading ability in pure culture has been shown for C. atramentaria, as long as the wood (sycamore, birch) was pre-rotted (Mohammed and Dix 1988). Likewise, cellulose and lignin from straw was digested in pure culture by C.atramentaria (Mohammed and Dix 1988), indicating that the organism has a principal capacity to use lignocellulosic material and may function as a secondary wood rotter. In a 4 months trial under laboratory conditions at room temperature, C. disseminatus decayed the wood from lateral ash roots by $20.0 \%$, wood from sinkers by $15.3 \%$, sapwood from the butt by $4.2 \%$ and heartwood only by $2.7 \%$. Most interestingly, in all cases decay by C. disseminatus was stronger than that in parallel experiments with A. mellea (Domański 1984). Trials in our laboratory indicated that 10 out of 20 different coprini 
strains tested have the potential to grow at $28^{\circ} \mathrm{C}$ on beech sawdust and 5 of these also on poplar sawdust. Of all tested isolates, C. strossmayeri, C.micaceus, C. radians, C. xanthothrix and Coprinellus sp 1-2 PS strains were the best (Navarro-González unpublished, Chapter 3 of this thesis).

Pathogenic interactions with grasses, winter cereals and straw have repeatedly been documented with Coprinopsis psychromorbida (C. psychromorbidus). This species has succeeded as a pathogen, possibly based on the ability of fast growing at low temperature when most other fungi are restricted. However, the substrates for this species are less or not lignified which makes it easier to attack them (Redhead and Traquair 1981, Smith 1981, Sprague 1962, Traquair and McKeen 1986).

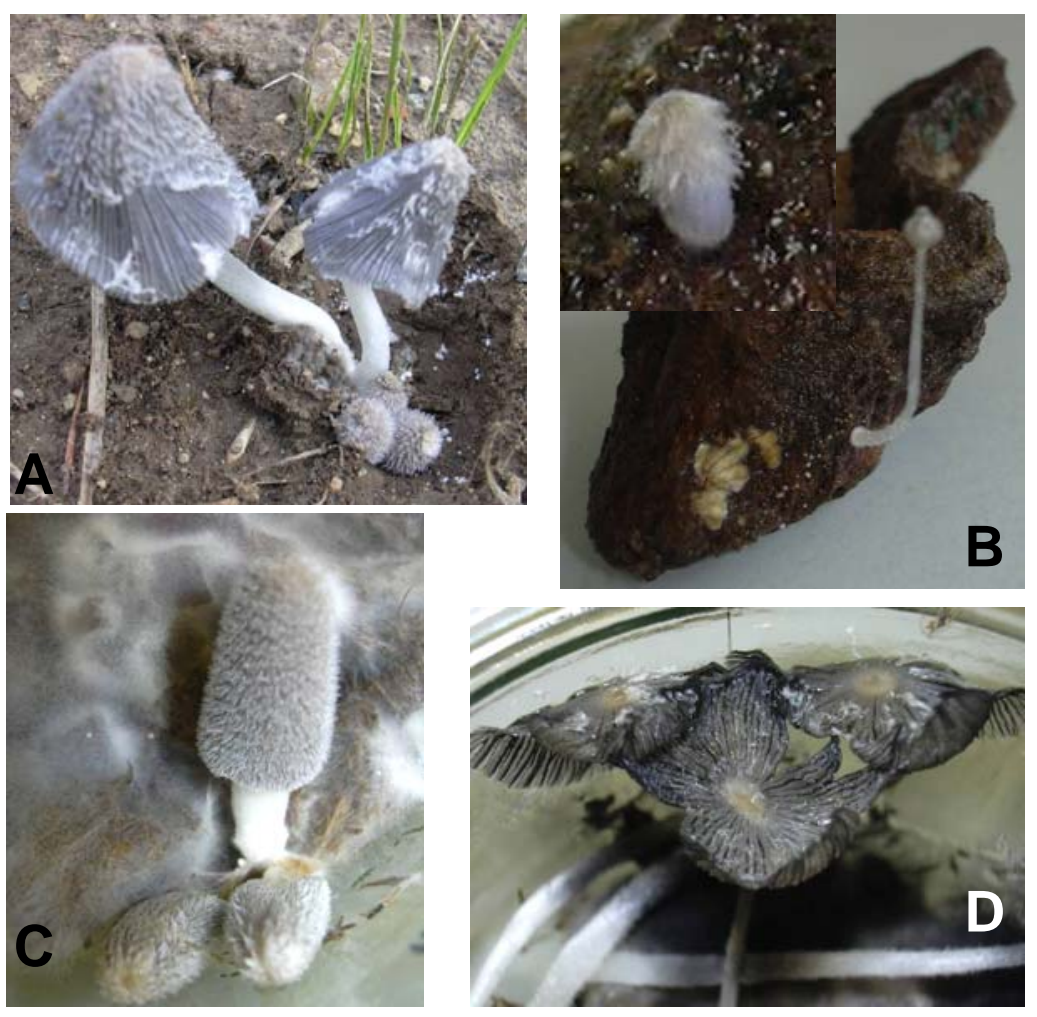

Figure 4 Coprinopsis lagopus (Coprinus lagopus) (about $6 \mathrm{~cm}$ in size) growing on a buried wood piece within soil in gardens of the North Campus of the Georg-Agust-University Göttingen (A). A piece of infested wood was taken to the laboratory and incubated in a moist chamber at room temperature in the normal day-light rythm. Within 3 days, a small fruiting body developed (B). A primordium at day 5 of development with a size of about $3 \mathrm{~mm}$ one day before maturation and autolysis is shown in the inset. From one of the mushrooms from the wild (A), an isolate was obtained and inoculated on horse dung. Vigorous fructifications emerged (C), maturated and autolysed (D). 
Table 1 Ocurrence of coprinoid mushrooms on wood and other plant material.

\begin{tabular}{|c|c|c|}
\hline \multicolumn{2}{|l|}{ Reclassified species $^{1}$} & \multirow[t]{2}{*}{ Observation(s) } \\
\hline Current name & Old name & \\
\hline \multicolumn{3}{|l|}{ Genus Coprinus } \\
\hline \multirow[t]{2}{*}{ Coprinus comatus } & Coprinus comatus & $\begin{array}{l}\text { Able to utilize cellulose and lignin in straw, cellulose in pre-white rotted but not in } \\
\text { sound sycamore or birch wood; utilizes probably non-woody plant debris as its } \\
\text { resources (Mohamed and Dix 1988), fruiting bodies on stumps [Byelorussia } \\
\text { (Serjanina and Yashkin 1986)] }\end{array}$ \\
\hline & Coprinus sterquilinus & Fruiting bodies on straw [Michigan (Kauffman 1918)] \\
\hline \multicolumn{3}{|l|}{ Genus Coprinopsis } \\
\hline Coprinopsis acuminata & Coprinus acuminatus & $\begin{array}{l}\text { Fruiting bodies in sandy soils with branches of deciduous trees [Switzerland (Griesser } \\
\text { 1992)], on very damp rotten wood [UK (Orton 1969)] }\end{array}$ \\
\hline Coprinopsis ammophilae & Coprinus ammophilae & $\begin{array}{l}\text { Fruiting bodies in groups on dead leaves of Ammophila arenaria [Netherlands, } \\
\text { France (Uljé and Noordeloos 1996)] }\end{array}$ \\
\hline Coprinopsis alutaceivelata & Coprinus alutaceivelatus & Fruiting bodies in bunches on soil and conifer needles [USA (Van de Bogart 1979)] \\
\hline Coprinopsis argentea & Coprinus argenteus & Fruiting bodies on grass [Canada (Redhead and Traquair 1981)] \\
\hline Coprinopsis atramentaria & Coprinus atramentarius & $\begin{array}{l}\text { Fruiting bodies in bunches in fertile soil, partially connected to roots of trees [Italy } \\
\text { (Bresadola 1931)], on roots of Quercus, Fraxinus and Salix spp. [Sweden (Fries 1828, } \\
\text { Fries 1838), some originally described as C. deliquescens and C. fuscescens (Orton } \\
\text { and Watling 1979)], on Populus, Fraxinus, Salix [Kazakhstan (Samgina 1985)], } \\
\text { amongst grass, against the exterior of a hollow stump of Salix sp. [South Africa (Reid } \\
\text { and Eicker 1999)], at the base of dead stumps of Salix [Switzerland (Griesser 1992), }\end{array}$ \\
\hline
\end{tabular}


Table 1 continued

\begin{tabular}{|c|c|c|}
\hline & & $\begin{array}{l}\text { Russia (Vasilieva 1979)], near Fagus [Austria (Karash 2001)], connected with the } \\
\text { upper tissues of an Ulmus spp. trunk [Russia (Ivanov 1985)], on timber in storage } \\
\text { [South Africa (Doidge 1950)], on partly buried stumps of poplars, logs, gate posts, } \\
\text { fences [Canada (Buller 1910), UK (Buller 1910), Germany (Runge 1982), Spain } \\
\text { (Saiz-Jimenez 1983), Turkey (Demirel and Nacar 2000, Kasik et al. 2000), Russia } \\
\text { (Ivanov 1989)], common at the base of standing aspen trees and stumps, associated } \\
\text { with butt rot, heart rot in hardwoods; possibly a brown cubical rot parasite in outer } \\
\text { sapwood in lower stems, butts and roots [USA (Gilbertson 1981, Lindsey and } \\
\text { Gilbertson 1978, Mitchel and Smith 1978, Ross 1976)]; mycelial culture isolated } \\
\text { from stump of Populus tremula [Estonia (Hanso and Hanso 1992)]; able to utilize } \\
\text { cellulose and lignin in straw, cellulose in pre-white rotted but not sound sycamore or } \\
\text { beech wood; may grow on buried wood functioning as a secondary wood rot } \\
\text { (Mohamed and Dix 1988) }\end{array}$ \\
\hline Coprinopsis austrofriesii & Coprinus austrofriesii & $\begin{array}{l}\text { Fruiting bodies on dead grasses on lawn [Venezuela (Uljé and Noordeloos 1996)], on } \\
\text { leaf litter of Typha and Carex [Canada (Redhead and Traquair 1981)] }\end{array}$ \\
\hline Coprinopsis bubalina & Coprinus bubalinus & $\begin{array}{l}\text { Fruiting bodies solitary or in small clusters on walnut and mulberry slash, lignicolous } \\
\text { [western North America (Van de Bogart 1979)] }\end{array}$ \\
\hline $\begin{array}{l}\text { Coprinopsis } \\
\text { brunneofibrillosa }\end{array}$ & Coprinus brunneofibrillosus & $\begin{array}{l}\text { Fruiting body solitary on fallen mahogamy fruits [Martinique (Pegler 1983)], on } \\
\text { decaying vegetable matter, on old fallen twig, on stumps [Sri Lanka (Pegler 1986)] }\end{array}$ \\
\hline Coprinopsis calospora & Coprinus calosporus & $\begin{array}{l}\text { Tufts of fruiting bodies against stem of Yucca in flowerpot [Netherlands (Uljé and } \\
\text { Noordeloos 1993)] }\end{array}$ \\
\hline
\end{tabular}


Table 1 continued

\begin{tabular}{|c|c|c|}
\hline Coprinopsis cinerea & $\begin{array}{l}\text { Coprinus cinereus } \\
\text { (=Coprinus fimentarius, } \\
\text { Coprinus macrorhizus) }\end{array}$ & $\begin{array}{l}\text { Fruiting bodies abundant in dung, in fertile soil and on trunks (Fries 1838), solitary or } \\
\text { loosely clustered on rotting hay and straw, forest litter, wood chips, hard wood sticks, } \\
\text { twigs and stumps [western North America (Van de Bogart 1979)], on grass tufts in } \\
\text { greenhouse and on decayed grass [South Africa (Doidge 1950)], common in } \\
\text { decomposing sisal waste [Tanzania (Härkönen et al. 1993)], on shredded straw of } \\
\text { elephant grass supplemented with pig manure in succession to zygomycetes, } \\
\text { ascomycetes and mitosporic fungi (Klamer and Sochting 1998); in wooden clogs } \\
\text { (English 1995), on wet and discoloured seed cotton, associated with cotton module } \\
\text { rot [Australia (Allen and Young 1993)], culture isolated from paper samples [France } \\
\text { (Guirad et al. 1999)], growth on wheat and mustard straw ["Karnal process" } \\
\text { (Chaturvedi et al. 2000, Prasad et al. 1990, Singh and Rai 1992, Singh et al. 1990)] }\end{array}$ \\
\hline Coprinopsis coniophora & Coprinus coniophorus & $\begin{array}{l}\text { Fruiting bodies in clusters on and around stumps of deciduous trees [Netherlands } \\
\text { (Uljé and Noordeloos 1997)] }\end{array}$ \\
\hline Coprinopsis cubensis & Coprinus cubensis & Fruiting body solitary on rotten log [Cuba (Pegler 1983)] \\
\hline Coprinopsis echinospora & Coprinus echinosporus & $\begin{array}{l}\text { Fruiting bodies in small groups on wood (Europe), on old leaves of Fagus } \\
\text { [Netherlands (Orton 1957, Uljé and Noordeloos 1996, Uljé and Noordeloos 1997)], } \\
\text { on buried branches [France (Kühner and Romagnesi 1953)] }\end{array}$ \\
\hline Coprinopsis episcopalis & Coprinus episcopalis & Fruiting bodies usually solitary among leaves of Fagus [England (Orton 1957)] \\
\hline Coprinopsis erythrocephala & Coprinus erythrocephalus & $\begin{array}{l}\text { Fruiting body solitary or in tufts on fallen small branches and sawdust [Germany } \\
\text { (Bender and Enderle 1988)] }\end{array}$ \\
\hline Coprinopsis fibrillosa & Coprinus fibrillosus & Fruiting bodies on fallen rotting tree trunk [Uganda (Pegler 1977)] \\
\hline
\end{tabular}


Table 1 continued

\begin{tabular}{|c|c|c|}
\hline Coprinopsis friesii & Coprinus friesii & $\begin{array}{l}\text { Fruiting bodies on plant debris, occasionally on rotten branches [Czechoslovakia } \\
\text { (Pilát and Svrček 1967)], on Artemisia [Russia (Vasilieva 1979)], on grass debris } \\
\text { [France (Kühner and Romagnesi 1953)] }\end{array}$ \\
\hline Coprinopsis geesterani & Coprinus geesterani & $\begin{array}{l}\text { Fruiting bodies solitary or in tufts on soil mixed with pieces of wood, on decaying } \\
\text { wood chips, on composted vegetable refuse [Netherlands (Uljé 1992)] }\end{array}$ \\
\hline Coprinopsis goudensis & Coprinus goudensis & $\begin{array}{l}\text { Fruiting bodies on a stump of Acer pseudoplanatus [Netherlands (Uljé and Bas } \\
\text { 1993)] }\end{array}$ \\
\hline Coprinopsis herinkii & Coprinus herinkii & $\begin{array}{l}\text { Fruiting bodies on dead grasses [Czechoslovakia (Pilát and Svrček 1967), Germany } \\
\text { (Uljé and Noordeloos 1997)] }\end{array}$ \\
\hline Coprinopsis insignis & $\begin{array}{l}\text { Coprinus insignis } \\
\text { (=Coprinus alopecia) }\end{array}$ & $\begin{array}{l}\text { Fruiting bodies on trunks of Quercus (Fries 1838), in a hollow beech stump [UK } \\
\text { (Reid 1958)], on wood [Michigan (Kauffman 1918)] }\end{array}$ \\
\hline Coprinopsis jamaicensis & Coprinus jamaicensis & $\begin{array}{l}\text { Fruiting bodies on fallen wood (Kenya), on decaying log (Tanzania), on decorticated } \\
\text { wood [Trinidad (Pegler 1977)], on decayed palm trunk [Jamaica (Pegler 1977)] }\end{array}$ \\
\hline Coprinopsis jonesii & Coprinus jonesii & $\begin{array}{l}\text { Solitary or in groups on burned areas, wood chips, or vegetable refuse [Europe, } \\
\text { America (Uljé and Noordeloos 1996)] }\end{array}$ \\
\hline Coprinopsis kimurae & Coprinus kimurae & $\begin{array}{l}\text { Fruiting bodies on straw in greenhouses, rice straw and on rotting coconut mattings, } \\
\text { lime ceilings mixed with straw, cotton textiles [Europe, Canada, Japan (Uljé and } \\
\text { Noordeloos 1997)] }\end{array}$ \\
\hline Coprinopsis krieglsteineri & Coprinus krieglsteineri & $\begin{array}{l}\text { Solitary or a few together on paths with wood chips [Germany, Netherlands (Uljé and } \\
\text { Noordeloos 1996)] }\end{array}$ \\
\hline Coprinopsis kubickae & Coprinus kubickae & $\begin{array}{l}\text { Fruiting bodies solitary or a few together on dead Phragmites, Juncus and Carex, in } \\
\text { greenhouses on rotten straw [Europe (Pilát and Svrček 1967), Belgium (De Meulder }\end{array}$ \\
\hline
\end{tabular}


Table 1 continued

\begin{tabular}{|c|c|c|}
\hline & & 1998)] \\
\hline Coprinopsis laanii & Coprinus laanii & $\begin{array}{l}\text { Fruiting bodies on stumps of Populus canadiensis in succession to primary invaders } \\
\text { [Germany (Runge 1975, 1982, 1986)] }\end{array}$ \\
\hline Coprinopsis lagopides & Coprinus lagopides & $\begin{array}{l}\text { Fruiting bodies on burned places, coaled wood [Poland (Sadowska 1988)], solitary or } \\
\text { in groups on woody debris in soil, most often on rotting stumps of Acer } \\
\text { macrophyllum [western North America (Van de Bogart 1979)], in clusters under } \\
\text { poplars, on burned stumps and charred wood, on plaster ceilings [UK (Orton 1957)], } \\
\text { very rotten wood [Michigan (Kauffman 1918)] }\end{array}$ \\
\hline Coprinopsis lagopus & Coprinus lagopus & $\begin{array}{l}\text { Fruiting bodies on decaying wood, in sandy soils [Switzerland, Germany (Griesser } \\
\text { 1992, Navarro-González 2006, Figure 4)], on wood chips [Poland (Sadowska 1988)], } \\
\text { on wood and fallen leaves [Armenia (Melik-Khachatryan 1980), Kazakhstan } \\
\text { (Samgina 1985)], on citrus waste supplemented with calcium hydroxide during and } \\
\text { after the final phases of composting [Tanzania (Van Heerden et al. 2002)], on fruits of } \\
\text { New Zealand spinach, on fruits or arils of Taxus cuspidata capitata, on the calyx and } \\
\text { bracts surrounding seeds of Scabiosa caucasica, and on glumes enclosing caryopses } \\
\text { of Agropyron species [New Mexico (Crosier et al. 1949)], fruiting body and } \\
\text { mycelium isolated from a thin layer of plywood under the cloth lining the door of an } \\
\text { automobile [Connecticut (Routien and Simonzi 1960)] }\end{array}$ \\
\hline Coprinopsis macrocephala & Coprinus macrocephalus & $\begin{array}{l}\text { Solitary or in groups on rotten hay or vegetable refuse [Netherlands (Uljé and } \\
\text { Noordeloos 1996)] }\end{array}$ \\
\hline Coprinopsis macropus & Coprinus macropus & $\begin{array}{l}\text { Fruiting bodies on fragments of decaying vegetable [Sri Lanka (Pegler 1986)], around } \\
\text { decaying tree stumps [Tanzania (Pegler 1977)] }\end{array}$ \\
\hline
\end{tabular}


Table 1 continued

\begin{tabular}{|c|c|c|}
\hline Coprinopsis marcida & Coprinus marcidus & $\begin{array}{l}\text { Solitary fruiting body on a piece of wood buried in a thick moss carpet on the floor of } \\
\text { a conifer forest [Montana (Van de Bogart 1979)] }\end{array}$ \\
\hline Coprinopsis martinii & Coprinus martinii & Fruiting bodies on Carex, Scirpus and Juncus debris [UK (Orton 1960)] \\
\hline Coprinopsis mexicana & Coprinus mexicanus & $\begin{array}{l}\text { Fruiting bodies on dead moss covered trunk, on logs [Mexico, Trinidad (Pegler } \\
\text { 1983)] }\end{array}$ \\
\hline Coprinopsis ochraceolanata & $\begin{array}{l}\text { Coprinus ochraceolanatus } \\
\text { (=Coprinus citrinovelatus) }\end{array}$ & $\begin{array}{l}\text { Fruiting bodies in tufts on sandy clay with much humus and deciduous forest litter, on } \\
\text { wood chips, near old stump of tree [Netherlands, Germany (Uljé and Bas 1993, Uljé } \\
\text { and Noordeloos 2000)] }\end{array}$ \\
\hline Coprinopsis pachyderma & Coprinus pachydermus & $\begin{array}{l}\text { Fruiting bodies in loose groups on an open compost pile of rotting wood chips and } \\
\text { sawdust [Washington (Van de Bogart 1979)] }\end{array}$ \\
\hline Coprinopsis paleotropica & Coprinus paleotropicus & $\begin{array}{l}\text { Fruiting bodies solitary on fallen Macaranga twig, on dead fallen twig [Kenya } \\
\text { (Pegler 1977), originally described as C. urticicola (Redhead and Traquair 1981)] }\end{array}$ \\
\hline Coprinopsis phaeospora & Coprinus phaeosporus & $\begin{array}{l}\text { Fruiting bodies on grass litter, on branches of deciduous trees (litter of Clematis and } \\
\text { Rubus) [Switzerland (Griesser 1992)], on decaying grasses [Finland (Uljé and } \\
\text { Noordeloos 1996)], on wood chips [France (Kühner and Romagnesi 1953)] }\end{array}$ \\
\hline Coprinopsis phlyctidospora & Coprinus phlyctidosporus & $\begin{array}{l}\text { Fruiting bodies on wood, generally on dead branches on the ground, also on burned } \\
\text { places [Europe, Japan (Uljé and Noordeloos 1997)]; mycelial growth on oak leaves } \\
\text { litter medium (Soponsathien 1998) }\end{array}$ \\
\hline Coprinopsis picacea & Coprinus picaceus & Fruiting bodies on leaves [Poland (Sadowska 1988), Ukraine (Zerova et al. 1979)] \\
\hline Coprinopsis pseudofriesii & Coprinus pseudofriesii & $\begin{array}{l}\text { Fruiting bodies on fragments of Juglans regia [Czechoslovakia (Pilát and Svrček } \\
\text { 1967)] }\end{array}$ \\
\hline
\end{tabular}


Table 1 continued

\begin{tabular}{|c|c|c|}
\hline $\begin{array}{l}\text { Coprinopsis } \\
\text { psychromorbida }\end{array}$ & Coprinus psychromorbidus & $\begin{array}{l}\text { Cottony snow mold on winter cereals, fall rye, grasses, and forage legumes (Canada, } \\
\text { Alaska); infection of winter wheat leaves shown (Broadfoot and Cormack 1941, } \\
\text { Cormack 1948, Cormack 1952, Gaudet and Kokko 1985, Gossen 1994, Gossen and } \\
\text { Reiter 1989, Lebeau and Logsdon 1958, Redhead and Traquair 1981, Smith 1981, } \\
\text { Sprague 1962, Traquair and McKeen 1986); possibly isolated from living winter } \\
\text { wheat roots [UK (Hall 1987)]; causes winter crown rot of alfalfa, injuries on alfalfa } \\
\text { and other forage legumes (Canada); infection of alfalfa crown buds shown (Gaudet } \\
\text { and Kokko 1985, Gossen 1989, Gossen et al. 1992, Spotts et al. 1981), cause of post } \\
\text { harvest rot of stored apples and pears [British Columbia, Oregon (Gaudet and } \\
\text { Sholberg 1990, Gaudet et al. 1989, Gaudet et al. 1990, Meheriuk and McPhee 1984, } \\
\text { Sholberg and Gaudet 1992, Spotts et al. 1981)] }\end{array}$ \\
\hline Coprinopsis rugosobispora & Coprinus rugosobisporus & Fruiting bodies on dead branches of Acer (Geesink and Imler 1979) \\
\hline Coprinopsis scobicola & $\begin{array}{l}\text { Coprinus scobicola } \\
(=\text { Coprinus bilanatus })\end{array}$ & $\begin{array}{l}\text { Fruiting body on begonia leaf cultures [Israel (Ross and Margalith 1987)]; on sawdust } \\
\text { [UK (Orton 1972)] }\end{array}$ \\
\hline Coprinopsis spelaiophila & $\begin{array}{l}\text { Coprinus spelaiophilus } \\
\text { (=Coprinus extinctorius) }\end{array}$ & $\begin{array}{l}\text { Fruiting bodies in soil in close relationship to roots of Fraxinus [Sweden (Fries } \\
\text { 1838)], solitary or a few together on wood, often in wounds of living deciduous trees } \\
\text { and on rotten stumps [Netherlands (Uljé and Noordeloos 1999), Europe (Enderle and } \\
\text { Bender 1990), Kazakhstan (Samgina 1985), Russia (Vasilieva 1979), Ukraine (Zerova } \\
\text { et al. 1979)] }\end{array}$ \\
\hline Coprinopsis stercorea & Coprinus stercoreus & Fruiting bodies on fallen leaves [Switzerland (Griesser 1992)] \\
\hline Coprinopsis strossmayeri & $\begin{array}{l}\text { Coprinus strossmayeri } \\
\text { (=Coprinus rhizophorus) }\end{array}$ & $\begin{array}{l}\text { Fruiting bodies in tufts on wood or woody remnants of broad-leaves trees [Europe, } \\
\text { Japan (Enderle and Bender 1990, Uljé and Noordeloos 1997)], on woody debries }\end{array}$ \\
\hline
\end{tabular}


Table 1 continued

close to Fraxinus sp. and Platanus orientalis [Armenia (Badalyan et al. in preparation)]

\begin{tabular}{lll}
\hline Coprinopsis subtigrinella & Coprinus subtigrinellus & Fruiting body on dead Arundo donax [Venezuela (Uljé and Noordeloos 1996)] \\
\hline Coprinopsis sylvicola & Coprinus sylvicola & Fruiting bodies on leaves and debris among chunks of rotten conifer wood lying on \\
soil in mixed forest [Oregon (Van de Bogart 1979)]
\end{tabular}


Table 1 continued

\begin{tabular}{|c|c|c|}
\hline Coprinellus angulatus & Coprinus angulatus & Fruiting bodies on charcoal [Byelorussia (Serjanina and Yashkin 1986)] \\
\hline $\begin{array}{l}\text { Coprinellus } \\
\text { aureogranulatus }\end{array}$ & Coprinus aureogranulatus & $\begin{array}{l}\text { Fruiting bodies on dead branches, sometimes seemingly on soil [Papua New Guinea } \\
\text { (Uljé et al 1998)] }\end{array}$ \\
\hline Coprinellus bisporiger & Coprinus bisporiger & $\begin{array}{l}\text { Fruiting bodies in woods among leaves and on fallen branches [Netherlands, } \\
\text { Germany, UK (Uljé and Bas 1991)] }\end{array}$ \\
\hline Coprinellus bisporus & Coprinus bisporus & Fruiting bodies in bunches on decaying straw [Netherlands (Uljé and Bas 1991)] \\
\hline Coprinellus callinus & Coprinus callinus & $\begin{array}{l}\text { Fruiting bodies on sandy soil with wood pieces and fallen leaves [Switzerland } \\
\text { (Griesser 1992)]; at or near wood fragments, particularly on paths covered with chips, } \\
\text { on sawdust [Netherlands, Germany (Enderle and Bender 1990, Uljé and Bas 1991)], } \\
\text { on wood [France (Kühner and Romagnesi 1953)] }\end{array}$ \\
\hline Coprinellus congregatus & Coprinus congregatus & Fruiting bodies on decaying stumps, fallen branches [Kazakhstan (Samgina 1985)] \\
\hline Coprinellus disseminatus & Coprinus disseminatus & $\begin{array}{l}\text { Fruiting bodies occur on or close to a wide range of deciduous trees (Dix and Webster } \\
\text { 1995), branches, above buried wood, at the base of dead stumps of Alnus and Salix } \\
\text { [Switzerland (Griesser 1992)], on rotting cherry wood alone or together with } \\
\text { Myxomycetes [Poland (Stojanowska 1981)], on dead stump of Acacia xanthophloea, } \\
\text { amongst leaf litter in Juniperus procera plantation, on dead bark, in large numbers on } \\
\text { rotting and very rotten stumps, logs and twigs [Kenya, Tanzania, Uganda (Pegler } \\
\text { 1977), Martinique, Trinidad (Pegler 1983) ], on degraded logs [Poland (Sadowska } \\
\text { 1988)], on and near wood [Netherlands (Uljé and Bas 1991)], on old wood [Sri Lanka } \\
\text { (Pegler 1986)], on old stumps, on manufactured wood [Armenia (Melik-Khachatryan } \\
\text { 1980), Kazakhstan (Samgina 1985)], on bark of elms and on aspen [Russia (Ivanov } \\
\text { 1981, Ivanov 1985)], on stumps after fire [Ukraine (Zerova et al. 1979)], on stumps of }\end{array}$ \\
\hline
\end{tabular}


Table 1 continued

\begin{tabular}{|c|c|c|}
\hline & & $\begin{array}{l}\text { Populus canadiensis and Tilia species in succession to primary invaders [Germany } \\
\text { (Runge 1975, 1982, 1986)], on stump and decayed leaves of Populus [Turkey (Kasik } \\
\text { 1994)], at the base of infected aspen trees, together with Armillaria cause of butt rots } \\
\text { on ash trees, infects Alnus glutinosa, causes brown rot of deciduous trees either alone } \\
\text { or together with white rot species Resinicium bicolor or Heterobasidion annosum, } \\
\text { cultures isolated from root collar [Poland (Domański 1983, Domański 1984)] and } \\
\text { stump of P. tremula [Estonia (Hanso and Hanso 1992)] }\end{array}$ \\
\hline Coprinellus domesticus & Coprinus domesticus & $\begin{array}{l}\text { Fruiting bodies on and close to wood of deciduous trees, in sandy soil [Switzerland } \\
\text { (Griesser 1992)], on wood [Russia (Denisova 1982)], on decaying stumps [Ukraine } \\
\text { (Zerova et al. 1979)], on dead twigs and fallen branches on forest floors, at the base of } \\
\text { old rotting trunks, on roots of living Eucalyptus [Kenya, Tanzania, Uganda (Pegler } \\
\text { 1977)], on manufactured wood (furniture) [Armenia (Melik-Khachatryan 1980)] }\end{array}$ \\
\hline Coprinellus ephemerus & Coprinus ephemerus & Fruiting bodies in groups on decaying straw [Netherlands (Uljé and Bas 1991)] \\
\hline Coprinellus eurysporus & Coprinus eurysporus & Fruiting bodies in groups on fallen branches [Oregon (Uljé and Bas 1991)] \\
\hline Coprinellus flocculosus & Coprinus flocculosus & $\begin{array}{l}\text { Fruiting bodies on sawdust, stumps and branches of deciduous trees, leaves [Germany } \\
\text { (Bender and Enderle 1988), France (Kühner and Romagnesi 1953)] }\end{array}$ \\
\hline Coprinellus furfurellus & Coprinus furfurellus & Fruiting bodies on dead wood [Sri Lanka (Pegler 1986)] \\
\hline Coprinellus heterothrix & Coprinus heterothrix & $\begin{array}{l}\text { Fruiting bodies in groups on mossy soil and branches [Netherlands (Uljé and Bas } \\
\text { 1991)], on wood [France (Kühner and Romagnesi 1953)] }\end{array}$ \\
\hline Coprinellus hiascens & Coprinus hiascens & $\begin{array}{l}\text { Fruiting bodies on small wood pieces [Germany (Enderle et al. 1986)], near Ulmus } \\
\text { [Kazakhstan (Samgina 1985)] }\end{array}$ \\
\hline
\end{tabular}


Table 1 continued

\begin{tabular}{|c|c|c|}
\hline & & $\begin{array}{l}\text { Romagnesi 1953)], near Fagus, Quercus [Armenia (Melik-Khachatryan 1980), } \\
\text { Kazakhstan (Samgina 1985)] }\end{array}$ \\
\hline Coprinellus marculentus & Coprinus marculentus & On mixtures of straw, decaying grass [Netherlands (Uljé and Bas 1991)] \\
\hline Coprinellus micaceus & Coprinus micaceus & $\begin{array}{l}\text { Fruiting bodies worldwide very frequently in larger groups on fertile soil, at the base } \\
\text { of trees, on wood pieces (Bresadola 1931), on buried wood [Russia (Ivanov 1989)], } \\
\text { decaying stumps [Ukraine (Zerova et al. 1979)], living Fraxinus [Austria (Brunswik } \\
\text { 1924)], standing trees, roots, stumps of Ulmus [Russia (Vasilieva 1979)], wood and } \\
\text { stumps of birch [Germany (Brunswik 1924), Finland (Hintikka and Korhonen 1970)], } \\
\text { old rotting trunks [Tanzania (Pegler 1977)], on living trees of Acer platanoides and } \\
\text { Robinia pseudoacacia [Germany (Navarro-González 2006-2007, unpublished. Figure } \\
1 \text { and 3)], on a broad-leaved stump [Turkey (Demirel and Nacar 2000)], beech logs } \\
\text { [UK (Chapela et al. 1988)], decaying logs of hardwood [Poland (Sadowska 1988)], on } \\
\text { soil near tree stumps [South Africa (Doidge 1950)], close to Fagus [Germany (Karash } \\
\text { 2001)], on Betula, Populus, Quercus, Salix, Ulmus [Russia (Lubarsky and Vasilieva } \\
\text { 1975, Samgina 1985), Azerbaijan (Sadikhov 1968), Mongolia (Uranchimeg 1983)], } \\
\text { on elm and willow trees, connected with an Ulmus sp. trunk [Russia (Ivanov 1981, } \\
\text { Ivanov 1985)], on rotten leaves of Ulmus and Acer spp. [Turkey (Kasik 1994)], in } \\
\text { succession to primary invaders on stumps of Tilia sp. [Germany (Runge 1975)], } \\
\text { growing from the roots of Acacia xanthophloea [Kenya (Pegler 1977)], associated } \\
\text { with hardwood stumps and their decay (aspen) [USA (Gilbertson 1981, Lindsey and } \\
\text { Gilbertson 1978)], on stumps of Aesculus, Fagus, Populus, Salix and Ulmus in } \\
\text { exceptional cases parasite on stumps and roots of Fraxinus, Grossularia and Robinia }\end{array}$ \\
\hline
\end{tabular}


Table 1 continued

\begin{tabular}{|c|c|c|}
\hline & & $\begin{array}{l}\text { [Germany (Kreisel 1979), Russia (Burova 1986)], at the base of collapsed and living } \\
\text { trees of Poncirus trifoliata, culture has been isolated from brown discoloured wood of } \\
\text { affected trees, dry root rot is associated with temporary water logging and poor soil } \\
\text { aeration [New South Wales (Broadbent and Fraser 1977, Shearman et al. 1996)]; } \\
\text { culture isolated from Populus tremuloides, stringy white rot of living aspen (heart } \\
\text { rot), sugar maple, yellow birch [Ontario (Basham 1958, Basham and Morawski } \\
\text { 1964)], culture isolated from a living Salix viminalis [France (Guirad et al. 1999)] }\end{array}$ \\
\hline Coprinellus plagioporus & Coprinus plagioporus & $\begin{array}{l}\text { Fruiting bodies in bunches in soils and in paths covered with wood chips [Netherlands } \\
\text { (Uljé and Bas 1991)], on small branches, sawdust and rotting leaves [Germany } \\
\text { (Enderle and Bender 1990)], on twigs [France (Kühner and Romagnesi 1953)] }\end{array}$ \\
\hline Coprinellus pyrrhantes & Coprinus pyrrhanthes & Fruiting bodies on old sawdust [Germany (Uljé and Bas 1991)] \\
\hline Coprinellus radians & Coprinus radians & $\begin{array}{l}\text { Culture isolated from Populus deltoides and Salix nigra pulp wood logs; classified as } \\
\text { white rot-fungus [Georgia (Bois and Eslyn 1966, Eslyn and Lombard 1984)]; fruiting } \\
\text { bodies on and mycelial isolations from Betula in succession to micromycetes } \\
\text { [Chechenia (Zarudnaya and Minkevich 1986)], on wood after fire [Ukraine (Zerova et } \\
\text { al. 1979)] }\end{array}$ \\
\hline $\begin{array}{l}\text { Coprinellus } \\
\text { sclerocystidiosus }\end{array}$ & Coprinus sclerocystidiosus & $\begin{array}{l}\text { Fruiting bodies in groups terrestrial on lawns, also on wood chips [Germany (Enderle } \\
\text { and Bender 1990), Netherlands (Uljé and Bas 1991)] }\end{array}$ \\
\hline Coprinellus subdisseminatus & Coprinus subdisseminatus & $\begin{array}{l}\text { Fruiting bodies on or near branches in very wet places [Netherlands (Uljé and Bas } \\
\text { 1991)], on twigs [France (Kühner and Romagnesi 1953)] }\end{array}$ \\
\hline Coprinellus subimpatiens & Coprinus subimpatiens & Fruiting bodies amongst forest debris [Tanzania (Pegler 1977)] \\
\hline & & \\
\hline
\end{tabular}


Table 1 continued

\begin{tabular}{|c|c|c|}
\hline & & Bas 1991)] \\
\hline Coprinellus truncorum & Coprinus truncorum & $\begin{array}{l}\text { Fruiting bodies solely or in groups on trunks, roots and buried wood, especially of } \\
\text { willow trees [Sweden (Fries 1838), Europe, Africa, Australia (Bresadola 1931), } \\
\text { Russia (Ivanov 1989)], inside a hollow willow tree, on roots of dying Celtis africana, } \\
\text { on dead trunks of trees [South Africa (Doidge 1950, Reid and Eicker 1999), Armenia } \\
\text { (Melik-Khachatryan 1980)] }\end{array}$ \\
\hline Coprinellus velatopruinatus & Coprinus velatopruinatus & $\begin{array}{l}\text { Fruiting bodies usually in groups on old sawdust and small pieces of wood mixed } \\
\text { with soil [Germany (Uljé and Bas 1991)] }\end{array}$ \\
\hline Coprinellus verrucispermus & Coprinus verrucispermus & Fruiting bodies under aspen and alder trees [Germany (Bender et al. 1984)] \\
\hline Coprinellus xanthothrix & Coprinus xanthothrix & $\begin{array}{l}\text { Fruiting bodies on sandy soil with decaying wood, straw [Switzerland (Griesser } \\
\text { 1992)], close to Fagus [Germany (Karash 2001)], on fallen branches, standing trees } \\
\text { [Azerbaijan (Sadikhov 1968)], on trunks [France (Kühner and Romagnesi 1953)], on } \\
\text { living tree of Tilia cordata [Germany (Navarro-González 2006-2007, unpublished. } \\
\text { Figure 2)] }\end{array}$ \\
\hline \multicolumn{3}{|l|}{ Genus Parasola } \\
\hline Parasola auricoma & Coprinus auricomus & $\begin{array}{l}\text { Fruiting bodies on wet soil in association with small pieces of rotting wood, also on } \\
\text { older burned areas [Germany (Bender et al. 1984)] }\end{array}$ \\
\hline Parasola kuehneri & Coprinus kuehneri & $\begin{array}{l}\text { Fruiting bodies on wood of deciduous trees, in sandy soils [Switzerland (Griesser } \\
\text { 1992)] }\end{array}$ \\
\hline Parasola leiocephala & Coprinus leiocephalus & $\begin{array}{l}\text { Fruiting bodies in sandy soils with branches of deciduous trees [Switzerland (Griesser } \\
\text { 1992)], on very damp rotten wood [UK (Orton 1969)] }\end{array}$ \\
\hline Parasola lilatincta & Coprinus lilatinctus & Fruiting bodies on paths of clayey soil covered with wood chips, on debris of \\
\hline
\end{tabular}


Table 1 continued

\begin{tabular}{|c|c|c|}
\hline & & deciduous wood [Germany, Netherlands (Uljé and Bender 1997)] \\
\hline Parasola megasperma & Coprinus megaspermus & $\begin{array}{l}\text { Fruiting bodies on Betula, Quercus, Populus [Russia (Burova 1986, Burova and } \\
\text { Nezdoiminogo 1982)] }\end{array}$ \\
\hline Parasola plicatilis & Coprinus plicatilis & $\begin{array}{l}\text { Fruiting bodies in succession to several other fungi on stumps of Tilia spec. at the end } \\
\text { phase of decay [Germany (Runge 1975)], on fallen leaves [Russia (Vasilieva 1979)] }\end{array}$ \\
\hline \multirow[t]{12}{*}{ Parasola setulosa } & Coprinus setulosus & $\begin{array}{l}\text { Fruiting bodies on rotting stump, on fallen leaves [Uganda (Pegler 1977)], on dead } \\
\text { wood [Sri Lanka (Pegler 1986)] }\end{array}$ \\
\hline & Coprinus alnivorus & $\begin{array}{l}\text { Fruiting bodies on scarcely rotted wood of Alnus sp. in hardwood rain forest [North } \\
\text { America (Van de Bogart 1976)] }\end{array}$ \\
\hline & Coprinus amphibius & $\begin{array}{l}\text { Fruiting bodies obtained from wood submerged in alkali lakes [Canada (Anastasiou } \\
\text { 1967)] }\end{array}$ \\
\hline & Coprinus candidatus & $\begin{array}{l}\text { Fruiting bodies terrestrial on bare soil, sometimes on or against fallen branches } \\
\text { [Netherlands (Uljé 1988)] }\end{array}$ \\
\hline & Coprinus cardiasporus & Fruiting bodies on and between wood chips [Germany (Enderle et al. 1986)] \\
\hline & Coprinus castaneus & Fruting bodies amongst rotting straw [Sri Lanka (Pegler 1986)] \\
\hline & Coprinus cortinatus & Fruiting bodies on sandy soil with decaying wood [Switzerland (Griesser 1992)] \\
\hline & Coprinus cylindricus & Fruiting bodies in soil, connected to trunks [Sweden (Fries 1838)] \\
\hline & Coprinus dryophilus & Fruiting body on Quercus trunk [Tunisia (Pegler 1966)] \\
\hline & Coprinus digitalis & Fruiting bodies on decaying leaves [Ukraine (Zerova et al. 1979)] \\
\hline & Coprinus ebulbosus & $\begin{array}{l}\text { Fruiting bodies in groups on or close to decaying trees or stumps [Michigan } \\
\text { (Kauffman 1918)] }\end{array}$ \\
\hline & Coprinus gelatinosus & Fruiting bodies on dead, not long fallen branches of Acacia galpinii [South Africa \\
\hline
\end{tabular}


Table 1 continued

\begin{tabular}{|c|c|}
\hline & (Reid and Eicker 1999)] \\
\hline Coprinus giganteoporus & Fruiting bodies on leaves of Fagus [Netherlands (Uljé and Noordeloos 1996)] \\
\hline Coprinus lacunosus & Fruiting bodies on trunks of trees [Sweden (Fries 1838)] \\
\hline Coprinus laniger & Fruiting bodies in groups on or close to decaying wood [Michigan (Kauffman 1918)] \\
\hline Coprinus nemoralis & $\begin{array}{l}\text { Fruiting bodies solely or in small groups on branches and other pieces of wood } \\
\text { [Germany (Uljé and Noordeloos 1997)] }\end{array}$ \\
\hline Coprinus pachypus & Fruiting bodies on Cocos nucifera stump [Tanzania (Pegler 1977)] \\
\hline Coprinus paleocephalus & Fruiting bodies on bark of Artocarpus [Sri Lanka (Pegler 1986)] \\
\hline Coprinus pallidissimus & $\begin{array}{l}\text { Fruiting bodies at the base of Broussonetia papyrifera tree [France (Romangnesi } \\
\text { 1976)] }\end{array}$ \\
\hline Coprinus patouillardii & Fruiting bodies on fallen leaves with decaying wood [Switzerland (Griesser 1992)], \\
\hline & on wood chips [Germany (Enderle et al. 1986)] \\
\hline Coprinus pilosotomentosus & $\begin{array}{l}\text { Fruiting bodies in bunches on dying grass (stems of Festuca) [Germany (Enderle and } \\
\text { Bender 1990, Uljé and Noordeloos 1997)] }\end{array}$ \\
\hline Coprinus ramosocystidiatus & $\begin{array}{l}\text { Fruiting bodies on leaves and wood debris of poplar [Germany (Enderle and Bender } \\
\text { 1990)] }\end{array}$ \\
\hline Coprinus saccharinus & $\begin{array}{l}\text { Fruiting bodies at the base of trunks, at the base of heap of leaves and woody debris } \\
\text { [France (Romangnesi 1976)] }\end{array}$ \\
\hline $\begin{array}{l}\text { Coprinus silvaticus } \\
\text { (=Coprinus tergiversans) }\end{array}$ & $\begin{array}{l}\text { Fruiting bodies on decaying wood of deciduous trees (beech) or seemingly on soil } \\
\text { when rooting on buried wood [Germany (Bender et al. 1984)], on wood [Poland } \\
\text { (Sadowska 1988), Russia (Vasilieva 1979)] }\end{array}$ \\
\hline Coprinus soboliferus & Fruiting bodies on trunks [Sweden (Fries 1838)] \\
\hline
\end{tabular}


Table 1 continued

Coprinus suburticicola

Fruiting bodies on stems of dead Glyceria species [Czechoslovakia (Pilát and Svrček

1967)]

\section{Not identified coprini}

Coprinus spp.

Fruiting bodies associated with brown rot of living and dead Prunus spp., on soil

above decaying woods of Prunus dulcis [California (Adaskaveg and Ogawa 1990)],

on wood chips, on stems of flowering plants (Campanula, Rhinanthus, Gentiana,

Rhododendron) [Andorra (Uljé and Bas 1991)], fruiting bodies in groups or solitary on wood chips [Germany (Navarro-González 2007, unpublished, Figures 5 and 6)] in groups on branches embedded in mud, solitary or few together on wood chips, on fallen branches, on dead stems and leaves of herbs [Netherlands (Uljé and Bas 1991, Uljé and Noordeloos 1997)], on rice straw and cotton waste in mushroom beds [Thailand (Pitakpaivan et al. 1991)], on a beam in the ceiling of a cellar [Germany (Uljé and Noordeloos 1997)]; cultures isolated from paper samples [France (Guirad et al. 1999)], from wheat root [South Australia (Harris and Moen 1985)], from a white rot of Acer saccharum Marsh [Illinois (Watling and Miller 1973)], from inner tissues of senescent needles of Pinus silvestris, from needles from Pinus contorta, from a stump of a deciduous tree [Estonia, Latvia (Hanso and Hanso 1985, Hanso and Hanso 1992)]; fermentation of groundnut shells [India (Gupta et al. 1986)]

${ }^{1}$ Species are listed according to the new classification suggested by Redhead et al. (2001). In some cases, synonyms have also been added when used as such in cited literature. 


\subsection{Brown-rot or white-rot fungi?}

The plant cell-wall is in general a complex structure consisting of a variety of polymers like cellulose, hemicelluloses, lignin and also minor polymeric substances (starch, pectines and proteins). The amount of each varies between cell types, tissues and plant species (Wegener and Fengel 1983, Evans and Hedger 2001). Within wood, cell walls contain up to $20-30 \%$ lignin, 35-50\% cellulose and 20-30\% hemicellulose (Subramaniyan and Prema 2002). Based on preferential degradation of certain cell-wall structures, two basic forms of wood decay are known in homobasidiomycetes.

In white rot, lignin, cellulose and hemicellulose are degraded with the consequence that the wood bleaches. The white to pale coloured remnants of the wood have a spongy, stringy or laminated structure (Rayner and Boddy 1988, Blanchette 1991, Worall et al. 1997, Schwarze et al. 2000). In contrast, in brown rot lignin is not appreciably degraded but only slightly modified whereas cellulose is selectively removed. The modified lignin is responsible for the characteristic colour of brown-rotted wood. Because of the preferential degradation of cellulose and hemicellulose, the brown-rotted wood acquires a brittle, amorphous consistency, splits into cubes and finally disintegrates into a fine lignin powder (Green and Highley 1997, Schwarze et al. 2000). Brown-rot fungi are primarily associated with conifers whereas whiterot fungi tend to associate with broad-leaves trees (Gilbertson 1980, Hibbett and Donoghue 2001). Most decay occurs primarily on dead conifer wood including dead standing and fallen trees, stumps, logging slash, other dead wood on the ground, and wood in service.

Our collection of data (Table 1) presents only reports linking coprini species to deciduous trees, with the one exception of one species isolated from needles (Hanso and Hanso 1985). In most cases where the wood was identified, coprinoid mushrooms were growing on wood from trees of the families Salicaceae [Populus and Salix (C. atramentaria, C. laanii, Coprinopsis lagopides (Coprinus lagopides), Coprinopsis stangliana (C. stanglianus), C. disseminatus, $C$. micaceus, Coprinellus radians (Coprinus radians), C. truncorum, C. urticicola, Coprinellus verrucispermus (Coprinus verrucispermus), Parasola megasperma (Coprinus megaspermus and C. ramosocystidiatus)], Fagaceae [Fagus and Quercus (C. atramentaria, Coprinopsis insignis (Coprinus insignis), C.micaceus, C. megaspermus and Coprinus dryophilus)], Sapindaceae [Acer and Aesculus (Coprinopsis goudensis (Coprinus goudensis), C. lagopides, 
Table 2 Use of different species of wood by coprini.

\begin{tabular}{|c|c|c|c|c|c|c|c|c|}
\hline \multicolumn{2}{|c|}{ Type of wood } & \multirow[t]{3}{*}{ Durability $^{1}$} & \multicolumn{6}{|c|}{ Number of species } \\
\hline \multirow[t]{2}{*}{ Plant families } & \multirow{2}{*}{$\begin{array}{c}\text { Tree species } \\
\text { /other substrates }\end{array}$} & & \multirow{2}{*}{$\begin{array}{c}\text { Coprinaceae } \\
\text { Coprinus } \\
\text { (Total 3) }\end{array}$} & \multicolumn{4}{|c|}{ Psathyrellaceae } & \multirow{2}{*}{$\begin{array}{r}\text { Total } \\
(\sim 191)\end{array}$} \\
\hline & & & & $\begin{array}{c}\text { Coprinopsis } \\
\text { (Total 102) }\end{array}$ & $\begin{array}{c}\text { Coprinellus } \\
\text { (Total } \sim 42)\end{array}$ & $\begin{array}{c}\text { Parasola } \\
\text { (Total } \sim 18)\end{array}$ & $\begin{array}{c}\text { Not } \\
\text { Reclassified } \\
(\sim 26)\end{array}$ & \\
\hline \multirow[t]{2}{*}{ Betulaceae } & Alnus (alder) & 5 & - & - & 1 & - & 1 & 6 \\
\hline & Betula (birch) & 5 & - & - & 3 & 1 & - & 4 \\
\hline Cannabaceae & Celtis (hackberry) & $\mathrm{NC}$ & - & - & 1 & - & - & 1 \\
\hline \multirow{2}{*}{ Euphorbiaceae } & Hevea (rubber tree) & $\mathrm{NC}$ & - & 1 & - & - & - & 1 \\
\hline & Macaranga & $\mathrm{NC}$ & - & 1 & - & - & - & 1 \\
\hline \multirow[t]{2}{*}{ Fabaceae } & $\begin{array}{l}\text { Acacia (thorntrees, } \\
\text { wattles) }\end{array}$ & $\mathrm{NC}$ & - & - & 2 & - & 1 & 3 \\
\hline & Robinia & $1-2$ & - & - & 1 & - & - & 1 \\
\hline \multirow[t]{2}{*}{ Fagaceae } & Fagus (beech) & 5 & - & 2 & 1 & - & 1 & 4 \\
\hline & Quercus (oak) & $2-3$ & - & 2 & 1 & 1 & 1 & 5 \\
\hline Juglandaceae & Juglans (walnut) & 3 & - & 2 & - & - & - & 2 \\
\hline \multirow[t]{2}{*}{ Salicaceae } & Populus (aspen) & 5 & - & 4 & 4 & 1 & 1 & 10 \\
\hline & Salix (willow) & $\mathrm{NC}$ & - & 2 & 4 & - & - & 6 \\
\hline \multirow[t]{2}{*}{ Sapindaceae } & Acer (maple) & 5 & - & 3 & 1 & - & - & 4 \\
\hline & Aesculus (chestnut) & 5 & - & - & 1 & - & - & 1 \\
\hline Oleaceae & Fraxinus (ash tree) & 5 & - & 3 & 2 & - & - & 4 \\
\hline Ulmaceae & Ulmus (elm, nettle) & 4 & - & 2 & 2 & - & - & 4 \\
\hline Malvaceae & Tilia (lime) & 5 & - & - & 3 & 1 & - & 4 \\
\hline \multirow[t]{3}{*}{ Moraceae } & Artocarpus & $\mathrm{NC}$ & - & - & - & - & 1 & 1 \\
\hline & $\begin{array}{l}\text { Broussonetia } \\
\text { (paper mulberry) }\end{array}$ & $\mathrm{NC}$ & - & - & - & - & 1 & 1 \\
\hline & Mulberry & $\mathrm{NC}$ & - & 1 & - & - & - & 1 \\
\hline Myrtaceae & Eucalyptus & $1,2,5$ & - & - & 1 & - & - & 1 \\
\hline Rutaceae & Poncirus (orange) & $\mathrm{NC}$ & - & - & 1 & - & - & 1 \\
\hline
\end{tabular}


Table 2 continued

\begin{tabular}{|c|c|c|c|c|c|c|c|c|}
\hline Platanaceae & Platanus & $\mathrm{NC}$ & - & - & - & - & 1 & 1 \\
\hline \multicolumn{3}{|c|}{ Total species on wood substrates from known tree species } & 1 & 14 & 6 & 2 & 7 & 30 \\
\hline \multicolumn{3}{|c|}{$\%$ of species per fungal genus ${ }^{2}$} & $\sim 33 \%$ & $\sim 13 \%$ & $\sim \mathbf{1 4 \%}$ & $\sim \mathbf{1 1 \%}$ & $\sim 26 \%$ & $\sim \mathbf{1 5 \%}$ \\
\hline \multirow[t]{10}{*}{ Unknown } & Wood chips/sawdust & - & - & 15 & 10 & 2 & 2 & 29 \\
\hline & Roots & - & - & 6 & 3 & - & - & 9 \\
\hline & $\begin{array}{l}\text { Stumps, trunks, logs, } \\
\text { wood }\end{array}$ & - & 1 & 12 & 9 & 2 & 12 & 36 \\
\hline & Twigs, branches & - & - & 8 & 10 & 1 & 2 & 21 \\
\hline & $\begin{array}{l}\text { Standing trees, } \\
\text { parasites }\end{array}$ & - & - & 2 & 3 & - & - & 5 \\
\hline & Grasses* & - & - & 13 & 1 & - & 2 & 16 \\
\hline & Straw & - & 2 & 4 & 4 & - & 1 & 11 \\
\hline & Plant litter & - & - & 18 & 7 & 3 & 4 & 32 \\
\hline & Soil & - & - & 8 & 7 & 2 & 4 & 22 \\
\hline & Others** & - & - & 14 & 5 & 1 & 2 & 22 \\
\hline \multicolumn{3}{|c|}{$\%$ of species per fungal genus ${ }^{2}$} & $\sim 66 \%$ & $\sim 33 \%$ & $\sim 54 \%$ & $\sim 27 \%$ & $\sim 42 \%$ & $\sim 39 \%$ \\
\hline
\end{tabular}

${ }^{1}$ Durability of the wood against fungi according to the European Standar for Natural Duration of Wood EN 350-2 1994 (1= very durable, $2=$ durable, $3=$ moderate durable, $4=$ low durable, $5=$ not durable). $\mathrm{NC}=$ not classified.

${ }^{2}$ Percentages were calculated considering species reported to grow on wood (for details see Table 1) in relation to the number of the known species within a genus as reassigned by Readhead et al. (2001).

*Ammophilia arenaria, Typha, Carex, Phragmites, Juncus, Scirpus and Glyceria.

**Others = fruits (Mahogany, New Zealand spinach and Taxus cuspidata capitata), stem of plants (Yucca, Campanula, Rhinanthus, Gentiana and Rhododendro), calyx and bracts of Scabiosa causica, glumes of Agropyron sp., Agave sisalana and citrus waste, Cocos nucifera stump, needles of Pinus silvestris and P. contorta, Artemisia, Grossularia, Arundo donax, dung, paper, palm trunk, charcoal, coconut mattings, cotton textiles, plaster ceilings, plywood, forage legumes, begonia leaf cultures, corn stalks, manufactured wood, beam in the ceiling of a cellar, groundnut shells, wood clogs and cotton seeds. 
Coprinopsis rugosobispora (Coprinus rugosobisporus) and C. micaceus)], and Betulaceae [Alnus and Betula (C. disseminatus, C. micaceus and C. radians)]. Wood from species of these families tends to be non-durable (EN 350-2, 1994). Coprini have also been detected on non-durable wood species from the families Oleaceae [Fraxinus (C. atramentaria, C. spelaiophila, C. disseminatus and C. micaceus)], Ulmaceae [Ulmus (C. atramentaria, C. urticicola, Coprinellus hiascens (Coprinus hiascens) and C. micaceus)], Fabaceae [Acacia and Robinia (C.disseminatus, C.micaceus and Coprinus gelatinosus)] and Malvaceae [Tilia (C.disseminatus, C. micaceus and P. plicatilis)]. In a few other cases, such fungi were observed on more resistant wood of species from the families Juglandaceae, Euphorbiaceae, Moraceae, Cannabaceae, Myrtaceae and Rutaceae (Table 1 and 2).

Even though many species have been observed to grow on wood, in very few cases the kind of degradation was identified. Ross (1976) observed C. atramentaria on brown brittle wood and suggested the species to be a brown cubical rot parasite from aspen. Domański (1984) isolated C. disseminatus from infected Fraxinus roots. In experimental trials with this isolate he reported that the fungus caused brown rot. C. micaceus isolated from Populus tremuloides was shown to produce stringy white rot (Shields and Shih 1975). C. micaceus with an apparently broader wood degrading ability attacks several kinds of deciduos trees (Table 1 and 2).

In wood degradation, both the wood structure and the enzymatic potential of the fungi are important (Schwarze et al. 2000). Degradation of plant material needs enzymes attacking the various polymers residing in the plant cell wall. Complexes of cellulases (exo- and endocellulases) depolymerize cellulose fibrils, which leads to release of glucose and cellobiose. Most wood-rotting fungi produce also peroxidases, haemcontaining enzymes which catalize reduction of $\mathrm{H}_{2} \mathrm{O}_{2}$ by oxidation of different organic substrates specifically; they oxidize methoxil-substituents on non-phenolic aromatic rings present in lignin molecules. As peroxidases, laccases have the ability to oxidize phenolic compounds. In presence of oxygen these enzymes convert mono- and diphenolic groups to quinones (Evans and Hedger 2001). Certain peroxidases and laccases are enzymes known to contribute to degradation of lignin (Piontek et al. 2001). However, C. cinerea secreted peroxidase (CiP) was found to be unable to attack lignin (Petersen et al. 1994). 
Most white-rotting fungi produce extracellular phenol oxidases and generally give positive reactions in oxidase tests on gallic and tannic medium and with gum guaiacol or SGZ reagents (Nobles 1958, Harkin and Obst 1973). Brown-rot fungi unable to degrade lignin might not produce extracellular phenol oxidases and generally give negative reactions in oxidase tests on gallic and tannic acid medium and with gum guaiacol and SGZ reagents. In our hands, 16 strains from a total of 20 different, submitted to the gallic and tannic acid tests, showed phenoloxidase activity. Particularly strong reactions have been seen with $C$. strossmayeri, $C$. micaceus, and four different Coprinellus sp. strains (Badalyan et al. unpublished, Chapter 3).

Lignin degradation was demonstrated by dephenolisation of lignin medium for C. cinerea, C. ephemeroides and C. patouillardii, as well as cellulase action by utilization of carboxyl cellulose in cellulosic medium (Hedger and Basuki 1982). On wheat straw, cellulase, xylanase and laccase activity was detected for $C$. cinerea (C. fimentarius) (Puniya and Singh 1995). Degradation of cellulose and hemicellulose by $C$. cinerea in straw occurs after treatment of the substrate with ammonia which is made use in the Karnal process in the production of better digestible foods for ruminants (Burrows et al. 1979, Gupta et al.1986, 1988, 1992; Gupta and Singh 1991; Rai et al. 1989; Singh et al. 1995).

The findings within laboratories raise the question what are the hindrances to the fungi to act in wood and straw degradation in nature. Compared to other basidiomycetes, coprini including species $C$. atramentaria, $C$. disseminatus and C. micaceus tend to grow very fast on artificial media in the laboratory, both in terms of increase in colony sizes as well as production of aerial mycelium and general biomass (Badalyan, unpublished). On malt extract, $C$. disseminatus showed antagonisms over a wide temperature range towards H. annosum (Hanso and Hanso 1992). Whether this antagonism takes place on wooden substrate in nature is not known. However, due to the abundant spore production of $H$. annosum and its fast germination on wooden substrate (Woodward et al. 1998) it is possibly of minor importance since otherwise we might expect many more reports on $C$. disseminatus occupying such substrates in nature. Its antagonism towards $H$. annosum could be however exerted at later stages of decay in which nutrients are more freely available. Supportive evidence was found in composting where $C$. cinerea as species with slight ligninolytic ability exhibited 
antagonistic reactions against various other fungi colonizing the same ecological niche (Hedger and Basuki 1982).

Despite a growth advantage on easily accessible medium, an invasion ability of compact wood by coprini species might be underdeveloped. Striking appear the increasing reports on fruiting bodies of $C$. disseminatus, C. micaceus and C. atramentaria and other coprini developing on wood chips and sawdust (Table 1). Wood chips and sawdust offer a large surface compared to trunks and logs and thus a superior aeration not given in compact wood - under conditions of low aeration, coprini exhibit poor growth (Badalyan unpublished, own observations) - and they might therefore be in growth disadvantage on intact wood. Phenolic impregnation of the wood can also be a factor that limits the invasion of the wood. However, on artificial medium C. micaceus showed efficient degradation of phenolic lignin model compounds (Guiraud et al. 1999). Further studies with C. micaceus (isolated from a living Salix viminalis) and C. cinerea (isolated from paper samples) showed an efficient degradation of phenolic lignin model compounds (catechol, guaiacol, phenol, ferulic, protocatechuic, syringic and vanillic acids) and pentachloronitrobenzene. It was suggested that phenoloxidases were not necessarily required for the metabolization of these compounds. Coprini species may share a common degrading system for monomeric phenolic and chloroaromatic compounds (Guiraud et al. 1999). From recent genome analysis it was deduced that $C$. cinerea has seventeen different genes for laccases (Hoegger et al. 2004, Kilaru et al. 2006).

Furthermore, there might be other ecological disadvantages which count to the reasons as why wood is seldom occupied by this group of fungi. Numerous factors of a physical, chemical or microbial nature may influence the growth of the mycelium in the wood substrate starting from the spore germination till full establishment of a fungal colony in the substrate. Temperature, moisture content, oxygen concentration and hydrogen ion concentration in the substrate are the physical conditions influencing fungal colonization (Dix and Webster 1995). The temperature range where fungi grow is as broad as species exist, however the optimum temperature for fungal growth of many coprini is between 20 and $30^{\circ} \mathrm{C}$. In a coprini screening test of 49 strains from 14 species, most of them developed well at $25^{\circ} \mathrm{C}$ (C. comatus, C. disseminatus, C. micaceus, C. atramentaria, C. cothurnata and P. plicatilis), while others (C. curtus, 
C. domesticus, C. micaceus, C. sp., C. xanthothrix, C. bilanatus, C. cinerea, C. lagopus and $C$. strossmayeri) grew well at $37^{\circ} \mathrm{C}$ on $1.5 \%$ malt extract agar (Badalyan et al. 2003). Humidity in the substrate as well as oxygen availability are seen as crucial factors for wood degradation, yet, this is again very variable depending on the fungal species. Oxygen seems to be more important for mycelial development, even though their requirements are much lower to survive (ca. 1\%) or to find optimum living conditions (ca. 10\%), than presented by the air where the concentration is ca. $21 \%$ (Schwarze et al. 2000). Coprini appear to be fungal organisms that require higher amounts of oxygen deduced from the fact that many species grow easily on "loose" substrates like wood chips or straw where due to ease of aereation the presence of oxygen is rather higher than in compact wood. Most important in the development of these fungi is also the $\mathrm{pH}$. Although most fungi prefer acidic conditions, they still tolerate a wide range of $\mathrm{pH}$ (Alexopoulos et al. 1996). However, few basidiomycetes grow well above pH 7.5 (Dix and Webster 1995). Coprini species favour alkaline conditions (Fries 1956, Soponsathien 1998). Consequently they are found on disturbed ground or grassy areas; and frequently along roadsides, paths covered with wood chips and in playing fields (Table 1, Figure 5 and 6) which tend to have a higher $\mathrm{pH}$ (Dix and Webster 1995, Olander et al. 2005). The disturbance of fungal communities in forest by nitrogenous substances such as urea or ammonia brings about a sequence of colonization by distinct fungi refered to as "ammonia fungi” (Sagara 1975).

\subsection{Lignocellulolytic enzymes from coprini species}

The increasing interest on wood rotting fungi lies on their ability to degrade diverse chloroaromatic, nitroaromatic and polyaromatic compounds which are important pollutants derived from the chemical, agricultural, oil, paper, textile and other industries (Durán and Esposito 2000, Reddy and Mathew 2001, Pointing 2001, Wesenberg et al. 2003, Couto and Herrera 2006, Husain 2006). The ligninolytic enzymes of white-rot fungi have broad substrate specificity and have been implicated in the transformation and mineralization of organo-pollutants with structural similarities to lignin (Pointing 2001). The interest in identifying polymer attacking, respectively degrading enzymes in recent years included also studies of coprini species (Table 3). 

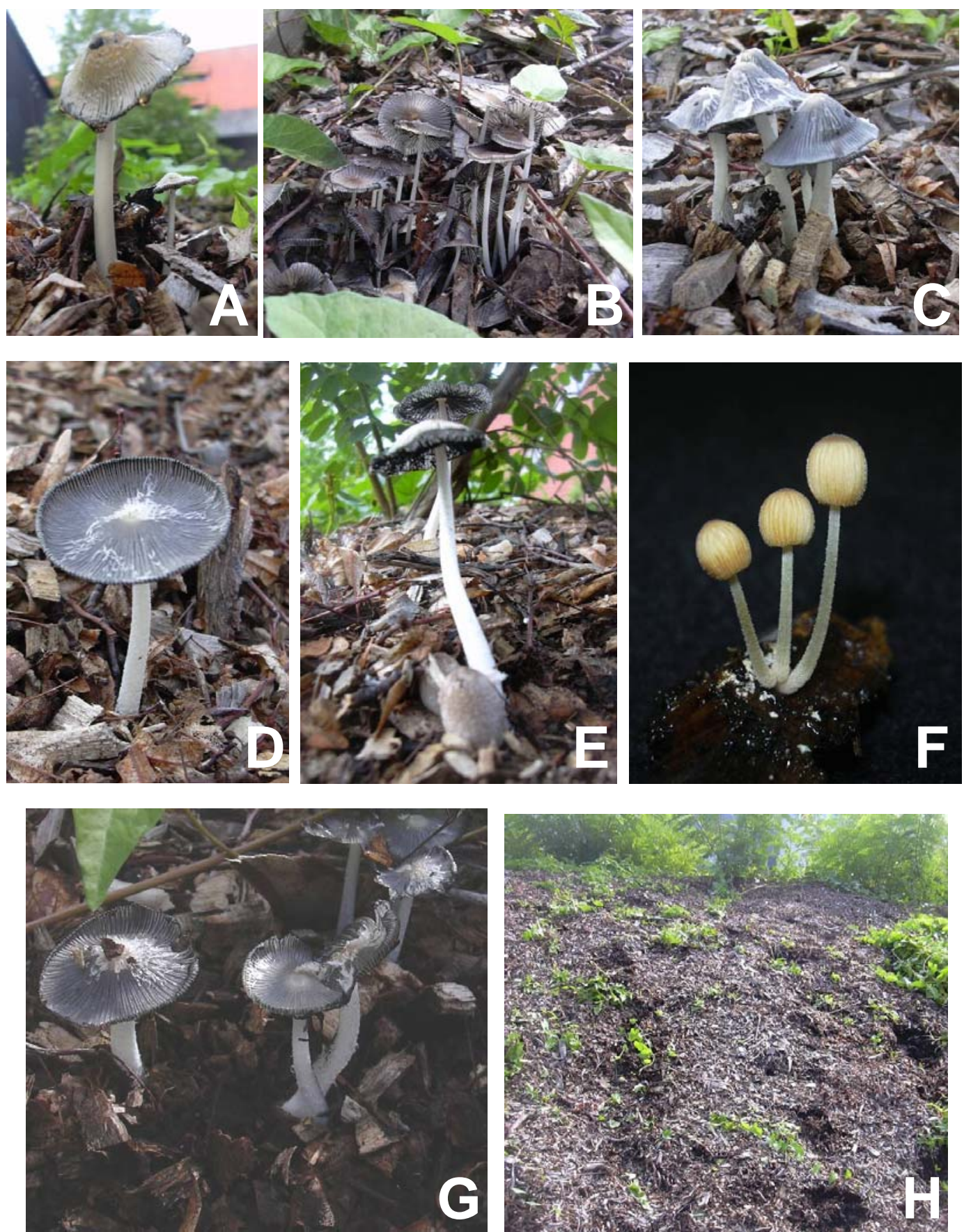

Figure 5 Seven morphologically different coprinoid mushrooms (A-G) growing on the same pile of wood chips $(\mathbf{H})$ observed in gardens of the North Campus of the Georg-AugustUniversity Göttingen. The specimens had a size between $5(\mathbf{G})$ and 9-13 cm (A-E). Several pieces of infested wood chips were taken to the laboratory and incubated in a moist chamber at room temperature in the normal day-light rythm. Within a week, coprini fruiting bodies about $2 \mathrm{~cm}$ developed (F). A sample of wood chips from the ground $(\mathbf{H})$ had a slightly alkaline $\mathrm{pH}$ (7.4). 

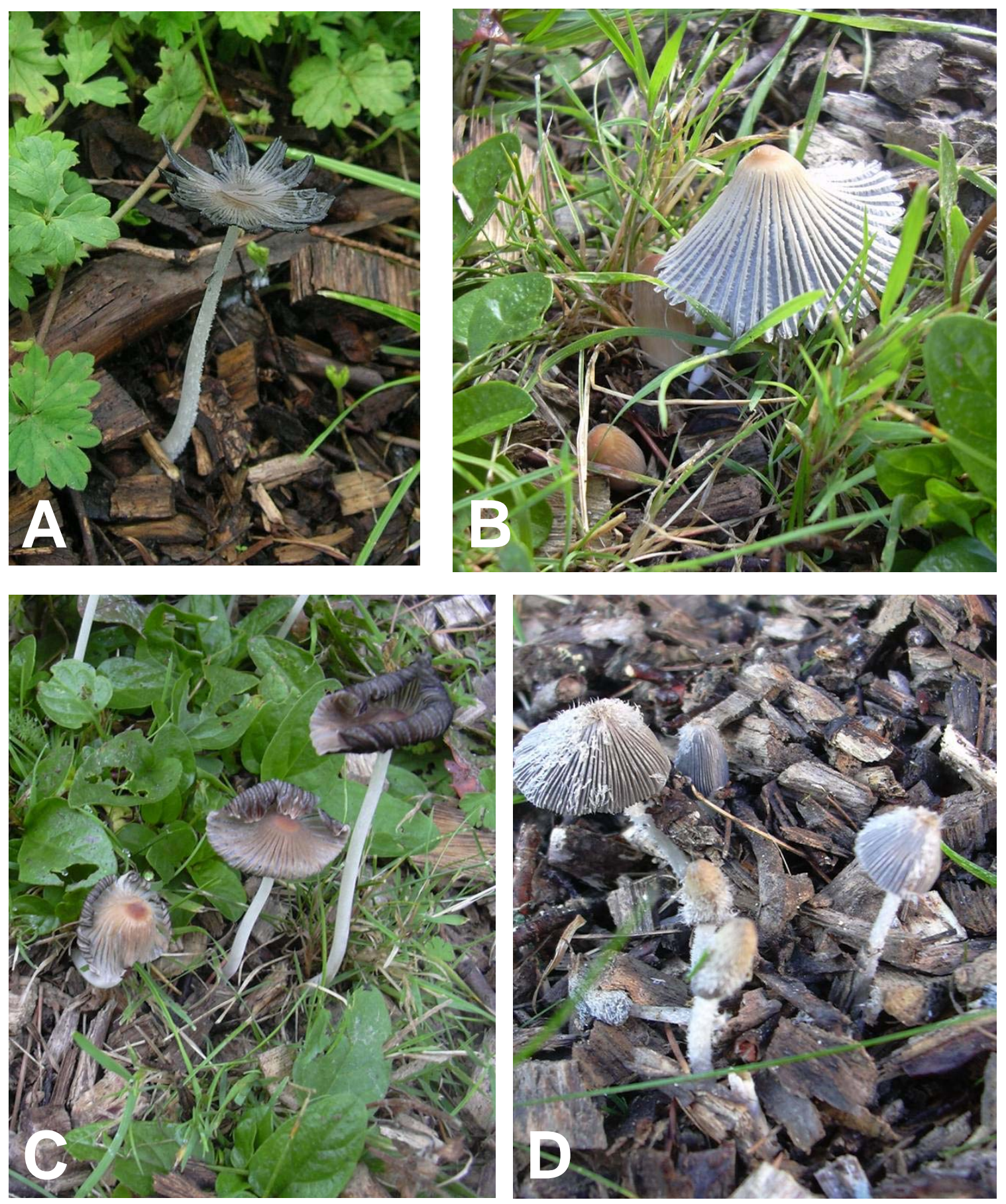

Figure 6 Four morphological different coprini species (A-D) growing on wood chips around trees. Mushrooms B-D were growing around the same tree (Cedrus diodara). The fruiting bodies were observed and harvested from the gardens of the North Campus of the GeorgAugust-University Göttingen.

Several methods as well as substrates and developmental stages have been used to study different coprini strains. Due to the high influence of factors such as temperature, type of substrate and strains of the fungi in the growth of the mycelia and consequently in their enzymatic activity, the overall results from such studies are difficult to compare. 
For example, Soponsathien (1998) tested several strains of C. cinerea, C. echinospora, C. neolagopus, Coprinopsis phlyctidospora (Coprinus phlyctidosporus) and C. sp. in a wood powder plate and by Bavendam tests with several substrates being indicators for laccase, tyrosinase and peroxidase. The activity was given in a scale from 0 (no reaction) to 6 (complete reaction). In order to have an easy overview and simplify the results obtained in the experiments, in Table $\mathbf{3}$ the enzymatic activity is shown only where positive results were obtained in any level and and the substrate utilized. The highest colour reactions were found in the wood powder plate tests. This effect is possibly enhanced because the fungi are confronted to phenolic and other organic wood compounds not present in artificial media which strongly promoted the phenoloxidative activity in some species (i.e. C. echinosporus). Depending on the media tested, the experiments showed that a same strain can exhibit different enzymatic activities (Soponsathien 1998).

Few enzymes acting in degradation of lignocellulosic substrates and on phenolic compounds have yet been isolated and characterized from the coprini (Table 3). Most extensively, the already mentioned peroxidase CIP of $C$. cinerea has been characterized (Klibanov et al. 1983, Al-Kassim et al. 1994a,b, Caza et al. 1999), because of its potential applications of CIP in treatment of phenolic waste water (Kauffmann et al. 1999) and in removal of phenolic compounds present in the drainage from oil refining, resin and plastic processing, and the fiber and dye industries (Masuda et al. 2001). In addition, laccase Lcc 1 of $C$. cinerea has been extensively studied for the use in biotechnology (Yaver et al. 1999). All together, 17 different laccases, respectively their genes are known from C. cinerea (Yaver et al. 1999, Bottoli et al. 1999, Kilaru et al. 2006). Finally, some other enzymes as xylanase and amylase of $C$. bilanatus have been described (Stephens et al. 1991). Cellulases activities have been studied in C.atramentaria, C. comatus and an unidentified Coprinus strain (Ahuja et al. 1991, Gupta et al. 1990, 1992, Abraham and Kurup, 1997). 
Table 3 Detection of several enzymes within some coprini species*.

\begin{tabular}{|c|c|c|c|c|c|c|c|c|c|c|}
\hline \multirow{3}{*}{$\begin{array}{l}\text { Species } \\
\text { (strain) }\end{array}$} & \multirow[t]{3}{*}{ Samples } & \multicolumn{7}{|c|}{ Enzyme $^{a}$} & \multirow{3}{*}{$\begin{array}{c}\text { Test } \\
\text { Peroxidase }\end{array}$} & \multirow[t]{3}{*}{ Reference } \\
\hline & & Phenoloxidase & Laccase & Tyrosinase & Peroxidase & Cellulase & Xylanase & Amylase & & \\
\hline & & \multicolumn{7}{|c|}{$\begin{array}{c}\text { Enzyme substrate } \\
\end{array}$} & & \\
\hline \multicolumn{11}{|l|}{ Coprinus } \\
\hline C. comatus & Mycelium & Tannic acid & & & & Cellulose powder & Xylan & & Plate test & Mohamed and Dix 1988 \\
\hline \multicolumn{11}{|l|}{ Coprinopsis } \\
\hline C. atramentaria & Mycelium & Tannic acid & & & & Cellulose powder & Xylan & & Plate test & Mohamed and Dix 1988 \\
\hline C. cinerea & $\begin{array}{l}\text { Mycelium, } \\
\text { fruiting } \\
\text { bodies }\end{array}$ & $\begin{array}{l}\text { Benzidine } \\
\text { 3,3'-dimetho- } \\
\text { xybenzidine } \\
\text { p-, o-phenyle- } \\
\text { nediamin }\end{array}$ & & & & & & & $\begin{array}{l}\text { Spectro- } \\
\text { photometric }\end{array}$ & $\begin{array}{c}\text { Vnenchak and Schwalb } \\
1989\end{array}$ \\
\hline \multirow[t]{2}{*}{$(571)$} & Mycelium & Guaiacol & $\begin{array}{l}\text { Guaiacol } \\
\alpha \text { - Naphthol } \\
\text { SGZ }\end{array}$ & \multirow[t]{3}{*}{$p$-Cresol } & \multirow[t]{2}{*}{ Peroxide } & \multirow[t]{4}{*}{ Free azur blue II } & & & $\begin{array}{l}\text { Wood-powder - } \\
\text { plate } \\
\text { Bavendam }\end{array}$ & Soponsathien 1988 \\
\hline & & Guaiacol & & & & & & & \multirow{3}{*}{$\begin{array}{l}\text { Plate test } \\
\text { Spectro- } \\
\text { photometric }\end{array}$} & \multirow{3}{*}{$\begin{array}{l}\text { Guiraud et al. } 1999 \text {, } \\
\text { Schneider et al. } 1999\end{array}$} \\
\hline & & & & & & & & & & \\
\hline & & $\begin{array}{l}\text { Guaiacol } \\
\alpha \text { - Naphthol } \\
\text { Benzidine } \\
\text { Gallic acid } \\
\text { Pyrogallol } \\
\text { R-56 }\end{array}$ & $\begin{array}{l}\text { SGZ } \\
o \text {-Anisidine } \\
\text { ABTS }\end{array}$ & & $\begin{array}{l}\mathrm{SGZ}+ \\
\mathrm{H}_{2} \mathrm{O}_{2}\end{array}$ & & & & & \\
\hline \multirow{5}{*}{$\begin{array}{l}\text { C. echinosporus } \\
(582) \\
(629) \\
(630)\end{array}$} & \multirow[t]{5}{*}{ Mycelium } & \multirow[t]{5}{*}{ Guaiacol } & \multirow{2}{*}{$\begin{array}{l}\text { Guaiacol } \\
\alpha \text { - Naphthol }\end{array}$} & $p$-Cresol & & & & & \multirow{5}{*}{$\begin{array}{l}\text { Wood-powder - } \\
\text { plate } \\
\text { Bavendam }\end{array}$} & \multirow[t]{5}{*}{ Soponsathien 1988} \\
\hline & & & & & Peroxide & & & & & \\
\hline & & & $\begin{array}{l}\text { Guaiacol } \\
\alpha \text { - Naphthol } \\
\text { SGZ }\end{array}$ & $p$-Cresol & & & & & & \\
\hline & & & $\begin{array}{l}\alpha \text { - Naphthol } \\
\text { SGZ }\end{array}$ & & \multirow[t]{2}{*}{ Peroxide } & & & & & \\
\hline & & & $\begin{array}{l}\text { Guaiacol } \\
\text { SGZ }\end{array}$ & & & & & & & \\
\hline C. friesii & & & ABTS, DMP & & & & & & & Heinzkill et al. 1998 \\
\hline
\end{tabular}


Table 3 continued

\begin{tabular}{|c|c|c|c|c|c|c|c|c|c|c|}
\hline $\begin{array}{l}\text { C. neolagopus } \\
\text { (614) }\end{array}$ & Mycelium & & & & Peroxide & & & & $\begin{array}{l}\text { Wood-powder - } \\
\text { plate }\end{array}$ & Soponsathien 1988 \\
\hline$(6538)$ & & Guaiacol & Guaiacol & & & & & & Bavendam & \\
\hline $\begin{array}{l}\text { C. } \\
\text { phlyctidosporus } \\
(333) \\
\text { (COP MIYA) } \\
(559) \\
\end{array}$ & & & $\begin{array}{l}\alpha \text { - Naphthol } \\
\text { SGZ }\end{array}$ & \begin{tabular}{|l} 
\\
$p$-Cresol \\
\end{tabular} & & & & & & \\
\hline & & Gallic acid & & & & & & & Plate test & Ceruti-Scurti et al. 1980 \\
\hline $\begin{array}{l}\text { C. scobicola } \\
(=\text { C.bilanatus })\end{array}$ & $\begin{array}{l}\text { Mycelium, } \\
\text { supernatant }\end{array}$ & & & & & $\begin{array}{l}\text { Carboxy- } \\
\text { methylce- } \\
\text { llulose }\end{array}$ & \begin{tabular}{|l} 
Xylan \\
Oat-spelt - \\
xylan
\end{tabular} & Starch & $\begin{array}{l}\text { Plate test } \\
\text { Spectro- } \\
\text { photometric }\end{array}$ & Stephens et al. 1991 \\
\hline $\begin{array}{l}\text { C. sp. } \\
\text { (CSP Sagara) } \\
\text { C. sp. (239) }\end{array}$ & Mycelium & Guaiacol & $\begin{array}{l}\text { Guaiacol } \\
\alpha \text { - Naphthol } \\
\text { SGZ }\end{array}$ & & & & & & $\begin{array}{l}\text { Wood-powder - } \\
\text { plate } \\
\text { Bavendam }\end{array}$ & Soponsathien 1988 \\
\hline Coprinellus & & & & & & & & & & \\
\hline C. congregatus & $\begin{array}{l}\text { Mycelium, } \\
\text { Protoplast- } \\
\text { cell } \\
\text { membranes }\end{array}$ & & $O$-tolidine & & & & & & $\begin{array}{l}\text { Spectro- } \\
\text { photometric }\end{array}$ & Choi and Ross 1990 \\
\hline & Mycelium & & $\begin{array}{l}\text { 3,3'- } \\
\text { dimethoxy- } \\
\text { benzidine }\end{array}$ & & & & & & & Ross 1982 \\
\hline & & & $O$-tolidine & & & & & & & Kim et al. 1991 \\
\hline C. micaceus & Mycelium & $\begin{array}{l}\text { Guaiacol } \\
\alpha \text { - Naphthol } \\
\text { Benzidine } \\
\text { Gallic acid } \\
\text { Pyrogallol } \\
\text { R-56 }\end{array}$ & $\begin{array}{l}\text { SGZ } \\
o \text {-Anisidine }\end{array}$ & $\begin{array}{l}p \text {-Cresol } \\
L \text {-Tyrosine }\end{array}$ & $\begin{array}{l}\mathrm{SGZ}+ \\
\mathrm{H}_{2} \mathrm{O}_{2}\end{array}$ & Free azur blue II & & & Plate test & Guiraud et al. 1999 \\
\hline
\end{tabular}

*The enzymatic activity is shown with the substrate that had a positive effect.

Substrates $^{\mathrm{a}}$ : ABTS $=2,2^{\prime}$-azinobis(3-ethylbenzthiazoline-6-sulfonate), DMP $=(2,6$-dimethoxy phenol), SGZ = Syringaldazine

Note that different strains of same species in some instances gave different results.

Numbers in the first column refer to different studied strains. 


\subsection{Conclusions}

In most of the reports of coprini associated with wood, the same few species appeared: C. atramentaria, C. disseminatus and C. micaceus. However, the ability to degrade wood and other compact plant materials among the coprini is likely more widespread than assumed so far. From our compilation of literature we found that growth on wood and possibly wood rotting abilities appears in all new genera in more than $30 \%$ of the coprini species. However, it seems that lignocellulosic abilities within the genus Coprinellus are most abundant; both in the number of species as well as in the strength of decay (C. disseminatus and C. micaceus). Repeatedly detected on wood, only few species have also a latent pathogenic potential. Wood colonized by coprini is often described as degraded and non-coprini species have often been observed in addition.

The studies suggest that coprini species might be rather secondary wood invaders colonizing wood in succession to other myxo-, asco- and basidiomycetes. With the change of gardening practices, coprini mushrooms are nowadays regularly observed on walkways and beds covered by wood chips. A better aeration and possibly a $\mathrm{pH}$ change into the alkaline range might favour development of the coprini on this woody substrate.

Little is yet known on enzymes produced by the fungi to attack compounds within wood. Most of the strains studied so far in the laboratory showed phenoloxidase activity. However, due to different methodological approaches it was difficult to compare all informations available for the literature. So far, only two enzymes activities CiP and Lcc1 of $C$. cinerea were tested for their potential biotechnological applications. In terms of biotechnology we are far away from exploiting these fungi.

\subsection{Acknowledgments}

I would like to thank Dr. Kateřina Svobodová, Edis Kasemi, Akiko Ono, Dr. František Vilčko and Dr. Andrzej Majcherczyk for translating publications in languages foreign to us. I also thank to all the colleagues from various countries that send reprints of their and other researchers work.

\subsection{References}

Abraham M, Kurup GM (1997) Pretreatment studies of cellulose wastes for optimization of cellulase enzyme activity. Appl. Biochem. Biotech., 62, 210-211. 
Adaskaveg JE, Ogawa JM (1990) Wood decay pathology of fruit nut trees in California. Plant Dis., 74, 341-352.

Agerer R, Ammirati J, Baroni TJ, Blanz P, Courtecuisse R, Desjardin DE, Gams W, Hallenberg N, Halling R, Hawksworth DL, Horak E, Korf RP, Mueller GM, Oberwinkler F, Rambold G, Summerbell RC, Triebel D, Watling R (2000) Open letter to the scientific community of mycologists: Provide voucher specimens. Mycotaxon, 76, 489-493.

Ahuja V, Singh A, Punj V, Dhillon GS, Gupta VK (1991) Effect of supplementation of cellobiase Alcaligenes faecalis on saccharification of rice straw and simultaneous fermentation to alcohol. J. Res. Punjab Agric. Univ., 28, 234-242.

Alexopoulos CJ, Mims CW, Blackwell M (1996) Introductory mycology. John Wiley and Sons, N.Y., USA.

Al-Kassim L, Taylor KE, Bewtra JK, Biswas N (1994a) Optimization of phenol removal by a fungal peroxidase from Coprinus macrorhizus using batch, continuous, and discontinuous semibatch reactors. Enzyme Microb. Tech., 16, $120-124$.

Al-Kassim L, Taylor KE, Nicell JA, Bewtra JK, Biswas N (1994b) Enzymatic removal of selected aromatic contaminants from waste water by a fungal peroxidase from Coprinus macrorhizus in batch reactors. J. Chem. Technol. Biotechnol., 61, 179182.

Allen SJ, Young AM (1993) Coprinus cinereus associated with a cotton module rot. The Mycologist, 7, 73-74.

Anastasiou CJ (1967) 2 species of Coprinus from alkali lakes. Can. J. Bot., 45, 22132217.

Arora D (1986) Mushrooms demystified. A comprehensive guide to the fleshy fungi (2nd ed.). Ten Speed Press, Berkeley, California.

Badalyan SM, Avetisyan HK, Navarro-González M, Kües U (2003) Eco-physiological characteristics of several Coprinus species related to Wood. In: Kües U (ed.), Conference book: Molecular biology of fungi 6th VAAM-Conference "Molekularbiologie der Pilze', 3.-5. September 2003 Göttingen, Germany Wissenchaftlicher Fachverlag Dr. Peter Fleck, Langgöns (Niederkleen), Germany, pp. 69.

Basham JT (1958) Decay of trembling aspen. Can. J. Bot., 36, 491-505. 
Basham JT, Morawski ZJR (1964) Cull studies, the defects and associated basidiomycete fungi in the heartwood of living trees in the forests of Ontario. Department of Forestry Publication No. 1043. Queen's Printer and Controller of Stationery, Ottawa, Canada.

Bender H, Enderle M (1988) Studien zur Gattung Coprinus Pers., Fr. S. F. Gray in der Bundesrepublik Deutschland. VI. Z. Mycol., 54, 45-68.

Bender H, Enderle M, Krieglsteiner GJ (1984) Studien zur Gattung Coprinus Pers.,Fr. S. F. Gray in der Bundesrepublik Deutschland. II. Z. Mycol., 50, 17-40.

Bensaude M (1918) Recherches sur le cycle évolutif et la sexualité chez les Basidiomycètes. Ph.D. thesis. Univ. Paris, Nemours, France.

Binninger DM, Skrzynia C, Pukkila PJ, Casselton LA (1987) DNA-mediated transformation of the basidiomycete Coprinus cinereus. EMBO J., 6, 835-840.

Blanchette RA (1991) Delignification by wood-decay fungi. Ann. Rev. Phytopathol., 29, 381-398.

Bois PJ, Eslyn AE (1966) Deterioration rates of willow and cottonwood during storage in Georgia. Forest Prod. J., 16, 17-22.

Bottoli APF, Kertesz-Chaloupková K, Boulianne RP, Granado JD, Aebi M, Kües U (1999) Rapid isolation of genes from an indexed genomic library of C. cinereus in a novel $\mathrm{pabl}^{(+)}$cosmid. J. Microbiol. Meth., 35, 129-141.

Brefeld O (1877) Botanische Untersuchungen über Schimmelpilze. III. Basidiomyceten. Arthur Felix, Leipzig, Germany.

Breitenbach J, Kräzlin F (1995) Pilze in der Schweiz, Vol. 4. Mykologia, Luzern, Swiss. Bresadola G (1931) Coprinus. Iconographia Mycological, 18, 851-900.

Broadbent P, Fraser LR (1977) Sudden death. A disease of citrus. Agr. Gaz. NSW, 88, 30-31.

Broadfoot WC, Cormack MW (1941) A low-temperature basidiomycete causing early spring killing of grasses and legumes in Alberta. Phytopathol., 31, 1058-1059.

Brodie HJ (1931) The oidia of Coprinus lagopus and their relation with insects. Ann. Bot., 45, 315-344.

Brown AJ, Casselton LA (2001) Mating in mushrooms: increasing the chances but prolonging the affair. Trends in Genetics, 17, 393-400.

Brunswick H (1924) Untersuchungen über die Geschlechts- und Kernverhältnisse bei der Hymenomyzetengattung Coprinus. Gustav Fisher Verlag, Jena, Germany. 
Buller AHR (1910) The function and fate of the cystidia of Coprinus atramentarius, together with some general remarks on Coprinus fruit-bodies. Ann. Bot., 24, 613-629.

Buller AHR (1917) Some critical remarks on the generic positions of Psathyra urticaecola Berk. et Broome, Coprinus plicatilis Fr.. Trans. Br. Mycol. Soc., 5, 482-489.

Buller AHR (1931) Researches on Fungi. vol. IV. Longmans Green and Co., London, UK.

Buller AHR (1933) Researches on Fungi. vol. V. Hyphal functions and protoplasmic streaming in the higher fungi, together with an account of the production and liberation of spores in Sporobolomyces, Tilletia, and Sphaerobolus. Hafner Publishing Co., New York, N.Y., USA.

Burova LG (1986) Ecology of macromycetes mushrooms. Nauka, Moscow, Russia.

Burova LG, Nezdoiminogo EL (1982) Trophic structure of macromycetes groups in forest plantings (The North Caspian Sea Cost). Mikol. Fitopatol., 16, 289-376.

Burrows DM, Elliot TJ, Casselton L (1990) DNA-mediated transformation of the secondarily homothallic basidiomycete Coprinus bilanatus. Curr. Genet., 17, 175-177.

Burrows I, Seal JK, Eggins HOW (1979) The biodegradation of barley straw by Coprinus cinereus for the production of rumiant feed. Proceedings of a Symposium on Straw Decay and Workshop on Assessment Techniques, Hatfield Polytechnic. Wiley-Interscience, Chichester, UK, pp. 147-154.

Casselton LA, Olesnicky NS (1998) Molecular genetics of mating recognition in basidiomycete fungi. Microbiol. Mol. Biol. Rev., 62, 55-70.

Casselton LA, Kües U (2007) The Origin of Multiple Mating Types in the Model Mushrooms Coprinopsis cinerea and Schizophyllum commune. In: Heitman J, James W. Kronstad JW, Taylor JW, Casselton LA. Sex in fungi: Molecular determination and evolutionary implications. ASM Press, Herndon, VA, USA.

Caza N, Bewtra JK, Biswas N, Taylor KE (1999) Removal of phenolic compounds from synthetic wastewater using soybean peroxidase. Wat. Res., 33, 3012-3018.

Ceruti-Scurti J, Fiussello N, Gullino ML, Farina F (1980) Attivita fenol-ossidasica e fruttificazione in alcuni basidiomiceti. Allionia, 24, 61-67. 
Challen MP, Bhattiprolu GR, Warner PJ, Elliot TJ (1994) Cloning the Coprinus bilanatus TRP2 gene and its use as a selectable marker in transformation. Mycol. Res., 98, 179-185.

Challen MP, Elliot TJ (1989) Segregation of genetic markers in the two-spored secondarily homothallic basidiomycete Coprinus bilanatus. Theor. Appl. Genet, 78, 601-607.

Chapela IH, Boddy L, Rayner ADM (1988) Structure development of fungal communities in beech four and a half years after felling. FEMS Microbiol. Ecol., $53,59-70$.

Chaturvedi OH, Santra A, Mishra AS, Mishra AK, Prasad R, Karim SA (2000) Effect of Coprinus fimentarius on the nutritive value of urea treated mustard straw. Indian J. Anim. Sci., 70, 874-876.

Choi HT, Ross IK (1990) Localization of phenoloxidases in Coprinus congregatus grown on a low-temperature-liquifying medium. Kor. J. Microbiol., 28, 274277.

Choi YO, Ha ES, Kim SJ, Choi HT, Yoon KS (1994) Regulation of membrane associated laccase synthesis in liquid culture of Coprinus congregatus. Kor. J. Mycol., 22, 46-49.

Cormack MW (1948) Winter crown rot or snow mold of alfalfa, clovers, and grasses in Alberta. I. Occurrence, parasitism, and spread of the pathogen. Can. J. Res., 26, 71-85.

Cormack MW (1952) Winter crown rot or snow mold of alfalfa, clovers, and grasses in Alberta. II. Field studies on host and varietal resistance and other factors related to control. Can. J. Bot., 30, 537-548.

Couto SR, Herrera JLT (2006) Industrial and biotechnological applications of laccases: A review. Biotechnol. Adv., 24, 500-513.

Crosier WF, Patrick SR, Heit CE, Mcswain E (1949) The harefoot mushroom, Coprinus lagopus Fr. on fruits used commercially as seedstocks. Science, 110, 13-14.

Crozier J, Thomas SE, Aime MC, Evans HC, Holmes A (2006) Molecular characterization of fungal endophytic morphospecies isolated from stems and pods of Theobroma cacao. Plant Pathology 55, 783-791.

Cummings WJ, Celerin M, Crodian J, Brunick LK, Zolan ME (1999) Insertional mutagenesis in Coprinus cinereus: use of a dominant selectable marker to generate tagged, sporulation-defective mutants. Curr. Genet., 36, 371-382. 
Dähncke RM (2001) 1200 Pilze. AT Verlag, Bechtermünz, Germany.

de Meulder H (1998) Coprinus kubickae Pilát \& Svrcek, een nieuwe inktzwam voor België. Antwerpse Mycologische Kring (AMK), 98, 105-108.

Demirel K, Nacar M (2000) Macrofungi of Çemisgezeg Tunceli District. Hacettepe Bull. Nat. Sciences Engineering, 29, 1-7.

Denisova NP (1982) Proteolytic activity of higher fungi in culture. Mikol. Fitopatol., $16,377-472$.

Dix NJ, Webster J (1995) Fungal ecology. 2nd edition. Chapman and Hall, London, UK.

Doidge E (1950) Fungi and lichens to the end of 1945. Bothalia, 5, 1-1094.

Domański S (1983) Fungi that destroyed a Populus tremula stand in Lagów Lubuski. Eur. J. For. Path., 13, 166-173.

Domański S (1984) Studies on the butt rots in common ash. Zeszyty Problemowe Postepów Nauk Rolniczych, 289, 9-33.

Durand R (1987) A photosensitive system for blue/UV light effects in the fungus Coprinus. CRC Press, Boca Raton, Florida, USA.

Durán N, Esposito E (2000) Potential applications of oxidative enzymes and phenoloxidases-like compounds in wastewater and soil treatment: a review. Appl. Cat B: Environ., 28, 83-99.

Economou A, Lees V, Pukkila PJ, Zolan ME, Casselton LA (1987) Biased inheritance of optional insertions following mitochondrial genome recombination in the basidiomycete fungus Coprinus cinereus. Curr. Genet., 11, 513-519.

Enderle M, Krieglsteiner GJ, Bender H (1986) Studien zur Gattung Coprinus Pers., Fr. S. F. Gray in der Bundesrepublik Deutschland. III. Z. Mycol, 52, 101-134.

Enderle M, Bender H (1990) Studien zur Gattung Coprinus Pers., Fr. S. F. Gray in der Bundesrepublik Deutschland. V. Z. Mycol., 56, 19-50.

English M (1995) The persistence of Coprinus cinereus. Mycologist, 9, 84.

Eslyn AE, Lombard FF (1984) Fungi associated with decayed wood in stored willow and cottonwood logs. Mycologia, 76, 548-550.

Europäisches Komitee für Normung (1994) DIN EN 350-2 Dauerhaftigkeit von Holz und Holzprodukten. Natürliche Dauerhaftigkeit von Vollholz. Teil 2. Leifaden für die natürliche Dauerhaftigkeit und Träkbarkeit von ausgewählten Holzarten von besonderer Bedeutung in Europa. CEN, Brüssel, Belgium. 
Evans CS, Hedger JN (2001) Degradation of plant cell wall polymers. In: Gadd GM (ed.), Fungi in bioremediation. Cambridge Univ. Press, Cambridge, UK, 1-26.

Ewald G (2000) Pilze mit Schnellbestimm-System. BLV, München, Germany.

Fischer R, Kües U (2003) Sexual and asexual development of selected filamentous model fungi. In: Prade RA and Bohnert HJ (eds.), Genomics of plants and fungi, Marcel Dekker, NY, USA, pp. 41-118.

Fries E (1828) Coprinarius. Sistens in systema mycologicum. Chapter 36. Elenchus Fungorum. Gryphiswaldiae, 1, 42-44.

Fries E (1838) Agaricus. Epicrisis systematis mycologici seu synopsis Hymenomycetum. Uppsala, Sweden, pp.230-255.

Fries L (1956) Studies in the physiology of Coprinus. II. Influence of $\mathrm{pH}$, metal factors and temperature. Svensk Botanisk Tidskrift, 50, 47-96.

Gaudet DA, Kokko EG (1985) Penetration and infection of winter-wheat leaves by Coprinus psychromorbidus under controlled environment conditions. Can. J. Bot., 63, 955-960.

Gaudet DA, Bhalla MK, Clayton GW, Chen THH (1989) Effect of cottony snow mold and low temperatures on winter wheat survival in central and northern Alberta. Can. J. Plant Pathol., 11, 291-296.

Gaudet DA, Sholberg PL (1990) Comparative pathogenicity of Coprinus psychromorbidus monokaryons and dikaryons on winter-wheat, alfalfa, grass, and pome fruit. Can. J. Plant Pathol., 12, 31-37.

Gaudet DA, Kokko EG, Sholberg PL (1990) Histopathology of apple fruit infected with strains of the low - temperature basidiomycete Coprinus psychromorbidus. Can. J. Plant Pathol., 12, 369-375.

Geesink J, Imler L (1979) Coprinus rugosobisporus Nov. SP. Sterbeeckia, 12, 7-9.

Gilbertson RL (1980) Wood-rotting fungi of North America. Mycologia, 72, 1-49.

Gilbertson RL (1981) North American wood-rotting fungi that cause brown rots. Mycotaxon, 12, 372-416.

Gossen BD (1989) Snow mold and winter injury on alfalfa and other forage legumes in Saskatchewan in 1988. Can. Plant Dis. Surv., 69, 52.

Gossen BD (1994) Field response of alfalfa to harvest frequency, cultivar, crown pathogens, and soil fertility. 2. Crown rot. Agronomy J., 86.1, 88-93.

Gossen BD, Reiter WW (1989) Incidence and severity of snow molds on winter cereals in Saskatchewan, 1985-1988. Can. Plant Dis. Surv., 69, 17-19. 
Gossen BD, Tanino K, Reiter WW (1992) Effect of inoculation with Coprinus psychromorbidus on survival and low-temperature tolerance of alfalfa. Can. J. Plant Pathol., 14, 243.

Granado JD, Kertesz-Chaloupková K, Aebi M, Kües U (1997) Restriction enzymemediated DNA integration in Coprinus cinereus. Mol. Gen. Genet., 256, 28-36.

Green F, Highley TL (1997) Mechanism of brown-rot decay: Paradigm or paradox. Int. J. Biodeter. Biodegr., 39, 113-124.

Griesser B (1992) Mykosoziologie der Grauerlen- und Sanddorn-Auen Alnetum Incanae, Hippophaëtum am Hinterrhein Domleschg. Veröff. Geobot. Instit. Eidg. Tech. Hochschule, Stiftung Rübel, Graubünden, Swiss.

Guerdoux JL (1974) Coprinus. In: King RC (ed.), Handbook of genetics. Plenum Press, New York, N.Y., USA.

Guiraud P, Steiman R, Ait-Laydi L, Seigle-Muri F (1999) Degradation of phenolic and chloroaromatic compoundds by Coprinus spp. Chemosphere, 38, 2775-2789.

Gupta BN, Rai SN, Walli TK, Singh K (1988) Evaluation of fungal treated rice straw at different fermentation periods in relation to dry matter intake and nutrient utilization in goats. Indian J. Anim. Nutr., 5, 273-279.

Gupta BN, Singh GP (1991) Bioconversion of ammonia to biological protein by Coprinus fimentarius during solid state fermentation of ammoniated (urea) paddy straw. Indian J. Anim. Nutr., 8, 163-168.

Gupta BN, Singh GP, Walli TK, Singh K (1992) Comparative in vitro gas-production rate of untreated, urea- treated and fungal-treated wheat straw for evaluation as feed. Indian J. Anim. Sci., 62, 456-460.

Gupta VK, Prasad KS, Bakshi MPS, Langar PN (1986) Improving the nutritive value of groundnut shells through fungal cultivation. Agr. Wastes, 16, 161-169.

Gupta VK, Singh A, Kalra MS (1990) Microbial proteins and cellulase production from cellulosic materials by Coprinus atramentarius. J. Res. Punjab Agric. Univ., 27, 623-631.

Hall G (1987) Sterile fungi from roots of winter wheat. Trans. Br. Mycol. Soc., 89, 447-456.

Hanna WF (1925) The problem of sex in Coprinus. Ann. Bot., 34, 431-457.

Hanso ME, Hanso SA (1985) Coprinus sp. isolated from the inner tissues of senescent scots pine needles. Symposium of the Baltic Republics and Byelorussia on Mycology and Lichenology II, pp. 52-54. 
Hanso ME, Hanso SA (1992) Search for antagonists to Heterobasidion annosum Fr. Bref., II. Forest. Res., 25, 124-142.

Harkin JM, Obst JR (1973) Syringaldazine, an effective reagent for detecting laccase and peroxidase in fungi. Experientia, 29, 381-387.

Härkönen M, Saarimäki T, Mwasumbi L (1993) Tanzanian mushrooms and their uses 2. An edible species of Coprinus section Lanatuli. Karstenia, 33, 51-59.

Harris JR, Moen R (1985) Secondary infection fertilizer response of wheat initially infected with Rhizoctonia solani. Trans. Br. Mycol. Soc., 84, 307-315.

Hedger JN, Basuki T (1982) The rôle of basidiomycetes in composts: a model system for decomposition studies. In: Frankland JC, Hedger JN, Swift MJ (eds.), Decomposer basidiomycetes. Cambridge University Press, Cambridge, UK, pp. 263-305.

Heinzkill M, Bech L, Halkier T, Schneider P, Anke T (1998) Characterization of laccases and peroxidases from wood-rotting fungi (family Coprinaceae). Appl. Environ. Microbiol., 64, 1601-1606.

Hibbett DS, Donoghue MJ (2001) Analysis of character correlations among wood decay mechanism, mating systems, and substrate ranges in homobasidiomycetes. Syst. Biol., 50, 215-242.

Hintikka V, Korhonen K (1970) Effects of carbon dioxide on the growth of lignicolous and soil-inhabiting hymenomycetes. Commun. Instit. Forest. Fennial, 69, 4-29.

Hiscock SJ, Kües U (1999) Cellular and molecular mechanisms of sexual incompatibility in plants and fungi. Int. Rev. Cytol., 193, 165-295.

Hoegger PJ, Navarro-González M, Kilaru S, Hoffmann M, Westbrook ED, Kües U (2004) The laccase gene family in Coprinopsis cinerea (Coprinus cinereus). Curr. Genet., 45, 9-18.

Hopple JS Jr, Vilgalys R (1999) Phylogenetic relationships in the mushroom genus Coprinus and dark-spored allies based on sequence data from the nuclear gene coding for the large ribosomal subunit RNA: Divergent domains, outgroups, and monophyly. Mol. Phylogenet. Evol., 13, 1-19.

Husain Q (2006) Potential applications of the oxidoreductive enzymes in the decolorization and detoxification of textile and other synthetic dyes from polluted water: A review. Cr. Rev. Biotechn., 26, 201-221.

Iakovlev A, Stenlid J (2000) Spatiotemporal patterns of laccase in interacting mycelia of wood-decaying basidiomycete fungi. Microbial Ecol., 39, 236-245. 
Ivanov AI (1981) Xylotrophic agarics ocurring in Penza region. Mikol. Fitopatol., 15, 192-197.

Ivanov AI (1985) Macromycetes in the oak forest of Penza region. Mikol. Fitopatol., 19, 383-388.

Ivanov AI (1989) Macromycetes from the willow and alder thickets in the Sura river flood-lands. Mikol. Fitopatol., 23, 305-408.

Jordan M (1995) The encyclopedia of fungi of Britain and Europe. David \& Charles, Italy.

Kamada T (2002) Molecular genetics of sexual development in the mushroom Coprinus cinereus. Bioessays, 24, 449-459.

Kamariah L, Knapp JS (1993) Problems and prospects of using Sephacryl S-200 for separation of cellulase and xylanase complexes of Coprinus cinereus. Mardi Res. J., 21, 179-186.

Karash P (2001) Contributions to a fungus flora of the Five-Lakes-Country I District of Weilheim, upper Bavaria. Z. Mycol., 67, 73-136.

Kasik G (1994) A Research on taxonomy of macrofungi on trees in Konya. Turkish J. Bot., 18, 23-27.

Kasik G, Öztürk C, Dogan HH (2000) Macrofungi of Ermenek Karaman District. Turkish J. Bot., 1, 61-65.

Kauffmann C, Petersen BR, Bjerrum MJ (1999) Enzymatic removal of phenols from aqueous solutions by Coprinus cinereus peroxidase and hydrogen peroxide. $J$. Biotechnol., 73, 71-74.

Kauffmann CH (1918) The Agaricaceae of Michigan. Michigan Geological and Biological Surveys Publication 26. Biological Series 5 SWAF, State Printers, Michigan, USA.

Kemp RFO (1970) Inter-specific sterility in Coprinus bisporus, C. congregatus and other basidiomycetes. Trans. Br. Mycol. Soc., 54, 488-498.

Kilaru S (2006) Identification of fungal multi-copper oxidase gene families: Overexpression and characterization of Coprinopsis cinerea laccases for applications in biotechnology. $\mathrm{PhD}$ Thesis. Georg-August University of Göttingen, Göttingen, Germany.

Kilaru S, Hoegger PJ, Kües U (2006) The laccase multi-gene family in Coprinopsis cinerea has seventeen different members that divide into two distinct subfamilies. Curr. Genet. 50, 45-60. 
Kim SJ, Choi HT, Kang SO, Hah YC (1991) Secretion of membrane-associated laccase in liquid culture of Coprinus congregatus. Kor. J. Microbiol., 29, 267-269.

Kim SJ, Leem Y, Kim K, Choi HT (2001) Cloning of an acidic laccase gene (clac2) from Coprinus congregatus and its expression by external pH. FEMS Microbiol. Lett., 195,151-156.

Klamer M, Søchting U (1998) Fungi in a controlled compost system - with special emphasis on the thermophilic fungi. In: Szmidt RAK (ed.), Proceedings IS Composting and Use of Composted Materials for agriculture; Acta Horticulturae Number 469; ISHS, Scotland, UK, pp. 405-413.

Klibanov AM, Tu T, Scott KP (1983) Peroxidase-catalyzed removal of phenols from coal-conversion waste waters. Science, 221, 259-261.

Knoll F (1909) Untersuchungen über Längenwachstum und Geotropismus der Fruchtkörperstiele von Coprinus stiriacus. Sitzgsber. Akad. Wiss. Wien Math.Naturwiss. Kl. I, 118, 575-634.

Kothe E (2001) Mating type genes for basidiomycete strain improvement in mushroom farming. Appl. Microbiol. Biotechnol., 56, 602-612.

Kreisel H (1979) Die phytopathogenen Grosspilze Deutschlands. Gustav Fischer Verlag, Jena, Germany.

Kües U (2000) Life history and developmental processes in the basidiomycete Coprinus cinereus. Microbiol. Mol. Biol. Rev., 64, 316-353.

Kües U, Granado JD, Hermann R, Boulianne RP, Kertesz-Chaloupková K, Aebi M, (1998) The $A$ mating type and blue light regulate all known differentiation processes in the basidiomycete Coprinus cinereus. Mol. Gen. Genet., 260, $81-91$.

Kües U, Künzler M, Bottoli APF, Walser PJ, Granado JD, Liu Y, Bertossa RC, Ciardo D, Clergeot P-H, Loos S, Ruprich-Robert G, Aebi M (2004) Mushroom development in higher basidiomycetes Implications for human and animal health. In: Kushwaha RKS (ed.), Fungi in Human and Animal Health. Scientific Publishers, Jodhpur, India, pp. 431-470.

Kües U, Polak E, Bottoli APF, Hollenstein M, Walser PJ, Boulianne RP, Hermann R, Aebi M (2002a) Vegetative development in Coprinus cinereus. In: Osiewacz HD (ed.), Molecular biology of fungal development. Marcel Dekker, New York, N.Y., USA. pp. 133-164. 
Kües U, Walser PJ, Klaus MJ, Aebi M (2002b) Influence of activated $A$ and $B$ mating type pathways on developmental processes in the basidiomycete Coprinus cinereus. Mol. Gen. Genom., 268, 262-271.

Kühner R, Romagnesi H (1953) Flora analytique des champignos supérieurs. Masson et Cie, Editeurs, Paris, France.

Lange M, Hora FB (1963) A guide to mushrooms and toadstools. Dutton, New York, N.Y., USA.

Læssøe T, Lincoff G (1998) Mushrooms. The visual guide to more than 500 species of mushrooms from around the world. Eyewitness Handbooks, DK Publishing, Inc. Singapore, Singapore.

Lebeau JB, Logsdon JM (1958) Snow mold of forage crops in Alaska and Yukon. Phytopathology, 48, 148-150.

Leem YE, Kim SJ, Ross IK, Choi HT (1999) Transformation and laccase mutant isolation in Coprinus congregatus by restriction enzyme-mediated integration. FEMS Microbiol. Lett., 172, 35-40.

Lindsey JP, Gilbertson RL (1978) Basidiomycetes that decay aspen in North America. Bibl. Mycologica, 63, 1-406.

Lu BC (1982) Replication of deoxyribonucleic acid and crossing over in Coprinus. In Wells K and Wells EK (ed.), Basidium and basidiocarp. Evolution, cytology, funtion and development. Springer-Verlag, New York, N.Y., USA. pp. 93-112.

Lu BC (2000) The control of meiosis progression in the fungus Coprinus cinereus by light/dark cycles. Fungal Genet. Biol., 31, 33-41.

Lubarsky LV, Vasilieva LN (1975) Wood inhabiting fungi from far East. Nauka, Novosibirsk, Russia.

Manachère G (1988) Regulation of sporophore differentiation in some macromycetes particularly in coprini: An overview of some experimental studies, from fruiting initiation to sporogenesis. Crypt. Mycol., 9, 291-323.

Manachère G (1994) Photomorphogenesis in fungi. In: Kendrick RE, Kronenberg GHM (eds.), Photomorphogenesis in plants (2nd ed.). Kluwer Academic Publishers, Dordrecht, Netherlands, pp. 753-782.

Masuda M, Sakurai A, Sakakibara M (2001) Effect of reaction conditions on phenol removal by polymerization and precipitation using Coprinus cinereus peroxidase. Enzyme Microb. Tech., 28, 295-300. 
May G, Taylor JW (1988) Patterns of mating and mitochondrial DNA inheritance in the agaric basidiomycete Coprinus cinereus. Genetics, 118, 213-220.

McLaughlin DJ (1982) Ultrastructure and cytochemistry of basidial and basidiospore development. In: Wells K, Wells EK (eds.), Basidium and Basidiocarp: Evolution, cytology, function and development. Springer-Verlag, New York, USA, pp. 37-74.

Meheriuk M, McPhee WJ (1984) Postharvest handling of pome fruits, soft fruits, and grapes. Agric. Can. Publ. 1768E. Research Brach, Ottawa, Canada.

Melik-Khachatryan GH (1980) Mycoflora of Armenia. Vol. 5. Agaricales. Yerevan St. University, Yerevan, Armenia.

Meskauskas AL, Novak Frazer L, Moore D (1999) Mathematical modeling of morphogenesis in fungi: a key role for curvature compensation ('autotropism') in the curvature distribution model. New Phytol., 143, 387-399.

Mitchel DH, Smith AH (1978) Notes on colorado fungi III, new and interesting mushrooms from the aspen zone. Mycologia, 70, 1040-1063.

Mohamed SH, Dix NJ (1988) Resource utilization and distribution of Coprinus comatus, Coprinus atramentarius, Lacrimaria velutina and Melanoleuca grammopodia. Trans. Br. Mycol. Soc., 90, 255-263.

Moore D (1998) Fungal morphogenesis. Cambridge Univ. Press, Cambridge, UK.

Moore D, Hock B, Greening JP, Kern VD, Frazer LN, Monzer J (1996) Centenary review: Gravimorphogenesis in agarics. Mycol. Res., 100, 257-273.

Moser M, Jülich W (1995) Farbatlas der Basidiomyceten. Gustav Fischer Verlag, Sttutgart, Germany.

Nobles MK (1958) Cultural characters as a guide to the taxonomy and phylogeny of the polyporaceae. Can. J. Bot., 36, 883-926.

Olander LP, Bustamante MM, Asner GP, Telles E, Prado Z, Camargo PB (2005) Surface soil changes following selective logging in an eastern amazon forest. Earth Interactions, 9, 1-19.

Orton PD (1957) Notes on British Agarics 1-5 observations on the genus Coprinus. Trans. Br. Mycol. Soc., 40, 263-276.

Orton PD (1960) Agarics and Boleti. Trans. Br. Mycol. Soc., 43, 201-203.

Orton PD (1969) Notes on British Agarics: III*. Notes from the Royal Botanic Garden Edinburgh, 29, 75-124. 
Orton PD (1972) Notes on British Agarics, IV. Notes from the Royal Botanic Garden, Edinburgh, 2, 135-150.

Orton PD, Watling R (1979) British fungus flora. Agarics and Boleti 2. Coprinaceae Part 1: Coprinus. Her Majesty's Stationary Office, Edinburg, UK.

Park DS, Go SJ, KimYS, Seok SJ, Ryu JC, Sung JM (1999a) Phylogenetic relationships of genera Coprinus and Psathyrella on the basis of ITS region sequences. Kor. J. Mycol., 27, 274-279.

Park DS, Go SJ, Kim YS, Seok SJ, Song JK, Yeo YS, Ryu JC, Sung JM (1999b) Genetic relationships of Coprinus spp. on the basis of sequences in ITS II region. Kor. J. Mycol., 27, 27-31.

Park DS, Go SJ, Ryu JC (1999c) Phylogenetic relationships of Coprinoid Taxa and an agaric-like gastroid Taxon based on the sequences of internal transcribed spacer (ITS) regions. Kor. J. Mycol., 27, 406-411.

Pegler DN (1966) Tropical african agaricales. Persoonia, 4, 73-124.

Pegler DN (1977) A preliminary agaric flora of east Africa. Kew Bull. Addit. Ser., 6, 386-440.

Pegler DN (1983) Agaric flora of the Lesser Antilles. Kew Bull. Addit. Ser., 9, 460-501.

Pegler DN (1986) Agaric flora of Sri Lanka. Coprinaceae. Kew Bull. Addit. Ser., 12, 357-395.

Petersen JFW, Kadziola A, Larsen S (1994) 3-dimensional structure of a recombinant peroxidase from Coprinus cinereus at 2.6 angstrom resolution. FEBS Lett., 339, 291-296.

Phillips R (1990) Der Kosmos-Pilzatlas. Kosmos, Sttutgart, Germany.

Pilát A, Svrček M (1967) Revisio specierum sectionis Herbicolae Pil. et Svr. generis Coprinus Pers. ex S. F. Gray. Česka Mykologie, 21, 136-145.

Piontek K, Smith AT, Blodig W (2001) Lignin peroxidase structure and function. Biochem. Soc. T., 29, 111-116.

Pitakpaivan P, Choobamroong W, Sontirat P, Tontyaporn S (1991) Study on species of fungi associated with the cultivation of straw, Volvariella volvacea Bull. ex Fr. Sing. in Thailand. In: Maher MJ (ed.), Science and Cultivation on Edible Fungi, Proc. 13th Int. Cong. Sci. Cult. Edible Fungi, Dublin, September 1991. A.A. Balkema, Rotterdam, The Netherlands, pp. 385-388.

Pointing SB (2001) Feasibility of bioremediation by white-rot fungi. Appl. Microbiol. Biotechnol., 57, 20-33. 
Polak E, Aebi M, Kües U (2001) Morphological variations in oidium formation in the basidiomycete Coprinus cinereus. Mycol. Res., 105, 603-610.

Polak E, Hermann R, Kües U, Aebi M (1997) Asexual sporulation in Coprinus cinereus: Structure and development of oidiophores and oidia in an Amut Bmut homokaryon. Fungal Genet. Biol., 22, 112-126.

Prasad JRK, Singh K, Neelakantan S (1990) Optimization of solid substrate fermentation of wheat straw by selected alkalophilic fungi. Indian J. Anim. Sci., 60, 1481-1490.

Pukkila PJ (1993) Methods of genetic manipulation in Coprinus cinereus. In: Chang ST, Buswell JA, Miles PG (eds.), Genetics and breeding of edible mushrooms. Gordon and Breach Science Publishers, Y-Parc, Switzerland, pp. 249-264.

Puniya AK, Singh K (1995) Determination of enzyme activities of lignocellulolytic strains in solid substrate fermented products. Indian J. Anim. Nutr., 12, 205-212.

Rai SN, Walli TK, Gupta BN (1989) The chemical-composition and nutritive-value of rice straw after treatment with urea or Coprinus fimentarius in a solid- state fermentation system. Anim. Feed Sci. Tech., 26, 81-92.

Rayner ADM, Boddy L (1988) Fungal communities in the decay of wood. Adv. Microb. Ecol., 10, 115-166.

Reddy CA, Mathew Z (2001) Bioremediation potential of white-rot fungi. In: Gadd, GM (ed.), Fungi in bioremediation. Cambridge Univ. Press, Cambridge, UK, pp. 52-78.

Redhead SA (2000) Bully for Coprinus - a story of manure, minutiae, and molecules. McIlvainea, 14, 5-14.

Redhead SA, Ginns JH (1985) A reappraisal of agaric genera associated with brown rots of wood. Trans. Mycol. Soc. Japan, 26, 349-381.

Redhead SA, Traquair JA (1981) Coprinus sect - herbicolae from Canada, notes on extralimital taxa, and the taxonomic position of a low-temperature basidiomycete forage crop pathogen from western Canada. Mycotaxon, 13, 373404.

Redhead SA, Vilgalys R, Moncalvo JM, Johnson J, Hopple JS Jr (2001) Coprinus Pers. and the disposition of Coprinus species sensu lato. Taxon, 50, 203-241.

Reid DA (1958) New or interesting records of British Hymmenomycetes. II. Trans. Br. Mycol. Soc., 41, 419-445. 
Reid DA, Eicker A (1999) South African fungi 10, New species, new records and some new observations. Mycotaxon, 73, 169-197.

Romagnesi H (1976) Quelques espèces rares ou nouvelles de macromycètes. 1. Coprinacées. Bull. Soc. Myc. Fr., 92, 189-206.

Ross IK (1982) The role of laccase in carpophore initiation in Coprinus congregatus. $J$. Gen. Microbiol., 128, 2763-2770.

Ross IK (1985) Determination of the initial steps in differentiation in Coprinus congregatus. In: Moore D, Casselton LA, Wood DA, Frankland JC (eds.), Developmental biology of higher fungi. Cambridge Univ. Press, Cambridge, UK, pp. 353-373.

Ross IK, Margalith P (1987) Nuclear behavior in the basidia of the secondarily homothallic Coprinus bilanatus. Mycologia, 79, 595-602.

Ross WD (1976) Fungi associated with root diseases of aspen in Wyoming. Can. J. Bot., 54, 734-744.

Routien JB, Simonzi S (1960) A Coprinus growing in an automobile. Mycologia, 52, 961-962.

Runge A (1975) Pilzsukzession auf Laubholzstümpfen. Z. Pilzkunde, 41, 31-38.

Runge A (1982) Pilzsukzession auf Pappelstümpfen. Z. Mykol., 48, 133-140.

Runge A (1986) Pilzsukzession während der Finalphase auf Pappelstümpfen. Z. Mykol., $52,217-224$.

Sagara N (1975) Ammonia fungi - A chemoecological grouping of terrestrial fungi. Contrib. Biol. Lab. Kyoto Univ., 24, 205-276.

Sadikhov AS (1968) Mushrooms from Lenkoranskii region of Azerbaijan. Synopsis of PhD Thesis. Baku, Azerbaijan.

Sadowska B (1988) Fungi of the genus Coprinus Pers. ex Fr. S. F. Gray. Folia Societatis Scientiarum Lublinensis, 30, 35-37.

Saiz-Jimenez C (1983) The chemical nature of the melanins from Coprinus spp. Soil Sci., 136, 65-74.

Samgina DI (1985) Flora sporic plants of Kazakhstan. Agarics fungi. Vol. 13. Book 2. Nauka, Alma-Ata, Kazakhstan.

Schlechte G (1986) Holzbewohnende Pilze. Jahn \& Ernst-Verlag, Hamburg, Germany.

Schmit JP (1999) Resource consumption and competition by unit restricted fungal decomposers of patchy substrates. Oikos, 87, 509-519. 
Schmit JP (2001) Intraspecific competition in two unit-restricted fungal decomposers, Coprinus cinereus and C. congregatus. Mycol. Res., 105, 112-118.

Schneider P, Caspersen MB, Mondorf K, Halkier T, Skov LK, Ostergaard PR, Brown KM, Brown SH, Xu F (1999) Characterization of a Coprinus cinereus laccase. Enzyme Microb. Tech., 25, 502-508.

Schwarze FWMR, Engels J, Mattheck C (2000) Fungal strategies of wood decay in trees. Springer Verlag, Heidelberg, Germany.

Serjanina GI, Yashkin IJ (1986) Mushrooms. Nauka i Technika, Minsk, Byelorussia.

Shaw CG, Kile GA (1991) Armillaria root disease. Agriculture Handbook No. 691. Forest Service United States Department of Agriculture, Washington, D.C. USA.

Shearman RL, Koppi AJ, Broadbent P. (1996) Dry root rot and its relationship to soil physical conditions. Proc. Brighton Crop Prot. Conf., pp. 413-414.

Shields JK, Shih M (1975) Catalogue of reference culture collection of wood-inhabiting micro-organisms. Rept. OPX9E. Eastern For. Prod. Lab., Ottawa, Canada.

Sholberg PL, Gaudet DA (1992) Grass as a source of inoculum for rot caused by Coprinus- psychromorbidus in stored apples. Can. J. Plant Pathol., 14, 221-226.

Singer R (1996) The agaricales in modern taxonomy. Koeltz Scientific Books, Königstein, Germany.

Singh K, Rai SN (1992) Wheat straw processing by solid substrate fermentation with Coprinus fimentarius. Indian J. Anim. Sci., 62, 381-382.

Singh K, Rai SN, Neelakantan S, Han YW (1990) Biochemical profiles of solid-state fermented wheat straw with Coprinus fimentarius. Indian J. Anim. Sci., 60, 984990.

Singh GP, Singh K, Gupta BN (1995) Bioconversion of ammonia to biological protein by Coprinus fimentarius during solid substrate fermentation of ammoniated (urea) wheat-straw. Indian J. Anim. Sci., 65, 602-605.

Smith AH (1948) Studies in the dark-spored agarics. Mycologia, 40, 669-684.

Smith JD (1981) Snow molds of winter cereals, guide for diagnosis, culture, and pathogenicity. Can. J. Plant Pathol., 3, 15-25.

Soponsathien S (1998) Some characteristics of ammonia fungi 1. In relation to their ligninolytic enzyme activities. J. Gen. Appl. Microbiol., 44, 337-345.

Spotts RA, Traquair JA, Peters BB (1981) D' Anjou pear decay by a low temperature basidiomycete. Plant Dis., 65, 151-153. 
Sprague R (1962) Some leaf spot fungi on western Graminaceae. XVI. Mycologia, 54, 593-610.

Stamets P (1993) Growing gourmet \& medicinal mushrooms. Ten Speed Press, Berkely, C.A., USA.

Steffen KT, Hofrichter M, Hatakka A (2000) Mineralisation of ${ }^{14}$ C-labelled synthetic lignin and ligninolytic enzyme activities of litter-decomposing basidiomycetous fungi. Appl. Microbiol. Biotechnol., 54, 819-825.

Stephens SK, Elliott TJ, Wood DA (1991) Extracellular enzyme mutants of Coprinus bilanatus. Enzyme Microb.Tech., 13, 976-981.

Stojanowska W (1981) Myxomycetes of the rotting cherry wood. Acta Mycologica, 17, 125-129.

Subramaniyan S, Prema P (2002) Biotechnology of microbial xylanases: Enzymology, molecular biology, and application. Crit. Rev. Biotechnol., 22, 33-64.

Thielke C (1982) Meiotic divisions in the basidium. In: Wells K, Wells EK (eds.), Basidium and basidiocarp. Springer-Verlag, New York, N.Y., pp. 75-92.

Traquair JA, Mckeen WE (1986) Fine structure of root tip cells of winter wheat exposed to toxic culture filtrates of Coprinus psychromorbidus and Marasmius oreades. Can. J. Plant Pathol., 8, 59-64.

Uljé CB (1988) Four new species of Coprinus from the Netherlands. Persoonia, 13, 479-488.

Uljé CB (1992) A new species of Coprinus from the Netherlands. Persoonia, 14, 56569.

Uljé CB, Aptroot A, Van Iperen A (1998) A new Coprinus from Papua New Guinea sporulating in pure culture. Persoonia, 16, 549-551.

Uljé CB, Bas C (1988) Studies in Coprinus. 1 Subsections auricomi and glabri of Coprinus section Pseudocoprinus. Persoonia, 13, 433-448.

Uljé CB, Bas C (1991) Studies in Coprinus. 2. Subsection Setulosi of section Pseudocoprinus. Persoonia, 14, 275-339.

Uljé CB, Bas C (1993) Some new species of Coprinus from the Netherlands. Persoonia, $15,357-368$.

Uljé CB, Bender H (1997) Additional studies in Coprinus subsection Glabri. Persoonia, $16,373-381$.

Uljé CB, Noordeloos ME (1993) Studies in Coprinus III. Coprinus section Veliformes. Subdivision and revision of subsection Nivei emend. Persoonia, 15, 257-301. 
Uljé CB, Noordeloos ME (1996) Type studies in Coprinus subsect. Alachuani. Proc. of the Koninklijke Nederlandse Akademie Van Wetenschappen-Biological Chemical Geological Physical and Medical Sciences, 99, 105-124.

Uljé CB, Noordeloos ME (1997) Studies in Coprinus IV. Coprinus section Coprinus. Subdivision and revision of subsection Alachuani. Persoonia, 16, 265-333.

Uljé CB, Noordeloos ME (1999) Studies in Coprinus V. Coprinus section Coprinus. Revision of subsection Lanatuli Sing. Persoonia, 17, 165-199.

Uljé CB, Noordeloos ME (2000) Type studies in Coprinus subsection Lanatuli. Persoonia, 17, 339-375.

Uljé CB, Doveri F, Noordeloos ME (2000) Additions to Coprinus subsection Lanatuli. Persoonia, 17, 465-471.

Uranchimeg C, Bondartzeva MA, Nezdoiminogo EL (1976) Notes on mycromycetes of the mountain-taiga and mountain-steppe vegetation belts of Mongolian Folk Republik. Mikol. Fitopatol., 17, 374-376.

Van de Bogart F (1976) The genus Coprinus in western North America, Part I, Section Coprinus. Mycotaxon, 4, 233-275.

Van de Bogart F (1979) The genus Coprinus in Western North America, Part II, section Lanatuli. Mycotaxon, 8, 243-291.

Van Heerden I, Cronje C, Swart SH, Kotze JM (2002) Microbial, chemical and physical aspects of citrus waste composting. Bioresource Technol., 81, 71-76.

Vasilieva LN (1979) Agaricales from Prymorski region. Nauka, Leningrad, Russia.

Vnenchak P, Schwalb MN (1989) Phenol oxidase activity during development of Coprinus cinereus. Mycol. Res., 93, 546-548.

Walser PJ, Hollenstein M, Klaus MJ, Kües U (2001) Genetic analysis of basidiomycete fungi. In: Talbot NJ (ed.), Molecular and cell biology of filamentous fungi: a practical approach. Practical Approach Series, IRL Press, Oxford, UK, pp. 59-90.

Waters H, Butler RD, Moore D (1975a) Structure of aerial and submerged sclerotia of Coprinus lagopus. New Phytol., 74, 199-205.

Waters H, Moore D, Butler RD (1975b) Morphogenesis of aerial sclerotia of Coprinus lagopus. New Phytol., 74, 207-213.

Watling R, Miller OK (1973) A Coprinus from white rot of sugar maple. Notes from the Royal Botanic Garden, Royal Botanic Gardens, Ediburgh, UK, pp. 445-447. 
Wegener G, Fengel D (1983) Lignin-macromolecule, cell-wall component, rawmaterial. Papier, 37 (10A), V22-V31.

Wesenberg D, Kyriakides I, Agathos SN (2003) White-rot fungi and their enzymes for the treatment of industrial dye effluents. Biotechnol. Adv., 22, 161-187.

Woodward S, Stenlid J, Karjalainen R, Hüttermann A (1998) Heterobasidium annosum: biology, ecology, impact and control. CAB International, Wallingford, UK.

Worall JJ, Anagnost SE, Zabel RA (1997) Comparison of wood decay among diverse lignicolous fungi. Mycologia, 89, 199-219.

Yaver DS, Overjero MD, Xu F, Nelson BA, Brown KM, Halkier T, Bernauer S, Brown SH, Kauppinen S (1999) Molecular characterization of laccase genes from the basidiomycete Coprinus cinereus and heterologous expression of the laccase Lcc1. Appl. Environ. Microbiol., 65, 4943-4948.

Zarudnaya GI, Minkevich II (1986) Biological wood destruction of birch walls in vineyards in the north Caucasus and some ways of increasing their bioresistence. Mikol. Fitopatol., 20, 291-295.

Zerova MY (1979) Viznachnik Gribov Ukraini. Vol. 5. Naukova dumka, Kiev, Ukraine.

Zolan ME, Stassen NY, Ramesh MA, Lu BC, Valentine G (1995) Meiotic mutants and DNA repair genes of Coprinus cinereus. Can. J. Bot., 73, S226-S233. 
Growth of selected coprini on lignocellulosic substrates and detection of laccase activities

Contribution to this chapter: Manuscript writing and test of coprini on lignocellulosic substrates was performed by the author of this thesis. Prof. S.M. Badalian and H.K Avetisyan (Laboratory of Fungal Biology and Biotechnology, Yerevan State University) contributed the test of strains on agar plates. 


\section{Growth of selected coprini on lignocellulosic substrates and detection of laccase activities}

\subsection{Abstract}

In a screening initiative, we determined growth parameters of several coprinoid mushrooms and evaluated extracellular phenoloxidases (laccase) activities with gallic, tannic acid, ABTS (2,2'-azino-di-(3-ethylbenzothiazoline-6-sulfonic acid)) and DMP (2,6-dimethoxy phenol). In total, 3 strains belonging to a species of the genus Coprinus, 4 strains belonging to the genus Coprinopsis, and 13 strains belonging to the genus Coprinellus were studied. In our coprinoid screening program, we attempted to elucidate decay abilities of isolated coprinoid species on Populus and Fagus wood (sawdust) as well as on wheat straw and various leave litters (Acer platanoides and Quercus robur). Most of the strains could establish well on straw and Quercus leave litter as well as on beech wood. On beech, Coprinus comatus, Coprinopsis strossmayeri, Coprinellus curtus, Coprinellus micaceus, and Coprinellus sp. C50 exhibited laccase activity either with DMP or ABTS. On agar medium supplemented with gallic acid, all tested strains but those of $C$. cinerea showed a more or less strong positive phenoloxidase activity.

Keywords: coprini, wood and straw degradation, saprotropic fungi, fimicolous fungi, phenoloxidase activity 


\subsection{Introduction}

The traditional genus Coprinus includes more than 200 species (Kühner and Romagnesi 1978, Orton and Watling 1979, Redhead et al. 2001). Coprini have been compiled in one genus until recently, when molecular data divided them into four new genera belonging to the Psathyrellaceae (Coprinopsis with an estimated 100 species, Coprinellus with more than 40 species and Parasola with currently 18 defined species) and the Agaricaceae (Coprinus with just three species), respectively (Redhead et al. 2001).

The coprini are known to be mainly fimicolous fungi, many of them grow also on plant litter in soil. However, a literature survey showed that around a third of the known species occurs also on decaying wood or wooden material (see chapter 2 of this thesis). Moreover, some coprini have been made responsible for decay of aspen in wide areas of North America. In various US states, Coprinopsis atramentaria was found associated with root rot, butt rot and heart rot in hardwoods. In Ontario, Coprinellus micaceus (Coprinus micaceus) caused stringy white rot of living aspen (heart rot), sugar maple and yellow birch (Basham 1958, Basham and Morawski 1964, Lindsey and Gilbertson 1978, Gilbertson 1981).

In Europe, Coprinellus disseminatus (Coprinus disseminatus) was found in Poland at the base of infected aspen trees (Domański 1983, 1984). In addition, coprinoid mushrooms have been observed growing on stumps of Populus canadiensis [Coprinopsis laanii (Coprinus laanii), C. disseminatus], Populus tremula (C. disseminatus) and Populus spp. (C. atramentaria, C. disseminatus, C. micaceus, Parasola megasperma [Coprinus megaspermus, Coprinus ramosocystidiatus]. Occasionally, mycelial isolates have been made directly from stumps of $P$. tremula (C. atramentaria), Populus tremuloides (C. micaceus) and Populus deltoides (Coprinellus radians [Coprinus radians]). Other isolates [C. atramentaria, Coprinopsis lagopides (Coprinus lagopides), Coprinellus verrucispermus (Coprinus verrucispermus), Coprinus stanglianus)] have been collected under or in close vicinity to standing poplars. Few reports are given for some coprini growing on beech [e.g. Coprinopsis insignis (Coprinus insignis), C. micaceus, and Coprinus silvaticus)] (Chapter 2 of this thesis). A number of coprini are often mentioned as being woodrotting, but there is no sound experimental evidence which supports this. 
In the last years, the study of white-rotting fungi has acquired importance due to the potential biotechnological application of some of their enzymes as cleaning agents of industrial effluents as well as bioremediation mediators to clean up herbicides and pesticides in soil (Durán and Esposito 2000, Pointing 2001, Wesenberg et al. 2003, Couto and Herrera 2006, Husain 2006). The study of morphological, ecological and physiological characteristics of mycelium is a basic stage towards biotechnological use of these fungi. As part of our research with the coprinoid group of fungi, we determined growth parameters of several coprini mushrooms and extracellular phenoloxidases (laccase) activity on growth on lignocellulosic substrates. In addition to sawdust from poplar and beech, we included Triticum sativum straw and leave litter from Acer platanoides and from Quercus robur as substrates. Strains were tested for phenoloxidase activities.

\subsection{Materials and methods}

Coprini strains (Table 1) were obtained from different strain collections (Duke University, Yerevan State University, and from our institute's collection). Coprini are species that, with a few exceptions, are difficult to distinguish from each other by morphological means (e.g. fruiting bodies or mycelial morphology). In order to secure the identity of strains as best as possible, they were subjected to an analysis of ITS sequences. Aerial mycelia were scraped from the surface of agar plates for chromosomal DNA isolation by the method of Zolan and Pukkila (1986).

\subsubsection{Evaluating ITS sequences from coprini}

PCR was performed with ca $5 \mathrm{ng}$ DNA of a fungal isolate in a total volume of $25 \mu \mathrm{l}$ containing $10 \mathrm{mM}$ Tris $\mathrm{pH} 8.8,50 \mathrm{mM} \mathrm{KCl}, 0.1 \%$ Triton $\mathrm{X}-100,1.5 \mathrm{mM} \mathrm{MgCl}_{2}, 0.2$ $\mathrm{mM}$ dNTPs (Fermentas, St. Leon-Rot, Germany), each $0.4 \mu \mathrm{M}$ of primer ITS1 [5'TCCGTAGGTGAACCTGCGG-3' (White et al. 1990)] and primer ITS4 [5'TCCTCCGCTTATTGATATGC-3', (White et al. 1990)], and 1 U of Taq DNA polymerase. PCR conditions were $2 \mathrm{~min}$ initial denaturation at $94^{\circ} \mathrm{C}$, followed by 35 cycles of $30 \mathrm{~s}$ at $94^{\circ} \mathrm{C}, 30 \mathrm{~s}$ at $55^{\circ} \mathrm{C}$, and $30 \mathrm{~s}$ at $72^{\circ} \mathrm{C}$, and a final extension at $72^{\circ} \mathrm{C}$ for 10 min. $20 \mu 1$ per PCR reaction were precipitated with isopropanol and resuspended in $20 \mu 1 \mathrm{H}_{2} \mathrm{O}$. Agarose gel electrophoresis of purified DNAs were performed by standard methods (Sambrook and Russell 2001). For cycle sequencing reactions, $2 \mu 1$ of the purified DNA were mixed with BigDye Terminator v3.1 (Applied Biosystems, 
Darmstadt, Germany) applying a quarter of the reagents recommended by the manufacturer and either primer ITS1 or ITS4. After cycling following the manufacturer's instructions, the reaction products were purified by sodium acetate/ethanol precipitation and washing with $70 \%$ ethanol and subsequently run on an ABI PRISM 3100 Genetic Analyzer (Applied Biosystems). Obtained sequences were compared against the nucleotide entries in the NCBI GenBank by using search tool blastn (http://www.ncbi.nlm.nih.gov/). Identity values were taken either from the blastn results or from alignments performed by the tool for blasting two sequences bl2seq (http://www.ncbi.nlm.nih.gov/). For phylogenetic analysis, appropriate sequences were taken from the NCBI database and aligned with sequences established in this study using ClustalX (http://www-igbmc.u-strasbg.fr/BioInfo/ClustalX/Top.html) and GeneDoc version 2.6.002 (http://www.psc.edu/biomed/genedoc/). Phylogenetic trees of the nucleotide sequence alignments were calculated by the neighbour joining method of the program MEGA version 3.1 (Kumar et al. 2004).

\subsubsection{Screening of the strains on different media}

In total, 21 strains from 8 defined species from clades Coprinus, Coprinopsis, and Coprinellus, as well as 6 Coprinellus sp. strains were used in our screening (Table 1). The strains were grown on $1.5 \%$ malt-extract-agar (MEA) under different temperatures $\left(4-37^{\circ} \mathrm{C}\right)$ and $\mathrm{pH}(3-12)$ at $25^{\circ} \mathrm{C}$. The diameter of the colonies was measured on the $6^{\text {th }}$ and $10^{\text {th }}$ day of growth, respectively.

\subsubsection{Phenoloxidase activity on solid media}

Extracellular phenoloxidase activity was tested on malt-extract-agar ( $\mathrm{pH}$ 6) supplemented with $0.5 \mathrm{~g} / 1$ gallic acid (GA) or $0.5 \mathrm{~g} / 1$ tannic acid (TA) (Soponsathien 1998). Cultures were inoculated on the different media, incubated at $25^{\circ} \mathrm{C}$ and evaluated after $7 \mathrm{~d}$ of incubation for the production of phenoloxidases by darkening of the media. The diameter of the colony was measured at the $8^{\text {th }}$ day of growth.

\subsubsection{Growth on lignocellulosic substrates}

Abilities to grow on lignocellulosic substrates were tested by inoculating selected strains on beech and poplar grinded sawdust (sieve of $2 \mathrm{~mm}$ ), leave litter of A. platanoides and Q. robur, and T. sativum straw. Flasks containing $10 \mathrm{~g}$ of grinded substrate, and $20 \mathrm{ml}$ of distilled water were autoclaved and inoculated with 10 agar 
plugs of mycelia and incubated at $28^{\circ} \mathrm{C}$. Periodically, the cultures were observed and the growth of the fungi on the substrate evaluated by changes in density of mycelia, in colony diameter and coloration on the substrates. After 4 months, a sample of the substrate colonized by the mycelium was taken in an Eppendorf tube of $1.5 \mathrm{ml}$. To the sample, $1 \mathrm{ml}$ of buffer (sodium acetate $120 \mathrm{mM}$, pH 5.0) plus $100 \mu 1$ of ABTS (5 mM) [2, 2-azino-bis-(3-ethylbenzothiazoline-6-sulphonic acid)] as laccase substrate were added (Matsumura et al. 1986). The sample was incubated for $15 \mathrm{~min}$ at RT, and laccase activity was considered positive if a green coloration appeared in the solution product of the interaction of the ABTS and the enzyme present in the sample. Different levels of activity were arbitrarily assigned according to the strength of the coloration in the supernatant. The same was performed with DMP (2,6-dimethoxy phenol) $(0.3 \%$ in ethanol) (Johannes and Majcherczyk 2000).

Additionally, selected cultures were tested for their capacity to release ${ }^{14} \mathrm{CO}_{2}$ from specifically ${ }^{14} \mathrm{C}$-labelled beech twigs. Measurements of the ${ }^{14} \mathrm{CO}_{2}$ released were performed as described by Trojanowsky and Hüttermann (1987). $500 \mathrm{ml}$ flasks containing a mixture of $10 \mathrm{~g}$ of grinded beech sawdust (sieve of $2 \mathrm{~mm}$ ), $10 \mathrm{mg}$ of labelled beech $(4.0 \mathrm{nCi} / \mathrm{mg}), 20 \mathrm{ml}$ of water, $10 \mathrm{ml}$ ammonium tartrate $(8 \mathrm{mM})$, and 10 plugs $(0.5 \mathrm{~cm} \varnothing)$ of strains to be tested where incubated for 45 days at $28^{\circ} \mathrm{C}$. Cultures were tightly closed with rubber stoppers to which a glass-cup containing $10 \% \mathrm{NaOH}$ ( $2 \mathrm{ml}$ changed in each measurement) for absorption of the ${ }^{14} \mathrm{CO}_{2}$ released were attached. The radioactive $\mathrm{CO}_{2}$ was collected and the radioactivity was measured, at different intervals of time for 45 days, in a liquid scintillation counter (LSA Packard) using Lumasafe. Tested were all the strains that showed well growth on beech sawdust (for details see Table 5). As positive and negative controls cultures of Trametes versicolor 6 and Aspergillus nidulans FGSC A4 were included. The experiment was performed once in triplicates.

\subsection{Results and discussion}

\subsubsection{Identification of the strains}

In total, 21 strains were analyzed, three of which were according to the designation originally received supposed to belong to the genus Coprinus, six to the genus Coprinopsis, eleven to the genus Coprinellus, and one to the genus Parasola. By ITS sequencing, the identity of three strains as Coprinus comatus was confirmed. Sequences 
obtained from two of the strains matched with $99 \%$ identity to the ITS sequence from the C. comatus reference strain (AY176346). The third sequenced strain is somewhat divergent with $97-98 \%$ identity to the C. comatus reference strains (Table 1).

Of the six strains originally assigned to the genus Coprinopsis, only four clearly belong to this genus (Table 1 and Figure 1). The ITS sequence of Coprinopsis strossmayeri (syn. Coprinus rhizophorus) strain 15-2C hit with 97\% a sequence of C. rhizophorus (syn. C. strossmayeri). The two other positive hits $(99-100 \%$ identity to C. cinerea reference strains) are C. cinerea strains JV6 and C344. [The C. cinerea strain AmutBmut (Table 1), not sequenced in this study, mates with the former strains and, accordingly, it is therefore also a $C$. cinerea strain]. The originally named strain C. atramentarius C67 is, according to our ITS analysis, possibly C. disseminatus since its ITS sequence matches with 98\% identity to the C. disseminatus sequence DQ093648 and in a phylogenetic analysis, the sequence groups with that of other Coprinellus species (Figure 1). The ITS sequence of strain C145 tested as Coprinopsis cothurnata (Coprinus cothurnatus) matched perfectly the GenBank entry AF345820 supposed to be a C. cothurnata strain. Furthermore, it was $100 \%$ and $89 \%$ identical to sequences assigned to the fungus Sistotrema brinkmannii (DQ093653) from the Corticiaceae and to the species Clavulina cf. cristata from the Clavulinaceae, respectively (Table 1). In a phylogenetic analysis of ITS sequences of coprinoid mushrooms, the supposed to be C. cothurnata ITS sequence groups apart from other coprinoid mushrooms (Figure 1). Including in this phylogenetic analysis also ITS sequences from a number of Corticiaceae and Clavulinaceae, the results suggest that probably neither the designation C. cothurnata nor the name S. brinkmanni is correct for the strain C145. Since the strain C145 was obtained from the coprinoid mushroom collection of Duke University, it is possible that J.-M. Moncalvo as a former member of the Duke laboratory (Redhead et al. 2001) sequenced with his colleagues the same strain and reported the sequence under the accession number AF345820 in Genbank.

According to ITS sequences, nine of eleven supposed to be Coprinellus strains (Table 1 and Figure 1) belong indeed to this genus. Assigned species names appear to be correct for the isolates called Coprinellus curtus (Coprinus curtus), C. micaceus (3x), C. radians and Coprinellus xanthothrix (Coprinus xanthothrix). Strains C50, C72 and 12PS are members of the genus Coprinellus but the species names appear to be incorrect, 
respectively are currently not possible to define (Table 1, Figure 1). Accordingly, we will refer to these strains in the following only to Coprinellus sp. with the respective strain name.

Strain C403 named Coprinellus bisporus (Coprinus bisporus) is different in its ITS sequence from a C. bisporus reference strain (AF345824, 85\% identity). The closest match was an unidentified coprinoid species listed in GenBank as Coprinus sp. CBS 118528 (AJ890441). In the phylogenetic tree of ITS sequences, strain C403 and the unidentified coprinoid cluster within the genus Coprinellus, indicating that the assignment of the genus of the strain was obviously not wrong. Strain C403 is therefore referred in the following as Coprinellus sp. C403. Another wrongly assigned strain is the isolate called so far C. angulatus (Coprinellus angulatus) C459. The ITS sequence hits closest a sequence from Coprinellus flocculosus (Coprinus flocculosus AF345818). In the phylogenetic tree, the species groups unambiguously to neither Coprinopsis nor Coprinellus and also not to Coprinus species (Figure 1). An ITS sequence from a

Table 1 Coprini used in this study and ITS sequence analysis.

\begin{tabular}{|c|c|c|c|c|c|c|}
\hline \multirow[b]{2}{*}{$\begin{array}{c}\text { Strain as } \\
\text { originally } \\
\text { named }\end{array}$} & \multirow[t]{2}{*}{ Strains } & \multirow{2}{*}{$\begin{array}{c}\text { Fragment } \\
\text { length (bp) } \\
\underset{\ddagger}{ }\end{array}$} & \multicolumn{3}{|c|}{ Hits in NCBI GenBank } & \multirow[t]{2}{*}{ New name* } \\
\hline & & & $\begin{array}{c}\text { Accession } \\
\text { number } \\
\text { (region) }\end{array}$ & Species & $\begin{array}{c}\% \\
\text { Identity }\end{array}$ & \\
\hline \multicolumn{7}{|c|}{ Genus Coprinus } \\
\hline \multirow[t]{2}{*}{ C. comatus } & I & 373 & $\begin{array}{c}\text { AY176346 } \\
(133-506) \\
\text { VOUCHER }\end{array}$ & $\begin{array}{l}\text { Coprinus } \\
\text { comatus }\end{array}$ & 99 & \\
\hline & & & $\begin{array}{c}\text { AF345803 } \\
(125-492)\end{array}$ & $\begin{array}{l}\text { Coprinus } \\
\text { comatus }\end{array}$ & 97 & \\
\hline \multirow[t]{2}{*}{ C. comatus } & II & 1035 & $\begin{array}{c}\text { AY176346 } \\
(1-633)\end{array}$ & $\begin{array}{l}\text { Coprinus } \\
\text { comatus }\end{array}$ & 99 & \\
\hline & & & $\begin{array}{c}\text { AF345803 } \\
(1-642)\end{array}$ & $\begin{array}{l}\text { Coprinus } \\
\text { comatus }\end{array}$ & 97 & \\
\hline \multirow[t]{2}{*}{ C. comatus } & $\mathrm{C} 108^{1}$ & 595 & $\begin{array}{c}\text { AY176346 } \\
(34-631)\end{array}$ & $\begin{array}{l}\text { Coprinus } \\
\text { comatus }\end{array}$ & 97 & \\
\hline & & & $\begin{array}{c}\text { AF345803 } \\
(22-618)\end{array}$ & $\begin{array}{l}\text { Coprinus } \\
\text { comatus }\end{array}$ & 98 & \\
\hline \multicolumn{7}{|c|}{ Genus Coprinopsis } \\
\hline $\begin{array}{l}\text { C. } \\
\text { atramentarius }\end{array}$ & $\mathrm{C} 278^{1}$ & 610 & $\begin{array}{c}\text { DQ093648 } \\
(50-655)\end{array}$ & $\begin{array}{c}\text { Coprinellus } \\
\text { disseminatus }\end{array}$ & 98 & $\begin{array}{c}\text { Coprinellus sp. } \\
\text { C278 }\end{array}$ \\
\hline \multirow[t]{2}{*}{ C. cinereus } & $\begin{array}{l}\text { Amut } \\
\text { Bmut }\end{array}$ & $\begin{array}{c}\text { Not } \\
\text { determined }\end{array}$ & & & & \\
\hline & JV6 & 344 & $\begin{array}{c}\text { AF345819 }^{\#} \\
(27-364)\end{array}$ & $\begin{array}{c}\text { Coprinopsis } \\
\text { cinerea }\end{array}$ & 100 & \\
\hline
\end{tabular}


Table 1 continued

\begin{tabular}{|c|c|c|c|c|c|c|}
\hline & & & $\begin{array}{c}\text { AB097563 } \\
(69-406) \\
\text { VOUCHER }\end{array}$ & $\begin{array}{l}\text { Coprinopsis } \\
\text { cinerea }\end{array}$ & 100 & \\
\hline & C344 ${ }^{1}$ & 621 & $\begin{array}{c}\text { AY461825 } \\
(56-677)\end{array}$ & $\begin{array}{l}\text { Coprinopsis } \\
\text { cinerea }\end{array}$ & 99 & \\
\hline C. cothurnata & $\mathrm{C} 145^{1}$ & 407 & $\begin{array}{c}\text { AF345820 } \\
(18-422)\end{array}$ & $\begin{array}{c}\text { Coprinopsis } \\
\text { cothurnata }\end{array}$ & 100 & $\begin{array}{l}\text { Unknown } \\
\text { fungus, } \\
\text { not coprini }\end{array}$ \\
\hline C. strossmayeri & $15-2 \mathrm{C}$ & 599 & $\begin{array}{c}\mathrm{AB} 071797^{¥ ¥} \\
(99-704)\end{array}$ & $\begin{array}{c}\text { Coprinus } \\
\text { rhizophorus } \\
\text { (C. } \\
\text { strossmayeri) }\end{array}$ & 97 & \\
\hline
\end{tabular}

\section{Genus Coprinellus}

\begin{tabular}{|c|c|c|c|c|c|c|}
\hline \multirow[t]{2}{*}{ C. angulatus } & \multirow[t]{2}{*}{$\mathrm{C} 459^{1}$} & \multirow[t]{2}{*}{548} & \multicolumn{3}{|l|}{$\begin{array}{c}\text { Not } \\
\text { available }\end{array}$} & \\
\hline & & & $\begin{array}{c}\text { AF345818 } \\
(218-622)\end{array}$ & $\begin{array}{l}\text { Coprinellus } \\
\text { flocculossus }\end{array}$ & 92 & \\
\hline \multirow[t]{3}{*}{ C. bisporus } & \multirow[t]{3}{*}{$\mathrm{C} 403^{1}$} & \multirow[t]{3}{*}{624} & $\begin{array}{c}\text { AJ890441 } \\
(17-641)\end{array}$ & $\begin{array}{l}\text { Coprinus sp. } \\
\text { CBS } 118528\end{array}$ & 95 & \multirow[t]{3}{*}{$\begin{array}{l}\text { Coprinellus sp. } \\
\text { C403 }\end{array}$} \\
\hline & & & $\begin{array}{c}\text { AF345824 } \\
(1-582)\end{array}$ & C. bisporus & 85 & \\
\hline & & & $\begin{array}{c}\text { AJ246160 } \\
(108-735)\end{array}$ & $\begin{array}{c}\text { Oat root } \\
\text { associated } \\
\text { basidiomycete }\end{array}$ & 95 & \\
\hline C. curtus & $\mathrm{C} 311^{1}$ & 541 & $\begin{array}{c}\text { AY461824 } \\
(8-548)\end{array}$ & $\begin{array}{l}\text { Coprinellus } \\
\text { curtus }\end{array}$ & 96 & \\
\hline \multirow[t]{3}{*}{ C. disseminatus } & \multirow[t]{3}{*}{$\mathrm{C} 50^{1}$} & \multirow[t]{3}{*}{366} & $\begin{array}{c}\text { AY969507 } \\
(45-412)\end{array}$ & $\begin{array}{c}\text { Uncultured } \\
\text { basidiomycete }\end{array}$ & 99 & \multirow[t]{3}{*}{$\begin{array}{l}\text { Coprinellus sp. } \\
\text { C50 }\end{array}$} \\
\hline & & & $\begin{array}{c}\text { AY461838 } \\
(59-416)\end{array}$ & $\begin{array}{l}\text { Coprinellus } \\
\text { disseminatus }\end{array}$ & 94 & \\
\hline & & & $\begin{array}{c}\text { DQ093648 } \\
(629-245) \\
\end{array}$ & $\begin{array}{c}\text { Coprinellus } \\
\text { disseminatus }\end{array}$ & 93 & \\
\hline C. domesticus & $\mathrm{C} 72^{1}$ & 582 & $\begin{array}{c}\text { AF361228 } \\
(31-612)\end{array}$ & $\begin{array}{l}\text { Coprinellus } \\
\text { xanthothrix }\end{array}$ & 99 & $\begin{array}{c}\text { Coprinellus sp. } \\
\text { (xanthothrix?) }\end{array}$ \\
\hline \multirow[t]{3}{*}{ C. micaceus } & S-2 & 258 & $\begin{array}{c}\text { AF345808 } \\
(193-448) \\
\end{array}$ & $\begin{array}{c}\text { Coprinellus } \\
\text { micaceus }\end{array}$ & 97 & \\
\hline & $9-1 \mathrm{C}$ & 540 & $\begin{array}{c}\text { AF345808 } \\
(69-609)\end{array}$ & $\begin{array}{c}\text { Coprinellus } \\
\text { micaceus }\end{array}$ & 98 & \\
\hline & $15-3 C$ & 1070 & $\begin{array}{c}\text { AF345808 } \\
(1-673) \\
\end{array}$ & $\begin{array}{c}\text { Coprinellus } \\
\text { micaceus }\end{array}$ & 98 & \\
\hline C. radians & $\mathrm{C} 22^{1}$ & 617 & $\begin{array}{c}\text { AY461815* } \\
(25-640)\end{array}$ & $\begin{array}{c}\text { Coprinellus } \\
\text { radians }\end{array}$ & 98 & \\
\hline Coprinus sp. & $1-2 \mathrm{PS}$ & 532 & $\begin{array}{c}\text { AF345822 } \\
(28-551)\end{array}$ & $\begin{array}{l}\text { Coprinellus } \\
\text { radians }\end{array}$ & 96 & $\begin{array}{c}\text { Coprinellus sp. } \\
\text { 1-2PS }\end{array}$ \\
\hline C. xanthothrix & $\mathrm{C} 144^{1}$ & 462 & $\begin{array}{c}\text { AF361228 } \\
(501-44) \\
\end{array}$ & $\begin{array}{l}\text { Coprinopsis } \\
\text { xanthothrix }\end{array}$ & 98 & \\
\hline \multicolumn{7}{|c|}{ Genus Parasola } \\
\hline P. plicatilis & $\mathrm{C} 65^{1}$ & 399 & $\begin{array}{c}\text { AF345818 } \\
(536-142)\end{array}$ & $\begin{array}{l}\text { Coprinellus } \\
\text { flocculosus }\end{array}$ & 98 & $\begin{array}{c}\text { Coprinellus sp. } \\
\text { C65 } \\
\text { (flocculosus?) }\end{array}$ \\
\hline
\end{tabular}

\# Origins of strains: ${ }^{1}$ obtained from T. James (Duke University); ${ }^{2}$ self-compatible C. cinerea strain used in studies of fungal development (Boulianne et al. 2000)

* Species names were newly assigned according to the results from the comparison with ITS sequences deposited in the NCBI GenBank.

$¥$ Partial sequence $\quad$ ¥ Complete sequence 


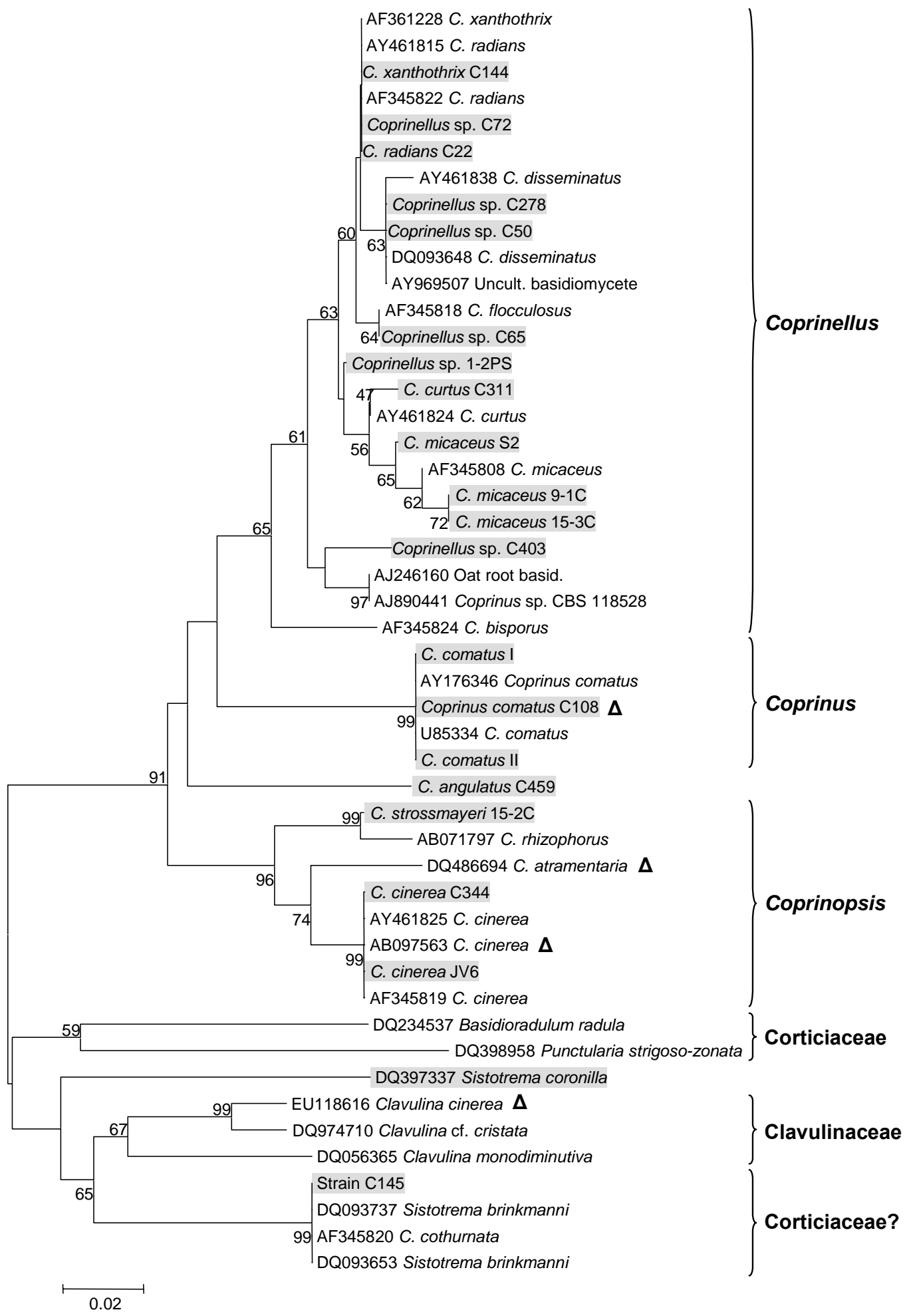

Figure 1 Phylogenetic tree of analyzed coprini in combination with some non-coprinoid species. Codes indicate NCBI GenBank accession numbers. Strains marked in grey are those analyzed in this study. Accepted reference strains for species are marked by the symbol $\Delta$. Bootstrap values (500 replications) above 50 are shown at tree branchings. The scale bar defines the number of nucleotide substitutions per site. 
Parasola strain to test if strain C459 belongs to this genus is currently not available. The ITS sequence of a single species supposed to be Parasola plicatilis was found $98 \%$ identical to a sequence of $C$. flocculosus. This strain is therefore a Coprinellus species (Figure 1) and referred in the following as Coprinellus sp. C65.

The overall results from molecular genetic analysis of strain identity demonstrate clearly how difficult it is to define coprinoid mushrooms (see also Naumman et al. 2007 for further examples). In conclusion from the presented work we could assign 3 strains to a species of the genus Coprinus, 4 strains to the genus Coprinopsis, and 13 strains to the genus Coprinellus. In order to define best conditions for comparable analysis of phenoloxidase productions, these strains were studied further in growth behavior. Note that strain C145 was eliminated from further analysis.

\subsubsection{Growth of the strains on artificial media (MEA) at different environmental conditions}

To obtain a first impression on growth behaviour of strains, they were inoculated on agar medium (MEA) and incubated under different environmental conditions.

A. Effect of temperature: Temperature effects on growth were tested with MEA, pH 6.0. Most of the strains were found to be mesophilic preferring a temperature range from $25-30^{\circ} \mathrm{C}$ (Table 2, Figure 2). The strains of the species C. cinerea, C. strossmayeri, and C. xanthothrix, Coprinellus sp. C65 and C72 grew also well at $37^{\circ} \mathrm{C}$ on MEA ( $\mathrm{pH} 6.0$ ) (Table 2) whereas all others did not grow or grew only poorly at this temperature. All tested species showed moderate growth at $15^{\circ} \mathrm{C}$, except C. cinerea strains. None of the strains grew at $4{ }^{\circ} \mathrm{C}$ (For details see Table 2).

Differences were seen in colony morphology (see Figure 2 for growth of strains at temperature of $25^{\circ} \mathrm{C}$ ). With the exception of C. curtus (Figure $\mathbf{2 K}$ ) and C. strossmayeri (Figure 2L) that developed a thinner mycelial colony and mycelial strands, respectively, most of the strains developed a cottony mycelial structure. Some species were distinguished by particular pigmentation: C. radians and C. xanthothrix developed a light brown-orange mycelial colour (Figure 2C,I), and Coprinellus sp. 1-2PS a yellowish mycelial colour (Figure 2). 
Table 2 Diameter $(\mathrm{mm})$ of coprini colonies at different temperatures after $10 \mathrm{~d}$ incubation on MEA agar plates $\mathrm{pH} 6$.

\begin{tabular}{|c|c|c|c|c|c|c|c|}
\hline \multirow{2}{*}{ Species } & \multirow{2}{*}{ Strains } & \multicolumn{6}{|c|}{ Temperature $\left({ }^{0} \mathrm{C}\right)$} \\
\hline & & 4 & 15 & 20 & 25 & 30 & 37 \\
\hline \multicolumn{8}{|l|}{ Genus Coprinus } \\
\hline \multirow[t]{3}{*}{ C. comatus } & I & NG & 22 & 34 & 68 & 25 & $\mathrm{NG}$ \\
\hline & II & NG & 24 & 36 & 74 & 35 & NG \\
\hline & $\mathrm{C} 108$ & NG & 26 & 36 & 64 & 24 & NG \\
\hline \multicolumn{8}{|c|}{ Genus Coprinopsis } \\
\hline \multirow[t]{3}{*}{ C. cinerea } & AmutBmut & $\mathrm{NG}$ & NG & 32 & $>85$ & $>85$ & $>85$ \\
\hline & JV6 & NG & NT & NT & 24 & 36 & 85 \\
\hline & C344 & NG & $\mathrm{NG}^{+}$ & 30 & $>85$ & $>85$ & 85 \\
\hline C. strossmayeri & $15-2 \mathrm{C}$ & NG & 24 & 46 & 66 & 78 & 60 \\
\hline \multicolumn{8}{|c|}{ Genus Coprinellus } \\
\hline C. angulatus & $\mathrm{C} 459$ & NG & 32 & 70 & 76 & 52 & 7 \\
\hline C. curtus & $\mathrm{C} 311$ & NG & 43 & 66 & 84 & $>85$ & 84 \\
\hline \multirow{3}{*}{ C. micaceus } & S-2 & NG & 51 & 80 & $>85$ & $>85$ & NG \\
\hline & $9-1 \mathrm{C}$ & NG & 44 & 70 & $>85$ & 74 & NG \\
\hline & $15-3 \mathrm{C}$ & NG & 44 & 78 & $>85$ & 72 & NG \\
\hline C. radians & $\mathrm{C} 22$ & NG & 56 & 58 & 85 & 85 & 48 \\
\hline C. xanthothrix & C144 & NG & 78 & $>85$ & $>85$ & $>85$ & $>85$ \\
\hline Coprinellus sp. & $1-2 \mathrm{PS}$ & NG & 66 & $>85$ & $>85$ & $>85$ & 12 \\
\hline Coprinellus sp. & C50 & NG & 32 & 70 & 84 & 56 & NG \\
\hline Coprinellus sp. & C65 & NG & 48 & 68 & $>85$ & $>85$ & 72 \\
\hline Coprinellus sp. & $\mathrm{C} 72$ & NG & 78 & $>85$ & $>85$ & $>85$ & 85 \\
\hline Coprinellus sp. & $\mathrm{C} 278$ & NG & 65 & 65 & 68 & 44 & NG \\
\hline Coprinellus sp. & $\mathrm{C} 403$ & NG & 22 & 25 & 42 & 24 & NG \\
\hline
\end{tabular}

$\mathrm{NG}=$ No growth, $\mathrm{NT}=$ not tested

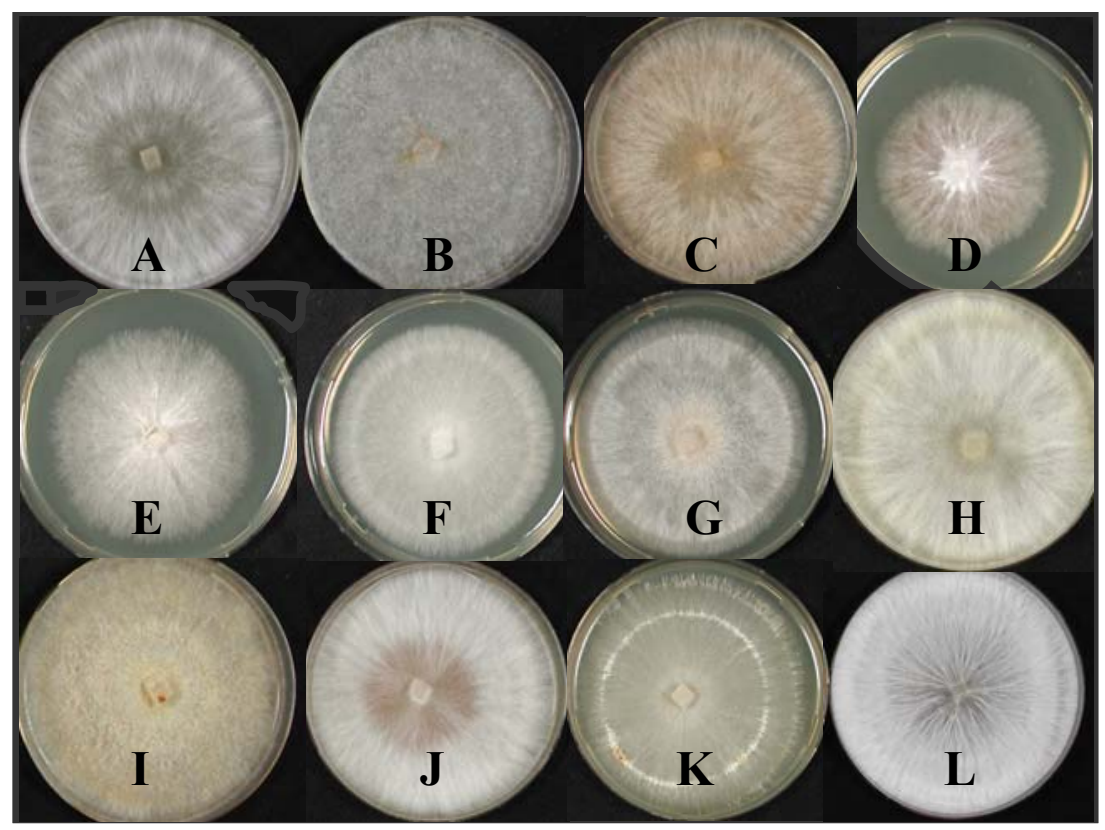

Figure 2 Colony morphology of selected strains grown for $10 \mathrm{~d}$ at $25^{\circ} \mathrm{C}$ on MEA plates. A. Coprinellus sp. C65; B. Coprinellus sp. C72; C. Coprinellus radians C22, D. Coprinus comatus C108; E. C. comatus II; F. Coprinopsis cinerea AmutBmut; G. C. cinerea C344; H. Coprinellus sp. 1-2PS; I. Coprinellus xanthothrix C144; J. Coprinellus micaceus S-2; K. Coprinellus curtus C311; L. Coprinopsis strossmayeri 15-3C. 
Well-developed fruiting bodies were observed specifically in cultures of C. cinerea (not shown), C. micaceus, C. xanthothrix, C. curtus, and Coprinellus sp. C72 at a temperature of $25^{\circ} \mathrm{C}$ (Figure 3). Restriction of fruiting of C. cinerea to a temperature of $\pm 25^{\circ} \mathrm{C}$ is a well known characteristic of this species (Kües 2000). Fruiting in the other species on artificial media, to my knowledge, is poorly studied or not described.
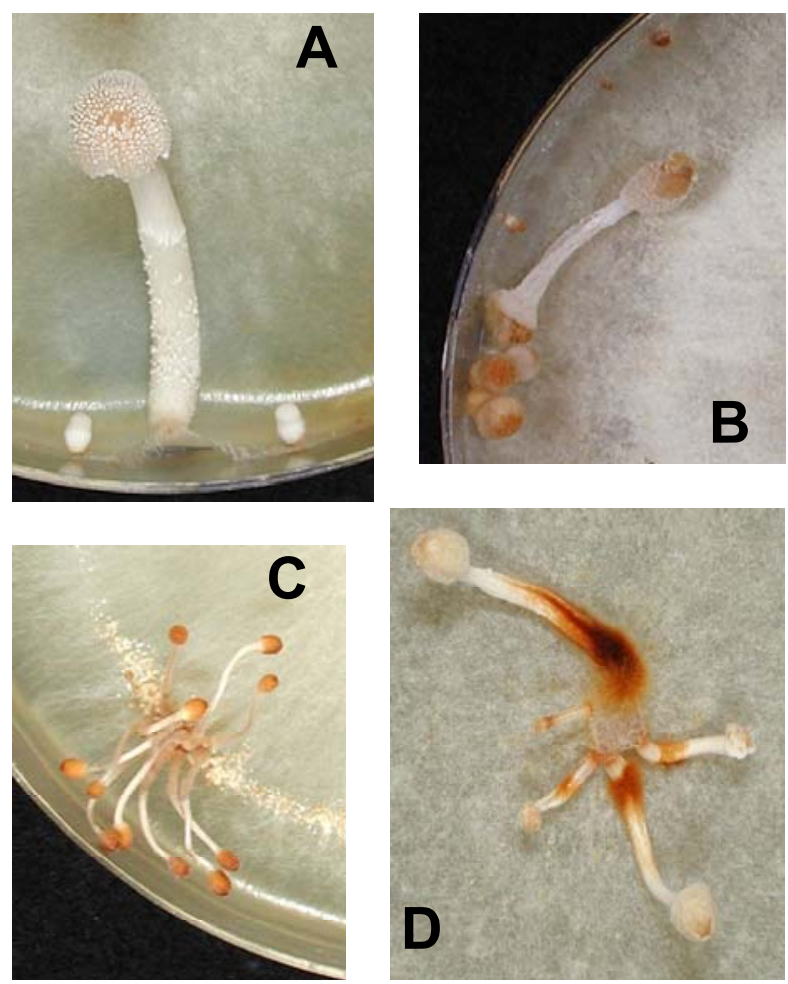

Figure 3 Fruiting bodies developed easily on MEA at $25^{\circ} \mathrm{C}$. A. Coprinellus micaceus 9-1C, B. Coprinellus xanthothrix C144; C. Coprinellus curtus C311, and D. Coprinellus sp. C72.

B. Effect of pH: All the tested strains but the three C. comatus strains grow at a $\mathrm{pH}$ range from 5.0-12.0. The C. comatus strains only accepted a $\mathrm{pH}$ range from 5.0-10.0. For most species, the preferred $\mathrm{pH}$ range was rather broad with $\mathrm{pH}$ 6.0-9.0. None of them tolerated pH 3.0 and 4.0 (Table 3). Fungal species, with preference of slightly acidic to alkaline conditions ( $\mathrm{pH}$ 6.0-9.0) are classified as ammonia fungi and are rather an exception (Sagara 1975). Coprinoid mushrooms have been described before to be typical ammonia fungi (Sagara 1975, Soponsathien 1998). Sagara (1992) and Soponsathien (1998) reported 8 species as ammonia fungi [C. cinerea, Coprinopsis echinospora (Coprinus echinosporus), Coprinopsis neolagopus (Coprinus neolagopus), Coprinopsis phlyctidospora (Coprinus phlyctidosporus), C. angulatus, Coprinopsis 
gonophylla (Coprinus gonophyllus), C. laanii, and Coprinopsis stercorea (syn. Coprinus stercorarius)]. C. cinerea was confirmed by our study to belong to the ammonia fungi. With our other tested isolates, the list of ammonia fungi has been prolonged by 6 species (C. comatus, C. strossmayeri, C. curtus, C. micaceus, C. radians, C. xanthothrix). It is interesting to note that ammonia fungi occur at least in three of the clades of coprini (Coprinus, Coprinopsis and Coprinellus).

Table 3 Diameter $(\mathrm{mm})$ of coprini colonies at different $\mathrm{pHs}$.

\begin{tabular}{|c|c|c|c|c|c|c|c|c|c|c|c|}
\hline \multirow{2}{*}{ Species } & \multirow{2}{*}{ Strains } & \multicolumn{10}{|c|}{ pH value } \\
\hline & & 3 & 4 & 5 & 6 & 7 & 8 & 9 & 10 & 11 & 12 \\
\hline \multicolumn{12}{|l|}{ Genus Coprinus } \\
\hline \multirow{3}{*}{ C. comatus } & $\mathrm{I}$ & $\mathrm{NG}$ & $\mathrm{NG}$ & 16 & 18 & 30 & 22 & 20 & 16 & $\mathrm{NG}^{+}$ & $\mathrm{NG}^{+}$ \\
\hline & II & NG & NG & 25 & 35 & 38 & 38 & 34 & 28 & $\mathrm{NG}^{+}$ & $\mathrm{NG}^{+}$ \\
\hline & $\mathrm{C} 108$ & $\mathrm{NG}$ & $\mathrm{NG}$ & 28 & 30 & 32 & 30 & 30 & 25 & $\mathrm{NG}^{+}$ & $\mathrm{NG}^{+}$ \\
\hline \multicolumn{12}{|c|}{ Genus Coprinopsis } \\
\hline \multirow[t]{3}{*}{ C. cinerea } & $\begin{array}{l}\text { Amut } \\
\text { Bmut }\end{array}$ & $\mathrm{NG}$ & $\mathrm{NG}$ & 42 & 50 & 56 & 50 & 50 & 48 & 45 & 42 \\
\hline & JV6 & NG & NG & 40 & 42 & 48 & 50 & 62 & 50 & 48 & 46 \\
\hline & C344 & $\mathrm{NG}$ & $\mathrm{NG}$ & 46 & 60 & 62 & 64 & 62 & 60 & 58 & 56 \\
\hline C. strossmayeri & $15-2 \mathrm{C}$ & $\mathrm{NG}$ & $\mathrm{NG}$ & 62 & 70 & 70 & 70 & 68 & 62 & 60 & 53 \\
\hline \multicolumn{12}{|c|}{ Genus Coprinellus } \\
\hline C. angulatus & $\mathrm{C} 459$ & $\mathrm{NG}$ & $\mathrm{NG}$ & 36 & 42 & 44 & 38 & 36 & 34 & 30 & 15 \\
\hline C. curtus & C311 & $\mathrm{NG}$ & $\mathrm{NG}$ & 48 & 58 & 66 & 62 & 60 & 60 & 59 & 55 \\
\hline \multirow[t]{3}{*}{ C. micaceus } & S-2 & $\mathrm{NG}$ & NG & 36 & 52 & 64 & 66 & 64 & 62 & 58 & 52 \\
\hline & $9-1 \mathrm{C}$ & $\mathrm{NG}$ & $\mathrm{NG}$ & 48 & 58 & 68 & 62 & 60 & 60 & 55 & 50 \\
\hline & $15-3 \mathrm{C}$ & $\mathrm{NG}$ & $\mathrm{NG}$ & 62 & 68 & 70 & 70 & 66 & 60 & 57 & 53 \\
\hline C. radians & $\mathrm{C} 22$ & $\mathrm{NG}$ & NG & 50 & 58 & 66 & 66 & 58 & 57 & 52 & 43 \\
\hline C. xanthothrix & $\mathrm{C} 144$ & $\mathrm{NG}$ & $\mathrm{NG}$ & 64 & 82 & 85 & 86 & 84 & 82 & 79 & 72 \\
\hline Coprinellus sp. & $1-2 \mathrm{PS}$ & NG & $\mathrm{NG}$ & 64 & 72 & 76 & 74 & 72 & 68 & 63 & 58 \\
\hline Coprinellus sp. & $\mathrm{C} 50$ & $\mathrm{NG}$ & $\mathrm{NG}$ & 58 & 64 & 70 & 70 & 66 & 64 & 60 & 55 \\
\hline Coprinellus sp. & C65 & $\mathrm{NG}$ & $\mathrm{NG}$ & 52 & 60 & 70 & 64 & 66 & 63 & 62 & 60 \\
\hline Coprinellus sp. & $\mathrm{C} 72$ & $\mathrm{NG}$ & $\mathrm{NG}$ & 64 & 84 & 85 & 86 & 84 & 80 & 70 & 62 \\
\hline Coprinellus sp. & $\mathrm{C} 278$ & $\mathrm{NG}$ & $\mathrm{NG}$ & 40 & 48 & 49 & 47 & 46 & 46 & 45 & 42 \\
\hline Coprinellus sp. & C403 & $\mathrm{NG}$ & $\mathrm{NG}$ & 14 & 26 & 36 & 36 & 22 & 20 & 18 & 18 \\
\hline
\end{tabular}

$\mathrm{NG}^{+}=$growth on inoculum

C. Phenoloxidase activity: Since a $\mathrm{pH}$ of 6.0 and a temperature of $25^{\circ} \mathrm{C}$ was well accepted by the fungi, phenoloxidase activity on MEA pH 6.0 was tested throughout growth at $25^{\circ} \mathrm{C}$ on agar supplemented with $0.5 \mathrm{~g} / \mathrm{L}$ gallic acid (GA) or $0.5 \mathrm{~g} / \mathrm{L}$ tannic acid (TA). GA or TA in the media inhibited the growth of the $C$. cinerea and C. comatus strains. However, C. comatus strains reacted and showed a medium intensity reaction against MEA $+\mathrm{GA}$ and a low intensity reaction towards MEA+TA whereas reactions were absent in C. cinerea strains (Table 4). Addition of GA and TA to the 
medium had also negative effects on the growth of other strains. Compared to the pure MEA pH 6.0 media all strains grow slowly when these compounds were added.

As recognized by a strong brown color underneath and around the fungal cultures, C. strossmayeri 15-3C, Coprinellus sp.1-2PS, Coprinellus sp. C50, Coprinellus sp. C65, Coprinellus sp. C278 and strains of C. micaceus showed strong phenoloxidases activity on MEA+GA (Figure 4). Weak phenoloxidase reactions were observed on MEA+TA media in cultures of C. angulatus, C. curtus, C. micaceus, C. strossmayeri, C. radians and Coprinellus sp. C72 (Table 4) (not shown by photographs).

Since all the tested strains except those of $C$. cinerea showed more or less a strong positive phenoloxidase activity, one might expect possible growth of the strains on lignocellulosic material.

Table 4 Phenoloxidase activity within strains of coprini after $7 \mathrm{~d}$ of incubation and diameter of colonies on $\mathrm{d} 8$ of mycelial growth on MEA, MEA + TA, and MEA + GA.

\begin{tabular}{|c|c|c|c|c|c|c|}
\hline \multirow{2}{*}{ Species } & \multirow{2}{*}{ Strains } & \multicolumn{3}{|c|}{ Growth rate (diameter) } & \multicolumn{2}{|c|}{ Phenoloxidase activity } \\
\hline & & MEA + GA & MEA + TA & MEA & MEA + GA & MEA + TA \\
\hline \multicolumn{7}{|l|}{ Genus Coprinus } \\
\hline \multirow[t]{3}{*}{ C. comatus } & $\mathrm{I}$ & $\mathrm{NG}$ & $\mathrm{NG}$ & - & ++ & + \\
\hline & II & $\mathrm{NG}$ & $\mathrm{NG}$ & 60 & ++ & + \\
\hline & C108 & $\mathrm{NG} / \mathrm{P}(+)$ & $\mathrm{NG}$ & 34 & ++ & + \\
\hline \multicolumn{7}{|c|}{ Genus Coprinopsis } \\
\hline \multirow[t]{3}{*}{ C. cinerea } & AmutBmut & $\mathrm{NG} / \operatorname{pigm}(+)$ & $\mathrm{NG}$ & 64 & - & - \\
\hline & JV6 & $\mathrm{NG}$ & $\mathrm{NG}$ & 24 & - & - \\
\hline & $\mathrm{C} 344$ & NG & NG & $>85$ & - & - \\
\hline C. strossmayeri & $15-2 \mathrm{C}$ & 54 & 80 & $>85$ & ++++ & + \\
\hline \multicolumn{7}{|c|}{ Genus Coprinellus } \\
\hline C. angulatus & $\mathrm{C} 459$ & 46 & 16 & 66 & - & + \\
\hline C. curtus & C311 & 36 & 10 & 64 & + & + \\
\hline \multirow[t]{3}{*}{ C. micaceus } & $\mathrm{S}-2$ & 54 & 50 & $>85$ & +++ & + \\
\hline & $9-1 \mathrm{C}$ & 38 & 52 & 85 & +++ & + \\
\hline & $15-3 \mathrm{C}$ & 54 & 68 & 82 & +++ & + \\
\hline C. radians & $\mathrm{C} 22$ & 64 & 30 & 84 & + & + \\
\hline C. xanthothrix & $\mathrm{C} 144$ & 75 & 20 & $>85$ & + & - \\
\hline Coprinellus sp. & $1-2 \mathrm{PS}$ & 60 & 53 & $>85$ & +++ & ++ \\
\hline Coprinellus sp. & $\mathrm{C} 50$ & 25 & 58 & 74 & +++ & ++ \\
\hline Coprinellus sp. & C65 & 18 & 22 & 84 & +++ & + \\
\hline Coprinellus sp. & C72 & 84 & 22 & $>85$ & - & + \\
\hline Coprinellus sp. & $\mathrm{C} 278$ & 22 & 62 & - & +++ & ++ \\
\hline Coprinellus sp. & C403 & $\mathrm{NG}$ & $\mathrm{NG}$ & 36 & + & - \\
\hline
\end{tabular}

$+=$ weak reaction, $++=$ medium reaction, $+++=$ strong reaction 


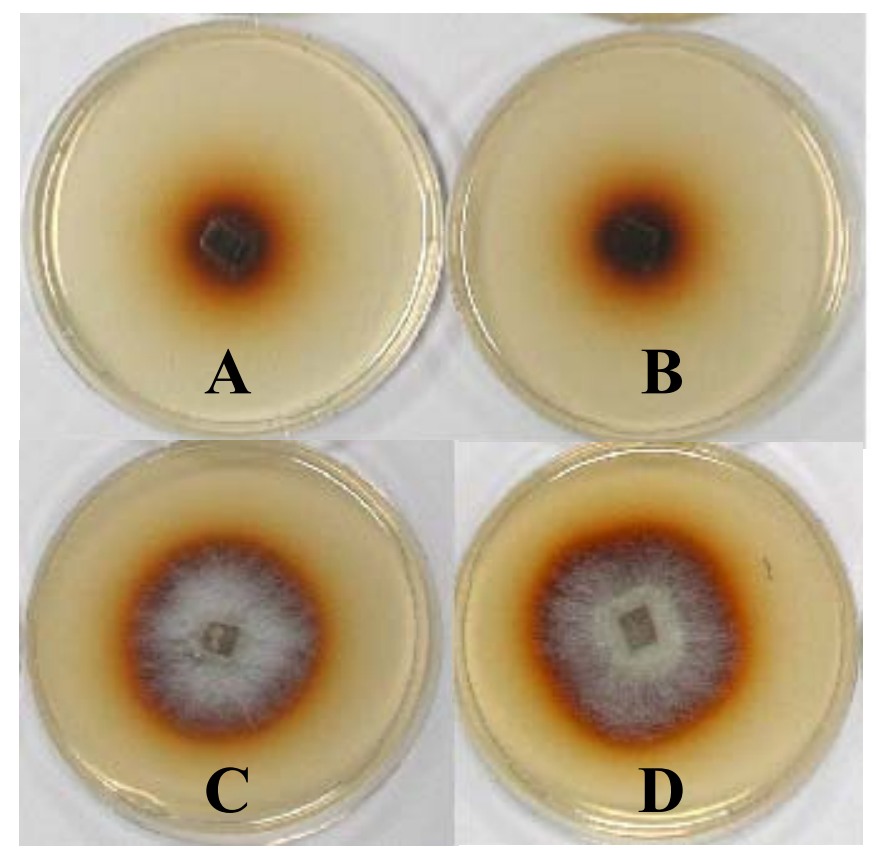

Figure 4 Phenoloxidase activity within strains of coprini after $7 \mathrm{~d}$ of incubation at $25^{\circ} \mathrm{C}$ on MEA + GA: A) Coprinellus sp. C278; B) Coprinellus sp. C65; C) C. micaceus 15-3C; D) C. micaceus 9-1C.

\section{Growth of selected strains on lignocellulosic substrates and laccase activities:}

Abilities to grow and degrade lignocellulosic substrates were studied at $25^{\circ} \mathrm{C}$ on Populus and Fagus sawdust judging from the formation of a cottony mycelium, wheat straw, and leave litter from oak and from maple, respectively.

Several species grew well on beech wood (C. strossmayeri, C. curtus, C. micaceus, C. radians, C. xanthothrix, Coprinellus sp. 1-2PS, and C72), whereas only C. comatus grew poorly on this substrate. Some strains of these (C. strossmayeri, C. micaceus 153C, C. xanthothrix, Coprinellus sp. 1-2PS, and C72) grew well on poplar sawdust, in contrast to C. comatus II that developed poorly on this substrate.

It was further tested whether increasing the nitrogen content of the samples improved fungal growth. Addition of ammonium tartrate (10 $\mathrm{ml} 8 \mathrm{mM}$ per flask) had only a strong positive effect on growth of beech wood in C. micaceus strains (Table 5). Most of the tested strains (17 strains) established also on Quercus leave litter, whereas only few could develop on A. platanoides leave litter (C. micaceus, Coprinellus sp. 1-2PS, C50, and C72). With the exception of Coprinellus sp. C50, all species established mycelium 
Table 5 Growth of selected coprini strains on lignocellulosic substrates.

\begin{tabular}{|c|c|c|c|c|c|c|c|c|}
\hline \multirow[b]{2}{*}{ Species } & \multirow[b]{2}{*}{ Strains } & \multicolumn{4}{|c|}{ Sawdust } & \multicolumn{2}{|c|}{ Leaves } & \multirow[b]{2}{*}{ Straw } \\
\hline & & beech & $\begin{array}{l}\text { beech } \\
+\mathrm{NH}_{4} \\
\end{array}$ & poplar & $\begin{array}{l}\text { poplar } \\
+\mathrm{NH}_{4} \\
\end{array}$ & $\begin{array}{c}\text { Acer } \\
\text { platanoides }\end{array}$ & $\begin{array}{l}\text { Quercus } \\
\text { robur }\end{array}$ & \\
\hline \multicolumn{9}{|l|}{ Genus Coprinus } \\
\hline \multirow[t]{6}{*}{ C. comatus } & I & $*$ & $*$ & - & - & - & $* *$ & $* * *$ \\
\hline & & & & & & & ABTS & ABTS \\
\hline & II & $*$ & $*$ & $*$ & - & - & $* *$ & $* * *$ \\
\hline & & DMP & DMP & & & & ABTS & ABTS \\
\hline & C108 & $*$ & $*$ & - & - & - & $* * *$ & $* * *$ \\
\hline & & & DMP & & & & ABTS & ABTS \\
\hline \multicolumn{9}{|c|}{ Genus Coprinopsis } \\
\hline \multirow[t]{6}{*}{ C. cinerea } & Amut & - & $*$ & - & - & - & $* *$ & $* * *$ \\
\hline & Bmut & & & & & & & ABTS \\
\hline & JV6 & - & - & - & - & - & - & $* * *$ \\
\hline & & & & & & & & ABTS \\
\hline & C344 & - & - & - & - & - & - & $* * *$ \\
\hline & & & & & & & & ABTS \\
\hline \multirow[t]{2}{*}{ C. strossmayeri } & $15-2 \mathrm{C}$ & $* * *$ & $* * *$ & $* *$ & $*$ & - & $* *$ & $* * *$ \\
\hline & & ABTS & ABTS & & & & ABTS & ABTS \\
\hline \multicolumn{9}{|c|}{ Genus Coprinellus } \\
\hline C. angulatus & $\mathrm{C} 459$ & - & - & - & - & - & $*$ & $* * *$ \\
\hline \multirow[t]{2}{*}{ C. curtus } & C311 & $*$ & $*$ & - & - & - & $* * *$ & $* * *$ \\
\hline & & ABTS & $\begin{array}{l}\text { ABTS } \\
\text { DMP } \\
\end{array}$ & & & & & ABTS \\
\hline \multirow[t]{5}{*}{ C. micaceus } & S-2 & - & - & - & - & - & $* *$ & $* * *$ \\
\hline & $9-1 \mathrm{C}$ & $*$ & $* * *$ & - & - & $*$ & $* *$ & $* * *$ \\
\hline & & DMP & $\begin{array}{c}\text { ABTS } \\
\text { DMP }\end{array}$ & & & & & ABTS \\
\hline & $15-3 \mathrm{C}$ & $*$ & $* * *$ & $*$ & $* *$ & $*$ & $* * *$ & $* * *$ \\
\hline & & DMP & $\begin{array}{c}\text { ABTS } \\
\text { DMP }\end{array}$ & & & & & \\
\hline \multirow[t]{2}{*}{ C. radians } & $\mathrm{C} 22$ & $* *$ & $* * *$ & - & - & - & $* * *$ & $* * *$ \\
\hline & & & & & & & & ABTS \\
\hline C. xanthothrix & $\mathrm{C} 144$ & $* * *$ & $* * *$ & $*$ & $* *$ & - & $* *$ & $* * *$ \\
\hline \multirow[t]{2}{*}{ Coprinellus sp. } & $1-2 \mathrm{PS}$ & $* *$ & $* *$ & $* *$ & $* *$ & $* *$ & $* * *$ & $* * *$ \\
\hline & & & & & & & & ABTS \\
\hline Coprinellus sp. & $\mathrm{C} 50$ & - & - & - & - & $*$ & $*$ & - \\
\hline Coprinellus sp. & $\mathrm{C} 65$ & - & - & - & - & - & $*$ & $* * *$ \\
\hline \multirow[t]{2}{*}{ Coprinellus sp. } & $\mathrm{C} 72$ & $* *$ & $* *$ & $* *$ & $* *$ & $* *$ & $* * *$ & $* * *$ \\
\hline & & ABTS & ABTS & ABTS & ABTS & & & \\
\hline Coprinellus sp. & C278 & - & - & - & - & - & - & $* *$ \\
\hline Coprinellus sp. & C403 & - & - & - & - & - & $* *$ & $* * *$ \\
\hline
\end{tabular}

*** high mycelial growth and wood destaining, ** high mycelia growth without obvious wood distaining

* mycelial growth only on the surface of the wood or close to the inoculum, - = did not show any growth

ABTS $=$ Laccase reaction with ABTS, DMP $=$ Laccase reaction with DMP

well on straw (C. comatus, C. cinerea, C. strossmayeri, C. angulatus, C. micaceus, C. radians, C. xanthothrix and C. curtus, Coprinellus sp. 1-2PS, C72, C278, and C403). 
With the GA and TA plate test done previously (see above) it was known that phenoloxidases are produced by most of the fungi, but the type of enzyme (laccase or peroxidase) is not clear from such tests. Here, by ABTS and DMP application, we tested more specifically to find out whether laccases were produced. Laccase activity on beech was observed in 6 species (C. comatus, C. strossmayeri, C. curtus, C. micaceus, and Coprinellus sp. C72). From the strains that grew on poplar, only Coprinellus sp. C72 showed laccase activity. None of the strains that developed on Acer leave litter showed laccase activities, whereas on Quercus leave litter, C. comatus and C. strossmayeri strains showed activity. On straw, the situation was very different and laccase activity was detected either with DMP or ABTS in C. comatus, C. strossmayeri, C. micaceus, C. radians, and Coprinellus sp. 1-2PS and even in C. cinerea (Table 5). As a side observation of this experiment, C. curtus produced fructifications on poplar (Figure 5A) and beech sawdust (Figure 5B) whereas Coprinellus sp. C72 and C. xanthothrix did so only on beech sawdust (Figure 5C-D).

E. Degradation of ${ }^{14} \mathbf{C}$-labelled lignin: In conclusion from the former plate assays and lignocellulosic substrate growth test, we knew that all strains can produce types of phenoloxidases that might be expected to react with lignin. To test this possibility, lignin-labelled beech powder mixed with unlabelled powdered beech was used as fungal substrate into sealed Erlenmeyer flasks equipped with glass-cups containing $\mathrm{NaOH}$ $(10 \%)$. Beech was selected for this experiment as it was seen before to allow growth of most of our strains (Table 5). With degradation of the lignin-labelled compounds, the ${ }^{14} \mathrm{CO}_{2}$ released into the air space of the closed bottles will be captured in the $\mathrm{NaOH}$ $(10 \%)$ and later on, measured in a liquid scintillation counter (Trojanowsky and Hüttermann 1987). When the ${ }^{14} \mathrm{CO}_{2}$ was determined during growth of the fungi on the lignin-labelled/unlabelled beech sawdust mixture, all coprinoid strains released over the time a comparable amount of ${ }^{14} \mathrm{CO}_{2}$. Yet, this amount was by far not such amount obtained by T. versicolor, a typical white rot fungus also included in this study (Figure 6). However, the percentage of ${ }^{14} \mathrm{C}$ released by coprini was in the same range than the ${ }^{14} \mathrm{CO}_{2}$ amounts released by the ascomycete A. nidulans, a non-wood-degrading filamentous fungus not able to attack lignocellulose used as a negative control. This result suggests that the ${ }^{14} \mathrm{CO}_{2}$ detected in the cultures of tested coprini originates from 
degradation of background compounds present in the labelled beech other than from lignin (Figure 5).

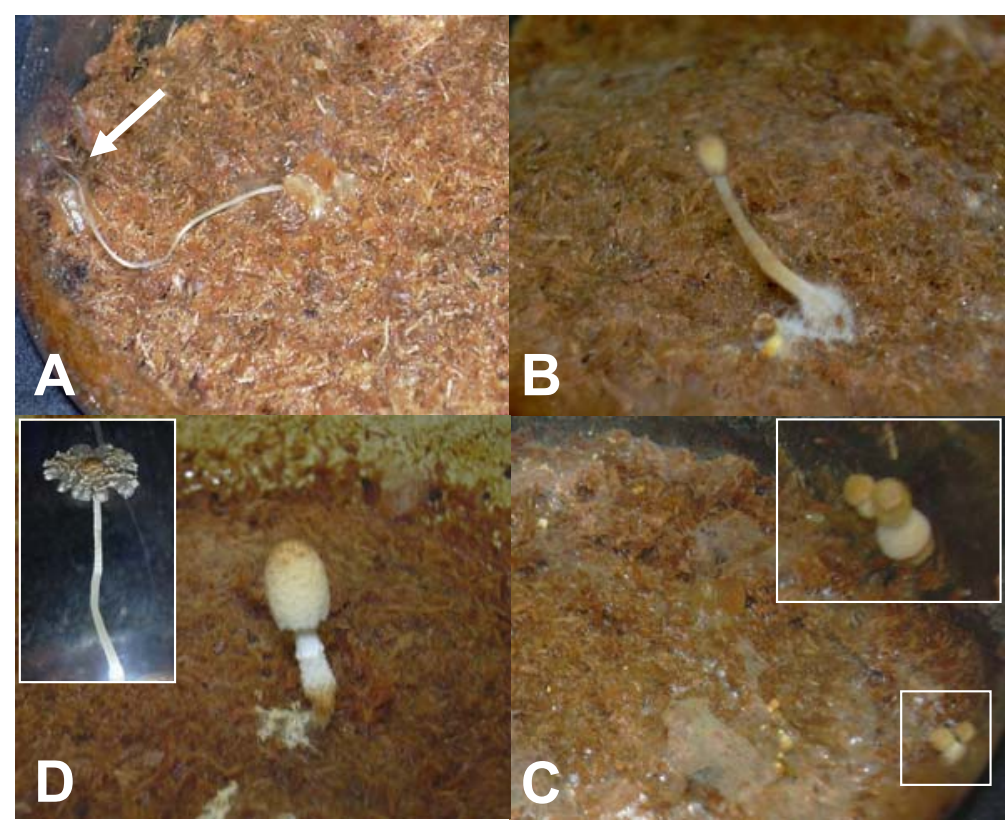

Figure 5 Growth of strains of coprini after 4 months of incubation at $28^{\circ} \mathrm{C}$ on poplar and beech sawdust. C. curtus produced fructifications on poplar, note the autolysing fruiting body (A, arrow), and beech sawdust (B), whereas Coprinellus sp. C72 (C) and C. xanthothrix (D) did so only on beech sawdust.

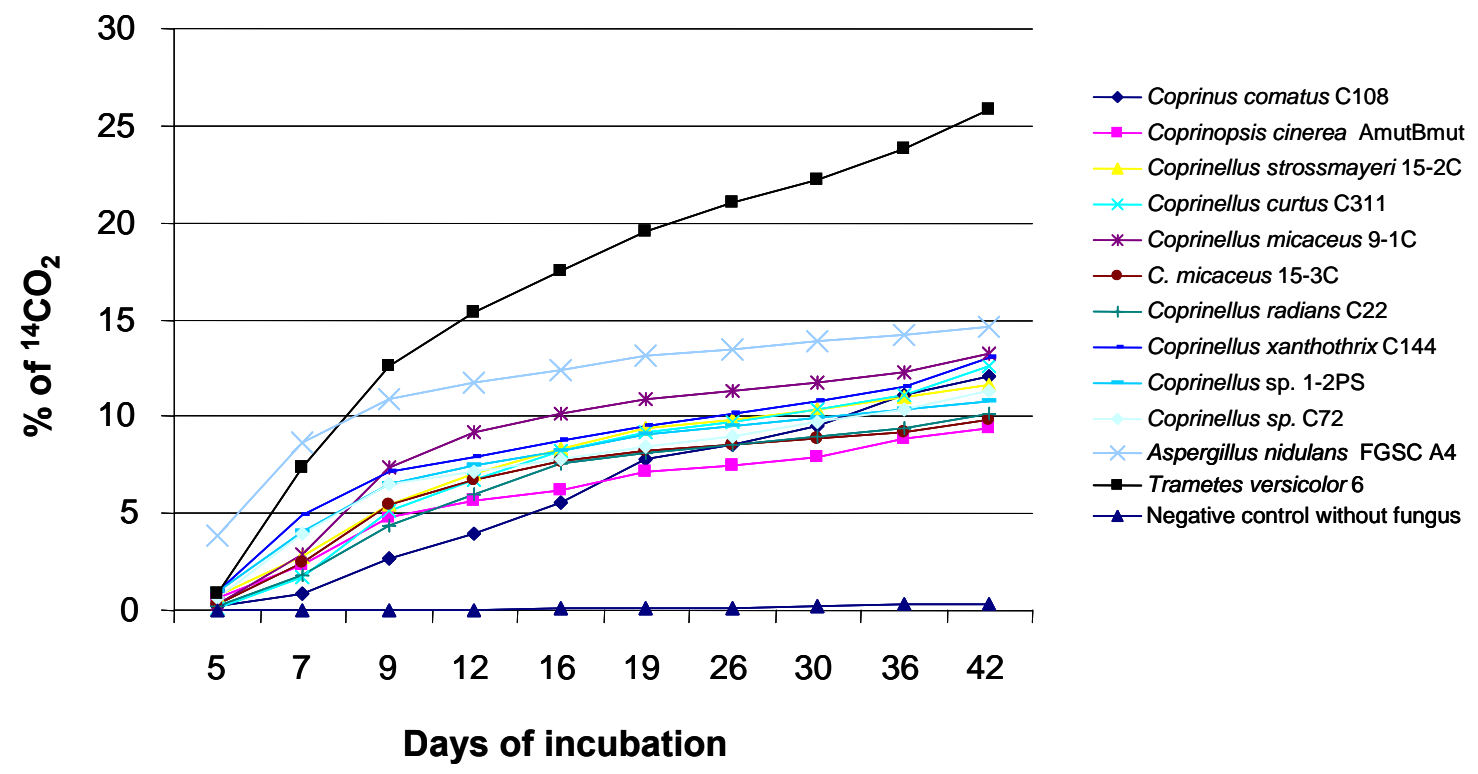

Figure 6 Release of ${ }^{14} \mathrm{CO}_{2}$ from ${ }^{14} \mathrm{C}$-labelled lignin from beech wood by strains of coprini during incubation at $28^{\circ} \mathrm{C}$ on grinded beech wood. 


\subsection{Conclusions and outlook}

From the literature review presented in chapter 2, it becomes clear that more coprinoid mushroom species grow on woody material than thought so far. Following this notion, a set of experiments were performed to obtain a first impression on this group of fungi regarding their phenoloxidase activities and, as a consequence, their potential abilities to colonize wood. A collection of coprinoid strains was obtained from different sources. A control by molecular means (ITS sequences) revealed that several of these strains were misidentified on species (4 species in total), and in one instance also on genus level, and one strain was found not to belong to the form group of the coprini. The results confirm the difficulty in correct identification of coprinoid species by morphological characters (see also Naumann et al. 2007). Although for various strains a species name could not be assigned due to a lack of suitable reference sequences, experiments on enzymatic activities and growth on lignocellulosic material were still performed.

Several of the tested strains were found to grow on wood sawdust and in some instances, phenoloxidases, respective laccases were principally produced by the strains. However, none of the coprini appeared to degrade the labelled lignin in the beech wood mixtures. Since $\mathrm{CO}_{2}$ released by the coprini was comparable to that of A. nidulans, we need to assume that the tested coprini rather grew e.g. on storage compounds in wood parenchyma.

In addition, growth was tested on leave litter since several coprini have been listed before as leave litter decomposing fungi (Soponsathien 1998, chapter 2 of this thesis). Here, we discovered that most fungi grew on Q. robur, but not on A. platanoides leave litter. This different behaviour might be caused by different tannin types (Barbehenn et al. 2006), and/or by a different C:N ratios (Gartner and Cardon 2006) in the tested leave litters. Future work needs to clarify this.

Previously in chapter 2 , it was repeatedly reported that several coprini species were growing on wood which was confirmed here for one Coprinus, one Coprinopsis, and for six Coprinellus species, respectively. In the same chapter, it had been questioned whether coprini are white-rot or brown-rot fungi. From the work presented in this chapter, neither can be supported. However, the work presented here is still preliminary and should be extended in the future to more species that have been perfectly defined 
and where it is documented that they grow on wood. Such species can be collected from fruiting bodies from the nature and morphologically be defined. Having obtained more experience with coprini morphology during the performance of this thesis, the author of this document has become towards the end of this work quite experienced in the very difficult species determination by fruiting body morphology (see chapter 2 and 5 of this thesis, Naumann et al. 2007 and further unpublished work). With new strains isolated from fruiting bodies grown during the summer and autumn periods in 2005-2007, and possibly in the next vegetative growth periods, in the future targeted experiments on fungal growth, enzyme production and wood colonization and degradation should be performed. At the present stage, about 60 new isolates are available from own collection for such tests (not shown in this thesis).

\subsection{Acknowledgments}

We thank Prof. J. Trojanowsky for the idea of testing the labelled lignin and for providing it. Marina Horstmann is gratefully acknowledged for her technical support by the measurements of the ${ }^{14} \mathrm{CO}_{2}$ lignin. The A. nidulans strain was kindly provided by Dr. Sven Krappmann.

\subsection{References}

Barbehenn RV, Jones CP, Karonen M, Salminen JP (2006) Tannin composition affects the oxidative activities of tree leaves. J. Chem. Ecol., 32, 2235-2251.

Basham JT (1958) Decay of trembling aspen. Can. J. Bot., 36, 491-505.

Basham JT, Morawski ZJR (1964) Cull studies, the defects and associated basidiomycete fungi in the heartwood of living trees in the forests of Ontario. Department of Forestry Publication No. 1043. Queen's Printer and Controller of Stationery, Ottawa, Canada.

Boulianne RP, Liu Y, Aebi M, Lu BC, Kües U (2000) Fruiting body development in Coprinus cinereus: regulated expression of two galectins secreted by a nonclassical pathway. Microbiol., 146, 1841-1853.

Couto SR, Herrera JLT (2006) Industrial and biotechnological applications of laccases: A review. Biotechnol. Adv., 24, 500-513.

Domański S (1983) Fungi that destroyed a Populus tremula stand in Lagów Lubuski. Eur. J. For. Path., 13, 166-173.

Domański S (1984) Studies on the butt rots in common ash. Zeszyty Problemowe Postepów Nauk Rolniczych, 289, 9-33. 
Durán N, Esposito E (2000) Potential applications of oxidative enzymes and phenoloxidases-like compounds in wastewater and soil treatment: a review. Appl. Cat B: Environ., 28, 83-99.

Gartner TB, Cardon ZG (2006) Site of leaf origin affects how mixed liiter decomposes. Soil Biol. Biochem., 38, 2307-2317.

Gilbertson RL (1981) North American wood-rotting fungi that cause brown rots. Mycotaxon, 12, 372-416.

Husain Q (2006) Potential applications of the oxidoreductive enzymes in the decolorization and detoxification of textile and other synthetic dyes from polluted water: A review. Cr. Rev. Biotechn., 26, 201-221.

Johannes C, Majcherczyk A (2000) Natural mediators in the oxidation of polycyclic aromatic hydrocarbons by laccase mediator systems. Appl. Environ. Microbiol., $66,524-528$.

Kües U (2000) Life history and developmental processes in the basidiomycete Coprinus cinereus. Microbiol. Mol. Biol. Rev., 64, 316-53.

Kumar S, Tamura K, Nei M (2004) MEGA3: Integrated software for molecular evolutionary genetics analysis and sequence alignment. Brief Bioinform., 5, 150163.

Kühner R, Romagnesi H (1978) Flore Analytique des Champignons Supérieurs. Masson, Paris, France.

Lindsey JP, Gilbertson RL (1978) Basidiomycetes that decay aspen in North America. Bibl. Mycologica, 63, 1-406.

Matsumura E, Yamamoto E, Numata A, Kawano T, Shin T, Murao S (1986) Structures of the laccase-catalyzed oxidation products of hydroxybenzoic acids in the presence of ABTS (2,2'-azino-di-(3-ethylbenzothiazoline-6-sulfonic acid)). Agric. Biol. Chem., 50, 1355-1357.

Naumann A, Navarro-González M, Sánchez-Hernández O, Hoegger PJ, Kües U (2007) Correct identification of wood-inhabiting fungi by ITS análisis. Curr. Trends Biotech. Pharm., In press.

Orton PD, Watling R (1979) British fungus flora. Agarics and Boleti 2. Coprinaceae Part 1: Coprinus. Her Majesty's Stationary Office, Edinburg.

Pointing SB (2001) Feasibility of bioremediation by white-rot fungi. Appl. Microbiol. Biotechnol., 57, 20-33. 
Redhead SA, Vilgalys R, Moncalvo JM, Johnson J, Hopple JS Jr. (2001) Coprinus Pers. and the disposition of Coprinus species sensu lato. Taxon, 50, 203-241.

Sagara N (1975) Ammonia fungi- A chemoecological grouping of terrestrial fungi. Contrib. Biol. Lab. Kyoto Univ., 24, 205-276.

Sagara N (1992) Experimental disturbances and epigeous fungi. Chapter 23. In: Carroll GC, Wicklow DT (eds.) The fungal community, Marcel Dekker, Inc, New York, N.Y., USA.

Sambrook J, Russell DW (2001) Molecular Cloning. A Laboratory Manual. 3rd Edn. Cold Spring Harbor Laboratory Press, Cold Spring Harbor, N.Y.

Soponsathien S (1998) Some characteristics of ammonia fungi 1. In relation to their ligninolytic enzyme activities. J. Gen. Appl. Microbiol., 44, 337-345.

Trojanowsky J, Hüttermann A. (1987) Screening of wood inhabiting fungi for their capacity to degrade and to solubilize ${ }^{14} \mathrm{C}$-labelled lignin. Microbios, 50, 91-97.

Wesenberg D, Kyriakides I, Agathos SN (2003) White-rot fungi and their enzymes for the treatment of industrial dye effluents. Biotechnol. Adv., 22, 161-187.

White TJ, Bruns T, Lee S, Taylor JW (1990). Amplification and direct sequencing of fungal ribosomal RNA genes for phylogenetics. In: Innis MA, Gelfand DH, Sninsky JJ, White TJ, (eds.), PCR Protocols: A Guide to Methods and Applications, Academic Press Inc., New York, pp. 315-322.

Zolan ME, Pukkila PJ (1986) Inheritance of DNA methylation in Coprinus cinereus. Mol. Cell. Biol., 6, 195-200. 



\section{4 \\ Biologically active metabolites \\ and medicinal properties \\ of coprinoid mushrooms}

Contribution to this chapter: The author of this thesis collected and sorted the literature together with Lilit Melikyan (Laboratory of Fungal Biology and Biotechnology, Yerevan State University). The preparation of figures 1, 2, 3 and 5, and table 1 was also done by the author. The writing of the manuscript was performed together with Prof. U. Kües and Prof. S.M. Badalian. 


\section{Biologically active metabolites and medicinal properties of coprinoid mushrooms}

\subsection{Abstract}

Data from the literature are compiled and analyzed on biologically active metabolites of Coprinoid mushrooms and their therapeutic significance. Various immune-modulating, antibacterial, antifungal, antioxidant, antiprotozoal, antiviral, cytotoxic, hypoglycemic and proteolytic activities have been detected in species from the four genera Coprinus, Coprinopsis, Coprinellus and Parasola were compiled in this work. Few species (Coprinus comatus, Coprinopsis cinerea, and Coprinellus micaceus) are occasionally or regularly consumed in different parts of the world. Toxic species appear not to be known. There is however the strong sickening effect when consuming Coprinopsis atramentaria fruiting bodies in combination with drinking alcohol, but symptoms disappear with the time. Allergic reactions against spores are also discussed.

Key words: Coprinoid mushrooms, coprine syndrome, fungal metabolites, hydrophobins, lectins 


\subsection{Introduction}

The traditional genus Coprinus Pers. (Coprinaceae, Homobasidiomycetes) comprises some 200 species, many of which are difficult to distinguish and, therefore, frequently misidentified. Amongst others, the dark spores, the autolysis of the cap and the inaequihymeniiferous hymenial development were the main criteria to incorporate a species into the genus (Buller 1909, Orton and Watling 1979). More recently, molecular data divided the genus into the four new clades Coprinus, Coprinopsis, Coprinellus and Parasola. The new clade Coprinus with Coprinus comatus (Shaggy Mane) as type species are now assigned to the family Agaricaceae, the other three to the new family Psathyrellaceae (Redhead et al., 2001). In this paper, we will use the new phylogenetic species names where given (Redhead et al. 2001). Since so far not all species have been reclassified into the new genera, in other cases we have to keep the traditional names. We will refer to all species forming together the classical genus Coprinus as coprinoid mushrooms.

Most of the coprinoid species are fimicolous (Orton and Watling 1979). However, within each of the new genera, species have also been found on decaying wood and on butts and roots of trees (Badalyan et al. 2003a; Navarro-González et al. unpublished, Chapter 2 of this thesis). From various species, it is relatively easy in the laboratory to produce fruiting bodies on artificial media, dung and/or wood (Badalyan et al. 2003b, Kües 2000). Nevertheless, fruiting bodies from coprinoid mushrooms are seldom exploited for human benefit (http://www.fao.org/docrep/007/y5489e/y5489e14.htm), probably because of the often small mushroom size and, most critical, because usually the fruiting bodies are only short-lived due to cap autolysis (Kurtzmann 1978).

In ancient Rome, "fungi candidi" were highly valued and it was apparently C. comatus (reviewed in Denisova 1998), the only broadly known edible species of coprini in Western and Asian cultures. Nowadays, the species is commercially produced mainly in China and also in Japan, USA and Western European countries (Lelley 1978, Chang 1999, Chen 2000). The palatable C. comatus mushrooms, resembling asparagus in taste, contain a high nutritional value as Agaricus brunnescens (Wang and Kang 1984, Winterboer and Eicker 1983). Similarly, mushrooms of the fast growing and developing Coprinopsis cinerea, a model species for basidiomycetes used in studies of genetics and development (Kües 2000), are said to contain nearly 30\% protein (Kurtzmann 1978). 
An isolate with delayed autolysis has been suggested for mass cultivation in combination with fast processing techniques such as cooling, blanching and drying (Kurtzmann 1978) but the idea was obviously not broadly implemented. In Africa, in some sisal and sugar plantations, workers eat adolescent coprinoid mushrooms of species that copiously develop with bulbous stipes and long thick pseudorrhizas within the continuously filled compost dumps of sisal and sugar cane wastes. The Tanzanian species growing in decomposing sisal has been identified as C. cinerea (Härkönen et al. 1993) and the species growing in waste from sugar-cane processing on the island Mauritius as Coprinus castaneus (Desai and Peerally 1990). The latter species is also reported to be consumed in Sri Lanka (Desai and Peerally 1990). Consumption of Coprinopsis africana (=Coprinus erethistes) in combination with alcohol is long known by Africans to cause Antabus-like reactions (Coprinus syndrome) why the fungus in Nigeria is called "Ajeimutin" $(j e=$ eat $+i m u=$ without drinking + otin $=$ alcohol $)($ Oso 1975). Well known in the Northern hemisphere for temporary mushroom poisoning upon consuming in connection with alcohol is Coprinopsis atramentaria (Bresinsky and Besl 1990, see below for details). From Chinese manuscripts we know that C. atramentaria (Common Ink Cap) was identified to help digestion and to reduce phlegm (Ying et al. 1987). This species was also used to heal burn wounds and ulcers in Western and Eastern Europe (reviewed by Denisova 1998). Other species were used to treat furuncles (boils), to improve digestion and to decrease phlegm (C. sterquilinus), as a remedy for hemorrhoids (piles) and for improving and stimulating digestion (Coprinus comatus) (Ying et al. 1987). Today, C. comatus is traded in powder form and/or in capsules, for example to ease constipation (see company advertisements in the Internet). On the whole, however, little is known concerning physiological activities and medicinal properties of coprini mushrooms. Here, we compile and discuss available material from literature on the medical potential of these fungi.

\subsubsection{Biological safety}

As far as known, with the exception of the few species giving rise to the Coprinus syndrome in combination with alcohol (see below), coprinoid mushrooms appear to be without severe immediate toxic effects when consumed. Still, since coprinoid mushrooms are usually not regular part of human diets, there is a lack in knowledge on health tolerance and caution is strongly advisable (Bresinsky and Besl 1990). In India, 
Coprinus fimentarius (syn. C. cinerea) fermented paddy and oat straw has been fed to goats in experimental trials. Compared to control experiments with untreated straw, the animals took less of the fermented straw in, showed body weight loss and the overall nitrogen intake and nitrogen retention (per feed intake) was lower. Whilst the animals did not show any gross lesions, histopathological examination revealed desquamation, oedema and infiltration in mucosa of intestines, focal necrosis, bile duct hyperplasia in liver, marked haemosiderosis in spleen and peribronchiolar lymphoid follicles in lung (Maan et al. 1994, 2000). It is possible, that these histopathological changes are a result of some unknown fungal metabolites showing long-term and/or dose-dependent effects. Data are not available on the health status of the African workers regularly consuming adolescent C. cinerea fruiting bodies (Desai and Peerally 1990, Härkönen et al. 1993) that could indicate any negative effects of long-term $C$. cinerea consumption in humans.

A few cases of allergic reactions against basidiospores (rhinitis, asthma, eczematous skin lesions) and extracts from mushroom tissues in skin tests have been reported [C. comatus: Helbling et al. (1998), Fischer et al. (1999); Coprinopsis variegata: Davis et al. 1988, O'Neil et al. (1990) Lehrer et al. (1994)]. A number of allergens from C. comatus have been screened in recombinant phage display libraries (Brander et al. 1999, Crameri et al. 2001) and some recombinant proteins were partially analyzed (Brander et al. 1999, Hoff et al. 2003). The thioredoxin rCop c2 (NIH GenBank accession number AJ242791) is a respiratory allergen (Hoff et al. 2003), the rCop c1 protein with unidentified biological function induces strong specific skin reactions in C. comatus sensitized individuals (Brander et al. 1999). C. comatus may induce and aggravate eczematous skin lesions in subjects with atopic dermatitis (Fischer et al. 1999). A few strains of Hormographiella aspergillata (anamorph of C. cinerea) and Hormographiella verticillata were isolated from human skin lesions (Gene et al. 1996, Guarro et al. 1992). From the about 20 known cases of human infections by higher basidiomycetes recorded worldwide in the last 50 years, a few of opportunistic mycoses were caused by coprinoid mushrooms (mostly by $C$. cinerea that has an optimal growth temperature of $37^{\circ} \mathrm{C}$ ). Two immunosuppressed heart patients died more than 30 years ago by mycelium grown upon surgery in their hearts. Fatal pulmonary infections have been reported in a patient with acute lymphoblastic leukemia receiving intensive cytotoxic treatment, in a patient with a lung abscess treated for a non-Hodgkin's lymphoma and in a leukemia patient in conjunction with the filamentous ascomycetes 
Aspergillus flavus. Given the fact, that spores of basidiomycetes are abundantly present in the environment, these infections are remarkably little in numbers. If occurring at all, infections appear to be concomitant with severe illness and loss of immunosuppression (reviewed in Kües et al. 2004).

\subsubsection{The Coprinus syndrome}

The non-fatal Coprinus syndrome (also called Antabuse syndrome) refers to intoxications elicited when alcoholic beverages are consumed with or, usually, sometime after eating fungi that by themselves are harmless. The sensitivity to alcohol can last for up to 5 days. Typically, a few to 30 minutes after drinking the alcohol, a person feels hot, starts to sweat and face, neck and chest intensively redden. Concentrations of $5 \mathrm{mg} / \mathrm{dl}$ alcohol in the blood will initiate first symptoms. With 50-100 $\mathrm{mg} / \mathrm{dl}$, symptoms are marked. Above, symptoms of the Coprinus syndrome intermingle with those of pure alcohol poisoning. In severe cases of the Coprinus syndrome, flushing of the skin spreads to other parts of the body. Moreover, there is a metallic taste in the mouth and a tingling sensation in arms and legs, the pulse rate quickens and breathing speeds up, the cardiac rhythm can be disturbed, the blood pressure fall and collapse. Other possible symptoms are throbbing headache, shaking of the limbs, feelings of tightness, anxiety and dizziness. Individuals occasionally experience nausea and vomiting but rarely colic and diarrhea. Symptoms will continue as long as there is alcohol in the system. With elimination of the alcohol, the patient recovers completely. However, with fresh alcohol consumption the symptoms return. Unless an affected person has a heart condition or high blood pressure, treatment is mostly unnecessary, as the symptoms normally disappear in the course of a few hours without any after-effects (Hatfield and Schaumberg 1978, Bresinsky and Besl 1990, Michelot 1992, Benjamin 1995). In animals, when administered with alcohol, hypotensions and hyperventilation in rabbits, prolongation of the sleep cycle in mice, swelling with increased tear production in rats and, in a cow, the same symptoms that the antabus-alcohol reaction produces in humans were reported (Benjamin 1995, Clémençon 1962).

The Coprinus syndrome is analogous to the responses caused by Antabuse ${ }^{\circledR}$ (from Greek anti = against, and Latin abusus $=$ misuse) [disulfiram, tetraethylthiuramdisulfide, bis(diethylthiocarbamyl)disulfide] that produces 
hypersensitivity to alcohol and is therefore applied in treatment of alcoholism since almost 60 years (Fuller and Gordis 2004). Disulfiram interferes with the metabolizing of acetaldehyde formed in the oxidation of ethanol by blocking enzymatic activities of the mitochondrial $\mathrm{NAD}^{+}$-dependent, low- $K_{\mathrm{m}}$ aldehyde dehydrogenases (ALDH) through irreversible binding to the enzyme. In consequence, there is a transient increase of acetaldehyde in the blood being responsible for the unpleasant bodily reactions (Pettersson and Tottmar 1982, Johannson et al. 1991). Early reports on presence of disulfiram in C. atramentaria (Simandl and Franc 1957) were not confirmed (Hatfield and Schaumberg 1975). Hatfield and Schaumberg (1975) and Lindberg et al. (1977) were able to isolate the atypical ("non-protein") amino acid coprine ( $\mathrm{N}^{5}-[1$ hydroxycyclopropyl]-L-glutamine, Figure 1A) from fruiting bodies of C. atramentaria. After administration of coprine to mice via a polyethylene stomach tube and intraperitoneally administration of alcohol, acetaldehyde was detected in blood (Hatfield and Schaumberg 1975). After feeding rats with coprine and alcohol, lachrymation and gradual swelling of the animals' faces occurred (Lindberg et al. 1977). The results suggested that the water-soluble substance in combination with alcohol is the origin of the Coprinus syndrome. Moreover, as the isolated fungal compound, synthetically produced coprine was active in rats at minimal doses of $10 \mathrm{mg} / \mathrm{kg}$ body weight (Lindberg et al. 1977, Tottmar and Lindberg 1977). In vivo, coprine is active both against mitochondrial low- $K_{\mathrm{m}}$ ALDH from brain and liver of rats but, as disulfiram, not against any high- $K_{\mathrm{m}}$ ALDHs (Pettersson and Tottmar 1982). However, coprine is only a pretoxin (Figure 1B) that in vitro shows no inhibitory activity towards low- $K_{\mathrm{m}}$ rat-liver ALDH unlike the hydrolytic coprine product 1-aminocyclo-propanol (ACP) (Tottmar and Lindberg 1977). ACP is also active in vivo against mitochondrial low- $K_{\mathrm{m}} \mathrm{ALDH}$, probably by irreversible binding to the enzyme (Marchner and Tottmar 1978). Coprine is more potent than disulfiram in increasing the acetaldehyde/ethanol ratio in the blood and decreasing ALDH-activity in the brain and it does not act as disulfiram against dopamine $\beta$-hydrolase (Carlsson et al. 1978, Nilsson et al. 1987, Nilsson and Tottmar 1989). Initial ideas of using the more specific and potent coprine like disulfiram in defeat of alcoholism had however to be abandoned when it became clear that the compound is potentially mutagenic and carcinogenic and exerts gonadotoxic properties (Michelot 1992). Coprine and benzcoprine were both positive in Ames tests suggesting they may have alkylating properties (Jönsson et al. 1979). Daily oral administration of coprine and the derivative benzcoprine [N-(1-ethoxycyclopropyl) benzamide] to male 
rats and dogs at doses above the level minimally needed for ALDH inactivation in rats (Tottmar and Lindberg 1977) lead to testicular injuries and blocking of

A. Coprine<smiles>NC(CCC(=O)NC1(O)CC1)C(=O)O</smiles>

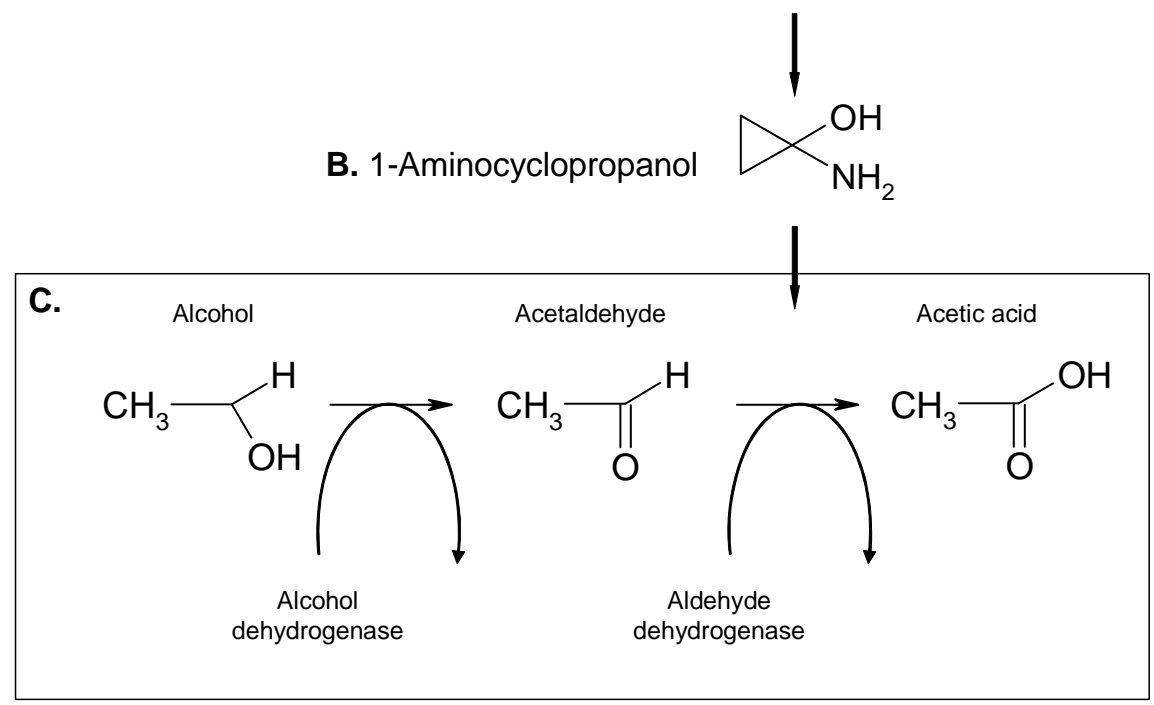

Figure 1 Molecular structure of the atypical amino acid coprine, which formally may be regarded as a condensation product of glutamine and cyclopropanone (A). Structure of 1-Aminocyclopropanol, the metabolite formed after hydrolysis of coprine (B). Alcohol metabolization in combination with coprine action (C). In the body, alcohol is normally oxidized to acetic acid through the actions of the enzymes alcohol dehydrogenase and aldehyde dehydrogenase. 1-Aminocyclopropanol inhibits the aldehyde dehydrogenase. As a consequence, the acetaldehyde accumulates in the body producing all described symptoms (modified after Clémençon 1962, Bresinsky 1990 and Benjamin 1995).

spermatogenesis. Effective doses in rats were $200 \mathrm{mg} / \mathrm{kg} /$ day feed for up to 14 days whilst $20 \mathrm{mg} / \mathrm{kg} /$ day was ineffective and effective doses in dogs were 25 and 75 $\mathrm{mg} / \mathrm{kg} /$ day feed for up to 28 days whilst $7.5 \mathrm{mg} / \mathrm{kg}$ /day was ineffective (Jönsson et al. 1979). Transferring these data to humans, a daily consumption of 3-6 $\mathrm{kg}$ C. atramentaria mushrooms by a $70 \mathrm{~kg}$ human male could lead to sterility (Benjamin 1995). The 1-aminocyclopropane-1-carboxylic acid a component of C. comatus affects on reproductivity of male mice of the SHN line (Nagasawa et al. 1995).

Coprinoid mushrooms shown to cause the Coprinus syndrome include C. atramentaria, Coprinopsis insignis, C. africana, and C. variegata. Furthermore, Coprinopsis 
acuminata and Coprinopsis romagnesiana as close relatives of C. atramentaria (Figure 2) are suspected to have the same property (Bresinsky and Besl 1990, Matthies and Laatsch 1992, Benjamin 1995). In contrast, C. comatus and Coprinellus micaceus (Hatfield and Schaumberg 1978) do not give rise to alcohol-inflicted indispositions. It appears that within the coprinoid mushrooms all troublemakers come from the genus Coprinopsis, and, within of the genus, reactive species are widely spread (Figure 2). Amongst species causing the Coprinus syndrome, coprine has been found in C. insignis and C. variegata (Hatfield and Schaumberg 1978). In C. atramentaria, coprine amounts of $130-360 \mathrm{mg} / \mathrm{kg}$ mushroom fresh weight were determined (Lindberg et al. 1977, Laatsch 1990, Matthies and Laatsch 1992). Furthermore, Matthies and Laatsch (1992) report coprine values as high as $300-400 \mathrm{mg} / \mathrm{kg}$ in Coprinopsis picacea, a species that probably will not be eaten by its disagreeable smell (Laatsch and Matthies 1992) and probably therefore is not known to cause the Coprinus syndrome. Hatfield and Schaumberg (1978) could not detect the substance in C. comatus and C. micaceus whilst Laatsch (1990) and Matthies and Laatsch (1992) claim from chromatography analysis presence of coprine also in C. comatus (supported by NMR-spectroscopy), C. disseminatus, and C. micaceus at varying low levels (between 10 and $34 \mathrm{mg} / \mathrm{kg}$ fresh weight) as well as in Coprinopsis lagopus and Parasola plicatilis. Such levels would be too small to give any problems for well-being. In Coprinellus xanthotrix and Parasola auricoma, no coprine was detected (Matthies and Laatsch 1992). Some case descriptions suggest consumption of Clitocybe clavipes, Boletus luridus, Verpa bohemia, Tricholoma flavovirens, Pholiota squarrosa or Morchella angusticeps in combination with alcohol may also lead to awkward effects (Laatsch 1990, Michelot 1992, Benjamin 1995). Coprine was not found in B. luridus, C. clavipes and V. bohemia by Hatfield and Schaumberg (1978) whilst Matthies and Laatsch (1992) detected in chromatography an amino acid with coprine-like migration properties in B. luridus and C. claviceps. Further work discarded occurrence of coprine in B. luridus but gave evidence for its presence in the related and easily mistakable species Boletus torosus (Kiwitt and Laatsch 1994). In the other species, alcohol-related symptoms are thought to be of different origin (Laatsch 1990, Matthies and Laatsch 1992) or, in case of $P$. squarrosa, they probably would equally have happened in absence of alcohol (Benjamin 1995). In conclusion, the available data in the literature on occurrence of coprine within mushrooms indicate a prevalence of the substance within the genus of Coprinopsis. Reports on coprine in taxonomically unrelated homobasidiomycetes (including the three 
other new genera of coprinoid mushrooms) are few and mostly little or not substantiated by appropriate documentation of supporting experiments and resulting data.
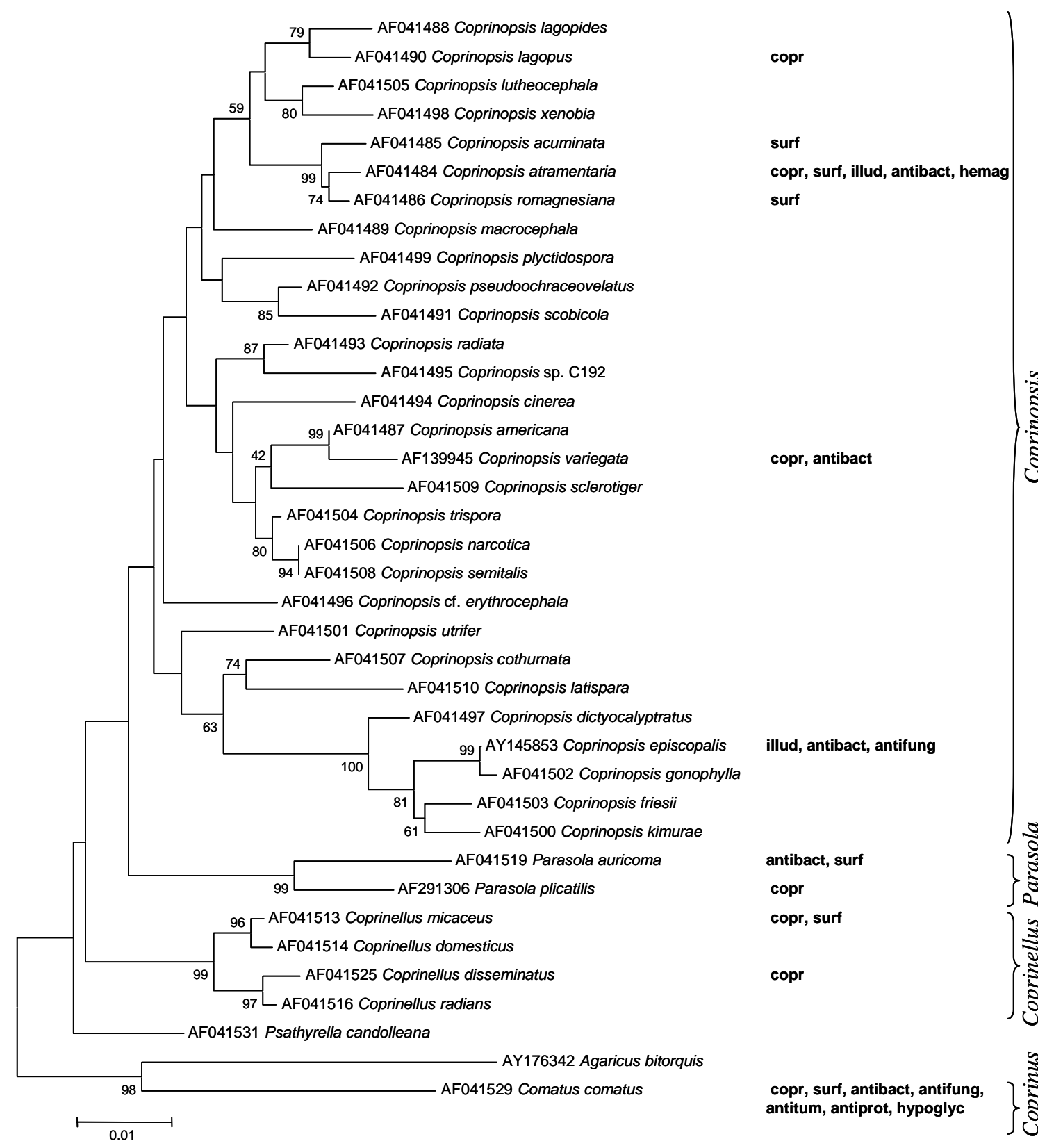

illud, antibact, antifung

antibact, surf

copr

copr, surf

copr

Figure 2 Phylogenetic relationships of Coprinopsis species causing Coprinus syndrome and/or producing coprine as well as other biological properties. Tree based on nucleotoid sequences of the region of the 25S large subunit ribosomal RNA gene. Codes indicate NCBI GenBank accession numbers. Bootstrap values (500 replications) above 50 are shown at tree branchings. The scale bar defines the number of nucleotide substitutions per site. The abbreviations in front of the species names indicate biological compounds reported in the literature: Copr $=$ coprine; surf $=$ surface proteins, illud $=$ illudins; antibact $=$ antibacterial; hemag $=$ hemagglutinating; antifung $=$ antifungal; antitum $=$ antitumor; antiprot $=$ antiprotozoal; hypoglyc $=$ hypoglycemic. Known examples for these different types of effects are discussed in the text. 


\subsubsection{Antimicrobial compounds within coprini}

Many coprini appear to be a useful natural source of antibacterial, antifungal and antiviral properties. Several species have variously been screened for antimicrobial activities, either in form of extracts from fruiting bodies and vegetative mycelium, by cultural supernatants and/or by antagonistic growth effects in plate tests (Table 1). Various compounds are responsible for these activities; however, only in some instances the chemical structures of the active compounds have been identified. For example, an antibacterial substance found in Coprinus similis has been determined to be 5-methoxyp-toluquinone (Anchel et al. 1948). In other species, such as C. comatus, C. cinerea, and C. atramentaria there are some experimental evidences that they possesses activity against several fungi but the active compound is not known (Badalyan and Gevorkyan 1998, Badalyan et al., 1998). Fruiting body extracts obtained from C. comatus and C. atramentaria reduced mycelial growth and inhibited sporulation of Penicillium expansum (Florianowicz 2000). Furthermore, seven diterpenoids (heptemerones A-G) with an ability to inhibit spore germination in the plant pathogenic fungus Magnaporthe grisea, were isolated from cultures of the basidiomycete Coprinus heptemerus (Valdivia et al. 2005).

The illudins are a family of fungal sesquiterpenes that have been widely studied as antibacterial and antitumor agents. These low molecular weight natural products are cytotoxic to human tumor cells in vitro (Kelner et al. 1990). The producers of illudinlike compounds reported in the literature are distributed among very few species of Basidiomycota. In spite of intensive screening of Poriales, Stereales and other groups which are known to produce other types of protoilludane derivatives (Gonzalez del Val et al. 2003), within coprini several different illudins have been detected. Coprinopsis episcopalis (Coprinus episcopalis) produce illudin $\mathrm{I}, \mathrm{I}_{2}, \mathrm{~J}, \mathrm{~J}_{2}$ and a Coprinopsis sp. (related to C. gonophylla) strain produces illudinic acid. These sesquiterpenes are stereoisomers, and their relative structures have been determined taking in consideration 2D NMR data (Gonzalez Del Val et al. 2003, Reina et al. 2004). Antimicrobial susceptibility in vitro tests using a methicillin-resistant Staphylococcus aureus (MRSA) strain were performed with these compounds. Illudins $I_{2}$ and $J_{2}$ were only moderately active against S. aureus, Escherichia coli and Bacillus subtilis. Illudin I was relatively active against E. coli and B. subtilis, but still weaker than the control antibiotics (fosfomycin, chloramphenicol and oxytetracycline). In contrast, the minimal inhibitor 
concentration of illudinic acid $\left(1 \mu \mathrm{g} \mathrm{ml}^{-1}\right.$ against $S$. aureus), was in the same range as control antibiotics. Illudins $I, I_{2}$ and $J_{2}$ were also tested for cytotoxicity against A-549, MDBK and HepG2 mammalian cell lines. Illudins $I_{2}$ and $J_{2}$ showed similar cytotoxicity against HepG2 as the positive controls actinomycin and methylmethasulfonate, which inhibited the growth of the three cells lines. The activity of illudin $\mathrm{I}_{2}$ was lower against A-549 cells, and illudin $\mathrm{J}_{2}$ was inactive in this cell line at the maximum concentration tested. Illudin I presented remarkable cytotoxicity against the three cell lines, with greater potency than the control compounds (Del Val et al. 2003). Similarly, in the fungus C. atramentaria illudin $\mathrm{C}$ derivatives were isolated and their structure determined. Illudins $\mathrm{C}_{2}$ and $\mathrm{C}_{3}$ were identified from fermentation broths and tested for their antimicrobial activities against several strains. Both compounds showed the same minimum inhibitory concentration of 12 and $25 \mu \mathrm{g} / \mathrm{mL}$ against S. aureus 209 and S. aureus R209 - multi-drug resistant strain, respectively (Lee et al. 1996).

Lagopodins are sesquiterpenoid quinones isolated from Coprinopsis lagopus and C. cinerea (Bottom and Siehr 1975, Bu'Lock and Darbyshire 1976). These compounds are expected to possess antibacterial activity; however, convincing experiments with the coprini are not presented. Coprinol, an antibacterial cuparane (sesquiterpenoid) was isolated from fermentation broth of a Coprinus sp.. The new antibiotic exhibited activity against multidrug-resistant Gram-positive bacteria in vitro (Johansson et al. 2001).

The low temperature basidiomycete Coprinopsis psychromorbida presented sesquiterpenes named Coprinolone and $\Delta 6$-Coprinolone, respectively, in extracts of the culture filtrate and the mycelium (Starratt et al. 1988, Starratt and Ward 1989). Coprinolone, however, did not show phytotoxicity when tested on seedlings of winter wheat and soybeans at a concentration of $10^{-3} \mathrm{M}$ and was also inactive when tested against fungi and bacteria (Starratt et al. 1988).

Quadrifidins are antibiotics of a structure of unsaturated aldehydes with several acetile bonds. Quadrifidins (A1, A2, A3, B1, B2 and B3) were isolated from cultures of Coprinus quadrifidus. One of them, Quadrifidin B2, was reported to reduce the growth of tubercular bacteria and was very toxic to mice (Doery et al. 1951). 
In a screening program of coprini performed by Badalyan et al. $(1998,2005)$, antifungal activity of $C$. cinereus, $C$. comatus and $C$. atramentarius was observed against $A$. niger, A. versicolor, A. flavus, P. simplicissimum, P. jensenii, P. chrysogenum, Fusarium sambucinum, Cladosporium atroseptum, and Stemphylium botryosum. C. comatus had the highest activity, followed by $C$. cinereus and then $C$. atramentarius whilst from the tested fungi, Aspergillus species were most resistent. C. disseminatus and C. micaceus prevented or markedly suppressed growth of numerous fungi potentially pathogenic for humans and animals (A. candidus, A. flavus, A. wentii, F. tricinctum, Stachybotris chartarum, Acremonium alternatum, Chrysosporium keratinophillum, P. aurantiogriseum, P. griseofulvum, Alternaria alternata, C. cladosporoides, Verticillium lecanii). Only A. flavus exhibited a relatively high resistance against C. micaceus (Badalyan 2004).

\subsubsection{Hypoglycemic properties}

C. comatus was able to lower blood glucose level when normal mice were fed with a diet containing powder of dried fruiting bodies of C. comatus. Plasma glucose concentrations were reduced after 11 days, and I/P glucose tolerance was improved. However, body weight gain was not substantially reduced. The results suggest a slowly generated, mild hypoglycemic effect of C. comatus in normal, non-diabetic mice, accompanied by metabolic effect with interrupting body weight gain (Bailey et al. 1984).

\subsubsection{Antitumor properties}

Four compounds (C-1, C-2, C-3 and C-4) were isolated from C. radiata (Anisova et al. 1987). From these compounds, the C-3 and C-4 substances inhibited Ehrlich carcinoma cells during intra-peritoneal (I/P) injection in rats. The $\mathrm{C} 3$ compound was described as a heterocyclic lactone with 4-hydroxy-4H-furo[3,2-c]pyran- $(6 \mathrm{H})$-one (Anisova et al. 1987). Furthermore, polysaccharides isolated from C. comatus showed tumor growth suppression (Cui et al. 2002). Extract of C. disseminatus culture broth (EDCB) obtained from CL inhibits proliferation and induces apoptosis in the human cervical carcinoma cells at $5 \mu \mathrm{g} / \mathrm{mL}$ (Han et al. 1999). 
Table 1 Metabolites produced by coprini and their effect in laboratory tests*.

\begin{tabular}{|c|c|c|c|c|c|c|c|c|}
\hline \multirow[t]{2}{*}{ Species } & \multirow[t]{2}{*}{ Compound } & \multirow{2}{*}{$\begin{array}{l}\text { Developmental } \\
\text { stage }\end{array}$} & \multirow[t]{2}{*}{ Test screen } & \multicolumn{4}{|c|}{ Effect } & \multirow[t]{2}{*}{ References } \\
\hline & & & & Antibacterial & Antifungal & Antitumor & Others & \\
\hline \multicolumn{9}{|l|}{ Coprinus } \\
\hline \multirow[t]{11}{*}{ C. comatus } & & Dried fruiting bodies & & & & & Hypoglycemic effect & $\begin{array}{l}\text { Bailey et al. } \\
1984, \text { Han et al. } \\
2006\end{array}$ \\
\hline & & Mycelium & Streak method & $\begin{array}{l}\text { E. coli, } \\
\text { S. aureus, } \\
\text { B. subtilis }\end{array}$ & & & & $\begin{array}{l}\text { Bianco et al. } \\
1969\end{array}$ \\
\hline & Mycolase I & $\begin{array}{l}\text { Extracts from fruiting } \\
\text { bodies }\end{array}$ & $\begin{array}{l}\text { Intraperitoneal } \\
\text { injections in } \mathrm{BALB} / \mathrm{c} \\
\text { mice }\end{array}$ & & $\begin{array}{l}\text { Aspergillus } \\
\text { fumigatus }\end{array}$ & & & $\begin{array}{l}\text { Davies and Pope } \\
1978\end{array}$ \\
\hline & & Fruiting bodies extracts & $\begin{array}{l}\text { Extracts on agar } \\
\text { against spore } \\
\text { suspension and } \\
\text { mycelia }\end{array}$ & & $\begin{array}{l}\text { Penicillium } \\
\text { expansum }\end{array}$ & & & $\begin{array}{l}\text { Florianowicz } \\
2000\end{array}$ \\
\hline & & $\begin{array}{l}\text { Water-based extracts of } \\
\text { fresh fruiting bodies }\end{array}$ & & & & Anti-breast cancer & & $\begin{array}{l}\text { Gu and Leonard } \\
2006\end{array}$ \\
\hline & & $\begin{array}{l}\text { Cultures on solid and } \\
\text { liquid cultures }\end{array}$ & $\begin{array}{l}\text { Streak, agar disc, and } \\
\text { serial dilution }\end{array}$ & \begin{tabular}{|l|} 
S. aureus, \\
E. coli
\end{tabular} & & & & Hervey 1947 \\
\hline & Coprine & Fresh fruiting bodies & & & & & & $\begin{array}{l}\text { Laatsch 1990, } \\
\text { Matthies and } \\
\text { Laatsch } 1992\end{array}$ \\
\hline & Ergothionina & Fresh fruiting bodies & & & & & & List 1957 \\
\hline & & Mycelium, supernatant & Mycelial strip & $\begin{array}{l}\text { Bacterium coli, } \\
\text { S. aureus }\end{array}$ & & & & Wilkins 1945 \\
\hline & Triptamine & Dried fruiting bodies & & & & & & $\begin{array}{l}\text { Worthen et al. } \\
1962\end{array}$ \\
\hline & & Fruiting bodies & & & & & $\begin{array}{l}\text { Helps digestion; in } \\
\text { treatment of piles }\end{array}$ & Ying et al. 1987 \\
\hline C. sterquilinus & & Fruiting bodies & & & & $\begin{array}{l}\text { Acts against } \\
\text { sarcoma and } \\
\text { carcinoma }\end{array}$ & $\begin{array}{l}\text { Helps digestion, } \\
\text { reduces phlegm, cures } \\
\text { sores or boils }\end{array}$ & Ying et al. 1987 \\
\hline \multicolumn{9}{|l|}{ Coprinopsis } \\
\hline $\begin{array}{l}\text { C. africana } \\
(=\text { C. erethistes })\end{array}$ & Coprine & Fresh fruiting bodies & & & & & $\begin{array}{l}\text { Aldehyde-dehydrogenase } \\
\text { inhibitor }\end{array}$ & Oso 1975 \\
\hline C. atramentaria & & Extracts from mycelia & & & & & $\begin{array}{l}\text { Hemagglutinating } \\
\text { activity in animal } \\
\text { erythrocytes }\end{array}$ & $\begin{array}{l}\text { Banerjee et al. } \\
1982\end{array}$ \\
\hline
\end{tabular}


Table 1 continued

\begin{tabular}{|c|c|c|c|c|c|c|c|c|}
\hline & & $\begin{array}{l}\text { Extracts from fresh } \\
\text { fruiting bodies }\end{array}$ & Serial dilutions & & & & $\begin{array}{l}\text { Hemagglutinating } \\
\text { activities }\end{array}$ & $\begin{array}{l}\text { Colceag et al. } \\
1984\end{array}$ \\
\hline & & Fruiting bodies extracts & $\begin{array}{l}\text { Extracts on agar } \\
\text { against spore } \\
\text { suspension and } \\
\text { mycelia }\end{array}$ & & P. expansum & & & $\begin{array}{l}\text { Florianowicz } \\
2000\end{array}$ \\
\hline & Illudins $\mathrm{C}_{2}$ and $\mathrm{C}_{3}$ & $\begin{array}{l}\text { Extracts from } \\
\text { supernatant }\end{array}$ & Agar dilution & S. aureus & & & & Lee et al. 1996 \\
\hline & Coprine & Fresh fruiting bodies & & & & & $\begin{array}{l}\text { Aldehyde-dehydrogenase } \\
\text { inhibitor }\end{array}$ & $\begin{array}{l}\text { Lindberg et al. } \\
\text { 1977, Matthies } \\
\text { and Laatsch } \\
1992\end{array}$ \\
\hline & Imidazol derivates & Fresh fruiting bodies & & & & & & $\begin{array}{l}\text { List and Reith } \\
1960\end{array}$ \\
\hline & Proteinase & $\begin{array}{l}\text { Extracts from fruiting } \\
\text { bodies }\end{array}$ & & & & & & $\begin{array}{l}\text { Otto and } \\
\text { Lipperheide } \\
1986\end{array}$ \\
\hline & & Fruiting bodies & & & & $\begin{array}{l}\text { Acts against } \\
\text { sarcoma } 180 \text { and } \\
\text { carcinoma }\end{array}$ & $\begin{array}{l}\text { Helps digestion, reduces } \\
\text { phlegm }\end{array}$ & Ying et al. 1987 \\
\hline & Triptamine & Dried fruiting bodies & & & & & & $\begin{array}{l}\text { Worthen et al. } \\
1962\end{array}$ \\
\hline \multirow[t]{2}{*}{ C. cinerea } & $\begin{array}{l}\text { Lagopodin A and } \\
\text { B; } \\
\text { Hydroxylagopodi } \\
\text { n B } \\
\end{array}$ & Shake flask cultures & & & & & & $\begin{array}{l}\text { Bu'Lock and } \\
\text { Darbyshire, } \\
\text { 1976, Bottom et } \\
\text { al. } 1975\end{array}$ \\
\hline & Proteinases & $\begin{array}{l}\text { Extracts from cultural } \\
\text { supernatants }\end{array}$ & $\begin{array}{l}\text { Models of } \\
\text { experimental thrombi }\end{array}$ & & & & Thrombolytic activity & $\begin{array}{l}\text { Denisova et al. } \\
1999\end{array}$ \\
\hline \multirow[t]{2}{*}{ C. episcopalis } & Illudins $\mathrm{I}, \mathrm{I}_{2}, \mathrm{~J}, \mathrm{~J}_{2}$ & $\begin{array}{l}\text { Extracts from fermented } \\
\text { broths }\end{array}$ & Microdilutions & $\begin{array}{l}\text { S. aureus, } \\
\text { E. coli, } \\
\text { B. subtillis }\end{array}$ & & & & $\begin{array}{l}\text { Gonzalez del Val } \\
\text { et al. 2003, } \\
\text { Reina et al. } 2004\end{array}$ \\
\hline & & $\begin{array}{l}\text { Extracts from fermented } \\
\text { broths }\end{array}$ & Seeded assay plates & $\begin{array}{l}\text { S. aureus, } \\
\text { B. subtilis }\end{array}$ & A. fumigatus & & & Suay et al. 2000 \\
\hline C. friesii & & & & & & $\begin{array}{l}\text { Acts against } \\
\text { sarcoma and } \\
\text { carcinoma }\end{array}$ & & Ying et al. 1987 \\
\hline $\begin{array}{l}\text { Coprinopsis sp. } \\
\text { related to } C \text {. } \\
\text { gonophylla }\end{array}$ & Illudinic acid & $\begin{array}{l}\text { Extracts from fermented } \\
\text { broths }\end{array}$ & & S. aureus & & & & $\begin{array}{l}\text { Gonzalez del Val } \\
\text { et al. } 2003\end{array}$ \\
\hline
\end{tabular}


Table 1 continued

\begin{tabular}{|c|c|c|c|c|c|c|c|}
\hline $\begin{array}{l}\text { C. insignis } \\
(=\text { C. alopecia) }\end{array}$ & Coprine & Fresh fruiting bodies & & & & $\begin{array}{l}\text { Aldehyde-dehydrogenase } \\
\text { inhibitor }\end{array}$ & $\begin{array}{l}\text { Hatfield and } \\
\text { Schaumberg } \\
1978, \text { Laatsch } \\
1990\end{array}$ \\
\hline \multirow[t]{3}{*}{ C. lagopus } & & Extracts from mycelia & & & & $\begin{array}{l}\text { Hemagglutinating } \\
\text { activity in animal } \\
\text { erythrocytes }\end{array}$ & $\begin{array}{l}\text { Banerjee et al. } \\
1982\end{array}$ \\
\hline & & $\begin{array}{l}\text { Mycelia and cultural } \\
\text { filtrates }\end{array}$ & & $\begin{array}{l}\text { Bacteria gram + } \\
\text { Bacteria gram - }\end{array}$ & & & $\begin{array}{l}\text { Bianco and } \\
\text { Striano } 2000\end{array}$ \\
\hline & Coprine & Fresh fruiting bodies & & & & $\begin{array}{l}\text { Aldehyde-dehydrogenase } \\
\text { inhibitor }\end{array}$ & $\begin{array}{l}\text { Matthies and } \\
\text { Laatsch } 1992\end{array}$ \\
\hline \multirow[t]{3}{*}{ C. picacea } & & $\begin{array}{l}\text { Cultures on solid and } \\
\text { liquid media }\end{array}$ & $\begin{array}{l}\text { Streak, agar disc, } \\
\text { serial dilutions }\end{array}$ & S. aureus & & & Hervey 1947 \\
\hline & Coprine & Fresh fruiting bodies & & & & $\begin{array}{l}\text { Aldehyde-dehydrogenase } \\
\text { inhibitor }\end{array}$ & $\begin{array}{l}\text { Laatsch 1990, } \\
\text { Matthies and } \\
\text { Laatsch } 1992\end{array}$ \\
\hline & & Mycelium, supernatant & $\begin{array}{l}\text { Mycelial strip, } \\
\text { liquid culture }\end{array}$ & S. aureus & & & Wilkins 1945 \\
\hline Coprinus radiatus & Patulin (Klavazin) & $\begin{array}{l}\text { Mycelium, liquid } \\
\text { cultures }\end{array}$ & $\begin{array}{l}\text { In vivo (brain } \\
\text { homogeneates) } \\
\text { In vitro }\end{array}$ & & $\begin{array}{l}\text { Against leukemia, } \\
\text { carcinoma }(100 \%)\end{array}$ & & $\begin{array}{l}\text { Anisova et al. } \\
1987\end{array}$ \\
\hline $\begin{array}{l}\text { C. spelaiophila } \\
\text { (C. extinctorius) }\end{array}$ & & Cultures on solid media & Streak & S. aureus & & & Hervey 1947 \\
\hline $\begin{array}{l}\text { C. } \\
\text { psychromorbidus }\end{array}$ & $\begin{array}{l}\text { Coprinolone and } \\
\Delta^{6} \text {-Coprinolone }\end{array}$ & $\begin{array}{l}\text { Extracts of the culture } \\
\text { filtrate and mycelium }\end{array}$ & & & & & $\begin{array}{l}\text { Starrat et al. } \\
1988 \text {, Starrat and } \\
\text { Ward } 1989\end{array}$ \\
\hline \multirow[t]{2}{*}{$\begin{array}{l}\text { C. variegata } \\
\text { (=C. quadrifidus) }\end{array}$} & & $\begin{array}{l}\text { Spores, cap and stipe } \\
\text { extracts }\end{array}$ & Skin test & & & allergens & Davis et al. 1988 \\
\hline & $\begin{array}{l}\text { Quadrifidina A1, } \\
\text { A2, A3, A4, B1, } \\
\text { B2, B3 }\end{array}$ & Crude extract & Wheel plate technique & $\begin{array}{l}\text { Mycobacterium } \\
\text { tuberculosis, } \\
\text { S. aureus, } \\
\text { B. coli, } \\
\text { Salmonella typhi, } \\
\text { S. enteritidis, } \\
\text { Shigella flexneri, } \\
\text { Mycobacterium } \\
\text { anthracis, } \\
\text { Bacillus anthracis } \\
\text { B. subtilis }\end{array}$ & & & Doery et al. 1951 \\
\hline
\end{tabular}


Table 1 continued

\begin{tabular}{|c|c|c|c|c|c|c|c|c|}
\hline & Coprine & Fresh fruiting bodies & & & & & $\begin{array}{l}\text { Aldehyde-dehydrogenase } \\
\text { inhibitor }\end{array}$ & $\begin{array}{l}\text { Hatfield and } \\
\text { Schaumberg } \\
1978, \text { Laatsch } \\
1990\end{array}$ \\
\hline & $\begin{array}{l}\text { Biformin, } \\
\text { nemotin, nemotic } \\
\text { acid, mycomycin }\end{array}$ & Supernatant & & & & & & $\begin{array}{l}\text { Jones and } \\
\text { Stephenson } 1959\end{array}$ \\
\hline \multicolumn{9}{|l|}{ Coprinellus } \\
\hline \multirow[t]{2}{*}{ C. disseminatus } & & Mycelial culture broth & & & & $\begin{array}{l}\text { Induces apoptosis } \\
\text { in the human } \\
\text { cervical } \\
\text { carcinoma cells }\end{array}$ & & Han et al. 1999 \\
\hline & Coprine & Fresh fruiting bodies & & & & & & $\begin{array}{l}\text { Laatsch 1990, } \\
\text { Matthies and } \\
\text { Laatsch } 1992\end{array}$ \\
\hline \multirow[t]{2}{*}{ C. domesticus } & & & & & & & $\begin{array}{l}\text { Hemagglutinating } \\
\text { activity }\end{array}$ & $\begin{array}{l}\text { Coulet et al. } \\
1964\end{array}$ \\
\hline & Proteinases & $\begin{array}{l}\text { Extracts from cultural } \\
\text { supernatants }\end{array}$ & & & & & Thrombolytic activity & $\begin{array}{l}\text { Denisova et al. } \\
1999\end{array}$ \\
\hline C. heptemerus & $\begin{array}{l}\text { Heptemerones } \\
A \sim G\end{array}$ & $\begin{array}{l}\text { Broth of submerged } \\
\text { cultures }\end{array}$ & & & $\begin{array}{l}\text { Magnaporthe } \\
\text { grisea }\end{array}$ & & & $\begin{array}{l}\text { Kettering et al. } \\
2005, \\
\text { Valdivia et al. } \\
2005\end{array}$ \\
\hline C. hiascens & & Cultures on solid media & Streak & S. aureus & & & & Hervey 1947 \\
\hline \multirow[t]{6}{*}{ C. micaceus } & Polysaccharides & $\begin{array}{l}\text { Extracts from culture } \\
\text { filtrate }\end{array}$ & & & & & & $\begin{array}{l}\text { Chaumeton et al. } \\
1993\end{array}$ \\
\hline & Coprine & Fresh fruiting bodies & & & & & & $\begin{array}{l}\text { Laatsch 1990, } \\
\text { Matthies and } \\
\text { Laatsch } 1992\end{array}$ \\
\hline & & & & & & $\begin{array}{l}\text { Acts against } \\
\text { sarcoma and } \\
\text { carcinoma }\end{array}$ & & Ying et al. 1987 \\
\hline & Triptamine & Dried fruiting bodies & & & & & & $\begin{array}{l}\text { Worthen et al. } \\
1962\end{array}$ \\
\hline & Micaceol & Dried fruiting bodies & & $\begin{array}{l}\text { Corynebacterium } \\
\text { xerosis, } \\
\text { S. aureus }\end{array}$ & & & & Zahid et al. 2006 \\
\hline & $\begin{array}{l}(Z, Z)-4-o x o- \\
2,5 \text {-hetpadienedio } \\
\text { ic acid }\end{array}$ & Dried fruiting bodies & & & & $\begin{array}{l}\text { Glutathione } S \text { - } \\
\text { transferase } \\
\text { inhibition }\end{array}$ & & Zahid et al. 2006 \\
\hline
\end{tabular}


Table 1 continued

\begin{tabular}{|c|c|c|c|c|c|c|c|}
\hline \multirow[t]{4}{*}{$\begin{array}{l}\text { C. radians } \\
=\text { Coprinus similis }\end{array}$} & $\begin{array}{l}\text { 5-methoxy-p- } \\
\text { toluquinone }\end{array}$ & Liquid culture & Serial dilution & S. aureus & & & $\begin{array}{l}\text { Anchel et al. } \\
1950\end{array}$ \\
\hline & Coprinina & & & Gram+ & fungi & & $\begin{array}{l}\text { Bianco et al. } \\
1995\end{array}$ \\
\hline & & Cultures on solid media & Streak, agar disc & $\begin{array}{l}\text { S. aureus and } \\
\text { E. coli }\end{array}$ & & & Hervey 1947 \\
\hline & & Fruiting bodies & & & & $\begin{array}{l}\text { Acts against } \\
\text { sarcoma and } \\
\text { carcinoma }\end{array}$ & Ying et al. 1987 \\
\hline \multicolumn{8}{|l|}{ Parasola } \\
\hline P. auricoma & & Cultures on solid media & Streak, agar disc & S. aureus & & & Hervey 1947 \\
\hline \multirow[t]{4}{*}{ P.plicatilis } & & $\begin{array}{l}\text { Mycelium and cultural } \\
\text { filtrates }\end{array}$ & & $\begin{array}{l}\text { Bacillus cereus } \\
\text { and B. subtilis }\end{array}$ & & & $\begin{array}{l}\text { Bianco and } \\
\text { Giardino } 1996\end{array}$ \\
\hline & & Cultures on solid media & Streak, agar disc & S. aureus & & & Hervey 1947 \\
\hline & Coprine & Fresh fruiting bodies & & & & & $\begin{array}{l}\text { Laatsch 1990, } \\
\text { Matthies and } \\
\text { Laatsch } 1992 \\
\end{array}$ \\
\hline & & & & & & $\begin{array}{l}\text { Acts against } \\
\text { sarcoma and } \\
\text { carcinoma }\end{array}$ & Ying et al. 1987 \\
\hline \multicolumn{8}{|l|}{ Not reclassified yet } \\
\hline C. nycthemerus & & Fermentation products & & & & Sarcoma 180 & $\begin{array}{l}\text { Espenshade and } \\
\text { Griffith } 1966\end{array}$ \\
\hline Coprinus sp. & Coprinol & $\begin{array}{l}\text { Extracts from liquid } \\
\text { cultures }\end{array}$ & $\begin{array}{l}\text { Plate-paper disc } \\
\text { diffusion assay }\end{array}$ & $\begin{array}{l}\text { Bacillus brevis, } \\
\text { B. subtilis }\end{array}$ & & & $\begin{array}{l}\text { Johansson et al. } \\
2001\end{array}$ \\
\hline Coprinus sp. & & Liquid cultures & Diffusion method & $\begin{array}{l}\text { Leuconostoc } \\
\text { mesenteroides, } \\
\text { Staphylococcus } \\
\text { aureus, } \\
\text { Pseudomonas } \\
\text { aeruginosa } \\
\end{array}$ & & & $\begin{array}{l}\text { Ershova et al. } \\
2001\end{array}$ \\
\hline Coprinus sp. & & $\begin{array}{l}\text { Water-based extracts of } \\
\text { fresh fruiting bodies }\end{array}$ & & & & Anti-breast cancer & $\begin{array}{l}\text { Gu and Leonard } \\
2006\end{array}$ \\
\hline
\end{tabular}

* Information is included where papers stated effects of mushrooms or mushrooms compounds without giving experimental evidence. In the accompanying text, those cases are discussed where more information was available. 


\subsubsection{Proteinases}

Culture medium of $C$. disseminatus, C. micaceus, C. radiatus, C. domesticus, C. cinereus, C. comatus, C. curtus, C. strossmayeri, C. xanthothrix and a non-identified species had caseinolytic (proteolytic) activity with a strong dose/effect correlation (Badalyan et al. 2006). The highest activity was observed after 4-weeks of cultivation, particularly in cultures of C. xanthothrix, C. strossmayeri and C. radiatus. Liquid cultures and mycelial extracts of $C$. comatus, C. disseminatus, C. domesticus and C. radiatus but not those of $C$. domesticus, C. lagopus and C. micaceus had a significant antioxidant activity (Badalyan et al. 2005).

\subsubsection{Surface proteins}

Two groups of outer surface proteins of potential medical interest are so far described from mushrooms: lectins and hydrophobins, both of which can be produced in large quantities (Walser et al. 2003).

Lectins are carbohydrate-binding proteins with agglutinating properties that are widespread found in eukaryotes from higher fungi to other organisms (Guillot and Konska 1997, Wang et al. 1998). Considerable blood-clotting activities have been described in C. comatus, C. acuminata and P. plicatilis, weak clotting activities in C. atramentaria, C. romagnesiana, C. disseminatus and C. micaceus (Pemberton 1994). A lectin with anti-O(H) specificity towards human red blood cells has been isolated from mycelium of C. atramentaria and a lectin with anti-A blood type specificity from Coprinellus domesticus fruiting bodies (Guillot and Konska 1997). The lectin CGL2 from C. cinerea has anti-A/B specificity (Walser et al. 2004). Lactose binding was shown for the C. atramentaria lectin (Colceag et al. 1984).

The best studied fungal lectins are two galectins of $C$. cinerea (CGL1 and CGL2) that bind $\beta$-galactosides (Cooper et al. 1997) by a typical carbohydrate recognition domain (Figure 3) and occur in the outer stipe and cap tissues of fruiting bodies (Boulianne et al. 2000, Walser et al. 2005). Glycolipids from fruiting bodies have been shown to be native receptors of CGL2 (Walser et al. 2005) and the tetrameric crystal structure of CGL2 was recently resolved (Walser et al. 2004). Amongst other cellular functions, animal galectins act in defense towards bacterial infection, repair of tissues after injury and modulation of inflammatory reactions and their therapeutic exploitation in these 
areas are under investigation (Almkvist and Karlsson 2004, Midwood et al. 2004, Young and Meeusen 2004). Whether fungal galectins can assist or substitute animal galectins in therapeutic application has to be tested (Kües et al. 2004). Another possible application of fungal galectins in clinical medicine is in coating semi-permeable chitosan membranes for better proliferation of cell lines (Chang et al. 2004).

The C. cinerea galectins have been shown in vitro to interact with hydrophobins isolated from fruiting bodies (Walser et al. 2003). Hydrophobins are non-toxic, slightly hydrophobic secreted proteins of about 100 amino acids in length that are specific to fungi.

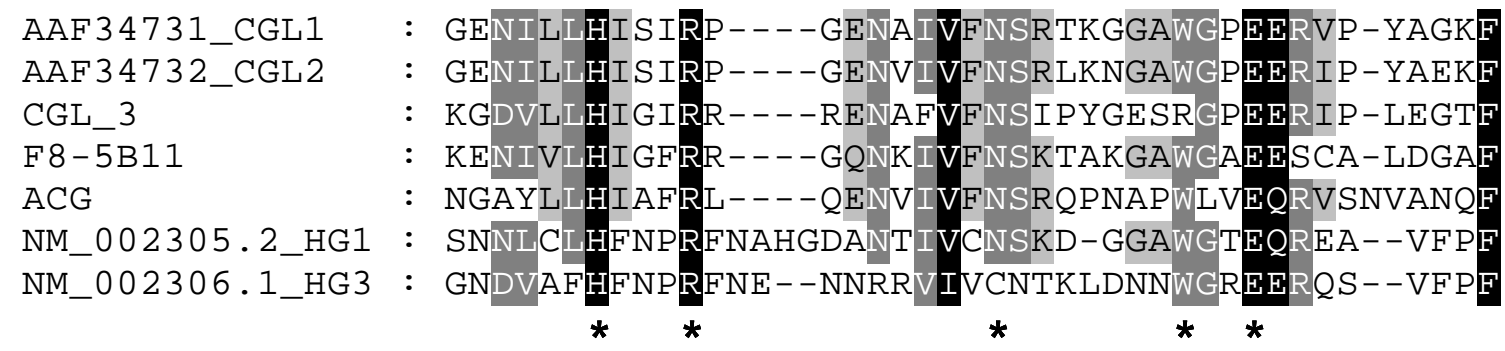

Figure 3 Sequence comparison of fungal and human galectins (ClustalW: http://www.ebi.ac.uk/clustalw). CGL1 and CGL2 C. cinerea galectins; CGL3 galectin deduced from contig 1.28 (position 715943 to 715452 ) from the $C$. cinerea genome sequence (http//www.broad.mit.edu/annotation/fungi/coprinus_cinereus/); F8-5B11 translation [nucleotides 38-451] of Genbank BM346915/BM34916 cDNA from Heterobasidion annosum; ACG Agrocybe cylindracea galectins, HG1 and HG3 human galectins (NM_002305.2 and NM_002306.1 respectively). Sequences with dark shadings represent identical residues shared by at least $50 \%$ of the sequences. Light shaded residues represent conservative substitutions. Asterisks mark residues known to interact with the $\beta$-galactoside in galectins (carbohydrate recognition domain).

All hydrophobins contain eight cysteine residues in a characteristic spacing pattern (Figure 4) being of importance to protein folding. By self-aggregation, the highly stable hydrophobins form amphipathic films on surfaces that render surface properties from hydrophilic to hydrophobic, respectively from hydrophobic to hydrophilic (Wösten 2001, Walser et al. 2003). Also hydrophobins have potential applications for medical purposes such as increasing biocompatibility of medical implants and devices, immobilisation of antibodies in a biosensor, stabilising oil vesicles for drug delivery, and patterning molecules at a surface with nanometre accuracy (Scholtmeijer et al. 
A

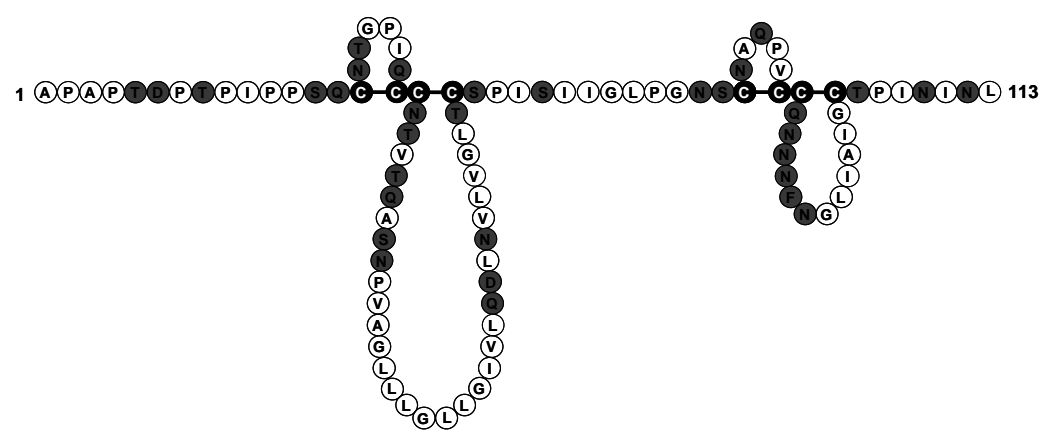

B

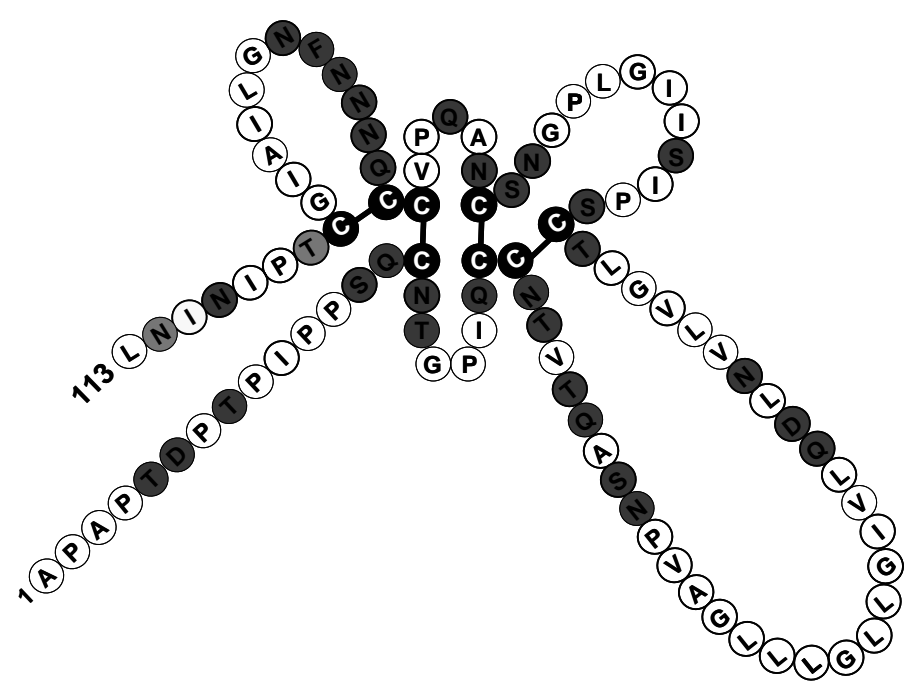

Figure 4 Models for folding mature Coprinopsis cinerea CoH1. A Folding according to the model published first by Wessels (2000) for the Sschyzophyllum commune SC3 hydrophobin and $\mathbf{B}$ according to biochemical data from HFBII a class II hydrophobin from Trichoderma reesei (Hakanpää et al. 2004). Disulphide bridges are indicated by bars. Cysteines are shown as circles with $\mathrm{C}$, hydrophobic amino acids are dark shaded and hydrophilic amino acids are light shaded, aminoacids are given in a one letter code. To define the specific positions of cysteines within the hydrophobin sequences $(\mathrm{C} 1$ to $\mathrm{C} 8)$, count the number of cysteines starting from the N-terminal end.

2001). Promotion of growth of fibroblasts on hydrophobin-coated Teflon membranes has already been demonstrated (Janssen et al. 2004). In C. cinerea, Ásgeirsdóttir et al. (1997) described the first two hydrophobins from vegetative mycelium (coH1 and coH2 Figure 5). From the genomic sequence of the fungus released by the Broad Institute (http://www.broad.mit.edu/annotation/fungi/coprinus_cinereus/), 34 different hydrophobins were deduced of often distantly related sequences promising different qualities. 
The existence of a number of these proteins has been verified by protein mass spectroscopy to be produced in vegetative mycelium and fruiting bodies (Velagapudi 2006).

Signal peptide

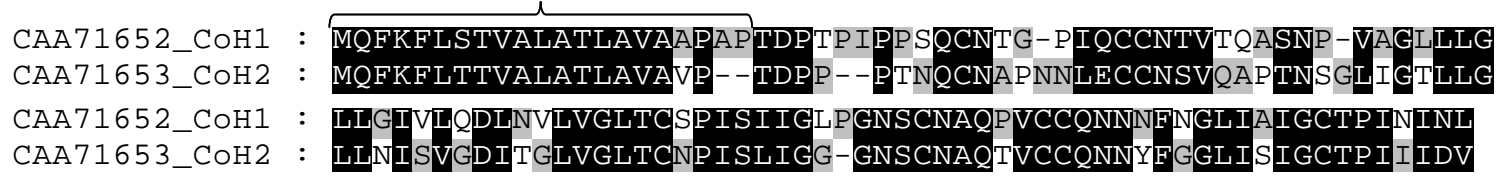

Figure 5 Comparison of the $\mathrm{coH} 1$ and $\mathrm{coH} 2$ proteins. Shaded area indicates identical amino acids. Signal peptide corresponds to the signal sequence that will be processed during secretion in order to release a mature hydrophobin into the hyphal surrounding (modified after Ásgeirsdóttir et al. 1997).

\subsection{Conclusions}

Currently, the information available on physiological activities of the coprinoid fungi is relatively sparse. Nevertheless data from some fungi suggest that these species present a perspective for biotechnological sources of biologically active compounds. A broad spectrum of activities such as antibacterial, antifungal, cytotoxic and hypoglycemic have been reported from different coprini species. For instance, illudins are compounds detected in certain coprini such compounds have been demonstrated to have antitumor and antibacterial properties.

The best known compound from coprini, coprine, has strong activities in combination with alcohol in curing alcoholism, but the compound has also side effects and is nowadays not anymore applied. As far as we are aware, no other compound from coprini is currently applied although C. comatus is sold in dried forms as healthsupporting food (nutraceutical) and food supplements (nutriceutical).

Further investigation of physiological activities and medical properties of this group of fungi will assist in obtaining new preventive and curative mushroom compounds with potentials for pharmaceutical uses. This includes also the hydrophobins for which applications in tissue cultures have been demonstrated (Scholtmeijer et al. 2001). 


\subsection{Acknowledgments}

I would like to thank Dr. Rajesh Velagapudi for the support in the production of alignments of galectins and hydrophobins, and to Alexandra Dolynska for translating some references in Russian language.

\subsection{References}

Almkvist J, Karlsson A (2004) Galectins as inflammatory mediators. Glycoconjugate J., $19,575-581$.

Anchel M, Hervey A, Kavanagh F, Polatnick J, Robbins WJ (1948) Antibiotic Substances from Basidiomycetes .3. Coprinus similis and Lentinus degener. Proc. Nat. Acad. Sci. USA, 34, 498-502.

Anisova LN, Bartoshevich YE, Efremenkova OV, Krasilnikova OL, Kudinova MK, Murenets NV, Klyuev NA, Chernyshev AI, Shorshnev SV, Terentyeva TG, Rudneva NA (1987) Isolation and identification of antileukosis substance from Coprinus radiatus. Antibiotiki I Meditsinskaya Biotekhnologiya, 32, 735-738.

Ásgeirsdóttir SA, Halsall JR, Casselton LA (1997) Expression of two closely linked hydrophobin genes of Coprinus cinereus is monokaryon-specific and downregulated by the oid-1 mutation. Fungal Genet., Biol., 22, 54-63.

Badalian SM, Abrahamian DH, Gevorkian SA, (1998) Study of antifungal activity of some Basidiomycete species in dual culture. Biol. J. Armenia, 51, 61-67.

Badalian SM, Gevorkian SA (1998) Antifungal activity of species from genus Coprinus (Basidiomycotina). In: Plant Biotechnology. Abstracts. II Int. Symp. October 48, 1998, Kiev, Ukraine. p. 17.

Badalyan SM, Avetisyan HK, Navarro-González M, Szafranski K, Hoegger PJ, Kües U (2003a) Two new Coprinus species in Armenia associated with wood: Coprinus strossmayeri (Coprinopsis strossmayeri) and a new species closely related to Coprinus radians (Coprinellus radians). In: Botanical research in Asian Russia. Proc. XI Congr. Russian Bot. Soc. 18-22 August, 2003, Novosibirsk-Barnaoul, Russia, pp. 8-9.

Badalyan SM, Navarro-González M, Avetisyan HK, Majcherczyk A, Kües U (2003b) Cultural characteristics of Coprinus spp. In: Botanical research in Asian Russia. Proc. XI Congr. Russian Bot. Soc. 18-22 August, 2003, Novosibirsk-Barnaoul, Russia, pp. 11-12. 
Badalyan SM (2004) Screening of antifungal activity of several Basidiomycete mushrooms. Probl. Med. Mycology, 6, 18-26.

Badalyan SM, Sakeyan CZ (2005) Antagonistic/antifungal activity of mycelia of several medicinal mushrooms. In: Biotechnology and Health, DAAD Alumni symposium. Abstracts. October 18-21, Yerevan, Armenia. pp. 100.

Badalyan SM, Sisakyan SH (2005) Study of antiprotozoal activity and mitogenic effect within medicinal mushrooms Lentinula edodes, Coprinus comatus and Flammulina velutipes. Int. J. Med. Mushrooms, 7, 382-383.

Badalyan SM, Kües U, Avetisyan HK (2005) Screening of antioxidant activity of several Coprinoid mushrooms. In: Advan. Med. Mycology. Proceed. Third Russian Congress of Medical Mycology. March 24-25, Moscow, Russia. pp. 176-178.

Badalyan SM, Avetisyan HK, Kües U (2006) Proteolytic activity of several Coprinoid mushrooms. IMC-8. August 20-25, 2006. Australia, Cairns. pp. 289.

Bailey CJ, Turner SL, Jakeman KJ, Hayes WA (1984) Effect of Coprinus comatus on plasma glucose concentrations in mice. Planta Medica, 50, 525-526.

Banerjee PC, Ghosh AK, Sengupta S (1982) Hemagglutinating activity in extracts of mycelia from submerged mushroom cultures. Appl. Environ. Microbiol., 44, 1009-1011.

Benjamin DR (1995) Mushrooms: poisons and panaceas. W. H. Freeman and Company, New York, N.Y., USA.

Bianco CMA, Ceruti-Scurti J, Filipello MV (1969) Investigations on wood-destroying and litter basidiomycetes and their antibiotic activity. II Antibacterial activity of mycelia and culture filtrates. Allionia, 15, 76-83.

Bianco CMA, Gillone C, Cesano C (1995) Antibiotics from Basidiomycetes: A review. Alliona, 33, 8-68.

Bianco CMA, Giardino L (1996) Antibiotic activity in Basidiomycetes. X. Antibiotic activity of mycelia and cultural filtrates of 25 new strains. Allionia, 34, 39-43.

Bianco CMA, Striano B (2000) Antibiotic activity in basidiomycetes. XIII. Antibiotic activity of mycelia and cultural filtrates. Allionia, 37, 253-255.

Bottom CB, Siehr DJ (1975) Hydroxylagopodin-B - sesquiterpenoid quinone from a mutant strain of Coprinus macrorhizus var. microsporus. Phytochem., 14, 1433. 
Boulianne RP, Liu Y, Aebi M, Lu BC, Kües U (2000) Fruiting body development in Coprinus cinereus: regulated expression of two galectins secreted by a nonclassical pathway. Microbiol., 146, 1841-1853.

Brander KA, Borbely P, Crameri R, Pichler WJ, Helbling A (1999) JgE-binding proliferative responses and skin test reactivity to Cop c 1, the first recombinant allergen from the Basidiomicete Coprinus comatus. J. Allergy. Clin. Immunol., $104,630-636$.

Bresinsky A, Besl H (1990) A colour atlas of poisonous fungi. Wolfe Publishing Ltd, London, UK.

Buller AHR (1909) Researches on fungi. Vol. I. An account of the production, liberation, and dispersion of the spores of hymenomycetes treated botanically and physically. Also some observations upon the discharge and dispersion of the spores of ascomycetes and of Pilobolus. Hafner Publishing Co., New York, N.Y., USA.

Bu'Lock JD, Darbyshire J (1976) Lagopodin metabolites and artifacts in cultures of Coprinus. Phytochem., 15, 2004.

Carlsson A, Henning M, Lindberg P, Martinson P, Trolin G, Waldeck B, Wickberg B (1978) On the disulfiram-like effect of Coprine, the pharmacologically active principle of Coprinus atramentarius. Acta Pharmacol. Toxicol., 42, 292-297.

Chang ST (1999) World production of cultivated edible and medicinal mushrooms in 1997 with emphasis on Lentinus edodes (Berk.) Sing. in China. Int. J. Med. Mushrooms, 1, 291-300.

Chang YY, Chen SJ, Liang HC, Sung HW, Lin CC, Huang RN (2004) The effect of galectin 1 on $3 \mathrm{~T} 3$ cell proliferation on chitosan membranes. Biomaterials, 25, 3603-3611.

Chaumeton JP, Chauveau C, Chavant L (1993) Water soluble polysaccharides excreted by mycelium of higher fungi: relationship with taxonomy and physiology. Biochem. Syst. Ecol., 21, 227-239.

Chen MM (2000) Cultivation techniques for Dictyophora, Polyporus umbellata, and Coprinus comatus. Mushroom Sci., 15, 543-548.

Clémençon H (1962) Antabus-wirkung bei Kühnen?. Schweiz. Z. Pilzkunde, 40, 170172.

Colceag J, Mogos S, Hulea S (1984) Studies on occurrence and characterization of phytolectins in some species of mushrooms. Rev. Roum. Biochem., 21, 263-266. 
Cooper DNW, Boulianne RP, Charlton S, Farrell EM, Sucher A, Lu BC (1997) Fungal galectins, sequence and specificity of two isolectins from Coprinus cinereus. J. Biol. Chem., 272, 1514-1521.

Coulet M, Mustier J, Marche AM (1964) Nouvelles recherches systematiques d'hemagglutinines chez les mycetes. Comptes Rendus des Seances de la Société de Biologie et de Ses Filiales, 158, 2344-2347.

Crameri R, Kodzius R, Konthur Z, Lehrach H, Blaser K, Walter G (2001) Tapping allergen repertoires by advanced cloning technologies. Int. Arch. Allergy. Immunol., 124, 43-47.

Cui M, Zhang HJ, An LG (2002) Tumor growth Inhibition by polysaccharide from Coprinus comatus. Sijie Huaren Xiaohua Zazhi, 9, 287-290.

Davis WE, Horner WE, Salvaggin JE, Lehrer SB (1988) Basidiospore allergens: analysis of Coprinus quadrifidus spore, cap, and stalk extracts. Clin. Allergy, 18, 261-267.

Davies DA, Pope AM (1978) Mycolase, a new kind of systemic antimycotic. Nature, $273,235-236$.

Denisova NP (1998) Medicinal properties of mushrooms. Ethnomycological draft. Sci. Acad., St. Petersburg, Russia (in Russian).

Denisova NP, Mikhailov VN, Petrishchev NN (1999) Thrombolitic activity of mushroom proteinases: thrombolitic activity of proteinases from Coprinus domesticus, C. cinereus, Cerrena unicolor. Int. J. Med. Mushrooms, 1, 187-190.

Desai, WB, Peerally MA (1990) Coprinus castaneus Berk. Br.: An indigenous, wild edible mushroom from Mauritius. Discov. Innovat., 2, 66-69.

Doery HM, Gardner JF, Burton HS, Abraham EP (1951) Antibiotics from a Basidiomycete, Coprinus quadrifidus. Antibiot. Chemother., 1, 409-417.

Espenshade MA, Griffith EW (1966) Tumor-inhibiting basidiomycetes. Isolation and cultivation in the laboratory. Mycologia, 58, 511-517.

Ershova EY, Efremenkova OV, Zenkova VA, Tolstych IV, Dudnik YV (2001) The revealing of antimicrobial activity of strains of the genus Coprinus. Mikol. Fitopatol., 35, 32-37.

Fischer B, Yawalkar N, Brander KA, Pichler WJ, Helbling A (1999) Coprinus comatus (shaggy cap) is a potential source of aeroallergen that may provoke a topic dermatitis. J. Allergy Clin. Immunol., 104, 836-841. 
Florianowicz T (2000) Inhibition of growth and sporulation of Penicillium expansum by extracts of selected basidiomycetes. Acta Soc. Bot. Pol., 69, 263-267.

Fuller RK, Gordis E (2004) Does disulfiram have a role in alcoholism treatment today? Addiction, 99, 21-24.

Gene J, Guillamon JM, Guarro J, Pujol I, Ulfig K (1996) Molecular characterization, relatedness and antifungal susceptibility of the basidiomycetous Hormographiella species and Coprinus cinereus from clinical and environmental sources. Anton. Leeuw. Int. J. G., 70, 49-57.

Gonzalez Del Val A, Platas G, Arenal F, Orihuela JC, Garcia M, Hernandez P, Royo I, De Pedro N, Silver LL, Young K, Vicente MF, Pelaez F (2003) Novel illudins from Coprinopsis episcopalis (syn. Coprinus episcopalis), and the distribution of illudin-like compounds among filamentous fungi. Mycol. Res.,107, 12011209.

Gu YH, Leonard J (2006) In vitro effects on proliferation, apoptosis and colony inhibition in ER-dependent and ER-independent human breast cancer cells by selected mushroom species. Oncol. Rep., 15, 417-423.

Guarro J, Gene J, de Vroey C, Gueho E (1992) Hormographiella a new genus of hyphomycetes from clinical sources. Med. Mycol., 40, 217-219.

Guillot J, Konska G (1997) Lectins in higher fungi. Biochem. Sys. Ecol., 25, 203-230.

Han CC, Yuan JH, Wang YZ, Li LJ (2006) Hypoglycemic activity of fermented mushroom of Coprinus comatus rich in vanadium. J. Trace Elem. Med. Bio., 20, 191-196

Han BY, Toyomasu T, Shinozawa T (1999) Induction of apoptosis by Coprinus disseminatus mycelial culture broth extract in human cervical carcinoma cells. Cell Struct. Funct., 24, 209-215.

Hakanpää (2004) Atomic resolution structure of HFBII hydrophobin, a self-assembling amphiphile. J. Biol. Chem., 279, 534-539.

Härkönen M, Saarimäki T, Mwasumbi L (1993) Tanzanian mushrooms and their uses 2. An edible species of Coprinus section Lanatuli. Karstenia, 33, 51-59.

Hatfield GM, Schaumberg JP (1975) Isolation and structural studies of coprine, disulfiram-like constituent of Coprinus atramentarius. Lloydia, 38, 489-496.

Hatfield GM, Schaumberg JP (1978) The disulfiram-like effects of Coprinus atramentarius and related mushrooms. In: Rumack BH, Salzman E. (eds.), 
Mushrooms poisoning: Diagnosis and treatment. CRC, West Palm Beach, Fla, pp. 181-186.

Helbling A, Gayer F, Pichler WJ, Brander KA (1998) Mushroom (Basidiomycete) allergy: diagnosis established by skin test and nasal challenge. J. Allergy Clin. Immunol., 102, 853-858.

Hervey AH (1947) A survey of 500 basidiomycetes for antibacterial activity. B. Torrey Bot. Club., 74, 476-503

Hoff M, Ballmer-Weber BK, Niggemann B, Cistero-Bahima A, Miguel-Moncin MS, Conti A, Haustein D, Vieths S (2003) Molecular cloning and immunological characterisation of potential allergens from the mould Fusarium culmorum. Mol. Immunol., 39, 965-975.

Janssen ML, van Leeuwen MBM, van Kooten TG, de Vries J, Dijkhuizen L, Wösten HAB (2004) Promotion of fibroblast activity by coating with hydrophobins in the beta-sheet end state. Biomaterials, 25, 2731-2739.

Johansson B, Angelo HR, Christensen JK, Moller IW, Ronstead P (1991) Dose-effect relationship of disulfuram in human volunteers. II: A study of the relation between the disulfiram-alcohol reaction and plasma concentration of acetaldehyde, diethyldithiocarbamide acid methyl ester, and erythrocyte aldehyde dehydrogenase activity. Pharmacol. Toxicol., 68, 166-170.

Johansson M, Sterner O, Labischinski H, Anke T (2001) Coprinol, a new antibiotic cuparane from a Coprinus species. Z. für Naturforsch C, 56, 31-34.

Jones ERH, Stephenson JS (1959) Chemistry of the higher fungi .9. Polyacetylenic metabolites from Coprinus quadrifidus. J. Chem. Soc., Jun, 2197-2203.

Jönsson M, Lindquist NG, Ploen L, Ekvarn S, Kronevi T (1979) Testicular Lesions of Coprine and Benzcoprine. Toxicol., 12, 89-100.

Kiwitt U, Laatsch H (1994) Beruht die angebliche Alkoholunverträglichkeit durch den Verzehr des Netzstieligen Hexenröhrlings (Boletus luridus) auf einer Verwechslung? Z. Mykol., 60, 423-430.

Kelner MJ, McMorris TC, Taetle R (1990) Preclinical evaluation of illudins as anticancer agents: Basis for selective cytotoxicity. J. Natl. Cancer I., 82, 15621565. 
Kettering M, Valdivia C, Sterner O, Heidrun A, Thines E (2005) Heptemerones A G, seven novel diterpenoids from Coprinus heptemerus: Producing organism, fermentation, isolation and biological activities. J. Antibiot., 58, 390-396.

Kües U (2000) Life history and developmental processes in the basidiomycete Coprinus cinereus. Microbiol. Mol. Biol. Rev., 64, 316-353.

Kües U, Künzler M, Bottoli APF, Walser PJ, Granado JD, Liu Y, Bertossa RC, Ciardo D, Clergeot P-H, Loos S, Ruprich-Robert G, Aebi M (2004) Mushroom development in higher basidiomycetes. Implications for human and animal health. In: Kushwaha RKS (ed.) Fungi in Human and Animal Health. Scientific Publishers, Jodhpur, India, pp. 431-470.

Kurtzmann RH Jr (1978) Coprinus fimentarius. In: The Biology and cultivation of edible mushrooms. Chang ST, Hayes WA (ed.), Academic Press, New York, N.Y., USA.

Laatsch H (1990) Wie giftig sind unsere Speisepilze? - Teil 1 - Part 1 - Toxins of edible fungi. Forum Mikrobiol., 10/90, 460-465.

Laatsch H, Matthies L (1992) The characteristic odor of Coprinus picaceus: a rapid enrichment procedure for apolar, volatile indoles. Mycologia, 84, 264-266.

Lee IK, Jeong CY, Cho SM, Yun BS, Kim YS, Yu SH, Koshino H, Yoo ID (1996) Illudins C-2 and C-3, new illudin C derivatives from Coprinus atramentarius ASI20013. J. Antibiot., 49, 821-822.

Lehrer SB, Hughes JM, Altman LC, Bousquet J, Davies RJ, Gell L, Li J, Lopez M, Malling HJ, Mathison DA, Sastre J, Schultze-Werninghaus G, Schwartz HJ (1994) Prevalence of basidiomycete allergy in the USA and Europe and its relationship to allergic respiratory symptoms. Allergy, 49, 460-465.

Lelley J (1978) Pilze aus dem eigenen Garten. Anbau Ernte Verwendung. BVL Verlagsgesellschaft, Munich, Germany.

Lindberg P, Bergman R, Wickberg B (1977) Isolation and structure of Coprine, the invivo aldehyde dehydrogenase inhibitor in Coprinus atramentarius: Synthesis of coprine and related cyclopropane derivatives. J. Chem. Soc., Perkins Trans., $1,684-691$.

List PH (1957) Occurrence of ergothioneine in shaggy-mane, Coprinus comatus. Arch. Pharm. Ber. Dtsch. Pharm. Ges., 290, 512-520. 
List PH, Reith H (1960) Basische Pilzinhaltsstoffe .10. Imidazolderivate Im Faltentintling, Coprinus atramentarius Bull. Hoppe-Seylers, Z. Physiol. Chem., $319,17-21$.

Maan NS, Kumar N, Dahiya DVS, Khatta VK (1994) Effect of Coprinus fimentarius on urea-treated crop residues and its utilization by goats. Ind. J. Anim. Sci., 64, 1086-1091.

Maan NS, Hakhar KK, Khatta VK, Kumar N (2000) Some unusual findings in goats fed Coprinus fimentarius treated paddy straw. Ind. J. Anim. Sci., 70, 1157-1159.

Marchner H, Tottmar O (1978) A comparative study on the effects of disulfiram, cyanamide and 1-aminocyclopropanol on the acetaldehyde metabolism in rats. Acta Pharmacol. Toxicol., 43, 219-232.

Matthies L, Laatsch H (1992) Ungewöhnliche Pilzvergiftungen: Coprin, ein Hemmstoff des Alkohol-Abbaus. Pharmazie in unserer Zeit 21/1, 14-20.

Michelot D (1992) Poisoning by Coprinus atramentarius. Nat. Toxins, 1, 73-80.

Midwood KS, Williams LV, Schwarzbauer JE (2004) Tissue repair the dynamics of the extracellular matrix. Int. J. Biochem. Cell. Biol., 36, 1031-1937.

Nagasawa H, Yasuda M, Ohta A, Inatomi H (1995) Effects of 1-amino-cyclopropane-1carboxylic acid, a component of Coprinus comatus, on reproductivity of male mice. Bull. Fac. Agr. Meiji Univ., 102, 9-15.

Nilsson GE, Tottmar O (1989) Effects of disulfiram and coprine on rat brain tryptophan hydroxylation in vivo. Neurochem. Res., 14, 537-540.

Nilsson GE, Tottmar O, Wahlström G (1987) Effects of aldehyde dehydrogenase inhibitors on hexobarbital sensitivity and neuroamine metabolism in rat brain. Brain Res., 409, 265-274.

O'Neil CE, Horner WE, Reed MA, Lopez M, Lehrer SB (1990) Evaluation of Basidiomycete and Deuteromycete (Fungi Imperfecti) extracts for shared allergenic determinants. Clin. Exp. Allergy, 20, 533-538.

Orton PD, Watling R (1979) British fungus flora. Agarics and Boleti 2. Coprinaceae, part 1 Coprinus. Her Majesty's Stationery Office, Edinburgh, UK.

Oso BA (1975) Mushrooms and the Yoruba people of Nigeria. Mycologia, 67, 311-319.

Otto K, Lipperheide C (1986) Studies on a proteinase inactivating enzyme from the basidiomycete Coprinus atramentarius. In: Turk V (ed.), Cysteine Proteinases 
and their inhibitors. Proceed. Int. Symp. Portoroz, Yugoslavia, September 1518, 1985. Walter de Gruyter and Co., Berlin, Germany, pp. 209-218.

Pemberton RT (1994) Agglutins (lectins) from some British higher fungi. Mycol. Res., 98, 277-290.

Pettersson H, Tottmar O (1982) Inhibition of aldehyde dehydrogenase in rat brain and liver by disulfiram and coprine. J. Neurochem., 39, 628-634.

Redhead SA, Vilgalys R, Moncalvo JM, Johnson J, Hopple JS Jr (2001) Coprinus Pers. and the deposition of Coprinus species sensu lato. Taxon, 50, 203-241.

Reina M, Orihuela JC, Gonzalez-Coloma A, de Ines C, de la Cruz M, Del Val AG, Torno JR, Fraga BM (2004) Four illudane sesquiterpenes from Coprinopsis episcopalis. Phytochem., 65, 381-385.

Scholtmeijer K, Wessels JGH, Wösten HAB (2001) Fungal hydrophobins in medical and technical application. Appl. Microbiol. Biotechnol., 56, 1-8.

Simandl J, Franc J (1957) Die Isolierung des Tetraäthylthiuramdisulphids aus dem Tintenmistpilz (Coprinus atramentarius). Collection Czechoslov Chem. Commun., 22, 331-332.

Starratt AN, Stothers JB, Ward EWB (1988) Coprinolone, an oxygen-bridged protoilludane from the fungus Coprinus psychromorbidus - Structure Determination by Chemical and Nmr-Studies Aided by Biosynthetic Incorporation of [1,2-C-13(2)]Acetate. J. Chem. Soc. Chem. Comm., 9, 590-591.

Starratt AN, Ward EWB (1989) Coprinolone and delta-6-coprinolone: new sesquiterpenes from Coprinus psychromorbidus. Can. J. Chem., 67, 417-427.

Suay I, Arenal F, Asensio FJ, Basilio A, Cabello MA, Díez MT, García JB, Gonzalez Del Val A, Gorrochategui J, Hernández P, Peláez F, Vicente MF (2000) Screening of basidiomycetes for antimicrobial activities. Anton. Leeuw. Int. J. G., 78, 129-139.

Tottmar O, Lindberg P (1977) Effects on rat liver acetaldehyde dehydrogenase in vitro and in vivo by coprine, the disulfiram-like constituent of Coprinus atramentarius. Acta Pharmacol. Toxicol., 40, 476-481.

Valdivia C, Kettering M, Anke A, Thines E, Sterner O (2005) Diterpenoids from Coprinus heptemerus. Tetrahedron, 61, 9527-9532.

Velagapudi R (2006) Extracellular matrix proteins in growth and fruiting body development of straw and wood degrading basidiomycetes. PhD Thesis. GeorgAugust University of Göttingen, Göttingen, Germany. 
Walser PJ, Velagapudi R, Aebi M, Kües U (2003) Extracellular matrix proteins in mushroom development. Recent. Res. Dev. Microbiol., 7, 318-415.

Walser PJ, Haebel PW, Künzler M, Sargent D, Kües U, Aebi M, Ban N (2004) Structure and functional analysis of the fungal galectin CGL2. Structure, 12, 689-702.

Walser PJ, Kües U, Aebi M, Künzler M (2005) Ligand interactions of the Coprinopsis cinerea galectins. Fungal Genet. Biol., 42, 293-305.

Wang HX, Ng TB, Ooi VEC (1998) Lectins from mushrooms. Mycol. Res., 102, 897906.

Wang SL, Kang ZL (1984) The domestication of cultivation of Coprinus comatus (or ovatus). Edible Fungi, 5, 7-8.

Wessels JGH (2000) Hydrophobins, unique fungal proteins. Mycologist., 14, 153-159.

Wilkins WH (1945) Investigation into the production of bacteriostatic substances by fungi. Cultural work on basidiomycetes. Trans. Brit. Mycol. Soc., 28, 110-114.

Winterboer A, Eicker A, Wehmeyer AS (1983) A Preliminary report on the nutrient content of Coprinus comatus. S. Afr. J. Bot., 2, 83-84.

Worthen LR, Stessel GJ, Youngken HW Jr (1962) The occurrence of indole compounds in Coprinus species. Econ. Bot., 16, 315-318.

Wösten HAB (2001) Hydrophobins: Multipurpose proteins. Ann. Rev. Microbiol., 55, 625-646.

Ying J, Mao X, Ma Q, Zong Y, Wen H (1987) Icones of medicinal fungi from China. Science Press, Beijing, China.

Young AR, Meeusem EN (2004) Galectins in parasite infection and allergic inflammation. Glycoconjugate J., 19, 601-606.

Zahid S, Udenigwe CC, Ata A, Eze MO, Segstro EP, Holloway P (2006) New bioactive natural products from Coprinus micaceus. Nat. Prod. Res., 20, 1283-1289. 
5

\section{Monstrosities under the inkcap mushrooms}

Contribution to this chapter: Analysis of the sequences, photography, microscopy and manuscript writing was performed by the author of this thesis. Growth of the strains on the different media was partially done by the students under my supervision: Samantha Navarro and Alberto Domingo.

A preliminary report of this work was published in: Pisabarro A. and Ramírez L. (eds.) Proc. VI Genetics and Cellular Biology of Basidiomycetes. Universidad Pública de Navarra, Pamplona, Spain (ISBN 84-9769-107-5). 


\section{Monstrosities under the inkcap mushrooms}

\subsection{Abstract}

Four new strains of Inkcaps were isolated from mushrooms grown on horse dung in the larger area of Mainz (Germany). In the laboratory on horse dung and or on agar media all four isolates formed in addition to normal shaped mushrooms structures of unusual shape. Structures formed by isolate sp. 1 were most mushrooms of crippled shape but some well-shaped umbrella-like mushrooms assigned this Inkcap to the clade Coprinellus. Isolates sp. 2 to sp. 4 formed fruiting body-like structures resembling the anamorphs of Rhacophyllus lilacinus, a species originally believed to be asexual and after teleomorphs were found, renamed as Coprinus clastophyllus, respectively Coprinopsis clastophylla. ITS sequencing identified isolates sp. 1 to be closely related to Coprinellus curtus and isolates sp. 2 to sp. 4 to the C. clastophylla type strain.

Keywords: fruiting body, anamorph, lysomeres, Coprinellus curtus, Coprinopsis stercorea 


\subsection{Introduction}

The traditional concept for Coprinus Pers. has existed for 200 years. The species belonging to this traditional genus are commonly recognized as Inkcaps. Mushrooms of this group of fungi are traditionally called inky caps because in many of the species, the gills and often the cap digest themselves at maturity, turning into an inky black fluid that drips onto the ground (Arora 1986). Specific characteristics of these mushrooms are presence of paraphyses (brachybasidia) in the hymenium so that they distantly space the basidia, dark pigmented spores and inaequihymeniiferous development (having basidia which mature and shed their spores in zones). Mostly, the inkcaps are fimicolous, meaning that they grow on dung of herbivorous. However many other species can be found growing on a wide variety of substrates, such as soil, decaying wood, straw, leaf litter, plant debris and organic litter (Breitenbach and Kräzlin 1995). Species are often difficult to recognize beyond doubt, and most likely, many species are still not characterized. Next to mushroom and spore morphology, the habitat of a fungus can add to their correct identification (Breitenbach and Kränzlin 1995).

About 200 basidiomycetes belonging to the traditional family Coprinaceae were until recently compiled under one single genus Coprinus. However, molecular data divided this group into four new genera: Coprinus, Coprinopsis, Coprinellus and Parasola (Redhead 2000, Redhead et al. 2001). The edible Coprinus comatus is the type species of the new genus Coprinus. Only two other species, Coprinus sterquilinus and Coprinus spadiceisporus, are known in this genus that clusters within the Agaricaceae. The three other newly defined genera belong to the family Psathyrellaceae. Coprinopsis forms the largest genus of these with more than hundred defined species (Hopple and Vilgalys 1999, Redhead et al. 2001, Keirle et al. 2004) and includes well known species such as Coprinus cinereus (Coprinopsis cinerea). Coprinellus is the second largest group of Psathyrellaceae with more than 50 defined species. The type species of this group is Coprinellus disseminatus (Coprinus disseminatus) (Redhead et al. 2001). Parasola is the smallest of the three new genera within the Psathyrellaceae with currently 18 defined species. The type species is Parasola plicatilis, previously called Coprinus plicatilis (Breitenbach and Kränzlin 1995, Redhead et al. 2001).

Here, we describe some species with unusual shaped mushrooms isolated from horse dung and were able to assign them to the genus Coprinellus and Coprinopsis, 
respectively, by both morphological characters such as described above and molecular analysis of ITS sequence. In the literature, a further species with unusual mushrooms has been presented (Maniotis 1964). In order to discriminate whether one of the new isolates corresponds to that species, the type strain of this species (Coprinopsis clasthophylla) was characterized in parallel to the new isolates from nature.

\subsection{Material and methods}

\subsubsection{Strains, culture conditions and spore germination}

Strains were cultivated on solid MEA (1.5\% malt extract), solid YMG/T (yeast extract, malt extract, glucose and tryptophan, Granado et al. 1997), solid corn meal-horse dung extract (HDE) according to Esser (2000), solid BSM (Hüttermann and Volger 1973), sterilized horse dung, oatflake agar (OFA), solid minimal medium modified (RM) and YpSs media (yeast, starch medium, Maniotis 1964), either within a fungal growth chamber at constant $28^{\circ} \mathrm{C}$ in the dark in ventilated boxes or in the laboratory at room temperature under normal day-night light conditions. Agar was always added at a concentration of $1 \%$.

Four different Coprinus sp. isolates (sp. 1 to sp. 4) were obtained from mushrooms grown on horse dung from different localities close to Mainz, Germany (sp. 1 from Ober-Olm in 2000; sp. 2 from Ginsheim-Gustavsburg in 2003 and sp. 3 and 4 from Ingelheim am Rhein in 2003). Isolates 3 and 4 came from the same collection of horse apples. Basidiospores from isolate were harvested and inoculated (dilutions of 1:10 000) on HDE media. Ten single spore cultures were isolated, grown in the same media and incubated at $28^{\circ} \mathrm{C}$ during 25 days one set under full darkness and another set of the same cultures under day/night cycle. C. cinerea strain AmutBmut (Swamy et al. 1984, Kertesz-Chaloupková et al. 1998) served in comparison of fruiting structures. The type strain Coprinosis clastophylla (Coprinus clastophyllus) (473.70), originally isolated from bark, was obtained from the CBS (Centraalbureau voor Schimmelcultures, Netherlands).

\subsubsection{Microscopy}

Fruiting bodies were studied under the stereo microscope (Stemi 200-C Zeiss). Light microscopy from fruiting body tissues was performed with a Zeiss Axiophot 
photomicroscope. Both microscopes were equipped with a Soft Imaging ColorView II Mega Pixel digital camera, linked to a computer equipped with analySIS ${ }^{\circledR}$ software program (Soft Imaging System, Germany). For observation of hyphal cells in the microscope, freshly mycelia grown on agar pieces were squeezed on a glass slide. Gills from different developing primordia and mature fruiting bodies were squashed on a glass slide. Elements of the universal veil from mushroom caps were isolated with a scalpel and dispersed in distilled water, and observed under a light microscope at $20 \mathrm{x}$ magnification. Sclerotia developed on the cultures were harvested and with the help of a razor blade, hand sections for light microscopy were made.

For light microscopic observations of oidia, sterile microscope slides (76 x $26 \mathrm{~mm}$ ) were overlaid with a thin film (1-2 mm) of solid HDE medium. In the middle of each slide, a section of medium of approximately $7 \times 10 \mathrm{~mm}$ was removed. The free area was covered with a coverslip (18 x $18 \mathrm{~mm})$. The strain was inoculated at both sides of the coverslip at a distance of approximately $5 \mathrm{~mm}$. The slide cultures were incubated in sterile petri dishes on glass triangles lying on wet sterile tissue paper for $24 \mathrm{~h}$ at $28^{\circ} \mathrm{C}$ and observed at $40 \mathrm{x}$ at different time intervals (Polak et al. 1997).

\subsubsection{DNA techniques}

Genomic DNA was isolated by the protocol of Zolan and Pukkila (1986), ITS sequences amplified with primers ITS1 and ITS4 (Gardes and Bruns 1993) were used for sequencing at the section of Forest Genetics and Forest Tree Breeding, Büsgen-Institute, Georg-August-University Göttingen. ITS sequences were submitted to the NCBI database under the accession numbers EU375238 to EU375242. Sequences were edited and assembled using the Staden package 2001 (http://www.mrcImb.cam.ac.uk/pubseq/). Alignments of DNA were generated with ClustalX (http://www.igbmc.u-strasbg.fr/BioInfo/ClustalX/Top.html) and manual adjustments were made in GeneDoc ver. 2.6.002 (http://www.psc.edu/biomed/genedoc/). Phylogenetic analysis of sequences was performed with Mega ver. 2.1 (http://www.megasoftware.net/). 


\subsection{Results and discussion}

\subsubsection{ITS analysis}

As a first step towards classification of the new strains, ITS sequences of the four new isolates and of the type strain C. clastophylla were amplified by PCR from genomic DNA and submitted to sequencing reactions. The ITS sequence obtained from sp. 1 (accession number EU375238) grouped the isolate into the genus Coprinellus close to the species Coprinellus curtus (accession number AY461824, 96\% identity of ITS sequence). Isolates sp. 2 (accession number EU375239), sp. 3 (accession number EU375240), sp. 4 (accession number EU375241) and the C. clastophylla type strain (accession number EU375242) were grouped by their ITS sequences into the genus Coprinopsis, close to the species Coprinopsis stercorea (syn. Coprinus stercorarius, Coprinus stercoreus) (91\% ITS sequence identity). ITS sequencing confirmed that isolates sp. 2, sp. 3 and sp. 4 belong with C. clastophylla into one species (99-100\% ITS sequence identity) (Figure 1).

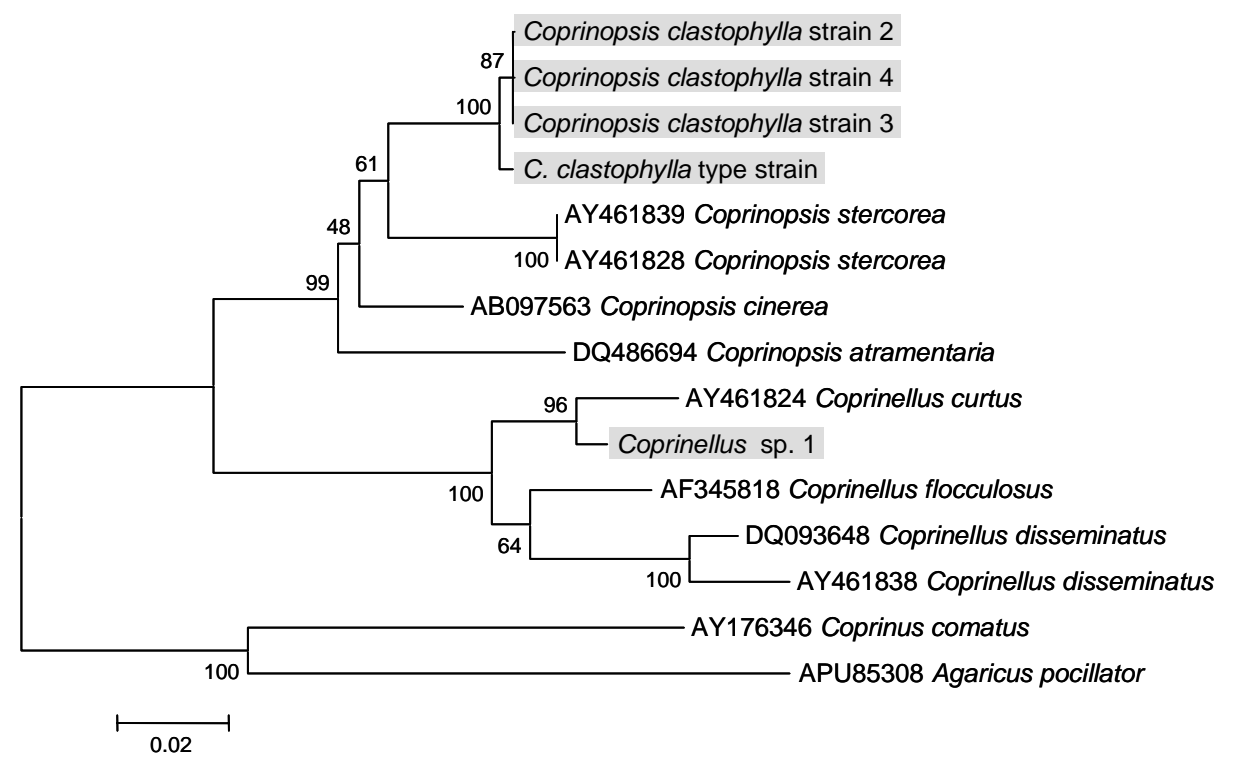

Figure 1 Phylogenetic tree of the ITS sequences from the four new different isolates Coprinellus sp. 1, Coprinopsis clastophylla strains 2 to 4 and the type strain (marked in grey), and selected basidiomycetes. Codes indicate NCBI GenBank accession numbers. The scale bar defines the number of nucleotide substitutions per site. Agaricus pocillator was used as an outgroup. 


\subsubsection{Culture and mycelial characteristics of the four newly isolated strains}

Cultivation on different agar media (YMG/T, MEA, BSM and HDE) showed for all four new strains Coprinellus sp. 1, Coprinosis clastophylla 2, 3 and 4, and for C. clastophylla that HDE was best supporting mycelial growth in terms of speed of growth and fruiting. Coprinellus sp. 1 was more dense and fluffy than the other four strains (Figure 2). Typical for the C. clastophylla strains 2, 3, 4 and the type strain was thin growth within the agar in the form of hyphal strands and very little or no aerial mycelium. Strain Coprinellus sp. 1 had no clamp cells at hyphal septa, unlike the other strains (Figure 2). This characteristic together with the fruiting bodies (see below) gave another hint that isolate Coprinellus sp. 1 could be related to the clamp-less Coprinellus curtus (Coprinus curtus) (Orton and Watling 1979, Uljé 2003).

Regularly in HDE cultures of C. clastophylla strains 2, 3, and 4 and C. clastophylla type strain grown at $28^{\circ} \mathrm{C}$ in dark boxes (opened once a day for controlling the growth), multi-cellular structures with long stipe and poorly developed caps appeared (Figure 2) that resembled etiolated stipes known from C. cinerea strain AmutBmut, underdeveloped fruiting structures formed in this species when appropriate light control of development is missing (Kües 2000) (Figure 3). Furthermore, cultures of the C. clastophylla strains 2, 3, and 4, and C. clastophylla type strain gave rise to white and brown sclerotia (Figure 4). White sclerotia were rather flat, irregular in shape (7-15 $\mathrm{mm}$ ) and hard but without a melanized rind (Figure 4B). Upon aging, spots of a melanized rind appeared sometimes on the structures. Drops of colorless exudates were frequently observed on their surface. Also the brown sclerotia produced exudates which were in this case of a brown coloration (Figure 4B, D). The brown sclerotia (10-30 $\mathrm{mm}$ ) were of convex and spherical to irregular shape, bigger and harder than the white ones. They had circular brown-dark rind spots of different sizes scattered over their overall light-brown rind surface (Figure 4C). 


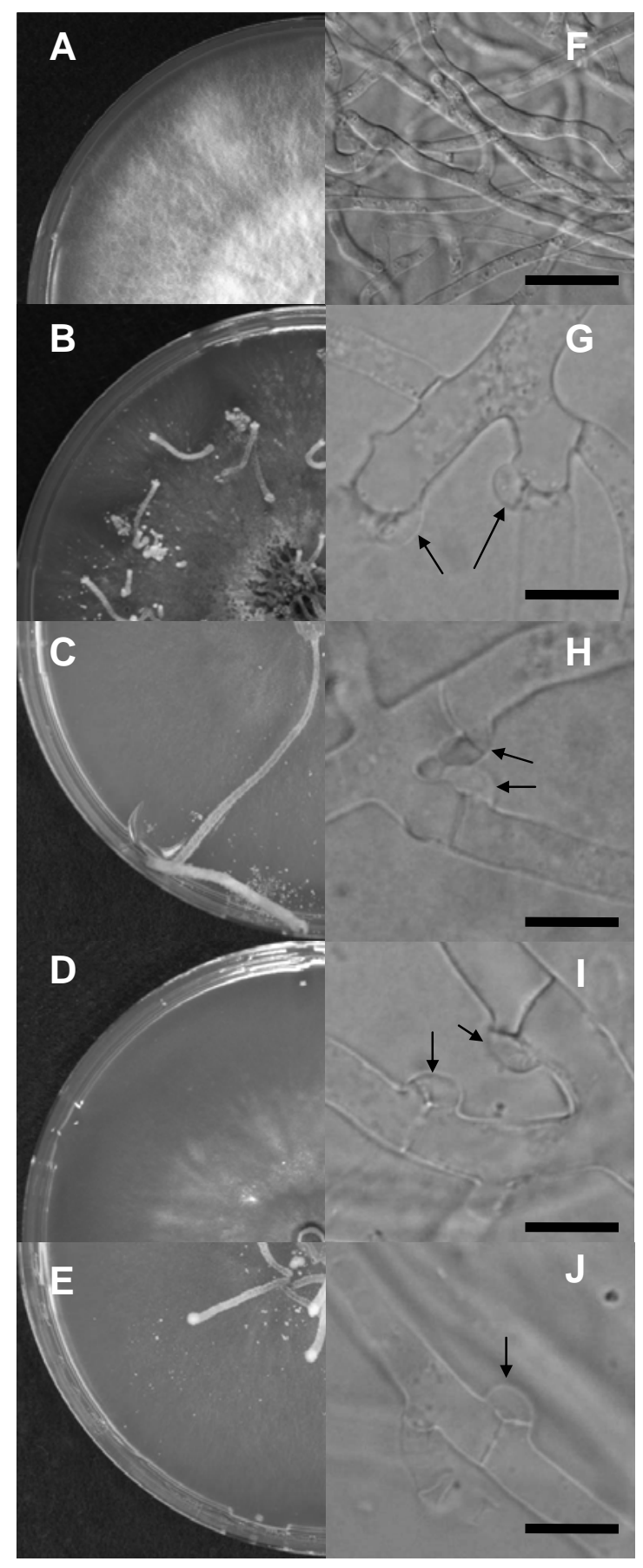

Figure 2 Colony morphology of isolates after $10 \mathrm{~d}$ of growth on HDE medium at $28^{\circ} \mathrm{C}$ in darkness receiving only short light pulses. Isolate Coprinellus sp. 1 (A), Coprinopsis clastophylla type strain (B), Coprinopsis isolates 2, 3, and 4 (C-E) on HDE medium grown at $28^{\circ} \mathrm{C}$ in the dark. Note the "etiolated stipe" structures on the plates of C. clastophylla type strain and Coprinopsis isolates 2 and 4 fully developed and still growing, respectively. Isolate sp. 1 had no clamp cells at hyphal septa (F) in contrast to the Coprinopsis clastophylla type strain (G), and isolates 2, 3, and 4, respectively (H-J, arrows). Note that the thickness of the hyphae of Coprinellus sp. 1 is about 1/4 from the C. clastophylla strains. Scale bar $10 \mu \mathrm{m}$. 


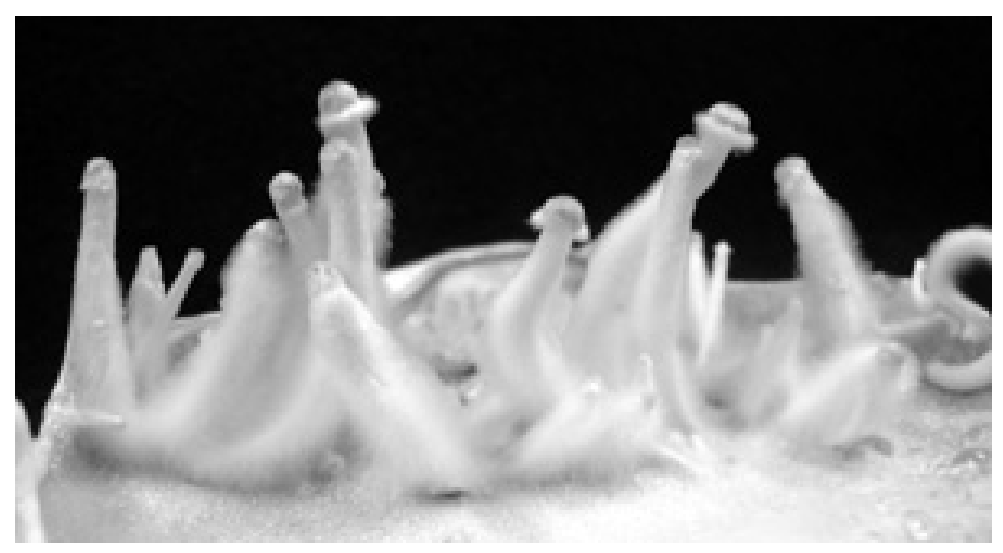

Figure 3 Etiolated stipes (also called dark-stipes) from C. cinerea strain AmutBmut that have an underdeveloped cap and an extra long stipe and form when the fungus has not enough light.

Brown sclerotia had an outer melanized rind and an inner white medulla (Figure 4C inset). The rind was composed of brown thin hyphae (Figure 4F) and the medulla of closely packed plectenchyma with thick and short hyphae (Figure 4G). In white sclerotia, the cells were longer and rounded in some areas (Figure 4H). Normally, sclerotia developed faster under dark conditions; already after 3-5 days incubation upon inoculation, sclerotia were observed in cultures. When incubated in light/dark cycles, cultures formed sometimes after 2-3 weeks first sclerotia and then, after several further days, fructifications developed from the sclerotia (Figure 4E). However, fructifications also occurred on mycelium without formation of sclerotia.

Sclerotia have been described as asexual, multicellular, dormancy structures characteristic of a coprini group defined as Stercorarius (van Waveren 1968), Stirp Narcoticus (Orton and Watling 1979), or Section Veliformes, Subsection Narcotici, respectively (http://www.grzyby.pl/coprinus-site-Kees-Uljee/species/curtus.htm). Fruiting bodies of this group of coprini frequently initiate from a sclerotium (Buller 1924, van Waveren 1968), as occurred repeatedly in our observations (Figure 4E). Specifically, sclerotia of the brown spotted type have been reported before to occur in the species $C$. stercorea, seen here as a closer relative to C. clastophylla 2, 3, and 4 isolates (Figure 1). Formation of sclerotia of C. stercorarius big in size and of hard consistence was the unusual reason to block flow in pipes and through distribution nozzles in a winery effluent tower treatment in New South Wales, Australia. When 

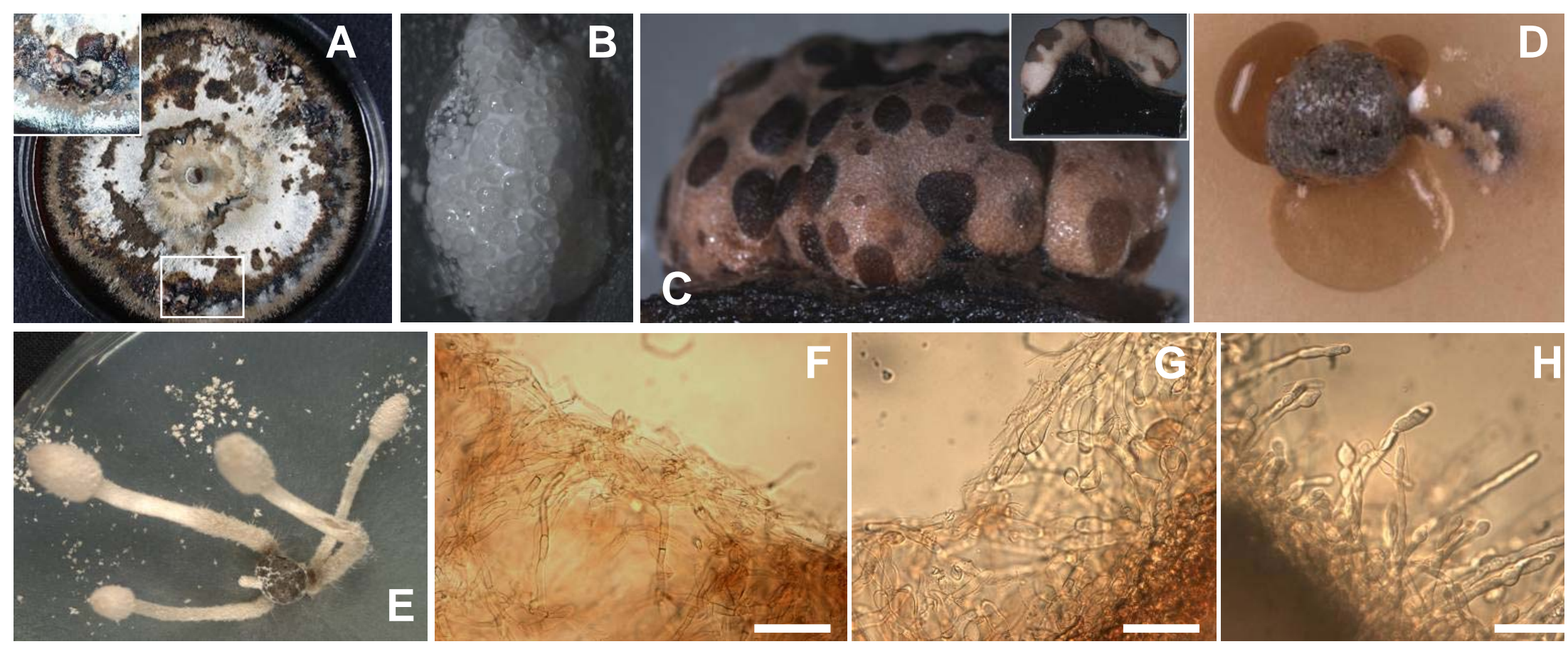

Figure 4 Strains sp 2, sp. 3 and sp. 4 constantly developed white and brown sclerotia $(1-3 \mathrm{~cm})$ on agar media and on horse dung (A-D). Sclerotia were able to develop fructifications after being stored at $4^{\circ} \mathrm{C}$ for 22 months, subsequently inoculated on fresh media for growth at $28^{\circ} \mathrm{C}$ and then transferred to room temperature into the laboratory $(\mathbf{E})$. Darker circular spots were scattered on the surface of brown sclerotia $(\mathbf{C})$, section of the sclerotium showing the melanized rind and the white medulla (C inset). The cells of the rind of the sclerotium were thin and brown (F). In brown and in white sclerotia, the hyphae from the inner medulla were of irregular thickness $(\mathbf{G}, \mathbf{H})$. Scale bar $50 \mu \mathrm{m}$. 
transferred to the laboratory and incubated on artificial media, these sclerotia were able to produce basidiocarps in culture, defining the mushroom as Coprinopsis stercorea. Sclerotia development was favored by urea. Elimination of urea stopped development of new sclerotia (Walker and Moore 1974). Morimoto et al. (1982) found that in medium supplemented with urea (0.25-4 g/l) C. stercorarius improved mycelial growth and produced in darkness sclerotia. Under light illumination, fruiting bodies were produced at lower urea concentrations (0.25-1.0 g/l), whereas at higher concentrations $(2-4 \mathrm{~g} / \mathrm{l})$ only sclerotia or rudimentary fruiting bodies appeared. Here, sclerotia formation occurred with the C. clastophylla isolates and type strain preferentially on HDE medium with probably a high natural nitrogen concentration.

\subsubsection{Fruiting abilities of the Coprinellus sp 1}

We observed the behavior of HDE cultures of Coprinellus sp. 1 at room temperature in the laboratory. The strain regularly produced many strangely shaped mushrooms of about 3 to $4.5 \mathrm{~cm}$ in size (Figure 5). Usually, they carried basidiospores (Figure 6, see below for the microscopic description) that germinated into monokaryons. These monokaryons constitutively produced oidia (Figure 7).

About $40 \%$ of fruiting structures in cultures regardless whether on artificial media (HDE) or on pure horse dung had a typical shape of coprinoid mushrooms (Figure 5A). Amongst misshaped mushrooms, there were always a few on a plate that looked like a typical umbrella shaped mushroom (Figure 5A). These classically shaped mushrooms were delicate with thin, hollow stipes and fine umbrellas with little inner pileus trama. Brittle, hollow stipes and delicate caps are typical for Coprinellus species (Orton and Watling 1979).

The macroscopic characteristics of the fructifications obtained in the laboratory from Coprinellus sp. 1 were: Closed pileus up to 3-10 mm ovoid when closed, 11-25 mm once expanded, convex to hemispherical and sometimes planar at maturity, plicate; cream or brown colored when young with yellow-brown to ochre-brown granularflocculose veil that keeps on the whole development; ochre brown at centre once mature with gray and light brown running along pileus ridges, and black on the tissue onto the gills. Lamellae 26-34 with 0-1 secondary gills, almost free to free, whitish, 

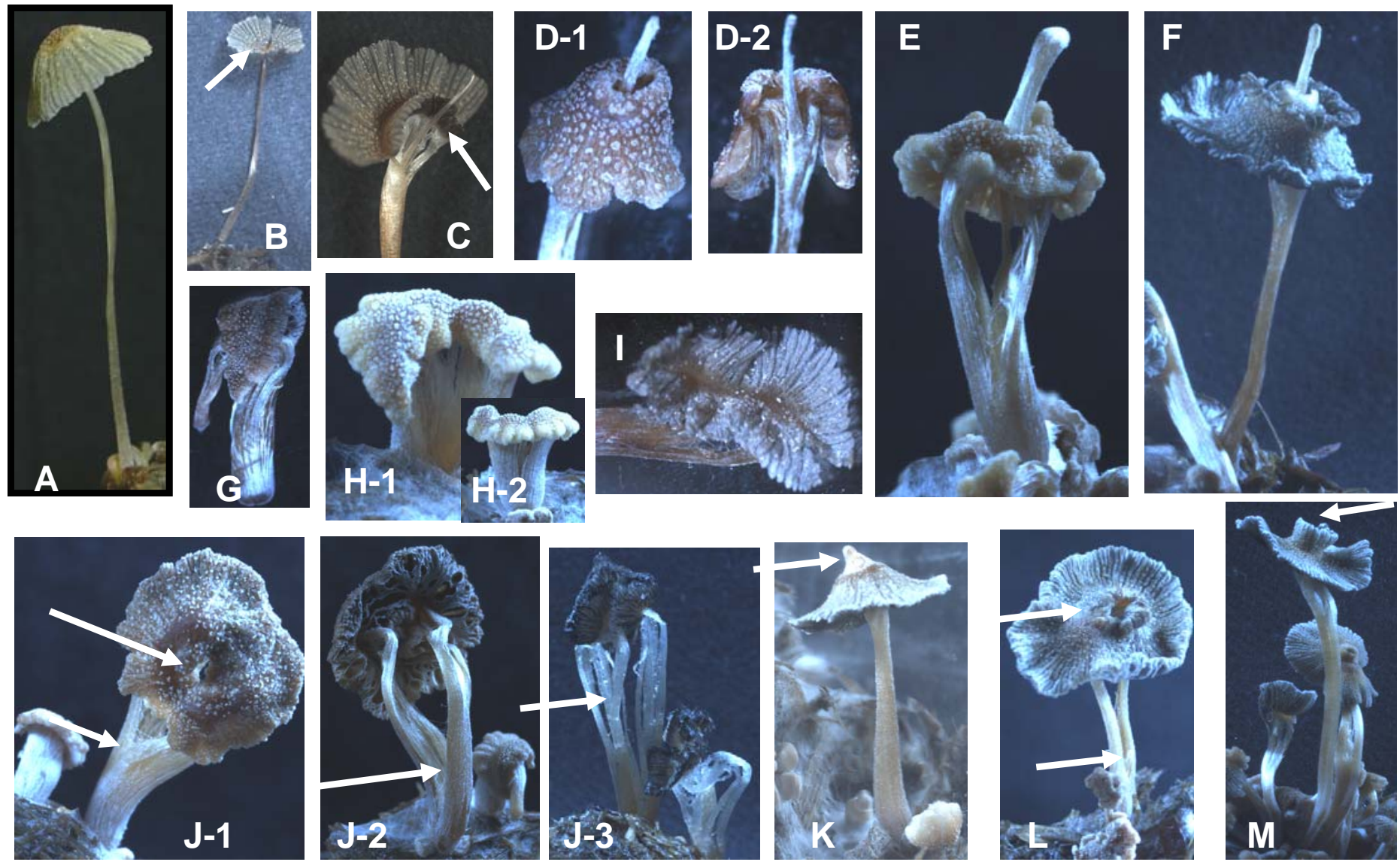

Figure 5 Isolate 1. Classical umbrella shaped mushroom (A), "picked helmet" mushroom (B-G), hollow mushroom (H), cap from "cedar shape" mushroom (I), different stages of stipe splitting (J), "split umbrella" still complete at the base, note the splitting causes a hole at the cap (J-1), stronger stipe splitting (J-2), splitting of stipe in many pieces (J-3); "hunchback" cap (K), and "split umbrella" (L) with gills towards outside on the top of the cap (M, arrow). 

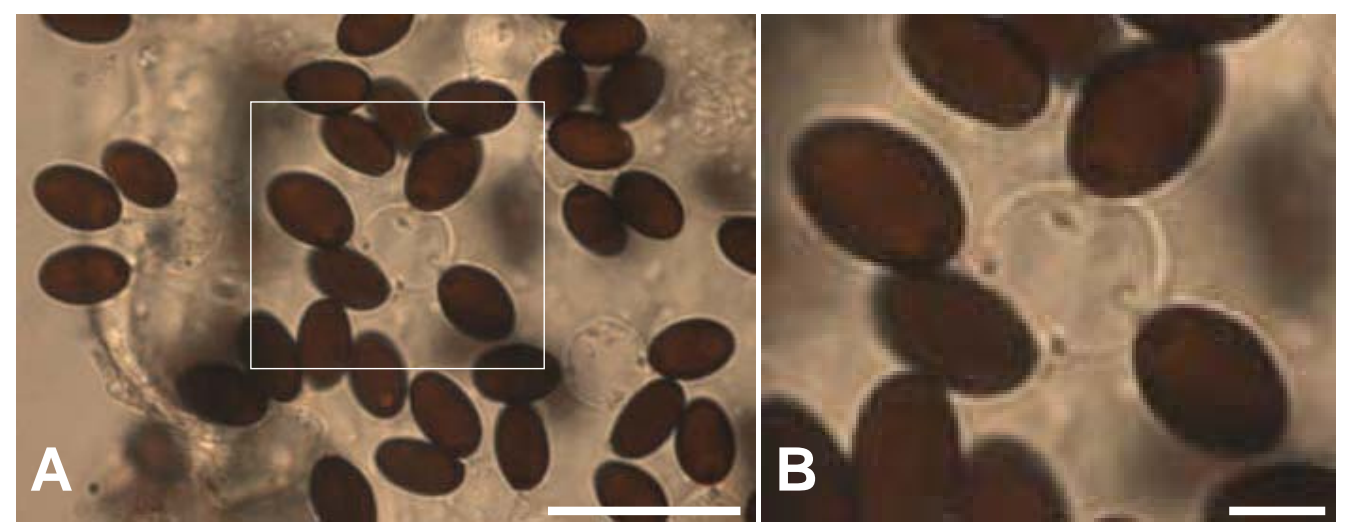

Figure 6 Basidia carrying 4 basidiospores of Coprinellus sp. 1 (A). 2x magnification of a single basidia showing the 4 spores linked to the sterigma. Scale bars $20 \mu \mathrm{m}$.

grey and finally blackish when spores maturate. Stipe $8-45$ x 0.5-3 mm, whitish when young, brown at maturity, hollow, sparsely pubescent from setule. No smell. Habitat: on horse-dung. Subgregarious.

Microscopic features: Spore print black. Spores dark reddish brown 11.6-15 x 7.4-9.6 $\mu \mathrm{m}(\mathrm{n}=20)$, smooth, ellipsoid with rounded base and apex; germ pore eccentric, $1.8 \mu \mathrm{m}$ wide, apiculus small. Basidia 20-31 x 10-13 $\mu \mathrm{m}$, 4-spored. Paraphyses 5-7 per basidium. Cheilocystidia globose (cystidia at the side of the gills), pleurocystidia absent. Pileocystidia capitate with cylindrical setules 68-78 $\mu \mathrm{m}$, capitulum up to 9-12 $\mu \mathrm{m}$. Velar brown sphaerocysts on pileipellis up to $30 \mu \mathrm{m}$ in diameter, rather strong incrusted. Clamp-connections not seen.

Typically in cultures $(\sim 60 \%$ of the cases), the stipe and often also the cap of the mushrooms split during development and often, inner stipe tissues shot up and appeared to pierce the cap during upward growth. As a result, mushroom caps look like "picked helmets". Microscopic observations revealed these stipe extensions to originate from the inner tissues of the hollow stipe (Figure 5D-2). Despite the irregular shape, the fruiting structures produced spores like the typical umbrella-shaped mushrooms and had a granular-floccose veil on their cap. 

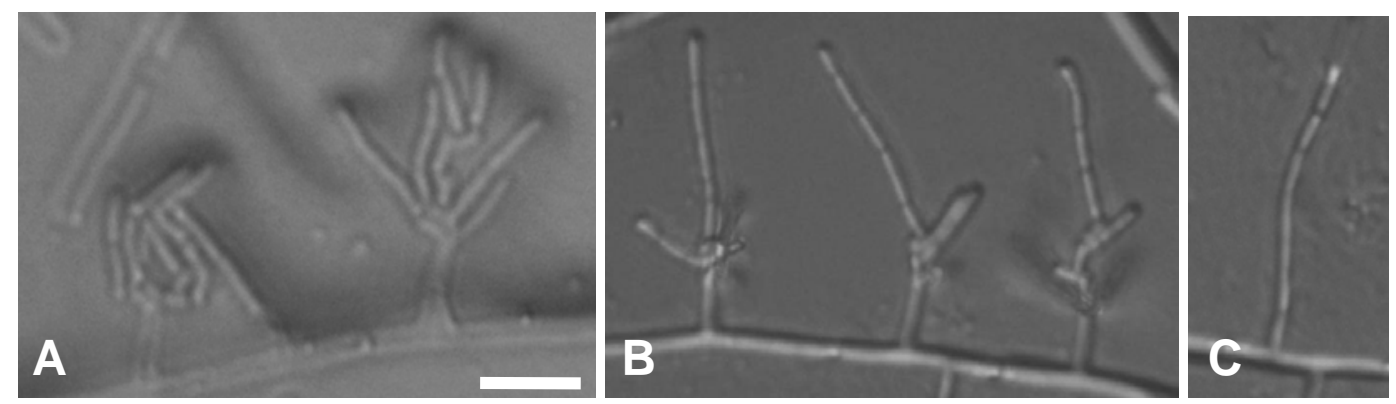

Figure 7 Monokaryons produced by spores of Coprinellus sp. 1 constitutively produced oidia. Short oidiophore with several oidia at their tips (A), long branched (B) and not branched (C). Scale bar $20 \mu \mathrm{m}$.

\subsubsection{Fruiting abilities of the Coprinopsis clastophylla 2, 3 and 4 isolates}

In C. cinerea, etiolated stipes are formed when the fungus obtained a short light signal and then stayed in the dark (Figure 2). To correctly follow the sequence of developmental events leading to mature fruiting bodies with basidiospores, C. cinerea needs alternating light and dark phases synchronized to the normal day/night rhythm (Lu 1974, 2000; Kües 2000). Since the multi-cellular structures of C. clastophylla 2, 3 and 4 isolates formed in the dark after a short light exposure (Figure 2) suggested that these came from aberrant fruiting body development possibly due to lack of light, new HDE cultures of these isolates were incubated at room temperature on a bench in the laboratory under a natural day/night light regime.

Previously, Rogers (1973) obtained from an isolate of C. stercorarius incubated at constant darkness aberrant fructifications with long stipes and reduced pilei that did not expanded, produced spores and autolyze. In a $12 \mathrm{~h}$ day/12 h night light regime, normal mushrooms formed in large groups resembling the grouping shown in Figure 8D for C. clastophylla. Under the day/night light regime, the production only of etiolated stipelike structures with underdeveloped caps did not occur. Instead, the three newly isolated strains regularly gave rise to many sterile fruiting body-like structures as well as some normal umbrella-shaped, fertile fruiting bodies carrying basidiospores (Figure 8). Mycelia obtained from germination of such single basidiospores always produced clamps. The mycelia were able to form etiolated stipe-like sterile fructifications, when incubated in total darkness; and fertile fruiting structures when exposed to light/dark cycle. Morphologically very similar underdeveloped fruiting structures with long stipes in dark-kept cultures have been observed by Rogers (1973) for a C. stercorea isolate. 
The macroscopic features of fructifications of C. clastophylla 2, 3, and 4 exposed to light/dark cycle were as follows: Pileus ovoid to ellipsoid up to 3-24 x 1-5 mm when still closed and in sterile fruiting bodies, up to 7-50 $\mathrm{mm}$ broad when expanded with revolute or split margin, densely covered with mealy to hairy floccose veil, first white, later becoming greyish. Lamellae 21-27 per cap with 0-1 secondary gills, lanceolate, free, first white then black when spores maturate and finally deliquescent. Stipe 26-110 x 0.5-3 mm, whitish, filiform, equal over its length or slightly attenuated upwards. The base of the stipe radiating with tufts of fine straight hyphae about 8-10 $\mathrm{mm}$ long. When present, pseudorhiza 15-50 mm. Odourless. Gregarious on horse dung.

The fruiting bodies produced by isolates 2-4 often developed a rooting stem also called pseudorhiza (Figure 8A) which appears to be a characteristic of the "stercorarius group" (van Waveren 1968). Apparently, carpophores of the species of this coprini group may easily develop a root when they have to rise from the depths of mixtures of dung and compost or from deep in dung or earth (van Waveren 1968).
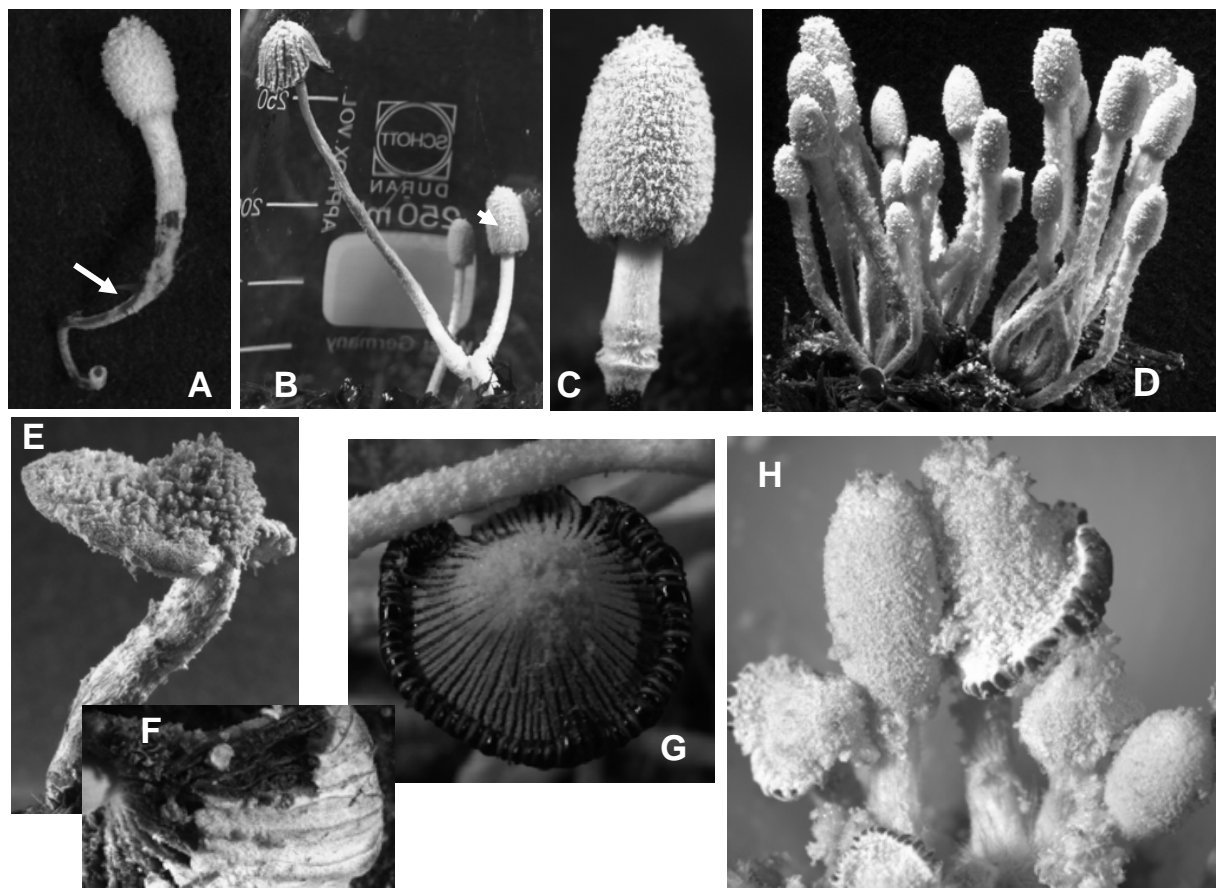

Figure 8 Isolate 2. Immature mushroom with long pseudorhiza (arrow) (A-D). Mature fruiting bodies (B). Young mushroom with spherocytes on the cap (arrow) (C). Isolate 3. Group of immature mushrooms (D). Isolate 4. Mushroom with uncompleted cap development (E). Fused gills (F). Autolysis of mushroom (G). Group of mushrooms with expanded and unexpanded caps $(\mathbf{H})$. 
Microscopic characteristics: Spores dark reddish brown 8.8-11.1 x 5.1-6.4 $\mu \mathrm{m}$, elongate elongate-ellipsoid or slightly ovoid in face view, with rounded base and apex, germ pore central, 1.0-1.1 $\mu \mathrm{m}$ wide, apiculus small, perisporial sac none or not visible in water. Basidia 8.3-22.8 x 7.2-8.5 $\mu \mathrm{m}$, 4-spored, surrounded by 3-5 hymenial physalides. Pleurocystidia (cystidia on the ridge of the gill) ovoid or ellipsoid 56.6-76.5 x 24.4-38.2 $\mu \mathrm{m}$, lanceolated in mature fruiting bodies. Cheilocystidia globose or ellipsoid. Elements of veil (round glittering bodies) 29.6-149.5 $\mu \mathrm{m}$ wide, made up of globose, warty cells connected with narrow, diverticulate hyphae (Figure 9D).

Characteristic for C. stercorea is a veil formed by round glitering bodies (Breitenbach and Kränzlin 1995) as described here for the four C. clastophylla strains. Van Waveren (1968) described that in two of his C. stercorarius specimens, round glittering bodies (spherocytes) were found also along the entire edge of the gills. Based on this characteristic, van Waveren (1968) gave the name of C. stercorarius f. diverticulatus to these exemplars. However, in our cultures of C. clastophylla the spherocytes developed seldom on the gills, showing that this behavior is not constitutive (Figure 9). In our studies, when spherocytes fall onto an appropriate substrate, they could develop into new mycelia that further on formed fruiting bodies (Figure 10B-D).

The macro- and microscopic descriptions of C. clastophylla 2, 3, and 4 isolates are alike to the descriptions of C. stercorea given by Orton and Watling (1979). Several authors in the past (Mounce in 1921, and 1922, Brunswik in 1924 and in Newton 1926 cited by Whitehouse 1949) described Coprinus stercorarius (=Coprinopsis stercorea) as a homotallic species, showing a discrepancy to other authors (Kniep in 1920, and Vandendries in 1923 cited by Whitehouse 1949) who stated C. stercoreus (=C. stercorea) to be heterothallic (Whitehouse 1949). When looking at basidia from the three newly isolated C. clastophylla strains as well as the type strain, they always had four sterigmata and basidiospores, supporting the species to be homothallic and not to be a secondary homothallic species. According to Orton and Watling (1979), their C. stercorea species is heterothallic. The data suggest that C. clastophylla and C. stercorea are easy to confuse when growing as normal shaped mushrooms but the genetic system obviously is different, possibly explaining the contradictory reports summarized by Whitehouse (1949). The reports cited by Whitehouse might refer to 

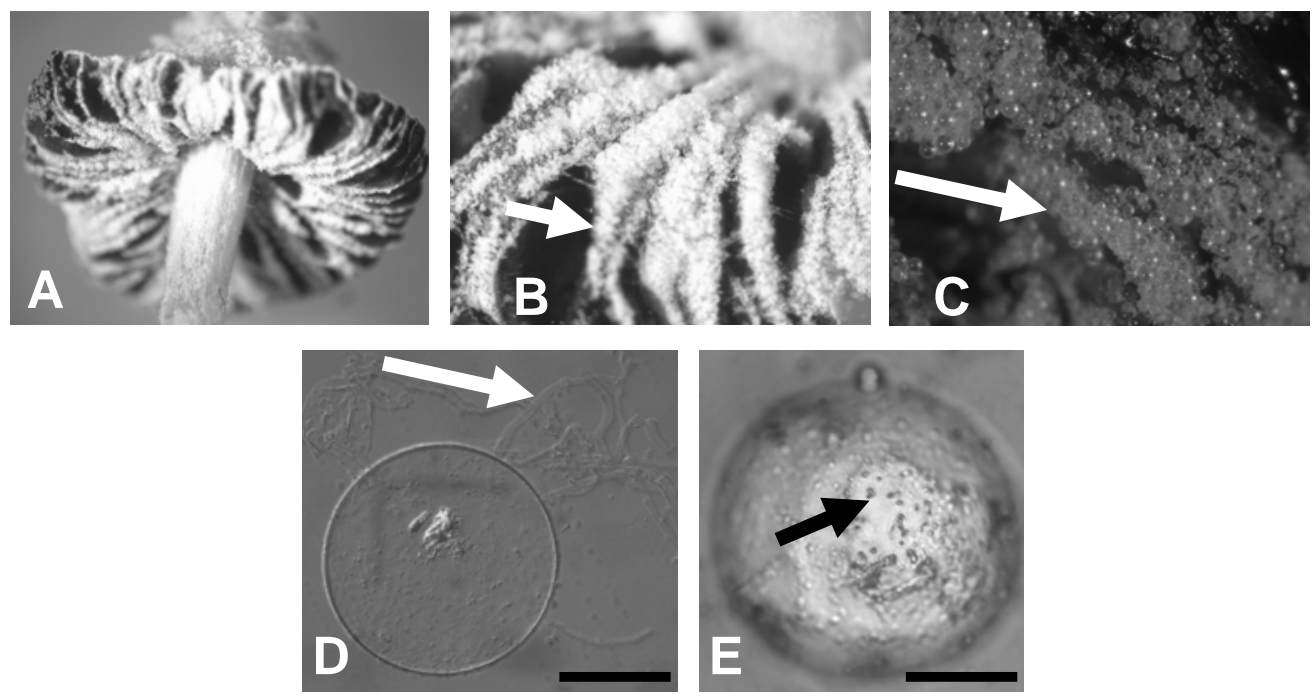

Figure 9 Coprinopsis clastophylla strains 2, 3 and 4 produced abundant spherocytes on the cap, and seldom on the gills of the teleomorph (A-C) which easily were released and deposited on the surface of the stipe, or onto the growing substrate. These spherocytes of variable size (29.6$149.5 \mu \mathrm{m})$, were interconnected by diverticulate hyphae (D), and had a warty surface (E). Scale bar $50 \mu \mathrm{m}$.

rather two different species, one of which might be C. clastophylla and the other C. stercorea.

\subsubsection{Fruiting abilities of the Coprinopsis clastophylla type strain}

The macroscopic features of fructifications of the C. clastophylla type strain exposed at RT to light/dark cycle were as follows: young pileus ovoid to ellipsoid up to 5-30 x 1-5 $\mathrm{mm}$ when still closed (Figure 10A); in sterile fruiting bodies, up to $30 \mathrm{~mm}$ broad, when expanded with typical revolute or split margin (Figure 10I); densely covered with mealy to hairy floccose veil cells in elongated groups; first white, later becoming grayish or light brown; 35-40 primary lamellae per cap with 0-1 secondary gills in between; lanceolate in shape, free, first white then black when spores maturate and finally deliquescent; stipes whitish, filiform, variable in shape and length (often radicate and thus slightly attenuated upwards; lower radicating part with smooth surface, pseudorhiza 15-50 $\mathrm{mm} \times$ 0.5-1.5 $\mathrm{mm}$ in diameters; upper part of wooly appearance by flocks of veil cells, $10-70 \times 0.5-2.0 \mathrm{~mm}$ in length and width; Figure 11) in sterile fruiting bodies and in mature fruiting bodies $(60-75 \times 2-3 \mathrm{~mm}$; more or less equal over its length with either a short, strong shaft at the base annulated by remains of the 

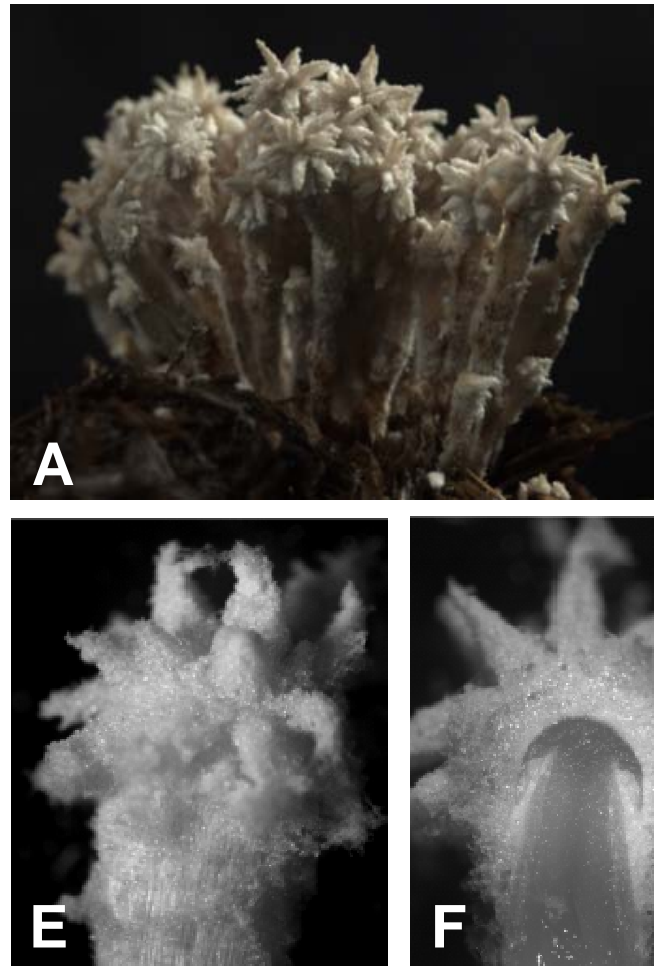
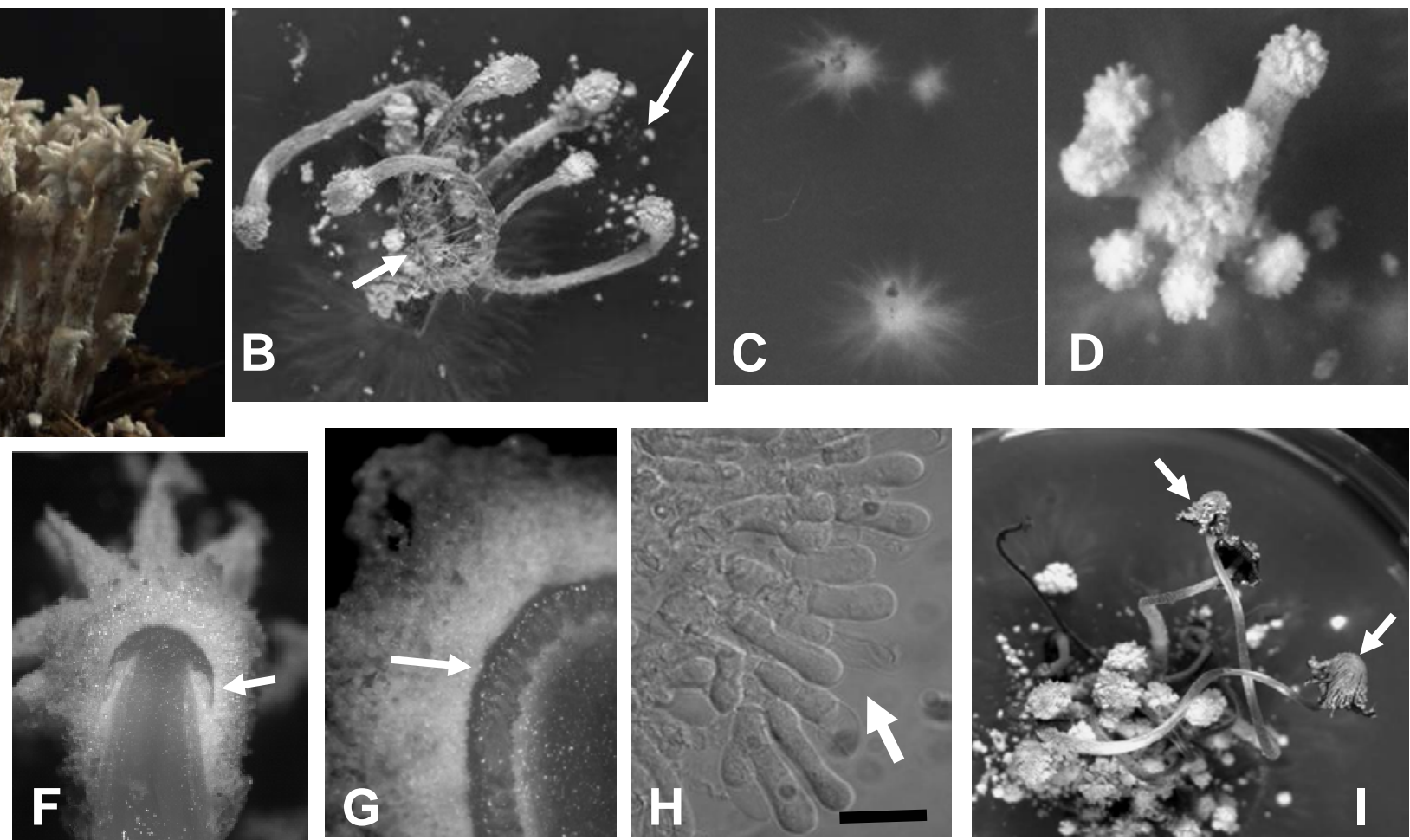

Figure 10 The type strain of C. clastophylla (strain CBS 473.70). Group of mushrooms growing on horse dung that arrested in development prior to maturation, note that the veil structures are densely produced on the cap in rows simulating "palm-like" leaves formed by crowded spherocytes (A). At the base of the stipes they developed tufts of fine straight hyphae (B, lower arrow). The spherocytes might easily fall onto the agar (B upper arrow), germinate and produce mycelia $(\mathbf{C})$ that further developed fruiting bodies (D). Veil details of an immature fruiting body (E), with longitudinal (F) and cross section $(\mathbf{G})$ showing underdeveloped gills (arrows). This structures developed basidia that were unable to produce basidiospores (H). Mixed between the sterile fructifications, very rarely mature fruiting bodies were developed on BSM media at room temperature (I). Scale bar $20 \mu \mathrm{m}$. 
universal veil or a slightly upwards attenuated pseudorhiza); pseudorhizas forming within and partially above horse dung substrate, on agar plates also fully above substrates; often, the pseudorhiza or simple shaped stipes radiating with tufts of fine straight hyphae about 8-10 mm long (Figure 10B, lower arrow targets to the base of the fruiting structures) directly above the substrate; normally shaped fruiting bodies or sterile structures or mixtures of both grow together in groups (gregarious); bunches of 60 and more sterile fructifications were largest on horse dung followed by HDE medium with 20 and more individuals per cluster; neither mature fruiting bodies nor sterile fructifications did smell; basidia 11.2-24.8 x 5.2-9.0 $\mu \mathrm{m}$ in size, 4-spored, surrounded by 3-5 hymenial paraphyses; in sterile fructifications, the basidia dimensions were 4.7-19.4 x 2.1-9.1 $\mu \mathrm{m} \quad(\mathrm{n}=10)$ (Figure 10H); when present, basidiospores were dark reddish brown, 6.8-7.7 x 4.8-5.1 $\mu \mathrm{m}$ in size, ovoid in shape, with rounded base and apex, germ pore central of 1.0-1.1 $\mu \mathrm{m}$ wide, minute apiculus, perisporial sac absent or not visible in water; elements of veil (round glittering bodies, Fig 10) $36.8-27.7 \mu \mathrm{m}$ wide $(\mathrm{n}=50)$, made up of globose, warty cells connected with narrow, diverticulate hyphae (Figure 9D).

\subsubsection{Fruiting bodies and related sterile structures in Coprinopsis clastophylla, and its anamorph Rhacophyllus lilacinus}

When comparing fruiting structures between C. clastophylla strain 2, 3, 4 and the type strain (CBS 473.70), there was an obvious difference in the overall shape at which fruiting body development arrested. The structure of strains 2-4 was more alike a typical umbrella shape. Cap tissues including sometimes the ridges of the lamellae, and partially the stipe of the sterile structures of C. clastophylla strains 2, 3, and 4 were covered by masses of large, round, glittering bodies as if cap and stipe have been dusted with icing sugar (Figure 8, Figure 9). In strains 2-4, fruiting structures appeared in larger dense groups. 


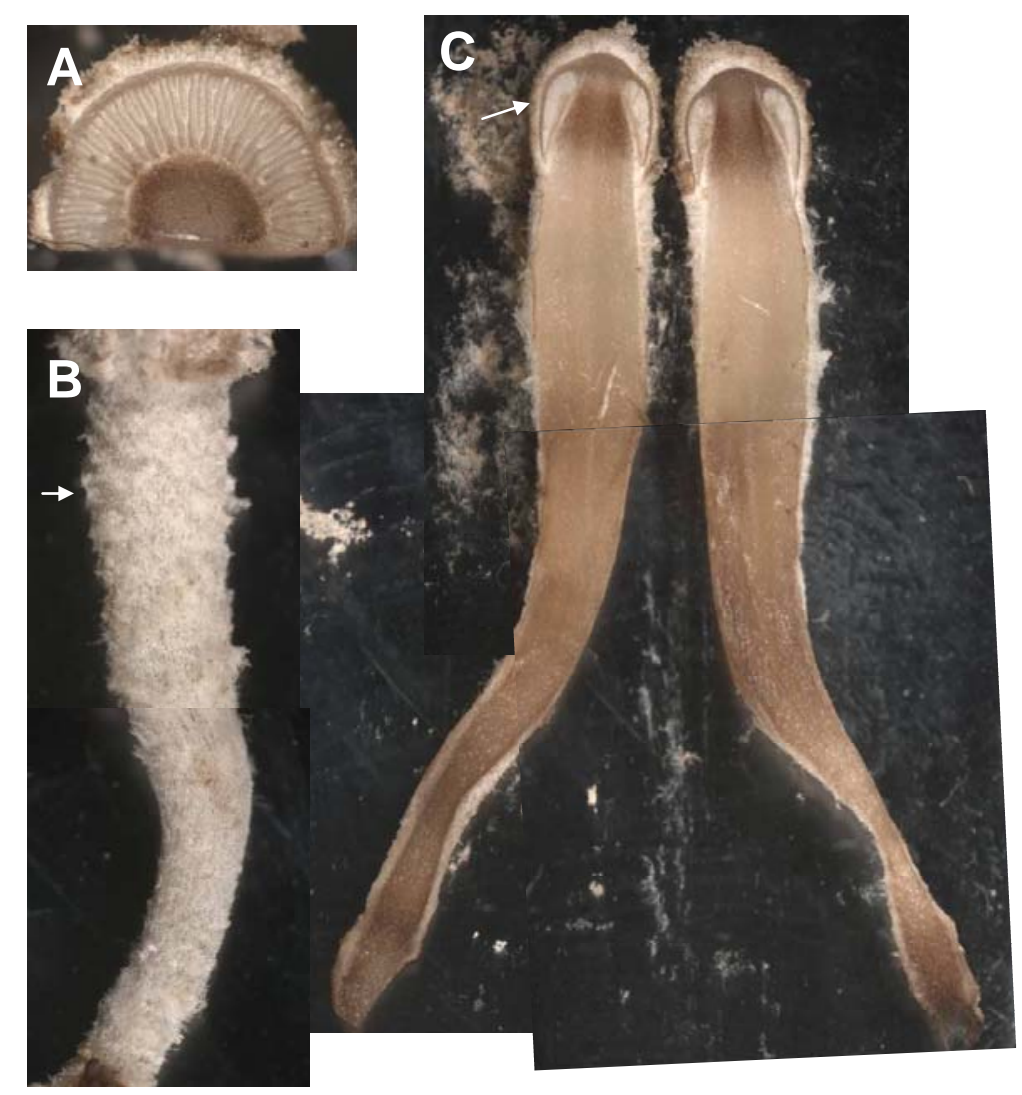

Figure 11 Coprinopsis clastophylla type strain. Cross section of the cap revealing that primary and secondary gills are fully developed, the whole development arrested most likely before karyogamy (A). The upper part of the pseudorhiza has a wooly surface (B, arrow). Notice that in the lower part of the pseudorhiza these wooly veil remnants disappear. Longitudinal section of a whole fruiting body about $4 \mathrm{~cm}$ in length (C). The cap shows the prekaryogamic gills (arrow), the stipe is downwards attenuated giving rise to the pseudorhiza. These lower tissues are of harder consistency and darker coloration. Due to the size of the fruiting structure, the presented image corresponds to an overlap of several pictures taken under the binocular.

The fruiting structures of the C. clastophylla type strain were less developed and arrested earlier in development. What is shared with strains $C$. clastophylla strains 2-4 is that fruiting structures appeared in larger dense groups (Figure 8D, Figure 10A). Moreover, the veils are formed by round glittering cells as shown (Figure 9D) for C. clastophylla strains 2, 3 and 4. From looking at the development of the gills, although basidia are already fully developed in the type strain (Figure 10H), the complete tissue development appeared to have arrested at an earlier time point in fruiting body development than in strains C. clastophylla strains 2-4. 
Interestingly, in the literature the C. clastophylla type strain had been described in the anamorph form as Rhacophyllus lilacinus. In the study of Maniotis (1964), the anamorph $R$. lilacinus as the type strain produced structures that had a more typical umbrella shape. In different specimens of the anamorph R. lilacinus, Maniotis (1964) and others (Berkeley and Broome 1871) described rows of round bodies developing on the gills. Obviously, the Rhacophyllus anamorph can adopt various different shapes, possibly depending at what stage fruiting development arrested and what type of tissue might differentiate the large round bodies, just on the gills or also on the outer cap. Clémençon (2004) referred to these unusual large round bodies on mushroom as lysomeres, Patouillard (1901) as bulbils. Lysomeres observed by Clémençon (2004) and Reijnders and Malençon (1969) on Rhacophylloid specimens contained many small cells and are probably different structures from those we saw in C. clastophylla strains 2, 3, 4 and the type strain.

In our hands, the C. clastophylla type strain rarely formed fruiting bodies with basidiospores on various media we used, including those reported by Maniotis (1964), to give consistently rise to normal fruiting bodies. Instead, the strain commonly formed sterile fruiting-body-like structures that resembled those of C. clastophylla strains 2, 3, and 4 (Figure 4). Although several trials were done, it was not possible to obtain the lysomeres described by Maniotis (1964) in the C. clastophylla type strain.

\subsection{Conclusions}

The macroscopic and microscopic descriptions of cultures and specimens from the newly isolated strains 2, 3, and 4 were identified by molecular analysis as C. clastophylla. However, the morphological descriptions fit perfectly to that given in the literature for Coprinopsis stercorea (Orton and Watling 1979, Breitenbach and Kränzlin 1995, Rogers 1973, Walker and Moore 1974). A major difference is seen in the breeding system. C. clastophylla was found to be homothallic, whereas C. stercorea seems to be heterothallic (Orton and Watling 1979).

Comparing isolates C. clastophylla strains 2, 3, and 4 with the C. clastophylla type strain and data from the literature on the anamorph $R$. lilacinus, there appear to be some differences between morphological features of sterile fruiting-body-like-structures. Obviously, strains of C. clastophylla have very variable shapes in their anamorphic 
structures. Most importantly, there is a doubt whether the round glittering structures on the caps and the ridges of gills of the fruiting bodies are identical to the lysomeres described by Maniotis (1964). Possibly, these latter structures are produced under very particular conditions very difficult to reproduce. It is also possible that the strain suffered mutations by being kept for over 40 years in fungal culture collections.

The fourth new isolate presented in this study according to analysis of ITS sequences, belong to the genus Coprinellus. Based on the morphological description, this isolate resembles mostly Coprinellus curtus. C. curtus is the only known species which has both sphaerocysts and (sub)capitate pileocystidia (Uljé and Bas 1991), that were also observed in fruiting bodies of the strain Coprinellus sp. 1. Nevertheless, the ITS sequences of the two species differ (identity 96\%).

The results presented in this chapter document once again the difficulties in correctly identifying coprini species by morphologically means, whilst its sequences can better differentiate between morphological identical or very similar species.

Since at least the type species of C. clastophylla is known to grow on wood (Maniotis 1964), these newly isolated strains should be included in future work on studying the wood degradation abilities in coprini.

\subsection{Acknowledgments}

We thank Dr. Peter Beutelmann from the Johannes Gutenberg-University of Mainz for providing the strains. Technical support from Alexandra Dolynska is greatly acknowledged.

\subsection{References}

Arora D (1986) Mushrooms demystified. A comprehensive guide to the fleshy fungi (2nd ed.). Ten Speed Press, Berkeley, California, USA.

Berkeley MJ, Broome CE (1871) The fungi of Ceylon. Journ. Linn. Soc. Bot. Lond., 11, 494-567.

Breitenbach J, Kräzlin F (1995) Pilze in der Schweiz Vol. 4. Mykologia, Luzern, Swiss. 
Buller AHR (1924) Researches on Fungi. vol. III.. The production and liberation of spores in hymenomycetes and Uredineae. Hafner Publishing Co., New York, N.Y., USA.

Clémençon H (2004) Cytologie and plectology of the Hymenomycetes. J. Cramer, Germany.

Esser K (2000) Kryptogamen. 1. Praktikum und Lehrbuch. Springer-Verlag, Berlin, Germany.

Gardes M, Bruns TD (1993) ITS primers with enhanced specificity for basidiomycetes Application to the identification of mycorrhizae and rusts. Mol. Ecol., 2, 113118.

Granado JD, Kertesz-Chaloupková K, Aebi M, Kües U (1997) Restriction enzymemediated DNA integration in Coprinus cinereus. Mol. Gen. Genet., 256, 28-36.

Hopple JS, Vilgalys R (1999) Phylogenetic relationships in the mushroom genus Coprinus and dark-spored allies based on sequence data from the nuclear gene coding for the large ribosomal subunit RNA: divergent domains, outgroups, and monophyly. Mol. Phylogenet. Evol., 13, 1-19.

Hüttermannn A, Volger C (1973) Induction of arylglucosidase in Fomes annosus by cellobiose. Arch. Microbiol., 93, 195-204.

Keirle MR, Hemmes DE, Desjardin DE (2004) Agaricales of the Hawaiian Islands. 8. Agaricaceae: Coprinus and Podaxis; Psathyrellaceae: Coprinopsis, Coprinellus and Parasola. Fungal Divers., 15, 33-124.

Kertesz-Chaloupková K, Walser PJ, Granado JD, Aebi M, Kües U (1998) Blue light overrides repression of asexual sporulation by mating type genes in the basidiomycete Coprinus cinereus. Fungal Genet. Biol., 23, 95-109.

Kües U (2000) Life history and developmental processes in the basidiomycete Coprinus cinereus. Microbiol. Mol. Biol. Rev., 64, 316-353.

Lu BC (1974) Meiosis in Coprinus. V. The role of light on basidiocarp initiation, mitosis and hymenium differentiation in Coprinus lagopus. Can. J. Bot., 52, 299-305.

Lu BC (2000) The control of meiosis progression in the fungus Coprinus cinereus by light/dark cycles. Fungal Genet. Biol., 31, 33-41.

Maniotis J (1964) Coprinoid state of Rhacophyllus lilacinus. Am. J. Bot., 51, 485-494. 
Morimoto N, Suda S, Sagara N (1982) The effects of urea on the vegetative reproductive growth of Coprinus stercorarius in pure culture. Trans. Mycol. Soc. Japan., 23, 79-83.

Orton PD, Watling R (1979) British Fungus Flora. Agarics and Boleti. 2 Coprinaceae: Coprinus. Roy. Bot. Garden. Her Majesty’s Stationery Office, Edinburgh, UK.

Patouillard N (1901) Champignons Algéro-Tunisiens nouveaux ou peu connus. Bull. Soc. Myc. France, 17, 182-188.

Polak E, Hermann R, Kües U, Aebi M (1997) Asexual sporulation in Coprinus cinereus: Structure and development of oidiophores and oidia in an Amut Bmut homokaryon. Fungal Genet. Biol., 22, 112-126.

Redhead SA (2000) Bully for Coprinus. A story of manure, minutiae, and molecules. McIlvainea, 14, 5-14.

Redhead SA, Vilgalys R, Moncalvo JM, Johnson J, Hopple JS (2001) Coprinus Pers. and the disposition of Coprinus species sensu lato. Taxon, 50, 203-241.

Reijnders AFM, Malençon G (1969) Recherches sur le dévelopment d'une espéce appartenant au genre Rhacophyllus Berk. et Br.. Bull. Soc. Mycol. France, 85, 295-304.

Rogers MA (1973) Photoresponses of Coprinus stercorarius: Basidiocarp development and maturation. Mycologia, 65, 907-913.

Swamy S, Uno I, Ishikawa T (1984) Morphogenetic effects of mutations at the $A$ and $B$ incompatibility factors in Coprinus cinereus. J. Gen. Microbiol., 130, 32193224.

van Waveren K (1968) The "Stercorarius Group" of the genus Coprinus. Persoonia, 5, 131-176.

Uljé CB (2003) All about inkcaps. (http://www.homepages.hetnet.nl/ idakees/)

Uljé CB, Bas C (1991) Studies in Coprinus. 2. Subsection Setulosi of section Pseudocoprinus. Persoonia, 14, 275-339.

Walker J, Moore K (1974) Coprinus stercorarius as an industrial contaminant. Trans. Br. Mycol. Soc., 63, 449-455.

Whitehouse HLK (1949) Multiple-allelomorph heterothallism in the fungi. New Phytol., 48, 212-244.

Zolan ME, Pukkila PJ (1986) Inheritance of DNA methylation in Coprinus cinereus. Mol. Cell. Biol., 6, 195-200. 


\section{6 \\ The course of fruiting body development in the basidiomycete Coprinopsis cinerea (Coprinus cinereus)}

Contribution to this chapter: The fruiting body development pattern analysis with fresh samples, karyogamy, meiosis and spore formation microscopy, selection of samples for paraffin embedding, analysis of the sections embedded in paraffin and writing of the manuscript was performed by the author of this thesis. Preparation of the paraffin embedded sections was done by Wassana Chaisaena. 


\section{The course of fruiting body development in the basidiomycete Coprinopsis cinerea (Coprinus cinereus)}

\subsection{Abstract}

Coprinopsis cinerea (Coprinus cinerea) is used as a model fungus for studying fruiting body development, mainly because of the ease to get fructifications in the laboratory within a short time. Another reason to study this fungus is the synchronized karyogamy and meiosis occurring within the basidia on the gills of the mushrooms. Stages of fruiting body development have been described in the past by several authors. However, the full process of fruiting body development is poorly documented in the literature. Particularly, the initial stages of fruiting body development - primary and secondary hyphal knots - and tissue development in the primordia are little studied. In this study, we present a picture catalogue of $C$. cinerea to unequivocally identify all the main cytological/physiological stages during fruiting body development.

Keywords: Hyphal knot, primordia, meiosis, hyphal tissues, tissue development 


\subsection{Introduction}

Metamorphosis, in the broadest sense, is conceived as a more or less radical morphological change between 2 multicellular phases in an organism's life cycle, often marking the transition from a pre-reproductive to a reproductive life stage. It involves structural reorganization and major physiological and habitat changes and is controlled by endogenous and exogenous factors (Hodin 2006). Coprinopsis cinerea (Schaeff. ex Fr.) S. F. Gray is one of the two model major organisms to study the developmental process of fruiting body formation in the basidiomycetes (Kües 2000). This fungus has a very short life cycle which means it will take only a few days from spore germination to form a mycelial colony able to produce fruiting bodies in seven further days from the first hyphal aggregation till the maturation of the fruiting body. Furthermore, this mushroom is characterized by its synchronized karyogamy and meiosis within the basidia on the gills of the mushrooms (Lu 1974, Morimoto and Oda 1974, Kamada et al. 1978). C. cinerea is therefore very attractive in studying basic questions of physiology and development within the basidiomycetes (for a review see Kües 2000).

Fruiting body development is regulated by several environmental factors, namely nutrient depletion, the $\mathrm{C}$ to $\mathrm{N}$ relationship, temperature, day/night rhythm, humidity, oxygen, and $\mathrm{CO}_{2}$ concentration (Kües 2000). Over the time, C. cinerea has been isolated under various names (cinereus, delicatulus, fimentarius, lagopus, macrorhizus f. microsporus and radiatus), making the analysis of older literature complicate and uncertain (Kües 2000). Currently, the species that fall under the name cinerea (formerly cinereus) are all isolates interfertile with C. lagopus sensu Buller (Pinto-Lopes and Almeida 1970).

Stages of fruiting body development have been described in the past by Buller (1909, 1922, 1931, 1933, 1934), Matthews and Niederpruem (1972, 1973), Lu (1974), Reijnders (1979), Moore and co-workers (1979) and Moore (1998). Surprisingly, nowhere in the literature, the full process of fruiting body development is documented in detail.

Fruiting body development in C. cinerea is a very complex process for which long observation training is needed. Therefore, we found it necessary to document in a picture catalogue all the main different developmental stages of $C$. cinerea that might be 
useful to unequivocally identify the main cytological/physiological stages during the process of fruiting body development.

\subsection{Material and methods}

6.3.1 Strain and general culture conditions. C. cinerea strain AmutBmut (A43mut, B43mut, pab-1) is a self-compatible homokaryon which produces fruiting bodies without mating to another compatible monokaryon (Swamy et al. 1984, KerteszChaloupková et al. 1998). The fungal cultures were cultivated on YMG/T agar plates (4 $\mathrm{g}$ yeast extract, $10 \mathrm{~g}$ malt extract, $4 \mathrm{~g}$ glucose, $10 \mathrm{mg}$ tryptophan, and $10 \mathrm{~g}$ agar,) in Petri dishes for 5 days at $37^{\circ} \mathrm{C}$ in the dark (Granado et al. 1997, Kertesz-Chaloupková et al. 1998). For fruiting, fully grown cultures were transferred into a climate chamber at a temperature of $26-28^{\circ} \mathrm{C}$ in a cycle of light $12 \mathrm{~h} /$ dark $12 \mathrm{~h}$.

6.3.2 Fruiting bodies dissection in fresh material. C. cinerea fruiting structures were daily harvested at the switch time from darkness to light, or at specific timings according to the desired cytological/physiological stage worked to study. Structures were observed and dissected by hand with the help of a razor blade and a needle. Microscopy from tissues was performed with a Zeiss Axiophot photomicroscope. Larger fruiting bodies were studied under the stereo microscope (Stemi 200-C Zeiss). Both microscopes equipped with a Soft Imaging ColorView II Mega Pixel digital camera, linked to a computer and analyzed with analySIS ${ }^{\circledR}$ software program (Soft Imaging System, Germany).

To study spore formation, gills were taken from primordia at different developing stages, squashed on a glass slide and the nuclei in the basidia were stained with DAPI (4', 6-diamidine-2-phenylindole dihydrochloride; Boehringer Mannheim, Germany) following the procedure for nuclear staining given by Polak et al. (1997). Microscopy and photographs were done with a Zeiss Axiophot photomicroscope and the digital camera already described.

6.3.3 Microscopic preparations. Immediately after harvest of primordia fruiting bodies at different developmental stages, the samples were transferred into $1.5 \mathrm{ml}$ eppendorf tubes for fixation with a solution of $40 \%$ formaldehyde, $99 \%$ acetic acid and $70 \%$ ethanol for $2 \mathrm{~h}$ at room temperature. Dehydration was achieved in a graded series of 
increasing ethanol (methylated) concentrations (70\%, 80\%, 90\%, and 96\%), incubating 30 minutes at room temperature in each solution. Previous to embedding, samples were infiltrated three times with roti-histol each $30 \mathrm{~min}$ at room temperature. Further, samples were two times incubated for $2 \mathrm{~h}$ in a saturated solution of roti-plast in rotihistol, at room temperature and at $40^{\circ} \mathrm{C}$ respectively. Final embedding was done with melted roti-plast at $60^{\circ} \mathrm{C}$ incubating first $2 \mathrm{~h}$ and after changing solution another $8 \mathrm{~h}$.

Sections $(12 \mu \mathrm{m})$ from the embedded samples were cut on a rotation microtome (R. Jung, Heidelberg). Both longitudinal and transverse sections of the different fruiting bodies stages were cut. The sections were floated onto drops of distilled water placed on slides coated with gelatine [0.125 g chromium (III) potassium sulphate dodecahydrate; $1.25 \mathrm{~g}$ gelatine; $250 \mathrm{ml}$ bi-distilled water] and dried on a hot block. Wax was completely eliminated from the tissue sections with roti-histol solution, which later was removed with isopropanol. Finally, samples were stained with toluidin blue $(0.1 \%$ in $0.2 \mathrm{M}$ phosphate buffer, $\mathrm{pH} 7.0$ ).

\subsection{Results and discussion}

\subsubsection{Time course of fruiting body development}

Careful observation of many different cultures over the time revealed that the whole fruiting process in C. cinerea is performed within 7 days. The overview of the process is shown in Figure 1. The overall process can be divided into: 1. hyphal aggregation, 2. primordia development, 3. sexual reproductive development, 4. fruiting body maturation, and 5. autolysis. This different stages are discussed in detail making use of own observations and microphotographs, and data provided by available literature. 


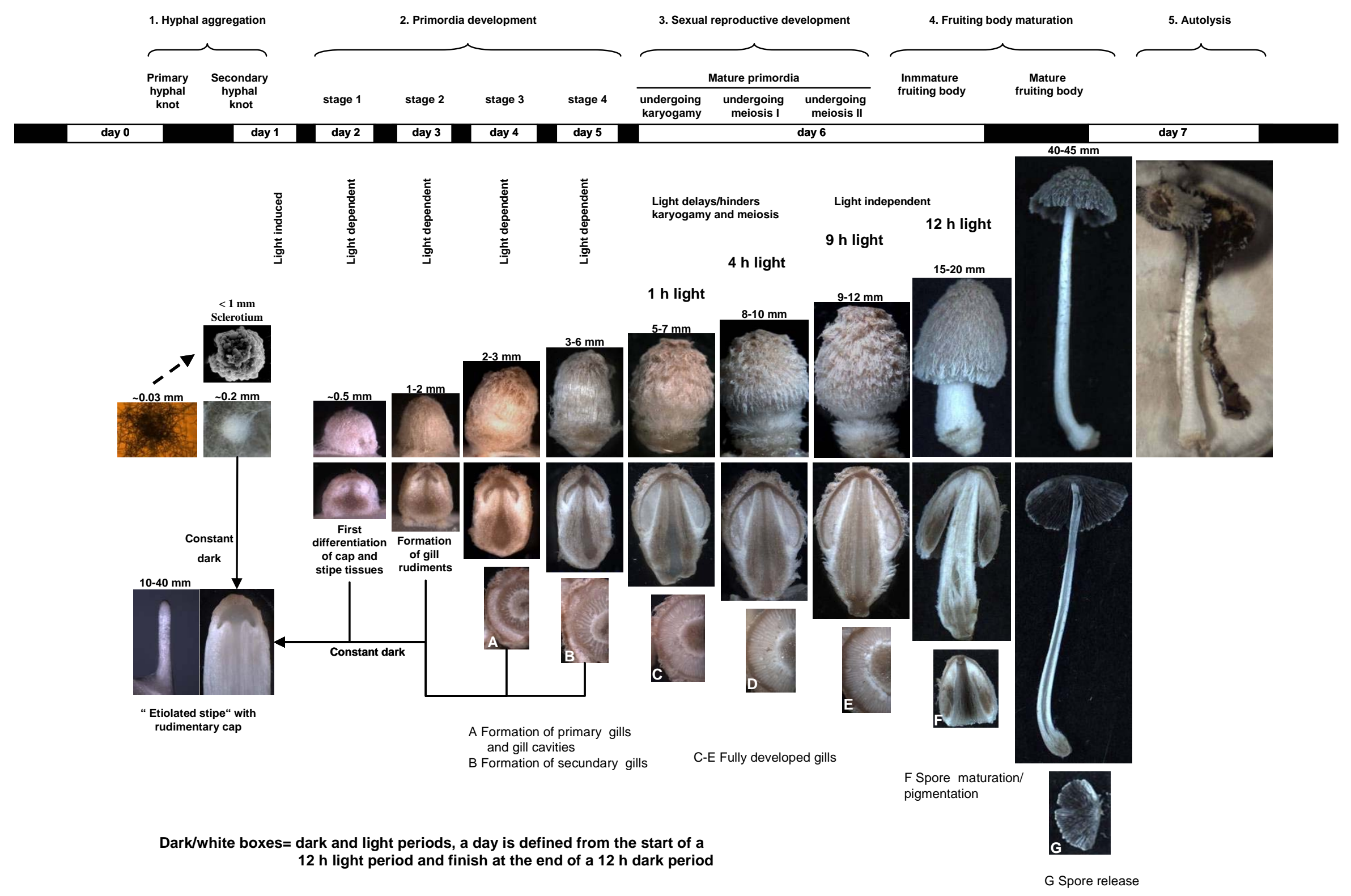


Figure 1 (previous page) Developmental pathway of Coprinopsis cinerea. Fruiting body development of homokaryon AmutBmut can be divided into six major stages, five of which are specific to the fruiting pathway. 1. Hyphal aggregation: Fruiting body development begins by intense hyphal branching that will form loose hyphal mass aggregate about $0.03 \mathrm{~mm}$ in size. Formation of these primary hyphal knots is not considered specific to the fruiting pathway since in the majority of cases also under standard fruiting conditions, the structures will turn into the multicellular sclerotia, melanized resting bodies (Kües et al. 2002b). Upon receipt of a light signal, the primary knots aggregate firmly into small round bodies, now called secondary hyphal knot, respectively secondary nodules (Clémençon, 1997, 2004; Kües et al. 2002a). They become visible in the aerial mycelium 1-7 days after cultures are transferred into the climate chamber at $28^{\circ} \mathrm{C} 12 \mathrm{~h}$ light $/ 12 \mathrm{~h}$ dark regime, but mostly at days $1-3$ of cultivation after transfer into standard fruiting conditions. 2. Primordia development: Within the relatively homogeneous structured secondary hyphal knots, differentiation of cap and stipe tissues commences, which is visible after a $12 \mathrm{~h}$ dark period (primordium stage 1, see also Matthews and Niederpruem 1973, van der Valk and Marchant 1978). Primordia maturation occurs over a period of four days. At the day after secondary hyphal knot appearance, primordia are $0.5-1 \mathrm{~mm}$ in size and round to oblong in shape and have already a clear internal differentiation into cap and stipe primordial tissue (primordium stage 1). One day after, egg shaped primordia are 1-2 $\mathrm{mm}$ in size (primordium stage 2). At this stage, the hymenium starts to develop (not shown), whose production has been reported to be light induced ( $\mathrm{Lu} \mathrm{1974).} \mathrm{Further} \mathrm{in} \mathrm{development,} \mathrm{fruiting}$ structure of 2-3 $\mathrm{mm}$ (primordium stage 3, see A) shows development of primary and secondary gills with hymenium structures defined (basidia, cystidia). Primordium development will continue one day more reaching the size of 3-6 mm (primordium stage 4 early in the morning of the day 6 of development, see B) until the gills and the hymenium are fully developed (mature primordium, see C-E). This structure corresponds to the stage when karyogamy, respectively

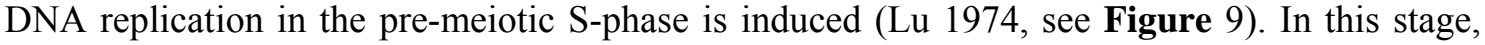
the outer veil becomes more and more free. In consequence, the immature cap and stipe can be distinguished by the naked eye. The cap has now a more round shape and, if not abortive, adopts a slightly pinkish colour. 3 . Sexual reproductive development: After another dark period, in the day 6 of development, mature primordia of a size of 5-7 $\mathrm{mm}$ stretch out during the following $12 \mathrm{~h}$. Early in the morning, karyogamy occurs, followed some hours later by meiosis, spore formation and pigmentation. The stipe begins to elongate slowly. The cap appears first pinkish and later, when spore pigmentation takes place, it will change to dark pigmentation. 4. Fruiting body maturation: During the following $12 \mathrm{~h}$ dark period, the spores in the caps maturate and stain dark brown and finally black. From now on, stipes elongate rapidly. A few hours later, the cap expands and opens like an umbrella (mature fruiting body) to release the spores. 5. Autolysis: Degeneration of the fruiting body starts simultaneously to the spore release in the mature fruiting body. It is finished within a few hours. In the early hours of the next light period, the cap autodigests completely, finishing in this way the cycle of the fungus.

\subsubsection{Hyphal aggregation}

At a stage a culture is ready for fruiting, minute hyphal aggregates can be observed overnight in the mycelium. They formed in the dark before the light period of day 0 (Figure 1) and have been called in the literature primary hyphal knots (Boulianne et al. 2000). Primary hyphal knots are defined as localized intense hyphal branching that initiate by single or more generative hyphae (Figure 2). Each of these branches, in turn will originate new generations of branches with restricted tip growth. Neighboring aerial 
hyphae growing alongside each other possibly merge by anastomosis. These branching and hyphal-hyphal interactions create first an easily distinguishable lattice which is slowly transformed first into a slightly round hyphal structure loosely aggregate (Figure 2) as described previously by Matthews and Niederpruem (1972). Primary hyphal knots are formed in darkness in a $12 \mathrm{~h}$ light/12 h dark cycles but are repressed in incubation by constant light (Waters et al. 1975, Moore and Jirjis 1976, Boulianne et al. 2000, Kües et al. 1998, 2000, Velagapudi 2006). They are less than $0.2 \mathrm{~mm}$ in size (Velagapudi 2006). If no light signal is given, hyphal knots further develop in the next day into sclerotia (Figure 1). Sclerotia are pseudoparenchymatous hyphal aggregations in which concentric zones of tissue form an outer rind and an inner medulla, with a cortex sometimes distinguishable between them. Sclerotia are multicellular resting bodies (see in scheme shown in Figure 1) (Waters et al. 1975, Kües 2000).
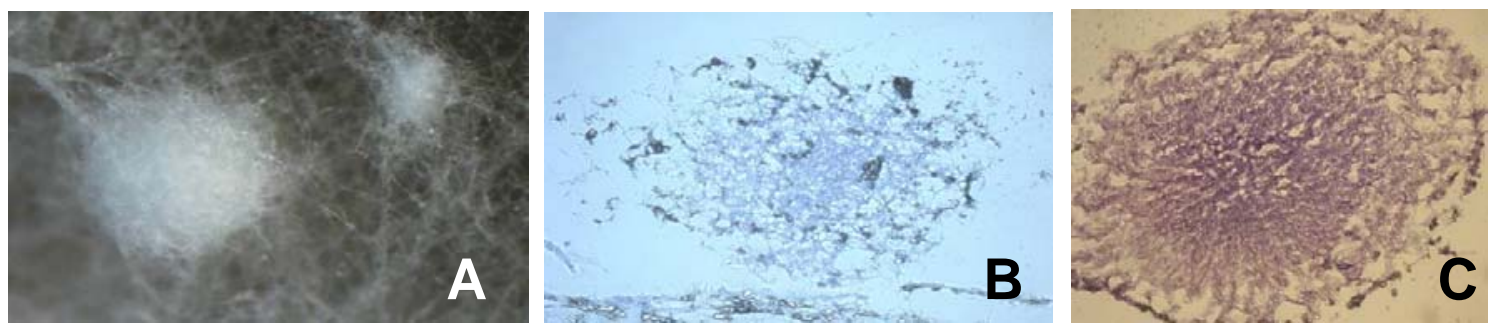

Figure 2 (A) Secondary hyphal knot on fresh cultures showing the round aggregated mycelial body connected to the rest of the mycelia by a net of hyphae. In contrast, in the upper right corner, a small primary hyphal knot shows a smaller and possibly younger mycelial body. (B) Median vertical section of a $0.2 \mathrm{~mm}$ diameter secondary hyphal knot embedded in wax. A prosenchymatous mass of hyphae is distinguished. (C) In a slightly larger secondary hyphal knot, aggregation is stronger. Secondary hyphal knots develop inflated cells.

The primary hyphal knot potentially might also develop into a secondary hyphal knot depending on light, temperature, carbon and nitrogen supplies (Moore et al. 1979, Kües et al. 1998). Extensive microscopic studies by Göbel (2003) and Velagapudi (2006) tried to proof this by observing hyphal lattice formation, primary and secondary hyphal knot development but by technical difficulties the authors were not successful. Currently, the only evidence that primary hyphal knots formation is an essential step in fruiting is indirectly. Genetic evidence shows that fruiting bodies and aerial sclerotia are of the same origin and share a common pathway of initiation (Moore 1981). Many 
efforts have still to be performed in the future to morphologically characterize the transition from primary to secondary hyphal knot formation. In this study, work we will focus on describing all subsequence stages clearly belonging to the fruiting process.

A secondary hyphal knot is an aggregation of undifferentiated hyphal mass up to $0.2 \mathrm{~mm}$, as measured from 10 independent structures. To form secondary hyphal knots it is essential that a culture obtains light at day 0 of cultivation (Figure 1). Cultures kept constantly in dark at otherwise fruiting conditions $\left(28^{\circ} \mathrm{C}, 90 \%\right.$ humidity) never give rise to secondary hyphal knots but to sclerotia (W. Chaisaena and U. Kües, personal communication). Secondary hyphal knots are present in the mycelium at the start of the light period of day 1 (Figure 1). The secondary hyphal knots at this time point can differ in size and in compactness of the tissue. Smaller ones are more loose than larger ones (Figure 2). Paraffin sections of secondary hyphal knots harvested at the start of day 1 were analyzed (Figure 2). Secondary hyphal knots are more compact than the primary hyphal knots, have no rind and are rather formed by equal prosenchymatous tissues (Figure 2 B,C), likely resulting from the tightly aggregated growth of one or more hyphae and their branches. The observations here confirm earlier reports by Mathews and Niederpruem (1972), which however referred to the structure as a primordium.

\subsubsection{Primordia development}

The mode of carpogenesis in C. cinerea is termed endocarpic because the primordium develops from the secondary hyphal knot inside the structure (Clémencon 2004). The development of different parts of the fruiting body - stipe and cap - is initiated more or less at the same time (isocarpous) (Reijnders 1986). At the start of day 2 of development, the young primordium stage $1(0.4-0.6 \mathrm{~mm}$ size, $\mathrm{n}=20)$ clearly presents an internal mushroom shape with young cap tissues at the top, and young stipe tissues at the bottom (Figure 3). This shows that there is clearly a direction in development. 

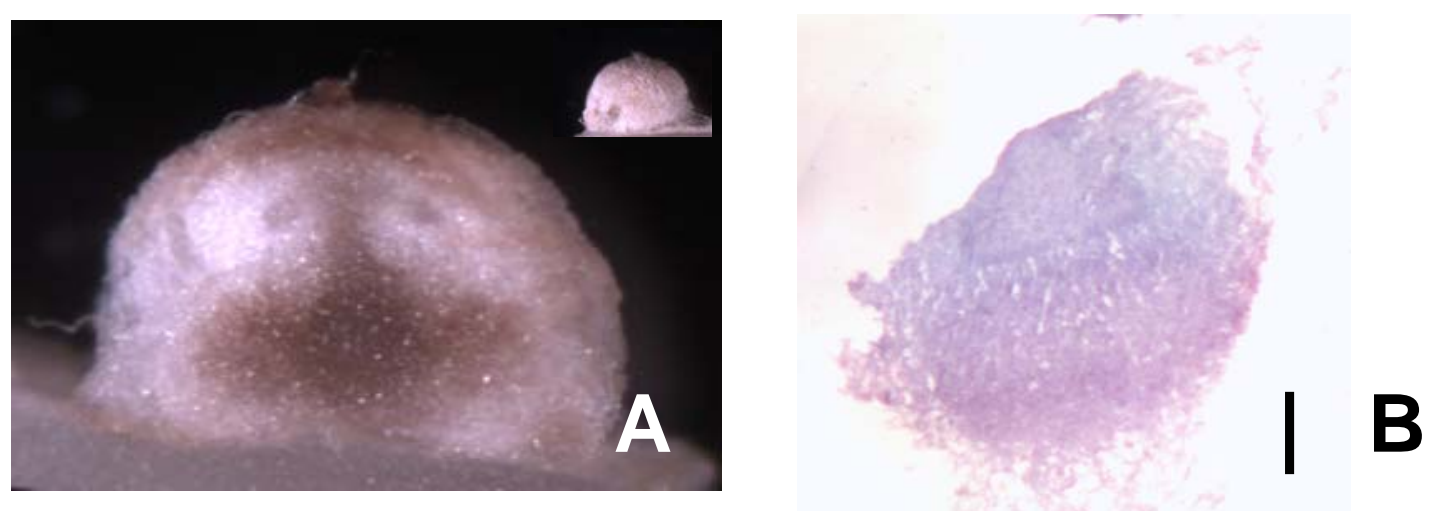

Figure 3 Primordium stage $1(0.5 \mathrm{~mm}$ high), tissues at this stage are clearly differentiated into what later is going to develop into a stipe and a cap, respectively (A). The inset shows the original round structure of primordium stage 1 before dissection. Slight tangential vertical section of the primordium embedded in wax in which the primordial structural tissues of cap and stipe in C. cinerea are discernible $(\mathbf{B})$. A veil covering the primordium is discernible. In the primordial stipe, middle, the cells appear to have vertical orientation. Strong staining is most evident in the stipe base and along the edge of the pileus. Scale bar $0.1 \mathrm{~mm}$.

At this stage, organization and regional development of cells in the fruiting structure begin to become evident. The upper third of the aggregation (the pre-pileus region) is an endogenous mass of densely packed cells initiating the inner pileus tissues (the hyphal mass between the superior surface and the subhymenium or the trama of the basidiocarp). In C. cinerea, the inner pileus is plectenchymatic with round to polyhedral, almost isodiametric cells (Clémençon 2004). In the central region (prestipe), cells appear to have taken a vertical orientation. Randomly oriented cells are found in the lower third of the primordium (Figure 3B). According to Matthews and Niederpruem (1973), the apex of the developing pileus and the cells below the stipe are rich in glycogen. At this stage of early internal differentiation, the whole complex is enclosed by a marginal veil made of hyphae which originate from the top of the pileus (Figure 3). Veil cells are large, septate and multinucleate and lack clamp connections (Lu 1974). According to Buller (1924), the function of the veil has been described as a protection for the primordium to emerge from horse dung, its natural substrate. Once the primordium has emerged, the tightly aggregated hyphae from the veil will break into loose, fugacious scales. In older primordia, these scales will develop as chains of elongated cells that persist up to maturation of the fruiting body giving a characteristic feature to this fungus (Figure 1 day 5). 
Continuing with dark and light incubation periods, the primordium develops into a mature fruiting body in about 4 days more (Figure 1). If absence of light occurs during the primordia development, they enlarge into an atypical elongated stipe with imperfect gill and hymenium differentiation (Figure 1, Chaisaena et al. 2006, Lu 1974, Morimoto and Oda 1973, Tsusué 1969). These structures that range in size 10 to $60 \mathrm{~mm}$ are also known as etiolated stipes (Kües 2000), pseudorhizal stipes (Blayney and Marchant 1977), dark stipes (Tsusué 1969), oversized stipes ( $\mathrm{Lu} \mathrm{1974)}$ or long slender stalks (Morimoto and Oda 1973).

With a further light signal in the primordia at stage 2, day 3 of development, the developing structure reaches a size about 1-2 $\mathrm{mm}$ where the presumptive pileus, the stipe and the basal region are clearly distinguishable from each other. At this stage, ridges made up of small closely packed cells appear at the edges of the young developing hymenium (Figure 4, arrows). These ridges are the initial differentiation of the lamellae ( $\mathrm{Lu} \mathrm{1991,} \mathrm{Rosin} \mathrm{and} \mathrm{Moore} \mathrm{1985b).} \mathrm{The} \mathrm{annular} \mathrm{cavity} \mathrm{is} \mathrm{also} \mathrm{developing}$ (Lu 1991, Rosin and Moore 1985b). According to Moore et al. (1979) the deposition of glycogen at the stipe base and edges of the pileus is now accentuated.
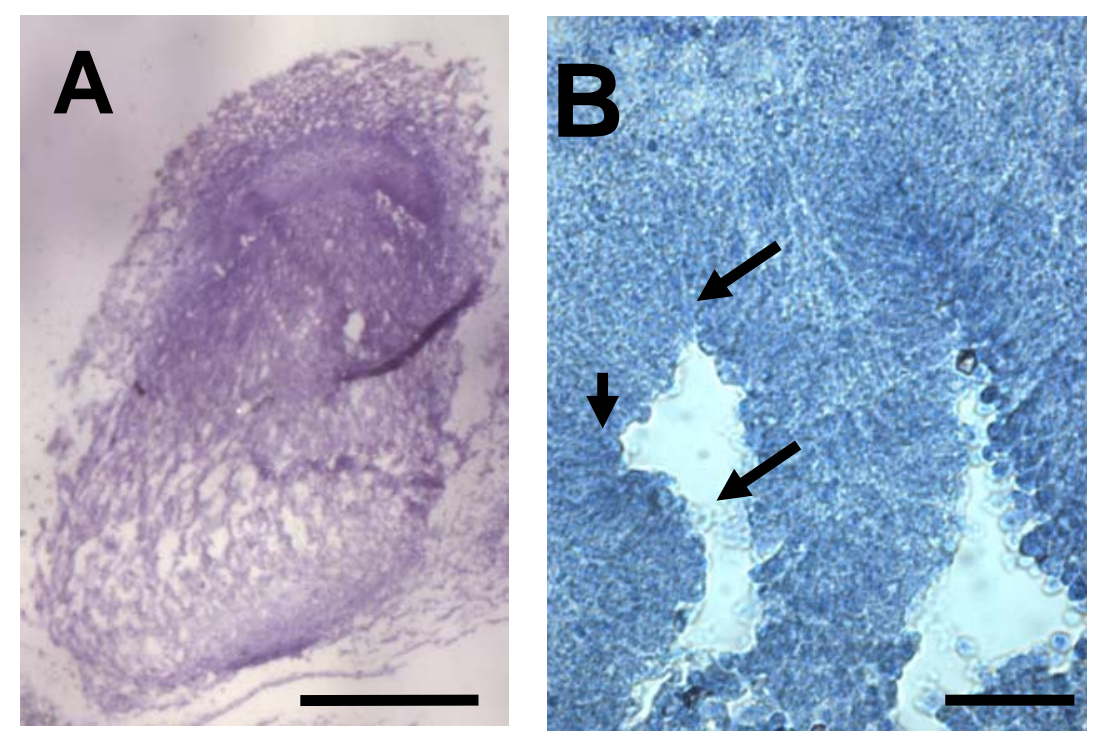

Figure 4 Longitudinal section of a primordium at stage 2 of development, where pileus and stipe are fully distinguishable (A). In the upper part the gills are developing and in the lower part, the stipe represents about $2 / 3$ of the total body. Longitudinal section of primordium at the same stage which shows details from gills cavities where loose probasidia are developing (B lower arrow). At this stage, the secondary gills start to develop [upper arrows refer to so called gill organizers (Moore 1995)]. Scale bar $0.5 \mathrm{~mm}$ and $20 \mu \mathrm{m}$, respectively. 

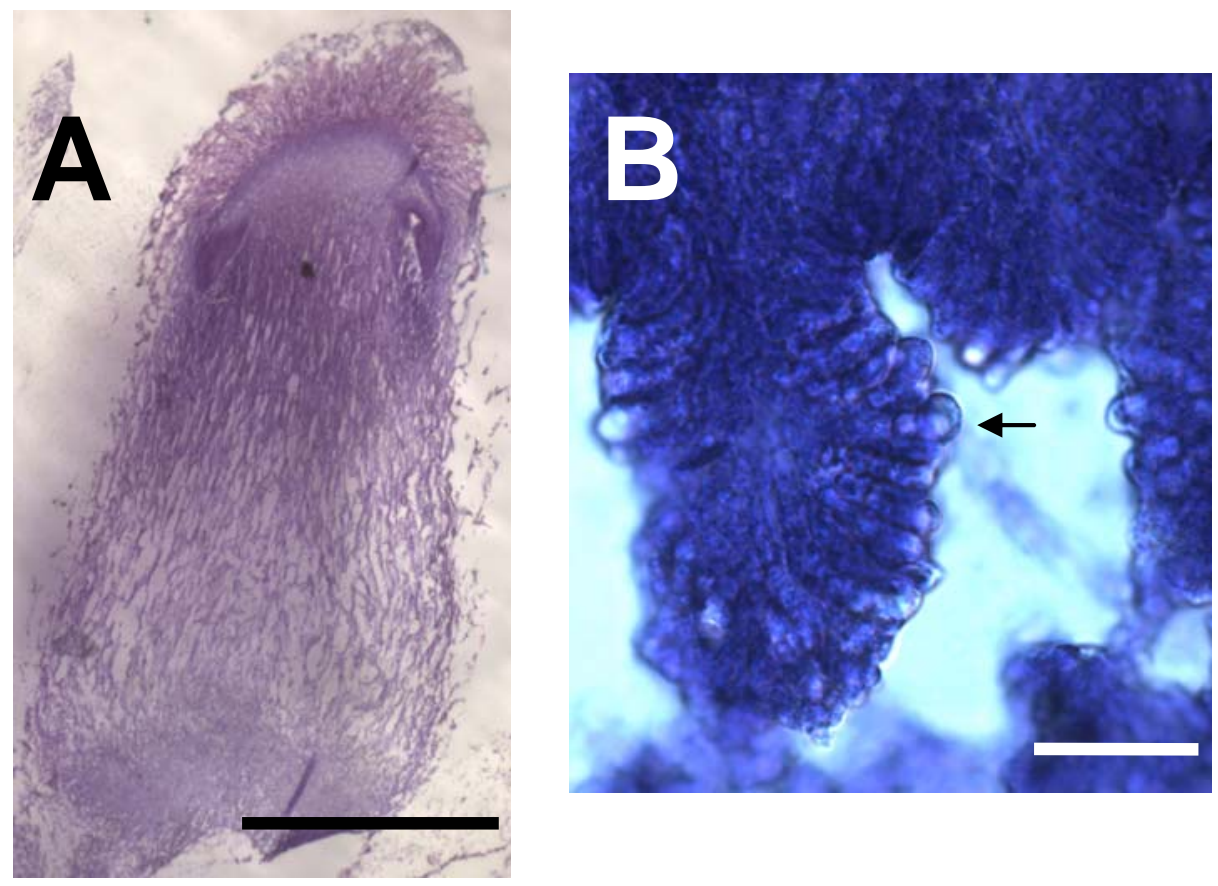

Figure 5 Longitudinal section of a primordium at stage 3 of development (A). At this stage the primordia is slightly larger. Cross section from a prekaryogamic primordium stage 3 presenting rows of probasidia with a more defined shape (B, arrow). Scale bar $1 \mathrm{~mm}$ and $20 \mu \mathrm{m}$, respectively.

From this stage onwards, the primordium needs 2 days more of light/dark incubation (primordia stage 3 and 4 of development) to fully develop the gills (Figure 5 and 6). At stage 4 (about 3-6 mm), the primordial stipe will elongate slowly and the main changes will occur in the basidia, where the probasidia continue developing. By the end of this stage, the probasidia are mature and ready to initiate karyogamy (Figure 6). Well developed lamellae and a distinct gill cavity are seen in the mature primordia of about 5-7 $\mathrm{mm}$ on day 6 of development (Figure 7). This structure is easily identified because the upper part of the primordium is broader due to the big number of gills developed inside. Furthermore, the veil is somehow loose and has a light pink coloration (Figure 1 day 6). Once primordia tissues are completely differentiated, light is needed to allow karyogamy to occur into the basidia (Kamada et al. 1978, Lu 1972). Meiosis will follow nuclear fusion (see below). 

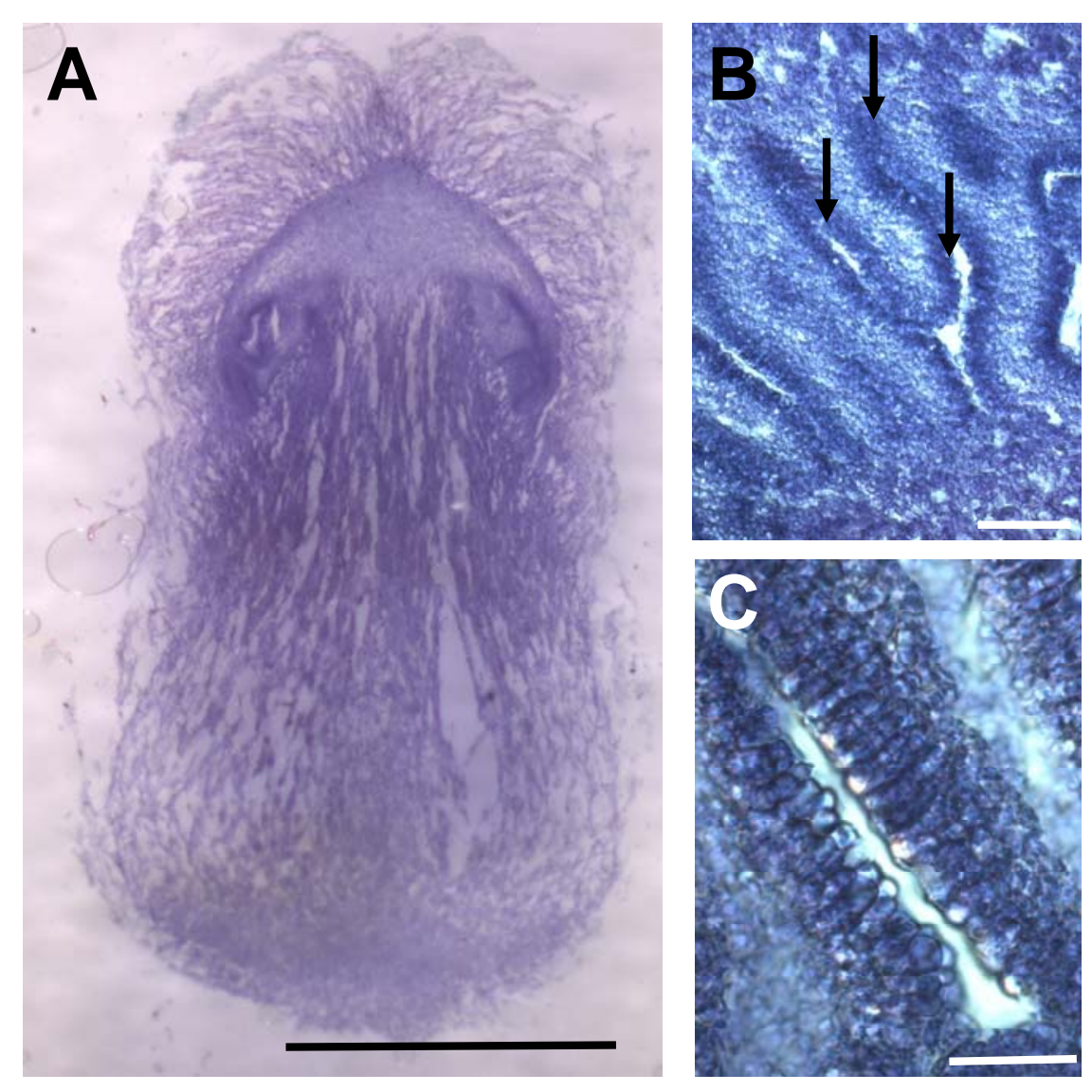

Figure 6 Longitudinal section of a primordium at stage 4 of development (A). Cross sections from a prekaryogamic primordium stage 4 presenting rows of probasidia in a secondary gill. Already cystidia are prominent over the rest of the cells (B, arrows). At this stage the primary and secondary gills are finishing their development. Stipe tissue is located in the bottom right corner of the picture. All of the gills which have their tramal tissue connected to the stipe are primary gills, and the free ones are secondary gills (B). Several rows of tightly packed probasidia are observed in a cross section of a prekaryogamic primordium stage 4 (C). Scale bar $1 \mathrm{~mm}, 50 \mu \mathrm{m}$, and $20 \mu \mathrm{m}$, respectively.

\subsubsection{Gill development}

In Coprinopsis cinerea the internal structure of the primordium is uniformly solid at the time that gills begin to arise. Gills and gills space develop together (Moore 1995), probably by a process of programmed cell death (Lu 1991).

Two types of gills are going to be formed already in primordium at stage 2 (day 3 of development). Primary gills with their inner tramal tissue connected the outer layers of the stipe (Figure 4); and secondary gills in which the hymenium is continuous over the gill edge (Figure 4, Moore 1995). In a cross section of the cap, gills are formed as vertical plates arranged radially around the stipe (Moore 1995). Primary gills keep 

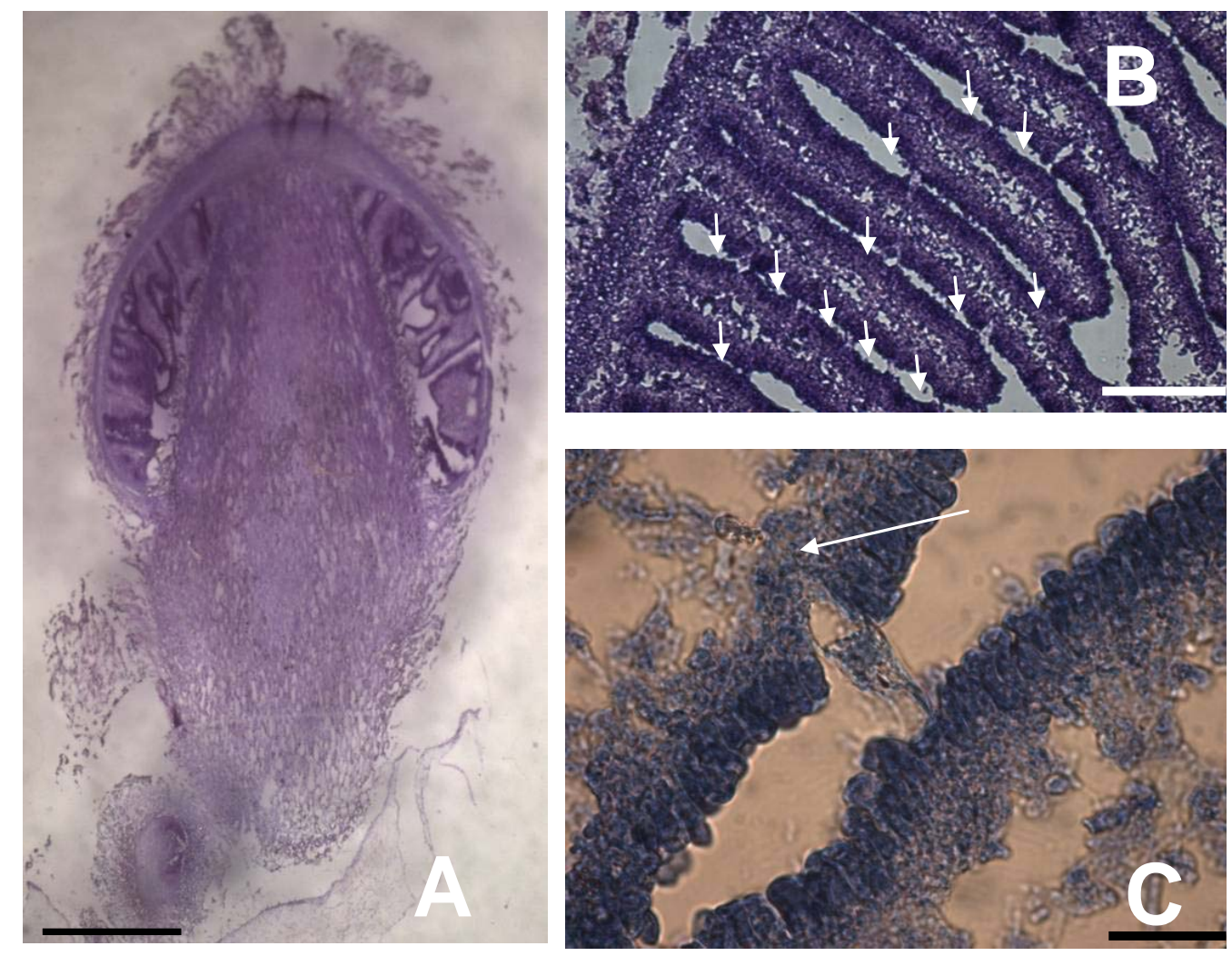

Figure 7 Longitudinal section of a mature primordium. At this stage, the hymenium is fully developed and is undergoing karyogamy (A) Cross section of a pileus from a mature primordium. Points where the cystidia are distributed are signaled by the arrows, these structures will avoid the gills collapse. (C) Detail of the gill, showing a cystidium inserting between the basidia into the front gill and attaching to the cystesia (arrow). Scale bar $11 \mathrm{~mm}, 100 \mu \mathrm{m}$ and $20 \mu \mathrm{m}$, respectively.

connected to the stipe tissues until the expansion of the pileus disconnect them from the stipe at the immature fruiting body stage (Rosin and Moore 1985b). Gills develop outwards, away from the stipe (Moore 1987). The beginning of gills development starts in the boundary between the stipe and the pileus by the development of vertical crest of closely packed cells in primordium day 2 .

These groups of cells become chromophilic, elongated and form two radially arranged rows of oblong cells which represent layers of poorly differentiated hymenia. A cavity will be form near the stipe and began to separate the paired rows of oblong cells. At this stage, the hymenium is discontinuous over the inner edge of primary gills (Rosin and Moore 1985b). The cavity elongates centrifugally towards the outer side of the pileus. There is a formative element, denominated "the gill organizer" which seems to be 
responsible for the progression of the gill cavity radially outwards, towards the pileus (Moore 1995). A gill organizer is located in the outmost tissues of the gill cavity, and is thought to form Y-shaped gill structures while moving radially outwards penetrating undifferentiated pileus tissues. With increasing primordium size, space for further gills becomes available. As the distance between neighboring organizers increases, a new one can arise between them. When a new gill organizer emerges, the margin of a secondary gill is formed (Rosin and Moore 1985a). This secondary gill grows by continued radial outward progression of the two gill organizers which drive into the undifferentiated prosenchyma of the pileus context (Moore 1995).

\subsubsection{Sexual reproductive development}

Basidiospores arise from the specialized cells called basidia located in the hymenium (Figure 9). In C. cinerea basidia develop from a terminal cell of a tramal hyphal branch of the hymenium (Horner and Moore 1987). Probasidia are earliest seen in the hymenium of primordia at primordia stage 2 of development (Figure 4B). More probasidia will be formed over the time by extruding hyphal branches from trama to the hymenium surface in the following days of development (Figure 5B and 6B). Probasidia will enlarge in size while being filled by cytoplasm (Figure 9A-C) and elongate to give mature basidia at day 5 of development when the basidia become susceptible to a light signal inducing karyogamy (Figure 7C and Figure 9D-F). The whole process from spore formation till spore discharge takes about $18 \mathrm{~h}$ (Figure 8).

During the $10 \mathrm{~h}$ period before karyogamy, probasidia are the only cells irreversibly committed as meiocytes to complete meiosis and sporulation ( $\mathrm{Lu} \mathrm{1972).} \mathrm{Once} \mathrm{meiosis}$ is initiated, the maturation of basidia is an autonomous endotrophic process (Chiu and Moore 1988). Basidia enlarge during maturation, while karyogamy and subsequent meiosis occur within (Figure 7C). In general, maturation of the basidia starts at the bottom of the gills and advances slightly towards the apex. Karyogamy and meiosis are in synchrony within the cap; about $70-75 \%$ of all basidia will be always in the same

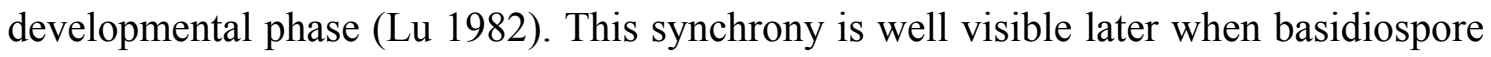
form and stain (see Figure 1F). 
Day 5: primordia stage $4 \quad$ Day 6: mature primordia

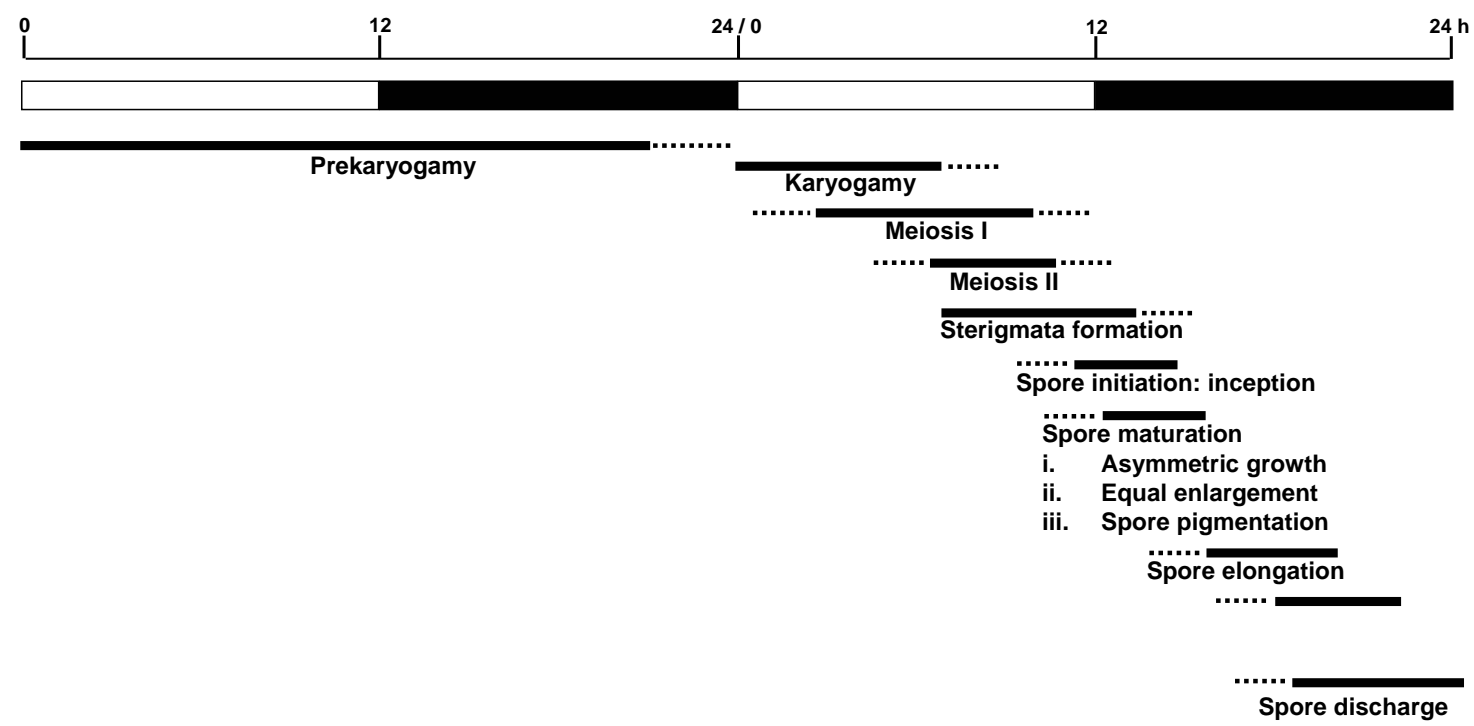

Figure 8 Scheme explaining the processes occurring in basidia over the time in fully established primordia from the pre-karyogamy stage up to spore formation according to observations under the microscope to fresh gill tissues stained with DAPI. Primordia stage 4 (pre-karyogamy stage) with fully established cap and stipe tissues are obtained under standard fruiting conditions on day 5 of incubation, whereas karyogamy, meiosis and spore formation happen in primordia stage 5 on day 6 of incubation. White and black boxes in the time scale represent light and dark phases, respectively.

At karyogamy, each young basidium contains a pair of oval haploid nuclei, provided by each monokaryotic parent. During the development of the basidium, both nuclei come in close vicinity and karyogamy occurs to form first a single large dumbbell-shaped and later oval-shaped diploid nucleus (Kimura and Takemaru 1955, Figure 9D-F). Under light microscope, chromatin looks diffuse before nuclear fusion and after, individual chromosomes are readily visible ( $\mathrm{Lu} \mathrm{1967).} \mathrm{Fusion} \mathrm{of} \mathrm{haploid} \mathrm{nuclei} \mathrm{(karyogamy,}$ Figure 9 D-F) occurs immediately prior to meiotic prophase (Pukkila 1994). The first meiotic division is subdivided in several phases namely prophase I, metaphase I, anaphase I and telophase I (Figure 9 G-I). Nuclear fusion is followed by prophase I, which comprises several stages: chromosomes condensation (leptotene); homologous chromosomes alignment (zygotene) and elaboration of a proteinaceous structure, the synaptonemal complex; recombination nodules appear (pachytene); desynapsis (diplotene), and finally transition to metaphase (diakinesis) occurs. 
In metaphase I, the chromosomes congregate at the equatorial region between the two spindle bodies. Soon later, the two sets of homologous chromosomes will separate in the anaphase I, and will assemble at the poles. In the telophase, the chromosomes become uncoiled. In the basidia, the two nuclei can be stained with DAPI (4', 6diamidine-2-phenylindole dihydrochloride; Boehringer Mannheim, Germany) and observed in the microscope in the gills of mature primordium day 5 between $4-8 \mathrm{~h}$ after the last light period before autolysis initiates (Figure 9-I). Shortly after interphase, the two daughter nuclei begin the second meiotic division (prophase II, metaphase II, anaphase and telophase II) which goes faster than the first division taking about one hour (Kües 2000). At the end of the second meiotic division, four nuclei, which will migrate towards the tip of the basidium, are formed (Figure 9J-K)

Four perpendicular sterigmata begin to project on the margins of the basidial apex onto where the four basidiospores will develop (Figure 9J-K, Kimura and Takemaru 1955). Sterigmata are the renewed tip growth at four restricted loci on the basidial apex (McLaughlin 1973). They develop first as blunt protuberances, become later tapered and finally curved as they enlarge (McLaughlin 1977). Vesicles apparently derived from Golgi cisternae and containing carbohydrate are present at the sterigmata tip apex. These vesicles are involved in tip growth of the sterigmata and basidiospore growth (McLaughlin 1972). After the completion of meiosis it will take about 10h until the discharge of the basidiospores start (Figure 1). Based on changes in spore size, shape, wall layering and cytoplasm the process of basidiosporogenesis can be divided into four stages. These are inception, asymmetric growth, equal enlargement and elongation (Figure 9K-O, McLaughlin 1977). The cytoplasm becomes more and more condensed as the development of a basidiospore progresses (Sundberg 1978).

The enlargement of the sterigmata apex to form a spherical spore initial that grows more or less vertical (parallel to the longitudinal axis of the sterigmata) is the main characteristic in the inception. A hilar appendix body - an electron dense, cytoplasmic region located on the adaxial side of the basidiospores initials - will persist during the whole spore development. This hilar appendix body predicts the site of the hilar appendix that may be involved in discharging basidiospores (McLaughlin 1977, 1982). Few vesicles are typical within the cytoplasm of the basidiospore initial and sterigma. 

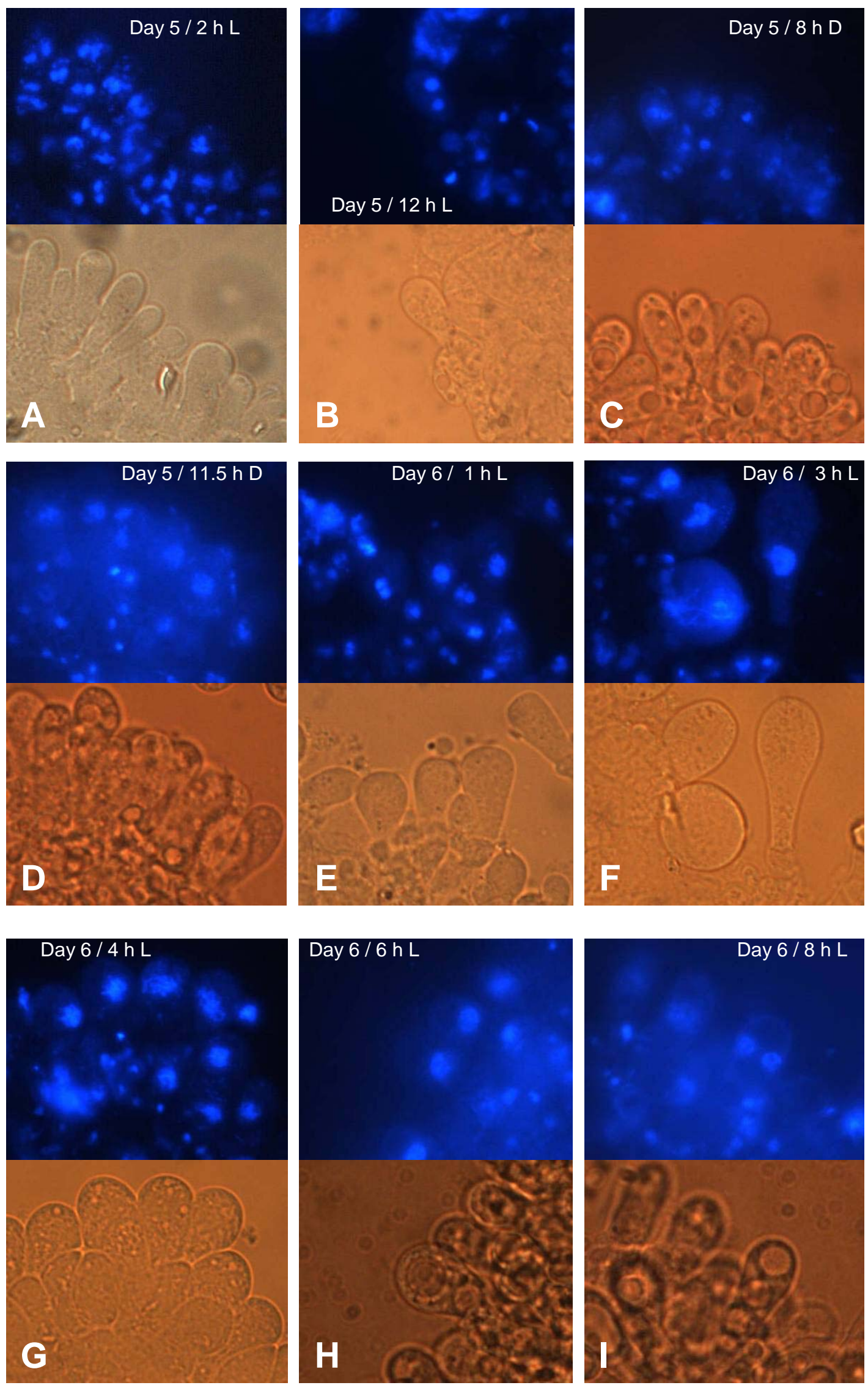

Figure 9 continues... 

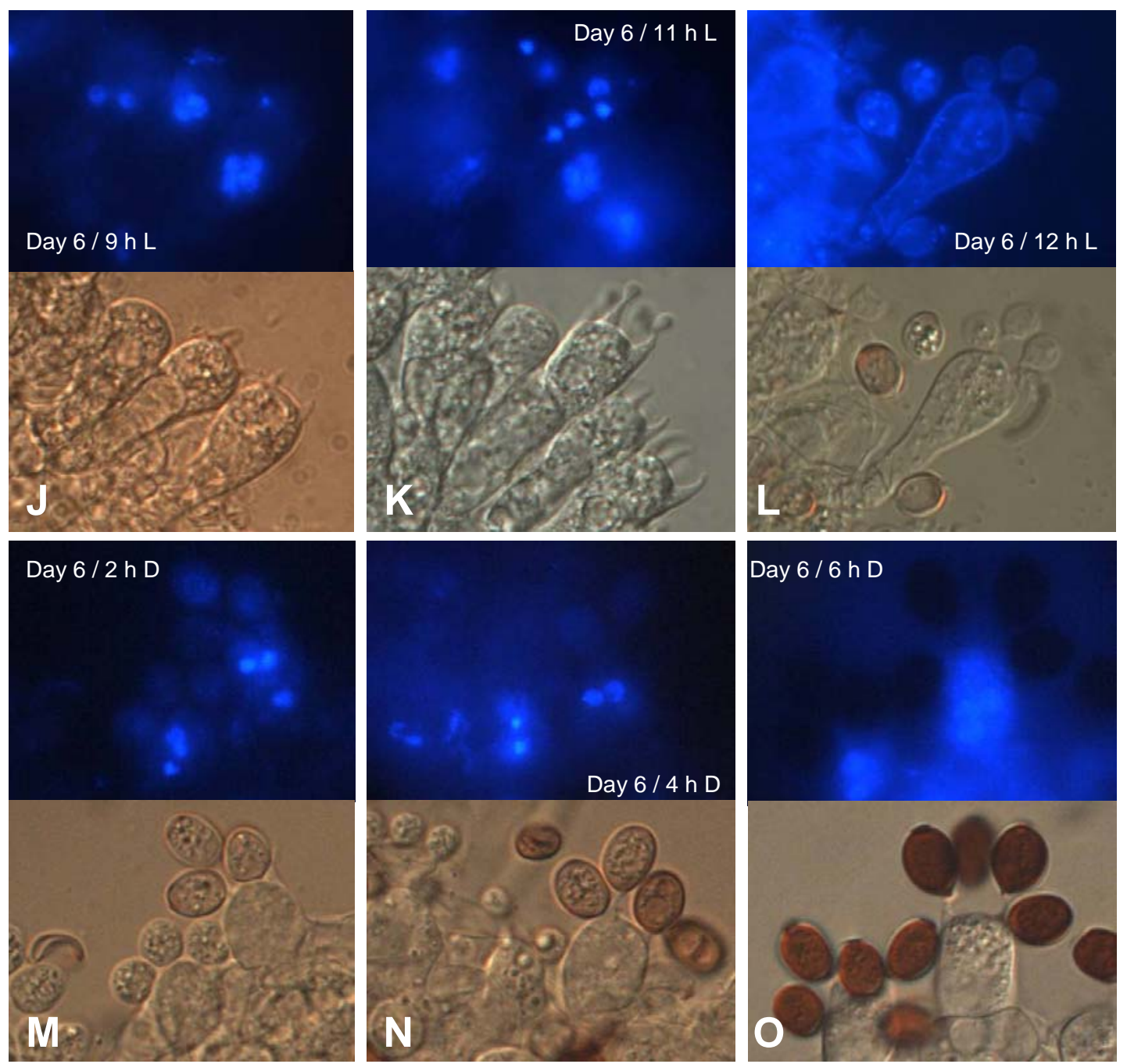

Figure 9 Light micrograph of basidia of Coprinopsis cinerea. Each pair of pictures show basidia stained with DAPI (4', 6-diamidine-2-phenylindole dihydrochloride) in the upper panel; in the lower one, the same basidia without staining. Day 5 and day 6 corresponds to the day of development, primordium stage 5 and mature primordia, respectively. The letters L and D denote the length of a light and dark phase, respectively. In pre-karyogamic basidia the two nuclei are visible (A-C). A few hours later, the nuclei fuse and undergo karyogamy (D-F). Some time after the nuclei undergo the first meiotic division, as a result two nuclei are visible in the upper part of the basidia (G-I). Immediately after these nuclei undergo the second meiotic division, consequently in the basidia four nuclei are visible (J). Simultaneously sterigmata start to develop and along with them tiny spores $(\mathbf{K})$. At the end of the light period of day 6 of development spores are developing and starting to pigment $(\mathbf{L})$. Spores require about $6 \mathrm{~h}$ more to complete pigmentation and maturation $(\mathbf{L}-\mathbf{O})$.

The basidiospore wall is three layered, enclosing a simple cytoplasm, and appears to be continuous with the sterigma wall (McLaughlin 1977).

In the second stage referred as asymmetric, the basidiospore initial grows more in length than in width. The orientation of growth changes from the vertical to the 
oblique/longitudinal axis. The hilar appendix becomes slightly conical reaching sizes between 80-260 $\mathrm{nm}$ long by 180-260 nm long (McLaughlin 1977, 1982). Detailed cytological processes in further development are described in electron microscopic observations by McLaughlin $(1977,1982)$. The wall of the basidiospores thickens and becomes six layered. At this stage, many vesicles (30-100 nm) appear in the cytoplasm. They might have been produced in the Golgi cisternae in the basidium because they lack in the basidiospore (McLaughlin 1977, 1982). Microtubules extend from the basidium into the sterigmata, suggesting that they may function as a cytoskeleton in the asymmetric growth or may direct the movement of vesicles during sterigmata development (McLaughlin 1973). By the end of this stage, the basidiospore will reach 1.2-2.5 $\mu \mathrm{m}$ (McLaughlin 1977).

At the equal enlargement stage, the basidiospore enlarges spherically. At the beginning of this stage appears a layer of rough endoplasmic reticulum lining lower part of the spore. The peripheral endoplasmic reticulum posses an asymmetric distribution of ribosomes, smooth on the wall side and rough on the cytoplasmic side. This suggests the role of those rough ER in producing enzymes for wall synthesis or expansion. The hilar appendix body projects further into the spore wall. By now, the spore wall still has six layers, but the outer three layers are fused. The basidiospore cytoplasm become more complex with the presence of numerous Golgi vesicles and vacuoles scattered throughout, some Golgi cisternae, mitochondria increased in number but never seen near the spore apex and abundant microbodies mainly in young spores (McLaughlin 1974, 1977). Microtubules are abundant in the sterigmata and in the lower end of the spores, but not associated with the hilar appendix body. The size of the spore is about 3 to $4.5 \mu \mathrm{m}$ in diameter (McLaughlin 1974).

\subsubsection{Fruiting body maturation}

Onset of fruiting body maturation starts when in the matured primordium at day 6 of development, karyogamy is induced in the basidia. First, there is minor stipe elongation occurring in parallel to meiosis and spore formation and maturation. Once basidiospores are staining, stipe elongation occurs by dramatic cell elongation (Hammad et al. 1993). The rapid stipe elongation takes about 4 h (Figure 1, dark period between day 6 and day 7 of development). 
Cap expansion correlates temporally and proportionally with rapid stipe elongation (Kües 2000). The shape of the cap is modified by cell expansion (Moore 1998). The process of cap expansion starts about $14 \mathrm{~h}$ after karyogamy and, once started, is completed in about $6 \mathrm{~h}$. Cap expansion is achieved by a gradual revolution of the edge of the cap in concert with radial splitting of cap and gill tissues, so as to allow the cap to open like an umbrella (Figure 1, Moore 1998). At the time when basidiospore pigmentation starts (ca. $8 \mathrm{~h}$ before the basidiospore discharge), hymenial cells become vacuolated and glycogen disappears (Iten and Matile 1970) from the subhymenium tissues (McLaughlin 1974). Unlike formerly developed but not fully differentiated sterile facial cystidia, multinucleate marginal cystidia arise from gill trama when primary gills pull away from the central stipe as the cap starts to expand (Chiu and Moore 1993, Lu 1974).

\subsubsection{Autolysis}

Degeneration of the cap of the fruiting body starts simultaneously to the spore release in the mature fruiting body and is finished within a few hours. Autolysis takes place soon after the basidiospores releasing starts (Figure 1, Iten and Matile 1970), to make space for the liberation of basidiospores from the inner cap regions (Buller 1933, Moore 1998). The gill autolysis follows the same pattern as spore pigmentation, starting at the edge of the gills towards the outer edge of the cap and from the cap margin to the apex (Rosin and Moore 1985b). Chitinases (Iten and Matile 1970) and glucanases (Miyake et al. 1980a) are responsible of the cell wall degradation that cause cap autolysis. The pileus tissues are affected by autolysis with the exception of the veil cells (Kües 2000). Metabolic control of autolysis may be related to NADP-linked glutamate dehydrogenase (Stewart and Moore 1974). These enzymes are not produced synchronically during the fruiting body development. NADP-linked glutamate dehydrogenase is produced during meiosis (Miyake et al. 1980b) increasing its activity in the pileus during fruiting body maturation (Stewart and Moore 1974). Chitinases and glucanases are postmeiotically produced (Miyake et al. 1980b). Chitinases are located in vacuoles of gill tissues and synthesized about $2 \mathrm{~h}$ before spore release (Iten and Matile 1970). In the early hours of the next light period at the day 7 of development the cap auto digests completely finishing in this way the cycle of the fungus (Figure 1). 


\subsection{Conclusions}

Among filamentous fungi, C. cinerea is an important model system for studying developmental processes in the basidiomycetes. In the past, the study of the morphology in basidiomycetes has had mainly taxonomic reasons. Another reason to study fruiting body development is to get insight in the complete cellular processes of tissue formation and cellular differentiation (e.g. see Boulianne et al. 2000, Walser et al. 2004). However, knowing the morphology of the fungi has also implications of more commercial importance. Mushroom cultivation in the recent years, has increased dramatically worldwide (Rühl and Kües 2007). Mushroom cultivation started with the cultivation several hundreds of years ago in China, but it is only recently that a better understanding of mushroom development gave rise to a wide variety of mushroom species cultivated all over the world. Still, for most of the existing species, the biology of fruiting body production is not at all or only poorly described. Understanding the physiology and cytology of fruiting body development is expected to contribute to better establish and improve cultural conditions in commercial mushroom production (Chiu et al. 2000, Kües et al. 2004, Rühl and Kües 2007). Studies of fruiting body development in the model fungus $C$. cinerea will help to understand generally more complex processes in development of other fungi.

\subsection{References}

Blayney GP, Marchant R (1977) Glycogen and protein inclusion in elongating stipes of Coprinus cinereus. J. Gen. Microbiol., 98, 467-476.

Boulianne RP, Liu Y, Aebi M, Lu BC, Kües U (2000) Fruiting body development in Coprinus cinereus: regulated expression of two galectins secreted by a nonclassical pathway. Microbiol., 146, 1841-1853.

Buller AHR (1909) Researches on Fungi. vol. I. Longman Green and Co., London, UK.

Buller AHR (1922) Researches on Fungi. vol. II. Longman Green and Co., London, UK.

Buller AHR (1924) Researches on Fungi. vol. III.. The production and liberation of spores in hymenomycetes and Uredineae. Hafner Publishing Co., New York, N.Y., USA.

Buller AHR (1931) Researches on Fungi. vol. IV. Further observations on the Coprini together with some investigations on social organization and sex in the hymenomycetes. Hafner Hafner Publishing Co., New York, N. Y., USA. 
Buller AHR (1933) Researches on Fungi. vol. V. Hyphal functions and protoplasmic streaming in the higher fungi, together with an account of the production and liberation of spores in Sporobolomyces, Tilletia, and Sphaerobolus. Hafner Publishing Co., New York, N. Y., USA.

Buller AHR (1934) Researches on Fungi. vol. VI. The biology and taxonomy of Pilobolus, the production and liberation of spores in the discomycetes, and pseudorhizae and gemnifers as organs of certain hymenomycetes. Hafner Publishing Co., New York, N. Y., USA.

Chaisaena W, Navarro-González M, Srivilai P, Kües U (2006) Coprinopsis cinerea mutants forming etiolated stipes under normal fruiting conditions. Poster. IXth International Fungal Biology Conference and 16th New Phytologist Symposium. 18-20 September. Nancy, France. pp. 19.

Chiu SW, Law SC, Ching ML, Cheung KW, Chen MJ (2000) Themes for mushroom exploitation in the 21 st century: sustainability, waste management, and conservation. J. Gen. Appl. Microbiol., 46, 269-282.

Chiu SW, Moore D (1988) Evidence for developmental commitment in the differentiating fruit body of Coprinus cinereus. Trans. Br. Mycol. Soc., 90, 247253.

Chiu SW, Moore D (1993) Cell form, function and lineage in the hymenia of Coprinus cinereus and Volvariella bombycina. Mycol. Res., 97, 221-226.

Clémençon H (1997) Anatomie der Hymenomyceten. Eine Einführung in die Cytologie und Plectologie der Krustenpilze, Porlinge, Keulenpilze, Leistlinge, Blätterpilze und Röhrlinge. F. Flück-Wirth, Teufen, Switzerland.

Clémençon H (2004) Cytologie and plectology of the Hymenomycetes. J. Cramer, Germany.

Göbel S (2003) Charakterisierung eines Genes in der Initiation der Fruchtkörperbildung des Basidiomyzeten Coprinus cinereus. Master Thesis. Georg-August University of Göttingen, Göttingen, Germany.

Granado JD, Kertesz-Chaloupkova K, Aebi M, Kües U (1997) Restriction enzymemediated DNA integration in Coprinus cinereus. Mol. Gen. Genet., 256, 28-36.

Hammad F, Ji JX, Watling R, Moore D (1993) Cell population dynamics in Coprinus cinereus: co-ordination of cell inflation throughout the maturing basidiome. Mycol. Res., 97, 269-274. 
Hodin J, (2006) Expanding networks: Signaling components in and a hypothesis for the evolution of metamorphosis. Integr. Comp. Biol. 46, 719-742.

Horner J, Moore D (1987) Cystidial morphogenetic field in the hymenium of Coprinus cinereus. Trans. Br. Mycol. Soc., 88, 479-488.

Iten W, Matile P (1970) Role of chitinase other lysosomal enzymes of Coprinus lagopus in the autolysis of fruiting bodies. J. Gen. Microbiol., 61, 301-309.

Kamada T, Kurita R, Takemaru T (1978) Effects of light on basidiocarp maturation in Coprinus macrorhizus. Plant Cell Physiol., 19, 263-275.

Kertesz-Chaloupková K, Walser PJ, Granado JD, Aebi M, Kües U (1998) Blue light overrides repression of asexual sporulation by mating type genes in the basidiomycete Coprinus cinereus. Fungal Genet. Biol., 23, 95-109.

Kimura K, Takemaru T (1955) Cytological studies of fungi: I Basidial development of Coprinus macrorhizus Rea f. microsporus Hongo. Biol. J. Okayama Uni., 2, 5161.

Kües U (2000) Life history and developmental processes in the basidiomycete Coprinus cinereus. Microbiol. Mol. Biol. Rev., 64, 316-353.

Kües U, Granado JD, Hermann R, Boulianne RP, Kertesz-Chaloupkova K, Aebi M (1998) The $A$ mating type and blue light regulate all known differentiation processes in the basidiomycete Coprinus cinereus. Mol. Gen. Genet., 260, 8191.

Kües U, Künzler M, Bottoli APF, Walser PJ, Granado JD, Liu Y, Bertossa RC, Ciardo D, Clergeot P-H, Loos S, Ruprich-Robert G, Aebi M (2004) Mushroom development in higher basidiomycetes; implication for human and animal health. In Kushwaha, R.K.S. (ed), Fungi in human and animal health, Scientific Publishers, Jodhpur, India. pp. 431-470.

Kües U, Polak E, Bottoli APF, Hollenstein M, Walser PJ, Boulianne RP, Hermann R, Aebi M (2002a) Vegetative development in Coprinus cinereus. In: Osiewacz HD (ed.), Molecular biology of fungal development. Marcel Dekker, New York, N.Y.pp. 133-164.

Kües U, Walser PJ, Klaus MJ, Aebi M (2002b) Influence of activated A B mating type pathways on developmental processes in the basidiomycete Coprinus cinereus. Mol. Gen. Genom., 268, 262-271.

Lu BC (1967) Meiosis in Coprinus lagopus: a comparative study with light electron microscopy. J. Cell Sci., 2, 529-536. 
Lu BC (1972) Dark dependence of meiosis at elevated temperatures in the basidiomycete Coprinus lagopus. J. Bacteriol., 111, 833-834.

Lu BC (1974) Meiosis in Coprinus. V. The role of light on basidiocarp initiation, mitosis and hymenium differentiation in Coprinus lagopus. Can. J. Bot., 52, 299-305.

Lu BC (1982) Replication of deoxyribonucleic acid and crossing over in Coprinus. In Wells K. and Wells E. K. (ed.). Basidium and basidiocarp. Evolution, cytology, funtion and development. Springer-Verlag, New York, N. Y., USA. pp. 93-112.

Lu BC (1991) Cell degeneration and gill remodelling during basidiocarp development in the fungus Coprinus cinereus. Can. J. Bot., 69, 1161-1169.

Matthews TR, Niederpruem DJ (1972) Differentiation in Coprinus lagopus. I. Control of fruiting and cytology of initial events. Arch. Mikrobiol., 87, 257-268.

Matthews TR, Niederpruem DJ (1973) Differentiation in Coprinus lagopus. II. Histology and ultrastructural aspects of developing primordia. Arch. Mikrobiol., $88,169-180$.

McLaughlin DJ (1972) Golgi apparatus in the postmeiotic basidium of Coprinus lagopus. J. Bacteriol., 110, 739-742.

McLaughlin DJ (1973) Ultrastructure of sterigma growth basidiospore formation in Coprinus and Boletus. Can. J. Bot., 51, 145-150.

McLaughlin DJ (1974) Ultrastructural localization of carbohydrate in the hymenium and subhymenium of Coprinus: evidence for the function of the Golgi apparatus. Protoplasma, 82, 341-364.

McLaughlin DJ (1977) Basidiospore initiation early development in Coprinus cinereus. Am. J. Bot., 64, 1-16.

McLaughlin DJ (1982) Ultrastructure cytochemistry of basidial basidiospore development. In Wells, K. and Wells, E.K. (eds), Basidium and Basidiocarp: Evolution, cytology, function and development. Springer-Verlag, New York, USA, pp. 37-74.

Miyake H, Takemaru T, Ishikawa T (1980a) Sequential production of enzymes and basidiospore formation in fruiting bodies of Coprinus macrorhizus. Arch. Microbiol., 126, 201-205.

Miyake H, Tanaka K, Ishikawa T (1980b) Basidiospore formation in monokaryotic fruiting bodies of a mutant strain of Coprinus macrorhizus. Arch. Microbiol., $126,207-212$. 
Moore D (1981) Developmental genetics of Coprinus cinereus: genetic evidence that carpophores and sclerotia share a common pathway of initiation. Curr. Genet., 3, 145-150.

Moore D (1987) The formation of agaric gills. Trans. Br. Mycol. Soc., 89, 105-108.

Moore D (1995) Tissue formation. In Gow, N.A.R. and Gadd, G.M. (eds.), The growing fungus. Chapman \& Hall, London, UK, pp. 423-465.

Moore D (1998) Fungal morphogenesis. Cambridge University Press, Cambridge, UK.

Moore D, Elhiti MMY, Butler RD (1979) Morphogenesis of the carpophore of Coprinus cinereus. New Phytol., 83, 695-722.

Moore D, Jirjis RI (1976) Regulation of sclerotium production by primary metabolites in Coprinus cinereus. Trans. Br. Mycol. Soc., 66, 377-382.

Morimoto N, Oda Y (1973) Effects of light on fruit-body formation in a basidiomycete, Coprinus macrorhizus. Plant Cell Physiol., 14, 217-225.

Morimoto N, Oda Y (1974) Photo-induced karyogamy in a basidiomycete Coprinus macrorhizus. Plant Cell Physiol., 15, 183-186.

Pinto-Lopes J, Almeida MG (1970) Coprinus lagopus A confusing name as applied to several species. Port. Acta Biol. Ser. B 11, 167-204.

Polak E, Hermann R, Kües U, Aebi M (1997) Asexual sporulation in Coprinus cinereus: Structure and development of oidiophores and oidia in an Amut Bmut homokaryon. Fungal Genet. Biol., 22, 112-126.

Pukkila PJ (1994) Meiosis in mycelial fungi, p. 267-282. In Wessels J.G.H and Meinhardt F. (ed.), The mycota, vol. I. Growth, differentiation and sexuality. Springer-Verlag, New York, N.Y., USA.

Reijnders AFM (1979) Developmental anatomy of Coprinus. Persoonia, 10, 383-424.

ReijndersAFM (1986) Development of the primordium of the carpophore. In Singer, R. (ed) The Agaricales in Modern Taxonomy (4th edn). Koenigstein, Koeltz, Germany. pp. 20-29.

Rosin IV, Moore D (1985a) Differentiation of the hymenium in Coprinus cinereus. Trans. Br. Mycol. Soc., 84, 621-628.

Rosin IV, Moore D (1985b) Origin of the hymenophore establishment of major tissue domains during fruit body development in Coprinus cinereus. Trans. Br. Mycol. Soc., 84, 609-619. 
Rühl M, Kües U (2007) Mushroom production. In: Kües, U. (ed) Wood production, wood technology and biotechnological impacts. Universitätsverlag-Verlag, Göttingen, Germany.

Stewart GR, Moore D (1974) The activities of glutamate dehydrogenases during mycelial growth and sporophore development in Coprinus lagopus (sensu Lewis). J. Gen. Microbiol., 83, 73-81.

Sundberg WJ (1978) Hymenial cytodifferentiation in Basidiomycetes. In: Smith, J.E., Biol, F.I. and Berry, D.R. (eds.), The Filamentous Fungi. Vol. 3. Developmental mycology. Edward Arnold, London, UK, pp. 298-314.

Swamy S, Uno I, Ishikawa T (1984) Morphogenetic effects of mutations at the $A$ and $B$ incompatibility factors in Coprinus cinereus. J. Gen. Microbiol., 130, 32193224.

Tsusué YM (1969) Experimental control of fruit-body formation in Coprinus macrorhizus. Dev. Growth Differ., 11, 164-178.

van der Valk P, Marchant R (1978) Ultrastructure in fruit-body primordia of the basiodiomycetes Schizophyllum commune and Coprinus cinereus. Protoplasma, $95,57-72$.

Velagapudi R (2006) Extracellular matrix proteins in growth and fruiting body development of straw and wood degrading basidiomycetes. PhD Thesis. GeorgAugust University of Göttingen, Göttingen, Germany.

Walser PJ, Haebel PW, Künzler M, Sargent D, Kües U, Aebi M, Ban N (2004) Structure and functional analysis of the fungal galectin CGL2. Structure, 12, 689-702.

Waters H, Moore D, Butler RD (1975) Morphogenesis of aerial sclerotia of Coprinus lagopus. New Phytol., 74, 207-213. 



\section{Effect of copper in Coprinopsis cinerea (Coprinus cinereus) development}

Contribution to this chapter: All experimental work and preparation of the manuscript was performed by the author of this thesis. The nitrate assimilation gene cluster annotation was performed by Dr. Sreedhar Kilaru. 


\section{Effect of copper in Coprinopsis cinerea (Coprinus cinereus) development}

\subsection{Abstract}

In extensive growth tests using a standard growth medium (YMG/T), extracellular laccase production was absent in Coprinopsis cinerea strain AmutBmut unless $0.2 \mathrm{mM}$ copper were added. Estimated by ABTS [2, 2-azino-bis-(3-ethylbenzothiazoline-6sulphonic acid)] and DMP (2,6-dimethoxy phenol) oxidation, only a small increase in enzyme activity in liquid culture was observed in the presence of copper compared to what is described for potent white rot-fungi. In addition to free enzymatic activity detected in the culture medium, laccase activity was detected bound to fungal mycelia of $C$. cinerea when cultures were induced by copper. In parallel, fruiting body formation was induced by copper at $28^{\circ} \mathrm{C}$ at earlier times and in higher numbers of primordia and, surprisingly, fruiting initiated also at $37^{\circ} \mathrm{C}$. Cultures grown at $37^{\circ} \mathrm{C}$ supplemented with either of two different sources of copper $\left(\mathrm{CuSO}_{4}, \mathrm{CuCl}_{2} \mathrm{x}_{2} \mathrm{H}_{2} \mathrm{O}\right)$ were able to produce etiolated stipes (structures with underdeveloped caps and elongated stipes) while untreated parallel cultures or cultures treated with equivalent concentrations of $\mathrm{MgCl} 66 \mathrm{H}_{2} \mathrm{O}, \mathrm{MgSO}_{4}, \mathrm{FeCl}_{3} \times 6 \mathrm{H}_{2} \mathrm{O}, \mathrm{FeSO}_{4} \times 7 \mathrm{H}_{2} \mathrm{O}$, or $\mathrm{Fe}\left(\mathrm{NO}_{3}\right)_{3} \times 9 \mathrm{H}_{2} \mathrm{O}$ did not. Furthermore, in copper sulphate supplemented cultures incubated at $37^{\circ} \mathrm{C}$, nitrate reductase activity within the mycelia was induced. However, no nitrite reductase activity was detected. Transcripts of the nitrate assimilation gene cluster (nitrate reductase, nitrite reductase and nitrite transporter) were detected in several developmental stages of the $C$. cinerea fruiting pathway, but not in secondary hyphal knots being early stages in fruiting body development.

Keywords: Inkcap mushroom, fruiting, etiolated stipes, phenoloxidases, laccase, inductor, copper, nitrate reductase 


\subsection{Introduction}

Coprinopsis cinerea (Coprinus cinereus) is a model organism to investigate developmental processes in basidiomycetous fungi. Its ability to grow on simple artificial media and its short life cycle enables to easily study the fungus under laboratory conditions. C. cinerea grows best at $37^{\circ} \mathrm{C}$, but, normally, it produces fruiting bodies only at moderate temperatures around $25-28^{\circ} \mathrm{C}$. Next to temperature, light plays also a decisive role in fruiting body development. Light is needed to induce fruiting and also for fruiting body maturation. Cultures kept after induction predominantly in the dark form however structures with an extended stipe and an underdeveloped cap (socalled etiolated stipes, pseudorhizas or dark stipes). However, in a day/night rhythm, caps develop further, and basidia are formed, in which karyogamy and meiosis occurs and of which the sexual melanin-stained basidiospores bud off (Kües 2000).

Besides light, fruiting body development in basidiomycetes has been repeatedly linked to enzymes belonging to the group of phenoloxidases, in particular the multi-copper containing laccases (Wessels 1993, Kües and Liu 2000, Kües et al. 2004). Although their roles in fruiting are not completely understood, laccases are discussed to function in a variety of processes during fruiting, in supply of nutrients by degradation of lignocellulosic substrate, in hyphal aggregation by chemical cross-linking via oxidative polymerization of phenolic cell wall constituents (Leatham and Stahmann 1981, Broxholme et al. 1991, Zhao and Kwan 1999), and/or in fruiting body and spore pigmentation (Leatham and Stahmann 1981, Vnenchak and Schwalb 1989, Kües and Liu 2000, Langfelder et al. 2003, Nosanchuk and Casadevall 2003). Repeatedly studied species in these aspects are Coprinellus congregatus (Coprinus congregatus), Schizophyllum commune, Agaricus bisporus, Lentinula edodes and Volvariella volvacea (Phillips and Leonard 1976, Wood 1980, Ross 1982a, 1982b, Leatham and Stahmann 1981, Bonnen et al. 1994, Ohga et al. 1999, Chen et al. 2003, Chen et al. 2004).

Most laccases are reported to be extracellular proteins (Wood 1980, Leatham and Stahmann 1981), and only few reports on intracellular laccase activities are known (Molitoris and Esser 1970, Phillips and Leonard 1976). The regulation of laccase gene expression and enzyme production is affected by culture conditions (Buswell et al. 1995, Yaver et al. 1996, Ohga and Royse 2001, Soden and Dobson 2001), and by different substances such as aromatic or phenolic compounds related to lignin 
derivatives (Gianfreda et al. 1999). Heavy metals present in the environment either naturally $(\mathrm{Cu})$ or as a result of human activities $(\mathrm{Cd}, \mathrm{Hg}, \mathrm{Pb}$, and $\mathrm{Mn})$ are also an important group of enzyme activity inducers (Soden and Dobson 2001, Baldrian and Gabriel 2002, Baldrian 2003, Jarosz-Wilkołazka et al. 2002). Addition of copper to culture broth has been repeatedly reported to be a strong inducer of laccase in Trametes versicolor, Phanerochaete chrysosporium, Pleurotus ostreatus, P. sajor-caju and T. pubescens (Collins and Dobson 1997, Dittmer et al. 1997, Palmieri et al. 2000, Soden and Dobson 2001, Baldrian and Gabriel 2002, Galhaup et al. 2002).

In this chapter, we report on a new physiological role for copper sulphate in the basidiomycete $C$. cinerea, and demonstrate that copper induces the production of laccases during the growth of the mycelium and that is involved in the initiation of the fruiting body development in C. cinerea. In addition to the effect of copper in fruiting body development, induction of ammonium production in the supernatant, and increase of nitrate reductase activity in the mycelia are also reported.

\subsection{Materials and methods}

\subsubsection{Coprinopsis cinerea strain and culture conditions}

In this study, the self-compatible homokaryon Coprinopsis cinerea AmutBmut, (A43mut, B43mut, pab-1) (Swamy et al. 1984) was used. For vegetative growth, a plug of mycelia was inoculated in the middle of agar plates with standard Coprinus YMG/T medium (yeast extract, malt extract, glucose and tryptophan, Granado et al. 1997), and all cultures were incubated at $37^{\circ} \mathrm{C}$ in darkness until the growing mycelium reached the edges of the Petri dishes. The YMG/T medium was prepared with yeast and malt extracts from OXOID (Basingstoke, UK). In solid cultures, the employed agar (1\%) was from Serva (Heidelberg, Germany). To induce fruiting body development, agar cultures were transferred to standard fruiting conditions $\left(28^{\circ} \mathrm{C}\right.$, light, $80-90 \%$ humidity in a $12 \mathrm{~h}$ light/12 $\mathrm{h}$ dark regime; in this $24 \mathrm{~h}$ scheme, the moment when the light is switched on is arbitrarily set zero, and the moment when light is switched off is arbitrarily set 12 hours, Granado et al. 1997).

Liquid standing cultures were inoculated with $1 \mathrm{ml}$ of suspended mycelium obtained from the homogenization of a 5 day old YMG/T agar pre-culture in $100 \mathrm{ml}$ of sterile YMG/T. 
To test the effect of different metals on the enzymatic activities and fruiting body development in solid and liquid standing cultures, the basic YMG/T medium was supplemented with either $\mathrm{CuSO}_{4}(0.2 \mathrm{mM}), \mathrm{CuCl}_{2} \times 2 \mathrm{H}_{2} \mathrm{O}, \mathrm{MgClx} 6 \mathrm{H}_{2} \mathrm{O}, \mathrm{MgSO}_{4}$, $\mathrm{FeCl}_{3} \times 6 \mathrm{H}_{2} \mathrm{O}, \mathrm{FeSO}_{4} \times 7 \mathrm{H}_{2} \mathrm{O}, \mathrm{Fe}\left(\mathrm{NO}_{3}\right)_{3} \times 9 \mathrm{H}_{2} \mathrm{O}$ at a concentration of $0.2 \mathrm{mM}$. Cultures were tested at three different conditions: A. incubated only at $37^{\circ} \mathrm{C}$ in dark with partially light illumination when checking cultures and taking samples; B. incubated at $37^{\circ} \mathrm{C}$ in dark with partial light as in condition A. until mycelium was fully grown to the edge of the Petri-dishes/flask, then they were transferred into the standard fruiting regime and $\mathbf{C}$. incubated only at the standard fruiting regime (see above). In order to study the effect of metals addition on hyphal knot formation in solid cultures, in $1 / 3$ of the plates were counted the number of primary and secondary hyphal knots on the $\mathrm{d} 7 \mathrm{~d}$ incubation $(\sim 0.03-0.2 \mathrm{~mm})$.

\subsubsection{Sampling procedures}

Enzymatic activities were studied in liquid cultures up to $18 \mathrm{~d}$ at specified time intervals. Extracellular laccase activity was measured in the culture supernatants. Fungal biomass was determined by filtering mycelia through Whatman No. 1 filter paper, washing with distilled water, drying at $102^{\circ} \mathrm{C}$, and weighing. All experiments were performed per triplicate.

\subsubsection{Enzymatic assays}

\subsubsection{Extracellular laccase activity}

To test the extracellular enzymatic activity, standing cultures were grown in $500 \mathrm{ml}$ Erlenmeyer flask containing $100 \mathrm{ml}$ of $\mathrm{YMG} / \mathrm{T}$ liquid medium and YMG/T supplemented with $\mathrm{CuSO}_{4}(0.2 \mathrm{mM})$ at $37^{\circ} \mathrm{C}$. Cultures were inoculated with $1 \mathrm{ml}$ of a mycelium suspension obtained from the homogenate of $6 \mathrm{~d}$ old YMG/T agar pre-culture in $100 \mathrm{ml}$ of sterile YMG/T medium. Each day, $0.5 \mathrm{ml}$ of culture supernatants was collected. The mycelial particles were separated by centrifugation for $1 \mathrm{~min}$ at 13,000 rpm. Laccase activity was determined at room temperature by monitoring separately the oxidation of $5 \mathrm{mM}$ ABTS at $420 \mathrm{~nm}$ and DMP (0.3 mM in ethanol) at $468 \mathrm{~nm}$ in 120 $\mathrm{mM}$ of sodium acetate buffer $(\mathrm{pH} 5.0)$ in a final volume of $200 \mu 1$ using $20 \mu \mathrm{l}$ of supernatant as a sample (Matsumura et al. 1986, Johannes and Majcherczyk 2000). One unit of enzyme activity (IU) represents the amount of laccase that oxidizes $1 \mu \mathrm{mol}$ substrate/min. 


\subsubsection{Nitrate reductase and nitrite reductase activity}

Nitrate reductase: Intracellular nitrate reductase activity was assayed in the mycelia of liquid cultures incubated continuously at $37^{\circ} \mathrm{C}$ in $100 \mathrm{ml}$ of either YMG/T or YMG/T $\left(\mathrm{CuSO}_{4} 0.2 \mathrm{mM}\right)$ in Erlenmeyer flasks, by using the method of Plassard et al. (1984a) modified as follows: mycelia was harvested from the cultures and rinsed with distilled water. One eighth from the mycelial layer growing in liquid medium $(\sim 1 \mathrm{~g}$ of fresh mycelia) was taken, grinded at $4{ }^{\circ} \mathrm{C}$ (on ice) in $2 \mathrm{ml}$ of $0.1 \mathrm{M}$ phosphate buffer $\mathrm{pH} 7.5$ containing $1 \mathrm{mM}$ EDTA, and centrifuged for $10 \mathrm{~min}$ at $4^{\circ} \mathrm{C} .600 \mu \mathrm{l}$ of supernatant were diluted with an equal volume of buffer supplemented with $2 \%$ casein and centrifuged 20 min at $4^{\circ} \mathrm{C}$. Extracts were then incubated for $30 \mathrm{~min}$ at $28^{\circ} \mathrm{C}$ in the presence of $800 \mu \mathrm{l}$ of solution containing $10 \mu \mathrm{M}$ FAD, $0.12 \mathrm{mM}$ NADPH and $10 \mathrm{mM} \mathrm{KNO}_{3}$ buffered with 50 $\mathrm{mM} \mathrm{KH} \mathrm{PO}_{4}$ (pH 7.5). The reaction was stopped by adding $0.1 \mathrm{ml}$ of $1 \mathrm{M}$ zinc acetate. Any nitrite produced was then quantified by addition of $1 \mathrm{ml}$ of $1.5 \mathrm{M} \mathrm{HCl}$ containing $10 \mathrm{~g} / 1$ sulfanilamide and $1 \mathrm{ml}$ of $0.2 \mathrm{~g} / 1 \mathrm{~N}$-(1-naphtyl)ethylenediamine hydrochloride. After 20 min at $20^{\circ} \mathrm{C}$, the reaction mixture was centrifuged and any nitrite produced was measured at $540 \mathrm{~nm}$ using $\mathrm{NaNO}_{2}(0.5 \mu \mathrm{M}-1 \mathrm{mM})$ as standard. Controls were treated identically but the reaction was stopped prior to addition of enzyme. Average values were calculated from each 3 replicates.

Nitrite reductase: Intracellular nitrite reductase activity was assayed in parallel to the nitrate reductase assay (modified after Plassard 1984b). Samples were treated equally until the casein treatment. After centrifugation step, $200 \mu 1$ of the extracts were transferred into a fresh Falcon tube $(15 \mathrm{ml})$ and incubated for $30 \mathrm{~min}$ at $28^{\circ} \mathrm{C}$ in the presence of $800 \mu \mathrm{l}$ containing $\left(10 \mu \mathrm{M}\right.$ FAD, $0.12 \mathrm{mM}$ NADPH, $0.1 \mathrm{mM} \mathrm{\textrm {NaNO } _ { 2 }}$ buffered with $50 \mathrm{mM} \mathrm{KH}_{2} \mathrm{PO}_{4} \mathrm{pH}$ 7.5). The reaction was stopped adding $100 \mu \mathrm{l} 1 \mathrm{M}$ zinc acetate. To quantify any nitrite in the solution $1 \mathrm{ml}$ of $1.5 \mathrm{M} \mathrm{HCl}$ containing $10 \mathrm{~g} / \mathrm{l}$ sulfanilamide and $1 \mathrm{ml}$ of $0.2 \mathrm{~g} / 1 \mathrm{~N}-(1$-naphtyl)ethylenediamine hydrochloride were added and incubate $20 \mathrm{~min}$ at $20^{\circ} \mathrm{C}$. After centrifugation, any $\mathrm{NaNO}_{2}$ depleted was measured at $540 \mathrm{~nm}$ against standards $\left(\mathrm{NaNO}_{2} 0.5 \mu \mathrm{M}-1 \mathrm{mM}\right)$.

\subsubsection{Ammonium determination}

The ammonium amount in supernatant of the cultures incubated continuously at $37^{\circ} \mathrm{C}$ was measured using the phenol-hypochlorite method, which is based on the capacity of ammonium to produce a blue indophenol chromophore in the presence of an alkaline 
solution of phenol and hyphochlorite (Botton and Chalot 1991). For this, a sample of 45 $\mu \mathrm{l}$ of the supernatant was taken into a $1.5 \mathrm{ml}$ tube, $750 \mu \mathrm{l}$ of the phenol reagent $(1.0 \%$ phenol, w/v; $0.05 \%$ sodium nitroprusside, w/v) were added, plus $750 \mu \mathrm{ml}$ of the hypochlorite reagent (2.5\% sodium hypochlorite, v/v; $0.05 \%$ sodium hydroxide, w/v). The solution was homogenized and incubated at $37^{\circ} \mathrm{C}$ for $15 \mathrm{~min}$. Finally, the absorbance was spectrophotometrically determined at a wavelength of $625 \mathrm{~nm}$, using $\mathrm{NH}_{4} \mathrm{Cl}(1-10 \mathrm{mM})$ as a standard. The results were expressed in $\mathrm{mM}$. The experiments were performed in triplicates.

\subsubsection{Glucose determination}

Glucose depletion by $C$. cinerea in both YMG/T liquid medium and YMG/T supplemented with $\mathrm{CuSO}_{4}(0.2 \mathrm{mM})$ cultures incubated at $37^{\circ} \mathrm{C}$ was measured using the glucose (HK) assay kit (Kit GAHK-20, Sigma ${ }^{\circledR}$ ) following the manufacturer's instructions [Sigma Tech. Bulletin No. GHKB-2 (5-97)].

\subsubsection{Nitrate assimilation gene cluster prediction}

The protein sequences of Hebeloma cylindrosporum nitrate reductase (Genbank CAB60010), nitrite reductase (Genbank CAB60008) and nitrate transporter gene (Genbank CAB60009) were used in a Blast search (tblastn) against the publicly available genome of C. cinerea (release July 2003, http://www.broad.mit.edu/annotation/fungi/coprinus_cinereus/index.html). Positions of the start codon and introns in C. cinerea nitrate reductase, nitrite reductase and nitrate transporter gene were predicted by comparison with exons and conserved intron positions of $H$. cylindrosporum genes and with $C$. cinerea intron splice junctions (Seitz et al. 1996, Kilaru et al. 2006). Alignments of the deduced amino acid sequences were generated with ClustalX (http://www-igbmc.u-strasbg.fr/BioInfo/ClustalX/Top.html) and manual adjustments in alignments of amino acid sequences were made in Genedoc version 2.6.002 (http://www.psc.edu/biomed/genedoc/).

\subsubsection{DNA isolation, RNA isolation, cDNA synthesis and transcript analysis}

Mycelial genomic DNA was extracted as described by Zolan and Pukkila (1986) from C. cinerea AmutBmut. Nitrate reductase, nitrite reductase and nitrate transporter gene specific primers (Table 1) were tested on the genomic DNA of the strain used in this study. Total RNA was daily isolated from day 3 to day 10 of incubation from the 
mycelium and from etiolated stipes of the incubated continuously at $37^{\circ} \mathrm{C}$ in dark with partially light illumination when checking cultures and taking samples. Samples of fresh tissues were ground to fine powdered material with liquid nitrogen and total RNA was extracted by using guanidine thiocyanate (Boulianne et al. 2000). cDNAs were synthesized using RevertAid M-MuLV Reverse Transcriptase (Fermentas) according to the manufacturer's instructions (Gerard and D'Alessio 1993). The quality of the synthesized cDNAs was analyzed using $\beta$-tubulin gene specific primers (Table 1). $2 \mu \mathrm{g}$ of total RNA was used in each reaction and the cDNA obtained was used for transcript profiling. $10 \mu \mathrm{l}$ aliquots of the PCR products were then analyzed on $1 \%$ agarose gels in TAE buffer, and for $60 \mathrm{~min}$ at $80 \mathrm{~V}$ constant (Sambrook and Russell 2001).

For nitrate reductase, nitrite reductase and nitrate transporter transcript analysis gene specific primers were used (Table 1). $25 \mu 1$ PCR reaction mixture (10 mM Tris, $\mathrm{pH} 8.8$, $50 \mathrm{mM} \mathrm{KCl}, 0.1 \%$ Triton X-100, $1.5 \mathrm{mM} \mathrm{MgCl}_{2}, 0.2 \mathrm{mM}$ dNTPs, $0.4 \mu \mathrm{M}$ each gene specific primer $4 \mu \mathrm{M}, 1$ unit of Taq polymerase and approximately 5 ng of cDNA) were used as standard throughout this study. PCR conditions were 2 min (PCR with isolated DNA) initial denaturation at $94^{\circ} \mathrm{C}$, followed by 35 cycles of $30 \mathrm{~s}$ at $94^{\circ} \mathrm{C}, 30 \mathrm{~s}$ at an annealing temperature of 55 and $58^{\circ} \mathrm{C}$, primer set-specific extension time at $72^{\circ} \mathrm{C}$ and a final extension step at $72^{\circ} \mathrm{C}$ for $10 \mathrm{~min}$ (Table 1). $10 \mu \mathrm{l}$ aliquots of the PCR products were then analyzed on $1 \%$ agarose gels run for $60 \mathrm{~min}$ at $80 \mathrm{~V}$ constant. 
Table 1 Primer sets and PCR conditions.

\begin{tabular}{|c|c|c|c|c|c|c|c|c|}
\hline \multirow[t]{2}{*}{ Gene } & \multirow[t]{2}{*}{ Primer } & \multirow[t]{2}{*}{ Forward primer (5' to 3') } & \multirow[t]{2}{*}{ Primer } & \multirow[t]{2}{*}{ Reverse primer (5' to 3') } & \multirow[t]{2}{*}{ Annealing } & \multirow[t]{2}{*}{ Extension } & \multicolumn{2}{|c|}{ Expected sizes (bp) } \\
\hline & & & & & & & genomic DNA & cDNA \\
\hline \multicolumn{9}{|c|}{ Nitrate reductase } \\
\hline nar1 & Nar1_f & ATGATCTCAGCAATGGGAGC & Nar1_r2 & CCAGCTACGAGGGTTATGGA & $55^{\circ} \mathrm{C}$ & $1 \mathrm{~min}$ & 2207 & 1707 \\
\hline \multicolumn{9}{|c|}{ Nitrite reductase } \\
\hline nir1 & nir_f & $\begin{array}{l}\text { ATGTCAGCATTCATTGAAAAACTG } \\
\text { C }\end{array}$ & nir_r2 & TTTGTCGGCTGTCATGATGT & $58^{\circ} \mathrm{C}$ & $2 \min 30 s$ & 3326 & 2428 \\
\hline \multicolumn{9}{|c|}{ Nitrate transporter } \\
\hline nrt2 & nrt_f & ATGTCGTTCTCTAATAGCCC & nrt_r & CTAGAATTCTGGCACTGGAA & $55^{\circ} \mathrm{C}$ & $1 \mathrm{~min} 45 \mathrm{~s}$ & 1983 & 1528 \\
\hline \multicolumn{9}{|c|}{ B-tubulin } \\
\hline B-tub & B-tubF & ATGCGTGAAATCGTCCACCTC & B-tubR & TCACACTGAGCGGTGAGAAC & $62^{\circ} \mathrm{C}$ & $2 \mathrm{~min}$ & 1600 & 1000 \\
\hline
\end{tabular}




\subsection{Results and discussion}

\subsubsection{Copper, laccase activity and fruiting in liquid cultures}

In attempts to induce laccase production in liquid standing cultures at $37^{\circ} \mathrm{C}$ with different known laccase inductors as ethanol, veratryl alcohol, xylidine (data not shown) and $\mathrm{CuSO}_{4}(0.2 \mathrm{mM})$, we found that only $\mathrm{CuSO}_{4}(0.2 \mathrm{mM})$ could enhance laccase activity in the culture supernatant at detectable amounts. Culture supernatants of C. cinerea grown on YMG/T media supplemented with $\mathrm{CuSO}_{4}$ showed a maximum laccase activity of $35 \mathrm{mU} / \mathrm{ml}$ with ABTS and $40 \mathrm{mU} / \mathrm{ml}$ with DMP while untreated cultures did not produce extracellular laccase. Amazingly, cultures treated with $\mathrm{CuSO}_{4}$ developed etiolated stipes at the unusual temperature of $37^{\circ} \mathrm{C}$ (Figure 1). These largely elongated fruiting body primordia are developed if only one light signal is given for fruiting initiation; therefore they are also called dark stipes (Kües 2000).

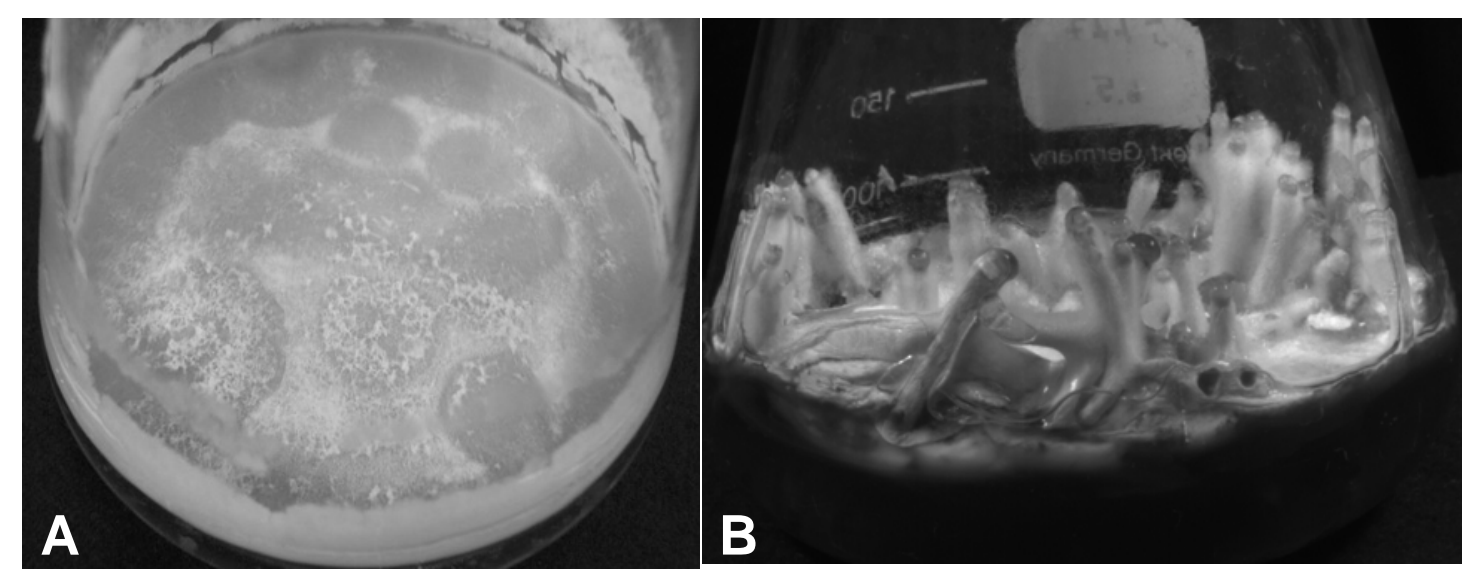

Figure 1 Effect of copper on primordia development on media at $37^{\circ} \mathrm{C}$. Untreated cultures of Coprinopsis cinerea on YMG/T liquid cultures (A), note that aerial mycelia did almost not develop. In contrast, $\mathrm{CuSO}_{4}$ treated $\mathrm{YMG} / \mathrm{T}$ developed aerial mycelia of harder consistency on which high number of etiolated stipes were produced $(\mathbf{B})$.

To test if the copper source was responsible for the fructification at these unusual conditions, a set of liquid cultures were investigated where copper and other metal ions compounds $\left(\mathrm{CuSO}_{4}, \mathrm{CuCl}_{2} \times 2 \mathrm{H}_{2} \mathrm{O}, \mathrm{MgCl} \times 6 \mathrm{H}_{2} \mathrm{O}, \mathrm{MgSO}_{4}, \mathrm{FeCl}_{3} \times 6 \mathrm{H}_{2} \mathrm{O}, \mathrm{FeSO}_{4} \times 7 \mathrm{H}_{2} \mathrm{O}\right.$, and $\left.\mathrm{Fe}\left(\mathrm{NO}_{3}\right)_{3} \times 9 \mathrm{H}_{2} \mathrm{O}\right)$ respectively, were alternatively added at the concentration of 0.2 $\mathrm{mM}$. In these experiments, three different incubation conditions were tested (see materials and methods). ABTS and DMP were applied to measure laccase activity as the most commonly used substrates (Johannes and Majcherczyk 2000), and because different laccases may show different reactivities to different substrates (Baldrian 2006). 
In liquid cultures, only in the treatments where copper was present the fungus produced extracellular laccase activity (Figure 2). Furthermore, culture samples tested with ABTS showed higher laccase reactivity than the samples tested with DMP (Figure 2).
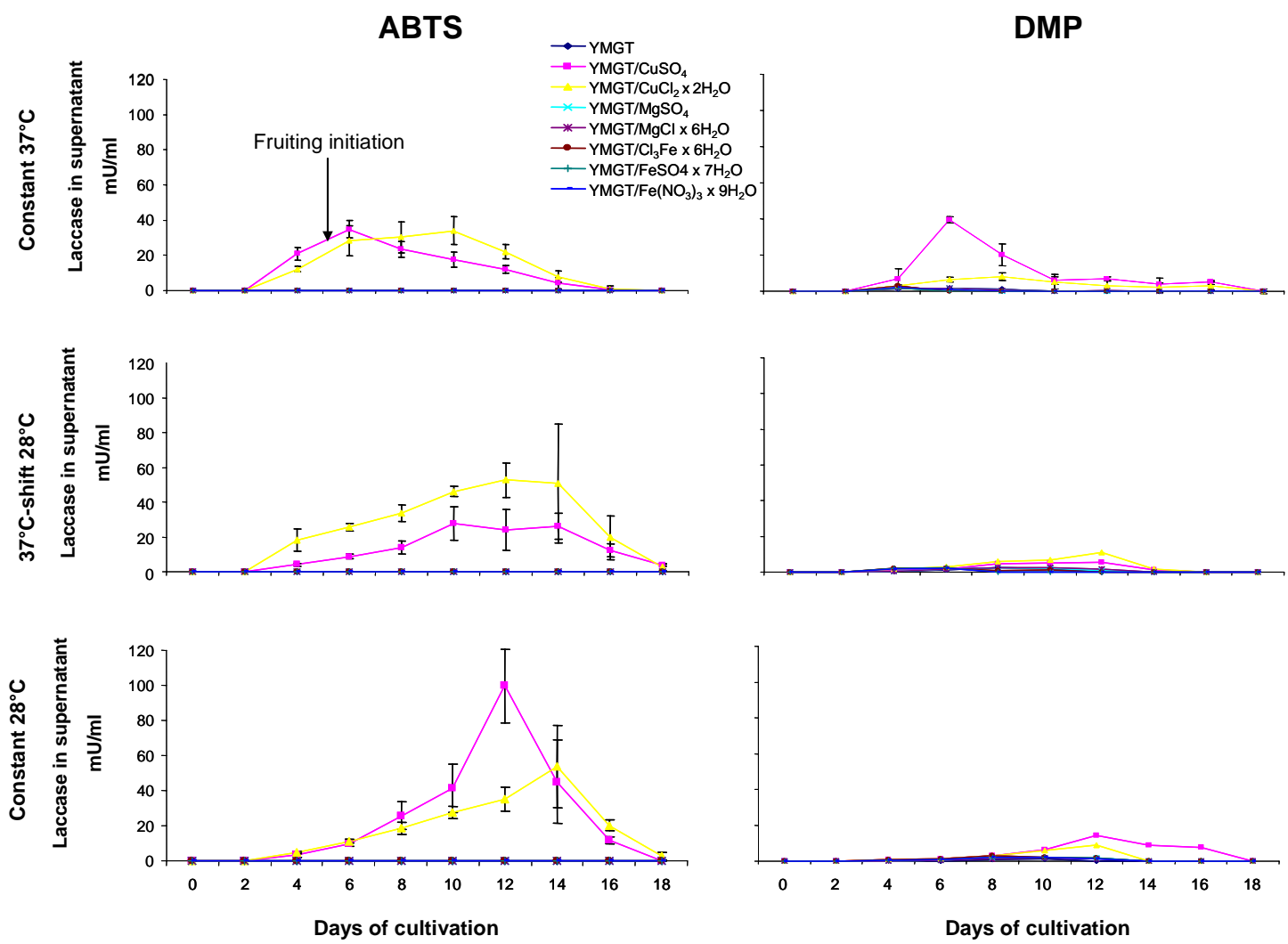

Figure 2 Laccase activities of cultures of Coprinopsis cinerea. ABTS tested cultures showed higher activity (left) than cultures tested with DMP (right). YMG/T liquid cultures supplemented either with $\mathrm{CuSO}_{4}$ or $\mathrm{CuCl}_{2} \times 2 \mathrm{H}_{2} \mathrm{O}$ were able to produce low amounts of laccase activity. Cultures treated with $\mathrm{MgCl} 6 \mathrm{H}_{2} \mathrm{O}, \mathrm{MgSO}_{4}, \mathrm{FeCl}_{3} \times 6 \mathrm{H}_{2} \mathrm{O}, \mathrm{FeSO}_{4} \times 7 \mathrm{H}_{2} \mathrm{O}$, $\mathrm{Fe}\left(\mathrm{NO}_{3}\right)_{3} \mathrm{x} \mathrm{CH}_{2} \mathrm{O}$ at the concentration of $0.2 \mathrm{mM}$ and untreated cultures did not show any or only negligible laccase activity.

Temperature strongly influenced the laccase activities. Incubation at $28^{\circ} \mathrm{C}$ was the optimal condition to produce the highest laccase activities $(100 \mathrm{mU} / \mathrm{ml})$ in cultures treated with $\mathrm{CuSO}_{4}$. At the other two tested incubation conditions (A. at $37^{\circ} \mathrm{C}$ in dark with partially light illumination when checking cultures and taking samples; and $\mathbf{B}$. at $37^{\circ} \mathrm{C}$ in dark with partial light as in condition A until mycelium was fully grown to the edge of the flask, which then were transferred into the standard fruiting regime at $28^{\circ} \mathrm{C}$ ), laccase activity reached activities of 28 and $25 \mathrm{mU} / \mathrm{ml}$, respectively. Cultures treated 
with $\mathrm{CuCl}_{2} \times 2 \mathrm{H}_{2} \mathrm{O}$ gave slightly higher laccase activities in these two environmental conditions with 53 and $34 \mathrm{mU} / \mathrm{ml}$, respectively. Also with $\mathrm{Cu}$, the best temperature for laccase production was $28^{\circ} \mathrm{C}$ and enzymatic activities up to $100 \mathrm{mU} / \mathrm{ml}$ were obtained (Figure 2).

Temperature is one of the most important environmental parameters that contribute to the regulation of fungal life cycles. In $C$. cinerea, vegetative growth is less sensitive to temperature variations than sexual development, although the mycelial growth rate varies significantly depending on the incubation temperature; the mycelium grows more vigorously at $37^{\circ} \mathrm{C}$ (see below for growth on solid medium). Temperature plays also a significant role in its fruiting body development (Figure 3, Lu 1974a, Madelin 1956b). Usually, C. cinerea fruiting bodies neither develop below $10^{\circ} \mathrm{C}$ nor above $30^{\circ} \mathrm{C}$ (Madelin 1956a, Tsusué 1969). In our experiments, we found that addition of copper salts to the liquid or solid media had also an effect on mycelium consistency and fruiting body development. In the set of liquid cultures supplemented with $0.2 \mathrm{mM}$ $\mathrm{CuSO}_{4}$ or $\mathrm{CuCl}_{2} \times 2 \mathrm{H}_{2} \mathrm{O}$ incubated continuously at $37^{\circ} \mathrm{C}$ in dark, the mycelium was well interwoven and more difficult to tear apart into pieces than the relatively soft mycelium from cultures grown without extra copper. Moreover, the copper supplemented cultures produced etiolated stipes (Figure 1). Etiolated stipes are known to form in fruiting competent cultures that obtained short light signals but are subsequently kept in the dark at otherwise fruiting promoting conditions ( $\mathrm{Lu} \mathrm{1974b).} \mathrm{Since} \mathrm{in} \mathrm{this} \mathrm{study,} \mathrm{the} 37^{\circ} \mathrm{C}$ with copper treated cultures were mostly kept in dark, we further tested the behaviour of the fungus under different light and temperature conditions. Cultures supplemented with $\mathrm{CuSO}_{4}$ incubated at $37^{\circ} \mathrm{C}$ always developed etiolated stipes, that arrested somewhere in the normal pathways of fruiting, but never mature fruiting bodies in the following conditions: i. with/without a daily short light pulse from the laboratory illumination in cultures incubated in dark boxes for 4 days and then transferred to a chamber with a glass door presented directly to a laboratory window following the normal day/night rythm; ii. when cultures were continuously incubated in a chamber with a glass door in front of the window following the normal day/night illumination, or in a chamber with artificial light regulated by a $12 \mathrm{~h}$ dark/ 12h light regime (Figure 3 and Figure 4). In constant darkness no developmental structures raised, confirming that light is needed to trigger and regulate fruiting body development (Kües 2000). However, when cultures after growth at $37^{\circ} \mathrm{C}$ for 4 days in darkness were continuously kept at the standard 


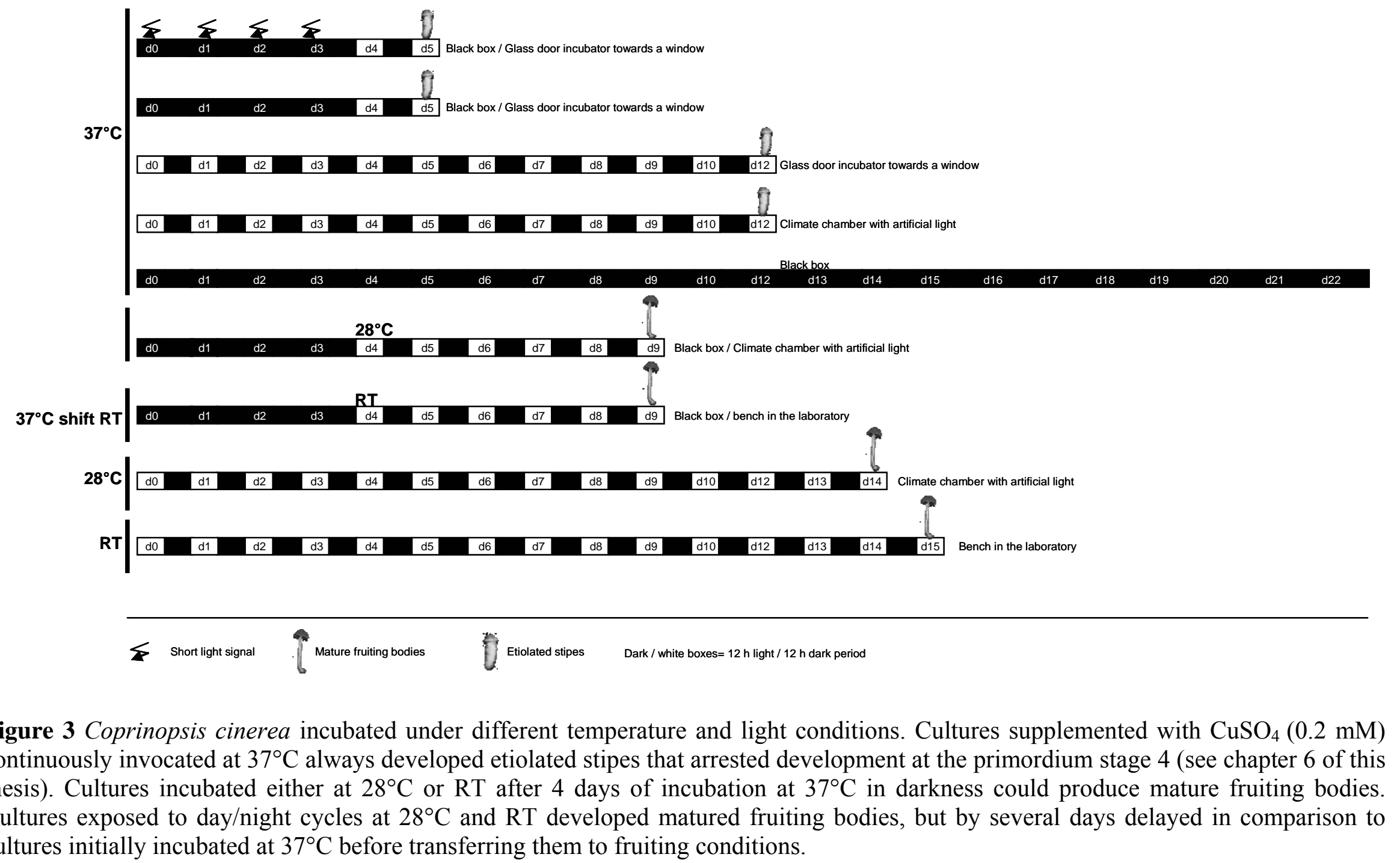


fruiting conditions or at room temperature $\left(22-25^{\circ} \mathrm{C}\right)$ this could lead to mature fruiting bodies (Figure 3 and Figure 4). Similarly such development occurred when cultures were continuously incubated at $28^{\circ} \mathrm{C}$ or room temperature under $12 \mathrm{~h}$ dark/ $12 \mathrm{~h}$ light rhythm in a acclimatized chamber and laboratory, respectively. Cultures without copper did not lead to induction of fruiting body development in any of the conditions tested.
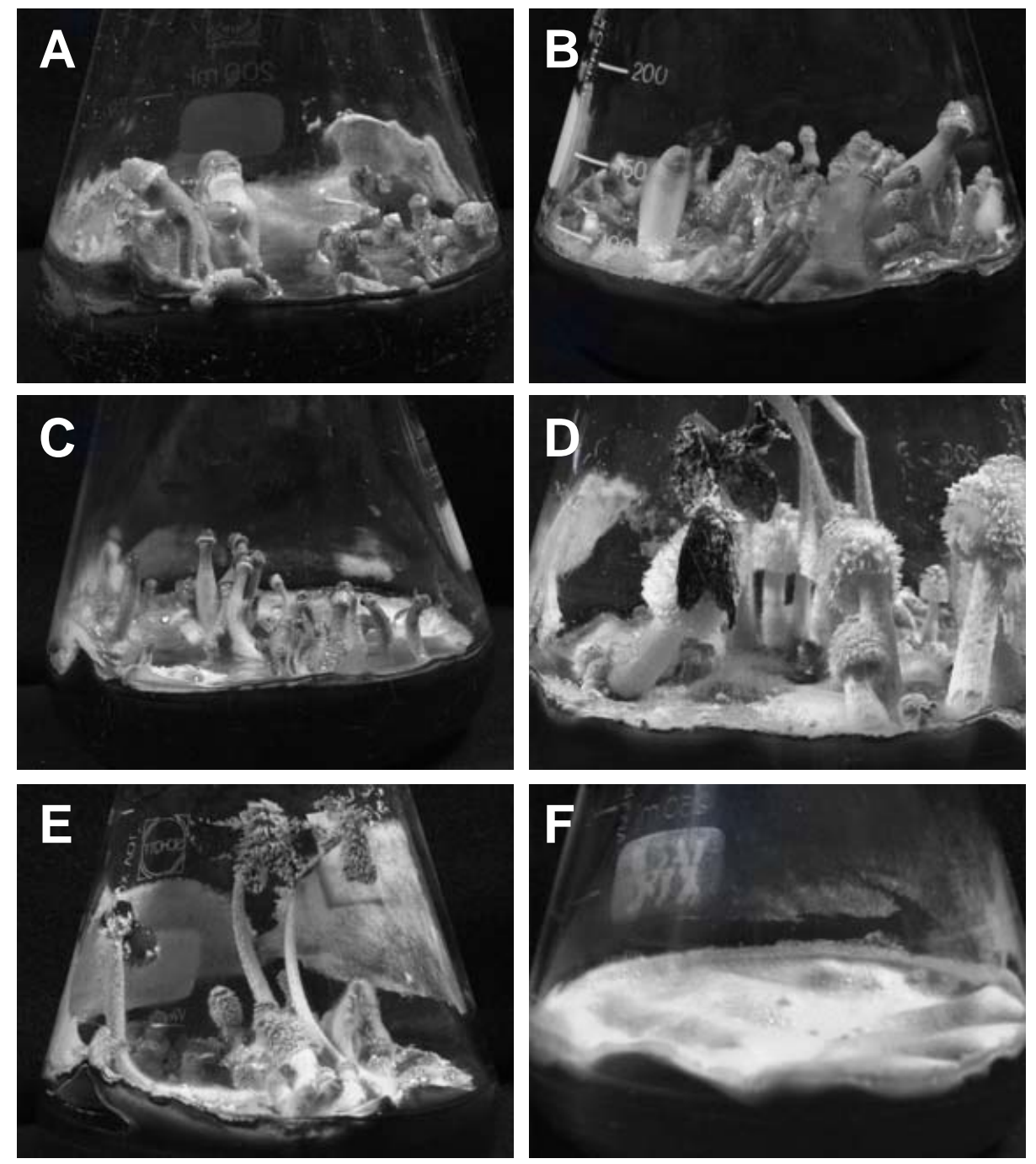

Figure 4 Development of fruiting structures in $\mathrm{CUSO}_{4}$ treated cultures of Coprinopsis cinerea. Etiolated stipes developed in cultures incubated at $37^{\circ} \mathrm{C}$ after 4 days of continuous darkness followed by day/night light periods (A). When cultures were incubated under continuous day/night light periods at $37^{\circ} \mathrm{C}$ in a chamber with a glass door in front of a window $(\mathbf{B})$ or under artificial light in a $12 \mathrm{~h}$ dark $/ 12 \mathrm{~h}$ light regime $(\mathbf{C})$, etiolated stipes developed. However, cultures incubated for 4 days at $37^{\circ} \mathrm{C}$ in darkness followed by incubation at $28^{\circ} \mathrm{C}$ or RT at day/night cycles developed matured fruiting bodies (D and E, respectively). Untreated cultures did not develop any fruiting structure although sometimes only small compact mycelial aggregates hard in structure appeared on the surface of the cultures (F, "rockeries", Kües 2000). 
Only small compact mycelial aggregates hard in structure appeared on the surface of the cultures ("rockeries"; Kües 2000) (Figure 3 and Figure 4). The overall results suggest that copper is an important element in induction of fruiting body development. Temperature however appears to the decisive whether, upon induction, the normal fruiting pathway is performed.

\subsubsection{Fruiting pathway of etiolated stipes in liquid cultures}

To find out at which stage the fruiting pathway stopped, a new set of cultures was prepared. Etiolated stipes were obtained from cultures grown at $37^{\circ} \mathrm{C}$ in darkness followed by incubation at the same temperature under $12 \mathrm{~h}$ dark $/ 12 \mathrm{~h}$ light rhythm. The etiolated stipes developed on these cultures were daily harvested in the morning, photographed and sectioned under a binocular microscope. The cultures were observed for 20 days. The first developmental structure visible was the hyphal knot at day 1 of incubation under dark/night rhythm (not shown). One day after, primordium stage 1 started to develop. These round compact structures were about $1 \mathrm{~mm}$ diameter (Figure 5, day 2). Under normal fruiting conditions $\left(28^{\circ} \mathrm{C}\right.$ dark/night rhythm), primordia maturation will take 4 days (see chapter 6 of this thesis). During the night from day 2 to day 3 , the primordial shaft will elongate abnormally giving raise to the so-called etiolated stipe of about $5 \mathrm{~mm}$ in length (Figure 5). In the rudimentary cap, gill cavities are starting to develop (Figure 5, day $3 \mathbf{A}$ ). After a further light signal, the etiolated stipe continued elongating, reaching a length up to $9 \mathrm{~mm}$. At this stage the primary and secondary gills are developing to accomplish the development of primordium stage 3 (Figure 5, day 4 B). One light signal after, the primordium reached the stage 4 where the mature veil is slowly free. The stipe elongated further, reaching about $12 \mathrm{~mm}$ in length (Figure 5, day $5 \mathrm{C}$ ). At this stage, the pre-karyogamic structure is completing the maturation of basidia in the gills that under normal conditions would lead to karyogamy some hours later. However, in etiolated stipes development arrested at this stage (Figure 5). 


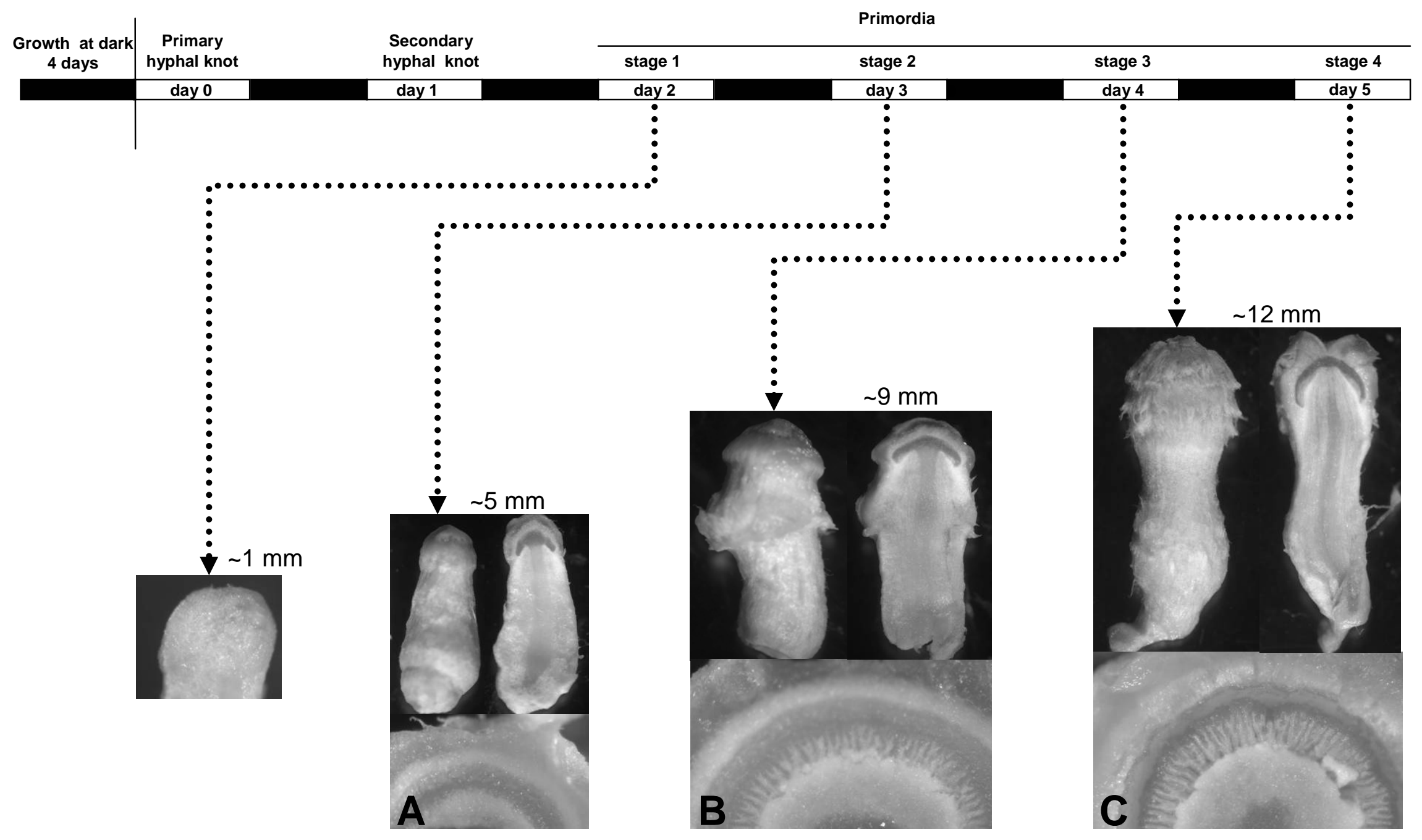


Figure 5 (previous page) Fruiting body development pathway of Coprinopsis cinerea in liquid cultures supplemented with $\mathrm{CuSO}_{4}$ incubated at $37^{\circ} \mathrm{C}$ in a $12 \mathrm{~h}$ dark $/ 12 \mathrm{~h}$ light regime, after 4 days growth in dark. Upon receipt of a light signal, primordia stage 1 will maturate over a period of 4 days. Within this period, gills on the cap develop (A-C). In parallel, the primordial shaft elongates during the night from day 2 to day 3 giving raise to an etiolated stipe. During the primordia maturation process, the stipe reaches about the double size from what a primordium should reach when incubated under standard fruiting conditions (see Figure 1 of chapter 6 of this thesis).

\subsubsection{Copper and fruiting in solid cultures}

The standard fruiting test for C. cinerea is performed on solid YMG/T media (Granado et al 1999). Regardless of whether cultures were previously grown at $37^{\circ} \mathrm{C}$ and $28^{\circ} \mathrm{C}$, under standard fruiting condition on $\mathrm{YMG} / \mathrm{T}$ plates, 1 to 2 mature fruiting bodies occurred (not shown, see statistics in Figure 6). Liquid YMG/T contains $0.43 \mu \mathrm{M}$ copper ions and YMG/T solidified with $1 \%$ agar contains $0.50 \mu \mathrm{M}$ copper ions (Kilaru et al. 2006). This small copper ions difference between liquid and solid media appears to have already an effect on the developmental decision to fruit (Figure 6), or not fruit (Figure 4), possibly together with the different consistency of the culture medium differentially supporting the appearance of aerial mycelium (Granado et al. 1997). To test effects of copper in solid medium in more detail, either $0.2 \mathrm{mM} \mathrm{CuSO}_{4}(0.2 \mathrm{mM})$ or $\mathrm{CuCl}_{2} \times 2 \mathrm{H}_{2} \mathrm{O}$ were added. For comparison, also the same series of metal ions tested before in liquid medium (Figure 2) were also included.

When C. cinerea was inoculated on solid YMG/T supplemented with either $\mathrm{CuSO}_{4}$, $\mathrm{CuCl}_{2} \times 2 \mathrm{H}_{2} \mathrm{O}, \mathrm{MgCl}_{6} 6 \mathrm{H}_{2} \mathrm{O}, \mathrm{MgSO}_{4}, \mathrm{FeCl}_{3} \times 6 \mathrm{H} 2 \mathrm{O}, \mathrm{FeSO}_{4} \times 7 \mathrm{H}_{2} \mathrm{O}, \mathrm{Fe}\left(\mathrm{NO}_{3}\right)_{3} \times 9 \mathrm{H}_{2} \mathrm{O}$ at a concentration of $0.2 \mathrm{mM}$, the cultures incubated directly from incubation onwards at the standard fruiting regime (constant $28^{\circ} \mathrm{C}$, day/night regime) showed a fluffy aerial mycelium. Magnesium and iron appeared to slightly induce growth speed. Cultures grown in presence of extra copper had colony sizes comparable to the controls (Figure 7A,B).

At $37^{\circ} \mathrm{C}$ in the dark, the fungus grows generally faster than at $28^{\circ} \mathrm{C}$. Also in such cultures, it was obvious that addition of $\mathrm{Mg}$ and $\mathrm{Fe}$ ions had often a positive effect on the growth speed. With addition of copper, there was a slight retardation in growth (Figure 7C, D). Furthermore, at $37{ }^{\circ} \mathrm{C}$ in dark with the occasional light signals due to 
daily checking cultures, there were dramatic effects on production of etiolated stipes in cultures containing extra copper and slight positive effects when adding either extra $\mathrm{Mg}$ or Fe ions (Figure 8).

If this effect is due to stimulation of fruiting body initiation, one would expect also more hyphal knots and primordia in cultures transferred into the standard fruiting condition at $28{ }^{\circ} \mathrm{C}$. When counting them in such plates, it was indeed the case (Figure 9). It is also interesting to note that in copper treated cultures, independently whether cultures were grown at $37^{\circ} \mathrm{C}$ or $28^{\circ} \mathrm{C}$, fruiting started all over the plates whilst in control plates this was not the case or less restricted to the edges of the plates (Figure 8,10 and not shown). However, whilst fruiting still initiated more or less scattered over the whole plates, the overall numbers of knots and primordia in cultures kept constantly at $28^{\circ} \mathrm{C}$ directly after inoculation were reduced (Figure 9). 

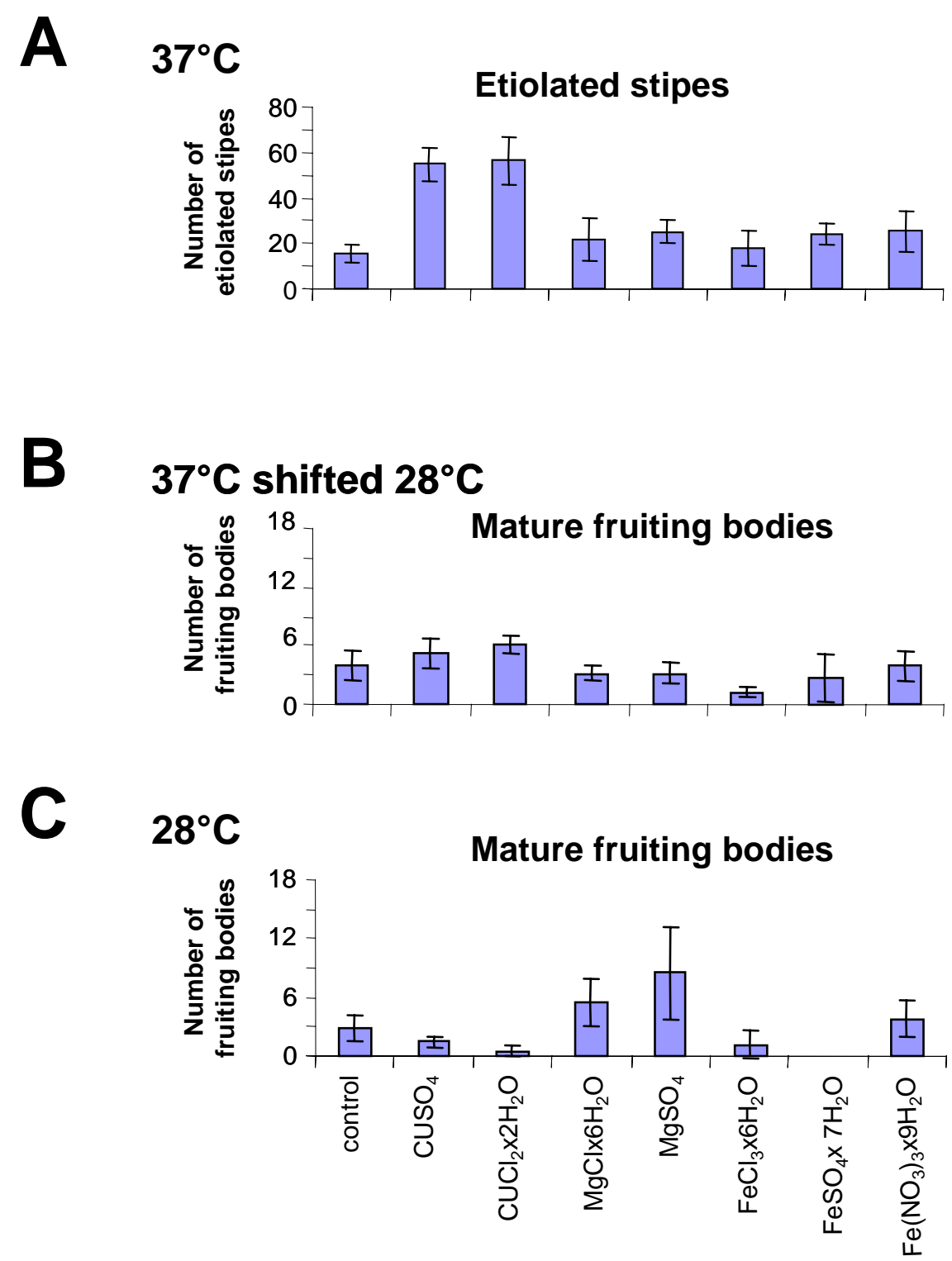

Figure 6 Amounts of etiolated stipes and fruiting bodies, respectively, in agar cultures of Coprinopsis cinerea AmutBmut in dependence of addition of metal ions. When cultures were kept constantly at $37^{\circ} \mathrm{C}$ in dark with short light pulses in between, etiolated stipes were formed and the number of etiolated stipes were enhanced by addition of metals, in particular by addition copper (A). At the standard fruiting conditions $\left(37^{\circ} \mathrm{C}\right.$ shift to $\left.28^{\circ} \mathrm{C}\right)$, copper sources enhanced the amount of mature fruiting bodies (B). However, in plates incubated continuously at $28^{\circ} \mathrm{C}$, magnesium sources enhanced fruiting body development. $\mathrm{FeSO}_{4} \times 7 \mathrm{H}_{2} \mathrm{O}$ treated cultures incubated continuously at $28^{\circ} \mathrm{C}$ were the only treated cultures unable to produce any fructification (C). Etiolated stipes in cultures were counted when structures were at least 0.5-1 $\mathrm{cm}$ in length. Fruiting bodies were counted when matured i.e. when stipe elongation and cap expansion occurred. In addition, in the cultures there were immature structures (e.g. hyphal knots and primordia) not counted in this analysis. 

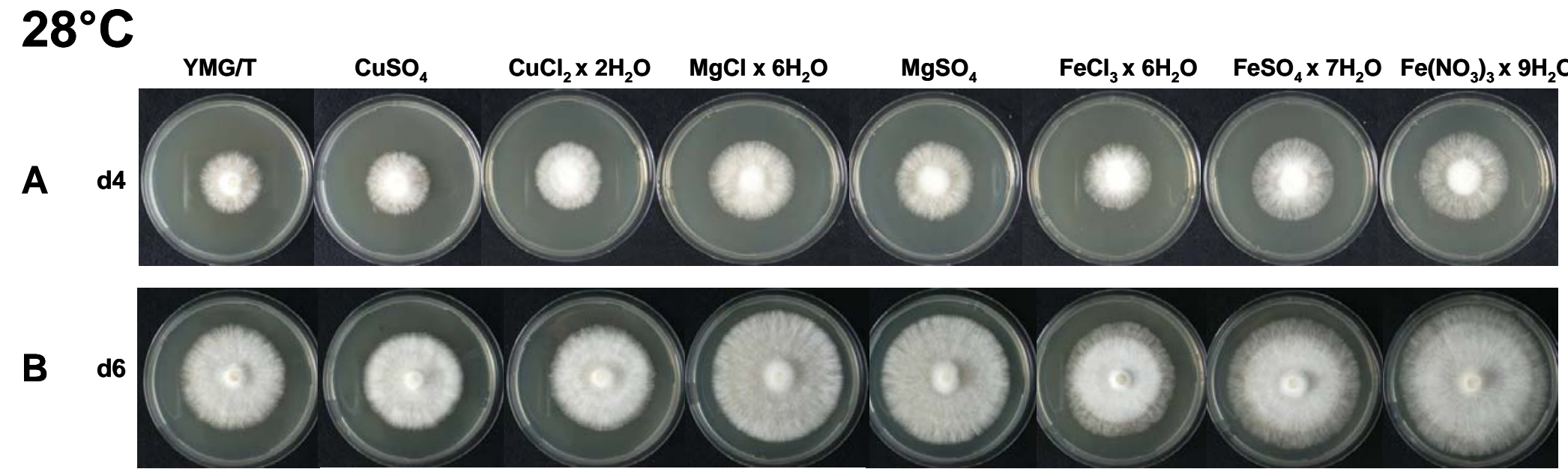

$37^{\circ} \mathrm{C}$

C d4

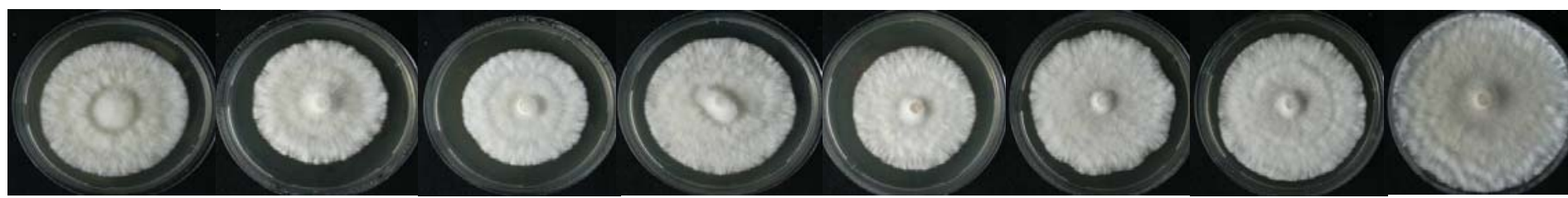

D d6

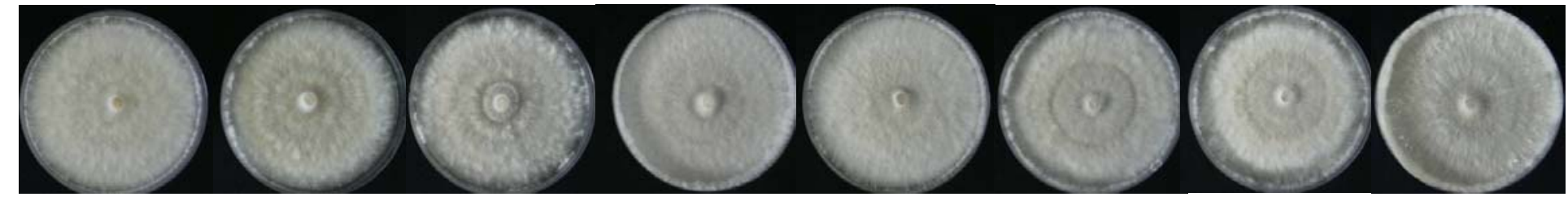

Figure 7 Appearance of cultures of Coprinopsis cinerea AmutBmut on agar media at the different treatments with metals incubated only at $28^{\circ} \mathrm{C}$ (standard fruiting regime $\left.\mathbf{A}, \mathbf{B}\right)$ and at $37^{\circ} \mathrm{C}(\mathbf{C}, \mathbf{D})$ at day 4 and day 6 of growth, respectively. Note that the mycelium grows faster and denser at $37^{\circ} \mathrm{C}$. 


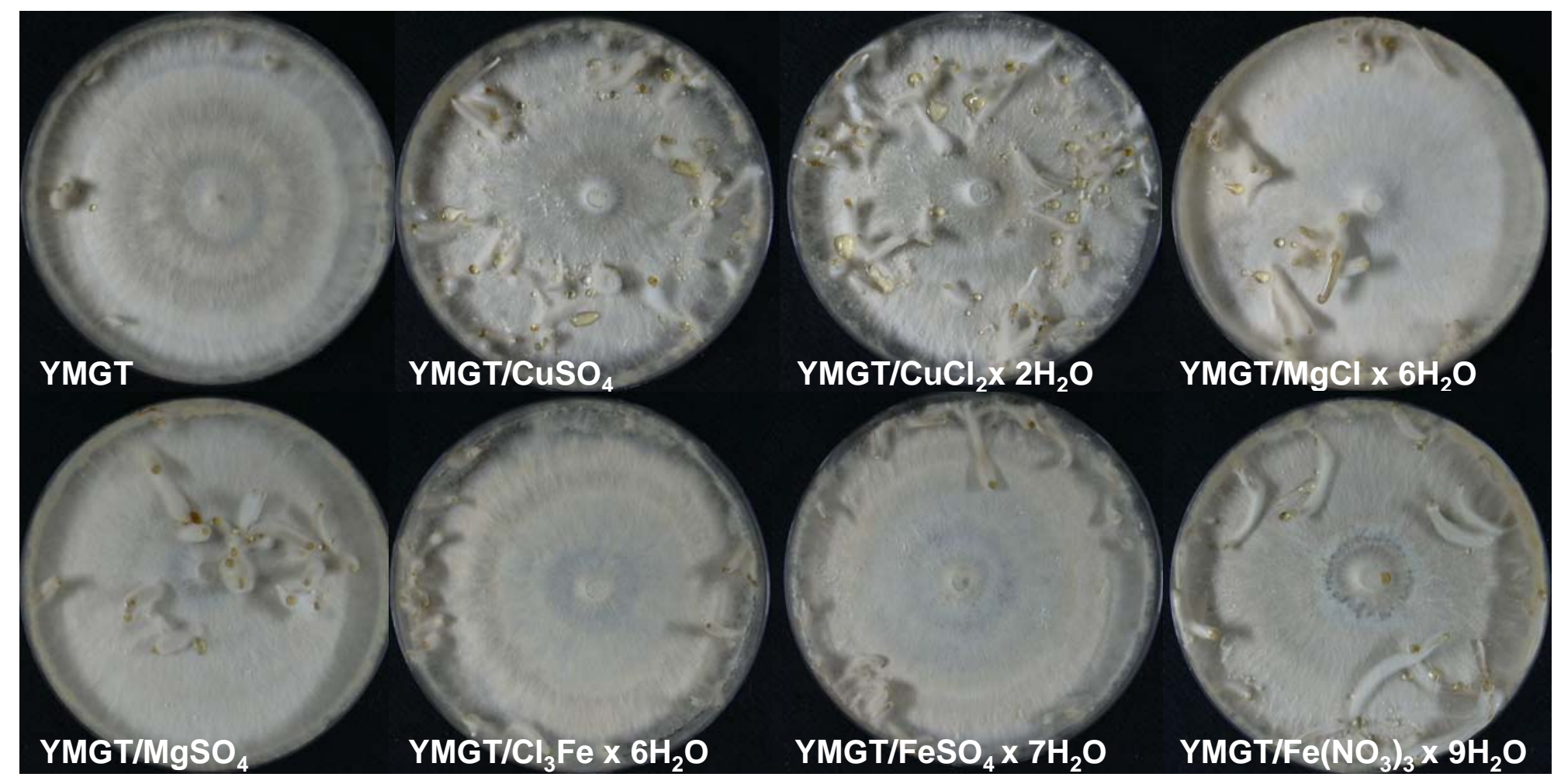

Figure 8 Etiolated stipes and mature fruiting bodies in cultures of Coprinopsis cinerea AmutBmut kept after inoculation at $37^{\circ} \mathrm{C}$ in the darkness with occasional light signals given due to daily checking and sampling of the cultures. Solid cultures treated with different metals affected fruiting body development in different ways. At $37^{\circ} \mathrm{C}$, all treatments lead to development of etiolated stipes but at different amounts. Note also the different positioning of the etiolated stipes in the different cultures (compare scheme in Figure 10). 
A $37^{\circ} \mathrm{C}$

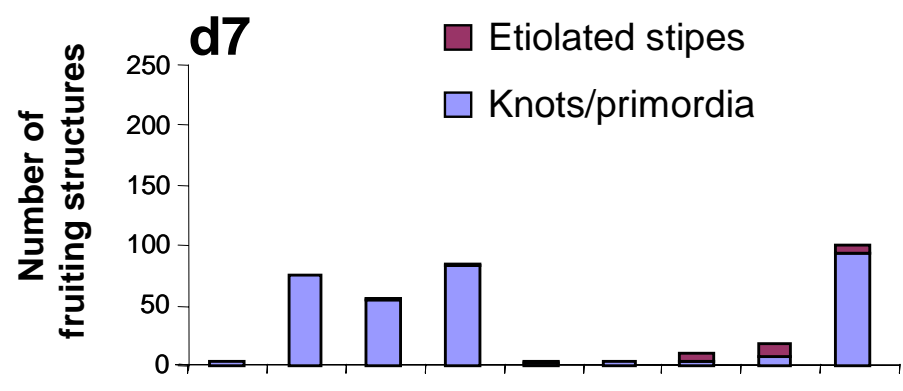

B $37^{\circ} \mathrm{C}$ shifted $28^{\circ} \mathrm{C}$

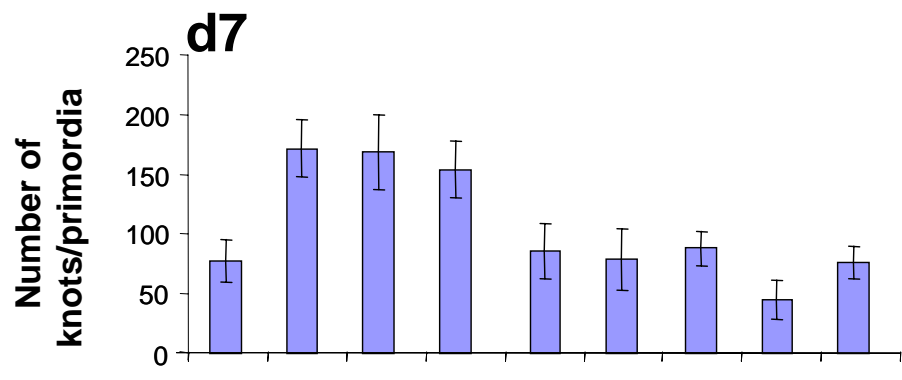

C $28^{\circ} \mathrm{C}$

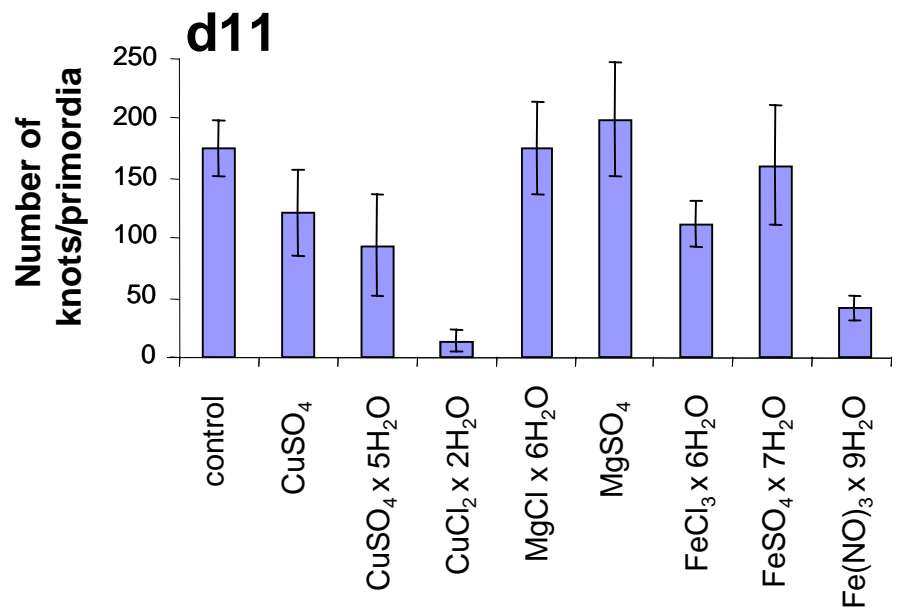

Figure 9 Hyphal knot and primordia/etiolated stipes formation in cultures of Coprinopsis cinerea AmutBmut cultivated an $\mathrm{YMG} / \mathrm{T}$ with different metals under three different temperature regimes. Solid cultures treated with the different metals showed a strong influence in fruiting body initiation in cultures grown at $37^{\circ} \mathrm{C}$. 


$\begin{array}{lllll}\mathrm{YMG} / \mathrm{T} & \mathrm{CuSO}_{4} & \mathrm{MgSO}_{4} & \mathrm{Cl}_{3} \mathrm{Fe} \times 6 \mathrm{H}_{2} \mathrm{O} & \mathrm{FeSO}_{4} \times 7 \mathrm{H}_{2} \mathrm{O} \\ & \mathrm{CuCl}_{2} \times 2 \mathrm{H}_{2} \mathrm{O} & {\mathrm{MgCl} \times 6 \mathrm{H}_{2} \mathrm{O}} & & \\ \mathrm{CuSO}_{4} \times 5 \mathrm{H}_{2} \mathrm{O} & & & \end{array}$

$37^{\circ} \mathrm{C}$
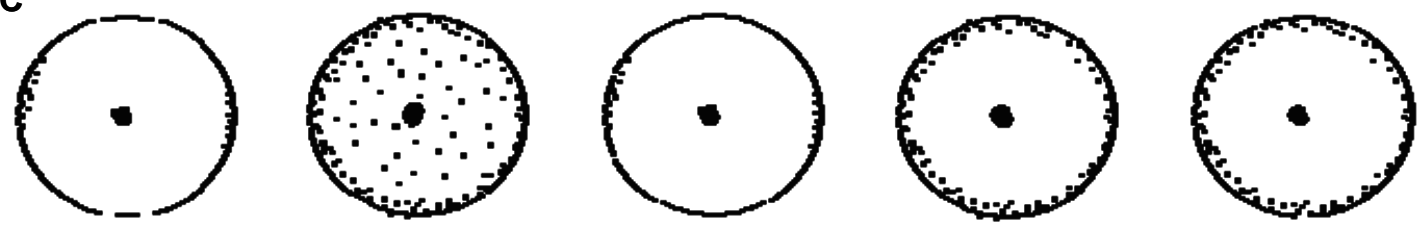

$37^{\circ} \mathrm{C}$ shifted $28^{\circ} \mathrm{C}$
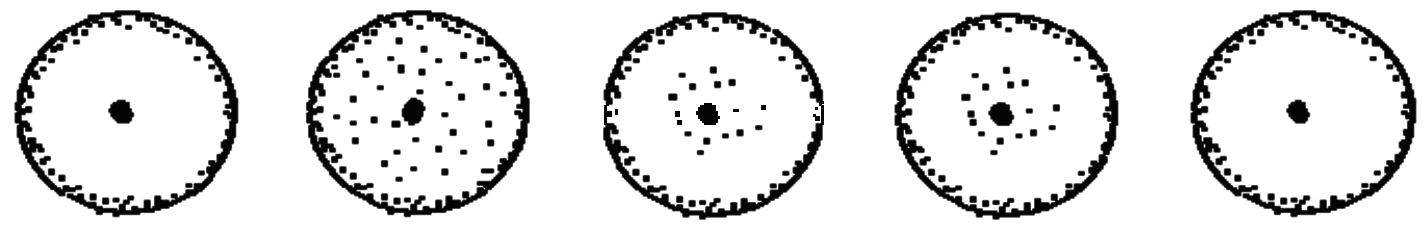

$28^{\circ} \mathrm{C}$
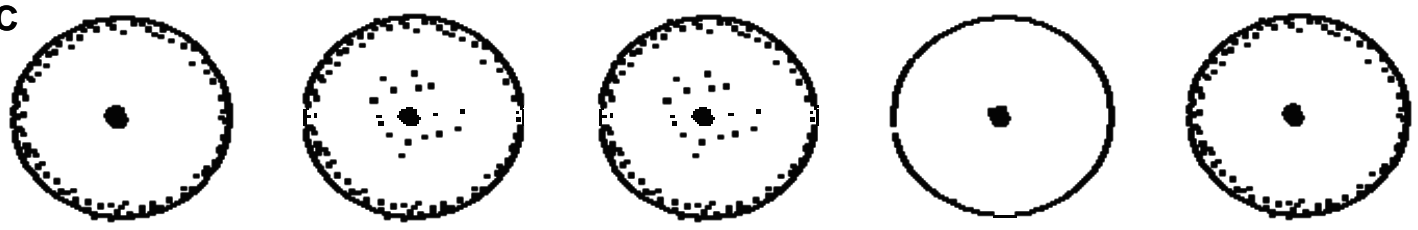

Figure 10 Metals supplemented to cultures of Coprinopsis cinerea had an influence on the distribution of the fruiting initiation. Copper sources induced fruiting abundantly all over the plates, magnesium at the edges and on the centre of the plate. In iron treated cultures fruiting body development initiated at the youngest mycelia at the edges of the plate as in control cultures.

\subsubsection{Other effects by copper in liquid cultures at $37^{\circ} \mathrm{C}$}

Initiation of etiolated stipes in cultures supplemented with $\mathrm{CuSO}_{4}(0.2 \mathrm{mM})$ incubated at $37^{\circ} \mathrm{C}$ (Figure 2) correlates with several changes in the supernatant: laccase production, an increase of $\mathrm{pH}$ from 5.5 to a slightly alkaline $\mathrm{pH}$, ammonium production, as well as nitrate reductase activity in fungal mycelium (Figure 11). A stronger enzymatic activity of cell wall bound laccase and even a stronger activity of intracellular nitrate reductase occurs just at the point when fructification starts $(\mathrm{d} 4$, hyphal knot formation), whilst nitrate reductase activity decreased abruptly 2 days after initiation, and laccase activity in the medium raised slowly after initiation of fruiting (Figure 11). 


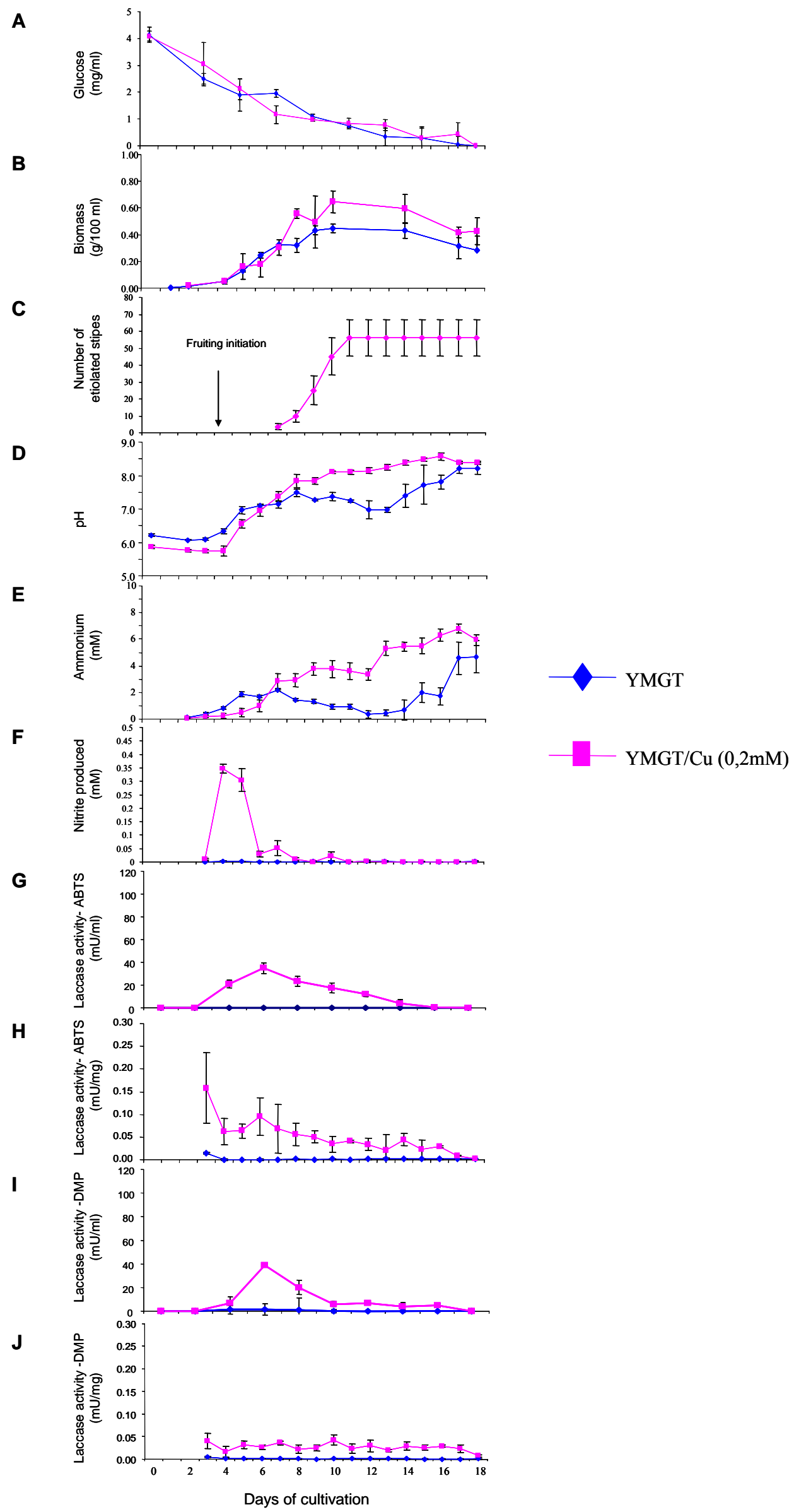


Figure 11 (previous page) During the growth of the $C$. cinerea AmutBmut cultures on YMG/T and $\mathrm{YMG} / \mathrm{T}$ supplemented with $\mathrm{CuSO}_{4}(0.2 \mathrm{mM})$ at $37^{\circ} \mathrm{C}$, several changes occur in the cultures. Particularly, fructification in form of hyphal knots initiated on day 4 of cultivation (see arrow in C). A. Glucose consumption over the time. B. Increase in biomass over the time. C. Fruiting initiation and etiolated stipe formation in cultures. D. Increase in $\mathrm{pH}$ over the time. E. Increase in ammonium concentration over the time. F. Nitrate reductase activity in the cultures. G. Laccase activity in supernatant as measured with ABTS. H. Cell wall laccase activity as measured with ABTS. I. Laccase activity in supernatant as measured with DMP. J. Cell wall laccase activity as measured with DMP.

Laccase production has repeatedly been linked to fruiting initiation. However, its direct role in fruiting body development is not clear. In laccase tests, cultures treated with $\mathrm{CuSO}_{4}$ showed higher laccase-bound activity as well as free activity in the medium, both with ABTS and DMP (Figure 11G-J). In contrast, in untreated cultures laccase activity was not detected (Figure 11G-J). With onset of fruiting and laccase activity in the copper treated cultures, the $\mathrm{pH}$ slowly decreased (Figure 11D). At highest laccase activity in the medium a pH of about 7.0 was measured (compare 11D and 11G). Unlike most other laccases (Baldrian 2006, Kilaru 2006), laccases of C. cinerea are reported to be active at pH 7.0 (Schneider et al. 1999, Kilaru 2006).

An increase in $\mathrm{pH}$ was quite surprising, since many fungi acidify media and prefer to grow in the range of 4.0 to 7.0 (Alexopoulos et al. 1996). In cultures of C. cinerea, we observed that the increase in $\mathrm{pH}$ correlated with ammonia production (Figure 11E). C. cinerea is a known ammonia fungus (Sagara 1975, Soponsathien 1998).

Ammonia fungi are mostly saprotrophic species reported to occur sequentially on soil after treatment with urea, aqueous ammonia, or nitrogen compounds that by decomposition into ammonia cause an alkaline condition in the soil by decomposition into ammonia (Sagara 1975, 1992). C. cinerea belongs to the small group of fungi that grow and fruit the under alkaline conditions (Morimoto et al. 1981, see chapter 5 of this thesis). Under laboratory experiments, presence of ammonia to the media at least for 24 $\mathrm{h}$ was enough to induce primordium formation in $5 \mathrm{~d}$ old colonies in darkness (Morimoto et al. 1981). That the fungus activity changes the $\mathrm{pH}$ into the alkaline range by ammonia production is a new observation in this thesis, although the principle capability of ammonia production by the fungus has been previously shown (Kaliz et al. 1986, Moore 1998). 
We tested activity of nitrate reductase but the activity was much localized over the developing time and did not correlate to ammonia production (Figure 11). Moreover, we tested nitrite reductase activity that transforms the product of nitrate reductase action into ammonia (Moore 1998), but could not detect any activity of the nitrite reductase (not shown). Thus, it is rather unlikely that these enzymes are responsible for the observed ammonia production. In future, other enzymes activities such as urease (Imamura et al. 2006) might be tested to define the origin of ammonium. For inducing fruiting body development, a change of $\mathrm{pH}$ in the media was not enough; when the cultures were treated with either $0.2 \mathrm{M} \mathrm{MgClx} 6 \mathrm{H}_{2} \mathrm{O}, \mathrm{MgSO}_{4}, \mathrm{FeCl}_{3} \mathrm{x} 6 \mathrm{H}_{2} \mathrm{O}$, $\mathrm{FeSO}_{4} \times 7 \mathrm{H}_{2} \mathrm{O}$, or $\left.\mathrm{Fe}\left(\mathrm{NO}_{3}\right)_{3} \times 9 \mathrm{H}_{2} \mathrm{O}\right)$, the $\mathrm{pH}$ also went alkaline in similar manners, but fructifications did not occur (not shown). Rao and Niederpruem (1969) reported that in standard fruiting conditions, fruiting is triggered upon exhaustion of the glucose in the substrate. In the experiments reported here, in copper treated cultures fruiting started once half of glucose has been depleted (Figure 11A). At this time point, considerable amounts of biomass were produced (Figure 11B).

\subsubsection{Transcript profiles for the nitrate assimilation gene cluster}

Nitrogen is a major component of nearly all of the complex macromolecules of all living organisms. In concordance, most organisms have elaborate control mechanisms to provide a constant supply of nitrogen. Fungi can use a wide array of compounds as nitrogen sources and are capable of expressing upon demand the catabolic enzymes of many different pathways of nitrogen metabolism. Extensive studies of nitrogen metabolism and its regulation have been conducted with Saccharomyces cerevisae, Aspergillus nidulans and Neurospora crassa (Marzluf 1997). Nitrogen is also an important signal for other aspects of growth including morphological development and the production of metabolites (Caddick 2004). In C. cinerea, there is little known about the nitrogen metabolism in the mycelia (Moore 1998). Nitrate reductase, a large homodimeric multiredox protein, catalyzes the conversion of nitrate to nitrite. This enzyme was found to have a high activity at the onset of fructification in cultures treated with copper and decreased abruptly once etiolated stipes were established (see above Figure 11F). According to Moore (1998), the fungus $C$. cinerea uses this energy demanding enzyme when no other nitrogen source is available to the fungus. Fruiting body initiation requires a lot of energy as well as carbon and nitrogen sources and activation of nitrate reductase activity may support the process by supplying accessible 
nitrogen to the quickly proliferating cells of the developing fruiting structure. In order to get further insight into nitrogen metabolism, transcription of these nitrate reductase gene was followed up together with transcript of the genes for nitrite reductase and nitrogen transporter being present together in the genome of the fungus in a nitrogen cluster. In semiquantitative cDNA analysis nitrate reductase (narl) and nitrite reductase (nirl) gave similar results in expression in copper treated and untreated mycelium over the time. It appears that these two genes are constitutively expressed in mycelium until day 10 (see Figure 12). When in the cultures glucose was fully used up, biomass entered the stationary phase and no further development of fruiting structures were observed (Figure 11A-C).

Looking at the expression of the gene nrt2 for the nitrogen transporter, there appears to be an effect by copper on expression during the logarithmic growth of the cultures (day 3 to day 6). Expression of $n r t 2$ in older cultures was similar between the treatments and there was low level expression at the stationary growth phase in both types of cultures and in etiolated stipes. In etiolated stipes, tested on day 9 and 10, there was also no expression of genes narland nirl.

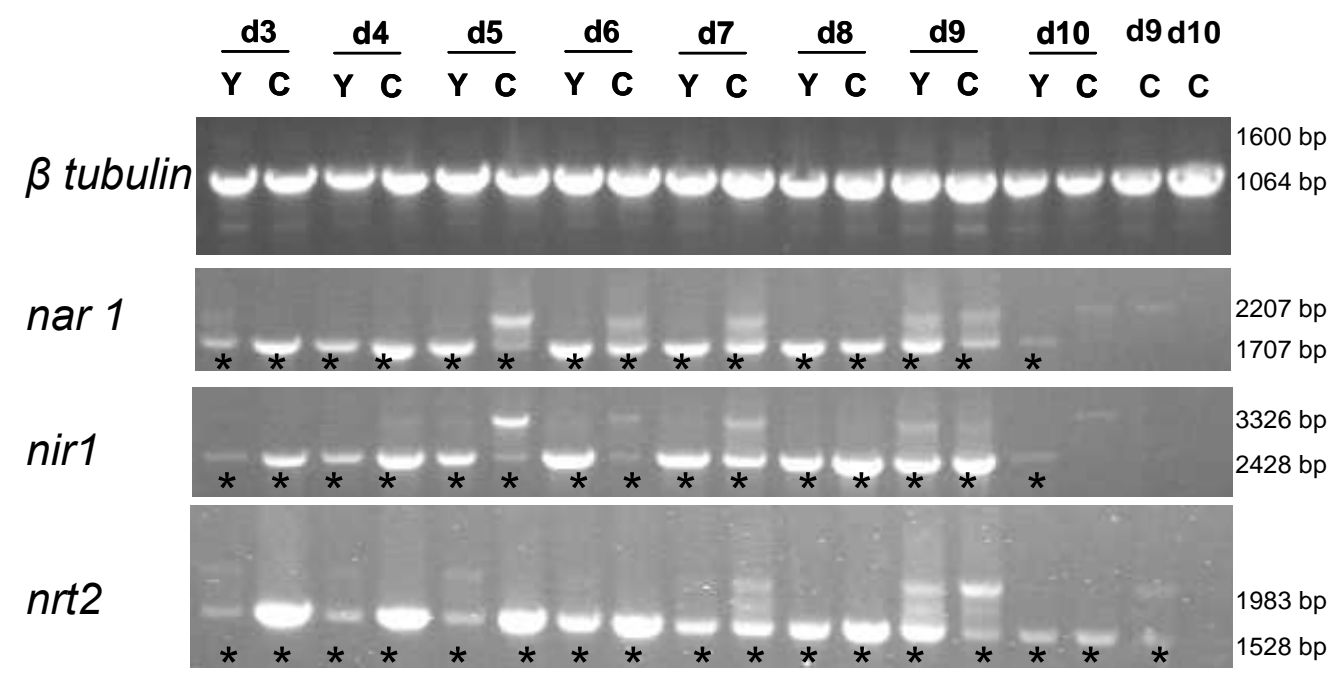

Figure 12 Transcript analysis of the nitrogen assimilation cluster in vegetative mycelium over the time. RNA was isolated as described in the methods, transformed into cDNA and specific cDNAs were amplified by PCR. Both mycelium from copper treated (C) and untreated (Y) mycelium were analyzed over several days of incubation in liquid medium at $37^{\circ} \mathrm{C}$. Amplification of the $\beta$-tubulin cDNA served as quality control of the cDNA and the PCR reactions. Samples $\mathrm{d} 9$ and $\mathrm{d} 10$ (C) correspond to etiolated stipes obtained from the copper treated cultures at $37^{\circ} \mathrm{C}$. The asterisk $(*)$ mark the PCR amplified cDNAs of expressed genes whereas the unmarked bands correspond to the genomic DNA sizes of the respective genes. 


\subsection{Conclusions}

From the different laccase inducers tested, copper sulphate and copper chloride $(0.2 \mathrm{mM})$ had a positive effect on laccase production of the basidiomycete $C$. cinerea. Laccase showed higher activity when cultures were tested in ABTS than with DMP. Besides laccase induction, copper had additional effects on the metabolism of the fungi, such as increasing ammonia production, inducing development of etiolated stipes at the temperature unusual temperature of $37^{\circ} \mathrm{C}$ and inducing enzymatic activity of nitrate reductase. However, transcript analysis shows the nitrate assimilation gene cluster is active also in untreated cultures. To clarify the effect of copper in this respect, further studies at standard fruiting body conditions are required. To our best knowledge, there is no report that copper induces fruiting at higher temperatures. Fruiting body development is a complex process that involves the synchrony of several factors, the way how copper dramatically affects the fruiting pathway is a question that keeps open; therefore further research on this issue is required in the future.

\subsection{Acknowledgments}

I would like to thank Dr. Patrik J. Hoegger for the support in the molecular biology work, and Dr. Kateřina Svobodová for her kind advices on the nitrate reductase assay.

\subsection{References}

Alexopoulos CJ, Mims CW, Blackwell M (1996) Introductory mycology. John Wiley and Sons, N.Y., USA.

Baldrian P, Gabriel J (2002) Copper and cadmium increase laccase activity in Pleurotus ostreatus. FEMS Microbiol. Lett., 206, 69-74.

Baldrian P (2003) Interactions of heavy metals with white rot fungi. Enzyme Microb. Tech., 32, 78-91.

Baldrian P (2006) Fungal laccases - occurrence and properties. FEMS Microbiol. Rev., $30,215-242$.

Bonnen AM, Anton LH, Orth AB (1994) Lignin-degrading enzymes of the commercial button mushroom, Agaricus bisporus. Appl. Environ. Microbiol., 60, 960-965.

Botton B, Chalot M (1991) Techniques for the study of nitrogen-metabolism in ectomycorrhiza. Methods in Microbiol., 23, 203-252. 
Boulianne RP, Liu Y, Aebi M, Lu BC, Kües U (2000) Fruiting body development in Coprinus cinereus: regulated expression of two galectins secreted by a nonclassical pathway. Microbiol., 146, 1841-1853.

Broxholme SJ, Read ND, Bond DJ (1991) Developmental regulation of proteins during fruit-body morphogenesis in Sordaria brevicollis. Mycol. Res., 95, 958-969.

Buswell JA, Cai Y, Chang S (1995) Effect of nutrient nitrogen and manganese on manganese peroxidase and laccase production by Lentinula (Lentinus) edodes. FEMS Microbiol. Lett., 128, 81-88.

Caddick MX (2004) Nitrogen regulation in mycelial fungi. In: Brambl R, Marzluf GA (eds.) The mycota III. Biochemistry and molecular biology, 2nd edition. Springer-Verlag, Berlin-Heidelberg, Germany.

Chen S, Ma D, Ge W, Buswell JA (2003) Induction of laccase activity in the edible straw mushroom Volvariella volvacea. FEMS Microbiol. Lett., 218, 143-148.

Chen S, Ge W, Buswell JA (2004) Molecular cloning of a new laccase from the edible straw mushroom Volvariella volvacea: possible involvement in fruit body development. FEMS Microbiol. Lett., 230, 171-176.

Collins PJ, Dobson ADW (1997) Regulation of laccase gene transcription in Trametes versicolor. Appl. Env. Microbiol., 63, 3444-3450.

Dittmer JK, Patel NJ, Dhawale SW, Dhawale SS (1997) Production of multiple laccase isoforms by Phanerochaete chrysosporium grown under nutrient sufficiency. FEMS Micriobiol. Lett., 149, 65-70.

Galhaup C, Goller S, Peterbauer CK, Strauss J, Haltrich D (2002) Characterization of the major laccase isoenzyme from Trametes pubescens and regulation of its synthesis by metal ions. Microbiol., 148, 2159-2169.

Gerard GF, D’Alessio JM (1993) Enzymes of Molecular Biology. Chapter 6. In: Burell MM (ed.), Methods in Molecular Biology. Human Press Inc., Totowa, NJ. USA. pp. 73-93.

Gianfreda L, Xu F, Bollag JM (1999) Laccases: a useful group of oxidoreductive enzymes. Biorem. J., 3, 1-25.

Granado JD, Kertesz-Chaloupková K, Aebi M, Kües U (1997) Restriction enzymemediated DNA integration in Coprinus cinereus. Mol. Gen. Genet., 256, 28-36.

Imamura A, Yumoto T, Yanai J (2006) Urease activity in soild as a factor affecting the succession of ammonia fungi. J. Forest Res., 11, 131-135. 
Jargeat P, Rekangalt D, Verner MC, Gay G, Debaud JC, Marmeisse R, FraissinetTachet A (2003) Characterization and expression analysis of a nitrate transporter and nitrite reductase genes, two members of a gene cluster for nitrate assimilation from the symbiotic basidiomycete Hebeloma cylindrosporum. Curr. Genet., 43, 199-205.

Jarosz-Wilkołazka A, Malarczyk E, Pirszel J, Skowroński T, Leonowicz A (2002) Uptake of cadmium ions in white-rot fungus Trametes versicolor: Effect of $\mathrm{Cd}$ (II) ions on the activity of laccase. Cell Biol. Int., 26, 605-613.

Johannes C, Majcherczyk A (2000) Natural mediators in the oxidation of polycyclic aromatic hydrocarbons by laccase mediator systems. Appl. Environ. Microbiol., $66,524-528$.

Kaliz HM, Moore D, Wood DA (1986) Protein utilization by basidiomycete fungi. Trans. Br. Mic. Soc., 86, 519-525.

Kilaru S, Hoegger PJ, Kües U (2006) The laccase multi-gene family in Coprinopsis cinerea has seventeen different members that divide into two distinct subfamilies. Curr. Genet., 50, 45-60.

Kües U (2000) Life history and developmental processes in the basidiomycete Coprinus cinereus. Microbiol Mol. Biol. Rev., 64, 316-353.

Kües U, Liu Y (2000) Fruiting body production in basidiomycetes. Appl. Microbiol. Biotechnol., 54, 141-152.

Kües U, Künzler M, Bottoli APF, Walser PJ, Granado JD, Liu Y, Bertossa RC, Ciardo D, Clergeot P-H, Loos S, Ruprich-Robert G, Aebi M (2004) Mushroom development in higher basidiomycetes. Implications for human and animal health. In: Kushwaha RKS (ed.) Fungi in Human and Animal Health. Scientific Publishers, Jodhpur, India, pp. 431-470.

Langfelder K, Streibel M, Jahn B, Haase G, Brakhage AA (2003) Biosynthesis of fungal melanins and their importance for human pathogenic fungi. Fungal Genet. Biol., 38, 143-158.

Leatham GF, Stahmann MA (1981) Studies on the laccase of Lentinus edodes: specificity, localization and association with the development of fruiting bodies. J. Gen. Microbiol., 125, 147-157.

Lu BC (1974a) Genetic recombination in Coprinus. IV A kinetic study of the temperature effect on recombination frequency. Genetics, 78, 661-677. 
Lu BC (1974b) Meiosis in Coprinus. V. The role of light on basidiocarp initiation, mitosis and hymenium differentiation in Coprinus lagopus. Can. J. Bot., 52, 299-305.

Madelin MF (1956a) The influence of light and temperature on fruiting of Coprinus lagopus Fr. in pure culture. Ann. Bot., 20, 467-481.

Madelin MF (1956b) Studies on the nutrition of Coprinus lagopus Fr. especially as affecting fruiting. Ann. Bot., 20, 307-330.

Marzluf GA (1997) Genetic regulation of nitrogen metabolism in the fungi. Microbiol. Mol. Biol. Rev., 61, 17-32.

Matsumura E, Yamamoto E, Numata A, Kawano T, Shin T, Murao S (1986) Structures of the laccase-catalyzed oxidation products of hydroxybenzoic acids in the presence of ABTS (2,2'-azino-di-(3-ethylbenzothiazoline-6-sulfonic acid)). Agric. Biol. Chem., 50, 1355-1357.

Molitoris HP, Esser K (1970) Phenoloxidases of Ascomycete Podospora anserina. V. Properties of laccase after purification. Arch. Mikrobiol., 72, 267-296.

Moore D (1998) Fungal morphogenesis. Cambridge University Press, Cambridge, UK.

Morimoto N, Suda S, Sagara N (1981) Effect of ammonia on fruit-body induction of Coprinus cinereus in darkness. Plant Cell Physiol., 22, 247-254.

Nosanchuk JD, Casadevall A (2003) The contribution of melanin to microbial pathogenesis. Cell. Microbiol., 5, 203-223.

Ohga S, Smith M, Thurston CF, Wood DA (1999) Transcriptional regulation of laccase and cellulase genes in the mycelium of Agaricus bisporus during fruit body development on a solid substrate. Mycol. Res., 103, 1557-1560.

Ohga S, Royse DJ (2001) Transcriptional regulation of laccase and cellulase genes during growth and fruiting of Lentinula edodes on supplemented sawdust. FEMS Microbiol. Lett., 201, 111-115.

Palmieri G, Giardina P, Bianco C, Fontanella B, Sannia G (2000) Copper induction of laccase isoenzymes in the lignolytic fungus Pleurotus ostreatus. Appl. Environ. Microbiol., 66, 920-924.

Phillips LE, Leonard TJ (1976) Extracellular and intracellular phenoloxidase activity during growth and development in Schizophyllum. Mycologia, 68, 268-276.

Plassard C, Mousain D, Salsac L (1984a) Mesure in vitro de l'activité nitrate réductase dans les thalles de Hebeloma cylindrosporum, champignon basidiomycete. Physiologie Végétale, 22, 67-74. 
Plassard C, Mousain D, Salsac L (1984b) Mesure in vitro et in vivo de l'activité nitrite réductase dans les thalles de Hebeloma cylindrosporum, champignon basidiomycete. physiologie Végétale, 22, 147-154.

Rao PS, Niederpruem DJ (1969) Carbohydrate metabolism during morphogenesis of Coprinus lagopus (sensu Buller). J. Bacteriol., 100, 1222-1228.

Ross IK (1982a) Localization of carpophore initiation in Coprinus congregatus. J. Gen. Microbiol., 128, 2755-2762.

Ross IK (1982b) The role of laccase in carpophore initiation in Coprinus congregatus. J. Gen. Microbiol., 128, 2763-2770.

Sagara N (1975) Ammonia fungi- A chemoecological grouping of terrestrial fungi. Contrib. Biol. Lab. Kyoto Univ., 24, 205-276.

Sagara N (1992) Experimental disturbances and epigeous fungi. In: Carroll GC, Wicklow DT (eds.), The fungal community: its organization and role in ecosystem. Dekker, New York, N.Y., USA. pp. 427-454.

Sambrook J, Russell DW (2001) Molecular cloning. A laboratory manual. 3rd edn. Cold Spring Harbor Laboratory Press, Cold Spring Harbor, N.Y., USA.

Schneider P, Caspersen MB, Mondorf K, Halkier T, Skov LK, Ostergaard PR, Brown KM, Brown SH, Xu F (1999) Characterization of a Coprinus cinereus laccase. Enzyme Microb. Tech., 25, 502-508.

Seitz LC, Tang KL, Cummings WJ, Zolan ME (1996) The rad9 gene of Coprinus cinereus encodes a proline-rich protein required for meiotic chromosome condensation and synapsis. Genetics, 142, 1105-1117.

Soden DM, Dobson ADW (2001) Differential regulation of laccase gene expression in Pleurotus sajor-caju. Microbiology, 147, 1755-1763.

Soponsathien S (1998) Some characteristics of ammonia fungi 1. In relation to their ligninolytic enzyme activities. J. Gen. Appl. Microbiol., 44, 337-345.

Swamy S, Uno I, Ishikawa T (1984) Morphogenetic effects of mutations at the $A$ and $B$ incompatibility factors in Coprinus cinereus. J. Gen. Microbiol., 130, 32193224.

Tsusué YM (1969) Experimental control of fruit-body formation in Coprinus macrorhizus. Dev. Growth Differ., 11, 164-178.

Vnenchak P, Schwalb MN (1989) Phenol oxidase activity during development of Coprinus cinereus. Mycol. Res., 93, 546-548. 
Wood DA (1980) Inactivation of extracellular laccase during fruiting of Agaricus bisporus. J. Gen. Microbiol., 117, 339-345.

Wessels JHG (1993) Fruiting in higher fungi. Adv. Microb. Physiol., 34, 147-202.

Yaver DS, Xu F, Golightly EJ, Brown KM, Brown SH, Rey MW, Schneider P, Halkier T, Mondorf K, Dalbøge H (1996) Purification, characterization, molecular cloning, and expression of two laccase genes from the white rot basidiomycete Trametes villosa. Appl. Environ. Microbiol., 62, 834-841.

Zhao J, Kwan HS (1999) Characterization, molecular cloning, and differential expression analysis of laccase genes from the edible mushroom Lentinula edodes. Appl. Environ. Microbiol., 65, 4908- 4913.

Zolan ME, Pukkila PJ (1986) Inheritance of DNA methylation in Coprinus cinereus. Mol. Cell. Biol., 6, 195-200. 

8

\section{Transcript profiles of laccase genes} during fruiting body development in Coprinopsis cinerea (Coprinus cinereus)

Contribution to this chapter: All experimental work and preparation of the manuscript was performed by the author of this thesis. cDNA samples from Coprinopsis cinerea AmutBmut were obtained from Dr. Rajesh Velagapudi. Specific laccase primers were obtained from parallel work of Dr. Sreedhar Kilaru. 


\section{Transcript profiles of laccase genes during fruiting body development in Coprinopsis cinerea (Coprinus cinereus)}

\subsection{Abstract}

Laccases are phenol-oxidizing multi-copper enzymes produced by fungi, plants, insects and bacteria. Fungal laccases are involved in important physiological processes such as fruiting body development. In order to further determine a role of fungal laccases in fruiting, we describe expression of laccase encoding genes in different stages of fruiting body development and different fruiting body tissues of the basidiomycete Coprinopsis cinerea (Coprinus cinereus). 17 different genes for laccases have been found previously in the genome of C. cinerea. In this work, of the total of 17 genes expression of 15 genes has been shown by RT-PCR analysis to occur during vegetative and/or fungal development in different $C$. cinerea strains. A few genes had transcripts in the mycelium (lcc2, lcc4, lcc5, lcc9, lcc11, lcc 12, lcc17) although there were some strainspecific differences. Most of the genes appear to function in fruiting. There is no tissue specific expression pattern that can be recognized.

Keywords: Inkcap mushroom, basidiomycete, phenoloxidases, laccase expression 


\subsection{Introduction}

The complex process of fruiting body development in basidiomycetes is regulated by several environmental and genetic factors. Between the environmental signals, nutrient depletion, the $\mathrm{C}$ to $\mathrm{N}$ relationship, temperature, day/night rhythm, humidity oxygen and $\mathrm{CO}_{2}$ concentration are the most remarkable factors (Kües 2000). On the other hand, only very few genetic factors influencing fruiting development are known so far. The main regulators of development are the mating type genes (Wessels 1993, Kües 2000, Kües and Liu 2000, Kües et al. 2004).

Although laccase specific physiological functions are not completely understood, there are several indications that they are also involved in the processes of fruiting body formation in ascomycetes (Labarère and Bernet 1978, Hermann et al. 1983, Broxholme et al. 1991) and basidiomycetes (Wessels 1993, Kües and Liu 2000). During fruiting body formation and maturation, the extracellular enzymatic activities of the basidiomycetes Schizophyllum commune, Agaricus bisporus, Lentinula edodes and Volvariella volvacea were found to alter (Phillips and Leonard 1976, Leatham and Stahmann 1981, Ohga et al. 1999, Chen et al. 2003).

Laccases (benzediol:oxygen oxidoreductase, EC 1.10.3.2) are polyphenol oxidase enzymes which belong to the family of blue multi-copper oxidases. These enzymes catalyze the oxidation of a range of aromatic compounds, under reduction of oxygen to water (Messerschmidt 1997, Burke and Cairney 2002, Piontek et al 2002). They are widespread in plants, bacteria, arthropods and mostly in wood rotting fungi (Gianfreda et al. 1999, Cardenas and Dankert 2000, Kramer et al. 2001, Claus 2003, Kumar et al. 2003, McCaig et al. 2005). Fungal laccases seem to play a prominent role in lignin degradation (Eggert et al. 1997, Leonowicz et al. 2001, Pointing 2001) and they are widely studied because of their potential biotechnological use as bioremediation agents (Durán and Esposito 2000, Pointing 2001, Wesenberg et al. 2003, Couto and Herrera 2006, Husain 2006). Some fungal laccases take part in the synthesis of catechol- and napthalenediol-melanins (Langfelder et al. 2003, Nosanchuk and Casadevall 2003) and possibly in pigment production in mushroom tissues and basidiospores (Leatham and Stahman 1981, Vnenchak and Schwalb 1989). Laccase defense reactions (protection against host oxidative responses, detoxification of adverse phenolic compounds, pigmentation) are also known in wood decay fungi during interactions with living trees 
(Burke and Cairney 2002) and between interacting mycelia of different organisms (Iakovlev and Stenlid 2000) and between fungi and bacteria (Rühl et al. 2007, own unpublished observation).

In the model fungus Coprinopsis cinerea (Coprinus cinereus), three complete laccase genes (lcc1, lcc2, lcc3) were described by Yaver et al. (1999). In addition, Hoegger et al. (2004) cloned and sequenced eight non-allelic laccase genes (amongst the genes lcc6 was cloned by the author of this thesis and gene lcc4 cloned by M. Hoffmann in cooperation with the author of this thesis) representing the largest laccase gene family identified at that time in a single haploid fungal genome. However, Kilaru et al. (2006) analyzed the complete genome of C. cinerea (release July 2003, http://www.broad.mit.edu/annotation/fungi/coprinus_cinereus/index.html) and deduced a total of 17 different laccase genes in this fungus. The different laccases divide into two distinct subfamilies defined by intron positions and similarity of deduced gene products, one subfamily with 15 members (lcc1-lcc15) and another subfamily with 2 members (lcc16, lcc17). Overexpression of the 17 laccase genes under the control of a constitutive promoter identified nine active enzymes (Kilaru et al. 2006, Kilaru 2006).

In this study, we report a transcript profile analysis of the laccase genes during different developmental stages of the C. cinerea life cycle. Mono- and dikaryotic mycelia and different stages in fruiting body development were analyzed for expression of laccases. Transcripts for 15 laccase genes were found in all C. cinerea strains tested. However, very few of these genes appeared to be stage-specific in their expression.

\subsection{Materials and Methods}

8.3.1 Coprinopsis cinerea strains and culture conditions. C. cinerea strains used in this study were the monokaryon PS002-1 (Srivilai 2006), OU3-1 (A43mut, B43mut, pab1-1, skn1), UFO1 (A43mut, B43mut, pab1-1, bad, eln) (Srivilai 2006) with a semidominant defect in stipe elongation (eln) and basidiospores defective (bad), a stipe elongation defective mutant PUK22 (A43mut, B43mut, dst2-1) (Chaisaena unpublished), and the homokaryon AmutBmut (A43mut, B43mut, pab ${ }^{-1}$ ) being selfcompatible by defects in the mating type genes (Swamy et al. 1984). Monokaryon PS002-1 is coisogenic from AmutBmut, and mutants of this strain are OU3-1, UFO1 and PUK22. 
To obtain aerial mycelium, all cultures were grown at $37^{\circ} \mathrm{C}$ in darkness on agar plates with standard Coprinus YMG/T medium (Granado et al. 1997) covered with sterile cellophane, until the growing mycelia reached the edges of the Petri dishes. For testing early stages in fruiting (Table 1), plates of the strains were cultivated one day further at $37^{\circ} \mathrm{C}$ (darkness) to obtain a high number of primary hyphal knots. Secondary hyphal knots and fruiting body development structures were induced by shifting cultures fully grown (5-6 d old) into a standard fruiting regime $\left(25^{\circ} \mathrm{C}\right.$, light, $90 \%$ humidity in a 12 light/ $12 \mathrm{~h}$ dark regime). In this $24 \mathrm{~h}$ scheme, the moment when the light is switched on is arbitrarily set zero and the moment when light is switched off is arbitrarily set 12 hours (Granado et al. 1997). To obtain fruiting bodies from homokaryon AmutBmut, the strain was cultivated in flasks containing sterile horse dung, and incubated at $37^{\circ} \mathrm{C}$ for $5 \mathrm{~d}$, and then transferred to the standard fruiting conditions. The different tissues vegetative mycelia, mycelia with primary hyphal knots and mycelia with secondary hyphal knots were harvested, transferred into liquid nitrogen and freeze dried. Further on, fruiting stages from AmutBmut and UFO1 were harvested from cultures incubated under the standard fruiting regime. Developing primordia and fruiting bodies were collected as described in Table 1. From primordia stage 2 onwards (Table 1, Figure 1), cap and stipe tissues were separated before freezing in liquid nitrogen and samples were used either immediately after harvest or stored at $-80^{\circ} \mathrm{C}$ for further use.

\subsubsection{DNA, and RNA isolation, cDNA synthesis and transcript analysis. Genomic} DNA was extracted as described by Zolan and Pukkila (1986) from plain mycelium of all the strains mentioned above. Laccase gene specific primers (Table 2) were tested on the genomic DNAs of all the strains used in this study. Total RNA was isolated from the mycelial and the fruiting samples described above (Table 1 and Figure 1). Samples were ground to fine powdered material and total RNA was extracted by using guanidine thiocyanate (Boulianne et al. 2000). cDNAs were synthesized using RevertAid MMuLV Reverse Transcriptase (Fermentas) according to the manufacturer's instructions (Gerard and D'Alessio 1993). $2 \mu \mathrm{g}$ of total RNA was used in each reaction and the cDNA obtained was used for transcript profiling with gene specific primers (Table 2). The quality of the synthesized cDNAs was analyzed using B-tubulin gene specific primers (ß-tubF, 5'-ATGCGTGAAATCGTCCACCTC-3', ß-tubR, 5'TCACACTGAGCGGTGAGAAC-3'). $25 \mu \mathrm{l}$ PCR reaction mixture (10 mM Tris, $\mathrm{pH} 8.8,50 \mathrm{mM} \mathrm{KCl}, 0.1 \%$ Triton X-100, $1.5 \mathrm{mM} \mathrm{MgCl}_{2}, 0.2 \mathrm{mM}$ dNTPs, $0.4 \mu \mathrm{M}$ each 
Table 1 Developmental stages of Coprinopsis cinerea from vegetative mycelium to fruiting body maturation used in transcript analysis in this study (mycelia for all the strains, up to secondary hyphal knots for strain OU3-1, up to primordia d1 for strain PUK22 and up to senescent fruiting bodies for strain UFO1 and homokaryon AmutBmut).

\begin{tabular}{|c|c|c|c|}
\hline $\begin{array}{l}\text { Sample } \\
\text { number }\end{array}$ & Sample* & Description of stage* & Time point of harvest \\
\hline \multicolumn{4}{|c|}{ Agar plate cultures } \\
\hline 0 & Vegetative mycelium & $\begin{array}{l}\text { Plain mycelium with no } \\
\text { highly ordered structures }\end{array}$ & $\begin{array}{l}\text { Cultures grown till the edge } \\
\text { of plate. Edges of the } \\
\text { cultures were taken for } \\
\text { analysis }\end{array}$ \\
\hline 1 & $\begin{array}{l}\text { Primary hyphal knot stage } \\
(\sim 0.03 \mathrm{~mm})\end{array}$ & $\begin{array}{l}\text { Primary hyphal knots within } \\
\text { outer ring of mycelium } \\
\text { about } 1 \mathrm{~cm} \text { width. } \\
\text { Edges of the cultures were } \\
\text { taken for analysis. }\end{array}$ & $\begin{array}{l}\text { Day } 0 \\
\text { (1 h after light on) }\end{array}$ \\
\hline \multirow[t]{2}{*}{2} & $\begin{array}{l}\text { Secondary hyphal knot stage } \\
(\sim 0.2 \mathrm{~mm})\end{array}$ & $\begin{array}{l}\text { Mycelium with secondary } \\
\text { hyphal knots. } \\
\text { Cultures from edges were } \\
\text { harvested }\end{array}$ & $\begin{array}{l}\text { Day } 1 \\
\text { (1 h after light on })\end{array}$ \\
\hline & $\begin{array}{l}\text { Primordia of }<1 \mathrm{~mm} \\
\text { (stage } 1 \text { primordia) }\end{array}$ & $\begin{array}{l}\text { Primordia } 1 \text { d old. First } \\
\text { differentiation of cap and } \\
\text { stipe tissues }\end{array}$ & $\begin{array}{l}\text { Day } 2 \\
\text { ( } 1 \text { h after light on })\end{array}$ \\
\hline \multicolumn{4}{|c|}{ *Horse dung cultures } \\
\hline 4 & $\begin{array}{l}\text { Primordia of } 4-6 \mathrm{~mm} \\
\text { (Stage } 4 \text { primordia) }\end{array}$ & $\begin{array}{l}\text { Prekaryogamic primordia } \\
\text { (4d old) developing primary, } \\
\text { secondary gills and gills } \\
\begin{array}{l}\text { cavities. Minor } \\
\text { elongation }\end{array}\end{array}$ & $\begin{array}{l}\text { Day } 5 \\
\text { (1h after light on) }\end{array}$ \\
\hline 5 & $\begin{array}{l}\text { Primordia of } 9-10 \mathrm{~mm} \\
\text { (Mature primordia) }\end{array}$ & $\begin{array}{l}\text { Fully develop primordia } \\
\text { undergoing karyogamy. } \\
\text { Minor stipe elongation }\end{array}$ & $\begin{array}{l}\text { Day } 6 \\
\text { (1h after light on) }\end{array}$ \\
\hline 6 & $\begin{array}{l}\text { Primordia of } \sim 15 \quad \mathrm{~mm} \\
\text { (Mature primordia) }\end{array}$ & $\begin{array}{l}\text { Young slowly elongating } \\
\text { fruiting body, undergoing } \\
\text { meiosis I }\end{array}$ & $\begin{array}{l}\text { Day } 6 \text { afternoon } \\
\text { ( } 4 \text { h after light on) }\end{array}$ \\
\hline 7 & $\begin{array}{l}\text { Primordia of } \sim 17 \quad \mathrm{~mm} \\
\text { (Mature primordia) }\end{array}$ & $\begin{array}{l}\text { Young slowly elongating } \\
\text { fruiting body, undergoing } \\
\text { meiosis II }\end{array}$ & $\begin{array}{l}\text { Day } 6 \text { afternoon } \\
\text { ( } 8 \text { h after light on) }\end{array}$ \\
\hline 9 & $\begin{array}{l}\text { Immature fruiting body of } \\
\sim 30 \mathrm{~mm}\end{array}$ & $\begin{array}{l}\text { Rapid stipe elongation, } \\
\text { basidiospore production- } \\
\text { pigmentation-maturation }\end{array}$ & $\begin{array}{l}\text { Day } 6 \text { evening } \\
\text { (At the point when the light } \\
\text { switch off) }\end{array}$ \\
\hline 11 & $\begin{array}{l}\text { Mature fruiting body of } \\
\sim 80-120 \mathrm{~mm}\end{array}$ & $\begin{array}{l}\text { Mature fruiting body spore } \\
\text { releasing }\end{array}$ & $\begin{array}{l}\text { Day } 7 \text { early morning } \\
\text { ( } 2 \mathrm{~h} \text { before light switch on) }\end{array}$ \\
\hline 12 & $\begin{array}{l}\text { Senescent fruiting body of } \\
\sim 80-120 \mathrm{~mm}\end{array}$ & Autolysed fruiting body & $\begin{array}{l}\text { Day } 7 \text { morning } \\
\text { (6 h after light switch on) }\end{array}$ \\
\hline
\end{tabular}

* Stages refer to the developmental fruiting programme as described in chapter 6. 


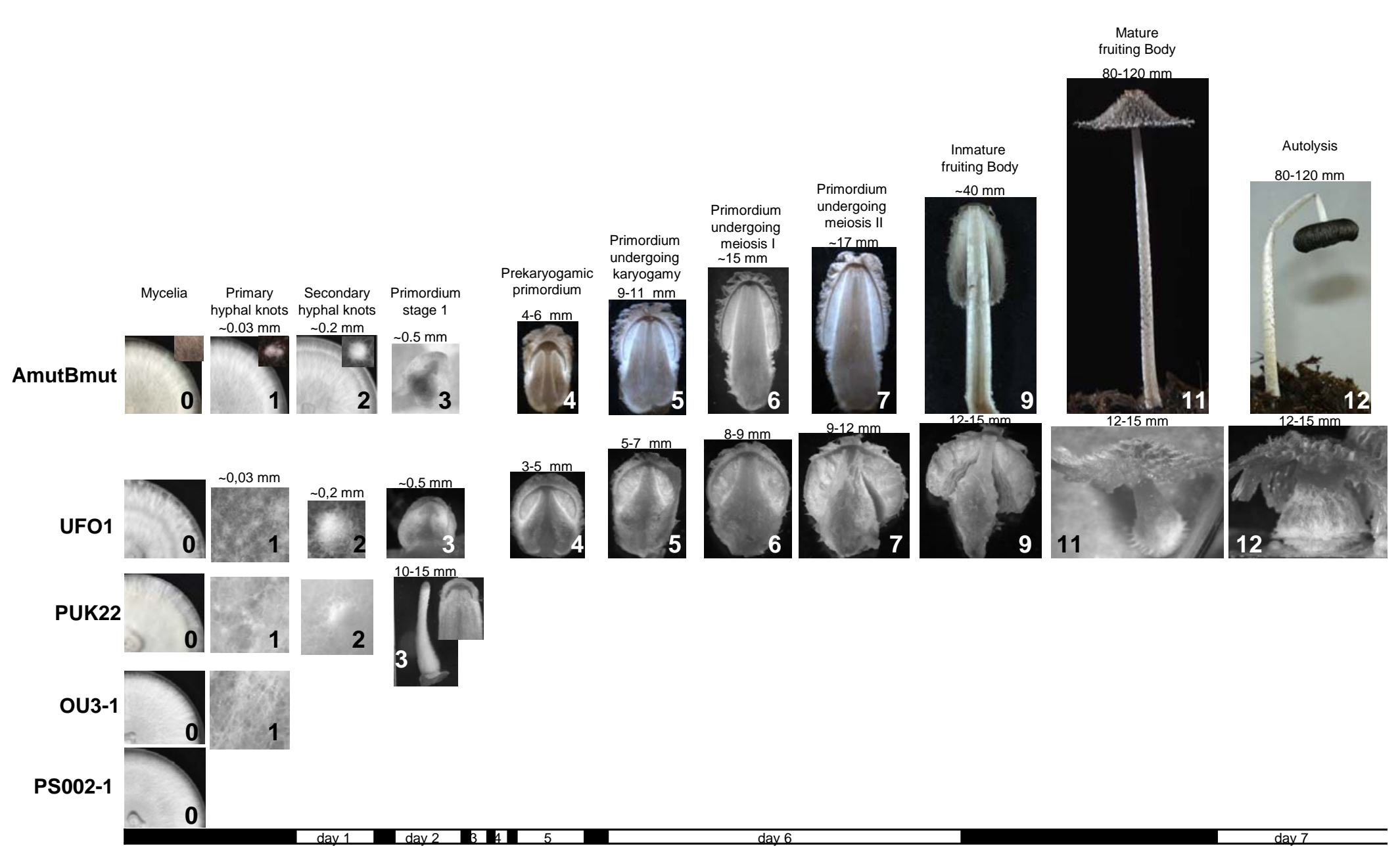

Figure 1 Stages of fruiting body development study in C. cinerea strains AmutBmut, UFO1, PUK22, OU3-1, PS002-1. Dark/white boxes = day and night periods; a day is defined from the start to the end of a $12 \mathrm{~h}$ light period. Numbers on pictures refer to descriptions given in Table 1. Note that samples of UFO1, PUK22, OU3-1 and PS002-1 were obtained from YMG/T agar cultures. Due to larger fruiting bodies homokaryon AmutBmut samples proceed from horse dung cultures. 
Table 2 Primer sets and PCR conditions.

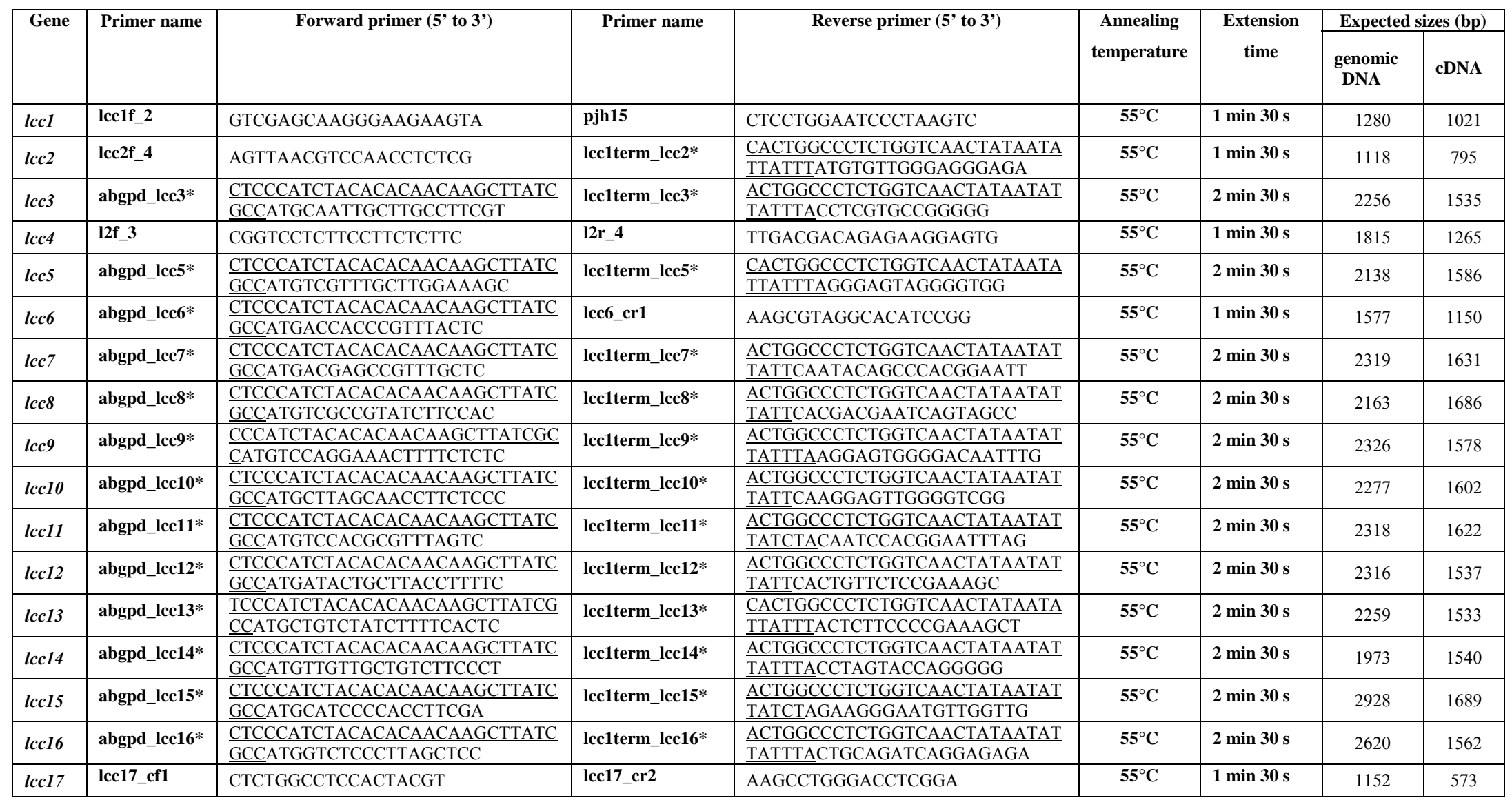

* Note that only the underlined part of primer is specific to the gene of interest. Primers were obtained from S. Kilaru, who used the primers previously in constructing of dimeric promoter-gene constructs (Kilaru 2006). 
gene specific primer $4 \mu \mathrm{M}, 1$ unit of Taq polymerase and approximately $5 \mathrm{ng}$ of cDNA) were used as standard throughout this study. PCR conditions were 2 min initial denaturation at $94^{\circ} \mathrm{C}$, followed by 35 cycles of $30 \mathrm{~s}$ at $94^{\circ} \mathrm{C}, 30 \mathrm{~s}$ at an annealing temperature of $55^{\circ} \mathrm{C}$, primer set-specific extension time (Table 2) at $72^{\circ} \mathrm{C}$ and a final extension step at $72^{\circ} \mathrm{C}$ for $10 \mathrm{~min} .10 \mu \mathrm{l}$ aliquots of the PCR products were then analyzed on 1\% agarose gels in TAE buffer (Sambrook and Russell 2001) run for $60 \mathrm{~min}$ at $80 \mathrm{~V}$.

\subsubsection{Enzymatic assays}

\subsubsection{Laccase activity in mycelial fresh tissues}

In order to test the enzymatic activity from the different tissues of $C$. cinerea AmutBmut (Table 1), the different developmental structures covering the main physiological stages of its life cycle (mycelia, primordia of different ages, immature and mature fruiting bodies) were harvested from plates of cultures kept under the conditions required for formation of the tissue to be tested (Figure 1, Table 1). About 10 plates per developmental stage were required to harvest enough material for laccase activity test.

The reaction mixture consisted of the tissues grinded in mortar and pestle, $900 \mu \mathrm{l}$ sodium acetate buffer (120 mM, pH 5.0), and $100 \mu \mathrm{l}$ of ABTS (5 mM) mixed in a $1.5 \mathrm{ml}$ Eppendorf tube. Thereafter, the samples were incubated at room temperature. Observations in change in coloration of the mixture were done after $30 \mathrm{~min}$ and $24 \mathrm{~h}$. In parallel, tests without tissue and tissues cooked at $100^{\circ} \mathrm{C}$ for $10 \mathrm{~min}$ were used as negative control.

\subsection{Results and discussion}

\subsubsection{PCR conditions for transcript detection}

To analyze the transcript profiles of the multiple laccase genes in C. cinerea, gene specific primers were designed (Table 2) based on the laccase gene sequences deduced from own subcloned genes (lcc6, M. Navarro-González; lcc4, M. Hofmann and M. Navarro-González, library screening and cloning described in Hoegger et al. 2004), and from genes cloned by other members of the group either by library screening (Hoegger et al. 2004) or after analyzing the sequenced genome of C. cinerea strain Okayama 7 (Kilaru et al. 2006). For some genes, primers were designed at the start and stop codons of the respective genes. Others were designed from internal gene sequences (Table 2). 
All analyses were done with primer pairs specific for individual laccase genes. Annealing conditions for the primer pairs were tested with genomic DNA from AmutBmut and a temperature of $55^{\circ} \mathrm{C}$ was found suitable for all primers (Table 2).

\subsubsection{Expression of laccase genes}

In cDNA from a mycelial sample of the monokaryon strain PS002-1, in total 5 different genes were found to be expressed (lcc2, lcc3, lcc4, lcc11 and lcc17). However, RT-PCR

gave weak bands when analyzed on an agarose gel, suggesting low transcript levels in the cDNA samples (not shown).

Transcripts for 8 different laccase genes were found in mycelia of the PUK22 (lcc2, lcc3, lcc4, lcc5, lcc9, lcc11, lcc12 and lcc17). In the strain OU3-1, 5 genes were expressed (lcc2, lcc4, lcc11, lcc12 and lcc17), 4 genes in the strain PS002-1 (lcc2, lcc3, lcc4, lcc11, and lcc17), and 3 genes only in the strain PUK22 (lcc3, lcc5, lcc9) (Figure 2). Similarly to the results obtained with the strain PS002-1, RT-PCR gave weak bands in the strain OU3-1, suggesting low transcript levels in the mycelium. However, in the case of lcc2, lcc9, lcc12 and lcc17 in the strain PUK22, the transcript levels were stronger. Transcript levels for $l c c 2$ were also particularly strong in the stage of primary and secondary hyphal knots in OU3-1 and PUK22. Later stages in fruiting in these strains could not be observed due to mutations in the fruiting pathway (Srivilai 2006).

Different stages during fruiting body development of the homokaryon AmutBmut were collected and analyzed (Table 1 and Figure 1). A total of 15 different laccase genes gave positive transcripts during fruiting body development of this self-fertile strain (Figure 3 and Figure 4). Only for lcc10 and lcc15, transcripts were never observed.

When mycelium of the fruiting structures (cap and stipes separately of homokaryon AmutBmut were tested for laccase activity, lower level mycelium bound laccase activity was detected starting at the stage of secondary hyphal knots (see Figure 7 for the reaction of mycelium with secondary hyphal knot). When primordia were fully developed undergoing karyogamy, mycelium-bound laccase activity increased first in stipe tissue and then alternately in cap tissue (Figure 7). Increase in activity is accompanied with detected expression of further laccase genes in the respective tissues (Figure 3 and Figure 4). Possibly, the detected laccase activity comes therefore from 
the sum of several different more or less strongly expressed genes. Identification of specific proteins should clarify this in future work.
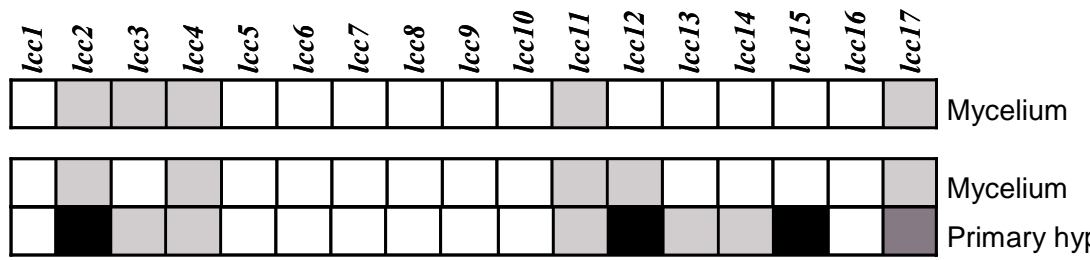

Mycelium

Primary hyphal knot

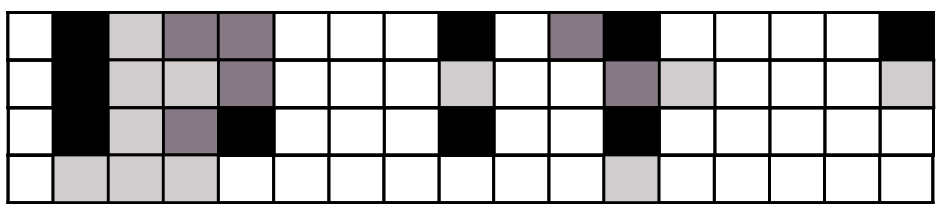

Mycelium

Primary hyphal knot

Secondary hyphal knot (2)

Etiolated fruiting body
(0) $\}$ PSO02-1

(0)

(1)

(0)

(1)

PUK22

Figure 2 Comparative analysis of the expressed laccase genes in different tissues of fruiting body development of monokaryon PS002-1, OU3-1 and PUK22. The top line indicates the laccase genes, the column at the right refers to different physiological stages in development (Figure 1). Cases where cDNAs of genes in PCR gave strong bands are marked in black, cases where cDNAs gave medium bands in darker grey, cases where cDNAs gave weak bands in light grey and cases where no cDNA was amplified are marked in white. Numbers in brackets refer to the stage described in Table 1. 


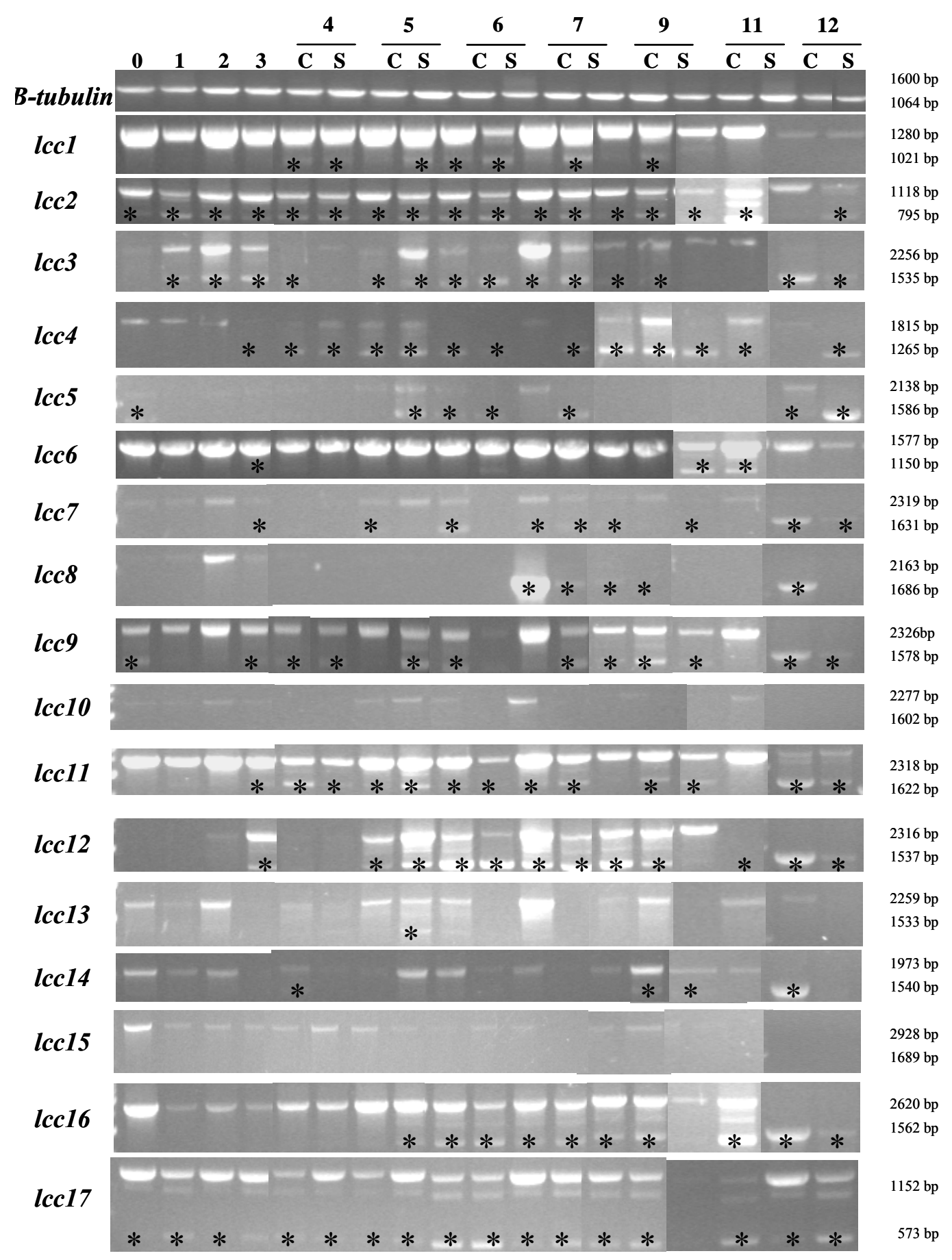

Figure 3 Expression profiles of laccase genes in different stages of fruiting body development in homokaryon AmutBmut. The top lane shows different developmental stages from mycelium to mature fruiting bodies. Specific tissues with "initials" C for cap and S for stipe (see Table 1 and Figure 2). The left column shows the laccase genes (for corresponding primers, see Table 2) and the right column shows the expected genomic cDNA sizes (Table 2). 


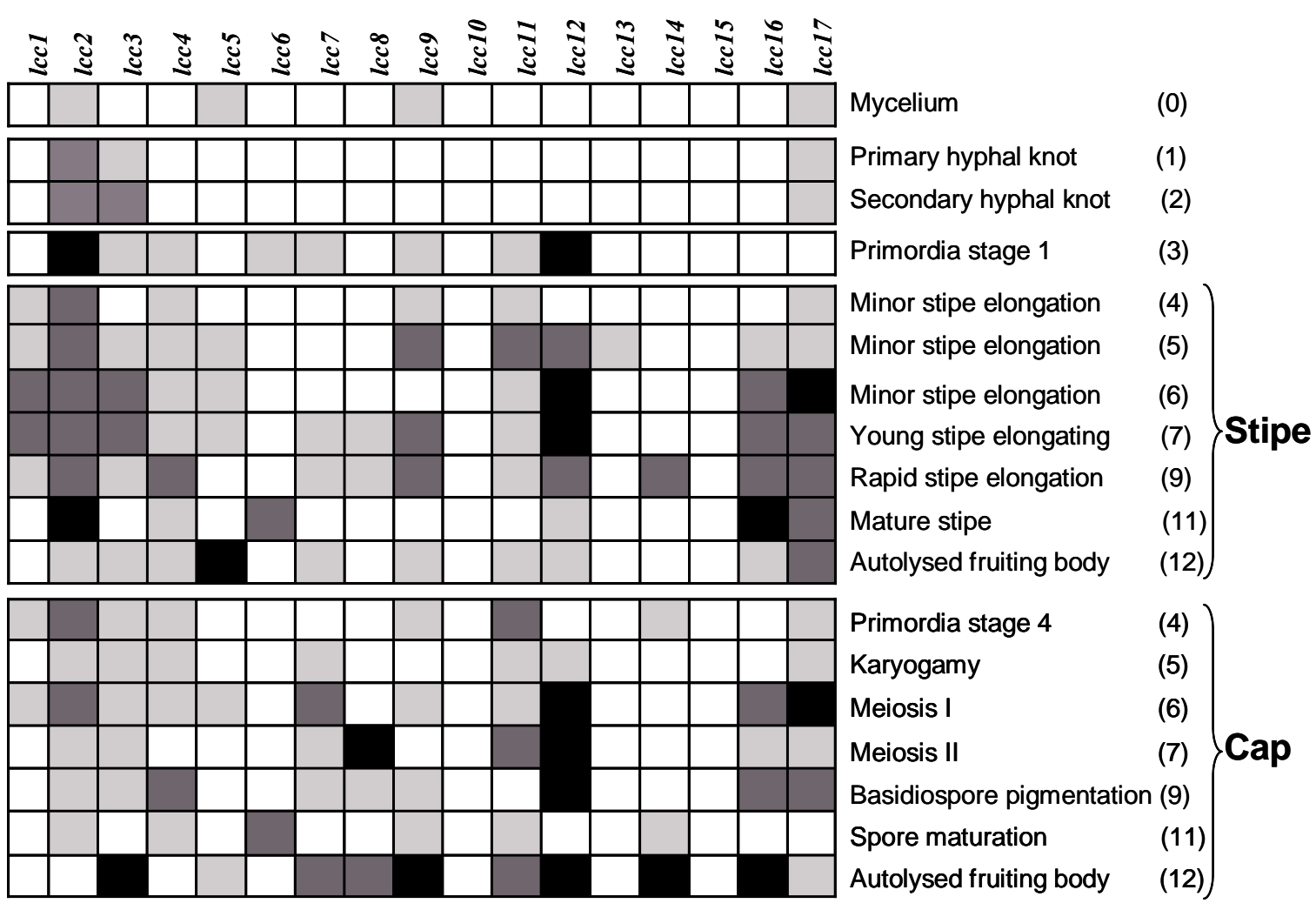

Figure 4 Comparative analysis of the expressed laccase genes in different tissues of fruiting body development of homokaryon AmutBmut. The top line, indicates the laccase genes, the column at the right refers to different physiological stages in development (Figure 2). Cases where cDNAs of genes in PCR gave strong bands are marked in black, cases where cDNAs gave medium bands in darker grey, cases where cDNAs gave weak bands in light grey and cases where no cDNA was amplified are marked in white. Numbers in brackets refer to the stage described in Table 


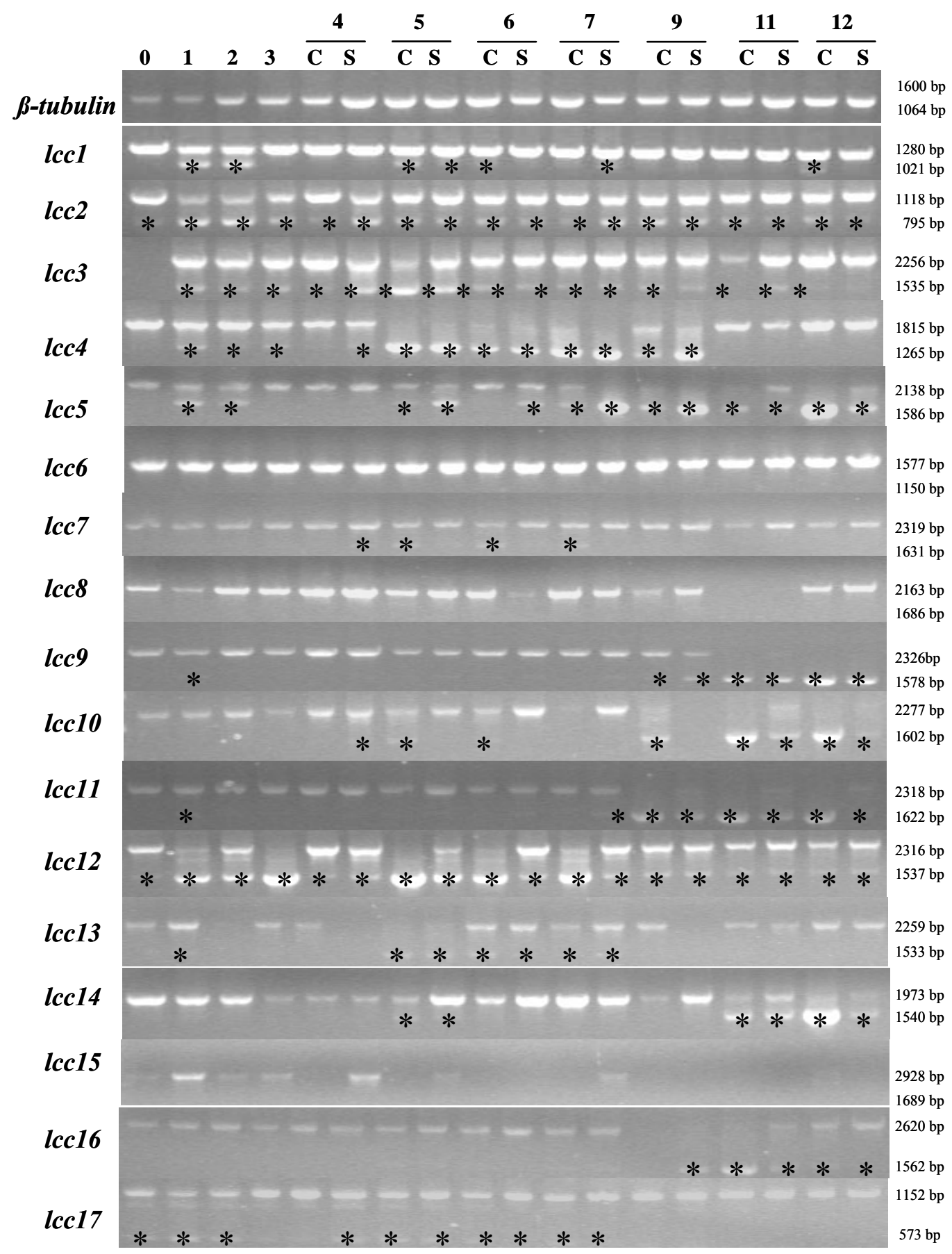

Figure 5 Expression profiles of laccase genes in different stages of fruiting body development in the mutant UFO1. The top lane shows different developmental stages from mycelium to mature fruiting bodies. Specific tissues with "initials" C for cap and S for stipe (see Table 1 and Figure 2). The left column shows the laccase genes (for corresponding primers, see Table 2) and the right column shows the expected genomic cDNA sizes. 


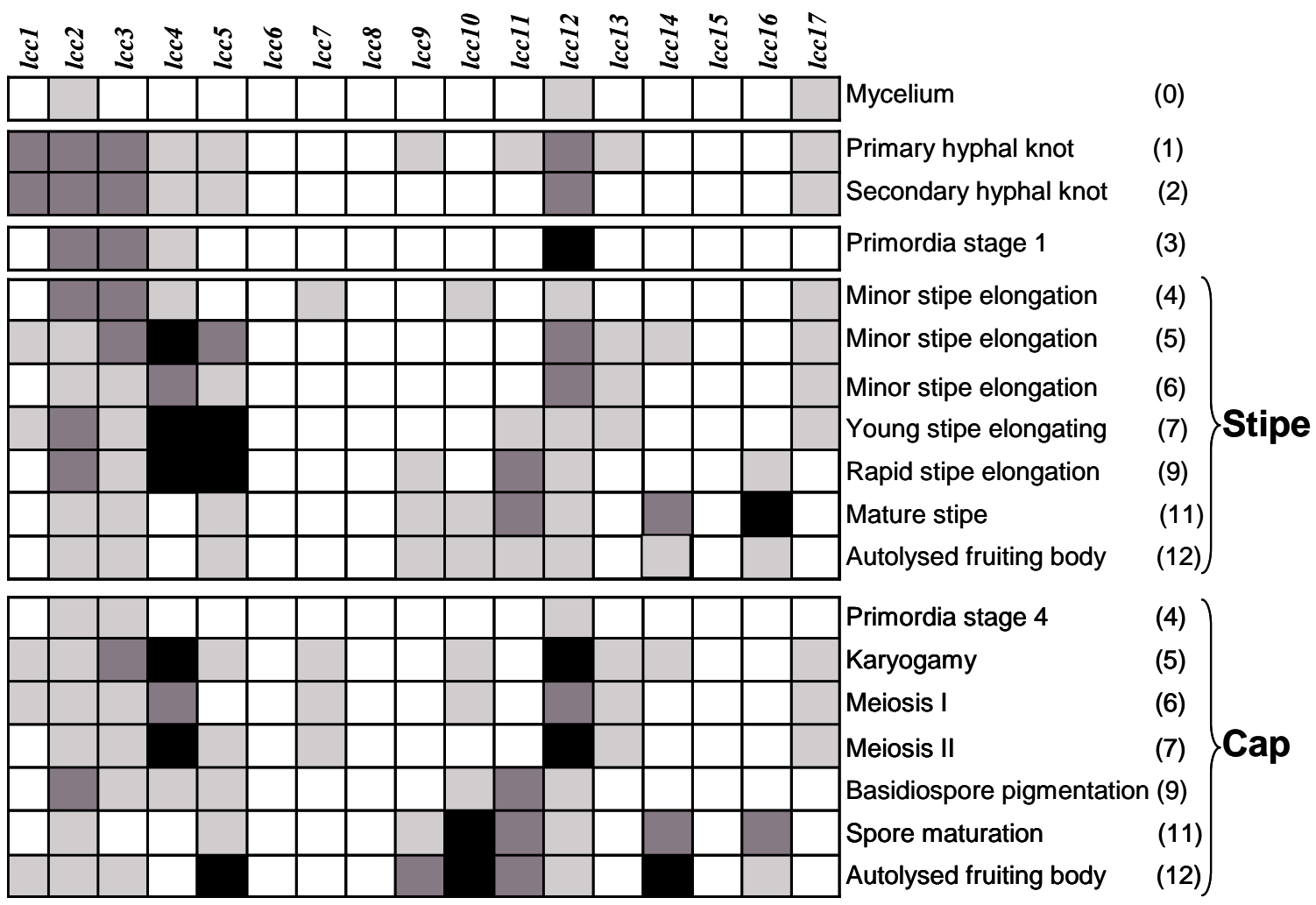

Figure 6 Comparative analysis of the expressed laccase genes in different tissues of fruiting body development of the mutant UFO1. The top line indicates the laccase genes, the column at the right refers to different physiological stages in development (Figure 2). Cases where cDNAs of genes that in PCR gave strong bands are marked in black, cases where cDNAs gave medium bands in darker grey, cases where cDNAs gave weak bands in light grey and cases where no cDNA was amplified are marked in white. Numbers in brackets refer to the stage described in Table 1. 


\section{Laccases in fruiting bodies}

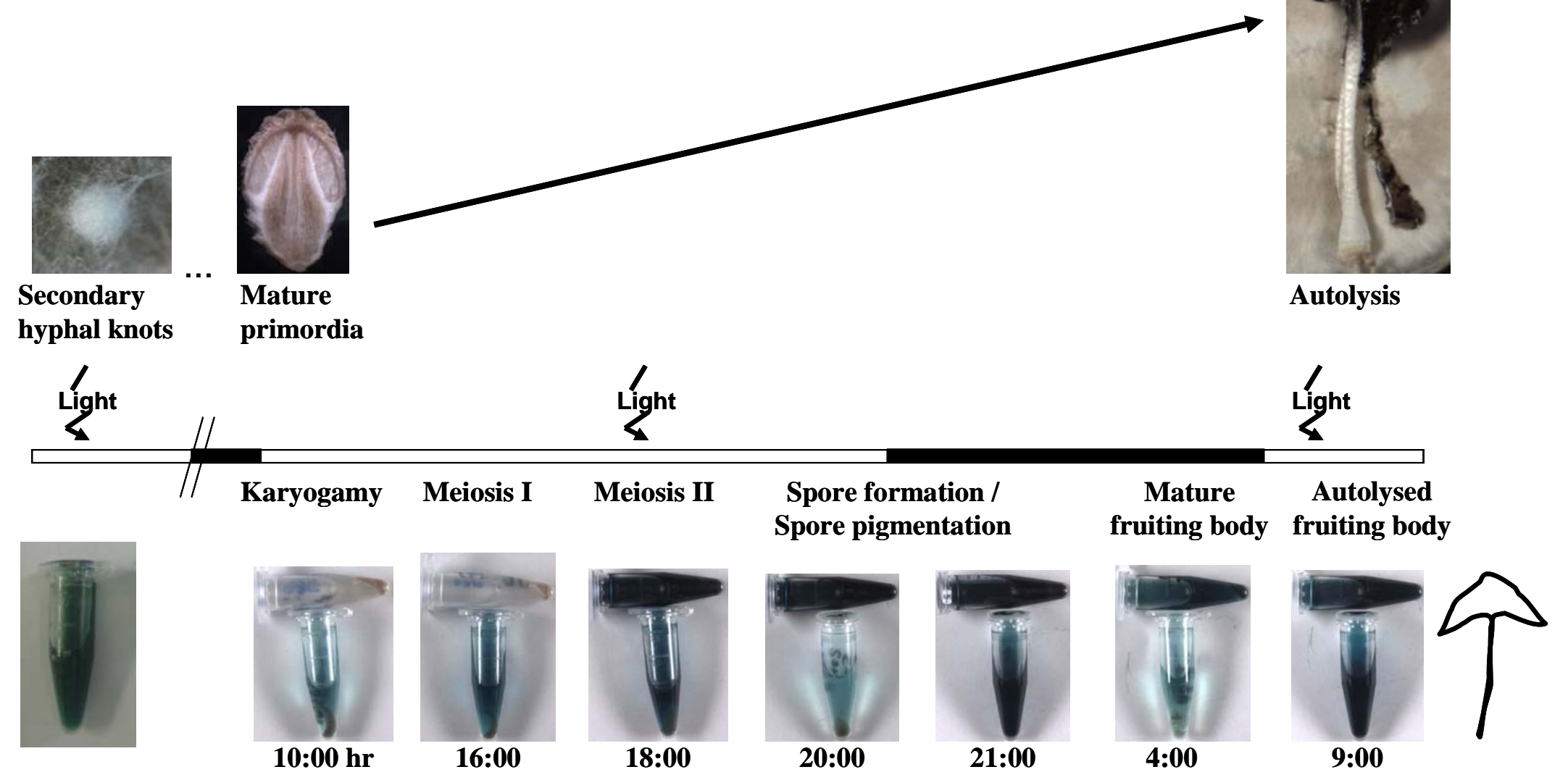

Figure 7 Laccase activity bond to the cell wall on tissue of secondary hyphal knots, and on tissues on the d6 of development on homokaryon Coprinopsis cinerea AmutBmut. Note that early in the morning the activity is higher on the stipe, but this localized activity changes to the cap at the stage of meiosis I. This high activity keeps on the cap tissues until autolysis. Note that the coloration in samples of hyphal knots, karyogamy and meiosis I coloration was visible after 5-7 h. The highest laccase activity is produced from meiosis II till the mature fruiting body. In these stages a strong coloration was visible in less that $30 \mathrm{~min}$. 


\subsection{Conclusions}

From the total 17 different laccase genes present in the genome of $C$. cinerea, transcript analysis was performed by using specific primers to the individual laccase genes. Different mycelial stages and different stages and tissues in fruiting body development of $C$. cinerea were analyzed. For 15 genes, transcripts were detected in most instances in tissues from structures in the fruiting body pathway.

In a parallel set of probes from fruiting stages of homokaryon in a mutant with short stipes but normal caps (Srivilai 2006) similarly 15 genes were found to be transcribed but genes lcc10 and lcc15. Overall in both strains, most genes appeared not to be poorly transcribed, as deduced from the results of the PCR amplifications showing often stronger bands that amplified from contaminating genomic DNA than amplified from cDNA. There was not a clear pattern of expression regarding specific developmental stages or tissues, likely because of the often low level of transcription.

\subsection{Acknowledgments}

I would like to thank Prayook Srivilai and Wassana Chaisaena for the mutants they provided to use in this study.

\subsection{References}

Boulianne RP, Liu Y, Aebi M, Lu BC, Kües U (2000) Fruiting body development in Coprinus cinereus: regulated expression of two galectins secreted by a nonclassical pathway. Microbiol., 146, 1841-1853.

Broxholme SJ, Read ND, Bond DJ (1991) Developmental regulation of proteins during fruit-body morphogenesis in Sordaria brevicollis. Mycol. Res., 95, 958-969.

Burke RM, Cairney JWG (2002) Laccases and other polyphenol oxidases in ecto- and ericoid mycorrhizal fungi. Mycorrhiza, 12,105-116.

Cardenas W, Dankert JR (2000) Cresolase, catecholase and laccase activities in haemocytes of the red swamp crayfish. Fish Shellfish Immunol., 10, 33-46.

Chen S, Ma D, Ge W, Buswell JA (2003) Induction of laccase activity in the edible straw mushroom Volvariella volvacea. FEMS Microbiol. Lett., 218, 143-148.

Claus H (2003) Laccases and their occurrence in prokaryotes. Arch. Microbiol., 179, 145-150. 
Couto SR, Herrera JLT (2006) Industrial and biotechnological applications of laccases: A review. Biotechnol. Adv., 24, 500-513.

Ducros V, Brzozowski AM, Wilson KS, Brown SH, Østergaard P, Schneider P, Yaver DS, Pedersen AH, Davies GJ (1998) Crystal structure of the type-2 Cu depleted laccase from Coprinus cinereus at $2.2 \AA$ resolution. Nature Struct. Biol., 5, 310-316.

Durán N, Esposito E (2000) Potential applications of oxidative enzymes and phenoloxidases-like compounds in wastewater and soil treatment: a review. Appl. Cat B Environ., 28, 83-99.

Eggert C, Temp U, Eriksson KEL (1997) Laccase is essential for lignin degradation by the white-rot fungus Pycnoporus cinnabarinus. FEBS Lett., 407, 89-92.

Gerard GF, D’Alessio JM (1993) Enzymes of Molecular Biology. Chapter 6. In: Burell MM (ed.), Methods in Molecular Biology, Human Press Inc., Totowa, NJ. Pp. 73-93.

Gianfreda L, Xu F, Bollag JM (1999) Laccases: A useful group of oxidoreductive enzymes. Bioremediation J., 3, 1-25.

Granado JD, Kertesz-Chaloupková K, Aebi M, Kües U (1997) Restriction enzymemediated DNA integration in Coprinus cinereus. Mol. Gen. Genet., 256, 28-36.

Hakulinen N, Kiiskinen L-L, Kruus K, Saloheimo M, Paananen A, Koivula A, Rouvinen J (2002) Crystal structure of a laccase from Melanocarpus albomyces with an intact trinuclear copper site. Nature Struct. Biol., 9, 601-605.

Hermann TE, Kurtz MB, Champe SP (1983) Laccase localized in hulle cells and cleistothecial primordia of Aspergillus nidulans. J. Bacteriol., 154, 955-964.

Hoegger PJ, Navarro-González M, Kilaru S, Hoffmann M, Westbrook ED, Kües U (2004) The laccase gene family in Coprinopsis cinerea (Coprinus cinereus). Curr. Genet., 45, 9-18.

Husain Q (2006) Potential applications of the oxidoreductive enzymes in the decolorization and detoxification of textile and other synthetic dyes from polluted water: A review. Cr. Rev. Biotechn., 26, 201-221.

Iakovlev A, Stenlid J (2000) Spatiotemporal patterns of laccase activity in interacting mycelia of wood-decaying basidiomycete fungi. Microbial. Ecol., 39, 236-245.

Kilaru S (2006) Identification of fungal multi-copper oxidase gene families: Overexpression and characterization of Coprinopsis cinerea laccases for 
applications in biotechnology. $\mathrm{PhD}$ Thesis. Georg-August University of Göttingen, Göttingen, Germany.

Kilaru S, Hoegger PJ, Kües U (2006) The laccase multi-gene family in Coprinopsis cinerea has seventeen different members that divide into two distinct subfamilies. Curr. Genet. 50, 45-60.

Kramer KJ, Kanost MR, Hopkins TL, Jiang HB, Zhu YC, Xu RD, Kerwin JL, Turecek F (2001) Oxidative conjugation of catechols with proteins in insect skeletal systems. Tetrahedron, 57, 385-392.

Kües U (2000) Life history and developmental processes in the basidiomycete Coprinus cinereus. Microbiol. Mol. Biol. Rev., 64, 316-53.

Kües U, Künzler M, Bottoli APF, Walser PJ, Granado JD, Liu Y, Bertossa RC, Ciardo D, Clergeot P-H, Loos S, Ruprich-Robert G, Aebi M (2004) Mushroom development in higher basidiomycetes. Implications for human and animal health. In: Kushwaha RKS (ed.), Fungi in Human and Animal Health. Scientific Publishers, Jodhpur, India, pp. 431-470.

Kües U, Liu Y (2000) Fruiting body production in basidiomycetes. Appl. Microbiol. Biotechnol., 54, 141-152.

Kumar SVS, Phale PS, Durani S, Wangikar PP (2003) Combined sequence and structure analysis of the fungal laccase family. Biotechnol. Bioeng., 83, 386-394.

Labarère J, Bernet J (1978) Mutation inhibiting protoplasmic incompatibility in Podospora anserina that suppresses an extracellular laccase and protoperithecium formation. $J$. Gen. Microbiol., 109, 187-89.

Langfelder K, Streibel M, Jahn B, Haase G, Brakhage AA (2003) Biosynthesis of fungal melanins and their importance for human pathogenic fungi. Fungal Genet. Biol., 38, 143-158.

Leatham GF, Stahmann MA (1981) Studies on the laccase of Lentinus edodes: specificity, localization and association with the development of fruiting bodies. J. Gen. Microbiol., 125, 147-157.

Leonowicz A, Cho NS, Luterek J, Wilkolazka A, Wojtaś-Wasilewska M, Matuszewska A, Hofrichter M, Wesenberg D, Rogalski J (2001) Fungal laccase: properties and activity on lignin. J. Basic. Microbiol., 41, 185-227.

McCaig BC, Meagher RB, Dean JFD (2005) Gene structure and molecular analysis of the laccase-like multicopper oxidase (LMCO) gene family in Arabidopsis thaliana. Planta, 221, 619-636. 
Messerschmidt A, ed (1997) Multi-copper oxidases. World Scientific, Singapore.

Nosanchuk JD, Casadevall A (2003) The contribution of melanin to microbial pathogenesis. Cell. Microbiol., 5, 203-223.

Ohga S, Smith M, Thurston CF, Wood DA (1999) Transcriptional regulation of laccase and cellulase genes in the mycelium of Agaricus bisporus during fruit body development on a solid substrate. Mycol. Res., 103, 1557-1560.

Phillips LE, Leonard TJ (1976) Extracellular and intracellular phenoloxidase activity during growth and development in Schizophyllum. Mycologia, 68, 268-276.

Piontek K, Antorini M, Choinowski T (2002) Crystal structure of a laccase from the fungus Trametes versicolor at 1.90 - $\AA$ resolution containing a full complement of coppers. J. Biol. Chem., 277, 37663-37669.

Pointing SB (2001) Feasibility of bioremediation by white-rot fungi. Appl. Microbiol. Biotechnol., 57, 20-33.

Rühl M, Kilaru S, Navarro-González M, Hoegger P, Kharazipour A, Kües U (2007) Production of laccase and other enzymes for the wood industry. In: Kües U (ed.), Wood production, wood technology and biotechnological impacts. Universitätsverlag-Verlag, Göttingen, Germany.

Sambrook J, Russell DW (2001) Molecular cloning. A laboratory manual. 3rd edn. Cold Spring Harbor Laboratory Press, Cold Spring Harbor, N.Y., USA.

Srivilai P (2006) Molecular analysis of genes acting in fruiting body development in basidiomycetes. PhD Thesis. Georg-August University of Göttingen, Göttingen, Germany.

Swamy S, Uno I, Ishikawa T (1984) Morphogenetic effects of mutations at the $A$ and $B$ incompatibility factors in Coprinus cinereus. J. Gen. Microbiol., 130, 32193224.

Thurston CF (1994) The structure and function of fungal laccases. Microbiology, 140, 19-26.

Vnenchak P, Schwalb MN (1989) phenol oxidase activity during development of Coprinus cinereus. Mycol. Res., 93, 546-548.

Wesenberg D, Kyriakides I, Agathos SN (2003) White-rot fungi and their enzymes for the treatment of industrial dye effluents. Biotechnol. Adv., 22, 161-187.

Wessels JHG (1993) Fruiting in higher fungi. Adv. Microb. Physiol., 34, 147-202. 
Yaver DS, Overjero MD, Xu F, Nelson BA, Brown KM, Halkier T, Bernauer S, Brown SH, Kauppinen S (1999) Molecular characterization of laccase genes from the basidiomycete Coprinus cinereus and heterologous expression of the laccase Lcc1. Appl. Environ. Microbiol., 65, 4943-4948.

Zolan ME, Pukkila PJ (1986) Inheritance of DNA methylation in Coprinus cinereus. Mol. Cell. Biol., 6, 195-200. 



\section{Grazing preferences on developmental structures of Coprinopsis cinerea: Symbiotic mite-fungal interaction?}

Contributions to this chapter: The microscopy and photography of the mites grazing on spores and mycelia, faecal pellets germination and eggs hatching, literature review and manuscript preparation was performed by the author of this thesis. The author also supervised the project student Olivia Sánchez, who determined the speed of the mites, sizes of mite's eggs, mites and faecal pellets, as well as germination rates of sclerotia and pellets. Dr. Pavel Plašil from the department Forest Zoology and Forest Conservation of the Büsgen-Institute identified the mite species and determined the male/female population ratio. Results from this chapter were presented in a talk at the Annual Meeting of the Association for General and Applied Microbiology (VAAM), April 1-4, 2007, Osnabrück, and Frankfurt (March 9-11, 2008), Germany. 


\section{Grazing preferences on developmental structures of Coprinopsis cinerea (Coprinus cinereus): Symbiotic mite-fungal interaction?}

\subsection{Abstract}

Mites of the species Tyrophagus putrescentiae were attracted to fungal cultures of the basidiomycete Coprinopsis cinerea in order to graze on the mycelium. Dikaryotic mycelium, sterile monokaryotic mycelium and mycelium of a self-fertile mutant were consumed including asexual spores (oidia). In vegetative cultures, only the melanized sclerotia were left, supporting a function in nature for duration: on fresh media, these sclerotia germinated. Upon fruiting body induction, developing primordia were also refused by the mites. When fruiting bodies maturated, mites were observed to climb up the stipe to feed on the cap tissues with the basidiospores. The fruiting body stipes were however refused. Further, we observed that basidiospores were ingested by the mites, but not digested. Faecal pellets containing around 400 basidiospores were formed. These spores germinated and easily formed new mycelia. The fast moving mites (6-29 $\mathrm{mm} / \mathrm{min}$ ) thus can contribute to the distribution of basidiospores in the environment and possibly to mixing fungal populations in nature inbreeding. The mites laid eggs in close vicinity to spore faecal pellets. This observation raised the idea that there might be a form of symbiotic interaction between mites and the fungus since newly germinated fungal colonies will serve as food for the hatching larvae.

Keywords: Inkcap mushroom, basidiomycete, spore dispersal, Tyrophagus putrescentiae 


\subsection{Introduction}

Worldwide, approximately 45,000 species of mites are described, which is only an estimated 5-6\% from the total number of species occurring in nature (Krantz 1978). One of the main problems is their minute size, and the fact that electron microscopic analysis has to be performed for an accurate identification (Baker and Wharton 1952). Within one $\mathrm{m}^{2}$ of soil, 250,000-500,000 individuals occur in coniferous forests (Johnston 2000). In nature, mites nourish on a wide variety of organic substrates such as litter, mosses, lichens, plants and fungi and they can also parasite on other animals (Baker and Wharton 1952, Krantz 1978, Behan-Pelletier 1999). In domestic environments, mites can be easily found in stored food such as grains, flour, dried egg, groundnuts, cheese, ham, herring meal, copra, dried bananas, wheat spillage, etc. (Hughes 1961). Fungi are important in the diet of mites, providing sterols and vitamins needed for their nutrition (Van Asselt 1999).

Although it is well known that mites are also fungivorous (Hubert et al. 2004, Schneider et al. 2005), and cause damages in mushroom cultivations (Kheradmand et al. 2007), the ecological relationship between fungi and mites is very little studied. It is necessary, for example, to understand the linkages of soil food webs and spore dispersal of fungi (Lilleskov and Bruns 2005). Mites (e.g. Oribatid mites) have a positive effect on a faster recovery of the microbial community after a strong disturbance by dispersing spores and by grazing on microbial populations (Maraun et al. 1998).

It is likely that mites are attracted to fungi by organic volatile compounds (Vanhaelen et al. 1980, Schiestl et al. 2006). In mycological laboratories, mites are seen as a major threat to growing fungal isolates since mites may invade the cultures (Janke and Lubkowitz 1953, Hughes 1961, Duek et al. 2001). Such danger occurs particularly when non-sterile material e.g. soil samples, plants, wood and other litter from the outside has been brought into a growth room, as it is typical for certain types of forest research. In nearly 25 years of active research at different institutes, incidents of mite invasions happened every now and then (U. Kües, personal communication). Usually, fast efficient actions are taken to eliminate all mites and contaminated material to avoid a higher infestation. In consequence, little work is done to further elucidate the interactions between mites and fungi. 
C. cinerea is a model fungus to study mushroom development in the higher basidiomycetes (Moore 1998). In its typical hymenomycete life cycle, the sexual basidiospores germinate into a self-sterile primary mycelium, generally called monokaryon because it contains one type of haploid nuclei. Hyphal fusions between two monokaryons of different mating type will generate the fertile dikaryon with two haploid nuclei, one of each mating type, in each cell. Under suitable environmental conditions, the dikaryotic mycelium will produce fruiting bodies. In the developing fruiting bodies, karyogamy and meiosis occur in basidia, specific cells found on the hymenium of the cap. Four basidiospores bud from the basidia as the result of meiosis, in this way closing the life cycle (Kües 2000).

In this study, after a coincidental infestation of fruiting cultures of the fimicolous basidiomycete $C$. cinerea with mites, we took the chance to observe for the first time the relations between the invading organisms and the fungus.

\subsection{Materials and methods}

\subsubsection{Strains, culture conditions and mites}

In this study, the co-isogenic monokaryotic strains C. cinerea PS001-1 (A42mut, B42mut), C. cinerea PS002-1 (A3mut, B1mut) (Srivilai 2006) and dikaryon C. cinerea PS001-1 x PS002-1 resulting from mating of the two monokaryons and C. cinerea homokaryon AmutBmut (A43mut, B43mut, pab $^{-1}$ ) were used. C. cinerea AmutBmut is a self-compatible homokaryon which produces fruiting bodies without mating to another compatible monokaryon (Swamy et al. 1984, Kertesz-Chaloupková et al. 1998). Fungal cultures were cultivated on YMGT agar plates for 5 days at $37^{\circ} \mathrm{C}$ in the dark (Granado et al. 1997, Kertesz-Chaloupková et al. 1998). To induce fructification in the cultures, plates were transferred to a climatized chamber at $26-28^{\circ} \mathrm{C}$ and $80-90 \%$ relative humidity in to a $12 \mathrm{~h}$ light/ $12 \mathrm{~h}$ dark cycle.

The mites were initially collected from an infested older culture of $C$. cinerea stored about 4 weeks at room temperature in a laboratory corner. Subsequently, they were constantly reared on fresh mycelia of the same fungus, and incubated at $28^{\circ} \mathrm{C}$ under shaded conditions in a greenhouse. To identify the mite species, 55 organisms were collected from an infested C. cinerea culture. They were washed in serial dilutions of alcohol $(70,75,80,85,90$, and 96\%) every $24 \mathrm{hrs}$. Afterwards, they were rinsed every 
half an hour in different mixing ratios $(3: 1,1: 1,1: 3)$ of $96 \%$ ethanol and 1,1,1,3,3,3hexamethyldisilazane. Subsequently, pure 1,1,1,3,3,3-hexamethyl-disilazane was used for drying the samples. The mites were gilded on the object holder (stub) with the "Sputter Coater", using argon as a carrier for 24 carat gold. After this, several photos of the mites were taken using the Scanning Electron Microscopy. Additionally, pictures from the endoskeleton were taken with a digital camera. The identification of the mite was performed according to Stammer (1957), Krantz (1978) and Hughes (1961).

\subsubsection{Grazing preferences on fungal developmental structures}

In order to test the grazing preferences of the mites on mycelia, developing and fruiting structures, by using a fine needle 25 agile adult mites were individually transferred from mycelial precultures. The precultures were incubated for about 2-4 weeks with mites. Mites were placed to the center of fungal cultures containing only mycelium, mycelium with developing primordia, mature and/or autolysed fruiting bodies. The Petri dishes were sealed with parafilm, covered with aluminum foil to avoid light, and incubated for 28 days in a greenhouse $\left(26-28^{\circ} \mathrm{C}\right)$. The grazing preferences were monitored weekly under the stereo microscope (Stemi 200-C Zeiss) and photographed with a digital camera (Soft Imaging ColorView II Mega Pixel) linked to a computer equipped with analySIS ${ }^{\circledR}$ software program (Soft Imaging System, Germany).

In order to find out the sex ratio of feeding preferences for spores, each one female mite about to lay eggs were transferred into Petri dishes containing a quarter of a C. cinerea agar medium culture with mature fruiting bodies. After transfer of the mites in the cultures, the plates were incubated for 60 to 77 days in the greenhouse at $28^{\circ} \mathrm{C}$. Mites were counted under a stereo microscope (Stemi 200-C Zeiss) and an inverse microscope (Axiovert, Zeiss) and sorted according to their sex and whether they had consumed spores or not.

\subsubsection{Faecal pellets and sclerotia isolation, microscopy and germination}

Light microscopy of the mites, faecal pellets and spores was performed with an Axiophot (Zeiss) photomicroscope, an inverse Axiovert (Zeiss) and a stereo microscope (Stemi 200-C Zeiss). All microscopes were equipped with a Soft Imaging ColorView II Mega Pixel digital camera, linked to a computer equipped with an analySIS ${ }^{\circledR}$ software program to take and analyze pictures. Using a stereo microscope for enlargement, 
several faecal pellets and sclerotia were collected from plates grazed by mites, transferred into a drop of distilled water onto a glass slide and gently covered with a cover glass. Single structures were studied under the light microscope and photographed at different magnifications. Each twenty sclerotia and faecal pellets were measured with the analySIS ${ }^{\circledR}$ software program.

Twenty other sclerotia and twenty other faecal pellets, were inoculated on agar slides, incubated at $28^{\circ} \mathrm{C}$ and observed under the microscope every $24 \mathrm{hrs}$. For this purpose, sterile microscope slides $(76 \times 26 \mathrm{~mm})$ were overlaid with a thin film $(1-2 \mathrm{~mm})$ of YMGT agar. In the middle of each slide a section of medium of approximately $7 \times 10$ $\mathrm{mm}$ was removed, leaving a square free of the medium. The faecal pellets and the sclerotia were inoculated separately at each side of the border of the square on the medium approximately 1-2 mm from the edge. The micro-slide cultures were incubated in sterile Petri dishes on glass triangles lying on wet sterile tissue paper either for $24 \mathrm{~h}$ at $28^{\circ} \mathrm{C}$ in a green house, or at $37^{\circ} \mathrm{C}$ for clamp formation studies, and observed under the microscope at an enlargement of 40 x every 24 hours (Polak et al. 1997). The medium used for the germination of faecal pellets, sclerotia and eggs hatching was supplemented with ampicillin $(0.1 \mathrm{mg} / \mathrm{ml})$ to avoid bacterial contamination in the cultures.

For counting the number of spores per faecal pellet, single pellets were isolated under the binocular, and then transferred into a drop of water on a glass slide, covered with a cover-glass and pressed to disaggregate the spores. Pictures were taken under the light microscope at $20 \mathrm{x}$ and $40 \mathrm{x}$ from which the spores were counted. Single spore germination within the faecal pellets was studied by isolating several pellets and incubating them in YMGT liquid media at $28^{\circ} \mathrm{C}$ during $24-48 \mathrm{hrs}$. Afterwards, single pellets were gently disaggregated between a glass and a cover slide, and photographed under the light microscope at $20 \mathrm{x}$ and $40 \mathrm{x}$.

\subsubsection{Larvae hatching}

In order to study the viability of the eggs laid by the mites, 45 eggs were collected from an infested C. cinerea culture and inoculated on micro-slide cultures supplemented with ampicillin. They were incubated at $28^{\circ} \mathrm{C}$ in the green house and observed under the microscope at $40 \mathrm{x}$ every $24 \mathrm{hrs}$ for 8 days. 


\subsubsection{Speed rate of mites walk}

The walking speed of the mites was calculated following the steps of 33 mites (young ones and adults). For this, single mites were gently deposited onto a YMGT agar Petri dish close to a paper ruler and observed under a binocular equipped with a digital camera. A sequence of 61 pictures was taken in frequency of 1 second, using the analySIS ${ }^{\circledR}$ software, in order to produce a video covering one minute of real time.

\subsection{Results}

\subsubsection{Identification of the mite}

Mites collected from infested cultures were identified according to Stammer (1957), Hughes (1961) and Krantz (1978) as Tyrophagus putrescentiae Schrank, 1781 (Figure 1) [(Sin. Acarus putrescentiae Schrank, 1781; Tyrophagus longior var. castellanii Hirst, 1912; T. noxius Zachvatkin, 1941; T. brauni E. \& F. Türk, 1957) (López 2002)].
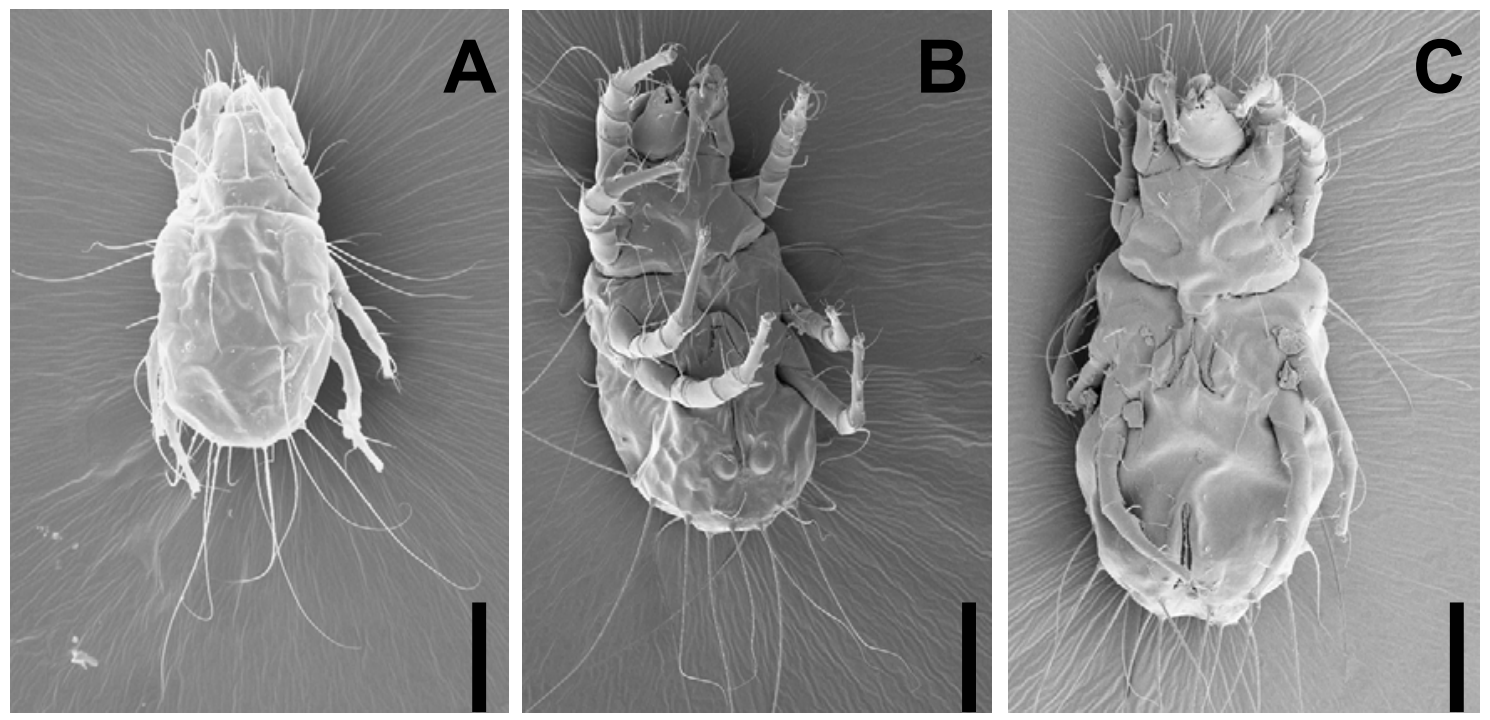

Figure 1 Electron microscopic view of the mite Tyrophagus putrescentiae. Dorsal view (A), ventral view of a male (B), and a female (C) specimen. Scale bar $100 \mu \mathrm{m}$. 


\subsubsection{Grazing on developmental structures of Coprinopsis cinerea}

\subsubsection{Mycelium}

Generally, in these series of experiments the mites were inoculated in the centre of the cultures, however they immediately moved towards the edges of the cultures where younger mycelium was available. No preference for any specific side of the cultures was observed. The mites moved radially but randomly to different places of the culture, and started grazing onto younger mycelium. The older mycelium was rejected in the first place; but after some time it was also consumed (Figure 2, 28d). The pattern of outside-inside grazing on fungal colonies is demonstrated in Figure 2.

25 initial mites and their progenies on the mycelium of C. cinerea AmutBmut cultures produced cavities in the outer area of the originally homogeneous aerial mycelium after $14 \mathrm{~d}$ of incubation. Within $28 \mathrm{~d}$ of incubation, the aerial mycelial layer was nearly completely gone. At the same time, the mycelia from parallel cultures of the strain C. cinerea PS001-1 x PS002-1 was severely damaged by larger cavities in the outer regions of aerial mycelium in the cultures (Figure 2).

Figure 2 (next page) Tyrophagus putrescentiae grazing on mycelia of Coprinopsis cinerea. Plates of mature cultures of monokaryons PS001-1 and PS002-1, the dikaryon PS0021 x PS0011 and the homokaryon AmutBmut are shown that were all infected with 25 mites. All cultures were grown for $5 \mathrm{~d}$ at $37^{\circ} \mathrm{C}$ in the dark, after which they were incubated for $7 \mathrm{~d}$ at $28^{\circ} \mathrm{C}$ in a 12 $\mathrm{h}$ light/12 $\mathrm{h}$ dark cycle. Note that the dikaryon and the homokaryon cultures have therefore mature fruiting bodies (arrows, d 7 of development, for details see chapter 6) undergoing autolysis shortly before 25 mites were transferred into the cultures (d 0). Damage of the cultures by the mites is shown 14 and $28 \mathrm{~d}$ after infestation with the mites and incubated at $28^{\circ} \mathrm{C}$ in a green house. During incubation, mites reproduced and both larvae and adults grazed on the mycelium (not shown). The fast grazing observed in all cultures can be explained by the speed and ability of $T$. putrescentiae to reproduce under suitable conditions. At temperature comparable to the present study $\left(25^{\circ} \mathrm{C}\right)$, $T$. putrescentiae can increase its population more than 9-fold per week (Sánchez-Ramos and Castañera 2005). 
d 0

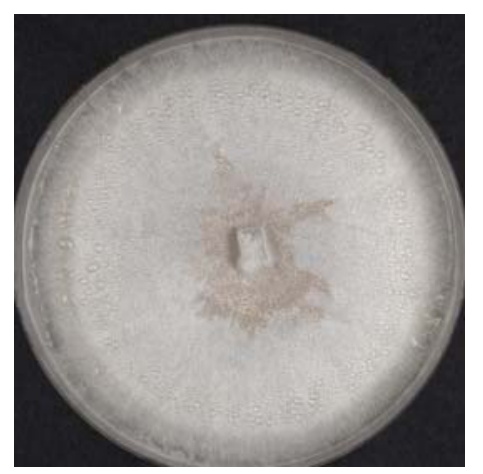

C. cinerea PS001-1
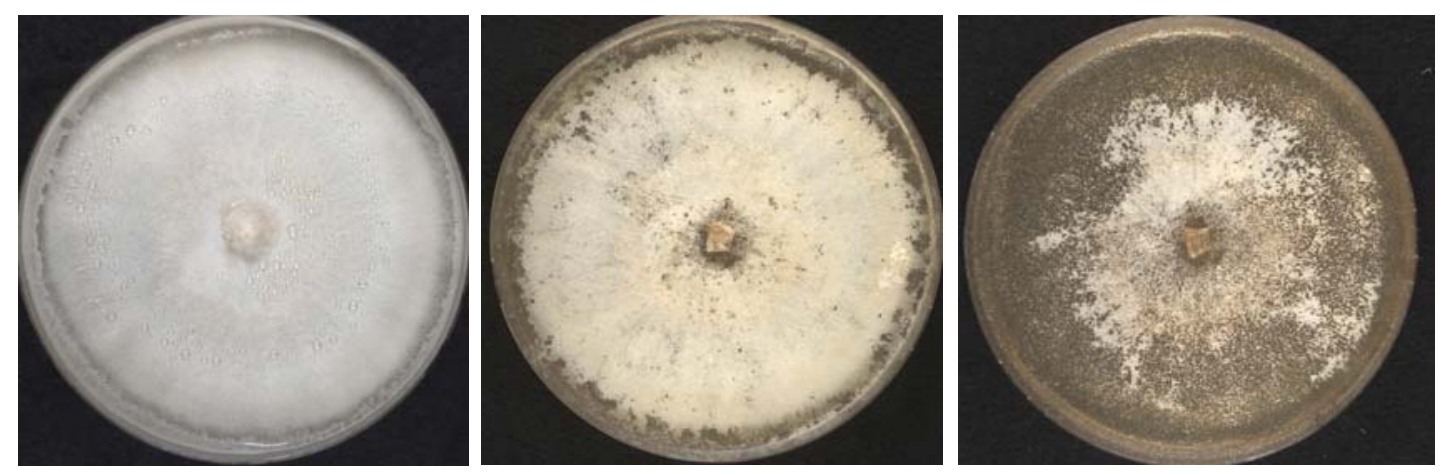

C. cinerea PS002-1
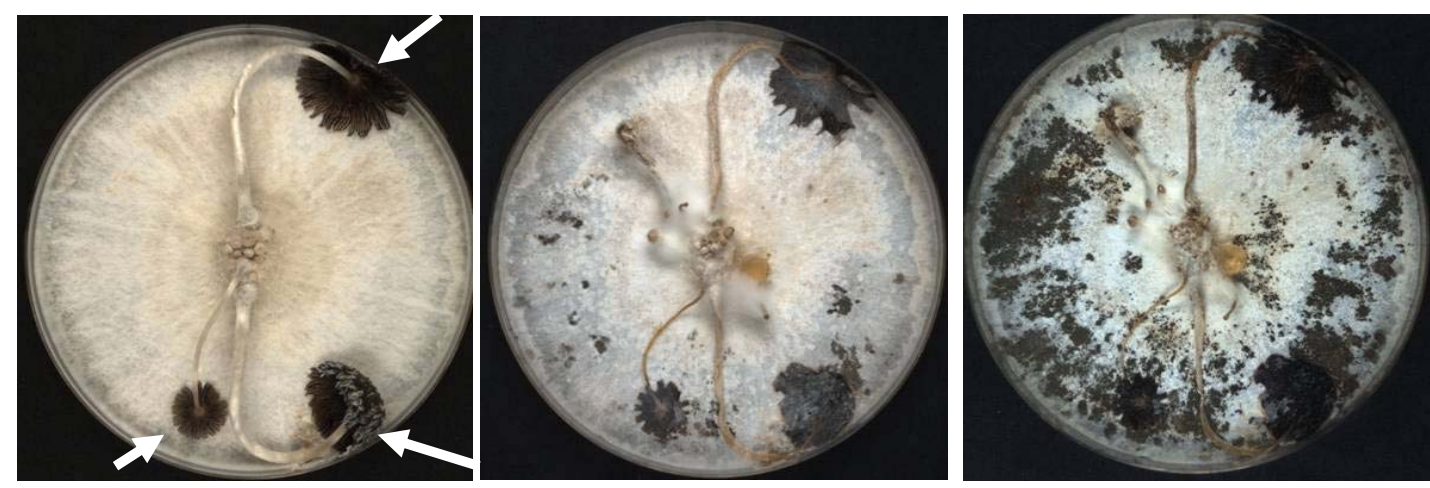

C. cinerea PS001-1 x PS002-1
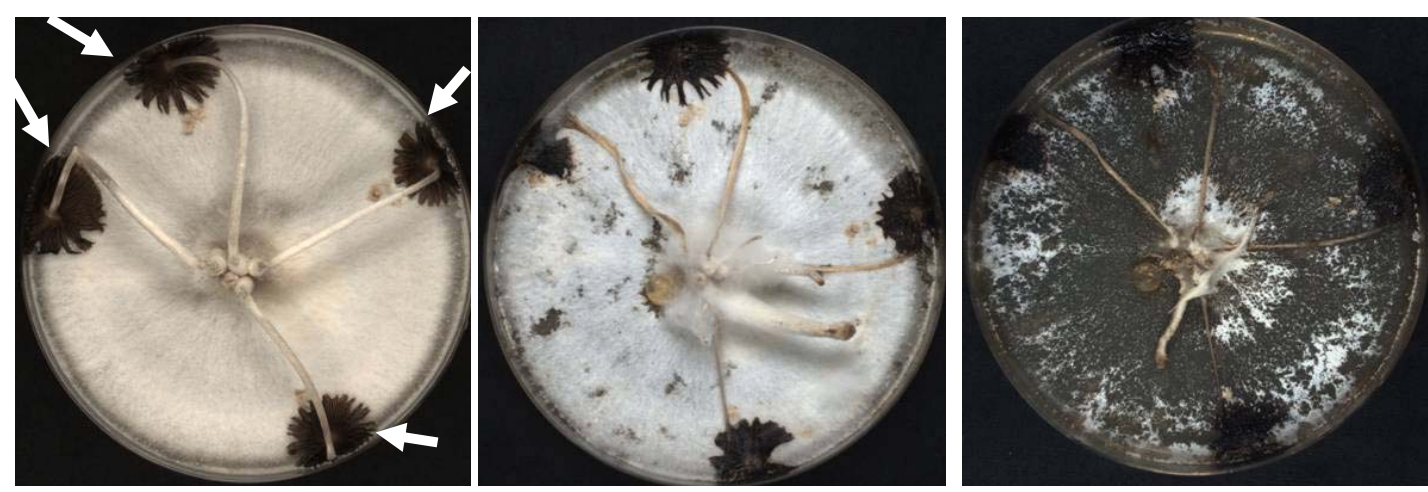

C. cinerea AmutBmut 


\subsubsection{Basidiospores}

Interesting was to see the behaviour of the mites with the fruiting structures present in the cultures of the dikaryon PS001-1 x PS002-1 and homokaryon AmutBmut. As documented in Figure 2 (homokaryon AmutBmut d 28), the stipes of fruiting structures were avoided. In contrast, basidiospores from the cap were consumed. Upon spores were swallowed by the animals into the pharynx, they pass through the esophagus into the ventriculus (Figure 3). Spores are first randomly distributed in the ventriculus (Figure 3A-B), a wide chamber that transforms into the colon posteriorly. Active peristaltic movement in the ventriculus of the translucent mites can be followed under the binocular by the movement of the brown spores of $C$. cinerea. In animals with a high consumption of spores, 2 food boli can be seen positioned in the
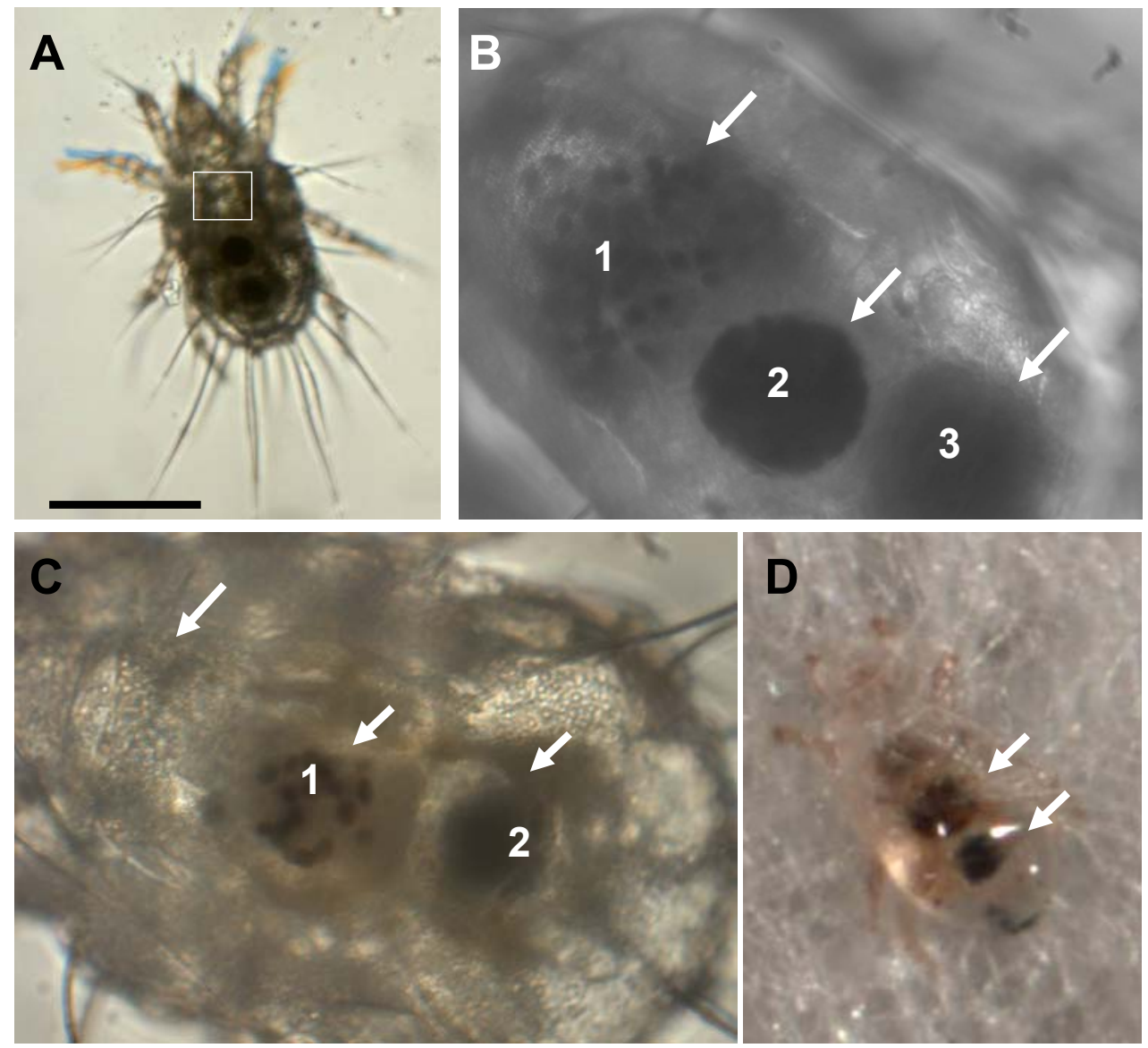

Figure 3 Basidiospores swallowed by the mites (A) were firstly kept free in the ventriculus (B, $4 \mathrm{x}$ section from $\mathbf{A}, 1$ arrow). Later on, the food bolus is compacted into round bodies transferred into the intercolon and post colon of the midgut of the mites (B2-3). The food bolus at the intercolon is rapidly transferred to the postcolon giving space in the intercolon for formation of a new bolus (C1). In animals with a high consumption of spores, 2 food boli can be easily seen through its translucent body (D). Scale bar $200 \mu \mathrm{m}$. 
intercolon of the midgut and the postcolon of the midgut, respectively (Figure 3B-C).

After passing the digestion tract of the animals through the midgut, the food bolus at the intercolon is rapidly transferred to the postcolon giving space in the intercolon for formation of a new bolus (Figure 3C-1). The excreted faecal pellets are round compact bodies in which the spores are pressed together, most likely with other food rests, into an aggregate surrounded by a peritrophic membrane (see below).

\subsubsection{Sclerotia}

Upon grazing all aerial hyphae, it was observed that the melanized sclerotia were left, supporting their function for duration in nature (Figure 4A). When 100 of these sclerotia were transferred onto fresh media containing antibiotic (not shown in picture), $100 \%$ of them germinated into mycelial cultures when incubated at $28^{\circ} \mathrm{C}$.

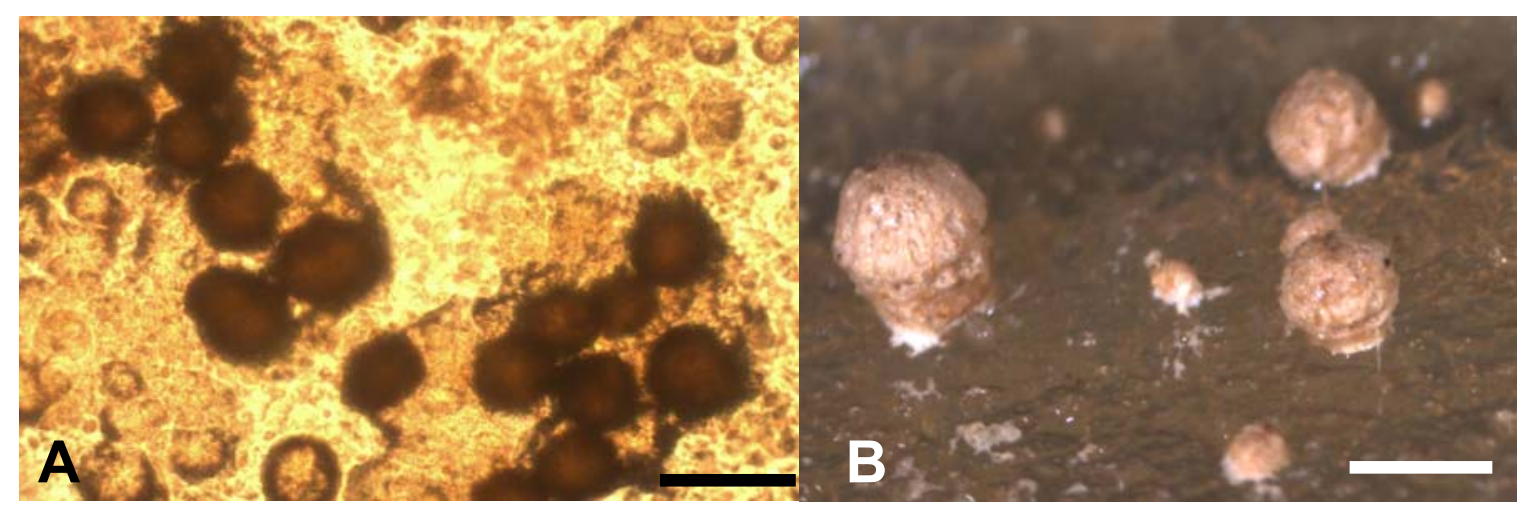

Figure 4 Sclerotia were not consumed by the mites and were left untouched on the agar (A). Primordia of different stages were also left intact on the agar $(\mathbf{B})$. Note that the mycelium was already consumed. Scale bar $200 \mu \mathrm{m}$ (A) and $5 \mathrm{~mm}$ (B).

\subsubsection{Fruiting bodies}

Plates containing fruiting structures including mature mushrooms, and developing primordia of the dikaryon and the homokaryon AmutBmut were further observed. The whole process of fruiting body development takes place in $7 \mathrm{~d}$ starting from hyphal aggregates in which different types of tissues (cap and stipe) will develop (primordia) over a time of 5 days. It will take only one day further to perform in the fully developed primordia within basidia karyogamy and meiosis, preceding fruiting body maturation and basidiospore formation (see chapter 6 for details). Primordia of all age (d 1 to d 5) 


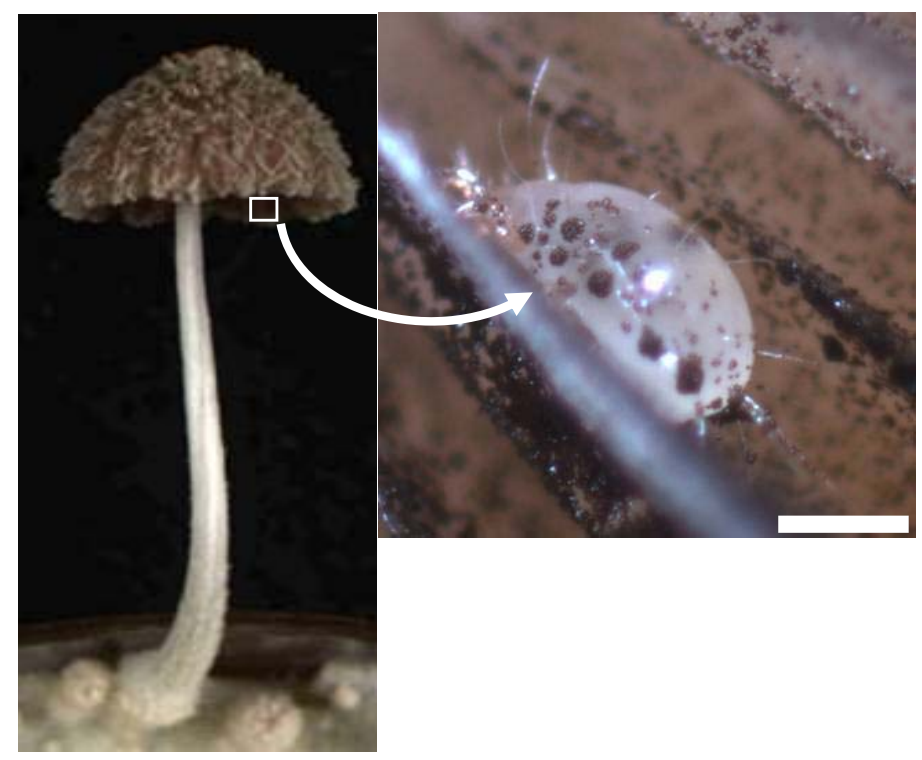

Figure 5 Tyrophagus putrescentiae consuming spores directly from the gills of a mature fruiting body of Coprinopsis cinerea. The brown spots on the surface of the mite are groups of spores attached to its body. Scale bar $200 \mu \mathrm{m}$.

were rejected as food by the mites (Figure 4). After fruiting bodies maturated by stipe elongation and by cap expansion, we observed the mites climbing up the stipe to then feed on the autolysing cap tissues with the basidiospores (Figure 5). Fresh stipes were always avoided from grazing (Figure 2). In contrast, in old cultures ( $\sim 40 \mathrm{~d})$, where no mycelia was left, stipes were finally also consumed by the mites.

Basidiospores attached to the cap or found free on the mycelia after their release from the cap, were ingested, however, not digested. Faecal pellets (size: $75.9 \pm 12.8 \times 67.8 \pm$ $11.4 \mu \mathrm{m}$ ) with basidiospores of intact shape were formed. These pellets contained $368 \pm$ 299 basidiospores of intact shape in the case of $C$. cinerea AmutBmut, and $268 \pm 149$ in the case of dikaryon C. cinerea PS001-1 x PS002-1. Spores from the faecal pellets were kept together by an outer peritrophic membrane (Figure 6) also described in the mite Dermatophagoides farinae and Acarus siro (Wharton and Brody 1972, Šobotník et al. 2007) and by an inner gelatinous-like substance gluing the spores together inside the pellet. Microscopy of the faecal pellets showed that the spores kept their shape and were apparently intact. 

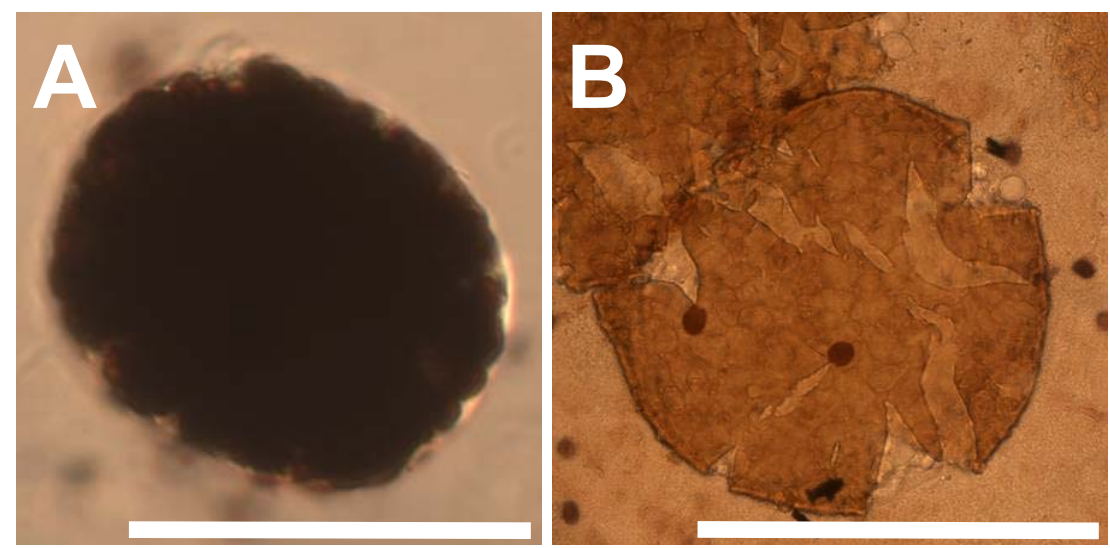

Figure 6 Spores were aggregated in compact more or less round bodies (A), and kept together by a peritropic membrane (B). Scale bar $50 \mu \mathrm{m}$.

In fungal cultures with mature fruiting bodies, we observed that mites lay their eggs next to the faecal pellets containing spores (Figure 7). This was particularly visible when the mycelium was consumed, however this behaviour occurred also in cultures were mycelium was still available.

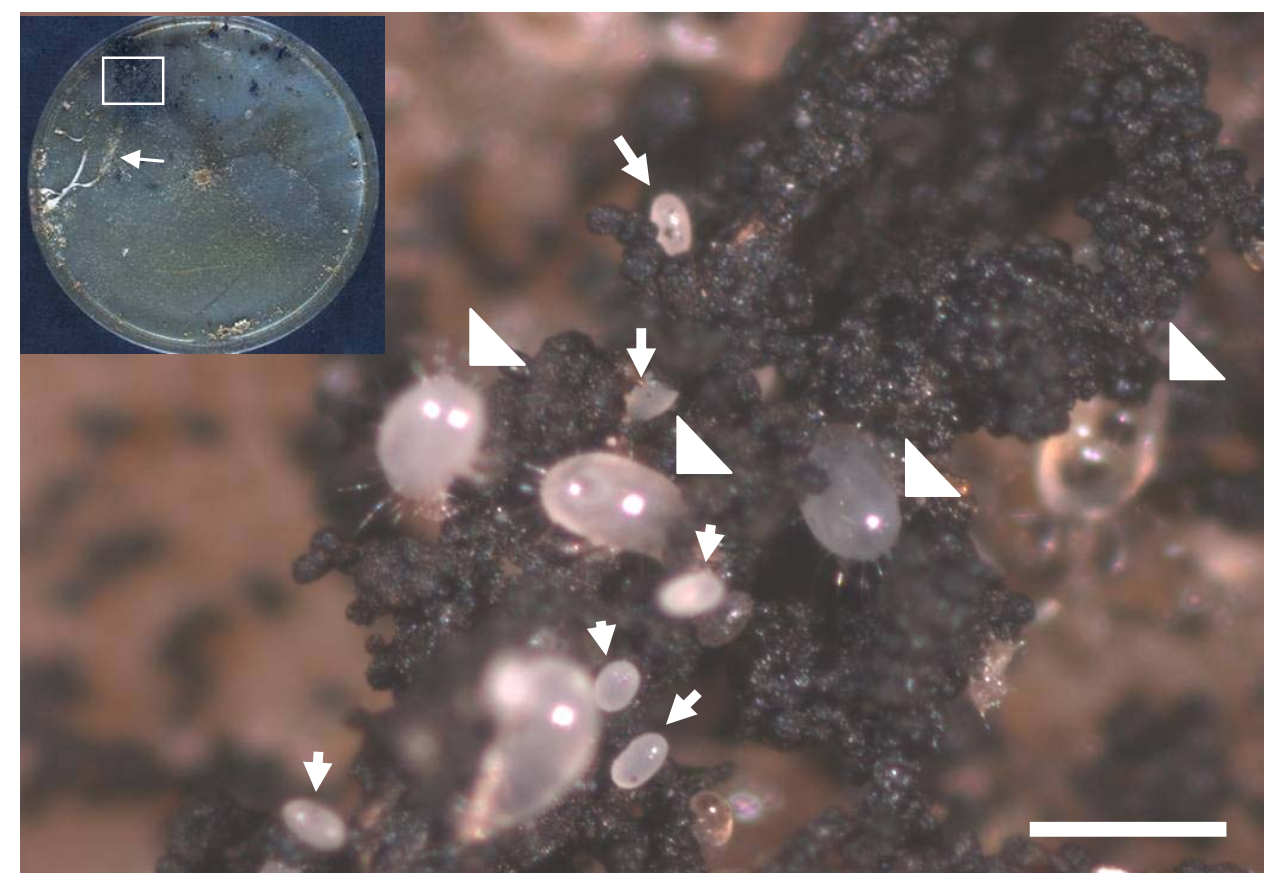

Figure 7 After Tyrophagus putrescentiae consumed the basidiospores, the faecal pellets were excreted very often in the same area where originally the autolysed cap laid (inset: the frame shows the cap and the arrow, rest of the stipe), hence groups of pellets accumulated at the places over the time. Often, mites laid their eggs (arrows) in close vicinity to the pellets. Mites appeared to be very active moving (triangle) in the area where the eggs were laid. Scale bar $300 \mu \mathrm{m}$. 

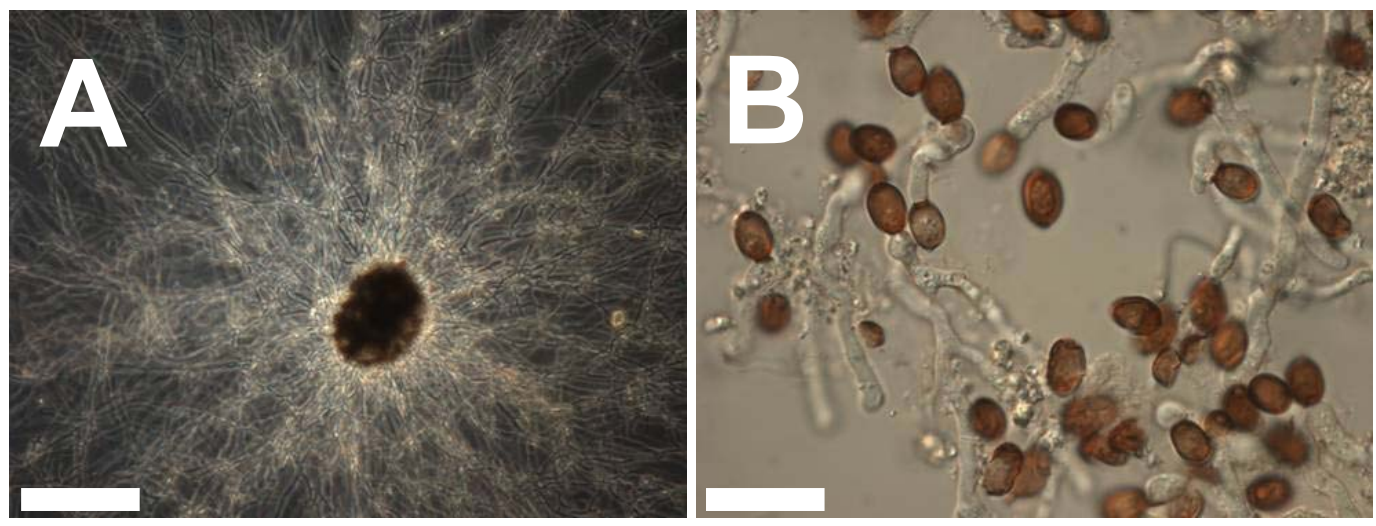

Figure 8 Germination of the spores contained in the faecal pellet after $24 \mathrm{~h}$ of incubation at $37^{\circ} \mathrm{C}$ (A).Closer microscopy of the inside of the faecal pellets shows that most of the spores germinated (B). Scale bar 50 and $20 \mu \mathrm{m}$ respectively

Pellets from the dikaryon C. cinerea PS001-1 x PS002-1 inoculated on fresh media produced within $24 \mathrm{hrs}$ a mycelial colony originated from the germination of single spores (Figure 8). The formation of the dikaryotic mycelia was followed in micro-slide cultures in order to observe whether clamp cell formation occurred in the colonies originated from the germinating spores in the faecal pellets. In cultures incubated at $37^{\circ} \mathrm{C}$, fully developed clamp cells were observed after 2 days of incubation, indicating that dikaryons were formed in the outgrowing mycelia. $100 \%$ of the germinated pellets $(\mathrm{n}=20)$ produced mature fruiting bodies when the germinated dikaryons were transferred to standard Petri dishes with fresh YMGT media under fruiting conditions.

\subsubsection{Larvae hatching}

To study the viability of the eggs laid by the mites, 45 eggs were collected from an infested C. cinerea culture and inoculated on micro-slide cultures supplemented with ampicillin and incubated at $28^{\circ} \mathrm{C}$ in the green house. The hatching of the animals was followed daily under the binocular hrs for 8 days. Since the age of the eggs was different, few started to hatch directly one day after of incubation. Altogether, 31 mites hatched (Figure 9) between 1-5 d after transferred onto the agar. The rest of the eggs were further observed for $3 \mathrm{~d}$ more, however no more larvae hatched. 


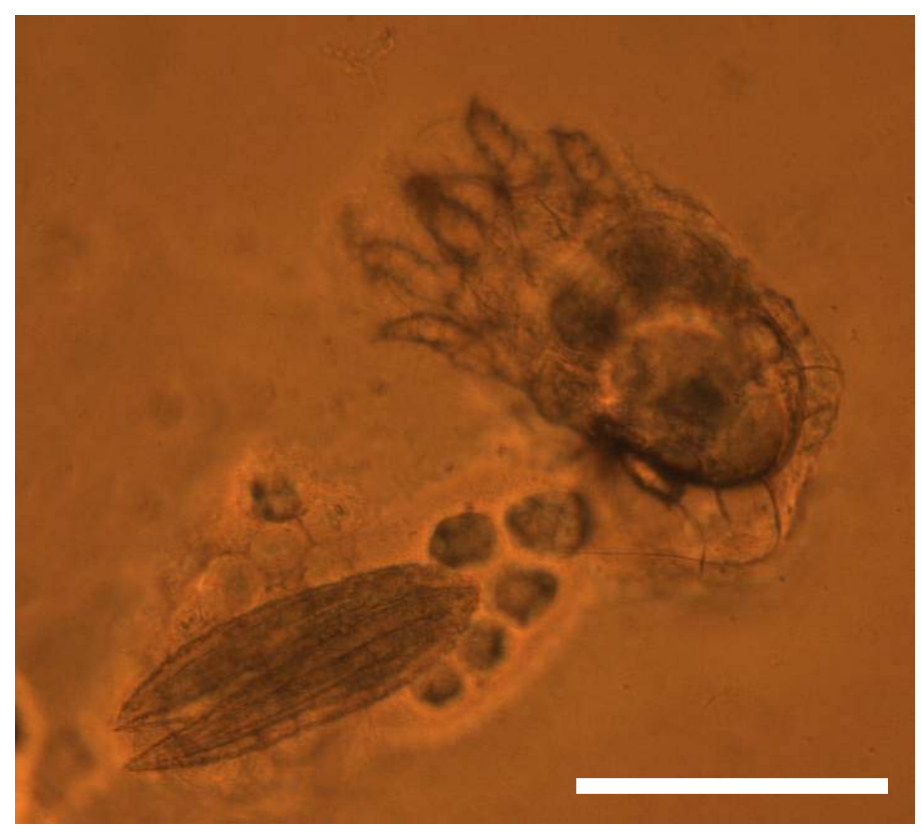

Figure 9 Tyrophagus putrescentiae larvae. After $4 \mathrm{~d}$ of incubation at $28^{\circ} \mathrm{C}$ in a green house, mite's eggs hatch. In the picture a larvae is seen just after hatching. At the left corner, the remnants of the egg are seen. Scale bar $100 \mu \mathrm{m}$.

From reports in the literature (Sánchez-Ramos and Castañera 2005, Kües 2000) and own observations in this study we conclude that mites and fungi prefer similar conditions for development. This raised the idea that there might be a form of symbiotic interaction between the mites and the fungus since the mites transfer basidiospores into new environments by the faecal pellets and germinated fungal colonies will serve as food for their hatching larvae. Larvae take 4-5 days to hatch from the eggs which will give the fungus enough time to grow into a larger colony and eventually initiate fruiting body development before the mites will start to graze on the mycelium. Since primordia are avoided by the mites, the fungus might have the chance to mature the fruiting structure and produce basidiospores.

The mite will later on consume the spores produced by the mature fruiting body and will potentially disperse them, where under appropriate conditions the fungus will start its cycle again (Figure 10). Interesting for spore dispersal is to know which distances mites can cover over the time. To give an idea, we determined the walking speed of these animals. In our experiments, the mites moved at a speed of $6 \mathrm{~mm} / \mathrm{min}$ in average. In best cases, we have observed that some could move at a speed of $29 \mathrm{~mm} / \mathrm{min}$. 


\subsubsection{Mite populations in fungal cultures}

Petri dishes, containing C. cinerea AmutBmut fruiting bodies were infested with per plate just one female mite at a stage of oviposition. From this, mite populations were generated over the time. At the end of the experiment (60-77 $\mathrm{d}$ of incubation) plates were used to count and sort hatched individuals. Altogether, 319 individuals were counted, of which $74 \%$ were females and $26 \%$ were males. Of the female mites, $71.8 \%$ $+/-20.3 \%$ did not consumed spores at the time of the investigation, and $28.2 \%+/-20.3 \%$ did. The males divided into $91.2 \%+/-12 \%$ without spores and $8.8 \%+/-12 \%$ with spores. After the statistical analysis, using the multiple Anova analysis method, we did not find significant differences $(\mathrm{p}=0.59)$ of the feeding behaviour between female and male mites. However, there was a significant difference $(p=0.004)$ of the sex-ratio of the hatched mites.

Figure 10 (next page) The life cycle of $C$. cinerea along with the mite $T$. putrescentiae. The mite's life cycle as linked to the fungus starts with the mite grazing the cap tissues of the mushroom and the spores (A). Round compact bodies containing the spores $(368 \pm 299)$ are usually formed inside their bodies in the intestinal tract (arrow) that after excretion are known as the faecal pellets $(\mathbf{B})$. When the fruiting body is completely autolysed, mites continue to ingest the spores. At the same time, eggs are laid in close vicinity to the faecal pellets containing the spores (C). These spores germinate and form a dikaryon (D). The larvae hatch once a new colony of mycelia is established (E). Monokaryotic and dikaryotic mycelia, as well as asexual spores (oidia) are consumed by the mites $(\mathbf{F})$, albeit possibly at different preference. The melanized sclerotia are rejected $(\mathbf{G})$. Primordia $(\mathbf{H})$, as well as stipes from mature fruiting bodies are also refused by the mites (I). 


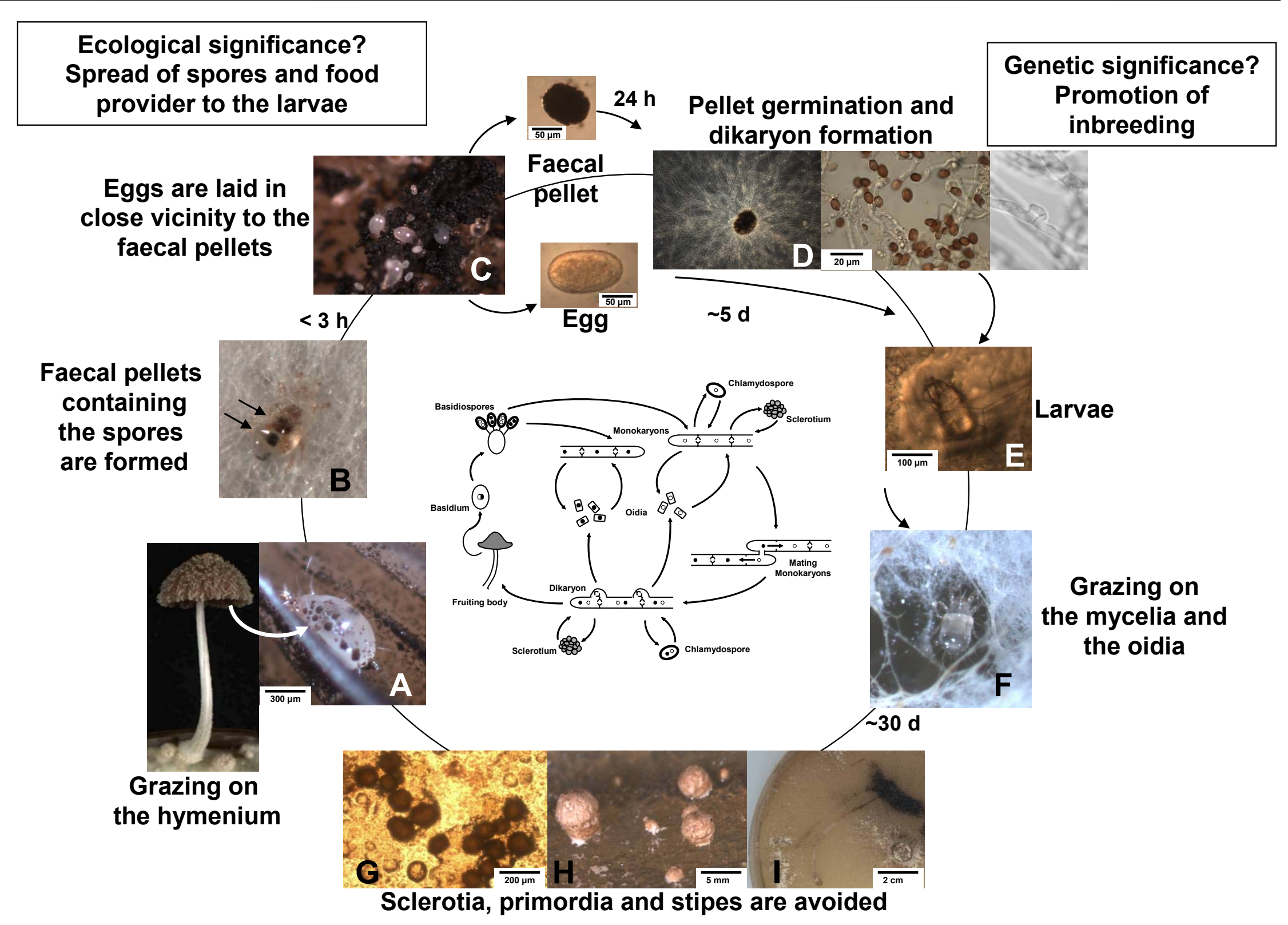




\subsection{Discussion}

T. putrescentiae is a mite of the Acaridae frequently found in a great variety of stored food with a relatively high fat and protein content (Hughes 1961). Other places are in houses within the dust coming e.g. from human skin. By the different habitats the mite is also known under the common names storage mite, stored product mite, food mite, cheese mite and house dust mite although those names are not exclusively used for the species. These arthropods are found in environments suitable also for fungi, particularly environments with high humidity and elevated temperatures (Sánchez-Ramos et al. 2007, Aspaly et al. 2007). Since the mite transfers also fungal spores to food, another common name is mold mite (Hubert et al. 2004).

Mushroom houses provide the perfect environment for different kind of mites, Tyrophagus spp. among them, with the consequence of causing damages on the fungal cultures (Krantz 1978). Tyrophagus spp. infestations have been repeatedly reported to be a problem for cheese maturation, causing losses up to $25 \%$ if the infestation is not controlled (Wilkin 1979). Cheddar cheese produces octadienols, such as 1-octen-3-one which are odor-active volatiles characteristic for a "fungus like" odour (Frank et al. 2006, Pyysalo 1976). These eight-carbon volatiles are ubiquitous among fungi and contribute to the fungal aroma (Combet et al. 2006). Similar to other basidiomycetes, C. cinerea produces 1-octen-3-ol and 3-octanone in its vegetative stage (Thakeow et al. unpublished). Fungal volatiles are fairly widespread and evidently implicated in the relation between Acaridae and fungi (Vanhaelen et al. 1980).

The life cycle of $C$. cinerea along with the mite $T$. putrescentiae starts with the mite feeding on the mushroom tissues including the spores (Figure 10). Spores from C. cinerea are melanized structures; this strong barrier protects the nuclei from adverse conditions until an appropriate environment is available for their germination (McLaughlin 1977). In nature, the spores of coprophilous fungi survive their passage through the animal digestive system when consumed by herbivorous (Richardson 2001). Also basidiospores ingested by the mites will not be digested (Figure 8). As a result, faecal pellets containing a number of fungal spores are formed and excreted. The spores in the faecal pellets easily germinate and form a dikaryon since the high number of consumed spores ensures that all four possible fungal mating types arising from meiosis within a fruiting body (Kües 2000) are represented. 
Mating type of $C$. cinerea is determined by different alleles at two unlinked genetic loci $A$ and $B$, with the consequence that within a progeny there is an expected mating type distribution of $\mathrm{AxBx}, \mathrm{AxBy}, \mathrm{AyBx}$, and $\mathrm{Ay}, \mathrm{By}$ ( $\mathrm{x}$ and $\mathrm{y}$ referring to different mating type alleles in a 25:25:25:25 frequency). Only two germinated spores that are different at both mating type loci will be able to form by mating a dikaryon, i.e. there is $25 \%$ likelihood to find a sexual partner with the same progeny (Casselton and Kües 2007). Generally, the mating type system of C. cinerea is though to serve outbreeding by promoting mating the spores from different mushrooms (Hiscock and Kües 1999). By keeping the spores of a same mushroom together by the mites in their faecal pellets, the possibility of mating of germinated mycelium with germinated mycelium from spores of other mushrooms is restricted and in consequence inbreeding is promoted. In this way, the promotion of dikaryon formation between siblings from the same mushroom and with it of fungal inbreeding, gives a genetic aspect to the relation between the fungus and the mite.

In nature, spore transfer via ingestion and via attachment to the exoskeleton of the mites is a phenomenon little studied in the acari. However, higher attention is given to spore dispersal in stored food because toxigenic and allergen-producing fungi are a threat for human food and animal feed safety (Hubert et al. 2004, Franzolin et al. 1999). Rare cases of mites that posses a sporotheca, a hollow body cavity that the mites use as a transport container for fungal spores, have so far only been seen in few families: Trochometridiidae (Trochometridium Cross, Lindquist 1985), Siterotiidae (Siteroptes cerealium, Suski 1973), Tarsonemidae (Tarsonemus ips, Moser 1985), and Scutacaridae (Imparipes haeseleri, I. apicola and I. breganti, Ebermann and Hall 2003, Hall and Ebermann 2004). In all cases, only females were responsible for fungal transfer. Although there is no data concerning the viability of the spores transported in the sporotheca, mites might act as fungi spreaders transporting spores inside or outside their bodies to other possible substrates, rewarded at the same time by being provided with mycelia for a new colony of mites (Janke and Lubkowitz 1953, Okabe 1999, RamírezSuárez et al. 2002). In this study we observed a minor possible route of fungal spore distribution by attachment of fungal spores to the mite body (Figure 5), and a major route through the mite's faeces. In case of T. putrescentiae, faecal pellets have been observed mainly in females, but this is due to their majority in their populations. Our results showed a non-significant relation between the sex of a mite and its feeding 
preference on the spores. We found that the greater number of females ingesting spores could be attributed to the sex-ratio in the mite population which, in our studies, revealed a majority of females in the population. In our laboratory experiments, eggs were laid among the faecal pellets, supporting nevertheless the idea that fungi probably play an important role in the mites' cycle of development (Ebermann and Hall 2005). Upon germination of fungal mycelium from the basidiospores, hatching larvae are supplied directly with food for their further development.

In this study, we demonstrated the grazing preferences of the mite T. putrescentiae on the fungus $C$. cinerea and the ecological significance of the relationship of these two organisms: spreading of fungal spores and providing food for the mites' larvae. Moreover, patterns of fungal spore dispersal could affect gene flow, population structure and fungal community structure (Lilleskov and Bruns 2005). Considering the biodiversity of mites still to be described, it is expected that the number of species having the same strategy to carry spores is higher; therefore further research is needed to understand the ecology of this organisms.

\subsection{Acknowledgments}

Technical support from Ulrike Eisenwiener of the Institute for Forest Zoology and Forest Conservation and Dr. Matthias Hahn from the Institute of Material physic of the Georg-August-University Göttingen for the REM microscopy is greatly acknowledged. Moreover I would like to thank Dr. Kateřina Svobodová for critical reading of the manuscript.

\subsection{References}

Aspaly G, Stejskal V, Pekar S, Hubert J (2007) Temperature-dependent population growth of three species of stored product mites (Acari : Acaridida). Exp. Appl. Acarol., 14, 37-46.

Baker EW, Wharton GW (1952) An introduction to acarology. The MacMillan Company, New York, N.Y., USA.

Behan-Pelletier VM (1999) Oribatid mite biodiversity in agroecosystems: role for bioindication. Agr. Ecosystems Environ., 74, 411-423.

Casselton LA, Kües U (2007) The origin of multiple mating types in the model mushrooms Coprinopsis cinerea and Schizophyllum commune. In: Heitman J, 
Kronstad JW, Taylor JW, Casselton L. Sex in fungi. Molecular Determination and Evolutionary Implications. ASM Press, Washington, D.C., USA.

Combet E, Henderson J, Eastwood DC, Burton KS (2006) Eight-carbon volatiles in mushrooms fungi: properties, analysis, biosynthesis. Mycoscience, 47, 317-326.

Duek L, Kaufman G, Palevsky E, Berdicevsky I (2001) Mites in fungal cultures. Mycoses, 44, 390-394.

Ebermann E, Hall M (2003) First record of sporothecae within the mite family Scutacaridae (Acari, Tarsonemina). Zool. Anz., 242, 367-375.

Ebermann E, Hall M (2004) A new species of scutacarid mites transferring fungal spores (Acari, Tarsonemina). Rev. Suisse Zool., 111, 941-950.

Frank D, O'Riordan P, Zabaras D, Varelis P (2006) Cheddar cheese volatile profiling using dynamic headspace gas chromatography-mass spectrometry olfactometry. Aust. J. Dairy Technol., 61, 105-107.

Franzolin MR, Gambale W, Cuero RG, Correa B (1999) Interaction between toxigenic Aspergillus flavus Link and mites (Tyrophagus putrescentiae Schrank) on maize grains: effects on fungal growth and aflatoxin production. J. Stored Prod. Res., $35,215-224$.

Granado JD, Kertesz-Chaloupková K, Aebi M, Kües U (1997) Restriction enzymemediated DNA integration in Coprinus cinereus. Mol. Gen. Genet., 256, 28-36.

Hall M, Ebermann E (2005) Zoogoegraphical aspects of some scutacarid mites and their phoresy hosts (Acari, Heterostigmata; Hymenoptera, Aculeata). Rev. Suisse Zool., 112, 215-224.

Hiscock SJ, Kües U (1999) Cellular and molecular mechanisms of sexual incompatibility in plant and fungi. Int. Rev. Cytol., 193, 165-295.

Hubert J, Stejskal V, Kubatova A, Munzbergova Z, Vanova M, Zd'arkova E (2003) Mites as selective fungal carriers in stored grain habitats. Exp. Appl. Acarol., 29, 69-87.

Hubert J, Stejskal V, Munzbergova Z, Kubatova A, Vanova M, Arkova EZ (2004) Mites and fungi in heavily infested stores in the Czech Republic. J. Econ. Entomol., 97, 2144- 2153.

Hughes AM (1961) The mites of stored food. Tech. Bull. Minist. Agric. Fish. Food, No. 9, London, UK. 
Janke D, Lubkowitz E (1953) Milben der gruppe Tarsonemus (Tarsonemus fusarii Cooreman 1941) als verunreiniger von Pilzkulturen. Klin. Wochenschr., 31, 289290.

Johnston JM (2000) The contribution of microarthropods to aboveground food webs: A review and model of belowground transfer in a coniferous forest. Am. Midl. Nat., 143, 226-238.

Kertesz-Chaloupková K, Walser PJ, Granado JD, Aebi M, Kües U (1998) Blue light overrides repression of asexual sporulation by mating type genes in the basidiomycete Coprinus cinereus. Fungal Genet. Biol., 23, 95-109.

Kheradmand K, Kamali K, Fathipour Y, Mohammadi Goltapeh E (2007) Development, life table and thermal requirement of Tyrophagus putrescentiae (Astigmata: Acaridae) on mushrooms. J. Stored Prod. Res., 43, 276-281.

Krantz GW (1978) A manual of acarology. O. S. U. Book stores Ltd., Corvallis, Oregon, USA.

Kües U (2000) Life history developmental processes in the basidiomycete Coprinus cinereus. Microbiol. Mol. Biol. Rev., 64, 316-353.

Lilleskov EA, Bruns TD (2005) Spore dispersal of a resupinate ectomycorrhizal fungus, Tomentella sublilacina, via soil food webs. Mycologia, 97, 762-769.

Lindquist EE (1985) Discovery of sporothecae in adult female Trochometridium Cross, with notes on analogous structures in Siteroptes Amerling (Acari: Heterostigmata). Exp. Appl. Acarol., 1, 73-85.

López JS (2002) Control de ácaros contaminantes del jamón Ibérico. Tesis doctoral. Universidad de Extremadura Facultad de Veterinaria, Depto. de Medicina y Sanidad Animal. Cáceres, España.

Maraun M, Visser S, Scheu S (1998) Oribatid mites enhance the recovery of the microbial community after a strong disturbance. Appl. Soil Ecol., 9, 175-181.

McLaughlin DJ (1977) Basidiospore initiation and early development in Coprinus cinereus. Am. J. Bot., 64, 1-16.

Moore D (1998) Fungal morphogenesis. Cambridge University Press, Cambridge, UK.

Moser JC (1985) Use of sporothecae by phoretic Tarsonemus mites to transport ascospores of coniferous bluestan fungi. T. Brit. Mycol. Soc., 84, 750-753.

Okabe K (1999) Vectoring of Hypocrea nigricans (Hypocreales: Hypocreaceae) by three fungivorous mite species (Acari: Acaridae). Exp. Appl. Acarol., 23, 653-658. 
Polak E, Hermann R, Kües U, Aebi M (1997) Asexual sporulation in Coprinus cinereus: Structure and development of oidiophores and oidia in an AmutBmut homokaryon. Fungal Genet. Biol., 22, 112-126.

Pyysalo H (1976) Identification of volatile compounds in seven edible fresh mushrooms. Acta Chem. Scand. B, 30, 235-240.

Ramírez-Suárez A, Zavaleta-Mejía E, Kawasoe SO, Sánchez GMC, Valdéz CJ (2002) A possible role for Rhizoglyphus robustus Nesbitt (Astigmata: Acaridae) in transmission of Sclerotium cepivorum Berk. (Deuteromycetes: Mycelia-Sterilia). Appl. Entomol. Zool., 37, 663-669.

Richardson MJ (2001) Diversity and occurrence of coprophilous fungi. Mycol. Res., $105,387-402$.

Sánchez-Ramos I, Castañera P (2005) Effect of temperature on reproductive parameters and longevity of Tyrophagus putrescentiae (Acari: Acaridae). Exp. Appl. Acarol., 36, 93-105.

Sánchez-Ramos I, Alvarez-Alfageme F, Castanera P (2007) Effects of relative humidity on development, fecundity and survival of three storage mites. Exp. Appl. Acarol., 41, 87-100.

Schiestl FP, Steinebrunner F, Schulz C, von Reuss S, Francke W, Weymuth C, Leuchtmann A (2006) Evolution of 'pollinator' - attracting signals in fungi. Biol. Lett.-UK, 2, 401-404.

Schneider K, Renker C, Maraun M (2005) Oribatid mite (Acari, Oribatida) feeding on ectomycorrhizal fungi. Mycorrhiza, 16, 67-72.

Šobotník J, Alberti G, Weyda F, Hubert J (2007) Ultrastucture of the digestive tract in Acarus siro (Acari: Acaridida). J. Morphol., DOI10.1002/jmor.10573.

Srivilai P (2006) Molecular analysis of genes acting in fruiting body development in basidiomycetes. PhD Thesis. Georg-August University of Göttingen, Göttingen, Germany.

Stammer HJ (1957) Beiträge zur Systematik und Ökologie mitteleuropäischer Acarina. Akademische Verlagsgesellschaft Geest \& Portig K.-G., Leipzig, Germany.

Suski ZW (1973) A revision of the Siteroptes cerealium (Kirchner) complex (Acarina, Heterostigmata, Pyemotidae). Ann. Zool., 30, 509-535.

Swamy S, Uno I, Ishikawa T (1984) Morphogenetic effects of mutations at the $A$ and $B$ incompatibility factors in Coprinus cinereus. J. Gen. Microbiol., 130, 32193224. 
Van Asselt L (1999) Interactions between domestic mites and fungi. Indoor built environ., 8, 216-220.

Vanhaelen M, Vanhaelen-Fastré R, Geeraerts J (1980) Occurrence in Mushrooms (Homobasidiomycetes) of Cis-Octa-1,5-Dien-3-Ol and Trans-Octa-1,5-Dien-3Ol, Attractants to the cheese mite Tyrophagus putrescentiae (Schrank) (Acarina, Acaridae). Experientia, 36, 406-407.

Wharton GW, Brody AR (1972) The peritrophic membrane of the mite, Dermatophagoides farinae: Acariformes. J. Parasitol., 58, 801-804.

Wilkin DR (1979) The control of mites in cheese stores. In: Recent advances in Acarology. Rodriguez JG (ed.), Academic Press, New York, N.Y., USA. 
General discussion and conclusions: Is it worth to work with coprini? 


\section{General discussion and conclusions:}

\section{Is it worth to work with coprini?}

The coprini are a group of fungi that easily produce fruiting bodies in the laboratory. Therefore they have been broadly used as model organism for few single basidiomycetes already since more than 100 years. Members of this group of organisms have been described since more than 200 years. However, due to their particular features, minute size and autolysing of the mushrooms of many species, most likely many species are still not described. In traditional taxonomy, species were described only according to morphological characteristics, but in recent years molecular studies have become an important tool, together with morphological descriptions, for correct identification of the species. Through molecular analysis, it has become clear that the originally considered monophyletic group of coprini is indeed polyphyletic (Redhead et al 2001). Up to now, many species have been reorganized into four newly defined genera (Coprinus, Coprinopsis, Coprinellus and Parasola), but this process is still ongoing.

In this study, several strains supposed to be coprini have been obtained from culture collections. Upon checking their identity by ITS sequencing, in a number of cases, species assignments were found to be wrong, and sometimes also the genus. The molecular analysis clearly documents the difficulty in correct identification of strains. Since we obtained mycelia and not fruiting bodies, it is not clear whether morphological misidentification has in the first place contributed to the wrong species names or whether strains were mixed up in culture. For those strains that can be induced in the laboratory to produce fruiting bodies, morphological identification might be possible, although fruiting bodies on artificial substrate might be smaller than fruiting bodies described in nature (own observations). However, a number of strains might never be correctly identified as long as no ITS sequences from clearly defined reference strains are available. In consequence, some of the strains analyzed in this study can only be assigned to a genus, but not to species (chapter 2 and 3). From the particularly negative experience with mycelial cultures from strain collections it appears to be advisable in the future to rather start with fresh newly collected material from the nature that can be used to microscope, photograph and desiccate the morphological features of an isolate. Storing mushroom voucher samples is advisable but, in case of coprini, usually not 
practical by the fast autolysing of the mushrooms. Describing morphological features of a mushroom is not sufficient to be sure about the identity, as seen in this study with species that morphologically were not distinguishable. Molecular data (ITS sequences) however clearly defined different species with identical morphological features (see chapter 5).

Coprini, as the name says, are often found growing on compost and dung (Orton and Watling 1979, Breitenbach and Kräzlin 1995). However, there were many individual reports suggesting that wood can also be a habitat for such fungi. Such reports were collected from literature and analyzed (chapter 2). These data were supplemented with own observations from collections of coprini at the grounds of the North Campus of the Georg-August-University of Göttingen. In most of the reports of coprini associated with wood, the same few species appeared: C.atramentaria, C.disseminatus and C. micaceus and these clearly, can degrade wood, probably by white rot mechanism. However, the ability to degrade wood and other compact plant materials among the coprini is likely more widespread than assumed so far. From our compilation of literature we found that growth on wood appears in all new genera in more than $30 \%$ of the coprini species. However, it seems that the abilities to grow on lignocellulose within the genus Coprinellus are more abundant, both in the number of species as well as in the strength of decay (C. disseminatus and C. micaceus). Repeatedly detected on wood, only few species have also a latent pathogenic potential. Wood colonized by coprini is often described as degraded and non-coprini species have often been observed in addition. The studies suggest that coprini species might be rather secondary wood invaders colonizing wood in succession to other myxo-, asco- and basidiomycetes. With the change of gardening practices, coprini mushrooms are nowadays regularly observed on walkways and beds covered by wood chips. A better aeration and possibly a $\mathrm{pH}$ change into the alkaline range might favour development of the coprini on this woody substrate. Several of the tested strains in the laboratory were found to grow on wood sawdust and in some instances, phenoloxidases, respective laccase was principally produced by the strains, none of the coprini appeared to degrade the labelled lignin in the beech wood mixtures. However, degradation of lignocellulose, if any, in these species and study was poor. More likely, growth work on the lignocellulosic materials was mediated to storage compounds present in the parechyma cells of the plant materials. In addition in this thesis, growth was tested on leave litter since several 
coprini have been listed before as leave litter decomposing fungi (Soponsathien 1998, chapter 2 of this thesis). Here we discovered that most fungi grew on Q. robur, but not on A. platanoides leave litter. This different behaviour might be caused by different tannin types (Barbehenn et al. 2006), and/or by a different C:N ratios (Gartner and Cardon 2006) in the tested leave litters or by beech of easily accessible nutrients in the leave litter. Future work needs to clarify this.

Little is yet known on enzymes produced by the fungi to attack compounds within wood. Most of the strains studied so far in the laboratory showed phenoloxidase activity. However, due to different methodological approaches it was difficult to compare all information available for the literature. So far, only two enzymes activities $\mathrm{CiP}$ and Lccl of C. cinerea were tested for their potential biotechnological applications. In terms of biotechnology we are far away from exploiting these fungi. In coprini, of the phenoloxidases, laccases has found more attention than peroxidases. Fungal laccases act in decomposition of compact organic substrates (natural substrate of C. cinerea: horse dung), delignification and phenolic compounds degradation (see above). For the future, these data might direct screening approaches for specific enzymatic activities in order to exploit them in biotechnological applications e.g. by cloning their genes, and overexpressing the genes products in a suitable expression host (Kilaru 2006, Kilaru et al. 2006). As a first such screening approach, detection of laccase activities in selected coprini on lignocellulosic substrates was tested in the laboratory. Mushroom formation on the cheap lignocellulosic substrates was recorded for some species (Chapter 3).

Laccases were found to be frequently active during fruiting body development of C. cinerea (Chapter 7). One of the functions discerned for the enzyme is in melanin pigment formation (Bell and Wheeler 1986, Langfelder et al. 2003). In C. cinerea, laccase activity has also been discussed in terms of basidiospore staining (Leatham and Stahmann 1981, Vnenchak and Schwalb 1989). Melanins are darkly pigmented polymers that mediate protection to cells against heat, toxic metals and free radicals, UV and other radiation, osmotic stress, lytic and antifungal agents (Butler and Day 1998, Jacobson 2000, Nosanchuk and Casadevall 2003). Protection to the fungal spores against enzymatic degradation from herbivorous and fungivorous small grazing animals is another function of the pigments (Richardson 2001, own unpublished observations on wild type and melanin free-laccase mutants of the ascomycete Sordaria macrospora). 
Mushrooms have been shown be a natural source of biological compounds with various medical properties; coprini mushrooms are so far poorly studied in terms of compounds of medical and pharmaceutical interest and not at all exploited. Hence another objective in this work was to review medicinal properties on this group of fungi that might help to direct further studies towards their biotechnological applications (Chapter 4). For commercial exploitation of mushrooms and mushrooms ingredients, well defined culture conditions are required. The knowledge on the biological processes of fruiting body initiation and development is limited and arises mostly from studies of selected model organisms that are accessible to molecular genetics. A better understanding of the developmental processes underlying fruiting in these selected model organisms is expected to help mushroom cultivation of other basidiomycetes in the future (Kües and Liu 2000). Surprisingly, even the best understood species, C. cinerea (C. cinereus), is only poorly described in the developmental course of events occurring during fruiting body development (Buller 1909, Moore 1998, Kües 2000, Kües et al. 2004, Walser et al. 2003). Therefore, in this work a catalogue of pictures was produced to define all the main cytological and physiological stages during fruiting body development (Chapter 6).

Mushroom houses provide the perfect environment for different kind of mites, Tyrophagus spp. among them, with the consequence of causing damages on the fungal cultures (Krantz 1978). Mites were seen repeatedly attracted to fruiting cultures of C. cinerea (U. Kües pers. comm.). When such mite infestation occurred in the laboratory, the chance was taken to observe interrelationships between the two organisms. In this study, we demonstrated the grazing preferences of the mite T. putrescentiae on the fungus C. cinerea and the ecological significance of the relationship of these two organisms: spreading of fungal basidiospores and providing food for the mites' larvae. Moreover, patterns of fungal spore dispersal could affect gene flow, population structure and fungal community structure (Lilleskov and Bruns 2005). For commercial cultivation of mushrooms our observations demonstrate the danger, these type of animals exert on the fungus. Mushrooms will be spoiled for consumption. Other coprini were studied in this thesis in fruiting body development. Attention was given to species forming regularly crippled mushrooms and sterile fruiting body like structures (chapter 5). The developmental programs of structure formation in these species are not very fixed, and much variability is allowed giving rise 
to "monstrous" mushrooms, but also to new reproductive vehicles, such as the large, glittering round spherocytes. Since these obviously do not arise from meiosis, they serve in distributing stabilized genomes and not in recombination of gene pools.

From the overall discussion in this chapter and more detailed discussion on specific subjects in the individual chapters 2 to 9 , it is obvious that for several reasons coprini are an interesting group of fungi to study. This thesis could only introduce into various questions linking to coprini but it is also opened up many new issues on what the fungi can offer in terms of development, substrate degradation and ecological relationships with other organisms.

\subsection{References}

Barbehenn RV, Jones CP, Karonen M, Salminen JP (2006) Tannin composition affects the oxidative activities of tree leaves. J. Chem. Ecol., 32, 2235-2251.

Breitenbach J, Kräzlin F (1995) Pilze in der Schweiz. Vol. 4. Mykologia, Luzern, Switzerland.

Buller AHR (1909) Researches on fungi. Vol. I. An account of the production, liberation, and dispersion of the spores of hymenomycetes treated botanically and physically. Also some observations upon the discharge and dispersion of the spores of ascomycetes and of Pilobolus. Hafner Publishing Co., New York, N.Y., USA.

Butler MJ, Day AW (1998) Fungal melanins: A review. Can. J. Microbiol., 44, $1115-$ 1136.

Gartner TB, Cardon ZG (2006) Site of leaf origin affects how mixed liiter decomposes. Soil Biol. Biochem., 38, 2307-2317.

Jacobson ES (2000) Pathogenic roles for fungal melanins. Clin. Microbiol. Rev., 13, 708-717.

Kilaru S (2006) Identification of fungal multi-copper oxidase gene families: Overexpression and characterization of Coprinopsis cinerea laccases for applications in biotechnology. $\mathrm{PhD}$ Thesis. Georg-August University of Göttingen, Göttingen, Germany.

Kilaru S, Hoegger PJ, Kües U (2006) The laccase multi-gene family in Coprinopsis cinerea has seventeen different members that divide into two distinct subfamilies. Curr. Genet., 50, 45-60. 
Krantz GW (1978) A manual of acarology. O. S. U. Book stores Ltd., Corvallis, Oregon, USA.

Kües U, Liu Y (2000) Fruiting body production in basidiomycetes. Appl. Microbiol. Biotechnol., 54, 141-152.

Kües U, Künzler M, Bottoli APF, Walser PJ, Granado JD, Liu Y, Bertossa RC, Ciardo D, Clergeot P-H, Loos S, Ruprich-Robert G, Aebi M (2004) Mushroom development in higher basidiomycetes. Implications for human and animal health. In: Kushwaha RKS (ed.), Fungi in Human and Animal Health. Scientific Publishers, Jodhpur, India, pp. 431-470.

Langfelder K, Streibel M, Jahn B, Haase G, Brakhage AA (2003) Biosynthesis of fungal melanins and their importance for human pathogenic fungi. Fungal Genet. Biol., 38, 143-158.

Leatham GF, Stahmann MA (1981) Studies on the laccase of Lentinus edodes: specificity, localization and association with the development of fruiting bodies. J. Gen. Microbiol., 125, 147-157.

Lilleskov EA, Bruns TD (2005) Spore dispersal of a resupinate ectomycorrhizal fungus, Tomentella sublilacina, via soil food webs. Mycologia, 97, 762-769.

Nosanchuk JD, Casadevall A (2003) The contribution of melanin to microbial pathogenesis. Cell. Microbiol., 5, 203-223

Moore D (1998) Fungal morphogenesis. Cambridge University Press, Cambridge, UK.

Orton PD, Watling R (1979) British fungus flora. Agarics and Boleti 2. Coprinaceae Part 1: Coprinus. Her Majesty's Stationary Office, Edinburg, UK.

Redhead SA, Vilgalys R, Moncalvo JM, Johnson J, Hopple JS (2001) Coprinus Pers. and the disposition of Coprinus species sensu lato. Taxon, 50, 203-241.

Richardson MJ (2001) Diversity and occurrence of coprophilous fungi. Mycol. Res., $105,387-402$.

Soponsathien S (1998) Some characteristics of ammonia fungi 1. In relation to their ligninolytic enzyme activities. J. Gen. Appl. Microbiol., 44, 337-345.

Vnenchak P, Schwalb MN (1989) Phenol oxidase activity during development of Coprinus cinereus. Mycol. Res., 93, 546-548.

Walser PJ, Velagapudi R, Aebi M, Kües U (2003) Extracellular matrix proteins in mushroom development. Recent Res. Devel. Microbiology, 7, 381-415. 



\section{Curriculum Vitae}

\section{Mónica Navarro-González}

\section{A. Personal data}

Born

Nationality

Marital status

\section{B. Education}

10.2001-02.2007

09.1997-09.1999

08.1991-08.1995

08.1987-07.1990

09.1984-07.1987

09.1978-07.1984

Languages

\section{Appointments}

Since 1.03.07

$1.09 .05-30.04 .06$

$02.2001-07.2001$
October $26^{\text {th }} 1971$ in Cuernavaca, Morelos, Mexico

Mexican

Single

$\mathrm{PhD}$ studies in Biology

(Begin of experimental work Summer Term 2002)

Büsgen-Institute, Section Molecular Wood Biotechnology and

Technical Mycology, Georg-August-University of Göttingen, Göttingen, Germany

Master studies in Strategies for Regional Agricultural

Development, Colegio de Postgraduados, Campus Puebla,

Puebla, Mexico

Examination: 10.02.2000

Bachelor studies in Biology,

Morelos University, Cuernavaca, Morelos, Mexico

Examination: 29.03.1996

High school No. 2. Antonio L. Mora del Castillo

Morelos University, Cuernavaca, Morelos, Mexico

Secondary school. Francisco González Bocanegra.

Cuernavaca, Morelos, Mexico

Primary school. Josefa Ortiz de Domínguez.

Cuernavaca, Morelos, Mexico

Spanish, English (written and spoken), German (fluent spoken and basic written), and French (fluent reading, basic spoken and written)

Scientific assistant at the Büsgen-Institute in the BMBF-Project:

"Verwertungsorientierte Untersuchungen an Buche und

Küstentanne aus nachhaltig bewirtschafteten Mischbeständen zur

Herstellung innovativer zukunftsfähiger Holzprodukte und

Holzwerkstoffe". Georg-August-University of Göttingen.

Student Assistant. Georg-August-Göttingen University.

Gleichstellungsbeauftragte of the Georg-August-University of

Göttingen.

Technical assistant in the Environmental Protection Department. City council of Cuernavaca, Morelos, Mexico. 
2000 - $2001 \quad$ Independent technical assistant to small mushroom growers (Pleurotus spp.). Morelos, Mexico.

$08.1996-08.1997$ Research assistant in the Laboratory of Mycology. Morelos University, Cuernavaca, Morelos, Mexico

$05.1995-07.1995$ Technical assistant in the Laboratory of Mycology. Morelos University, Cuernavaca, Morelos, Mexico

\section{Grants}

2001-2005 CONACYT Scholarship for doctoral studies in the Georg-AugustUniversity, of Göttingen, Göttingen, Germany

1997-1999 CONACYT Scholarship for Master studies in Colegio de Postgraduados, Campus Puebla. Puebla, México

\section{E. Students supervised}

Arndt M. (2008) Effect of several antibiotics in clamp formation in Coprinopsis cinerea. Bachelor thesis. Ongoing.

Ris D. (2007) Clamp formation in faecal pellets of the fungivorous mite Tyrophagus putrescentiae. Bachelor thesis. Ongoing.

Kleemann F. (2007) Interaction between Coprinopsis cinerea and other microorganisms: Effect on the laccase production. Master thesis. Georg-August University of Göttingen, Göttingen, Germany.

Sánchez-Hernández O. (2006-2007) Introduction in laboratory techniques in mycology and microbiology. Bachelor project student. Georg-August University of Göttingen, Göttingen, Germany.

Domingo-Martínez A. (2005) Crecimiento y productividad enzimática de hongos del género Coprinus sobre residuos lignocelulosicos y caracterización de una especie anamorfa de Coprinus denominada Rhacophyllus spp. Master thesis. Escuela Politécnica Superior de Lugo Spain, and Georg-August University of Göttingen, Göttingen, Germany.

Yen-Méndez C. (2004) Introduction in laboratory techniques in mycology, microbiology and enzimology. Bachelor project student. Supervision during an interchange program between the Forestry Sciences Faculty of Linares, Monterrey and the Georg-August-University. Georg-August University of Göttingen, Göttingen, Germany.

\section{F. Other activities}

Equal opportunities officer at the Faculty of Forest Sciences and Forest Ecology.

(Gleichstellungsbeauftragte of the Georg-August-University of Göttingen). Summer and Winter Term 2003-2004. 


\section{G. Research publications}

Navarro-González M., Domingo-Martínez A., Navarro-González S.S., Beutelmann P. \& Kües U. (2008) Monstrosities under the inkcap mushrooms. Mycol. Res. Submitted.

Naumann A.*, Navarro-González M.*, Sánchez-Hernández O., Hoegger P.J. \& Kües U. (2007) Correct identification of wood-inhabiting fungi by ITS analysis. Current Trends in Biotechnology and Pharmacy Vol. 1 (1) 41-61.

* Shared first autorship

Kües U., Navarro-González M., Srivilai P., Chaisaena W. \& Velagapudi R. (2007) Mushroom Biology and Genetics. In: Kües U. (Ed.) Wood production, wood technology and biotechnological impacts. Universitätsverlag-Verlag, Göttingen, Germany pp. 396414.

Rühl M., Kilaru S., Navarro-González M., Hoegger P.J., Kharazipour A. \& Kües U. (2007) Production of laccase and other enzymes for the wood industry. In: Kües U. (Ed.) Wood production, wood technology and biotechnological impacts. Universitätsverlag-Verlag, Göttingen, Germany pp. 361-398.

Badalyan S.M., Gharibyan N.G., Sakeyan C.Z., Avetisyan H.K., Grigoryan M.O., Navarro-González M., \& Kües U. (2007). Biological characteristics and genetic diversity of several Basidiomycetes medicinal mushrooms. Int. J. Med. Mushrooms. 9 (3): 276 .

Badalyan S.M., Avetisyan H.K., Navarro-González M., \& Kües U. (2007) Phylogenetic significance of morphological, ecological and physiological mycelial characteristics of several Coprinoid mushrooms (Holobasidiomycetidae). XV Congress of European Mycologist. Sept. 16-21, S.-Petersburg, Russia.

Rühl M., Kilaru S., Majcherczyk A., Hoegger P.J., Navarro-González M., Chaisaena W., Naumann A., Peddireddi S., Malik I. \& Kües U. (2006). Biotechnological research on basidiomycete fungi. In: Kharazipour A., Müller C., and Schöpper C. (Eds.) Review of Forests, Wood Products and Wood Biotechnology of Iran and Germany. DAAD, Germany. pp. 58-69.

Navarro-González M.*, Domingo-Martínez A., Navarro-González S.S., Beutelmann P. \& Kües U. (2006) Monstrosities under the inkcap mushrooms. In: Pisabarro G. \& Ramirez L. (Eds.) Proc. Genetics and Cellular Biology of Basidiomycetes VI. Pamplona, 3-6 June 2005, Spain.

*Corresponding author

Naumann A., Navarro-González M., Peddireddi S., Kües U. \& Polle A. (2005) Fourier transform infrared microscopy and imaging: Detection of fungi in wood. Fungal Genet. Biol. 42: 829-835.

Hoegger P.J., Navarro-González M., Kilaru S., Hoffmann M., Westbrook E.D. \& Kües U. (2004) The laccase gene family in Coprinopsis cinerea (Coprinus cinereus). Current Genetics 45: 9-18. 
Badalyan S.M., Avetisyan H.K., Navarro-González M., Szafranski K., Hoegger P.J. \& Kües U. (2003a) Two new Coprinus species in Armenia associated with wood: Coprinus strossmayeri (Coprinopsis strossmayeri) and a new species closely related to Coprinus radians (Coprinellus radians). In: Botanical Research in Asian Russia. Proc. XI Congr. Russian Bot. Soc. 18-22 August, 2003, Novosibirsk-Barnaoul, Russia. pp. 8-9.

Badalyan S.M., Navarro-González M., Avetisyan H.K., Majcherczyk A. \& Kües U. (2003b) Cultural characteristics of Coprinus spp. In: Botanical Research in Asian Russia. Proc. XI Congr. Russian Bot. Soc. 18-22 August, 2003, Novosibirsk-Barnaoul, Russia. pp. 11-12.

\section{In preparation}

Navarro-González M., Sánchez O., Chaisaena W., Plašil P., Schütz S. \& Kües U. (2008) Grazing preferences on developmental structures of Coprinopsis cinerea (Coprinus cinereus): symbiotic mite-fungal interaction?

Navarro-González M., Avetisyan H., Badalian S., Holdenrieder O. \& Kües U. (2008) Lignocellulolytic activities within Coprinus species.

Navarro-González M., Majcherczyk A. \& Kües U. (2008) Effect of copper in Coprinopsis cinerea development.

\section{H. Oral presentations}

03, 2008 Fungivorous mites promote inbreeding in Coprinopsis cinerea. VAAM 2008 Annual Meeting. March 9-11. Frankfurt, Germany.

01,2008

Fruiting body development in Coprinaceae. Seminar of the Section Molecular Wood Biotechnology and Technical Mycology, and the Section Forest Botany and Physiology of Trees of the Büsgen-Institute. Georg-August-University of Göttingen, Göttingen, Germany.

11, $2007 \quad$ Fruiting body development in Coprinaceae. GZMB Kolloquium. Georg-August-University of Göttingen, Göttingen, Germany.

04,2007

Grazing preferences on developmental structures of Coprinopsis cinerea (Coprinus cinereus): Symbiotic mite-fungal interaction?. Institute of Forest Botany, Georg-August-University of Göttingen, Göttingen, Germany.

04,2007

Mites act in distribution of fungal spores in Coprinopsis cinerea. VAAM 2006 Annual Meeting. April 1-4. Osnabrück, Germany.

06,2005

Monstrosities under the Inkcap mushrooms. Genetics and Cellular Biology of Basidiomycetes VI. Pamplona, Spain. 
06,2005

Laccases in development of Coprinopsis cinerea. Institute of Forest Botany, Georg-August-University of Göttingen, Göttingen, Germany.

05,2003

Laccases in the fungi Coprinus cinereus. Institute of Forest Botany, Georg-August-University of Göttingen, Göttingen, Germany.

\section{Conference contributions (Posters)}

\section{8}

Cherdchim B.*, Navarro-González M.*, Zomorrodi M., Majcherczyk A. \& Kües U. (2008) Fungal Degradation of Grand Fir (Abies grandis) and Induction of Oxidative Enzymes by Wood Extractives. VAAM 2008 Annual Meeting. March 9-11. Frankfurt, Germany.

Wei D-S.*, Navarro-González M.* \& Kües U. (2008) Molecular identification of wood-inhabiting and wood degrading fungi of grand fir (Abies grandis) and beech (Fagus sylvatica). VAAM 2008 Annual Meeting. March 9-11. Frankfurt, Germany.

Navarro-González M., Sánchez O., Chaisaena W., Plašil P., Schütz S. \& Kües U. (2008) Fungivorous mites promote inbreeding in Coprinopsis cinerea by distribution of basidiospores in faecal pellets. Multitrophic interactions Workshop. March 6-7. Göttingen, Germany.

2007

Navarro-González M., Nowrousian M., Neg. I., Sánchez O. \& Kües U. (2007) Effect of mutations on grazing of the mite Tyrophagus putrescentiae in the ascomycete Sordaria macrospore. Molecular Biology of Fungi. September 23-26, Hamburg, Germany.

Navarro-González M., Chaisaena W., Sánchez O., Plašil P., Schütz S. \& Kües U. (2007) Fungivorous mites promote inbreeding in Coprinopsis cinerea by distribution of basidiospores in faecal pellets. Molecular Biology of Fungi. September 23-26, Hamburg, Germany.

Navarro-González M., Hoegger P.J., Cherdchim B., Majcherczyk A. \& Kües U. (2007) Fungal degradation of wood composites. Molecular Biology of Fungi. September 23-26, Hamburg, Germany.

Navarro-González M., Chaisaena W., Sanchez-Hernandez O., Schütz S. \& Kües U. (2007) Mites act in distribution of fungal spores in Coprinopsis cinerea. $24^{\text {th }}$ Fungal Genetics Conference, 20-25 March. Asilomar; USA.

Chaisaena W., Navarro-González M. \& Kües U. (2007) Defects in light regulation of sexual and asexual development in Coprinopsis cinerea. $24^{\text {th }}$ Fungal Genetics Conference, 20-25 March. Asilomar; USA. 
Srivilai P., Navarro-González M. \& Kües U. (2007) A constitutively activated Rasprotein has multiple effects on vegetative and sexual development in Coprinopsis cinerea. $24^{\text {th }}$ Fungal Genetics Conference, 20-25 March. Asilomar; USA,

2006

Chaisaena W., Navarro-González M., Srivilai P. \& Kües U. (2006) Light regulates fruiting body morphology in Coprinopsis cinerea. VAAM, Frankfurt, Germany.

Navarro-González M., Chaisaena W. \& Kües U. (2006) Tissue development and differentiation during fruiting in the basidiomycete Coprinopsis cinerea. IXth International Fungal Biology Conference and $16^{\text {th }}$ New Phytologist Symposium. 18-20 September. Nancy, France.

Srivilai P., Navarro-González M. \& Kües U. (2006) A small GTPase affects vegetative and sexual development in Coprinopsis cinerea. IXth International Fungal Biology Conference and $16^{\text {th }}$ New Phytologist Symposium. 18-20 September. Nancy, France.

Chaisaena W., Navarro-González M., Srivilai P., \& Kües U. (2006) Coprinopsis cinerea mutants forming etiolated stipes under normal fruiting conditions. IXth International Fungal Biology Conference and $16^{\text {th }}$ New Phytologist Symposium. 18-20 September. Nancy, France.

Navarro-González M., Velagapudi R. \& Kües U. (2006) The course of fruiting body development in the basidiomycete Coprinopsis cinerea. $8^{\text {th }}$ European Conference on Fungal Genetics. 8-11 April. Vienna, Austria.

Chaisaena W., Srivilai P., Navarro-González M. \& Kües U. (2006) Aberrant fruiting body in Coprinopsis cinerea: the etiolated stipe phenotype. $8^{\text {th }}$ European Conference on Fungal Genetics. 8-11 April. Vienna, Austria.

Srivilai P., Kilaru S., Navarro-González M., Chaisaena W. \& Kües U. (2006) A constitutively activated Ras-GTPase alters mycelial growth in Coprinopsis cinerea and affects B mating type regulated phenotypes in dikaryons and fruiting development. $8^{\text {th }}$ European Conference on Fungal Genetics. 8-11 April. Vienna, Austria.

Kilaru S., Rühl M., Saathoff A., Navarro-González M., Zomorrodi M., Lange K., Majcherczyk A., Hoegger P.J. \& Kües U. (2006) Characterization of laccases from Coprinopsis cinerea. $8^{\text {th }}$ European Conference on Fungal Genetics. 8-11 April. Vienna, Austria.

Kües U., Velagapudi R., Pemmasani J.K, Navarro-González M., Hoegger P.J., Kilaru S., Srivilai P., Majcherczyk A., Peddireddi S., Chaisaena W. \& Dwivedi R.C. (2006) Analysis of multi-gene families with functions in fruiting body development of Coprinopsis cinerea. VAAM 2006 Annual Meeting. March 19-22. Jena, Germany.

2005

Navarro-González M., Domingo-Martínez A., Navarro-Gonzáles S., Beutelmann P. \& Kües U (2005) Monstrosities under the Inkcap mushrooms. $23^{\text {rd }}$ Fungal Genetics Conference, 15- 20 March. Asilomar; USA, (Poster); Basidio 2005, Warwickshire, UK 
(Poster) and Genetics and Cellular Biology of Basidiomycetes VI. 3-6 June. Pamplona, Spain (Oral presentacion and Poster).

Navarro-González M., Kilaru S., Majcherczyk A. \& Kües U. (2005) Copper in Fruiting Body Development of Coprinus cinereus. Genetics and Cellular Biology of Basidiomycetes VI. 3-6 June. Pamplona, Spain.

Kilaru S., Navarro-González M., Saathoff A., Zomorrodi M., Lange K., Dwivedi R.C., Majcherczyk A., Hoegger P.J. \& Kües U. (2005) Characterization of multiple laccases obtained from overexpression in Coprinopsis cinerea. $7^{\text {th }}$ VAAM Symposium Molecular Biology of Fungi. 4-7 September. Bochum, Germany.

Naumann A., Navarro-González M., Peddireddi S., Schützendübel A., Kües U. \& Polle A. (2005) Species identification and detection of fungi in biological materials by FTIR microscopy. Cellular Biology of Basidiomycetes VI. 3-6 June. Pamplona, Spain.

2004

Navarro-González M., Srivilai P., Majcherczyk A. \& Kües U. (2004) Initiation of fruiting body development in the basidiomycete Coprinopsis cinerea. VAAM 2004 Annual Meeting, Braunschweig. March 28-31. Braunschweig, Germany.

Navarro-González M., Badalyan S.M., Domingo-Martinez A., Majcherczyk A. \& Kües U. (2004) Decay of poplar wood by Coprinoid mushrooms. Understanding poplar: from genes to functions. 13-14 May. Göttingen, Germany.

Naumann A., Navarro-González M., Kües U. \& Polle A. (2004) Simultaneous localization of organic compounds in wood by FTIR microscopy. The Forestry Woodchain. 28-30. Sept. Edinburgh, UK.

Naumann A., Schützendubel A., Navarro-González M., Kües U. \& Polle A. (2004) Towards localization and identification of fungi in trees by Fourier Transform Infrared (FTIR) microscopy. Botanikertagung. 5-10. Sept. Braunschweig, Germany.

Badalyan, S.M., Avetisyan H.K., Navarro-González M., Majcherczyk A. \& Kües U. (2004) Morphological, physiological and ecological characteristics of several woodrelated coprinoid mushrooms. CBS Centenary: 100 Years of fungal biodiversity and Ecology. 13-14 May. Amsterdam, Holland.

Velagapudi R., Kilaru S., Hoegger P.J., Dwivedi R.C., Srivilai P., Peddireddi S., Navarro-González M., Pemmasani L.K., Zomorrodi M., Lange K., Majcherczyk A. \& Kües U. (2004) Multi-gene families in the basidiomycete Coprinopsis cinerea, Gordon Research Conferences. 20-25 June. Plymouth, USA.

2003

Navarro-González M., Majcherczyk A. \& Kües U. (2003) Copper in fruiting body development and enzyme production of Coprinus cinereus. Molecular biology of fungi, 6th VAAM-Conference. 3.-5. Sept. Göttingen, Germany. 
Navarro-González M., Hoegger P.J., Hoffmann M., Kilaru S., Dwivedi R., Zomorrodi M., Majcherczyk A. \& Kües U. (2003) Laccases in the dung fungus Coprinus cinereus. $22^{\text {nd }}$ Fungal Genetics Conference. 18-23 March. Pacific Grove, California.

Navarro-González M., Badalyan S.M., Avetisyan H.K., Holdenrieder O. \& Kües U. (2003) Lignocellulose degrading activities within Coprinus species. Molecular biology of fungi, 6th VAAM-Conference. 3.-5 Sept. Göttingen, Germany.

Hoegger P.J., Navarro-González M., Hoffmann M., Kilaru S., Westbrook E.D., James T.Y., Vilgalys R. \& Kües U. (2003) Evolution of laccase multi-gene in Coprinus cinereus and other organisms. Molecular biology of fungi, 6th VAAM-Conference. 3.-5 Sept. Göttingen, Germany.

Dwivedi R.C., Navarro-González M., Kües U. \& Majcherczyk A. (2003) Cell wall associated redox enzymes in white fungi. Molecular biology of fungi, 6th VAAMConference. 3.-5 Sept. Göttingen, Germany.

Kilaru, S., Hoegger P.J., Navarro-González M., Hoffmann M., Majcherczyk A. \& Kües U. (2003) Expression and characterization of laccases in Coprinus cinereus. Molecular biology of fungi, 6th VAAM-Conference. 3.-5 Sept. Göttingen, Germany.

Badalyan, S.M., Avetisyan H.K., Navarro-González M. \& Kües U. (2003) Ecophysiological characteristics of several Coprinus species related to Wood. Molecular biology of fungi, 6th VAAM-Conference. 3.-5 Sept. Göttingen, Germany.

2002

Navarro-González M., Hoffmann M., Holdenrieder O. \& Kües U. (2002) Coprinaceae in wood and straw degradation: implications for ecology and biotechnological use. 7th International Mycological Congress. 11-17 August. Oslo, Norway. 